Midwest Geological Sequestration Consortium

\title{
Sequestration and Enhanced Coal Bed Methane: Tanquary Farms Test Site, Wabash County, Illinois
}

Final Report

October 1, 2007-January 6, 2012

Principal Investigator: Robert Finley

Illinois State Geological Survey

Prairie Research Institute

University of Illinois

(217) 244-8389

finley@isgs.illinois.edu

Report Issued: January 6, 2012

\section{U.S. DOE Contract: DE-FC26-05NT42588}

The Board of Trustees of the University of Illinois

Sandy Moulton, Director c/o Grants \& Contracts Office

1901 S. First Street, Suite A

Champaign, IL 61820

Illinois State Geological Survey

with Team Members:

Gallagher Drilling, Inc.

Indiana Geological Survey

Southern Illinois University

Trimeric Corporation

ILLINOIS STATE GEOLOGICAL SURVEY

Prairie Research Institute

University of Illinois at Urbana-Champaign 


\section{Disclaimer}

This report was prepared as an account of work sponsored by an agency of the United States Government. Neither the United States Government nor any agency thereof, nor any of their employees, makes any warranty, express or implied, or assumes any legal liability or responsibility for the accuracy, completeness, or usefulness of any information, apparatus, product, or process disclosed, or represents that its use would not infringe privately owned rights. Reference herein to any specific commercial product, process, or service by trade name, trademark, or manufacturer, or otherwise does not necessarily constitute or imply its endorsement, recommendation, or favoring by the United States Government or any agency thereof. The views and opinions of authors expressed herein do not necessarily state or reflect those of the United States Government or any agency thereof. 
Midwest Geological Sequestration Consortium

\section{Sequestration and Enhanced Coal Bed Methane: Tanquary Farms Test Site, Wabash County, Illinois}

Final Report

October 1, 2007- January 6, 2012

Principal Investigator: Robert Finley

Illinois State Geological Survey

Prairie Research Institute

University of Illinois

(217) 244-8389

finley@isgs.illinois.edu

Report Issued: January 6, 2012

\section{U.S. DOE Contract: DE-FC26-05NT42588}

The Board of Trustees of the University of Illinois

Sandy Moulton, Director c/o Grants \& Contracts Office

1901 S. First Street, Suite A

Champaign, IL 61820

Illinois State Geological Survey

with Team Members:

Gallagher Drilling, Inc.

Indiana Geological Survey

Southern Illinois University

Trimeric Corporation

\section{ILLINOIS STATE GEOLOGICAL SURVEY}

Prairie Research Institute

University of Illinois at Urbana-Champaign

615 E. Peabody Drive

Champaign, Illinois 61820-6964

http://www.isgs.illinois.edu 


\section{Contributors}

Robert J. Finley and Scott M. Frailey, Illinois State Geological Survey (ISGS), Prairie Research Institute, conducted the technical review of this document. Charles C. Monson (ISGS) worked with contributors and reviewers to assemble the report and prepared the Abstract and Executive Summary.

David G. Morse (ISGS) led the effort to find a suitable injection site and all of the well drilling work to the casing point including the coring and open hole logging operations. Morse coordinated the Coal Characterization program and was the primary author for the coal characterization section of this report. Contributors to the coal characterization are as follows: ISGS contributors were Keith Hackley, gas chromatographic and isotopic characterization; and Christopher Korose, Geographic Information Systems and volumetrics. Laboratory experiments on coal adsorption, shrinkage, and swelling were conducted by Satya Harpalani, Southern Illinois University at Carbondale. Maria Mastalerz, Agnieszka Drobniak, and John Rupp (Indiana Geological Survey) were involved with planning, performed some desorption and gas chemistry and all maceral characterization analyses, and studied the roles of various coal macerals and coal pore size distribution in sequestration.

Ivan G. Krapac (ISGS) coordinated the monitoring, verification, and accounting (MVA) program at the Tanquary site. He designed and developed the general MVA requirements of the site and worked with individual contributors towards the synergistic and collaborative effort of this program. Krapac coordinated, compiled, and edited the MVA strategy and MVA observations and discussions sections. ISGS contributors to both field efforts and data analysis and interpretation included Peter Berger (geochemical modeling), Gayathri Gopalakrishnan (GFLOW modeling), Keith Hackley (gas characterization), Donald Luman (color infrared imagery), Ed Mehnert (groundwater modeling, water well installation and development), and William Roy (geochemical modeling). Abbas Iranmanesh and Bracken Wimmer assisted with monitoring well installation and development, conducted the monthly water and gas sampling of the domestic and injection site ground water and the injection coal seam monitoring wells, and contributed to documentation of sampling methodology. ISGS well drilling crew led by Jack Aud installed groundwater monitoring wells. Bob Butsch (Schlumberger Carbon Services) completed the cased hole $\log$ analyses.

Scott Frailey led the pilot planning, scheduling, and logistics of implementing the plan through post-carbon dioxide $\left(\mathrm{CO}_{2}\right)$ injection testing and ultimate abandonment of wells and reclamation of the site. Frailey designed the pressure transient tests and performed real time analyses of the data. He coordinated the numerical modeling and pressure transient analyses for analyzing the pressure and injection rate from the $\mathrm{CO}_{2}$ and water injection periods. Frailey was the primary author for the introduction and sections on site selection; pilot site design modification and well arrangement; drilling operations, open hole tests, and casing; completion; coal seam (in situ) characterization (pre- $\mathrm{CO}_{2}$ ); field observations during active $\mathrm{CO}_{2}$ injection; interpretation, analyses, and modeling of pilot results; and conclusions. Text for these sections was also contributed by David Morse, Charles Monson, and Satya Harpalani.

Ray McKaskle, Kevin Fisher, Andrew J. Sexton, and Joe Lundeen (Trimeric) were responsible for $\mathrm{CO}_{2}$ injection equipment design, procurement, and testing; they also provided operational support. McKaskle was the primary author for the injection operations section of this report. Additional contributors to this section were Scott Frailey, Damon A. Garner, Jessica Hinton, Charles Monson, and Steve Sargent (ISGS). Ray McKaskle, Kevin Fisher, and Joe Lundeen (Trimeric) were responsible for injection equipment design, procurement, and testing.

Mike Gallagher, Shawn Gallagher, Dan Gallagher, and Victor Gallagher of Gallagher Drilling, Inc. provided site and field logistic support and engineering and geologic design. Ed Applegate and Billy Wormack (GDI) provided general field operations support. After the wells were drilled and completed, Jim Kirksey (Schlumberger Carbon Services) coordinated many of the pre-injection site activities.

The primary contributors to the section on the effects of $\mathrm{CO}_{2}$ on coal were Bob Butsch (SCS), Satya Harpalani (SIUC), David Morse, and Scott Frailey (ISGS).

Gary Crawford (Well Test Solutions, Inc.) and Anne Oudinot (ARI) performed pressure transient analysis and numerical modeling, respectively, and contributed text to the coal characterization and interpretation, analyses, and modeling of pilot results sections.

Damon Garner provided extensive data management, archiving, and analysis tool development. Steve Sargent supported the data acquisition program from inception through completion.

Charles Monson (ISGS) was the author of the well plugging and abandonment and site reclamation section. Mike Gallagher (Gallagher Drilling, Inc.) supplied information for this section. 
Michael S. Dodd (ISGS) supervised $\mathrm{CO}_{2}$ pumping operations and production and injection equipment setup. Bill Ellis, Billy Ellis, Rob Lowery, and Wayne Hammel provided field support.

Other ISGS personnel who assisted with this report: Jessica Hinton was responsible for some of the initial report organization, text writing and figures, and working with third-party contributors. Charles Monson, Daniel Klen, Kathryn Menichetti, and Kevin Brown provided editing, figure drafting, unit conversions, and data compilation. Kevin Wolfe was responsible for pre-injection pilot coordination and the data acquisition setup. Andrew Anderson performed pre-injection numerical modeling. Daniel L. Byers and Michael Knapp contributed equipment and site technical drawings and illustrations, graphic design, and layout of final report. Cheryl K. Nimz and Jon Goodwin provided technical editing. 


\section{Abstract}

The Midwest Geological Sequestration Consortium (MGSC) carried out a pilot project to test storage of carbon dioxide $\left(\mathrm{CO}_{2}\right)$ in the Springfield Coal Member of the Carbondale Formation (Pennsylvanian System), in order to gauge the potential for large-scale $\mathrm{CO}_{2}$ sequestration and/or enhanced coal bed methane recovery from Illinois Basin coal beds.

The pilot was conducted at the Tanquary Farms site in Wabash County, southeastern Illinois. A four-well designan injection well and three monitoring wells-was developed and implemented, based on numerical modeling and permeability estimates from literature and field data. Coal cores were taken during the drilling process and were characterized in detail in the lab. Adsorption isotherms indicated that at least three molecules of $\mathrm{CO}_{2}$ can be stored for each displaced methane $\left(\mathrm{CH}_{4}\right)$ molecule. Microporosity contributes significantly to total porosity. Coal characteristics that affect sequestration potential vary laterally between wells at the site and vertically within a given seam, highlighting the importance of thorough characterization of injection site coals to best predict $\mathrm{CO}_{2}$ storage capacity.

Injection of $\mathrm{CO}_{2}$ gas took place from June 25, 2008, to January 13, 2009. A “continuous" injection period ran from July 21, 2008, to December 23, 2008, but injection was suspended several times during this period due to equipment failures and other interruptions. Injection equipment and procedures were adjusted in response to these problems. Approximately 92.3 tonnes (101.7 tons) of $\mathrm{CO}_{2}$ were injected over the duration of the project, at an average rate of 0.93 tonne (1.02 tons) per day, and a mode injection rate of $0.6-0.7$ tonne/day ( $0.66-0.77$ ton/day).

A Monitoring, Verification, and Accounting (MVA) program was set up to detect $\mathrm{CO}_{2}$ leakage. Atmospheric $\mathrm{CO}_{2}$ levels were monitored as were indirect indicators of $\mathrm{CO}_{2}$ leakage such as plant stress, changes in gas composition at wellheads, and changes in several shallow groundwater characteristics (e.g., alkalinity, pH, oxygen content, dissolved solids, mineral saturation indices, and isotopic distribution). Results showed that there was no $\mathrm{CO}_{2}$ leakage into groundwater or $\mathrm{CO}_{2}$ escape at the surface. Post-injection cased hole well log analyses supported this conclusion.

Numerical and analytical modeling achieved a relatively good match with observed field data. Based on the model

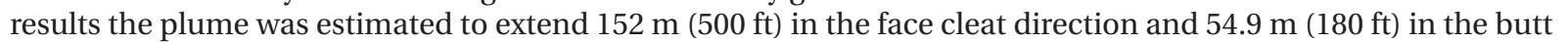
cleat direction. Using the calibrated model, additional injection scenarios-injection and production with an inverted five-spot pattern and a line drive pattern — could yield $\mathrm{CH}_{4}$ recovery of up to $70 \%$. 


\section{Executive Summary}

The Midwest Geological Sequestration Consortium (MGSC) has investigated the potential for sequestering carbon dioxide $\left(\mathrm{CO}_{2}\right)$ in the largest bituminous coal reserve in the United States: the Illinois Basin. A pilot project was carried out to test storage of $\mathrm{CO}_{2}$ in the Springfield Coal Member of the Carbondale Formation (Pennsylvanian System), in order to gauge the potential for large-scale $\mathrm{CO}_{2}$ sequestration and/or enhanced coal bed methane recovery from Illinois Basin coal beds.

The pilot was conducted at the Tanquary Farms site in Wabash County, southeastern Illinois. Numerical modeling was applied iteratively to determine monitoring well locations relative to the injection well. Locations were based on the need to measure pressure and gas composition changes at the monitoring wells during the planned injection period. Permeability estimates were obtained from the literature and from drill-stem and pressure transient tests. Cleat directions were measured at a nearby mine. Ultimately, a four-well design was developed and implemented-an injection well, two monitoring wells with approximately $30-\mathrm{m}$ (100-ft) spacing from the injection well, and one monitoring well with approximately $15-\mathrm{m}(50-\mathrm{ft})$ spacing from the injection well. Surface and bottomhole pressure and temperature gauges were installed at each well to permit monitoring of pressure and temperature data.

Coal cores were taken during the drilling process and were characterized in detail in the lab. Well-developed coal cleats occur with 1- to 2-cm (0.4- to 0.8-in) spacing and contain partial calcite and/or kaolinite fillings that may decrease coal permeability. Coal maceral composition averaged $76.5 \%$ vitrinite. Microporosity is a significant contributor to total porosity. Lithotype and mineral matter content influence coal properties such as porosity and permeability, which in turn affect $\mathrm{CO}_{2}$ adsorption capacity and rates and, hence, sequestration potential. Because coal characteristics vary across the Basin and also laterally between wells at the site and vertically within a given seam, it is critical to characterize injection site coals to best predict the potential for $\mathrm{CO}_{2}$ injection and storage capacity. Volumetric strain measurements demonstrated higher, pressure-dependent strain during $\mathrm{CO}_{2}$ replacement of methane $\left(\mathrm{CH}_{4}\right)$, verifying that $\mathrm{CO}_{2}$ injection may influence the cleat porosity and the flow system. Adsorption isotherms indicate that at least three molecules of $\mathrm{CO}_{2}$ can be stored for each displaced molecule of $\mathrm{CH}_{4}$.

The $\mathrm{CO}_{2}$ injection commenced with a series of $\mathrm{CO}_{2}$ pressure transient tests on June 25, 2008, and was completed on January 13, 2009. A “continuous” injection period ran from July 21, 2008, to December 23, 2008, but injection was suspended several times during this period due to equipment failures and other interruptions. Pressure responses during injection occurred most quickly and intensely at the face cleat well, M-2. However, methane was detected at the butt cleat wells (M-1 and M-3) within hours of $\mathrm{CO}_{2}$ injection startup but did not occur at the face cleat well for about 4 months. $\mathrm{CO}_{2}$ breakthrough first occurred at $\mathrm{M}-1$ (the butt cleat well nearest the injector) about a month after injection started, followed by M-3 (the distal butt cleat well) at about 120 days. Initial $\mathrm{CO}_{2}$ concentrations in both of these wells were low but eventually climbed to $70-95 \%$. The $\mathrm{CO}_{2}$ breakthrough at face cleat well M-2 did not occur until 136 days after injection began.

A total of approximately 92.3 tonnes (101.7 tons) of $\mathrm{CO}_{2}$ were injected over the life of the project, at an average rate of 0.93 tonne (1.02 tons) per day, and a mode injection rate of $0.6-0.7$ tonne (0.66-0.77 ton)/day. Injection rates decreased from 1.36 tonnes ( 1.5 tons)/day to 0.45 ton ( 0.5 ton)/day during the "continuous" injection period. Rates increased to near the maximum initial sustained rates after each suspension of injection, suggesting that rate changes were not primarily due to coal swelling or $\mathrm{CO}_{2}$ adsorption, which would likely cause more permanent changes in rate.

Additional numerical modeling was conducted after injection was completed. After several iterations, the models gave relatively good matches for injected volume, measured bottomhole pressures, effective permeability, and size and shape of $\mathrm{CO}_{2}$ plume based on $\mathrm{CO}_{2}$ detection at monitoring wells. Post-injection logging measured the capture cross section and neutron porosity, finding the greatest gas volume in the injector and face cleat wells (as opposed to the butt cleat wells) at about $4-5 \%$ of formation bulk volume. The results suggested that hydrocarbon gas and $\mathrm{CO}_{2}$ remained in the Springfield Coal at about $274 \mathrm{~m}(900 \mathrm{ft})$. Post-injection water transient tests showed that water permeability decreased following $\mathrm{CO}_{2}$ injection.

Before injection began, a Monitoring, Verification, and Accounting (MVA) program was set up to detect any $\mathrm{CO}_{2}$ leakage. Four shallow groundwater wells were installed near the injection well, and conditions at two residential wells farther from the immediate site were also monitored. The MVA techniques included groundwater flow modeling, atmospheric monitoring for direct detection of excess $\mathrm{CO}_{2}$, and monitoring of indirect indicators of $\mathrm{CO}_{2}$ and $\mathrm{CH}_{4}$ leakage, such as plant stress, changes in gas composition at wellheads, and changes in several shallow groundwater characteristics (alkalinity, $\mathrm{pH}$, oxygen content, dissolved solids, mineral saturation indices, and isotopic distribution, among others). Baseline (pre-injection or pre-breakthrough) values for those parameters were measured and compared with results during and post-injection. Modeling results indicated that a plume from 
an injection well leak would travel only a short distance and would not pose a significant risk to groundwater or surface water. Monitoring results indicated no $\mathrm{CO}_{2}$ leakage into groundwater or $\mathrm{CO}_{2}$ escape at the surface. Isotopic composition and carbon-14 activity of $\mathrm{CO}_{2}$ samples collected after breakthrough at the coal seam observation wells helped confirm that increased $\mathrm{CO}_{2}$ concentrations at those wells originated from injected $\mathrm{CO}_{2}$.

Numerical and analytical modeling achieved a relatively good match with observed field data. Based on the model results, the plume was estimated to extend $152 \mathrm{~m}(500 \mathrm{ft})$ in the face cleat direction and $54.9 \mathrm{~m}(180 \mathrm{ft})$ in the butt cleat direction. Using the calibrated model, additional injection scenarios-injection and production with an inverted five-spot pattern and a line drive pattern-were simulated. A line-drive pattern with injection and production wells aligned in the face cleat direction gave the highest enhanced coal bed methane (ECBM) estimate of $71.4 \%$ of original gas in place. The $\mathrm{CO}_{2}$ storage efficiency and $\mathrm{CH}_{4}$ production efficiency as a fraction of the original $\mathrm{CH}_{4}$ gas in place were $2.5 \mathrm{scf}$ of $\mathrm{CO}_{2} / \mathrm{scf}$ of $\mathrm{CH}_{4}$ and $71 \% \mathrm{scf}$ of $\mathrm{CH}_{4} / \mathrm{scf}$ of $\mathrm{CH}_{4}$. 


\section{CONTENTS}

Contributors

Abstract iv

Executive Summary

Introduction 1

Midwest Geological Sequestration Consortium Background 1

MGSC Phase I Illinois Basin Coal Assessment Summary 1

Phase II Coal Seam Pilot Objectives 1

Site Screening: General Pilot Requirements 2

Site Selection 2

Coal and Geology 4

Geographic Description and Site Logistics 4

Initial Well Pattern Design Modeling Sensitivity 4

Pilot Site Design Modification and Well Arrangement 7

Drilling Operations, Coring, and Logging 11

Well Completion and Wellhead Design 11

Well Completion 11

Wellhead Design $\quad 13$

Coal Characterization: Core, Log, and Pressure Transient Analyses 15

Core Description 15

Macerals and Coal Composition $\quad 15$

Gas Content and Composition $\quad 17$

Gas Adsorption Capacity 21

$\begin{array}{ll}\text { Log Analyses } & 21\end{array}$

Pore Size Description 23

Pressure Transient Analyses $\quad 28$

Analytical Solution $\quad 28$

$\begin{array}{ll}\text { Numerical Solution } & 28\end{array}$

$\begin{array}{ll}\text { Model construction } & 28\end{array}$

$\begin{array}{ll}\text { History matching (calibration) } & 28\end{array}$

MVA Techniques and Baseline Characterization 28

MVA Plan $\quad 28$

MVA Geologic Description 31

Glacial Drift Thickness 31

Stack Unit Map $\quad 31$

Bedrock $\quad 32$

Site Hydrology $\quad 32$

Tanquary MVA Baseline $\quad 33$

Coal Seam Wells 33

Geologic and Hydrogeologic Data from the Drilling and Installation of

Groundwater Wells 38

$\begin{array}{ll}\text { Chemical characterization } & 38\end{array}$

$\begin{array}{ll}\text { Isotopic characterization } & 38\end{array}$

Mineral Equilibria of Groundwater Samples $\quad 38$

CIR Imagery $\quad 40$

$\begin{array}{ll}\text { Injection Equipment and Operations } & 40\end{array}$

$\begin{array}{ll}\text { Pumping Equipment } & 40\end{array}$

$\begin{array}{ll}\text { Overview } & 40\end{array}$ 
$\begin{array}{ll}\text { Portable Storage Tank } & 41\end{array}$

Booster Pump $\quad 43$

Main Pump Skid $\quad 43$

$\begin{array}{ll}\text { Piston pumps } & 47\end{array}$

$\begin{array}{lr}\text { Pressure-regulating valves } & 47\end{array}$

Liquid Turbine Flow Meter $\quad 48$

Gas Turbine Meter and Gas Orifice Meter $\quad 49$

In-line Heater 49

Data Acquisition Equipment $\quad 50$

Pressure and Temperature Sensors $\quad 50$

Data Acquisition System $\quad 50$

General Operations $\quad 50$

Operational Challenges $\quad 51$

Insulation $\quad 51$

Booster Pump $\quad 52$

$\mathrm{CO}_{2}$ Pump Pressure Regulating Valves $\quad 52$

Metering Low Rate $\mathrm{CO}_{2}$

Routine Operations $\quad 53$

Field Observations During Active $\mathrm{CO}_{2}$ Injection 53

Injection Schedule

Injection Rate and Injectivity $\quad 55$

Injection Rate $\quad 55$

Injectivity $\quad 55$

Pressure Response of Coal Seam Monitoring Wells 57

Gas Volume and Composition Field Response of Monitoring Wells 57

$\mathrm{CO}_{2}$ Effect on the Springfield Coal at the Tanquary Site 59

$\mathrm{CO}_{2}$ Injection $\quad 59$

Laboratory Cores: Sorption-induced Volumetric Strain $\quad 59$

Effective Permeability to $\mathrm{CO}_{2}$ (Pressure Transient Analyses) 62

$\mathrm{CO}_{2}$ Plume Shape and Size (Numerical Modeling) 63

Post-injection $\quad 64$

Logging $\quad 64$

Methodology 65

Interpretation of Results $\quad 67$

Post- $\mathrm{CO}_{2}$ Injection Water Pressure Transient Analyses $\quad 75$

$\begin{array}{ll}\text { MVA Observations and Interpretations } & 75\end{array}$

Results and Discussion $\quad 75$

Groundwater Modeling Results $\quad 75$

Hydrogeologic Data from the Monitoring Wells $\quad 76$

Coal Seam Observation Wellhead Gas Sampling $\quad 77$

Chemical Characterization of Groundwater Wells $\quad 83$

Isotopic Characterization of Groundwater Wells $\quad 85$

Mineral Equilibria of Samples from Groundwater Monitoring Wells $\quad 88$

Mineral Equilibria of Samples from Residential Wells 91

CIR Imagery $\quad 91$

Interpretation, Analyses, and Modeling of Pilot Results 93

Case 1: Producing Coal Seam Monitoring Wells 93

Case 2: Inverted Five-Spot $\quad 93$

Case 3: Line Drive $\quad 99$

$\mathrm{CH}_{4}$ Recovery and $\mathrm{CO}_{2}$ Storage Factors $\quad 99$

Well Plugging and Abandonment and Site Reclamation 99

$\begin{array}{lr}\text { Conclusion } & 99\end{array}$

$\begin{array}{ll}\text { References } & 100\end{array}$ 


\section{Appendices}

1 State of Illinois Drilling Permits 105

2 Geological Unit and Marker Bed Log Tops 110

3 Geological Unit and Marker Bed Log Elevation 111

4 Core Descriptions, Log Tops, and Coal Lithotypes 112

5 Springfield Coal Core from Each Well at Tanquary 124

6 Experimental Details for Coal Characterization 127

7 Proximate Analysis, Ultimate Analysis, and Vitrinite Reflectance $\begin{array}{ll}\text { of Springfield Coal } & 129\end{array}$

8 Gas Content of Coal and Shale Samples 130

9 Desorbed Coal Gas Composition 131

10 Langmuir Parameters of Coal Samples Run for High-Pressure Isotherms 132

11 Coal Micropore and Mesopore Characteristics 133

12 Langmuir Parameters for $\mathrm{CO}_{2}$ in Coal Lithotypes 134

13 Pressure Transient Analysis Equipment and Modeling 135

14 MVA Methods 140

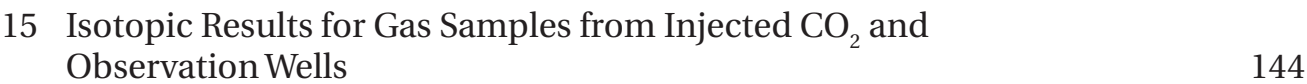

16 Detailed Geologic Logs for ECBM1 and ECBM4 148

17 Construction Details for ECBM Groundwater Monitoring Wells 152

18 Isotopic Results for Water Samples from the ECBM Site 159

19 Schematics of Data Acquisition and Transmission Equipment 161

20 Sequence of Events 165

21 Procedure for Volumetric Strain Measurement during the Swelling/Shrinkage Experiment $\quad 169$

$22 \mathrm{CO}_{2}$ Plume Modeling Figures $\quad 171$

23 Gas Chromatography Results for Gas as Samples from Injection $\mathrm{CO}_{2}$ and Coal Seam Observation Wells during and Post- $\mathrm{CO}_{2}$ Injection $\quad 178$

24 Gas Chromatography Results for Gas Samples from the ECBM Site 182

\section{List of Tables}

1 Coal seam depths and thicknesses at the Tanquary project site from M-3 (I-1A) well logs

2 Whole core recovered for the Tanquary pilot wells

3 Thicknesses of the Springfield Coal in the Tanquary pilot wells as measured from core descriptions and well logs

4 Summary geologic log for geologic materials collected from ECBM1

5 Pre- $\mathrm{CO}_{2}$ gas chromatography results for gas samples from ECBM1, ECBM2, ECBM3, and ECBM4 groundwater wells at the Tanquary site 40

6 Pre- $\mathrm{CO}_{2}$ injection isotopic results for water samples from Tanquary site 40

7 Gas production at monitoring wells, October-November 2008

8 Estimated model parameters for Springfield Coal samples 62

9 The effective permeability of $\mathrm{CO}_{2}$ calculated from pressure falloff tests throughout the injection period and cumulative injected mass

10 Effective permeability to water calculated from pressure falloff tests before and at individual wells after $\mathrm{CO}_{2}$ injection

11 Effective permeability anisotropy to water calculated from pressure fall off tests before and after $\mathrm{CO}_{2}$ injection

12 Saturation indices for selected minerals for the upgradient well samples (ECBM1 and ECBM2) and the downgradient well samples (ECBM3 and ECBM4)

13 Plugging depths 


\section{List of Figures}

1 Location of the Tanquary site, Wabash County, Illinois

2 Thickness of the (a) Herrin Coal, (b) Springfield Coal, and (c) correlative Seelyville Coal and Davis Coal near the Tanquary site, as well as (d) cumulative average thickness of the seven major coal seams assessed in the Phase I regional study conducted by the Midwest Geological Sequestration Consortium

3 Geologic column showing Pennsylvanian System stratigraphy in southern Illinois and the principal coal units in the Carbondale Formation

4 Springfield Coal structural elevation map in the vicinity of the Tanquary project area

5 Tanquary site plan showing locations of monitoring and injection wells and Springfield Coal cleat orientations

6 Aerial imagery showing (a) the farms in the area immediately around the Tanquary site and (b) structures on the site itself

7 Example of one of the model grids used for pilot design and well spacing

8 Example of one of the models used for the pilot design and well spacing showing that the outer ring of monitoring wells ( $300 \mathrm{ft}$ ) would not have detectable gas saturation

9 Pressure step rate test data at well M-3 (1-1A), summer 2007

10 Falloff test at well M-1, summer 2007

11 The surface and subsurface well locations superimposed over the cleat orientation

12 Segment of type well log for Tanquary site, showing coals, including Springfield and Seelyville coal seams

13 Schematic of I-1B injection well

14 Schematic of representative monitoring well (M-1)

15 Design of wellhead for injection well I-1B and photo of wellhead

16 Design of M-1 wellhead and photo of M-1

17 Slabbed Springfield Coal from the M-2B well

18 Proximate distribution of Springfield Coal samples from wells M-1, M-3 (I-1A), and I-1B with depth

19 Maceral analysis of Springfield Coal samples from wells (a) M-1 and (b) M-3 (I-1A)

20 Proximate comparison of Springfield Coal samples from wells M-1 and M-3 (I-1A)

21 Total gas contents on an as-received basis for Springfield Coal samples from wells M-1 and M-3 (I-1A) versus depth

22 Gas content for Springfield Coal samples from wells M-1, M-3 (I-1A), and I-1B with depth on a dry, mineral matter free basis

23 Desorbed methane stable isotopes cross-plot chart indicating origin of methane

24 High-pressure isotherms for $\mathrm{N}_{2}, \mathrm{CH}_{4}$, and $\mathrm{CO}_{2}$ at $22.8^{\circ} \mathrm{C}\left(73^{\circ} \mathrm{F}\right)$, showing volume of gas sorbed to Springfield Coal samples taken from well M-3 (I-1A) at $899.5-901.5 \mathrm{ft}$

25 High-pressure $\mathrm{CH}_{4}$ and $\mathrm{CO}_{2}$ isotherms

26 Injection well (I-1B) open-hole log signatures in the Springfield Coal

27 Comparison of maceral content from coal and open-hole log resistivity, M-1 well

28 Comparison of Springfield Coal resistivity logs for wells M-2, M-1, I-1B, and M-3 (I-1A)

29 Micropore volume of the Springfield Coal from wells I-1A and M-1 at various depths

30 Brunauer-Emmett-Teller surface area and mesoporosity 
32 (a) Quantity of adsorbed $\mathrm{N}_{2}$ at low pressure in isolated lithotypes of the Springfield Coal in location I-1B. Both adsorption and desorption curves are included. (b) Quantity of adsorbed $\mathrm{CO}_{2}$ at low pressure in isolated lithotypes of the Springfield Coal

33 Maceral-specific high-pressure $\mathrm{CO}_{2}$ adsorption isotherms from Tanquary site Springfield Coal samples, on (a) as-received basis and (b) dry ash free basis

34 Particle tracking results calculated from GFLOW to show the travel path of particles released into the groundwater and allowed to flow for 10 years

35 Drift thickness map with T1S R14W highlighted and site identified

36 Stack unit map for the area surrounding the study site

37 Bedrock geology of Wabash and Edwards Counties, Illinois with T1S R14W highlighted

38 Potential groundwater supplies from sand and gravel aquifers with T1S R14W highlighted

39 Potential groundwater supplies from bedrock aquifers with T1S R14W highlighted

41 The $\mathrm{O}_{2}$ concentrations in gas samples collected from the coal seam observation wells at the Tanquary site

42 Tanquary site showing the location of the injection well (I-1B), Coal seam monitoring wells (M-1, M-2, and M-3), and groundwater monitoring (ECBM1, ECBM2, ECBM3, and ECBM4)

43 Natural gamma logs recorded in ECBM1, ECBM2, ECBM3, and ECBM4

44 Construction details of groundwater monitoring well ECBM1

45 Alkalinity concentrations in groundwater samples collected from ECBM monitoring and residential wells at the Tanquary site

46 Chloride concentrations in groundwater samples collected from ECBM monitoring and residential wells at the Tanquary site

47 The $\delta^{18} \mathrm{O}$ and $\delta \mathrm{D}$ values in samples of shallow groundwater from ECBM monitoring and residential wells and from coal seam observation well M-2 at the Tanquary site

48 Saturation indices of siderite, calcite, quartz, and gypsum for groundwater samples collected at well ECBM3 (and of siderite for well ECBM1) plotted as a function of time

49 Saturation indices of witherite, smithsonite, quartz, and calcite for water samples collected at the residential wells

50 Color near-infrared (CIR) digital aerial orthophotography taken June 11, 2007

51 Color near-infrared (CIR) digital aerial orthophotography taken August 23, 2007

52 Air Liquide 54.4-tonne (60-ton) portable $\mathrm{CO}_{2}$ storage tank

53 The outlet and inlet lines underneath the portable $\mathrm{CO}_{2}$ storage tank

54 Booster pump model SRZS 221, horizontally mounted side channel pump manufactured by SERO Pump Systems

55 Booster pump control panel

56 Front view of main pump skid with control panel in front

58 Pressure-regulating valves above and to the right of the Grainger motors above the frosted lines

59 Flow meter on the discharge line of the main pump skid

60 Propane-fired line heater placed on top of flatbed trailer

61 The I-1B data acquisition enclosure from the Tanquary site

62 The $\mathrm{CO}_{2}$ injection pressure transient testing and responses of the injection and monitoring well 
63 The $\mathrm{CO}_{2}$ injection rates during the continuous injection period

64 (a) Rates of $\mathrm{CO}_{2}$ injection during pressure transient tests. (b) Histogram of $\mathrm{CO}_{2}$ injection rates showing a mode of $0.6-0.7$ tonne (0.66-0.77 ton)/day 56

65 Injectivity index during the (a) initial injection and pressure transient tests, (b) continuous $\mathrm{CO}_{2}$ injection, and (c) final pressure transient periods using 2.65 MPag (385 psig) initial pressure

66 Gas head for each well over time

67 Volumetric strain with helium injection for the Springfield and Seelyville coal seams

68 Volumetric strain with $\mathrm{CH}_{4}$ flooding for the Springfield and Seelyville coal seams

69 Volumetric strain for $\mathrm{CH}_{4} / \mathrm{CO}_{2}$ exchange for the Springfield Coal seam

70 Coal matrix swelling coefficient for methane for the Herrin, Springfield, and Seelyville coal samples

71 The pressure derivative of five of the falloffs during active $\mathrm{CO}_{2}$ injection

72 Log analysis of I-1B. Description of log curves: depth track; resistivity track; porosity-OH track; porosity-RST track; sigma track; porosity/ $\mathrm{CO}_{2}$ track; combined volumes track

73 Log analysis for well M-1

74 Log analysis for well M-2B (M-2)

75 Log analysis for well M-3

76 Log analysis for well I-1B

77 Log analysis for well "M-2B" (M-2), magnified showing the continuous volume of $\mathrm{CO}_{2}$

78 Log analysis for well M-1, magnified

79 Log analysis for well M-3, magnified

80 The enhanced coal bed methane site with major hydrologic features identified

81 GFLOW model for the site

82 Water levels in the four groundwater monitoring ECBM wells at the Tanquary site

83 The $\mathrm{CO}_{2}$ concentrations in gas samples collected from the coal seam observation wells M-1, M-2, and M-3 at the Tanquary site

84 The $\mathrm{CH}_{4}$ concentrations in gas samples collected from the coal seam observation wells M-1, M-2, and M-3 at the Tanquary site

85 The $\mathrm{CH}_{4}$ and $\mathrm{CO}_{2}$ concentrations in gas samples collected from the coal seam observation wells M-1, M-2, and M-3 at the Tanquary site

86 The $\delta^{13} \mathrm{C}$ values of $\mathrm{CO}_{2}$ in gas samples collected from the coal seam observation wells $\mathrm{M}-1, \mathrm{M}-2$, and $\mathrm{M}-3$ at the Tanquary site

87 The $\delta^{13} \mathrm{C}$ values of $\mathrm{CO}_{2}$ versus concentrations of $\mathrm{CO}_{2}$ in gas samples collected from the coal seam observation wells at the Tanquary site

The ${ }^{14} \mathrm{C}$ analyses for $\mathrm{CO}_{2}$ in samples from coal seam observation wells M-1 and M-3

9 The $\delta^{13} \mathrm{C}$ values of $\mathrm{CH}_{4}$ versus concentrations of $\mathrm{CH}_{4}$ in gas samples from coal seam observation wells at the Tanquary site

90 The $\mathrm{pH}$ of groundwater samples from groundwater ECBM monitoring and residential wells at the Tanquary site

91 Alkalinity of groundwater samples collected from monitoring and residential wells at the Tanquary site

92 Sulfate concentrations in groundwater samples from monitoring and residential wells at the Tanquary site

93 Sodium concentrations in groundwater samples from monitoring and residential wells at the Tanquary site

The $\delta^{13} \mathrm{C}$ values for dissolved organic carbon in samples of shallow groundwater from monitoring and residential wells at the Tanquary site

Redox potential of groundwater samples collected from monitoring and residential wells at the Tanquary site 
96 Dissolved oxygen concentrations in groundwater samples collected from monitoring and residential wells at the Tanquary site

97 Silica concentrations in groundwater from two of the monitoring wells at the Tanquary site

98 Calcium plus magnesium and sodium concentrations in groundwater from the monitoring wells and one of the residential wells at the Tanquary site $\quad 88$

99 Saturation indices for selected minerals for samples collected from well ECBM1 (upgradient) compared with ECBM3 (downgradient)

100 Color near-infrared digital aerial orthophotograph taken June 23, 2008

101 Color near-infrared digital aerial orthophotograph taken June 23, 2008, converted to natural color

102 Color near-infrared digital aerial orthophotograph taken September 10,2008

103 Color near-infrared digital aerial orthophotograph taken June 27, 2009

104 Color near-infrared digital aerial orthophotograph taken June 27, 2009

105 Color near-infrared digital aerial orthophotograph taken October 2, 2009, (natural color rendition)

$106 \mathrm{CH}_{4}$ and $\mathrm{CO}_{2}$ production at each of the monitoring wells for the injection case and the non-injection case

107 Inverted 5-spot model view.

108 (a) Inverted 5-spot $\mathrm{CO}_{2}$ injection profile. (b) Inverted 5-spot face cleat well production profile. (c) Inverted 5-spot butt cleat well production profile 96

109 Line drive model view

110 (a) Line drive $\mathrm{CO}_{2}$ injection profile. (b) Line drive middle well production profile. (c) Line drive corner well production profile

\section{List of Appendix Tables}

A2-1 Elevation, total well depth, and geological unit thickness and depth to top and base for wells M-1, M-3, M-2, and I-1B

A3-1 Total well depth and elevation of geological units for wells M-1, M-3, M-2, and I-1B

A4-1 Core descriptions for well M-1

$\begin{array}{ll}\text { A4-3 Core descriptions for well M-2B } & 114\end{array}$

A4-4 Log tops for Gallagher Drilling, L.P. Daughters et al. \#M-2B 115

A4-5 Detailed lithotypes of the Springfield Coal at well M-2B 116

$\begin{array}{ll}\text { A4-6 Core descriptions for well M-3 (I-1A) } & 118\end{array}$

A4-7 Log tops for Gallagher Drilling, L.P. Daughters et al. \#I-1A (M-3) 121

A4-8 Core description for well I-1B 122

A4-9 Log tops for Gallagher Drilling, L.P. Daughters et al. \#I-1B 123

A7-1 Proximate and ultimate analyses and vitrinite reflectance of the Springfield Coal samples from locations M-1, M-3 (I-1A), and I-1B $\quad 129$

A8-1 Gas content of Tanquary Project coal and shale samples 130

A9-1 Composition of desorbed gases from selected coal samples from well M-1 131

A10-1 Langmuir parameters for $\mathrm{CO}_{2}, \mathrm{CH}_{4}$, and $\mathrm{N}_{2}$ of the coal samples run for high-pressure isotherms

A11-1 Micropore and mesopore characteristics of the coal samples from wells M-1 and M-3 (I-1A)

A12-1 Langmuir parameters for $\mathrm{CO}_{2}$ of isolated lithotype samples of Springfield Coal from well I-1B at $20.6^{\circ} \mathrm{C}\left(69^{\circ} \mathrm{F}\right)$

A14-1 Input parameters for GFLOW

A15-1 Isotopic results for gas samples from injected $\mathrm{CO}_{2}$ and observation well $\mathrm{M}-1$. The concentrations of $\mathrm{CO}_{2}$ were too low for isotopic analysis for many samples

A15-2 Isotopic results for gas samples from observation well M-2. The concentration of $\mathrm{CO}_{2}$ was too low for isotopic analysis for some samples 
A15-3 Isotopic results for gas samples from observation well M-3. The concen$\begin{array}{ll}\text { tration of } \mathrm{CO}_{2} \text { was too low for isotopic analysis for some samples } & 147\end{array}$

A16-1 Sample description for samples from groundwater wells ECBM1 148

A16-2 Sample description for samples from groundwater wells ECBM4 150

A17-1 Well construction details for ECBM1 152

A17-2 Well construction details for ECBM2 153

A17-3 Well construction details for ECBM3 154

A17-4 Well construction details for ECBM4 155

A18-1 Isotopic results (\%o) for groundwater samples from ECBM1, ECBM2, ECBM3, ECBM4, Hering, and Kieffer wells.

A23-1 Gas chromatography results for gas as samples from injection $\mathrm{CO}_{2}$ and observation well M-1

A23-2 Gas chromatography results for gas as samples from observation well M-2

A23-3 Gas chromatography results for gas as samples from observation well M-3

A24-1 Gas chromatography results for gas samples from wells ECBM1, ECBM2, ECBM3, and ECBM4

\section{List of Appendix Figures}

$\begin{array}{lll}\text { A1-1 The M-2 water supply well permit } & 105\end{array}$

$\begin{array}{lll}\text { A1-2 The M-1 water supply well permit } & 106\end{array}$

$\begin{array}{lll}\text { A1-3 The I-1A gas injection well permit } & 107\end{array}$

A1-4 Amended M-3 (I-1A) water supply well permit 108

A1-5 I-1B enhanced hydrocarbon recovery well permit 109

A4-1 M-2 Springfield Coal lithotypes: 5, vitrain; 4, banded-bright clarain; 3, banded clarain; 2, banded dull clarain; 1 , dull fusain

A5-1 Photograph of embedded core from well M-2B and whole core from well M-2B, I-1B, M-1, and M-3 (I-1A)

$\begin{array}{lll}\text { A13-1 } & \text { Components of water injection equipment } & 136 \\ \text { A13-2 } & \text { Water pump skid schematic } & 136\end{array}$

A13-3 Permeability changes during $\mathrm{CO}_{2}$ injection with pressure and concentration

A13-4 (a) Model top view; (b) Close-up view of model 137

$\begin{array}{lll}\text { A13-5 Model three-dimensional view } & 137\end{array}$

$\begin{array}{lll}\text { A13-6 History matching: Water injection profile } & 138\end{array}$

A13-7 History-match results for pressure response at (a) the injection well I-1B and coal seam monitoring wells (b) M-1, (c) M-2, and (d) M-3

A14-1 Project layout plan for color infrared imagery acquisition at the Tanquary ECBM site

A17-1 Details of groundwater monitoring well construction, ECBM2 156

A17-2 Details of groundwater monitoring well construction, ECBM3 157

A17-3 Details of groundwater monitoring well construction, ECBM4 158

A19-1 Datalogger setup for injection well I-1B 161

A19-2 Datalogger setup for monitoring wells M-1 and M-2 162

A19-3 Datalogger setup for monitoring well M-3 163

$\begin{array}{ll}\text { A19-4 ECBM modes of data transmission } & 164\end{array}$

A21-1 Schematic of the experimental setup to measure volumetric strain $\quad 170$

A22-1 Model view: full-size grid and zoom of well area illustrating grid refinement after multiple simulations

A22-2 $\mathrm{CO}_{2}$ injection rate profile

A22-3 Pressure history-match for (a) injection well I-1B and monitoring wells (b) M-1, (c) M-2, and (d) M-3

A22-4 Illustration of permeability evolution due to coal swelling (increasing swelling from left to right; see text for details) 
A22-5 Model permeability versus pressure (face cleat at left and butt cleat at right). Blue or lower graph is the permeability change due to $\mathrm{CO}_{2}$ only and the red or upper curve is the permeability change due to $\mathrm{CH}_{4}$ only

A22-6 Optimized relative permeability curves

A22-7 Face cleat permeability at the end of $\mathrm{CO}_{2}$ injection (not to scale)

A22-8 Butt cleat permeability at the end of $\mathrm{CO}_{2}$ injection (not to scale)

A22-9 The $\mathrm{CO}_{2}$ plume view at the end of $\mathrm{CO}_{2}$ injection (not to scale) 



\section{Introduction}

\section{Midwest Geological Sequestration Consortium Background}

The Midwest Geological Sequestration Consortium (MGSC) is assessing the options for geological carbon dioxide $\left(\mathrm{CO}_{2}\right)$ sequestration in the $155,400 \mathrm{~km}^{2}\left(60,000 \mathrm{mi}^{2}\right)$ Illinois Basin. Within the Basin, which underlies most of Illinois, western Indiana, and western Kentucky, there are deep uneconomic coal resources, numerous mature oil fields, and deep saline reservoirs potentially capable of storing $\mathrm{CO}_{2}$. The objective of the assessment is to determine the technical and economic feasibility of using these geological sinks for long-term storage to avoid atmospheric release of $\mathrm{CO}_{2}$ from fossil fuel combustion at electrical generation facilities and industrial sources.

The MGSC is a consortium of the geological surveys of Illinois, Indiana, and Kentucky, joined by subcontractors and consultants, to assess carbon capture, transportation, and storage processes and their costs and viability within the three-state Illinois Basin region. The Illinois State Geological Survey serves as the lead technical contractor for the MGSC. The Illinois Basin region has annual emissions of about 265 million metric tonnes (292 million tons) of $\mathrm{CO}_{2}$ primarily from 122 coal-fired electric generation facilities, some of which burn almost 4.5 million tonnes/yr (5 million tons/year) of coal (U.S. Department of Energy, 2010, p. 162).

Initial MGSC work during 2003-2005, termed Phase I, involved an assessment of carbon capture and transportation options in the region. All available data were compiled on potential $\mathrm{CO}_{2}$ sinks and on applicable carbon capture approaches. Transportation options focused on small-scale options for field tests and the pipeline requirements for long-term sequestration. Research primarily focused on storage reservoirs in order to assess each of the three geological sinks: coals, oil reservoirs, and saline reservoirs. Results were linked with integrated options for capture, transportation, and geological storage and the environmental and regulatory framework to define sequestration scenarios and potential outcomes for the region. A final task was to generate an action plan for possible technology validation field tests involving $\mathrm{CO}_{2}$ injection, thus setting the stage for Phase II of the project and actual small-scale field tests during 2005-2009. A 477-page final report (MGSC, 2005), plus two topical reports, on Phase I results are available at www.sequestration.org, the MGSC website.

A key outcome of Phase I was that the geology of the Illinois Basin is favorable for $\mathrm{CO}_{2}$ sequestration. In some localities, two or more potential $\mathrm{CO}_{2}$ sinks are vertically stacked. The primary focus of this study, however, was the properties of the rock units that control injectability of $\mathrm{CO}_{2}$, the total storage resources, the safety of injection and storage processes, and the security of the overlying rock units that act as seals for the reservoirs. For Phase II (2005-2009), a series of four small-scale field tests were initated. They included testing of the ability of a deep, unminable coal seam to adsorb gaseous $\mathrm{CO}_{2}$ and the ability to store $\mathrm{CO}_{2}$ and enhance oil production in mature oil fields. Each of these field tests have an extensive monitoring program for sampling of air, shallow groundwater, and fluids from the injection zone, as well as geophysical and cased hole logging and monitoring of pressure changes to understand the fate of injected $\mathrm{CO}_{2}$ at our test sites. The integrity of the entire process is being scrutinized to understand what contribution Illinois Basin geological sinks can make to national and international carbon sequestration goals and what technology developed here can be extrapolated to other regions.

\section{MGSC Phase I Illinois Basin Coal Assessment Summary}

The Illinois Basin includes substantial coal resources. Illinois has the largest bituminous coal resource of any state: 191 billion tonnes (211 billion tons) (Jacobson and Korose, 2007). The opportunity to sequester $\mathrm{CO}_{2}$ in coals currently considered to be unminable is based on both technical and economic generalizations. In Phase I, no sequestration consideration was given to coals at depths less than $152 \mathrm{~m}$ ( $500 \mathrm{ft}$ ). In the depth interval of 152 to $305 \mathrm{~m}$ ( 500 to 1,000 ft), coals with thickness from 0.46 to $1.1 \mathrm{~m}$ ( 1.5 to $3.5 \mathrm{ft}$ ) were assessed as possible $\mathrm{CO}_{2}$ sequestration resources. At depths greater than $305 \mathrm{~m}(1,000$ $\mathrm{ft}$ ) in depth, all individual coal seams greater than $1.1 \mathrm{~m}(1.5 \mathrm{ft})$ in thickness were assessed.

Updates to the Phase I assessment of $\mathrm{CO}_{2}$ storage resources and enhanced coal bed methane (ECBM) gas resources were made for the 2010 National Atlas. These estimates are 1.6 to 3.2 billion tonnes (1.8 to 3.5 billion tons) of $\mathrm{CO}_{2}$ and 85 to 309 billion standard cubic meters (scm) (3.0 to 10.9 trillion standard cubic feet [scf]) of methane $\left(\mathrm{CH}_{4}\right)$ (U.S. Department of Energy, 2010).

\section{Phase II Coal Seam Pilot Objectives}

The purpose of this project was to determine the $\mathrm{CO}_{2}$ injection and storage capability and the ECBM recovery potential of Illinois Basin coal seams. The results of the test will be compared to the storage estimates made in the Phase I assessment. The target formation was the Pennsylvanian Springfield Coal. The test site (Figure 1) is on the Tanquary Farms in southeastern Illinois, between Albion and Mt. Carmel, Illinois.

The adsorption of $\mathrm{CO}_{2}$ onto coals is known to cause the coal matrix to swell, which reduces the cleat apertures, absolute permeability, and $\mathrm{CO}_{2}$ injection rates. However, there are other phenomena that will also decrease injection rates. In a field pilot 
test with $\mathrm{CO}_{2}$ injection into a coal seam with the cleat system $100 \%$ saturated with brine water, continued injection will increase the pressure of the fluids in the cleat system and reduce the pressure differential between the wellbore and the coal, further reducing the injection rate. When $\mathrm{CO}_{2}$ is injected into a brine-saturated system, $\mathrm{CO}_{2}$ relative permeability is initially low and increases with increasing $\mathrm{CO}_{2}$ saturation, which causes $\mathrm{CO}_{2}$ injection rate to increase with time. Furthermore, coals have pressure-dependent permeability and are expected to have higher permeability with increasing cleat pressure and decreasing permeability with decreasing cleat pressure. Consequently, injection rate alone cannot be used to infer reduced permeability or coal swelling. This pilot was designed to acquire data that could eliminate or quantify the other effects so that any in situ changes to $\mathrm{CO}_{2}$ injectivity could be determined.

Because of the anticipated coal seam pressure and temperature at the depths of sequestration-target coals in the Basin, $\mathrm{CO}_{2}$ was injected as a gas. In many $\mathrm{CO}_{2}$ ECBM pilots, the ECBM test followed conventional coal bed methane (CBM) production via pressure depletion, which results in a combination of ECBM and CBM production data. The ECBM component can only be estimated or inferred through reservoir modeling or an analytical solution. To avoid ambiguity identifying the mechanism causing the presence of methane at observation wells, a site without previous CBM production was sought, and the pilot was designed such that the bottomhole pressures of all of the monitoring wells at the coal seam were maintained above the initial methane saturation pressure of the coal.

This pilot had an extensive monitoring program to provide data to enhance understanding of the fate of injected $\mathrm{CO}_{2}$ at the site. Monitoring included air, shallow groundwater, color near-infrared (CIR) imagery, and fluids produced from the coal.

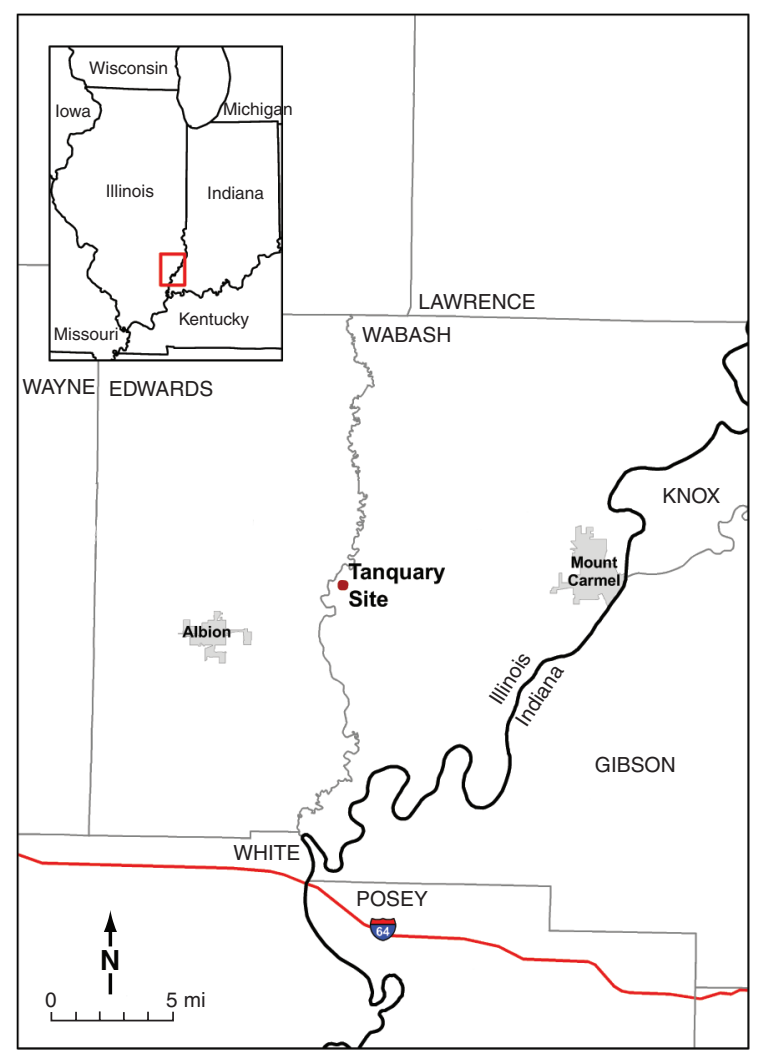

Figure 1. Location of the Tanquary site, Wabash County, Illinois.

\section{Site Screening: General Pilot Requirements}

Coal Characterization: The first-tier screening was primarily designed to classify the coal seam at the site using regional maps of coal thickness and depth (Figure 2). Because use of existing wells might not be an option and because all-new pilot wells might need to be drilled, budget and levels of geologic risk were both important considerations. Areas with thicker, shallower coals were chosen, because thicker coals reduced geologic risk, and shallower coals reduced expenses. Because of the quantity and quality of data available, the Herrin Coal Member and the Springfield Coal Member seams were anticipated to be the targets.

Surface Conditions: The second tier of screening was the surface conditions that would accommodate the injection and data acquisition equipment and $\mathrm{CO}_{2}$ tank truck delivery. Other surface features considered included proximity to lakes/ ponds, floodplains, homes, and major roads. Township road commissioner cooperation was also required.

Operation and Development History. The third-tier screening was the number of wellbores in the immediate area that penetrated the coal seams. Areas with fewer penetrations were given stronger consideration.

Operator and Owner Cooperation: The fourth and final tier of screening was interest in the project and cooperation by the owner of the coal seams and by a field operator who would provide field logistics for all aspects of the pilot.

\section{Site Selection}

A site was chosen near Browns, Illinois, in western Wabash County (Figure 1) in the southeastern part of the state. The project is called Tanquary based on the local farm name. The location was chosen because several potential coal seams were identified in nearby oil well logs. Well records existed for all plugged and cased wells within a $0.8-\mathrm{km}(0.5$-mi) radius. These records indicated that there was overlying groundwater protection provided by casing or plugging cement over the entire aquifer interval, which meant that the site met Illinois regulatory requirements for injection wells in oil and gas fields. The site had adequate size for the pilot operations, good road accessibility, and no surface considerations nearby (e.g., residences). Finally, the owners of the coal rights were agreeable to granting a lease for access, drilling, and $\mathrm{CO}_{2}$ injection and monitoring for the duration of the project. 

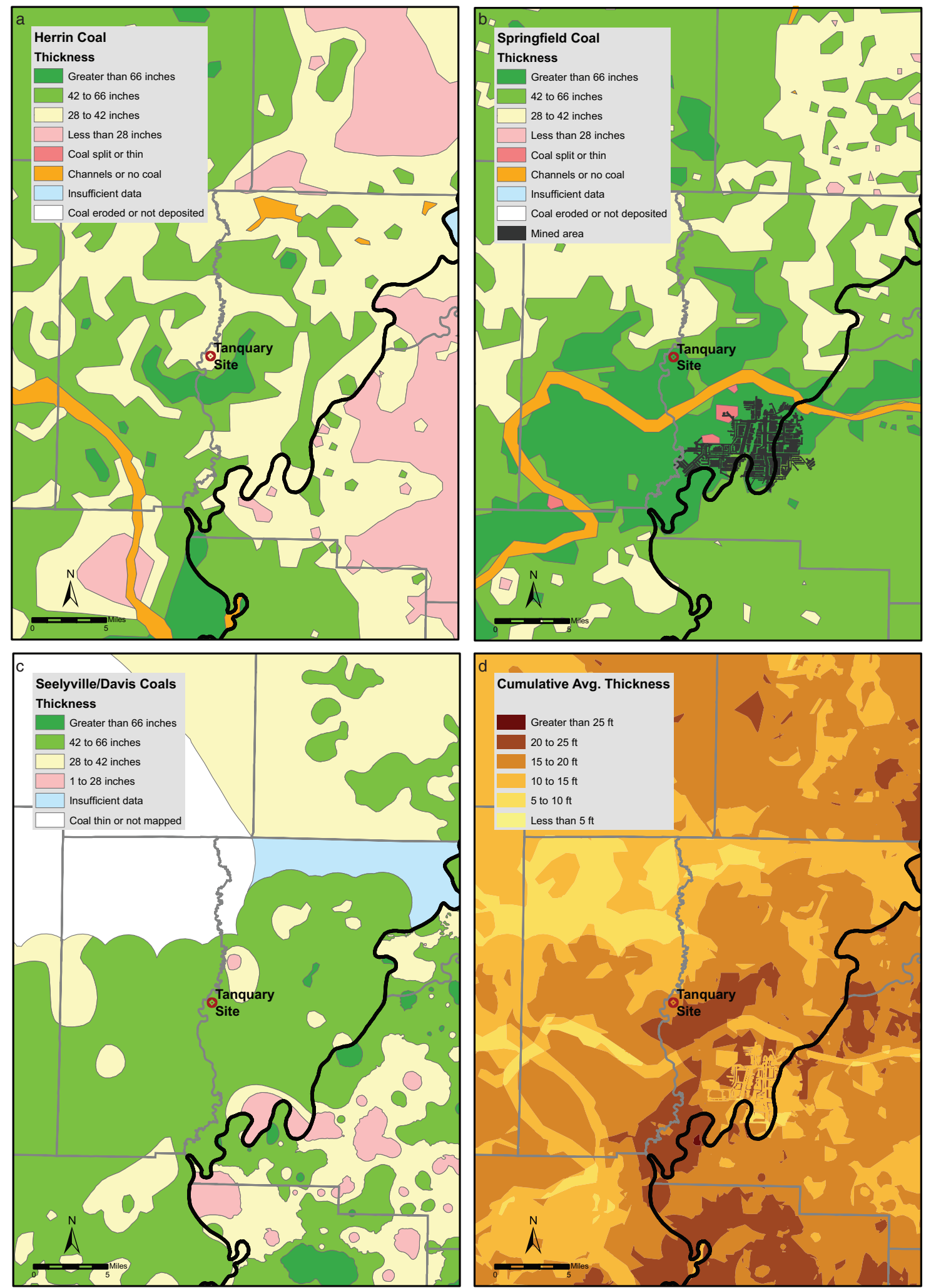

Figure 2. Thickness of the (a) Herrin Coal, (b) Springfield Coal, and (c) correlative Seelyville Coal and Davis Coal near the Tanquary site, as well as (d) cumulative average thickness of the seven major coal seams assessed in the Phase I regional study conducted by the Midwest Geological Sequestration Consortium (MGSC, 2005). 


\section{Coal and Geology}

The Middle Pennsylvanian (Desmoinesian Series) coals of the Carbondale Formation (Figure 3) were the target for $\mathrm{CO}_{2}$ sequestration in the Illinois Basin. They are the thickest, most widespread, and most actively mined coals in the Basin (Johnson et al., 2009). These coals are targets for local CBM exploration (Demir et al., 2004) and range in depth from about 230 to $380 \mathrm{~m}$ (750 to 1,250 ft) in the project area. The Herrin, Springfield, and Seelyville coal seams were considered the main targets prior to drilling any of the pilot wells. Table 1 gives typical depths and thicknesses of the coals in the project area.

The structure map showing the elevation of the top of the Springfield Coal (Figure 4), based on oil well logs within a mile of the Tanquary site, shows the project area lies in the bottom of a small synclinal basin with relatively low dip in all directions except southeast. Southeast of the Tanquary site lies a narrow elongate dome that extends in a northeast-southwest direction. The dome rises $9 \mathrm{~m}(30 \mathrm{ft})$ at its peak from the Tanquary wells at a distance of about $300 \mathrm{~m}(1,000 \mathrm{ft})$.

A visit to the Wabash Mine, located $10 \mathrm{~km}(6 \mathrm{mi})$ southeast of the Tanquary site, provided measurements on the Springfield Coal cleat orientations. The face and butt cleat orientations were well delineated, suggesting that good cleat development might be expected at the site (Figure 5). The butt cleat direction was approximately $\mathrm{N} 23^{\circ} \mathrm{W}$, and the face cleat was $\mathrm{N} 67^{\circ} \mathrm{E}$.
Table 1. Coal seam depths and thicknesses at the Tanquary project site from $\mathrm{M}-3(\mathrm{I}-1 \mathrm{~A})$ well logs.

\begin{tabular}{|l|c|c|}
\hline $\begin{array}{l}\text { Coal } \\
\text { seam }\end{array}$ & Depth (ft) & $\begin{array}{c}\text { Thickness } \\
\text { (ft) }\end{array}$ \\
\hline Danville & 759 & 3.6 \\
\hline Herrin & 787 & 5.1 \\
\hline Briar Hill & 1 & 2.1 \\
\hline Springfield & 856 & 7.0 \\
\hline Houchin Creek $^{1}$ & 999 & 2.8 \\
\hline Survant & 1,009 & 1.4 \\
\hline Colchester & 1,069 & 1.0 \\
\hline Seelyville & 1,142 & 6.3 \\
\hline
\end{tabular}

${ }^{1}$ Briar Hill and Houchin Creek coal seams were not part of the MGSC Phase I $\mathrm{CO}_{2}$ storage resource assessment; the Jamestown Coal seam, not found at the Tanquary site, was included in the Phase I assessment.

\section{Geographic Description and Site Logistics}

The area immediately around the pilot site is relatively flat and farmed annually in soybeans and field corn (Figure 6a). The specific site (Figure 6b) has a small storage barn used for grain wagons and a grain storage bin and is accessible via a welltraveled, durable gravel road. West of the site about $0.8 \mathrm{~km}(0.5 \mathrm{mi})$ is a small wooded area along Bonpas Creek, which is also the county line between Wabash and Edwards Counties. This site is located in a prolific oil-producing part of the Illinois Basin near some of the larger oil fields: Clay City Consolidated, Lawrence, and New Harmony Consolidated. The exact site

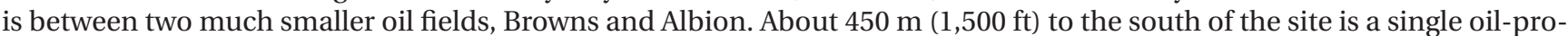
ducing well. About 15 wells have been drilled in the section where this site is located. The closest communities are Browns and Belmont, Illinois; the large cities within 16-24 km (10-15 miles) are Albion and Mt. Carmel, Illinois. The site is about 1.6 $\mathrm{km}(1 \mathrm{mi})$ north of Illinois Highway 15. There are three residences on the road leading to the site from the state highway. The Wabash underground coal mine is present about $10 \mathrm{~km}$ (6 mi) southeast of the site near Mt. Carmel.

Access with $\mathrm{CO}_{2}$ tanker trucks was possible, but winter road limits on vehicle weight restricted drilling, work over rig activity, and $\mathrm{CO}_{2}$ delivery.

\section{Initial Well Pattern Design Modeling Sensitivity}

During Phase I, a general purpose model of Illinois Basin coal was developed using COMET3 ECBM software (Reeves and Pekot, 2001; Pekot and Reeves, 2003) to assess $\mathrm{CO}_{2}$ storage potential. The input parameters were based on data specific to the Basin coals, the published literature, and staff experience with CBM production. A rigorous study of the parameters was performed to develop high, medium, and low estimates of each parameter. These input parameters and the COMET3 software were the basis for the coal simulation model used to aid in the design of the MGSC Phase II Tanquary ECBM project.

The modeling work used to determine the monitoring well locations with respect to the $\mathrm{CO}_{2}$ injection well was an iterative process and was closely tied to field work and test results. As part of the early site selection process, a drillstem test (DST) was conducted in a well drilled into the Springfield Coal in Effingham County, Illinois. (Unfortunately, the oil company that drilled the well declined to participate further in an ECBM study, so the site was not used for the pilot project.) The results of this test were about $0.05 \mu^{2}(50 \mathrm{mD})$ for the cleat permeability of the coal. Although the DST looked like a good test and confidence in the analyses was strong, $0.05 \mu \mathrm{m}^{2}(50 \mathrm{mD})$ was considered relatively high for Illinois Basin coal permeability. As such, lower permeability values of $0.01,0.025$, and $0.05 \mu \mathrm{m}^{2}(10,25$, and $50 \mathrm{mD})$ were used in the ECBM modeling cases to design the pilot site's well locations and ultimately the size of the site required for this pilot. Proximity of face and butt cleat monitoring wells to the $\mathrm{CO}_{2}$ injection well was desired. The requirement was that within 30-60 days of continuous $\mathrm{CO}_{2}$ injection, there would be a detectable and measureable change in pressure (with downhole gauges) and gas saturation (post-injection cased hole logging) at the monitoring wells. These thresholds were set at $7 \mathrm{kPa}(1 \mathrm{psi})$ pressure and $10 \%$ gas saturation. 


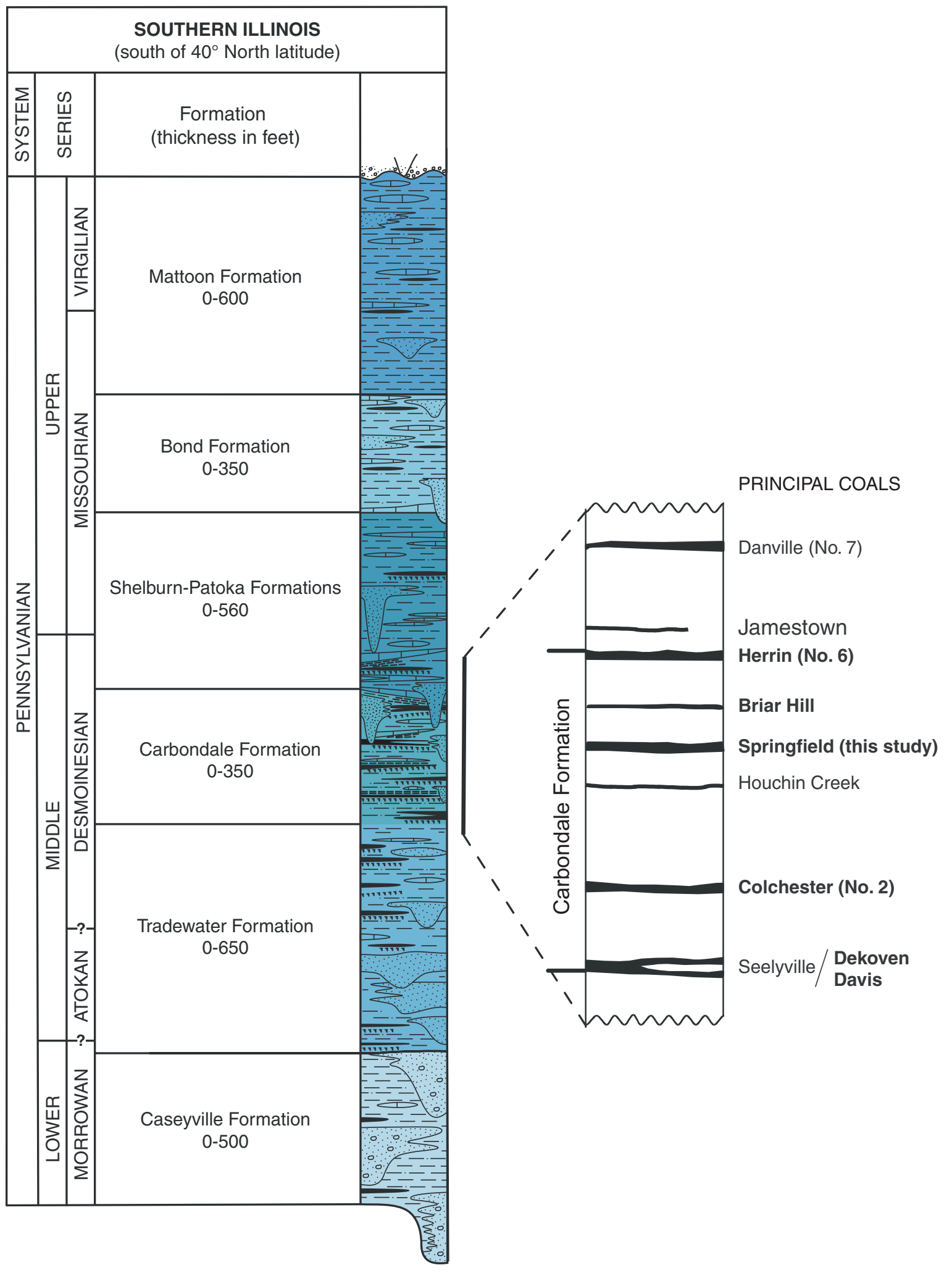

Figure 3. Geologic column showing Pennsylvanian System stratigraphy in southern Illinois and the principal coal units in the Carbondale Formation, including the Springfield Coal, the target of this study. 


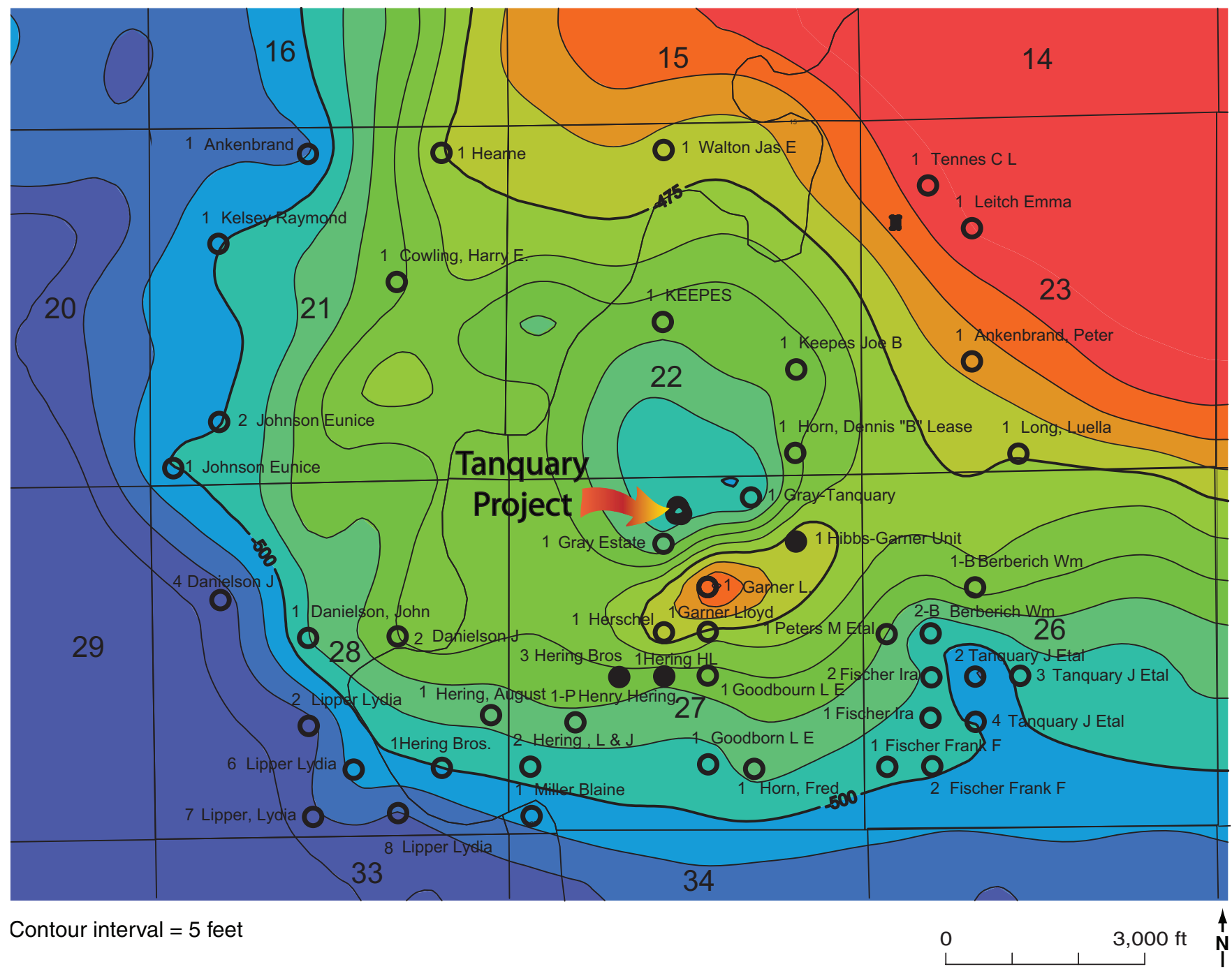

Figure 4. Springfield Coal structural elevation map in the vicinity of the Tanquary project area.

Due to the large number of oil well penetrations in the Basin, data on the thickness, depth, and structure of the Basin's coal seams were abundant. These data, along with the permeability data obtained from the DST, were used to generate model inputs. A grid sensitivity analysis was also conducted to find the smallest grid size that would have negligible effect on the pressure response and saturation profile at potential monitoring well locations. The primary influences on grid sensitivity were found to be the size of each well's grid cell and, to a much lesser degree, the size and number of cells between wells. Two hybrid grids $(0.76 \mathrm{~m} \times 0.76 \mathrm{~m}[2.5 \mathrm{ft} \times 2.5 \mathrm{ft}]$ and $1.5 \times 1.5 \mathrm{~m}[5 \times 5 \mathrm{ft}])$ were used (example hybrid grid, Figure 7$)$. Because of the vast expanse of coals in the Basin, the finely gridded model was surrounded by a few rows of larger cells, and an analytical aquifer function was assigned to the outer cells to represent an open boundary. The properties of the aquifer function

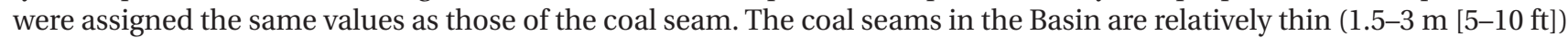
and encased vertically between shale beds, so a single model layer was used to represent the coal.

After the grid and coal properties were selected, projected pilot injection rates and duration were simulated as part of a parametric study. Variables in the study were matrix and pore compressibility, cleat spacing, initial gas concentration, stressdependent permeability, porosity, skin, matrix swelling, $\mathrm{CH}_{4}$ and $\mathrm{CO}_{2}$ sorption time, differential permeability (kx/ky), $\mathrm{CH}_{4}$ Langmuir constants, and relative permeability. Thirty-six scenarios based on the most likely values were simulated. The wellbores were simulated with rate and pressure constraints; however, the designated $\mathrm{CO}_{2}$ injection rates were chosen so that the maximum pressure constraint (90\% of the projected fracture gradient) would be invoked.

For the sensitivity study with lower permeability $\left(0.01,0.025\right.$, and $0.05 \mu \mathrm{m}^{2}[10,25$, and $\left.50 \mathrm{mD}]\right)$, well locations were chosen

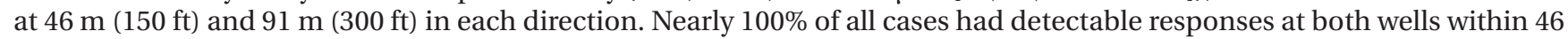
$\mathrm{m}(150 \mathrm{ft})$. If the wells were spaced at $91 \mathrm{~m}(300 \mathrm{ft})$, only the face cleat well would have an adequate gas saturation increase. 


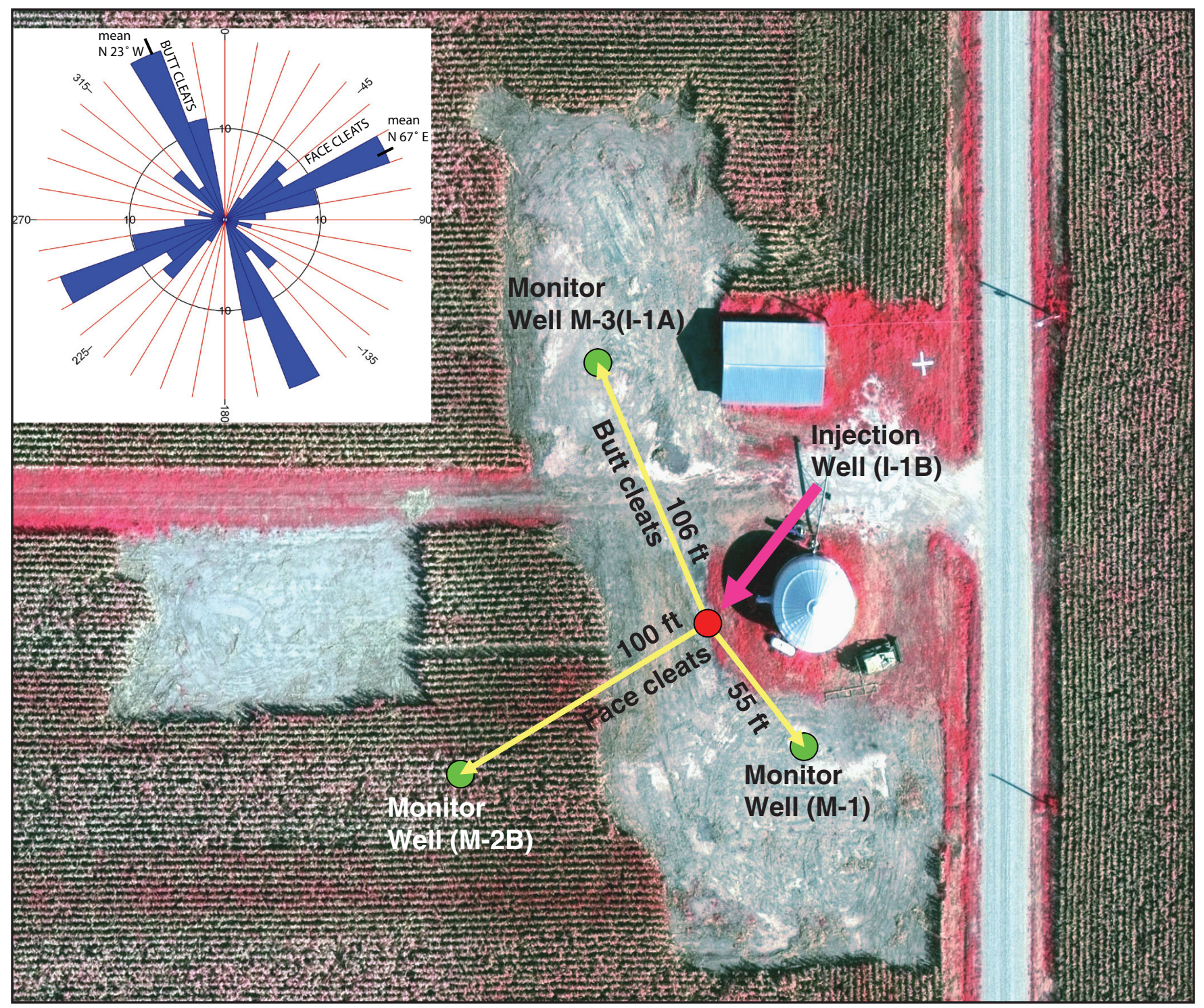

Figure 5. Tanquary site plan showing locations of monitoring and injection wells and Springfield Coal cleat orientations. Distances between wells shown in this plan do not exactly match actual distances.

These results suggested that $46 \mathrm{~m}$ (150 ft) between injector and observation wells would be adequate to observe a change in field-detectable pressure $(7 \mathrm{kPa}[(\geq 1 \mathrm{psi}])$ and saturation $(\geq 10 \%)$ during the planned $1-2$ month injection period of up to the budgeted 544 tonnes (600 tons) of $\mathrm{CO}_{2}$ (Figure 8). Based on these results, a three-well pilot was initially planned that included two monitoring wells at $46 \mathrm{~m}$ (150 ft) from the injection well in the butt and face cleat directions.

\section{Pilot Site Design Modification and Well Arrangement}

During the summer of 2007, wells M-1 and M-3 (Figure 5) were drilled about $46 \mathrm{~m}$ (150 ft) apart in the butt cleat direction to the depth of the Seelyville Coal. M-3 was planned to be the injector. The Seelyville Coal was cored at $366 \mathrm{~m}$ (1,200 ft) and the Springfield Coal at $275 \mathrm{~m}$ (900 ft). To get an indication of permeability, a DST was conducted on each of these coals. The permeability estimated from the pressure data acquired from the DST was slightly higher for the shallower Springfield Coal. For these wells, the estimated permeability was 0.002 and $0.007 \mu \mathrm{m}^{2}$ ( 2 and $7 \mathrm{mD}$ ) for the Springfield Coal. An update to the flow simulations with the lower permeability suggested that $46 \mathrm{~m}$ (150 ft) was too far between injector and monitoring well to allow observation of $\mathrm{CO}_{2}$ or desorbed $\mathrm{CH}_{4}$ in the observation wells. The modeling results indicated that the wells needed to be within $30 \mathrm{~m}$ (100 ft) of the injection well, revealing that the initial design had the wells too far apart to meet pilot objectives. 

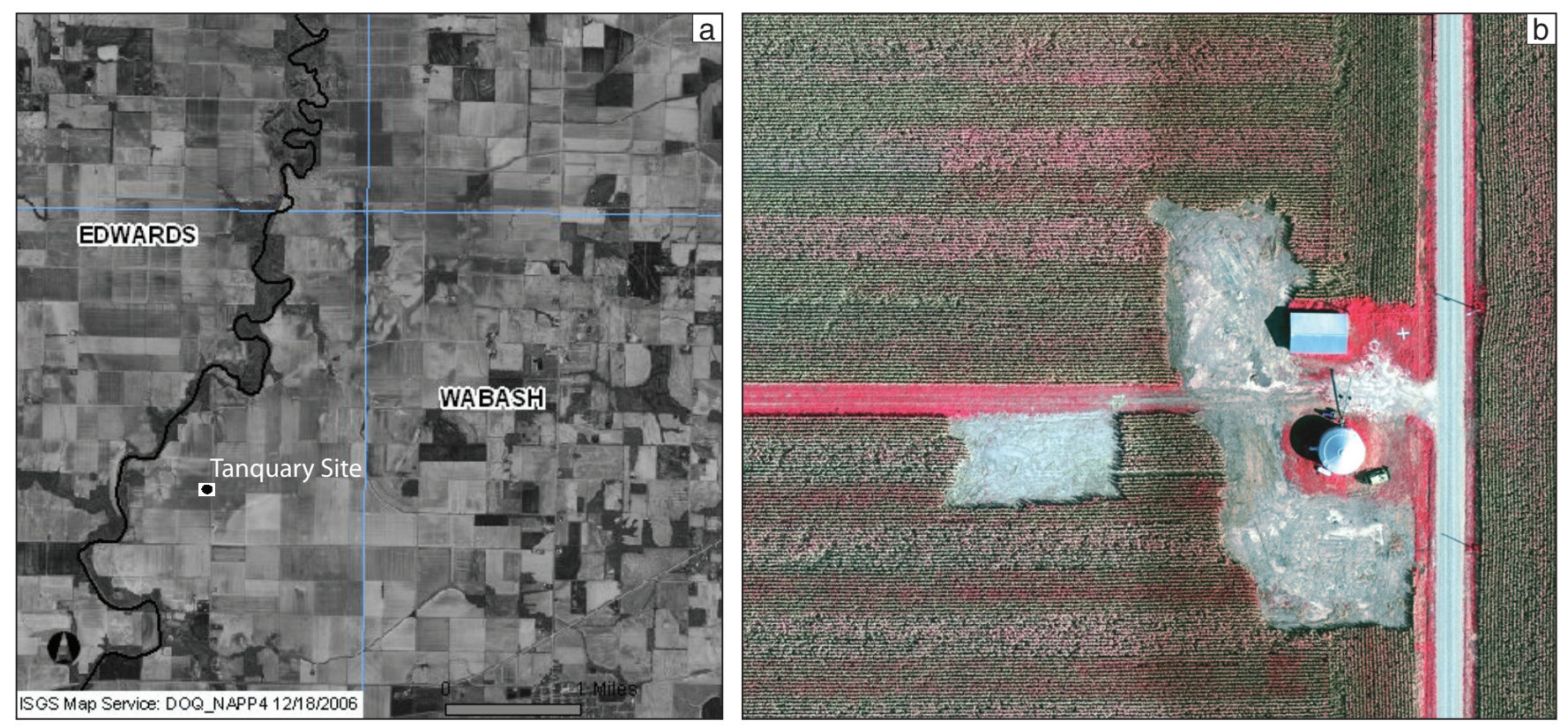

Figure 6. Aerial imagery showing (a) the farms in the area immediately around the Tanquary site and (b) structures on the site itself.

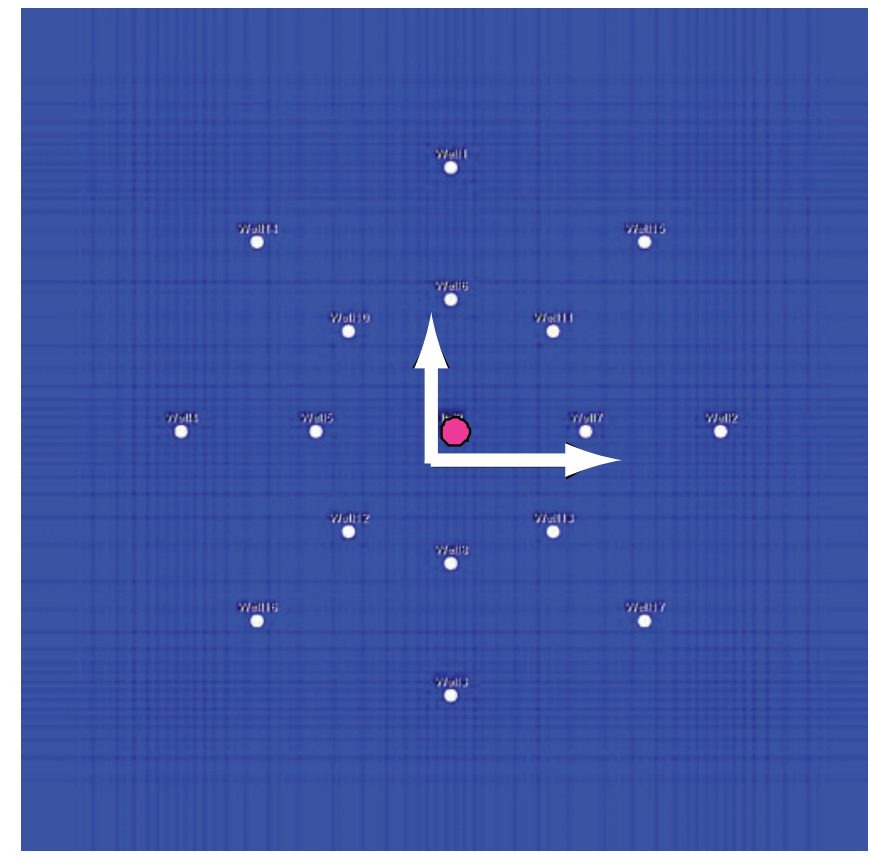

Figure 7. Example of one of the model grids used for pilot design and well spacing. Cleat orientation is along $x-y$ grid direction (face cleat is along the $x$-axis, and butt cleat is along the $y$-axis). Sixteen monitoring wells were placed around the central injector in 150- and 300-ft rings. Wells were placed on the diagonals in case the cleat orientations, determined from a nearby mine, did not match up well with the location of the drilled wells.

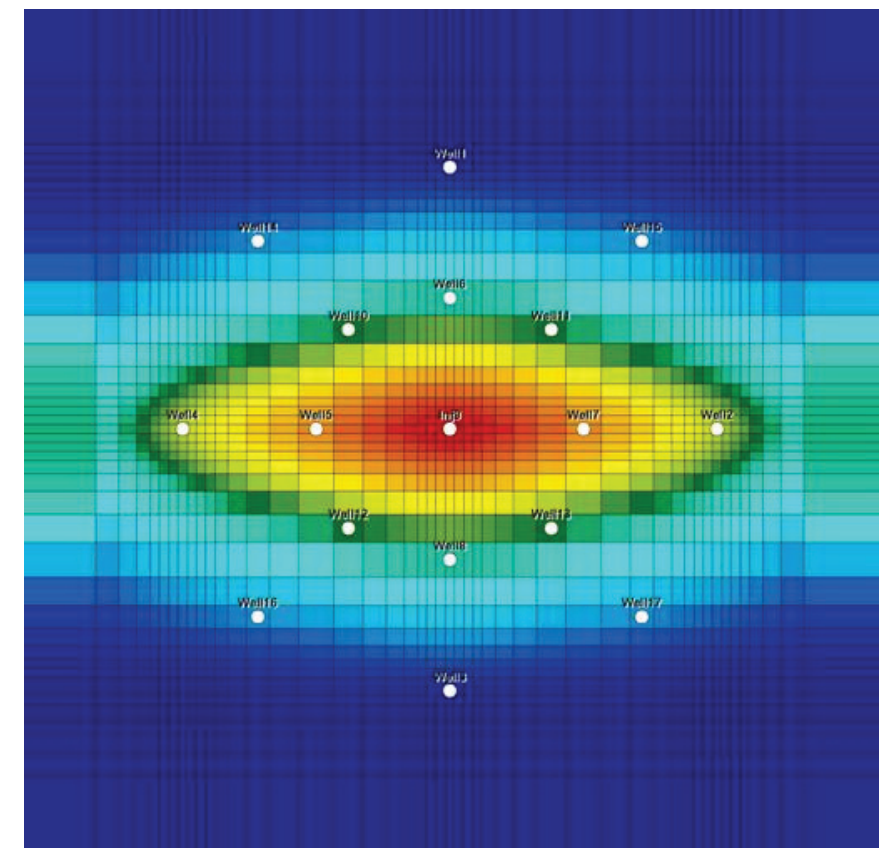

Figure 8. Example of one of the models used for the pilot design and well spacing showing that the outer ring of monitoring wells $(300 \mathrm{ft})$ would not have detectable gas saturation. Consequently, 150-ft well spacing was used for the initial pilot design. The face cleat direction is left to right, and the butt cleat direction is top to bottom. Light blue indicates $10 \%$ gas saturation. Green, yellow, and orange represent increasing gas saturation up to $50 \%$ saturation for red. 
In general, DST results are considered to be less reliable than a pressure falloff test due to the changing rate prior to the shutin period. Consequently, drilling operations ceased until falloff and pulse tests could be conducted to confirm the DST permeability. The DST also showed positive skin $(+6$ and +9$)$ and coal cleat pressure very close to the fresh water gradient. These wells were cased and perforated. (More details are given in the completion and coal seam characterization sections).

As part of the pressure falloff tests to confirm the lower permeability indicated by the DST analyses, downhole pressure gauges with surface readouts were placed in both wells. A step rate test was conducted in the first well (M-3) so that injection rate and pressure could be maximized without fracturing the coal. Injection rates were maintained for about $2 \mathrm{hr}$ for each rate. A step rate test (Figure 9) gave a fracture pressure gradient of $22.6 \mathrm{kPa} / \mathrm{m}(0.96 \mathrm{psi} / \mathrm{ft})$. This corresponded to a water injection rate of $4.25 \mathrm{~m}^{3} / \mathrm{day}(0.78 \mathrm{gal} / \mathrm{min}$ [gpm] $)$ or 26.7 barrels of water per day. (These tests results were used to complete the $\mathrm{CO}_{2}$ injection permit application.)

During the step rate test, pressure in the second well (M-1) was recorded. The butt cleat direction permeability was estimated at $0.003 \mu \mathrm{m}^{2}(3.3 \mathrm{mD})$, and storativity was estimated at $3.6 \times 10^{-9} / \mathrm{Pa}\left(25 \times 10^{-6} / \mathrm{psi}\right)$. A constant rate injection period of 9 hours followed the injections of the step rate test at a rate below the parting pressure $\left(3.3 \mathrm{~m}^{3} / \mathrm{d}[0.6 \mathrm{gpm}]\right)$. Afterwards, well M-3 was shut-in for a 24-hr falloff test. Because the wells' water level was at the surface, well M-3 was shut-in at the surface and very little wellbore storage occurred. The M-3 falloff (Figure 10) gave $0.004 \mu \mathrm{m}^{2}(4.0 \mathrm{mD}$ ) and skin of -1.5. After the falloff test, a two-cycle pulse test with 10-hr flow and 10-hr shut-in periods was conducted. For each injection pulse, a pressure increase of 34-41 kPa (5-6 psi) after about $10 \mathrm{hr}$ was measured at the observation well. An inter-well permeability of 0.003 $\mu \mathrm{m}^{2}(3.3 \mathrm{mD})$ and storativity of $3.9 \times 10^{-9} / \mathrm{Pa}\left(27 \times 10^{-6} / \mathrm{psi}\right)$ were calculated. Finally, a falloff of well M-1 gave a permeability of $0.0043 \mathrm{kPa}(4.4 \mathrm{mD})$ and skin of -3.0 .

Falloff tests confirmed the low DST permeability estimates. A comparison of the single well permeability and interwell permeability showed very little difference, suggesting that the face and butt cleat permeability may not be very different. Based on the two well tests only and assuming that the falloff permeability is equal to the geometric average of the face and butt cleat permeability, the face to butt cleat permeability ratio is 1.5:1. However, this ratio is not necessarily very reliable because at the time there was no well in the face cleat direction. When the injection pattern was completed, another pulse test was conducted to estimate the face cleat permeability. (See the coal seam in situ characterization section for more details.)

ECBM modeling with the lower permeability required reduced well spacing for measurable results during the planned injec-

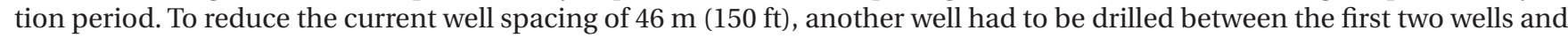
a fourth in the face cleat direction. The final four-well design (Figure 11) had injection well I-1B drilled in the butt cleat direction between the first two wells (M-1 and M-3), $16 \mathrm{~m}$ (52 ft) from one and $30 \mathrm{~m}$ (98 ft) from the other. The face cleat monitoring well (M-2) was drilled $32 \mathrm{~m}$ (105 ft) from the injection well in the face cleat direction to the southwest. (The southwest direction was chosen based on the location of surface buildings, access driveway, and grain storage bin.)

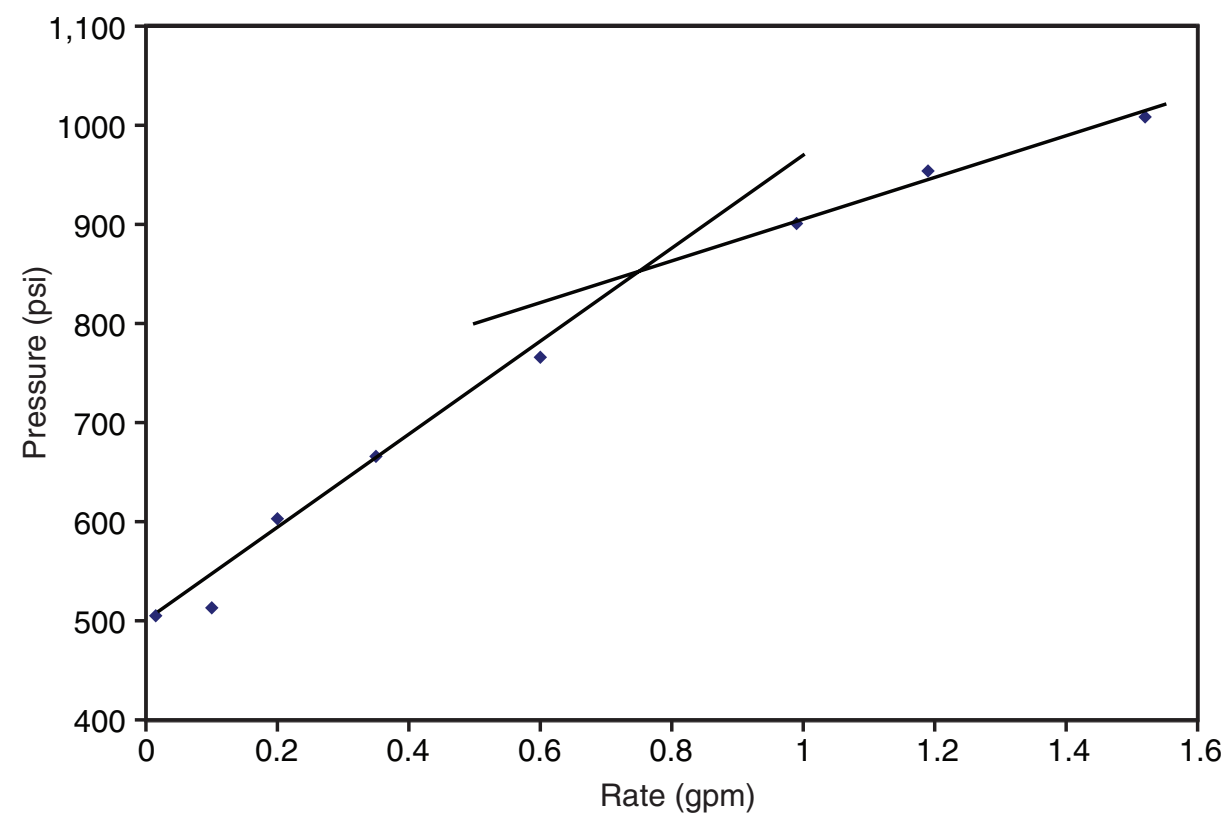

Figure 9. Pressure step rate test data at well M-3 (1-1A), summer 2007. 


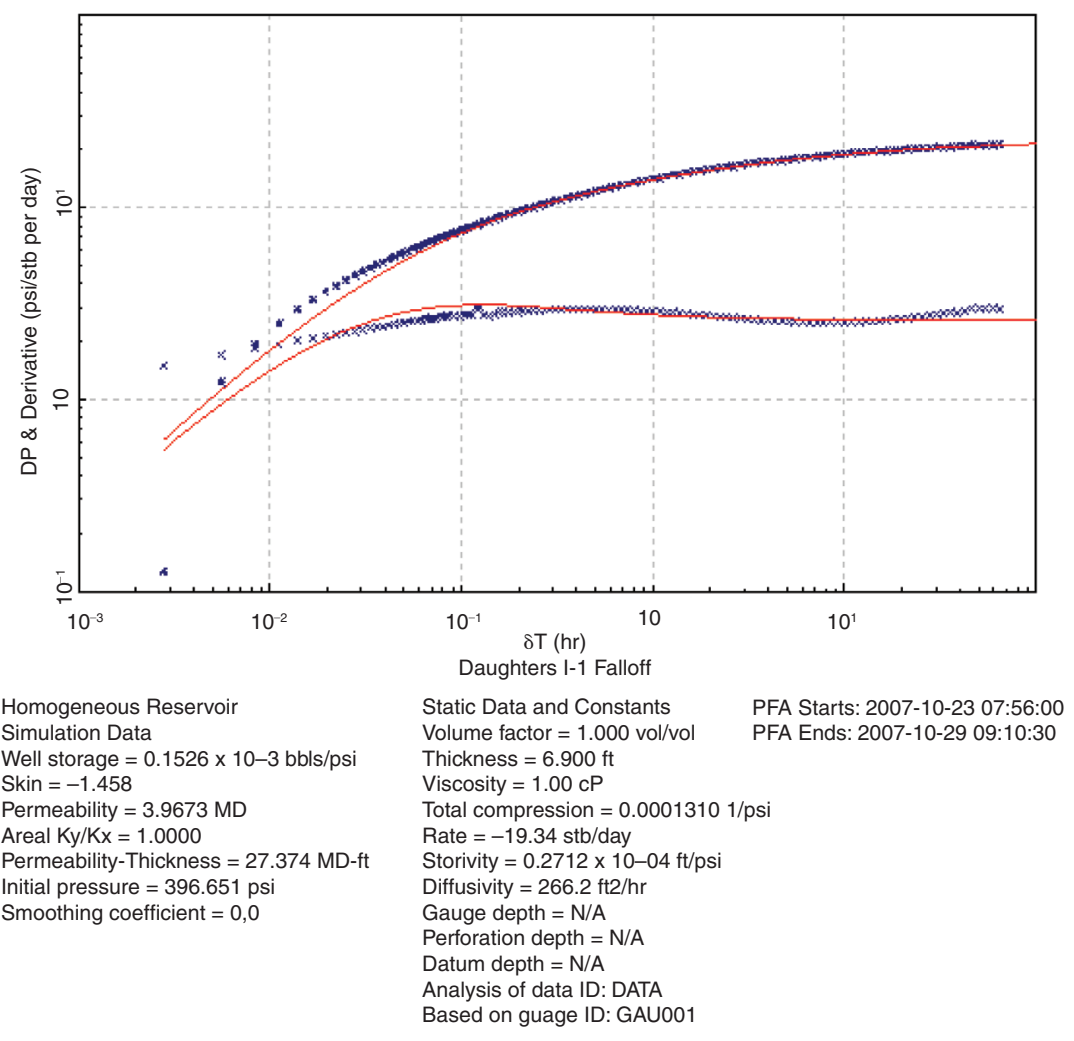

Figure 10. Falloff test at well M-3, summer 2007.

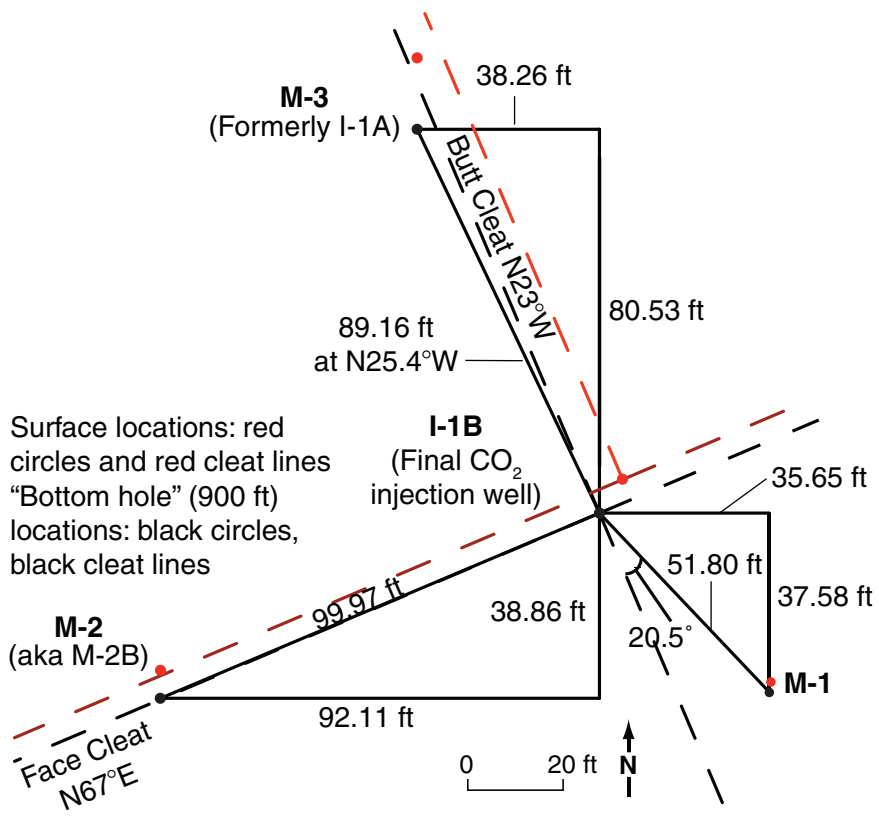

Figure 11. The surface and subsurface well locations superimposed over the cleat orientation. Surface locations and cleat alignments are indicated by red circles and red cleat lines. Downhole locations and cleat alignments are represented by black circles and black cleat lines. 


\section{Drilling Operations, Coring, and Logging}

The M-1 and M-2 (permitted as M-2B) wells were permitted as water supply wells. Well M-3 was initially permitted as the gas injection well (I-1A) and was subsequently used as a monitoring well and re-permitted as a water supply well. Well I-1B was permitted for gas injection as an enhanced hydrocarbon recovery well. State of Illinois drilling permits were issued to Gallagher Drilling in June and July 2007, and April 2008 (Appendix 1).

The four pilot wells were drilled conventionally as vertical wells using freshwater drilling fluid $(0.120 \mathrm{~kg} / \mathrm{L}$ [8.34 lb/gal]). The

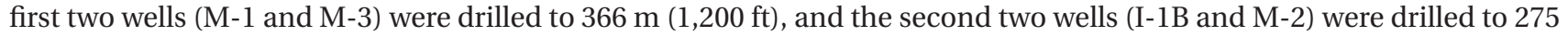
$\mathrm{m}(900 \mathrm{ft})$ after the Springfield Coal was chosen as the injection target for this pilot. The surface wellbore was drilled with a

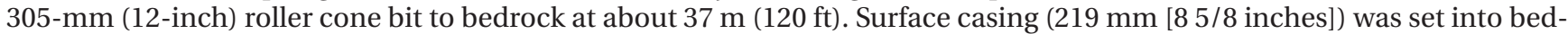
rock and cemented to the surface.

The wells were drilled to total depth (TD) with cores taken in the selected coal intervals shown in Table 2, using a split core barrel and conventional drill pipe retrieval. Drillstem tests were conducted in the Springfield Coal in all four wells and the Seelyville Coal in M-1. Thickness values for the Springfield Coal at these wells are given in Table 3.

The M-2 well is structurally the highest of the four wells, lying about $0.9 \mathrm{~m}(3 \mathrm{ft}$ ) higher than the M-1 well and about $1.5 \mathrm{~m}$ (5 ft) higher than the I-1B and the M-3 wells. Of all the different coal seams present in the Basin, the Springfield (Table 3) and the Seelyville seams were the thickest at this location (Figure 12).

After the core barrel was opened, the rock (coal and shale) was described, sampled, and boxed. Coal segments $0.3 \mathrm{~m}$ ( $1 \mathrm{ft}$ ) long were quickly removed from the core barrel and sealed in airtight gas desorption canisters on site. In order to account for lost gas, clock time was recorded when the coal was cored, when it was lifted off the bottom of the wellbore, when the core arrived at the surface, and when the cores were sealed in canisters. The canisters were kept close to the reservoir temperature of $21^{\circ} \mathrm{C}\left(70^{\circ} \mathrm{F}\right)$.

An extensive logging suite was run in each well. High resolution (2.54-cm [1-inch] vertical data sampling interval) open-hole logging including gamma-ray, density, compensated neutron, photoelectric effect, caliper, and induction logs were run in each well. In addition, full wave sonic and borehole acoustic imaging logs were run in the M-1 and M-3 (I-1A) wells. Marker bed tops and elevations were determined from the logs and are shown in Appendices 2 and 3, respectively.

\section{Well Completion and Wellhead Design}

\section{Well Completion}

The surface wellbore for the four wells was drilled with a $30.5-\mathrm{cm}$ (12-inch) bit and cased with 21.9-cm (8.63-inch) surface casing. Surface casing was J-55 grade and weighed $35.71 \mathrm{~kg} / \mathrm{m}(24 \mathrm{lb} / \mathrm{ft})$. The production wellbore was drilled with a $20-\mathrm{cm}$ (7.9-inch) bit and cased with 14-cm (5.5-inch), $23.06 \mathrm{~kg} / \mathrm{m}$ (15.5 lb/ft), J-55 production casing.

Table 2. Whole core recovered for the Tanquary pilot wells.

\begin{tabular}{|l|c|c|c|l|}
\hline Well & Core & $\begin{array}{c}\text { Cored } \\
\text { interval (ft) }\end{array}$ & $\begin{array}{c}\text { Recovery } \\
(\mathrm{ft})\end{array}$ & \multicolumn{1}{|c|}{ Target seam } \\
\hline M-1 & 1 & $883-903$ & 19.35 & Springfield Coal \\
\hline M-1 & 2 & $1,142-1,154$ & 12.1 & Seelyville Coal \\
\hline M-2 & 1 & $885-905$ & 20 & Springfield Coal \\
\hline M-3 (I-1A) & 1 & $755-772$ & 17 & Danville Coal \\
\hline M-3 (I-1A) & 2 & $784-797$ & 10.6 & Herrin Coal \\
\hline M-3 (I-1A) & 3 & $888-908$ & 20 & Springfield Coal \\
\hline M-3 (I-1A) & 4 & $995-1,005.7$ & 10.3 & Houchin Creek Coal \\
\hline M-3 (I-1A) & 5 & $1,136-1,154$ & 16.9 & Seelyville Coal \\
\hline I-1B & 1 & $887-906.5$ & 19.5 & Springfield Coal \\
\hline
\end{tabular}


Table 3. Thicknesses of the Springfield Coal in the Tanquary pilot wells as measured from core descriptions and well logs.

\begin{tabular}{|l|l|cl|}
\hline Well & \multicolumn{1}{|c|}{ Core } & \multicolumn{1}{|c|}{$\begin{array}{c}\text { Tops } \\
\text { depth (ft) }\end{array}$} & $\begin{array}{c}\text { Thickness } \\
(\mathbf{f t})\end{array}$ \\
\hline \multirow{2}{*}{ M-1 } & Core \#1, Springfield Coal & 895.5 & 6.4 \\
& Log tops for Gallagher Drilling & 893.75 & 6 \\
\hline \multirow{2}{*}{ M-2B } & Core \#1, Springfield Coal & 888.55 & 5.96 \\
& Log tops for Gallagher Drilling & 889.2 & 6.7 \\
\hline \multirow{2}{*}{ I-1A (M-3) } & Core \#3, Springfield Coal & 895.5 & 6.95 \\
\hline \multirow{2}{*}{ I-1B } & Log tops for Gallagher Drilling & 894 & 7 \\
& Core \#1, Springfield Coal & 893.5 & 6.7 \\
\hline
\end{tabular}

The annular volume was filled from bottom to surface with Class A cement with 10\% calseal (gypsum), $10 \%$ salt (sodium chloride), and 1\% latex fluid loss; 175 sacks of cement were used. A cement-bond log was run to confirm the integrity of the casing cement. Cased-hole reservoir saturation tool (RST) logs were run before and after $\mathrm{CO}_{2}$ injection.

At I-1B (Figure 13), surface casing extended to $29.6 \mathrm{~m}(97 \mathrm{ft})$ depth—slightly past the bedrock top at $29.0 \mathrm{~m}(95 \mathrm{ft})$-and production casing extended to $297 \mathrm{~m}(975 \mathrm{ft})$. The Springfield Coal was perforated with 6 shot/ft, 60 degree phasing, and $0.95-\mathrm{cm}$ (3/8-inch) diameter perforations. The coal seam was $2.0 \mathrm{~m}(6.6 \mathrm{ft})$ thick at I-1B. Perforations were at 273-274.9 $\mathrm{m}$ (896-902 ft). The tubing string was $257 \mathrm{~m}$ (843 ft) of 6.033 $\mathrm{cm}$ (2.375 in) oil field tubing (4.7\#, J-55) with a Map Oil Tools model AD-1 packer at the end of the tubing. (The packer is set and released mechanically by turning and pulling the tubing.) The bottomhole pressure gauge for I-1B was originally at $271.2 \mathrm{~m}$ (889.6 ft) but was moved to a depth of $265.7 \mathrm{~m}$ (871.6 $\mathrm{ft}$ ) late in the project (bottomhole pressure readings at all four wells were adjusted to a $900-\mathrm{ft}$ datum for comparison with one another).

There were minor variations in casing lengths and perforation depths among the monitoring wells. Figure 14 shows M-1. M-1, M-2, and M-3 had $368.5 \mathrm{~m}$ (1,209 ft), $300.2 \mathrm{~m}$ (985 $\mathrm{ft}$ ), and $370.3 \mathrm{~m}$ (1215 ft) of production casing, respectively. Surface casing lengths were $36.6 \mathrm{~m} \mathrm{(120} \mathrm{ft),} 29.6 \mathrm{~m}(97 \mathrm{ft})$, and $33.8 \mathrm{~m}$ (111 ft) for M-1, M-2, and M-3, respectively. None of the monitoring wells contained tubing. The Springfield Coal was $1.87 \mathrm{~m}(6.15 \mathrm{ft})$ thick at M-1, with perforations at 272.5$274.3 \mathrm{~m}$ (894-900 ft); $1.91 \mathrm{~m}(6.25 \mathrm{ft})$ thick at M-2, with perforations at $271.6-273.5 \mathrm{~m}(891.2-897.2 \mathrm{ft})$; and $2.07 \mathrm{~m}(6.8 \mathrm{ft})$ thick at M-3, with perforations at 272.9-274.5 m (895.5-900.5 $\mathrm{ft}$ ). Well M-3 had only 30 perforation holes; the other three wells had 36 holes. Bottomhole pressure gauges were at 274.9 $\mathrm{m}$ (902 ft), $274.6 \mathrm{~m}(901 \mathrm{ft})$, and $275.2 \mathrm{~m}$ (903 ft), respectively, for M-1, M-2, and M-3.

A 946-L (250-gal), 9\% formic acid treatment was used to break down the perforations; the acid was displaced with $3,785 \mathrm{~L}$ (1,000 gal) of water. Following the acid treatment, the wells were swabbed using a swabbing tool on slick line with a workover rig. The swabbing action was intended to produce the acid from the coal. During this process, a small volume of hydrocarbon gas was brought to surface. All wells were filled

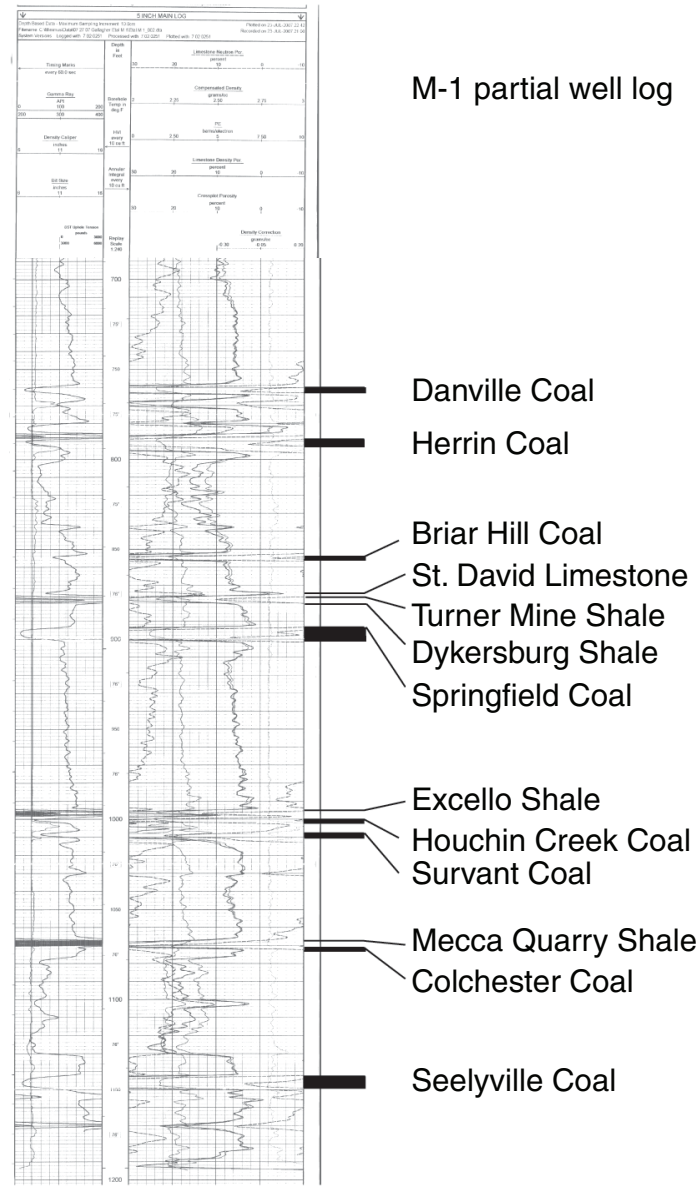

$\mathrm{T} \mathrm{D}=1,210$

Figure 12. Segment of type well log for Tanquary site, showing coals, including Springfield and Seelyville coal seams. Abbreviation: TD, total depth. 

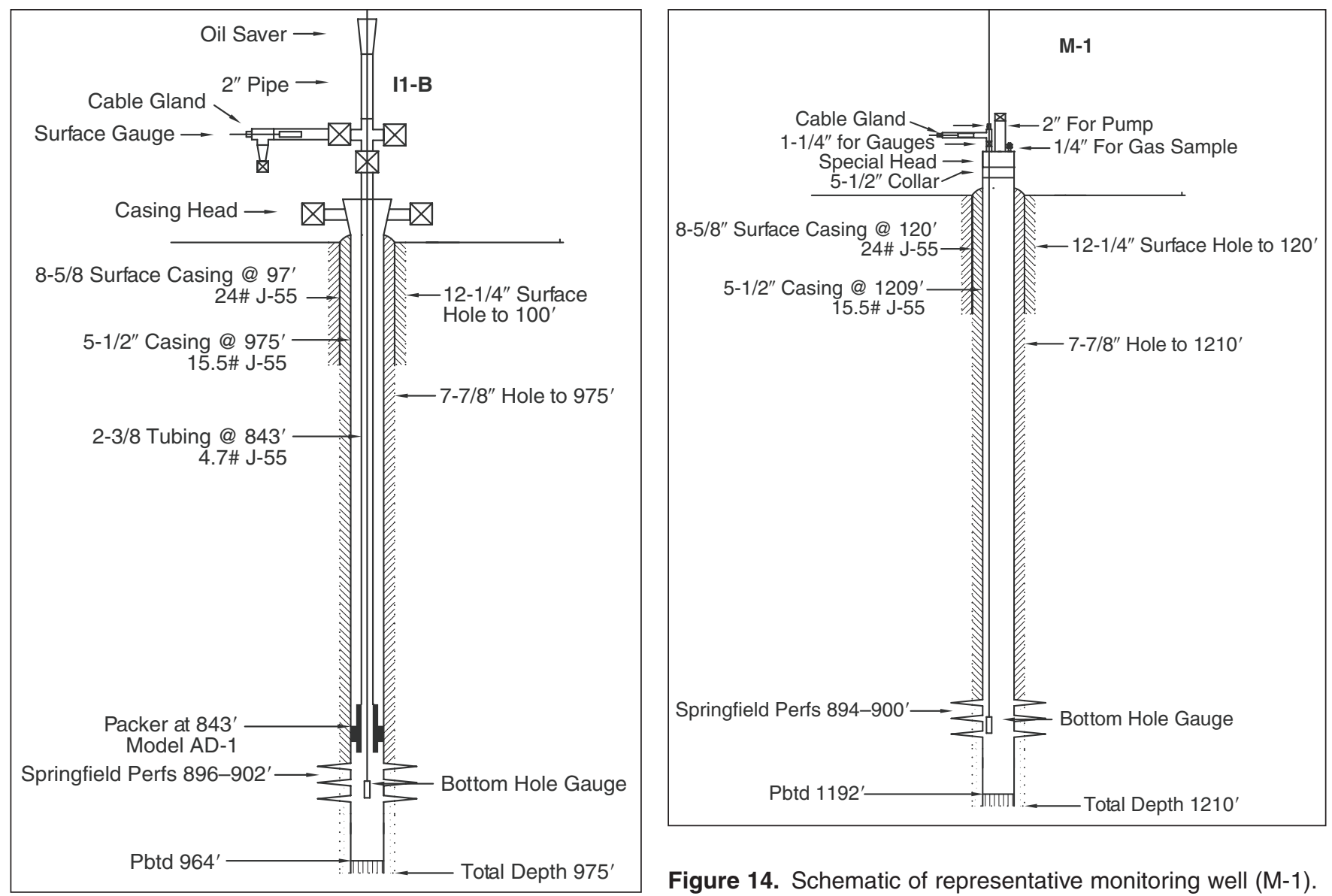

Figure 14. Schematic of representative monitoring well (M-1).

Figure 13. Schematic of I-1B injection well.

to the surface with fresh water, although the water level in the injection well did not reach the surface for a few days due to air entrained in the tubing. (The effectiveness of the acid stimulation treatment was indicated by the substantial reduction of the skin factors from the DSTs to that estimated from the pressure falloff tests.)

All wellbore casings and tubing were filled to the surface with water prior to starting $\mathrm{CO}_{2}$ injection. Bottomhole pressure was allowed to stabilize at the initial pressure of $2.65 \mathrm{MPag}(385 \mathrm{psig}$ ) at all wells. Because the coal seam was slightly overpressured, water flowed from each well when it was opened to the atmosphere at the surface.

The M-wells did not have tubing in the wellbores. The injection well had tubing and packer set near the perforations. Fluids could be analyzed directly at the surface from any of the M-wells using the field infrared gas analyzer (or field IR) or by acquiring a sample that was sent to the ISGS laboratory.

\section{Wellhead Design}

At I-1B, a casing head was threaded directly onto the surface casing to provide support to the injection wellhead (Figure 15) and the riser pipe (attached to the uppermost joint of injection tubing). The casing head also provided the surface seal between the tubing and the casing.

The I-1B injection well had injection tubing and packer placed within the casing. The wellhead, a Larkin Type K $\left(5 \frac{1}{2} \times 2\right.$ $3 / 8$ inches), is rated to $7 \mathrm{MPa}$ (1,000 psi) and is standard for the Illinois Basin. The wellhead was designed to monitor the casing-tubing annulus and the tubing. At the base of the I-1B wellhead, attached to one side of the casing head, was a short pipe nipple, a gate valve, and a mechanical pressure gauge that measured the annulus pressure between the casing and the tubing. On the opposite side of the casing head, another opening was blocked with a bull plug. Above the casing head was a riser pipe that connected to a pipe cross fitting. Short, horizontal pipe extended from each side of the cross. 

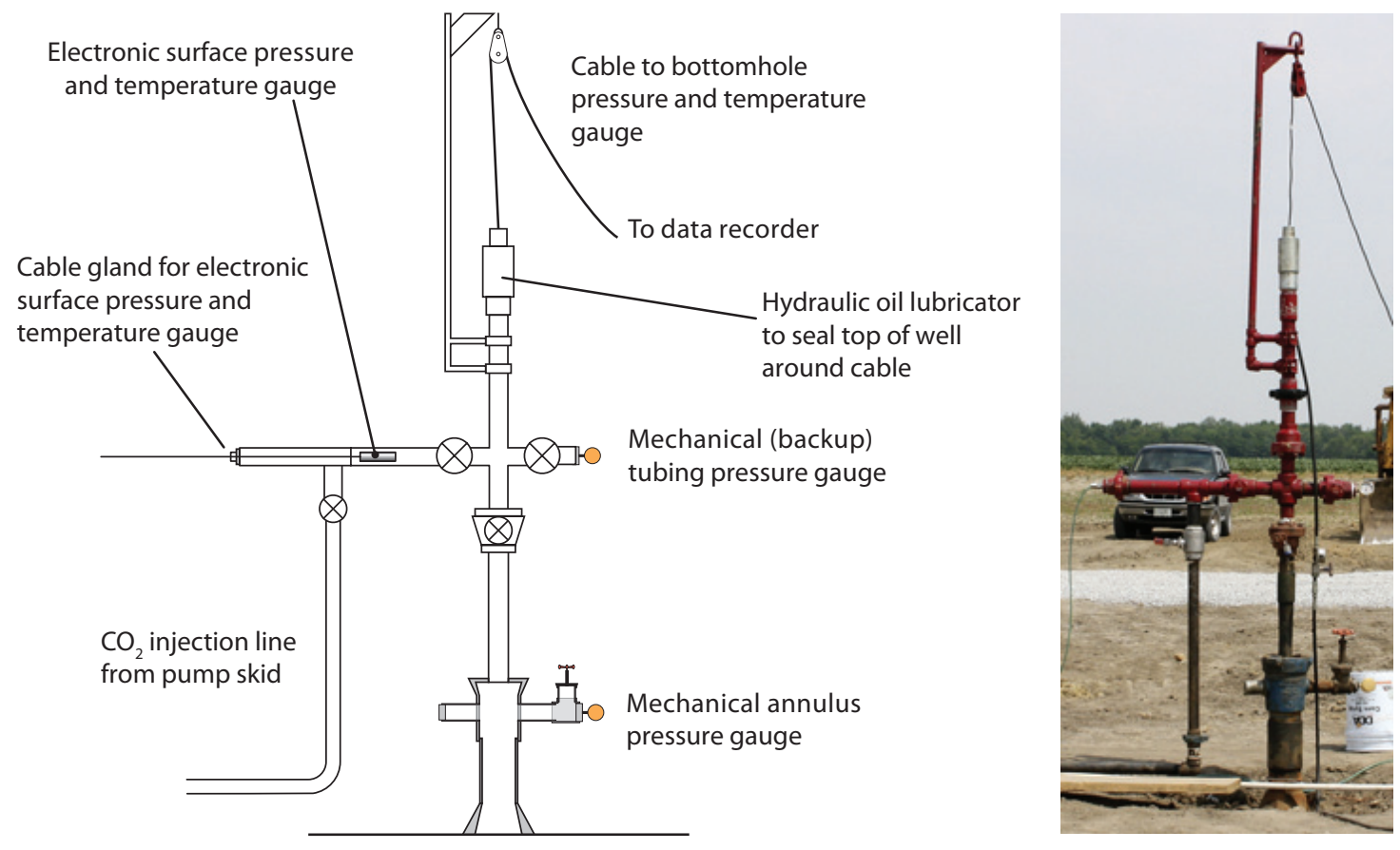

Figure 15. Design of wellhead for injection well I-1B (at left) and photo of wellhead (at right).

One side of the cross was connected to the $\mathrm{CO}_{2}$ injection line from the pump skid. On this side of the cross were the Geokon gauges to measure the $\mathrm{CO}_{2}$ injection surface pressure and temperature. A cable gland at the tip of this arm was sealed around the gauge cable. In the middle of this horizontal pipe, the $3.8-\mathrm{cm}(1.5-\mathrm{in})$ steel injection line fed $\mathrm{CO}_{2}$ into the I-1B wellhead via a pipe tee. The $\mathrm{CO}_{2}$ injection shut-off ball valve was on the vertical $\mathrm{CO}_{2}$ flow line rising vertically to the tee. The shut-off valve is manufactured by Balon and has an aluminum bronze body with Viton seals rated for $14 \mathrm{MPa}(2,000 \mathrm{psi})$. The ball valve was modified for $\mathrm{CO}_{2}$ service by drilling a small hole into the downstream side of the ball. Except for the seal composition and the modification, this type of valve is standard for Illinois Basin oil fields.

On the opposite side of the cross (shorter horizontal pipe) was a mechanical backup tubing pressure gauge with a ball valve between the cross and pressure gauge. Above the crossbar was a vertical length of 5-cm (2-in) pipe topped with a hydraulic oil lubricator. Double E, Inc. manufactured the lubricator, which has stainless steel construction and a 34-MPa (5,000-psi) pressure rating. The elastomer in the lubricator was standard Buna N. The electrical cable to the Geokon electronic downhole pressure and temperature gauges extended out of the top of the wellhead and lubricator through a sheave at the top of the well assembly, from which it hung down to connect to a data logger.

Because one of the objectives of this pilot was to account for free gas due to $\mathrm{CO}_{2}$ injection only, monitoring wells $\mathrm{M}-1$, $\mathrm{M}-2$, and M-3 were designed to have no pressure drawdown, and gas was sampled at the surface only. However, without a small pressure sink around the wells, it was possible that desorbed or free $\mathrm{CO}_{2}$ or $\mathrm{CH}_{4}$ might not enter the perforations of each observation well and would not be detected at the wellbores. A pressure drop that was too large might cause the coal near the wellbore to desorb gas due to pressure decrease and not $\mathrm{CO}_{2}$ competitive desorption. Consequently, the wellheads of the monitoring wells were designed so that a pump could be lowered a few hundred feet into the wellbore. This design enabled the bottomhole pressure to be reduced while maintaining it above the $\mathrm{CH}_{4}$ desorption pressure and ensured that any free gas detected was a result of $\mathrm{CO}_{2}$ injection rather than pressure reduction. This approach reduced ambiguity when free $\mathrm{CH}_{4}$ gas was detected at the observation wells and improved the data available for modeling and analyses.

As was done for the injection well, each monitoring well (Figure 16) had electronic surface pressure and temperature gauges and a mechanical pressure gauge (backup) placed in a horizontal arm of a tee-fitting. The cable for the downhole pressure and temperature gauges emerged through a gland at or near the top of the wellhead. Needle valves with quick-connect couplers were on all of the monitoring wells to allow for casing gas sampling with minimal pressure disturbance. Plugs were placed in the $5.1-\mathrm{cm}(2.0$-inch) collars on the casing head in the event that it became necessary to pump these wells. 
Cable glands for electronic pressure and temperature gauges
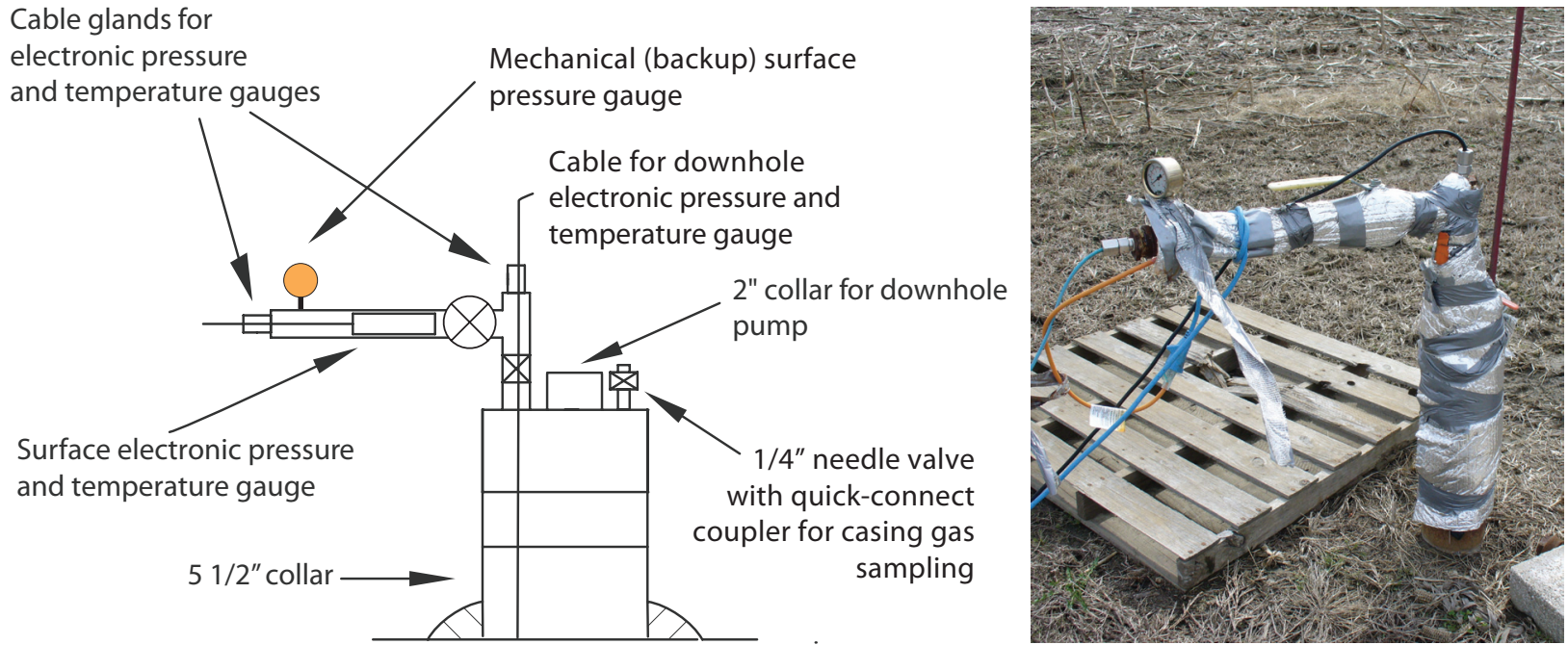

Figure 16. Design of $\mathrm{M}-1$ wellhead (at left) and photo of $\mathrm{M}-1$ (at right). This design is representative of all the monitoring wells. Insulation and heat tape in photograph are to protect the wellhead during the winter months.

\section{Coal Characterization: Core, Log, and Pressure Transient Analyses}

The main goal of the coal characterization was to identify properties and spatial variations (vertical and horizontal) of the Springfield Coal to define the baseline, in-situ coal characteristics and to better understand mechanisms and effects of $\mathrm{CO}_{2}$ injection and storage at the Tanquary pilot site.

\section{Core Description}

Full-diameter 7.6-cm (3-inch) cores, including overlying and underlying non-coal rocks, were described (Appendix 4) and photographed in the field (Appendix 5). These included a succinct and quick description of the coals before they were placed in desorption canisters. A detailed coal lithology description was prepared of the M-2 Springfield Coal, which was not desorbed. This coal was embedded in polyester resin and then slabbed to better view the lithology and structures of the coal (Figure 17).

The Springfield Coal is generally a highly banded clarain with minor layers that are "banded bright" where vitrain is very abundant. Most of the coal is average brightness, and a very few intervals are "banded dull". There are localized bands or blebs of pyrite. Vitrain bands are well cleated with $1.0-2.0 \mathrm{~cm}(0.4-0.8 \mathrm{inch})$ spacing. Commonly the cleats are filled with calcite and, to a lesser extent, kaolinite.

\section{Macerals and Coal Composition}

There are three basic groups of macerals, or distinct organic entities, in coal: vitrinite, liptinite, and inertinite. Vitrinite is the most abundant coal component and is formed by the thermal alteration of the woody tissue of land plants. It has a glassy or shiny appearance. The reflection of incident light off grains of vitrinite varies with the thermal maturity of the coal. This reflection has been calibrated against known standards to generate what is now called "vitrinite reflectance". Liptinite is derived from the resinous and waxy parts of plants and include spores, pollen, and leaf cuticle. Inertinite is derived from charred and biochemically altered plant cell wall material and has a very dull appearance, much like charcoal. Illinois coals may have a banded appearance that reflects the interbedding of these three components. Banded coal has the generic name of "clarain". The brightness of this banded coal increases with its vitrinite content.

Experimental details of coal characterization can be found in Appendix 6. Appendix 7 presents proximate and ultimate analyses (weight percent) as well as vitrinite reflectance $\left(\mathrm{R}_{\mathrm{o}}\right)$ of coal samples encompassing the entire Springfield Coal seam thickness in wells M-1, M-3, and I-1B. A composite histogram chart presents these data for each successive foot for each well (Figure 18). For M-1, the average seam moisture is $9.90 \%$, ash $7.36 \%$ (dry basis), sulfur content $1.59 \%$ (on dry basis), and heating value $33.89 \mathrm{MJ} / \mathrm{kg}(14,571 \mathrm{Btu} / \mathrm{lb})$ on dry ash-free basis [daf]. The coal is high-volatile bituminous B rank, as indicated by $\mathrm{R}_{\mathrm{o}}$ of $0.63 \%$. In M-3 and I-1B, these characteristics are similar (Figure 18, ash and sulfur contents). The differences of these parameters between wells are of the same magnitude as the differences between individual benches $(0.3-\mathrm{m}$ [1-ft] intervals) in one well (Appendix 7). 
Figure 17. Slabbed Springfield Coal from the M-2B well. Coal was embedded with polyester resin and white limestone granules. Several large fractures were induced by drilling. The basal foot of the coal was from the equivalent zone in the I-1B well and contains natural fractures that were filled with diagenetic kaolinite, as were smaller cleats. (For completeness, the lower foot of $\mathrm{I}-1 \mathrm{~B}$ was added to the preserved $\mathrm{M}-2 \mathrm{~B}$ core because this portion of the $\mathrm{M}-2 \mathrm{~B}$ core was crushed during the coring process and could not be preserved.) Local areas in the coal contain pyrite and are indicated by artificial brown staining on the limestone granules. The coal is thinly laminated with bright and dull coal layers typical of the coal lithotype called "clarain". Pure vitrain and fusain (inertinite) layers are also common but are only a few millimeters thick.

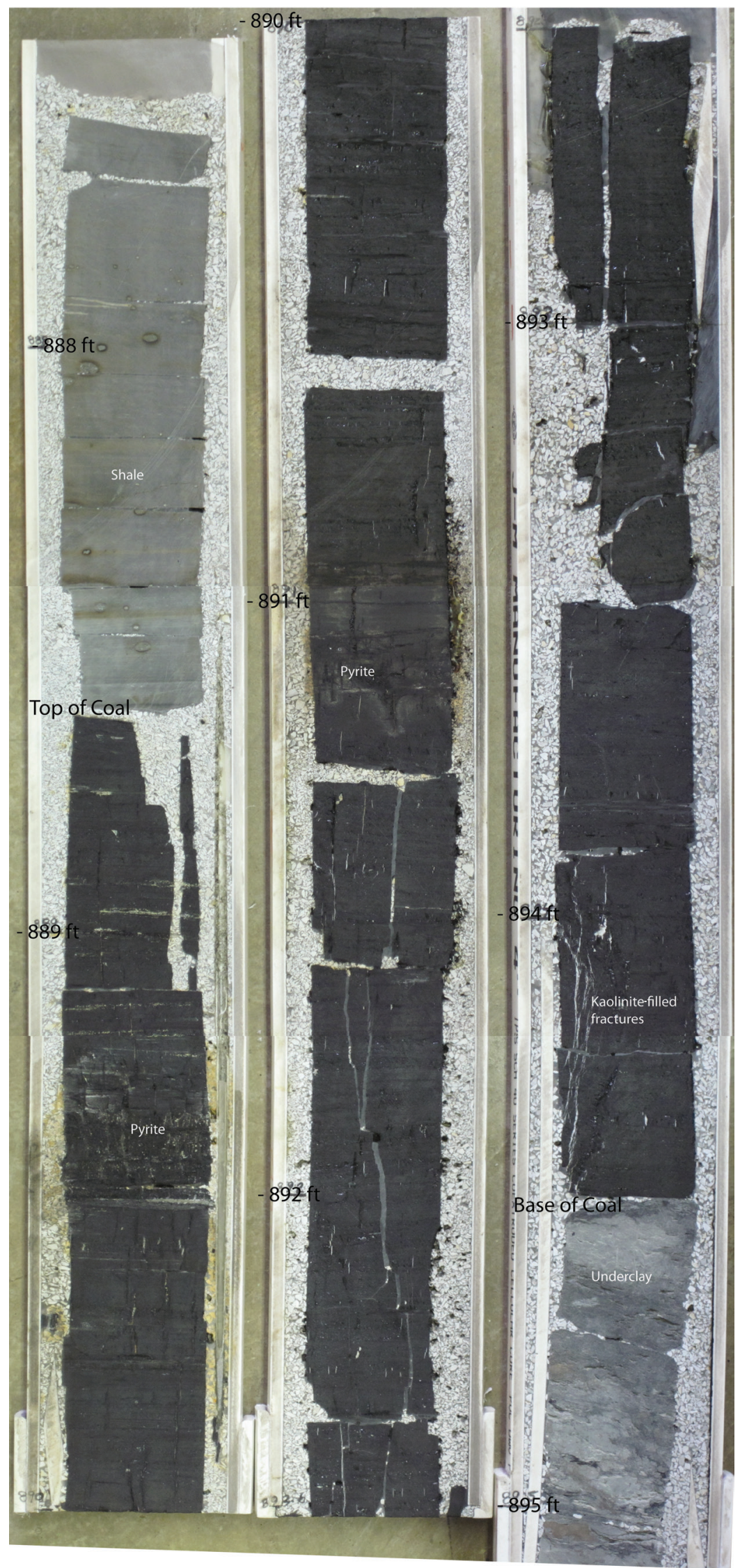




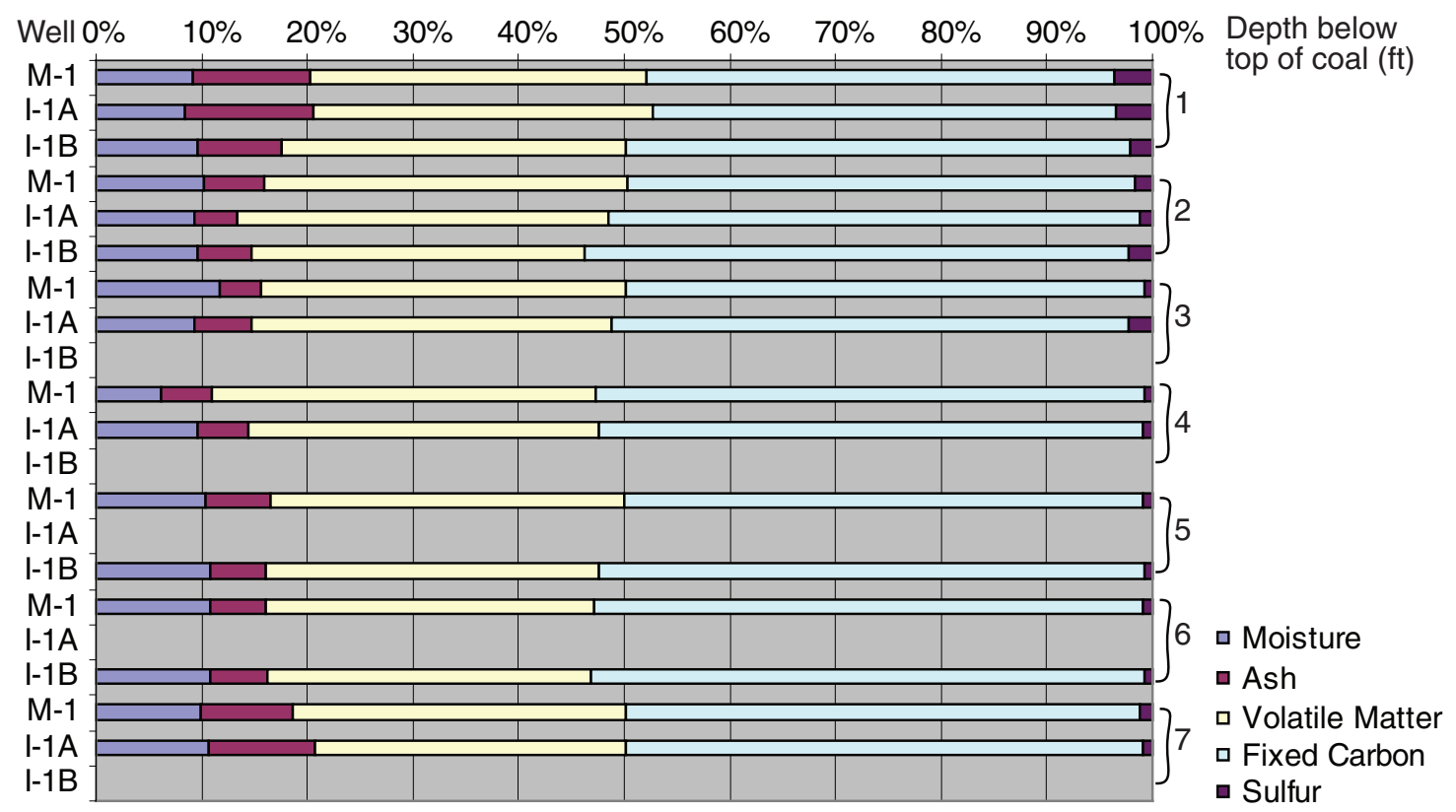

Figure 18. Proximate distribution (percent moisture, ash, volatile matter, fixed carbon, and sulfur) of Springfield Coal samples from wells M-1, M-3 (I-1A), and I-1B with depth.
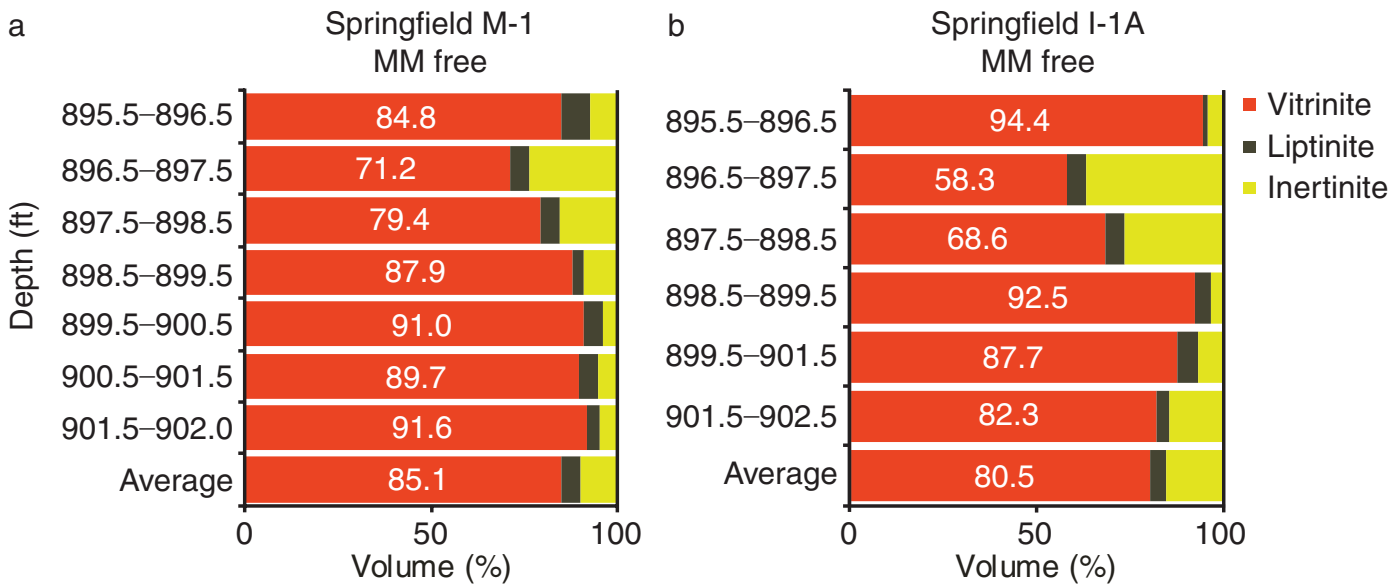

Figure 19. Maceral analysis (vitrinite, liptinite, inertinite on a mineral matter [MM] free or ash free basis) of Springfield Coal samples from wells (a) M-1 and (b) M-3 (I-1A).

Petrographically, the Springfield Coal is dominated by vitrinite, averaging $80.5 \%$ in M-3 and $85.1 \%$ in M-1 (Figure 19). Liptinite content is similar in both wells; however, M-3 has higher average inertinite content. Both wells show a similar trend in maceral composition from the top to the bottom of the seam; vitrinite content is higher in the lower part of the seam and in the uppermost bench. Inertinite is highest within the upper half of the coal, below the top interval. Mineral matter (ash) is the highest at the top and bottom interval in each well's coal (Figure 20), reflecting clastic dilution during the transition to and from the peat mire depositional environment.

\section{Gas Content and Composition}

Well M-1 was cored in the Springfield and Seelyville coals. Approximately 0.3-m (1-ft)-long segments of each coal (seven and six samples, respectively) were sealed in canisters for gas desorption measurements. After 6 months, the coals were removed from the canisters and their residual gas was determined. This was followed by Langmuir isotherm, proximate, sulfur, Btu determinations, vitrinite reflectance, and maceral composition measurements. 

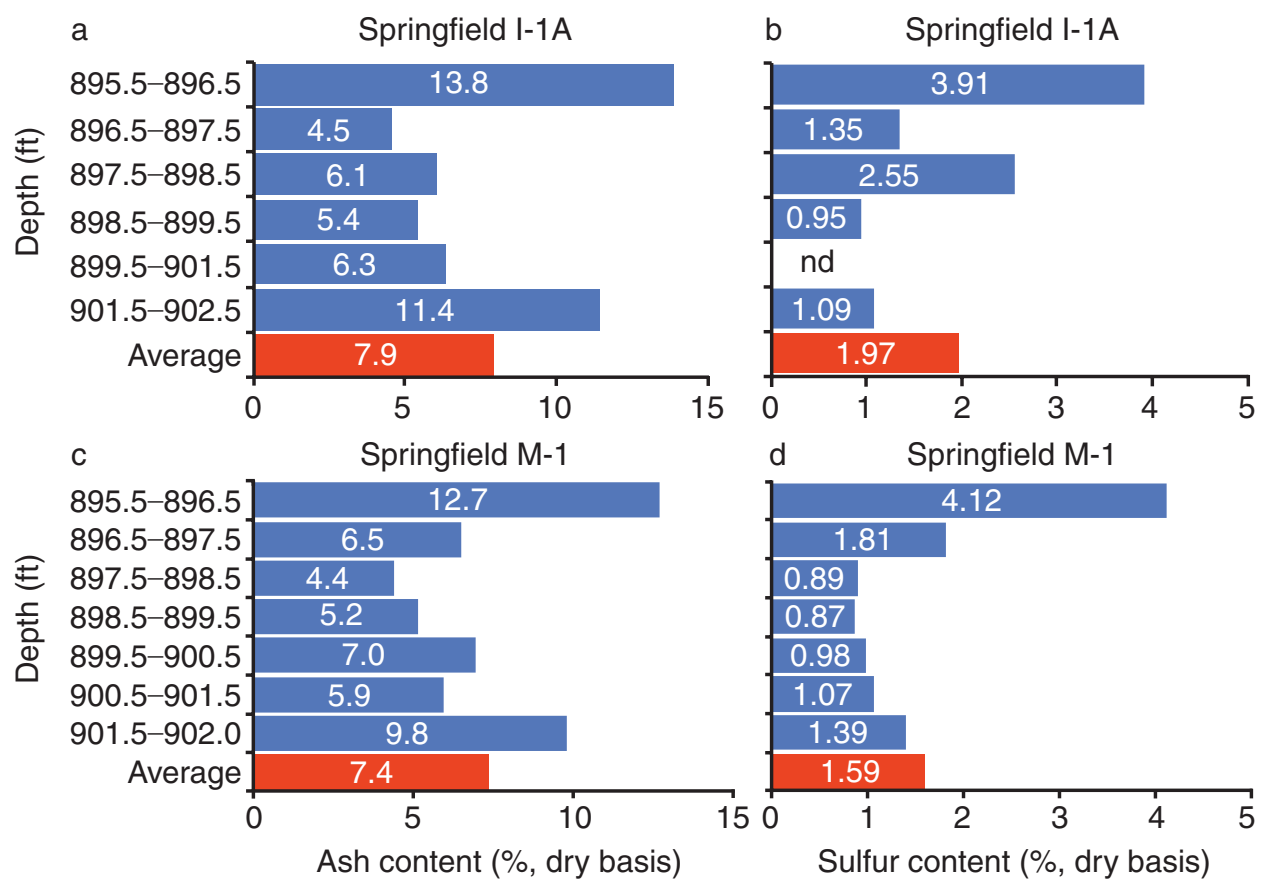

Figure 20. Proximate comparison (ash and sulfur, on a dry basis) of Springfield Coal samples from wells $M-1$ and $M-3(I-1 A)$.
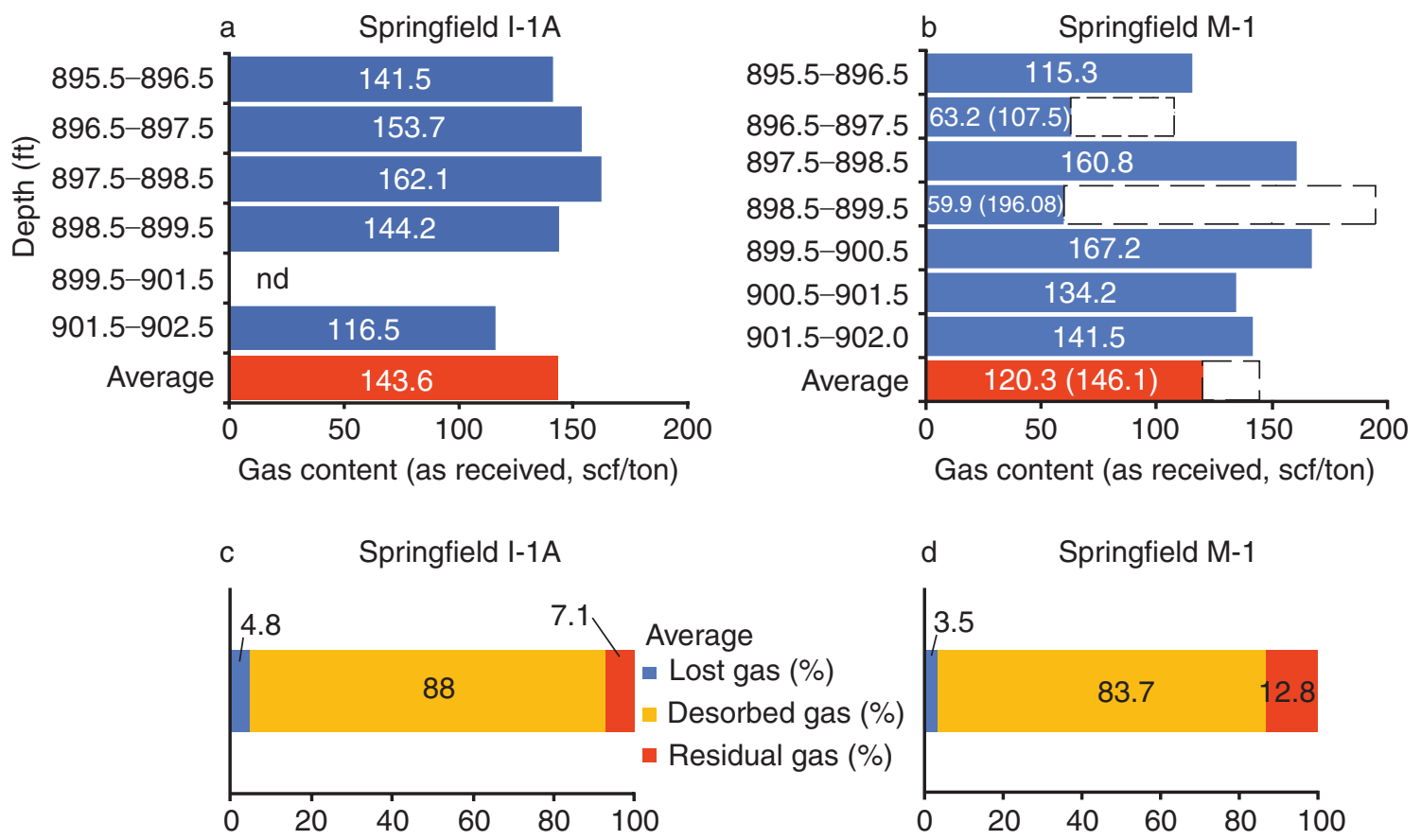

Figure 21. Total gas contents on an as-received basis for Springfield Coal samples from wells $M-1$ and $\mathrm{M}-3(\mathrm{I}-1 \mathrm{~A})$ versus depth. Values in parentheses and dashed lines were estimated based on residual gas. 
Five different coals were cored in M-3, yielding 19 canister samples for desorption. A year later, M-2 and I-1B were drilled and cored in the Springfield Coal only. Four Springfield core segments were desorbed from the I-1B well. The core from M-2 was preserved for geologic study and not used for gas content or adsorption tests, which destroy the core.

All gas content data are summarized in Appendix 8. Variations in gas content as determined by the desorption canister technique in Springfield Coal samples for M-1 and M-3 are presented in Figures 21 and 22. Average gas content for M-1 (based on seven canister analyse covering the whole seam thickness) is $3.7 \mathrm{scm} / \mathrm{g}$ (120.3 scf/ton) (on as-received basis). For M-3, average gas content is $3.9 \mathrm{scm} / \mathrm{g}$ (126.6 scf/ton). (M-3 average gas content is based on six canister analyses; interval 274.2 m-274.8 m [899.6-901.6 ft] was not desorbed.) Gas content variation among individual canisters for a single well was significant, which indicated the importance of desorbing the entire coal thickness. Other researchers (Strappoc et al., 2008a, 2008b; Mastalerz et al., 2008a, 2008b) have made similar observations for Illinois Basin coals in other locations.

The highest gas content appears to be in the middle and lower part of the seam. However, there is uncertainty in this distribution because the $0.6-\mathrm{m}$ (2-ft) interval was not desorbed for M-3 and because two M-1 canisters leaked. For these two canisters, total gas was estimated based on their residual gas contents and was significantly larger, yielding the adjusted gas content on an as-received basis (Figure 21) and on a dry, mineral matter free (dmmf) basis (Figure 22). On average, lost gas accounted for $4.8 \%$, and residual gas for $7.1 \%$, of the total gas (as-received basis) in M-3. In M-1, lost gas accounted for 3.5\% and residual gas for $12.8 \%$ of the total gas (as-received basis) (Figure 21). The difference in the relative amount of residual gas between the two wells may have resulted from lower desorbed gas content in the two leaky canisters in location M-1. Both of these series of samples were desorbed for 5 months, so this difference cannot result from different desorption time.

The composition of selected gas samples from M-1 is presented in Appendix 9. Average $\mathrm{CH}_{4}$ content is $91.23 \%$ and average ethane is $0.31 \%$. Propane and butane are almost totally absent. The $\mathrm{CO}_{2}$ content averages $0.92 \%$, ranging from 0.35 to $1.39 \%$. A large variation occurs in nitrogen content among individual samples, ranging from 1.37 to $17.41 \%$, yielding an average value of $7.53 \%$. Desorption canisters were not purged with inert gas before placing the coal in them. The high nitrogen content may possibly be an artifact of the experimental procedure (Jin et al., 2010), even though an air-free correction was made which subtracted some nitrogen based on the measured oxygen and the natural proportion of nitrogen to oxygen in air.

Stable carbon isotope values of $\mathrm{CH}_{4}$ are at $-61 \%$, ethane at $-46 \%$, propane at $-34 \%$, and isobutane at $-34 \%$. The $\delta^{13} \mathrm{C}$ and $\delta \mathrm{D}$ of desorbed $\mathrm{CH}_{4}$ fall in the range of -59 to $-61 \%$ and -198 to $-225 \%$ o, respectively (Figure 23 ). Such gas compositions and carbon isotopic values indicate a microbial origin of the coal bed gas. They indicate that microbes were able to access even greater depths than those on the Indiana side of the Illinois Basin where microbial gases were documented to a depth of 243 m (800 ft) (Strapoc et al., 2008a, 2008b). Demir et al. (2004) and Morse and Demir (2007) found comparable desorbed $\mathrm{CH}_{4}$ isotope values with microbial origin values as deep as $457 \mathrm{~m}(1,500 \mathrm{ft})$ in more than 10 cored wells drilled throughout Illinois.

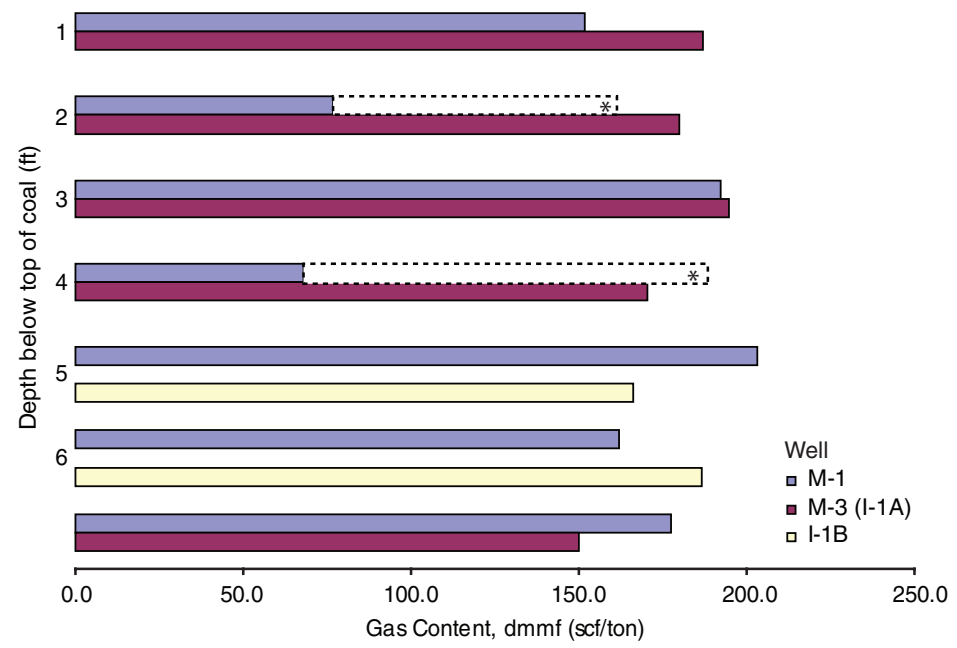

Figure 22. Gas content for Springfield Coal samples from wells $\mathrm{M}-1, \mathrm{M}-3(\mathrm{I}-1 \mathrm{~A})$, and $\mathrm{I}-1 \mathrm{~B}$ with depth on a dry, mineral matter free (dmmf) basis. Asterisk indicates canister leaked; gas content was estimated based on residual gas values.

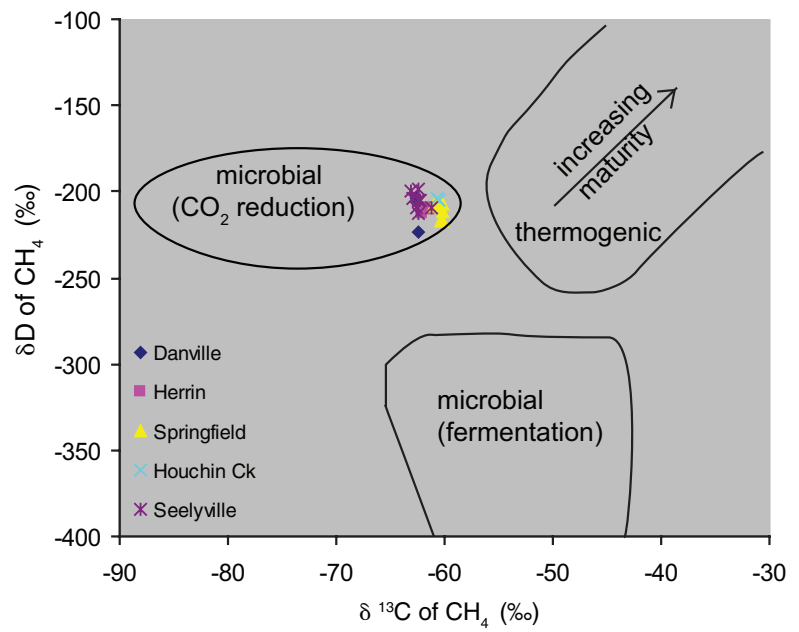

Figure 23. Desorbed methane stable isotopes crossplot chart indicating origin of methane. Abbreviation: $\mathrm{Ck}$, Creek. 


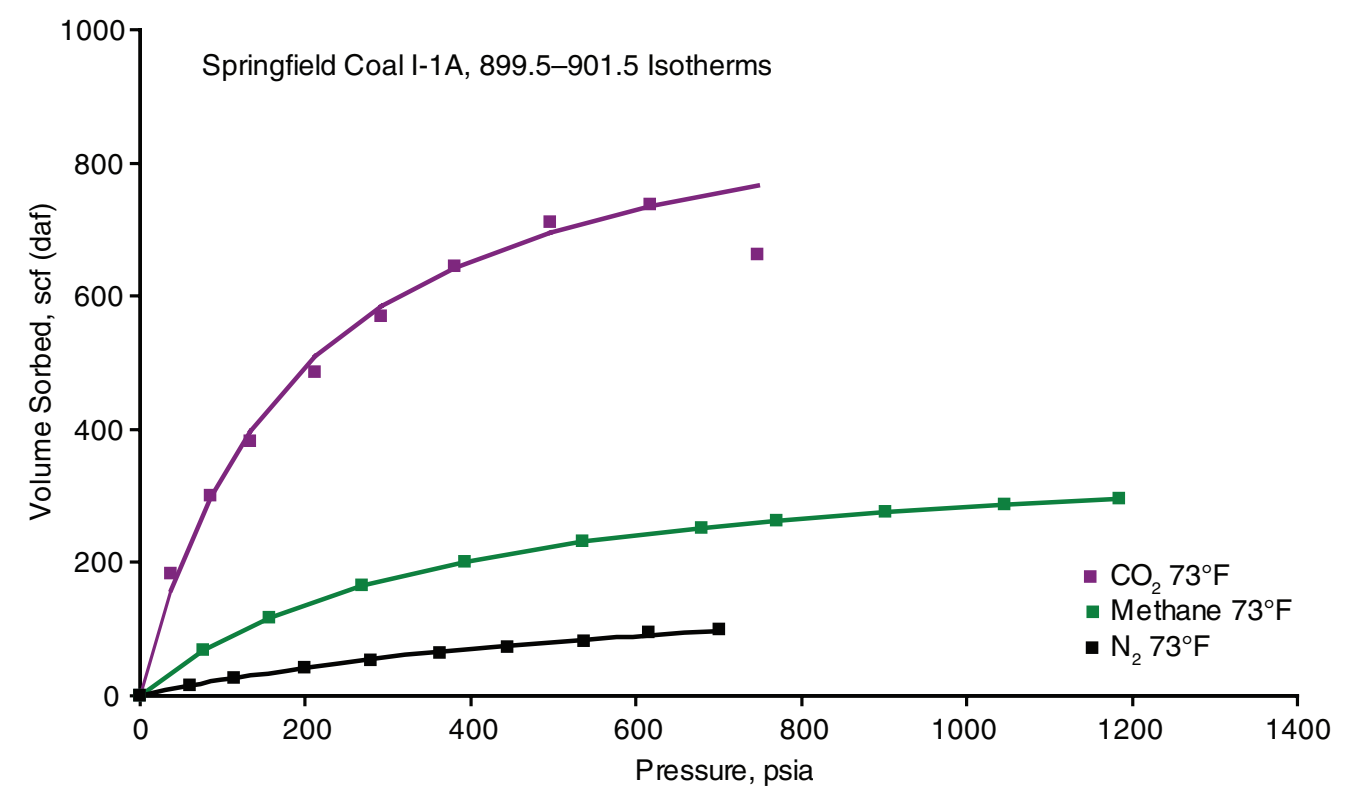

Figure 24. High-pressure isotherms for $\mathrm{N}_{2}, \mathrm{CH}_{4}$, and $\mathrm{CO}_{2}$ at $22.8^{\circ} \mathrm{C}\left(73^{\circ} \mathrm{F}\right)$, showing volume of gas sorbed to Springfield Coal samples taken from well M-3 (I-1A) at 899.5-901.5 ft.

a

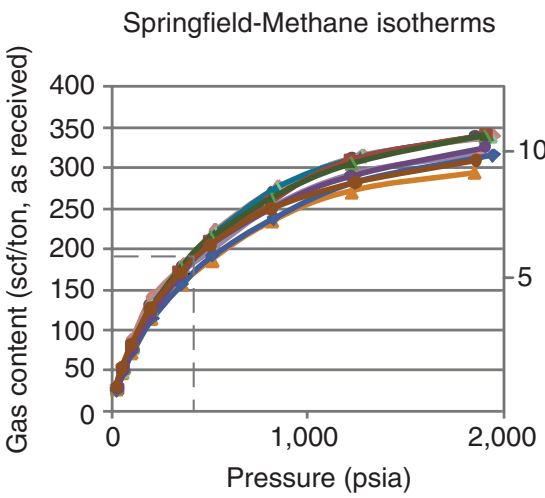

C

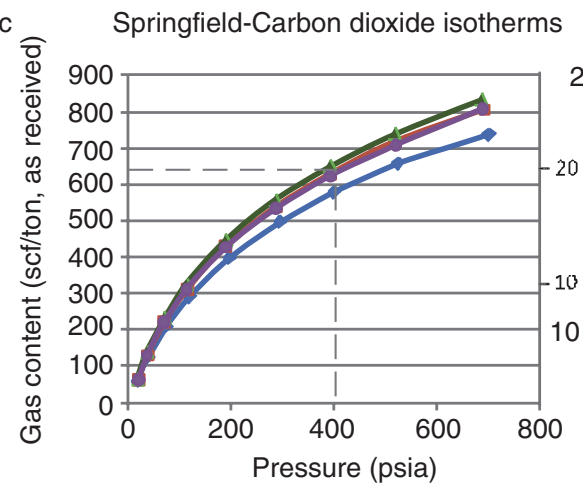

b Springfield-Methane isotherms
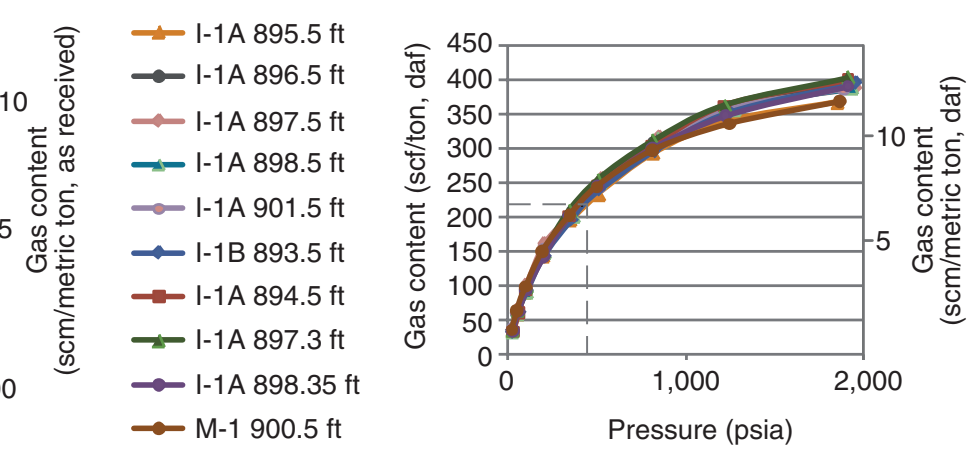

d

Springfield-Carbon dioxide isotherms

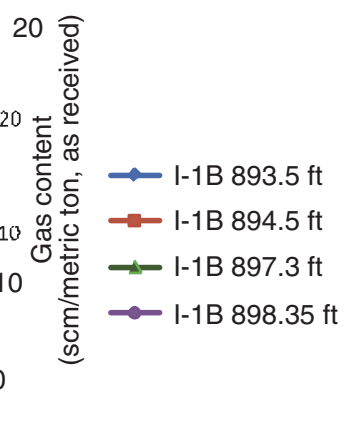

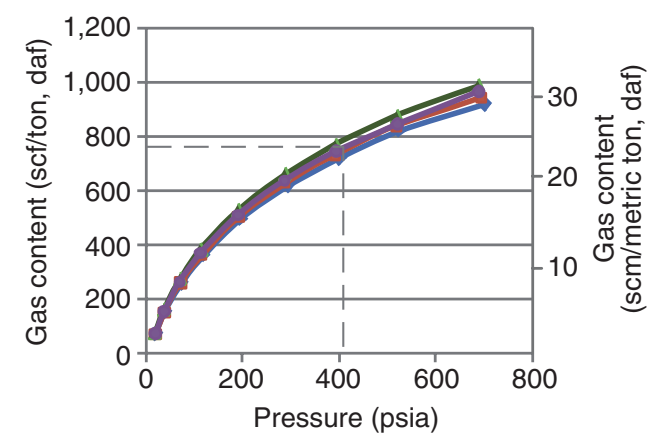

Figure 25. High-pressure $\mathrm{CH}_{4}$ and $\mathrm{CO}_{2}$ isotherms on an as-received (a and c) and a dry-ash free (b and d) basis. Dashed lines denote average sorption capacity at the Tanquary site where the Springfield Coal occurs at a reservoir pressure of $2.79 \mathrm{MPa}$ (404 psia). 


\section{Gas Adsorption Capacity}

Figure 24 compares high-pressure isotherms for $\mathrm{CO}_{2}, \mathrm{CH}_{4}$, and nitrogen gas $\left(\mathrm{N}_{2}\right)$ at $22.8^{\circ} \mathrm{C}\left(73^{\circ} \mathrm{F}\right)$ that present a typical example of sorption capacities for these three gases in the Springfield Coal for M-3. Coal has the most affinity for $\mathrm{CO}_{2}$, followed by $\mathrm{CH}_{4}$, followed by $\mathrm{N}_{2}$.

Langmuir isotherm volumes $\left(\mathrm{V}_{\mathrm{L}}\right)$ (Appendix 10) at $20.0^{\circ} \mathrm{C}$ to $22.8^{\circ} \mathrm{C}\left(68^{\circ} \mathrm{F}\right.$ to $73^{\circ} \mathrm{F}$ ) for $\mathrm{CH}_{4}$ for the Springfield Coal samples studied from three of the project wells range from 9.7 to $13.2 \mathrm{scm} / \mathrm{g}$ (309 to $423 \mathrm{scf} / \mathrm{ton}$ ) on an as-received basis and a range from 12.1 to $15.5 \mathrm{scm} / \mathrm{g}$ (386 to $497 \mathrm{scf} /$ ton) on a daf basis. These volumes are achieved at pressures from 2.45 to $3.39 \mathrm{MPa}$ (355 to $491 \mathrm{psi}$ ). At the in situ coal hydrostatic pressure of $2.66 \mathrm{MPa}$ [387 psi] (depth of $274 \mathrm{~m}$ [899 ft]) and geothermal temperature of $20.5^{\circ} \mathrm{C}\left(69^{\circ} \mathrm{F}\right), \mathrm{CH}_{4}$ adsorption capacity is $\sim 5.3 \mathrm{scm} / \mathrm{g}(170 \mathrm{scf} / \mathrm{ton})$ (as-received basis) and $\sim 7.2 \mathrm{scm} / \mathrm{g}(230 \mathrm{scf} / \mathrm{ton}$ [daf basis]) (Figure 25a and b). Canister gas composition from the Springfield Coal in each of the wells was less than the pure $\mathrm{CH}_{4}$ isotherm values at this pressure, which indicated that the in situ coal was undersaturated with respect to $\mathrm{CH}_{4}$.

For $\mathrm{CO}_{2}, \mathrm{~V}_{\mathrm{L}}$ determined from the Springfield Coal in wells M- $1, \mathrm{M}-3$ and $\mathrm{I}-1 \mathrm{~B}$ at $20.0^{\circ} \mathrm{C}$ to $22.8^{\circ} \mathrm{C}\left(68^{\circ} \mathrm{F}\right.$ to $\left.73^{\circ} \mathrm{F}\right)$ range from 24.0 to $36.8 \mathrm{scm} / \mathrm{g}$ (767 to $1,178 \mathrm{scf} /$ ton) on an as-received basis and 29.9 to $43.8 \mathrm{scm} / \mathrm{g}$ (958 to $1,401 \mathrm{scft} /$ ton) on a daf basis at Langmuir pressure $\left(\mathrm{P}_{\mathrm{L}}\right)$ ranging from 1.3 to $2.3 \mathrm{MPa}$ (187 to $329 \mathrm{psi}$ ) (Appendix 10). To determine the adsorption capacity at the Springfield Coal reservoir conditions, the reservoir pressure of $2.79 \mathrm{MPa}$ (404 psi) is used with the Langmuir equation and the measured $\mathrm{P}_{\mathrm{L}}$ and $\mathrm{V}_{\mathrm{L}}$. This determination results in a $\mathrm{CO}_{2}$ adsorption capacity of $\sim 19.6 \mathrm{scm} / \mathrm{g}(639 \mathrm{scf} / \mathrm{ton})$ on an asreceived basis or $\sim 23.7 \mathrm{scm} / \mathrm{g}$ (769 scf/ton) on a daf basis (Figure $25 \mathrm{c}$ and d).

The Springfield Coal Member, a high volatile bituminous coal, has good $\mathrm{CH}_{4}$ gas content $\left(4.7-6.6 \mathrm{~cm}^{3} / \mathrm{g}\left[150\right.\right.$ to $210 \mathrm{ft}^{3}$ / ton] dmmf). At reservoir pressure and temperature conditions, the Springfield Coal should adsorb at least three times the amount of $\mathrm{CO}_{2}$ as $\mathrm{CH}_{4}$.

\section{Log Analyses}

High-resolution geophysical well logs (3-cm [0.1-ft] interval data measurements) reveal different features of the coal. Although gamma-ray and bulk density logs (Figure 26) are relatively uniform, the shallow induction log curve (Figure 27) shows much higher resistivity in the lower 0.6-0.9 $\mathrm{m}$ ( 2 to $3 \mathrm{ft}$ ) of the Springfield Coal bed than the medium or deep curves. This relationship is seen in all four wells (Figure 28) and is thought to reflect increased freshwater drilling fluid invasion, possibly indicating higher permeability. The fluid invasion generally occurs in the intervals of greatest vitrinite content (vitrinite is the maceral that shows the highest number of cleats). This resistivity effect may potentially be a relative indicator of permeability.
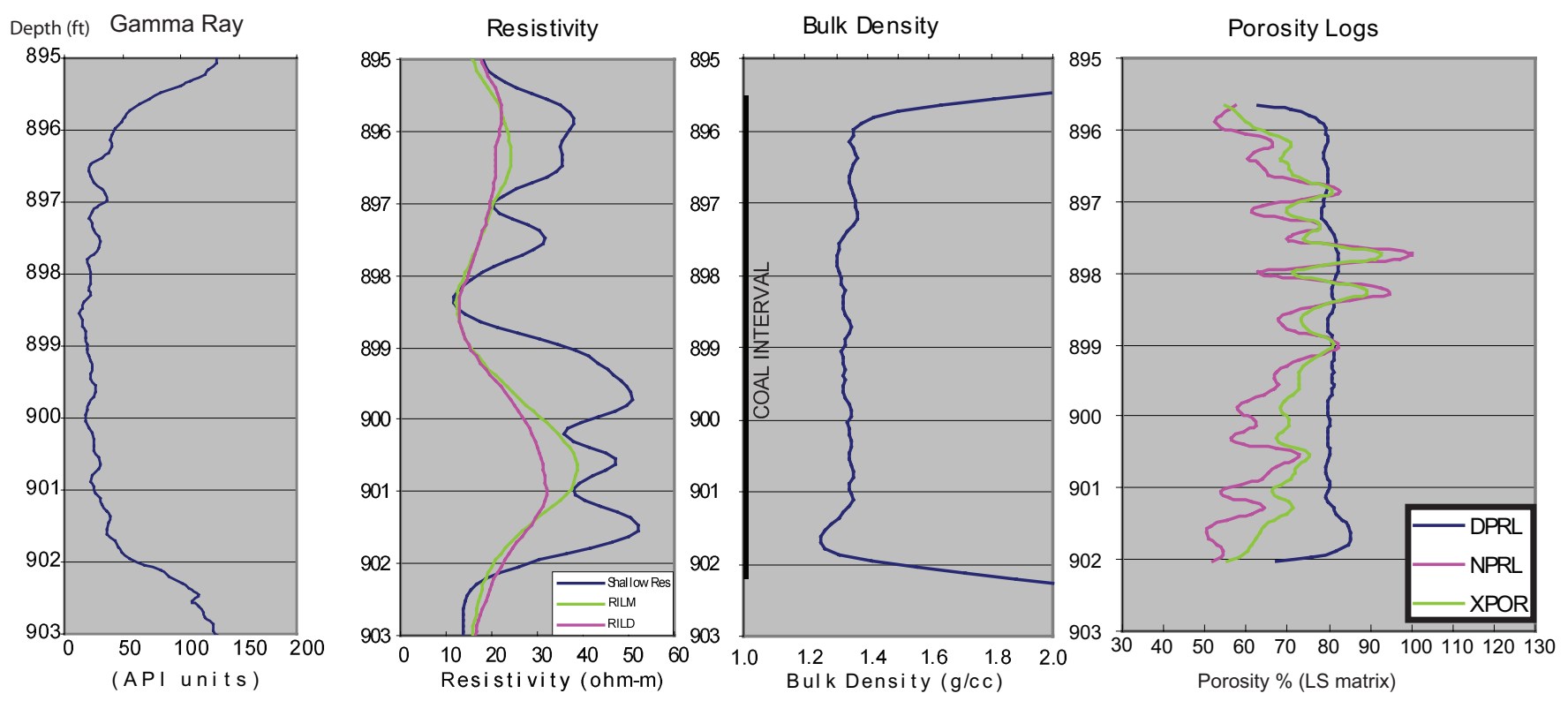

Figure 26. Injection well (I-1B) open-hole log signatures (gamma ray, resistivity, bulk density, and porosity) in the Springfield Coal. Abbreviations: RILM, medium induction log resistivity; RILD, deep induction log resistivity; DPRL, density porosity; NPRL, neutron porosity; XPOR, crossplot porosity; LS, limestone. 

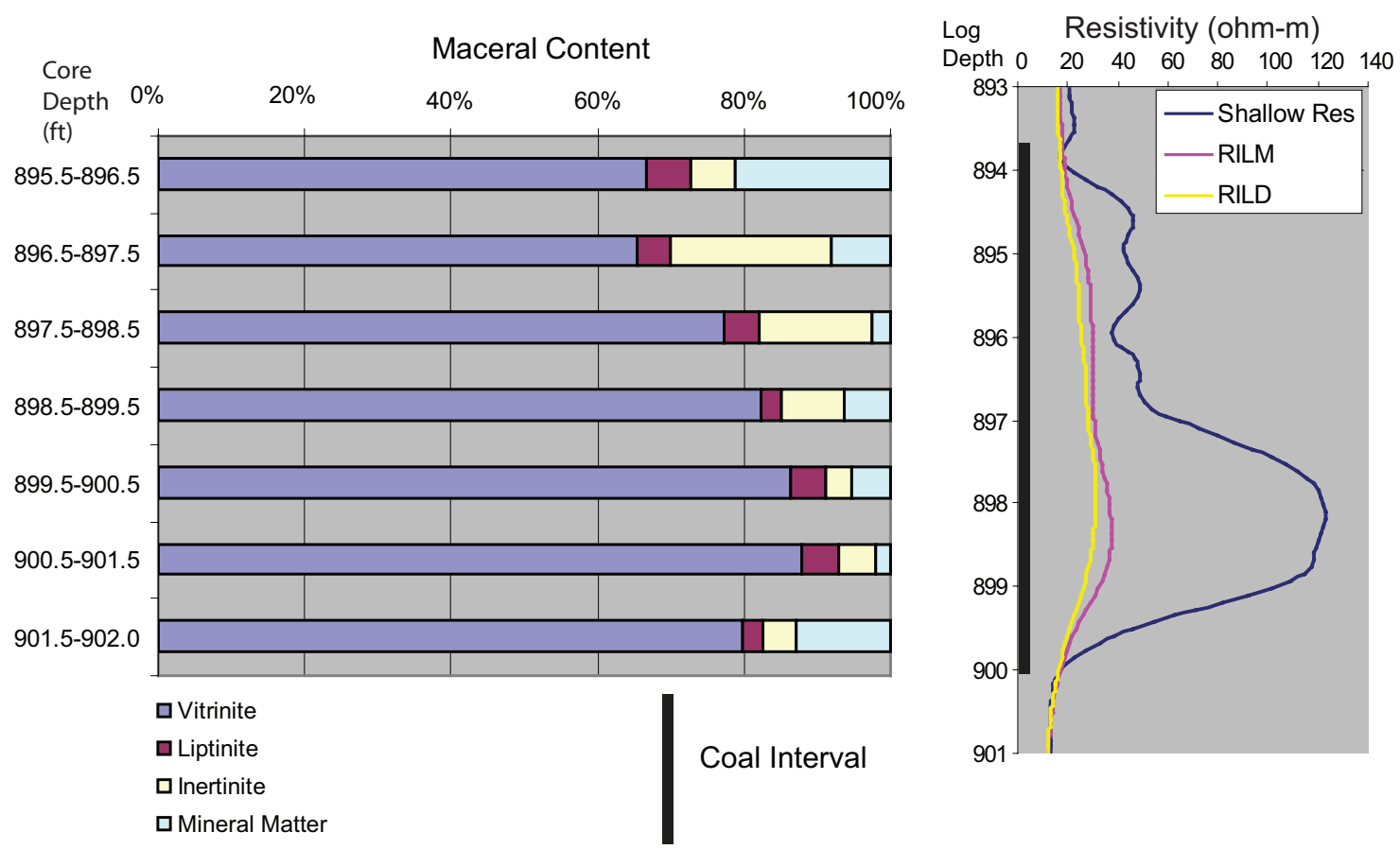

Depth $0 \quad 20 \quad 40 \quad 60 \quad 80 \quad 100 \quad 120 \quad 140$

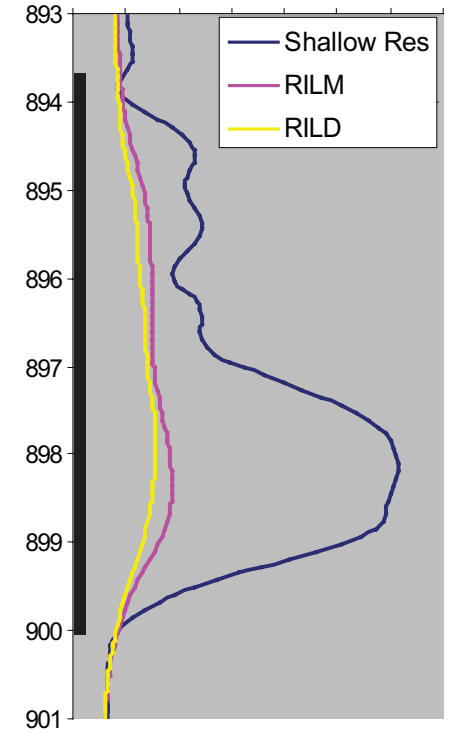

Figure 27. Comparison of maceral content from coal and open-hole log resistivity, M-1 well. Abbreviations: RILM, medium induction log resistivity; RILD, deep induction log resistivity.

\section{$\mathrm{M}-2 \mathrm{~B}$}

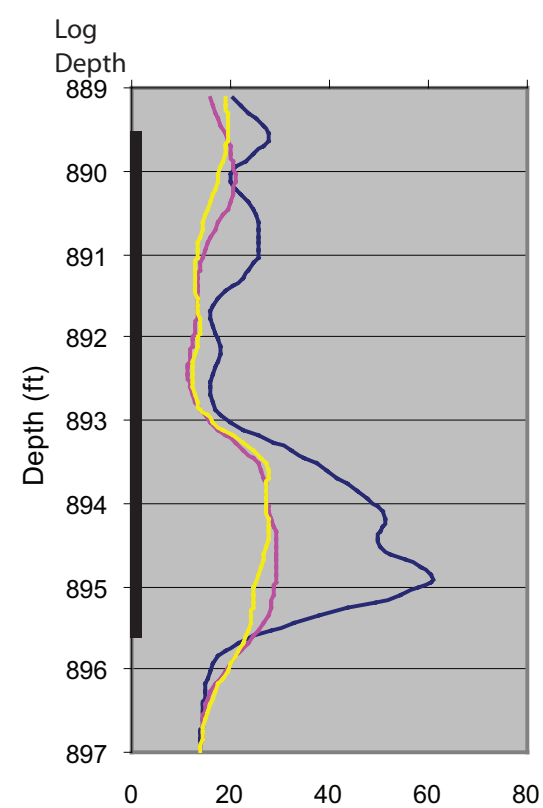

Resistivity (ohm-m)
$\mathrm{M}-1$

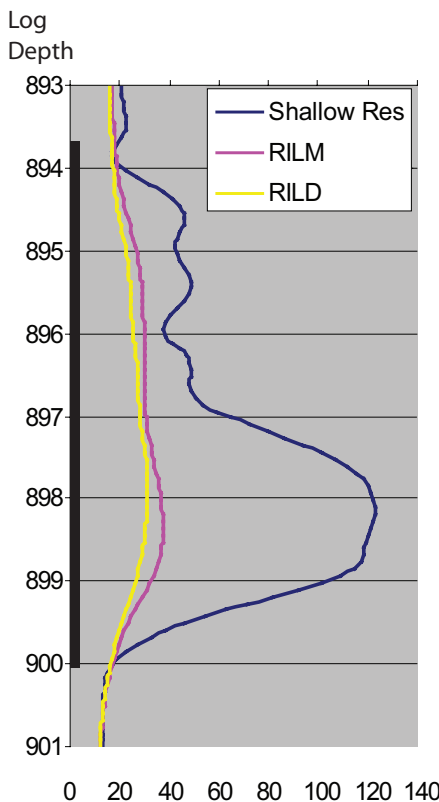

Resistivity (ohm-m)
I-1B

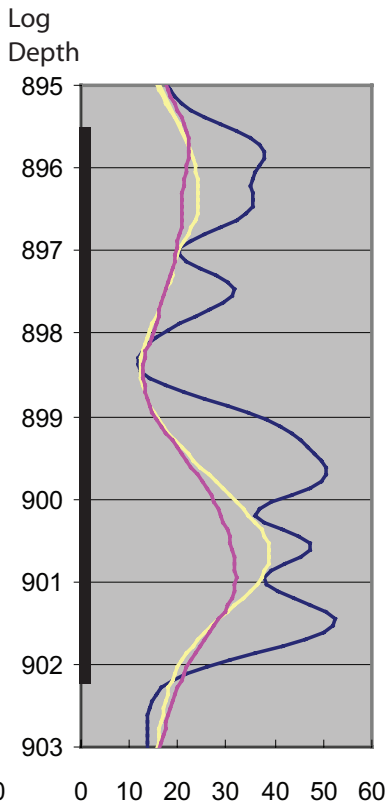

Resistivity (ohm-m)
M-3 (I-1A)

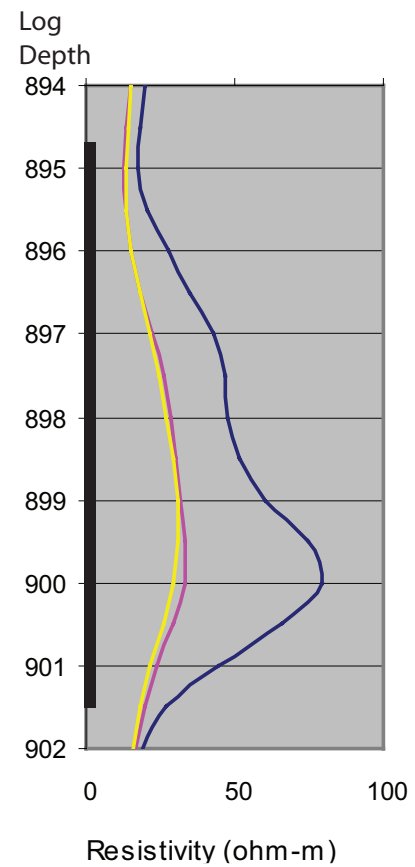

Figure 28. Comparison of Springfield Coal resistivity logs for wells $M-2 B, M-1, I-1 B$, and $M-3(I-1 A)$. 
For pressure transient and numerical modeling, porosity is required. The porosity logs are generally unreliable in coals. Consequently, the deep resistivity logs were used with Archie's equation relating porosity and resistivity via the formation resistivity factor for completely water saturated pore space. Because the porosity type is in the cleats or fractured, a value of 1 was used for the cementation exponent $\mathrm{m}$. The porosity calculated was about $3 \%$, which compared well with expected porosity for cleated coal seams.

\section{Pore Size Description}

An important observation of this study is the wide range of variations in coal characteristics from the top to the bottom of the seam for all the parameters analyzed. One of the reasons for such variations is the change in coal lithotype, being relatively bright at the very top, becoming duller below, and getting brighter again in the lower part (Figure 27). (Brightness is a descriptive modifier for clarain, the banded coal. Brightness indicates varying amounts of inertinite and mineral matter, which dulls the brightness of the coal.) This trend is also expressed well by the maceral composition on a mineral matter free basis (Figure 19), where in both the M-1 and M-3 (I-1A) wells the Springfield Coal vitrinite content is higher at the very top, decreases in the middle, and increases again in the lower part of the seam.

With liptinite content being similar throughout the coal seam section, the ratio of vitrinite to inertinite ratio will influence the coal properties, such as micropore volume (Figure 29), or to a lesser extent, the Brunauer-Emmett-Teller (BET) surface area or mesopore volume (Figure 30). Mineral matter (ash) content in the coal (Figure 18) is another factor that, in addition to maceral composition, significantly influences coal properties. Coal beds with higher ash content on bulk volume basis by definition have less coal. The surface area available for adsorption increases or decreases inversely with the ash content (Figures 18 and 20). A negative correlation between coal surface areas and ash contents has been documented for some Illinois Basin coals (Mastalerz et al., 2008a), although it is not a universal regularity. Such differences in coal properties or composition within a coal bed influence $\mathrm{CO}_{2}$ injection.

Combined data of low-pressure adsorption of $\mathrm{N}_{2}$ and $\mathrm{CO}_{2}$ and high-pressure adsorption of $\mathrm{CH}_{4}$ and $\mathrm{CO}_{2}$ indicate that lithotype composition in combination with mineral matter content influences microporosity, mesoporosity, and gas adsorption capacity to a large extent. In general, vitrain with low mineral matter content has the highest surface area and mesopore and micropore volume. Fusain has the lowest surface area and mesopore and micropore volume; fusain also has a lower $\mathrm{CO}_{2}$ adsorption capacity. Unexpectedly, for the Tanquary coal samples, vitrain had lower adsorption capacity than did clarain and bright clarain. This difference is discussed in a subsequent paragraph of this section.

Small pore dimensions and surface area of the coals were examined because they affect adsorption and change with $\mathrm{CO}_{2}$ adsorption. Laboratory microporosity (<2 nm $\left.\left[7.9 \times 10^{-8} \mathrm{inch}\right]\right)$ and mesoporosity (2-50 nm $\left.\left[7.9 \times 10^{-8}-2.0 \times 10^{-6} \mathrm{inch}\right]\right) \mathrm{stud}-$ ies of the coal before and after saturation with high-pressure $\mathrm{CO}_{2}$ (Mastalerz et al., 2008b, 2010) were conducted to examine changes in coal structure. Low-pressure gas adsorption measurements were conducted on a Micromeritics ASAP-2020 apparatus (Mastalerz et al., 2008b). Coal samples weighing 1 to $2 \mathrm{~g}(0.04-0.07 \mathrm{oz})$ were analyzed with $\mathrm{N}_{2}$ and CO $\mathrm{CO}_{2}$ gases to obtain information about the mesopore (accessible to both gases) and micropore structures (accessible only to carbon dioxide). The instrument's computer software automatically generates adsorption isotherms and calculates surface areas, pore
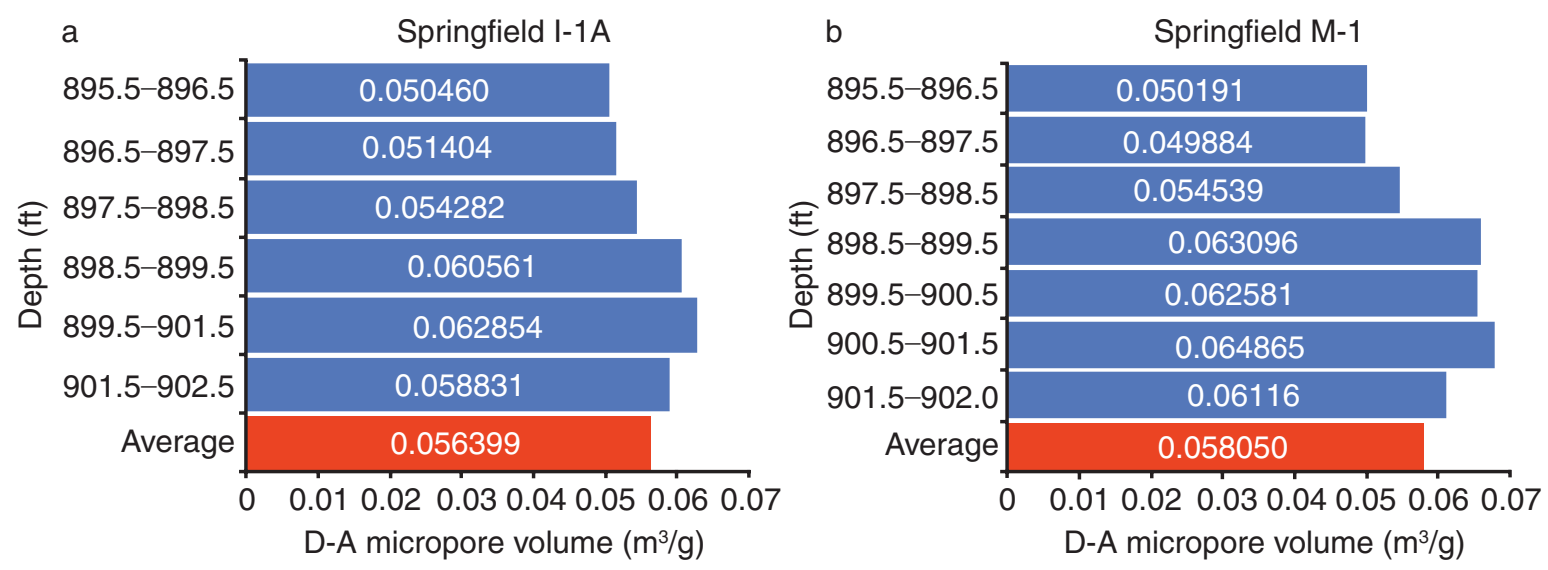

Figure 29. Micropore volume of the Springfield Coal from wells I-1A and M-1 at various depths. 
a

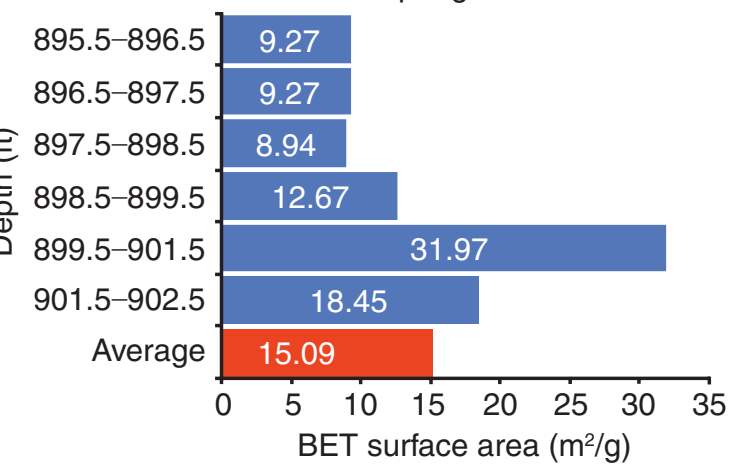

C

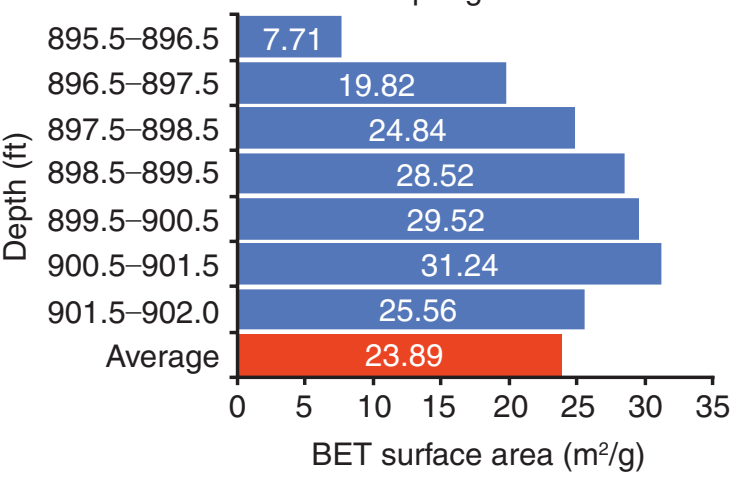

b

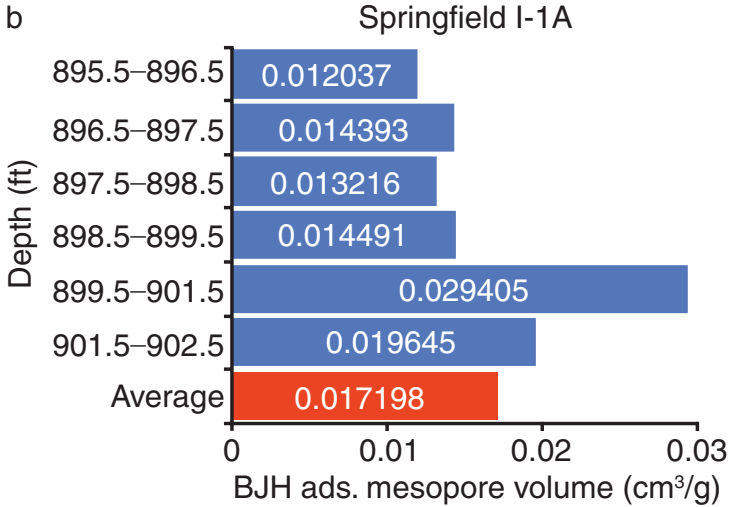

d

Springfield M-1

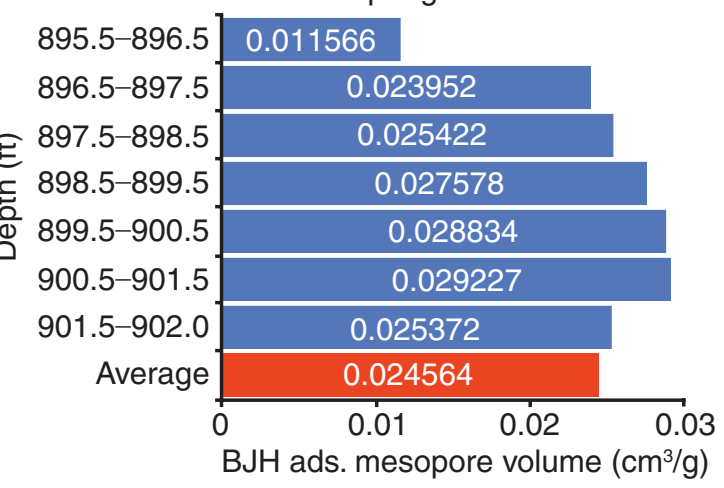

Figure 30. Brunauer-Emmett-Teller (BET) surface area and mesoporosity.

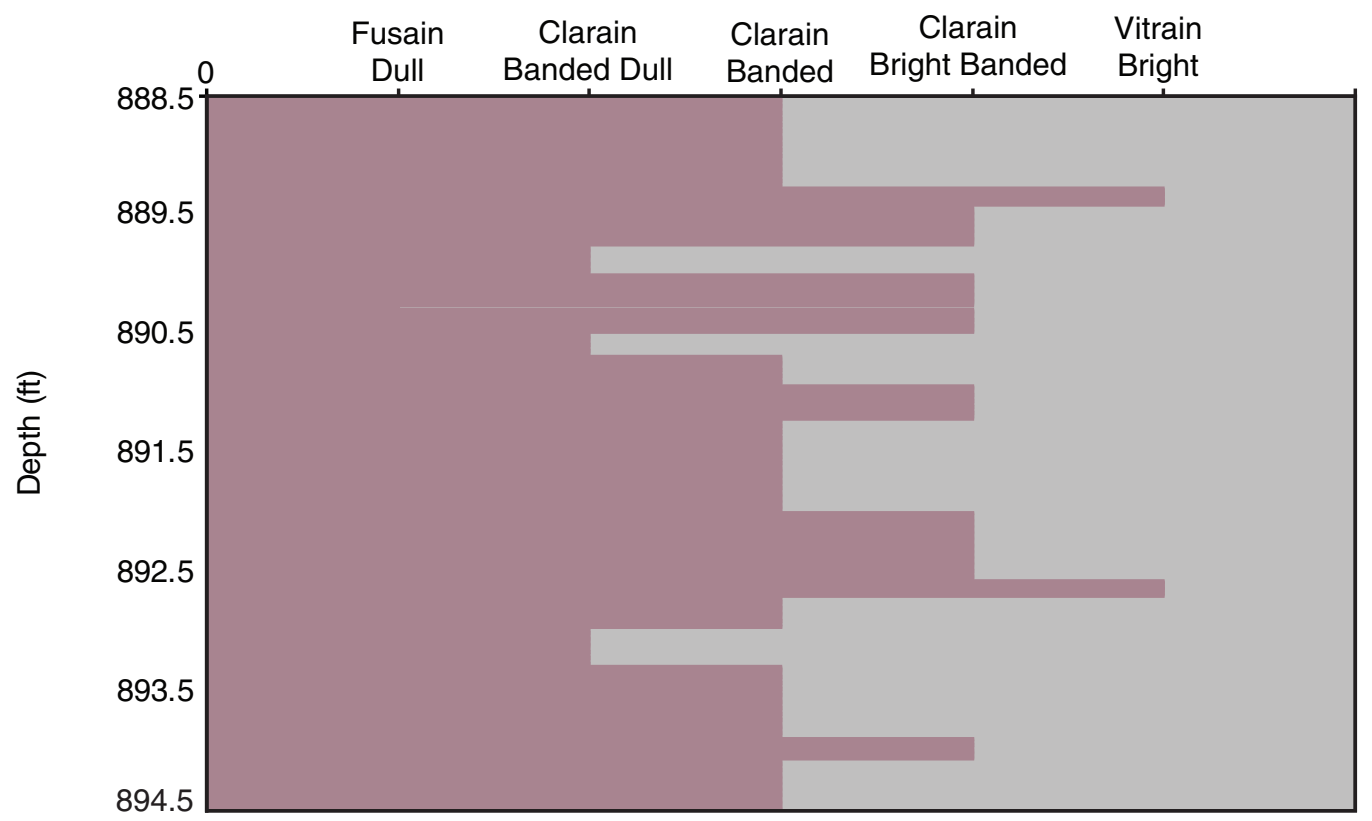

Figure 31. Distribution of Springfield Coal lithotypes at the M-2 well. 
volumes, and pore distributions based on multiple adsorption theories, i.e., Langmuir, BET surface area, Barrett-JoynerHalenda (BJH mesopore volume), Dubinin-Radushkevich (D-R), and Dubinin-Astakhov (D-A), among others (Clarkson and Bustin, 1996, 1999; Webb and Orr, 1997). A detailed description of these theories and techniques can be found in Gregg and Sing (1982).

Appendix 11 shows surface area, mesopore characteristics (determined by $\mathrm{N}_{2}$ adsorption technique), and micropore characteristics (determined by $\mathrm{CO}_{2}$ adsorption technique) of whole coal samples from $\mathrm{M}-1$ and M-3. These data (Figure 30) show that the average BET surface area and BJH mesopore volume are about 1.6 times as large in location $\mathrm{M}-1$ as in $\mathrm{M}-3$ (I-1A). In $\mathrm{M}-1$, the BET surface area averages $23.9 \mathrm{~m}^{2} / \mathrm{g}$, in contrast to $15.1 \mathrm{~m}^{2} / \mathrm{g}$ in $\mathrm{M}-3$; the average BJH mesopore volume is 0.0246 $\mathrm{cm}^{3} / \mathrm{g}\left(0.7871 \mathrm{ft}^{3} /\right.$ ton $)$ in M-1 and $0.0172 \mathrm{~cm}^{3} / \mathrm{g}\left(0.5510 \mathrm{ft}^{3} /\right.$ ton $)$ in M-3. These are large differences considering the small distance between the well locations. The analyses were repeated several times, interchangeably for both locations, to eliminate any experimental errors. In contrast to mesopore characteristics, micropore characteristics are very similar in both locations. The Springfield Coal at location M-1 does have larger micropore surface area and micropore volume, but these differences are small compared with those registered by mesopores (Appendix 11 and Figure 29).

Mesopore and micropore characteristics depend significantly on lithotype composition. Coal lithotypes have been described in detail for the Springfield Coal in M-2 (Figure 31). The coal is generally well-banded clarain, which varies in brightness. The very bright bands are due to the predominance of vitrain, whereas the duller layers of clarain are due to the presence of fusain and/or mineral matter. Typically, vitrain adsorbs the most $\mathrm{N}_{2}$ and $\mathrm{CO}_{2}$, followed by bright clarain and clarain (Figure 32). Fusain adsorbs significantly less nitrogen and $\mathrm{CO}_{2}$. This result supports the expected relationship between adsorption, surface area, mesopore volume, and micropore volume with lithotypes. The "brighter" lithotypes of Illinois Basin coals are expected to have greater surface area and pore volume and adsorb greater $\mathrm{CO}_{2}$ volume (Mastalerz et al., 2008a, 2008b).

Figure 33 compares high-pressure $\mathrm{CO}_{2}$ adsorption isotherms of hand-picked lithotype samples from the Tanquary site's Springfield Coal samples. As expected, fusain has the least adsorption capacity (Figure 33b). However, for the vitrain, bright clarain, and clarain, the relative adsorption capacity was not as expected. Even though vitrain has the largest surface area and mesopore and micropore volume (Figure 29), it does not have the greatest adsorption capacity (Figure 32). Bright clarain and clarain, at reservoir pressure of $2.66 \mathrm{MPa}$ (386 psi), have adsorption capacity 133\% greater than vitrain. The adsorption capacity of fusain is $25 \%$ less than that of vitrain. Langmuir parameters for these lithotypes are given in Appendix 12 . Bright clarain and clarain are nearly identical for pressure less than $2.8 \mathrm{MPa}(400 \mathrm{psia})$.

Mastalerz et al. (2008a, 2008b) documented the higher adsorption capacity of vitrain than of other lithotypes for several Illinois Basin coals, including the Springfield Coal Member. Bright clarain and clarain have similar adsorption capacities (Figure 33); petrographically they differ from vitrain by having significantly larger inertinite and mineral matter. Inertinite in clarain and bright clarain is represented dominantly by micropore-rich semifusinite and inertodetrinite, not fusinite, which dominates the fusain lithotype. Additionally, a possible explanation for the increased adsorption capacity of clarain is the effect of macropores (pores wider than $50 \mathrm{~nm}\left[2.0 \times 10^{-6} \mathrm{inch}\right]$ ) on $\mathrm{CO}_{2}$ and $\mathrm{CH}_{4}$ adsorption isotherms. Macropores are not accounted for in the mesopore and micropore analyses. The presence of macropores in semifusinite and inertodetrinite of the clarain and bright clarain may contribute to some increased adsorption capacity, in addition to the more abundant micropores and mesopores. However, macropores would not add significantly to the very low mesopore and micropore volumes of fusain and thus would not significantly increase the low adsorption values seen in this analysis (Figure 33).

Differences in coal properties and lithotypes influence $\mathrm{CO}_{2}$ adsorption significantly. Furthermore, these differences may influence the $\mathrm{CO}_{2}$ injection process significantly. Comparing a resistivity log to maceral composition in location M-1 (Figure 27 ), it is clear that high shallow resistivity values correspond to high vitrinite and low mineral matter intervals. It is expected that such intervals have higher permeability and will respond differently to $\mathrm{CO}_{2}$ injection than the intervals of lower vitrinite and higher mineral matter content that show lower resistivity. Owing to generally higher micropore volume, such vitriniterich intervals are expected to have higher adsorption capacity but lower adsorption rates than intervals richer in inertinite materials (Karacan and Mitchell, 2003).

In addition to vertical differences in coal properties within the same seam at a single well, some differences were found laterally within the same coal. The largest distance between surface locations of the wells at the site is between M-1 and M-3 (45.9 m [150.7 ft]), which is considered very short compared with commercial CBM well spacing. Although some parameters are similar, for example, ash content (Figure 20) and gas content (Figure 21), differences are noted in maceral composition. Well M-1 had greater vitrinite (average $85.1 \%$ compared with $80.5 \%$ ) and smaller inertinite contents than M-3 (Figure 19). Similarly, compared with M-3 (I-1A), M-1 has a much larger BET surface area (average $23.9 \mathrm{~m}^{2} / \mathrm{g} \mathrm{vs} 15.1 \mathrm{~m}^{2} / \mathrm{g}$; Figure 30 ) and mesopore volume (average $0.0246 \mathrm{~cm}^{3} / \mathrm{g}$ vs. $0.0172 \mathrm{~cm}^{3} / \mathrm{g}$; Figure 30), and slightly larger micropore volume (average 0.0580 $\mathrm{m}^{3}$ /g vs. $0.0564 \mathrm{~m}^{3} / \mathrm{g}$; Figure 29). These variations are large considering the short distance between wells and might result in unexpected differences in response to $\mathrm{CO}_{2}$ injection, such as the injection rate and, consequently, the time needed for the injected $\mathrm{CO}_{2}$ to migrate to a monitoring well. The differences in pore size, surface area, and lithotypes may also explain the slightly lower M-3 permeability to water estimated from the pre- $\mathrm{CO}_{2}$ water pressure falloff tests. 


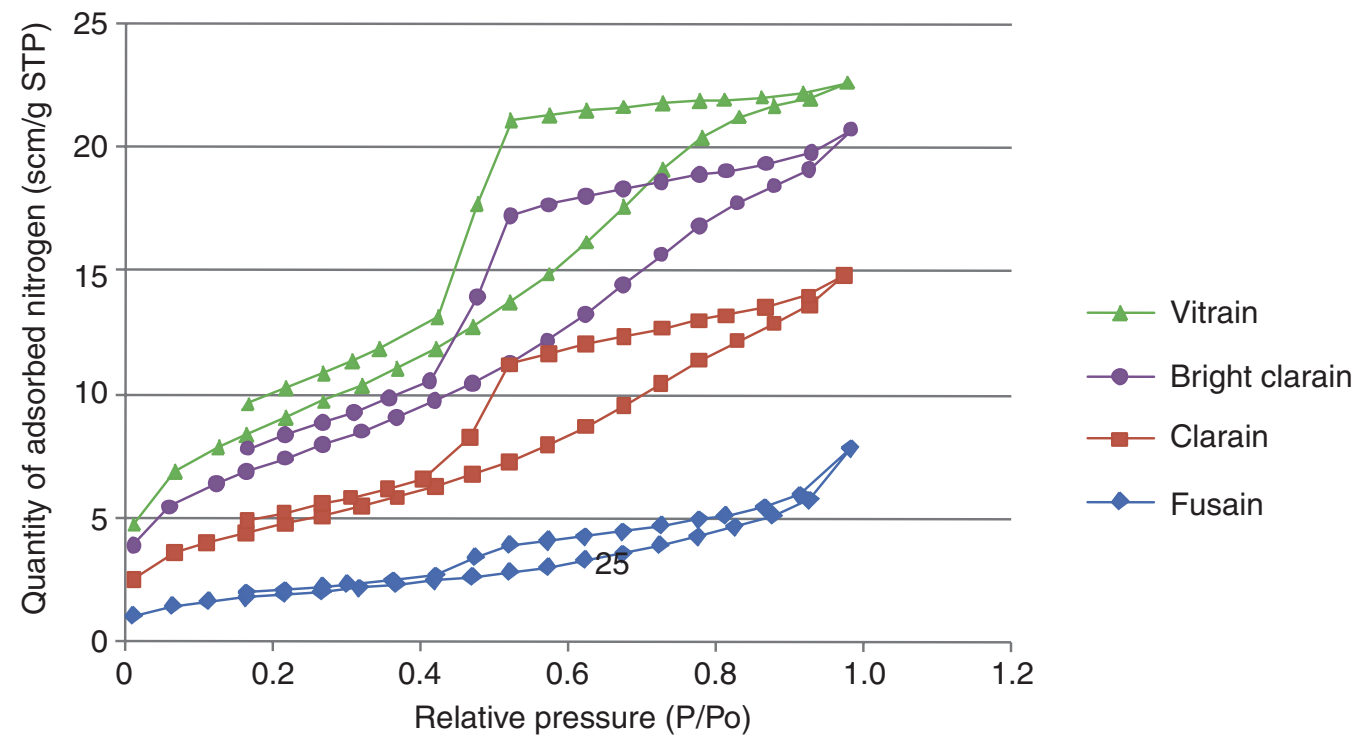

b

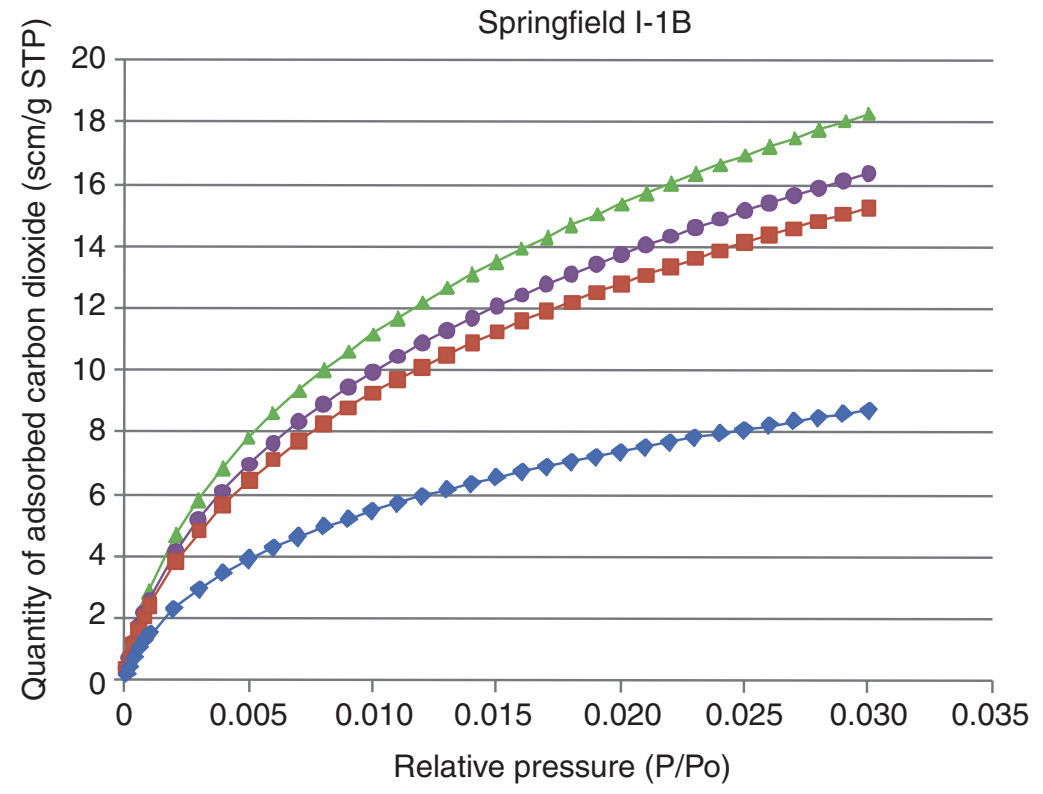

Figure 32. (a) Quantity of adsorbed $\mathrm{N}_{2}$ at low pressure in isolated lithotypes of the Springfield Coal in location l-1B. Both adsorption and desorption curves are included. (b) Quantity of adsorbed $\mathrm{CO}_{2}$ at low pressure in isolated lithotypes of the Springfield Coal. Note the decrease in the quantity of adsorbed $\mathrm{N}_{2}$ and $\mathrm{CO}_{2}$ from vitrain through clarains to fusain.

Based on $\mathrm{CO}_{2}$ phase diagram and considering reservoir temperature and pressure conditions $\left(21^{\circ} \mathrm{C}\left[69.8^{\circ} \mathrm{F}\right]\right.$ and $2.66 \mathrm{MPa}$ [386 psi]) alone, the $\mathrm{CO}_{2}$ injected in the Springfield Coal Member would be expected to be in the gas phase and have a density of $\sim 0.2 \mathrm{~g} / \mathrm{cm}^{3}$. However, as demonstrated by recent studies (Melnichenko et al., 2009) on the Seelyville Coal Member of the Linton Formation (Pennsylvanian) from the Illinois Basin in western Indiana, at simulated reservoir conditions, the apparent density of the adsorbed $\mathrm{CO}_{2}$ becomes significantly larger (by a factor of 3 to 4 ) in micropores, indicating that about half of the micropore volume is occupied by liquid-like, not gas-like, $\mathrm{CO}_{2}$. In even smaller nanometer-size pores, nearly all the pore space is filled with liquid-like $\mathrm{CO}_{2}$. A sample from the Springfield Coal Member from the Tanquary site behaved in a similar way. The densification of $\mathrm{CO}_{2}$ from a gaseous phase to a liquid state in the micro- and nanoscale pores has very significant operational and reservoir capacity ramifications. The sorption capacity of coal is also strongly affected by the phase state (subcritical or supercritical) of the injected fluid (Krooss et al., 2001). 

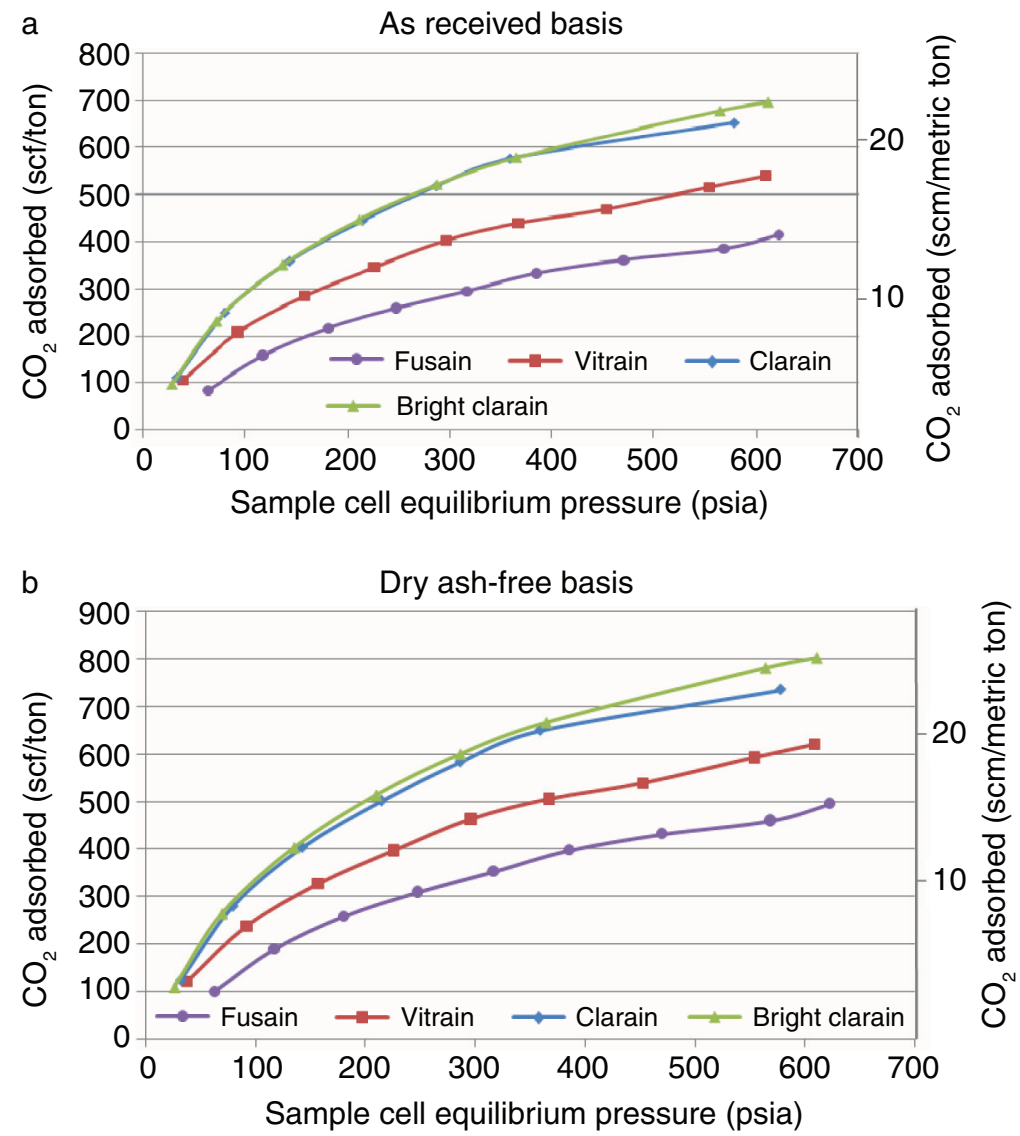

\begin{tabular}{|l|c|c|c|c|}
\cline { 2 - 5 } \multicolumn{1}{c|}{} & V & L & I & MM \\
\hline Vitrain & 93.8 & 1.8 & 2.8 & 1.6 \\
\hline Bright clarain & 72.0 & 4.2 & 16.6 & 7.2 \\
\hline Clarain & 64.6 & 4.6 & 25.2 & 5.6 \\
\hline Fusain & 5.4 & 1.0 & 93.6 & 0.0 \\
\hline
\end{tabular}

Figure 33. Maceral-specific high-pressure $\mathrm{CO}_{2}$ adsorption isotherms from Tanquary site Springfield Coal samples, on (a) as-received basis and (b) dry ash free basis.

The $\mathrm{CO}_{2}$ isotherms indicate that the coal can accommodate at least three times as much $\mathrm{CO}_{2}$ as $\mathrm{CH}_{4}$ at the initial coal pressure of 2.65 MPag (384 psig) (Figure 25). This ratio agrees with previous estimates on the Illinois Basin coals by Mastalerz et al. (2004, Figure 97) based on $17^{\circ} \mathrm{C}\left(62^{\circ} \mathrm{F}\right)$ isotherms, where a 3.7 to $5.7 \mathrm{CO}_{2} / \mathrm{CH}_{4}$ ratio was documented at a pressure of 2.100 $\mathrm{MPa}(300 \mathrm{psi})$ and had a slightly decreasing trend with increase in pressure. However, as mentioned in the previous paragraph, possible densification of $\mathrm{CO}_{2}$ and its transformation into the liquid-like phase (with $\mathrm{CH}_{4}$ remaining unchanged) may raise this potential storage ratio of $\mathrm{CO}_{2} / \mathrm{CH}_{4}$ significantly.

The Springfield Coal (I-1B well, $895.6 \mathrm{ft}$ ) was analyzed using small-angle neutron scattering (SANS) at Oak Ridge National Lab and ultrasmall-angle neutron scattering (USANS) at the Center for Neutron Research, National Institute of Standards and Technology (NIST). The total porosity, volume fraction of pores accessible to gas, and specific surface area were determined under vacuum and at high-pressure conditions up to $380 \mathrm{bar}$. Total porosity was determined to be $8 \%$, and the fraction of total porosity accessible to $\mathrm{CO}_{2}$ was calculated to be $26 \%$ of the total porosity. The remaining pore fraction is smaller than the micropore size and is thought to be too small to be accessible to $\mathrm{CO}_{2}$. This study supports previous observations (Melnichenko et al, 2009) on the Seelyville Coal that $\mathrm{CO}_{2}$ densifies in the microporous coal network and provided another determination of the $\mathrm{CO}_{2}$ accessible fraction of the pore volume. 


\section{Pressure Transient Analyses}

As part of the site development and design, water pressure transient tests between the first two wells drilled were conducted to provide information that would lead to a decision on the location of the remaining wells at the site. (Pressure transient water injection equipment is described in Appendix 13.)

Analytical Solution. PIE pressure transient software (WTS Ltd., 1997) was used for the analytical pressure transient analyses. Homogenous and isotropic models were used for the analyses. Pressure falloff tests of M-1 and M-3 gave permeability estimates of $0.0044 \mu \mathrm{m}^{2}(4.4 \mathrm{mD})$ and $0.0035 \mu \mathrm{m}^{2}(3.5 \mathrm{mD})$, respectively. After wells $\mathrm{M}-2$ and I-1B were drilled, additional pressure falloff tests were completed using water injection. The injection of water into these two wells also provided data for a pulse test analysis between all four wells. The permeability of M-2 and I-1B was $0.0048 \mu^{2}(4.8 \mathrm{mD})$ and $0.005 \mu \mathrm{m}^{2}(5.0$ $\mathrm{mD})$. The arithmetic average for permeability is $0.0044 \mu \mathrm{m}^{2}(4.4 \mathrm{mD})$.

Results of the four-well pulse test analyses gave a butt and face cleat permeability of $0.0012 \mu \mathrm{m}^{2}(1.2 \mathrm{mD})$ and $0.0096 \mu \mathrm{m}^{2}$ $(9.6 \mathrm{mD})$, respectively, which is a butt cleat to face cleat permeability ratio of 0.12 . The geometric average of the directional permeability is $0.0046 \mu \mathrm{m}^{2}(3.4 \mathrm{mD})$, which compares relatively well with the average permeability from the analyses of the individual well pressure falloff tests $\left(0.0044 \mu \mathrm{m}^{2}[4.4 \mathrm{mD}]\right)$.

Numerical Solution. The reservoir simulator used for the study was the COMET3 (binary isotherm: $\mathrm{CH}_{4}$ and $\mathrm{CO}_{2}$ ) model. General details on the model theory are provided in Appendix 13.

Model construction. A grid was generated based on the exact bottomhole locations of the coal seam monitoring wells M-1, M-2, and M-3 (Figure 11). Due to the very short distance between the injector I-1B and the coal seam monitoring wells (from $15.79 \mathrm{~m}$ to $30.47 \mathrm{~m}$ [51.80 ft to $99.97 \mathrm{ft}]$, Figure 11), the grid was refined with grid blocks as small as $0.6 \mathrm{~m} \times 0.6 \mathrm{~m}(2 \mathrm{ft} \times 2 \mathrm{ft})$.

A one-layer, 3.2-ha (7.9-acre) model was constructed for the simulation study. The simulation grid was oriented to respect the face-cleat orientation of $\mathrm{N} 67^{\circ} \mathrm{E}$ (X-axis). $\mathrm{M}-2$ was perfectly aligned with the injector, thus allowing the implementation of a permeability anisotropy and higher permeability in that direction. M-3 is slightly to the west of the butt cleat orientation of $\mathrm{N} 32^{\circ} \mathrm{W}$, and $\mathrm{M}-1$ is east of the butt cleat orientation (Appendix Figure A13-4).

An aquifer (Carter-Tracy unsteady state) was added on each side of the model to simulate the infinite extent of the coal beyond the gridded model. The aquifer was given the same attributes as the reservoir itself (thickness, porosity, permeability, anisotropy, and compressibility). A three-dimensional view of the model is also shown on Appendix Figure Al3-5. A multiplication factor of 5 between the vertical axis and the horizontal axis was used to improve the view of the model.

History matching (calibration). Two slugs of water were injected at I-1B for a total volume of $2.0 \mathrm{~m}^{3}$ (12.5 bbls) followed by two slugs at M-2 for a total volume of $2.2 \mathrm{~m}^{3}$ (13.5 bbls) between June 17, 2008, and June 20, 2008. Appendix Figure A13-6 shows the injection profile (in dark blue for I-1B and in light blue for $\mathrm{M}-2$ ), which was replicated in the model.

During the manual history matching process, the field measured water injection rates (I-1B and M-2) were specified and the bottomhole pressures at all the wells were matched. The specification of a water injection rate did not necessarily mean that a given model was capable of injecting this water volume; consequently, a review of the model output was made to ensure that the field observed injection water volume was attained. The pressure transient analyses (analytical) were used as a starting basis for the numerical model characteristics. Based on these results, the average permeability varied between 0.0034 and $0.0054 \mu \mathrm{m}^{2}$ (3.4 and $5.4 \mathrm{mD}$ ) and anisotropy between 5:1 and 10:1. A value of $1.04 \times 10^{-8} / \mathrm{Pa}\left(72 \times 10^{-6} / \mathrm{psi}\right)$ for pore compressibility was used in the model, based on a study of properties of coal in general and for Illinois Basin coals.

Appendix Figure A13-7 illustrates the history matching results for the injector and the three monitoring wells. Each plot clearly illustrates the pressure response to the water injection with four very distinct peaks. In general, the results were very good except for coal seam monitoring well M-3, which exhibits a small difference in pressure response.

Calibrating the model to match the pre- $\mathrm{CO}_{2}$ water injection data provided the baseline parameters to the $\mathrm{CO}_{2}$ injection history match. An average permeability value of $0.0049 \mu \mathrm{m}^{2}(4.9 \mathrm{mD})$ was found for the best match with an anisotropy of 8.2 corresponding to a face cleat permeability of $0.014 \mu \mathrm{m}^{2}(14 \mathrm{mD})$ and a butt cleat permeability of $0.0017 \mu \mathrm{m}^{2}(1.7 \mathrm{mD})$. The initial value of $1.04 \times 10^{-8} / \mathrm{Pa}\left(72 \times 10^{-6} / \mathrm{psi}\right)$ for the pore compressibility gave the best results. These results are consistent with analytical solutions.

\section{MVA Techniques and Baseline Characterization}

\section{MVA Plan}

The Monitoring, Verification, and Accounting (MVA) program at the Tanquary ECBM pilot site was designed specifically to the planned injection duration and $\mathrm{CO}_{2}$ volume. The short duration of the pilot study (18 months) and small $\mathrm{CO}_{2}$ injection volume, 92.3 tonnes (101.7 tons), meant that only limited resources were needed for the MVA program. 
The goals of the MVA program were (1) to deploy and test the monitoring capabilities of a few MVA techniques, and (2) use the techniques to detect significant $\mathrm{CO}_{2}$ leakage events should they occur.

The MVA techniques deployed at the site consisted of the following:

- atmospheric monitoring of $\mathrm{CO}_{2}$ concentrations for human health and safety,

- modeling of groundwater flow and particle tracking,

- monitoring of the inorganic compounds and isotopes in the shallow groundwater,

- compositional analysis of gas samples collected from monitoring wells installed in the Springfield Coal seam, and

- CIR imagery of the pilot site to locate and examine plant stress as an indicator of $\mathrm{CO}_{2}$ leakage.

A short summary of some of the MVA methods is provided here, and further details are given in Appendix 14. Additional operational activities that were included in the MVA program, such as monitoring $\mathrm{CO}_{2}$ injection rates and volumes and injection reservoir temperature and pressures, are reported in another section of this report: Field Observations During Active $\mathrm{CO}_{2}$ Injection.

Groundwater modeling was required to design a groundwater monitoring system capable of detecting any small and large $\mathrm{CO}_{2}$ leaks to shallow groundwater from the injection well and well annulus. The modeling provided estimates of the likely flow rate and transport direction of any $\mathrm{CO}_{2}$ leakage from the injection point into the groundwater and the risks to the environment and human health from any $\mathrm{CO}_{2}$ leakage. The software used for the modeling was GFLOW v2.1.0 (Haitjema, 2005). An assumption was made that if a leak occurred at the injection well or the well's annulus, the $\mathrm{CO}_{2}$ would enter the surficial aquifer at that point. The particle tracking option of GFLOW was used to determine the direction and travel time for a hypothetical $\mathrm{CO}_{2}$ leak at the ECBM project site. The model assumed a non-reactive particle that is not subject to any retardation processes such as sorption or chemical/biological transformations with groundwater constituents, aquifer materials, or microbes. Thus, the model was predicated on conservative parameters and likely to predict the greatest distances the particle would travel from the source. Model results indicated that a $\mathrm{CO}_{2}$ plume released from the hypothetical leak at the injec-

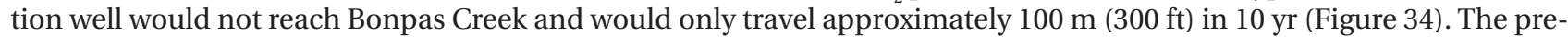
dicted distance that $\mathrm{CO}_{2}$ would travel in the groundwater under the leak conditions is small because the hydraulic gradient near the injection well is very low, resulting in slow groundwater flow. Thus, for the scenario modeled, $\mathrm{CO}_{2}$ leakage would not pose a significant risk to groundwater resources in the vicinity of the injection site.

Because of the site's proximity to the Wabash River, a Wabash River flood was simulated by increasing the assigned hydraulic heads in the Wabash River by $4.5 \mathrm{~m}$ (14.8 ft). This increase in the river level did not significantly change the flow in Bonpas Creek or the hydraulic heads at the three test points.

Chemical and isotopic analyses of the gas and water samples collected from the shallow groundwater monitoring wells were completed to help characterize the original, pre-injection groundwater composition. These analyses provided a baseline for subsequent samples that could be used to compare and monitor changes that might occur from $\mathrm{CO}_{2}$ or $\mathrm{CH}_{4}$ migration into the local groundwater aquifer due to the $\mathrm{CO}_{2}$ injection experiment. When an external source of $\mathrm{CO}_{2}$ encounters water, much of the $\mathrm{CO}_{2}$ may dissolve into the water and change the chemistry and the isotopic composition of the dissolved inorganic carbon (DIC) (assuming the isotopic composition of the external source of $\mathrm{CO}_{2}$ is significantly different from the $\mathrm{CO}_{2}$ in the natural system). Continuous pre- $\mathrm{CO}_{2}$ injection monitoring of the shallower aquifer allowed determination of the natural variation in groundwater composition. Sources of naturally occurring fluctuations are seasonal changes that could occur such as precipitation, recharge, and anthropogenic disturbances other than the $\mathrm{CO}_{2}$ injection.

Geochemical modeling coupled with monitoring data is a vital technique for understanding the chemical fate of injected $\mathrm{CO}_{2}$, as well as any changes in groundwater composition resulting from $\mathrm{CO}_{2}$ escaping from the injection formation and migrating into groundwater. For example, the U.S. Geological Survey (USGS) geochemical model PHREEQC (Parkhurst and Appelo, 1999) has been used to predict the extent of mineral trapping of $\mathrm{CO}_{2}$ and potential changes in porosity (Gaus et al., 2008) and the long-term fate of $\mathrm{CO}_{2}$ in the Alberta Basin (Strazisar et al., 2006). Berger et al. (2009) used React 7.0.4 (Bethke and Yeakel, 2007) and PHREEQCI 2.13.2 (USGS, 2007) to create kinetic and equilibrium models for an enhanced oil recovery project led by the MGSC. In this study, the chemical composition of groundwater samples collected from the MVA monitoring wells was input to the USGS geochemical model PHREEQCI. The solid-phase phase equilibria of groundwater samples collected upgradient from the $\mathrm{CO}_{2}$ injection well were compared with those for the downgradient wells to determine whether there was any evidence that $\mathrm{CO}_{2}$ had migrated from the coal seam into the unlithified materials above the bedrock.

Low-altitude aerial remote sensing technology was used to acquire temporal, spatial, and spectral information to support the MVA project goals. This technology provided a detailed analysis and documentation of the ground conditions adjacent to the ECBM site. The digital CIR also provided documentation of the pigmentation and cell structure of green vegetation. If an outside stressor changed the reflectance patterns of the vegetation, the impacted area could be detected and mapped with CIR imagery. 


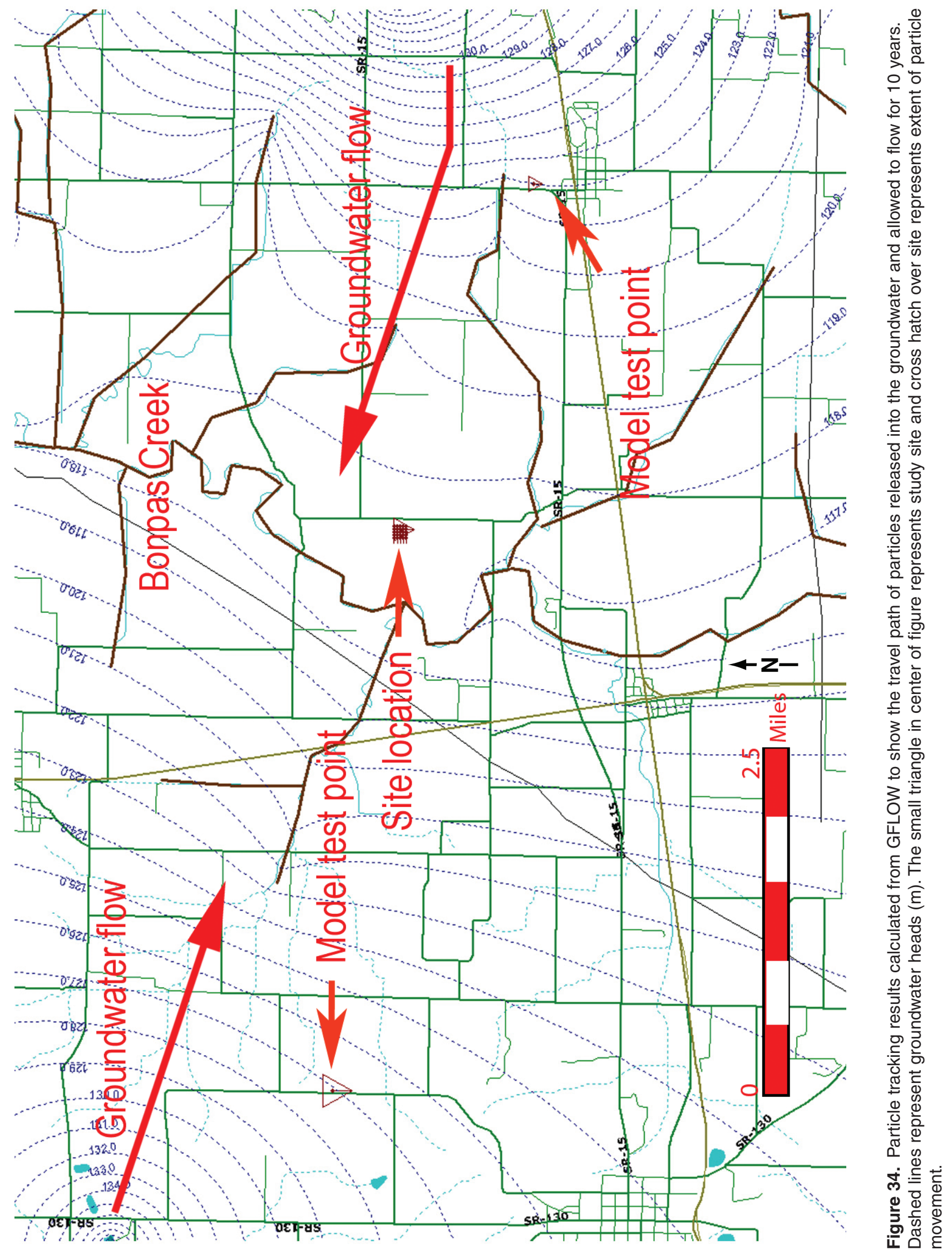




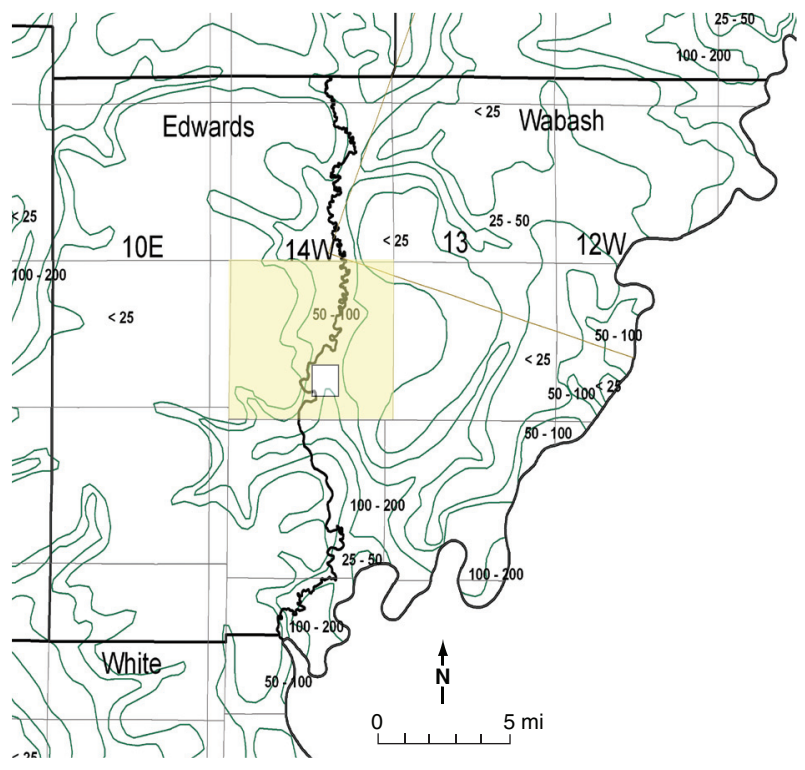

Figure 35. Drift thickness map with T1S R14W highlighted in yellow; the white box within the yellow shaded area identifies the site. Data are from the ISGS database: GISDB_QTGEO. IL_Drift_Thickness_Py (ISGS, 1994), which includes data from Piskin and Bergstrom (1975) and other updated data, accessed March 2008. Township lines are shown in gray. Light brown lines show Indian treaty boundaries.

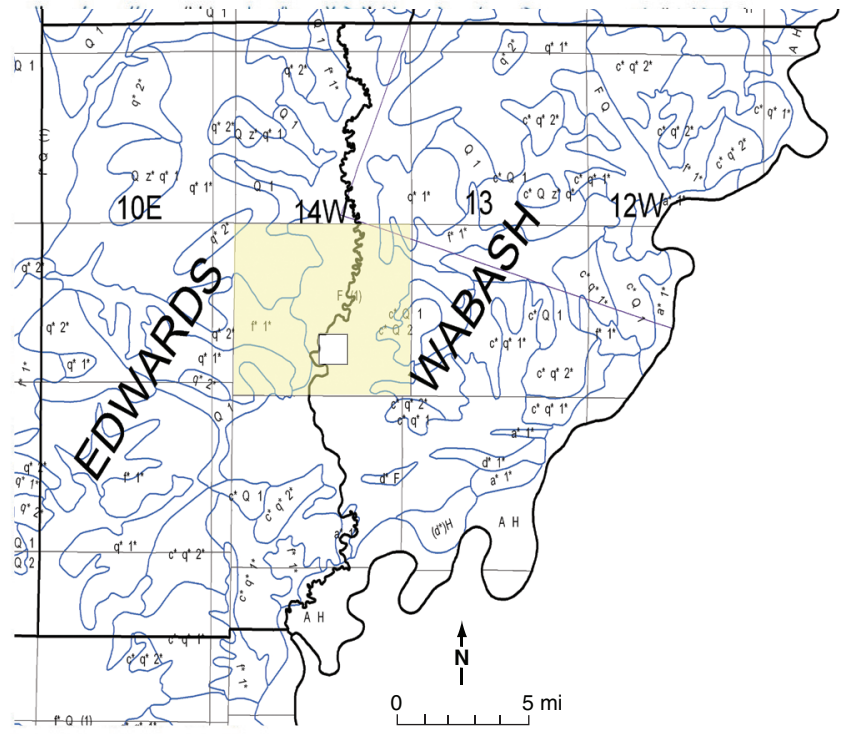

Figure 36. Stack unit map for the area surrounding the study site, with T1S R14W highlighted in yellow. Data are from the ISGS database: GISDB_QTGEO.IL_Stack_Units_ To_15m_Py (ISGS, 1995) which includes data from Berg and Kempton (1988) and other updated data, accessed March 2008. Township lines are shown in gray. Purple lines show Indian treaty boundaries.

\section{MVA Geologic Description}

Glacial Drift Thickness. As in most of Illinois, unlithified sedimentary deposits overlie the bedrock and form the land surface at the Tanquary site. These materials, commonly called glacial drift, or simply drift, consist of various types of sediments that were deposited by ice, wind, and water, including diamicton (till), sand and gravel, and loess. Near the study site, along Bonpas Creek, the drift is 15 to $30 \mathrm{~m}$ (50 to $100 \mathrm{ft}$ ) thick (Figure 35). (The yellow box on Figure 35-39 is the section containing the site; the white box within the yellowed section is the local site area.) Elsewhere, in the centers of Edwards and Wabash counties, the drift thins to less than $7.6 \mathrm{~m}$ ( $25 \mathrm{ft}$ ), but it thickens to 30 to $60 \mathrm{~m}$ (100 to $200 \mathrm{ft}$ ) to the south. Close to the Wabash River valley, the glacial drift consists primarily of valley-train deposits (sand and gravel and some finer-grained material) laid down during both the Wisconsin and Illinois Episodes of glaciation. The valley train deposits laid down in the Wabash River valley become finer grained and have less gravel downstream (Frankie et al., 1996). Late in the Wisconsin Episode, the outlets of the Little Wabash River and Bonpas Creek into the main drainage of the Wabash River were blocked, causing lakes to form. Huge quantities of meltwater that flowed down the Wabash River as the continental glaciers were melting away backed up into Bonpas Creek and the Little Wabash River and formed lakes that persisted for many years. The floors of these valleys are wide and extremely level because they are filled with the fine-grained, lakebed sediments (Frankie et al., 1996).

Stack Unit Map. The stack unit map shown in Figure 36 depicts the succession of geologic materials to a depth of $15 \mathrm{~m}$ (50 $\mathrm{ft}$ ). At the Tanquary site (within section T1S, R14W), the surficial geologic materials are mapped as F(1). The Carmi Member of the Equality Formation, coded as F and $\mathrm{f}$ on the map, comprises the slackwater silt and clay laid down in the lakes that formed at the end of the Wisconsin Glacial Episode (Willman et al., 1975). Bold or upper case characters indicate that the materials are greater than $6 \mathrm{~m}$ (20 feet) thick. Pennsylvanian shale bedrock is coded with the number "1" on the map. The parentheses around the number 1 indicate that the Pennsylvanian bedrock may be found less than $15 \mathrm{~m}$ (50 ft) beneath the ground surface, but it generally lies at or just below that depth (Berg and Kempton, 1988). A few miles east and west of Bonpas Creek, there are areas mapped as $C$ and Q over bedrock ( 1 and 2). C denotes wind-blown silt deposits such as the Peoria Loess or Roxana Silt. Q denotes loamy and sandy diamictons (glacial tills) of the Illinoian Episode, Glasford Formation. The "2" denotes Pennsylvanian sandstones.

In general, the stack unit map shows that the surficial materials are approximately $15 \mathrm{~m}(50 \mathrm{ft})$ thick and overlie Pennsylvanian bedrock. The stack unit map is in general agreement with the drift thickness map (Figure 35), which indicates that up to $30 \mathrm{~m}$ (100 ft) of glacial drift can be found beneath the site. 


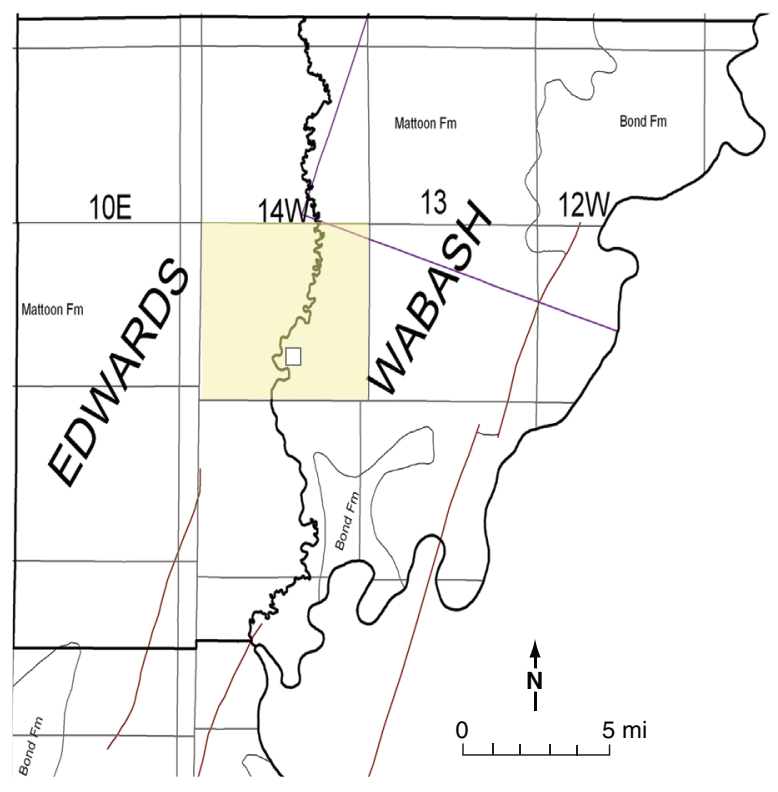

Figure 37. Bedrock geology of Wabash and Edwards Counties, Illinois with T1S R14W highlighted in yellow; the white box within the yellow shaded area identifies the site. Data are from the ISGS database: GISDB_ BEDGEO.IL_Bedrock_Geology_500K_2005 (ISGS, 2005), which includes data from Kolata (2005) and other updated data, accessed March 2008. Township lines are shown in gray. Light brown lines show northnortheast to south-southwest- trending faults; purple lines designate Indian treaty boundaries.

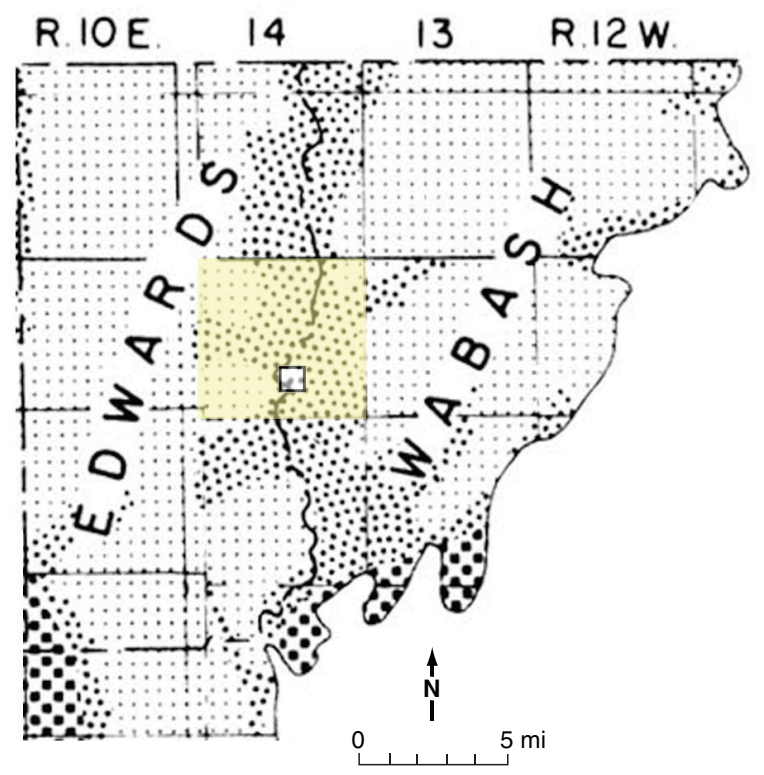

Good to excellent: highly permeable and widely distributed

Fair to good: variable in permeablity; scattered and discontinous

Poor: sand and gravel deposits generally absent

Figure 38. Potential groundwater supplies from sand and gravel aquifers with T1S R14W highlighted in yellow (modified from Pryor, 1956); the white box within the yellow shaded area identifies the site.

Bedrock. The bedrock surface beneath the glacial drift in Wabash County exposes Pennsylvanian formations (Figure 37) - the Mattoon Formation in western Wabash County and the Bond Formation in eastern and southern Wabash County (Kolata, 2005). These formations include thinly bedded sandstones, shale, limestones, and coal. The Mattoon Formation is the youngest Pennsylvanian formation in Illinois, and its top is an erosional surface (Willman et al., 1975). The Bond Formation is characterized by a greater percentage of limestone and calcareous clays and shales than other Pennsylvanian units (Willman et al., 1975). The Bond Formation includes the Mt. Carmel Sandstone, which supplies groundwater in eastern Wabash County. Beneath the rocks of the Pennsylvanian System lie deeper bedrock units that include Mississippian limestone, dolomite, sandstone and shale; Devonian and Silurian formations that consist of limestone and dolomite; and Ordovician and Cambrian formations that consist of shale, dolomite, and sandstone (Kolata, 2005). The bedrock geology map (Kolata, 2005) also shows that the northern end of the northeast-southwest-trending Wabash Valley Fault System extends into Wabash County. The approximate position of this fault system is shown by the brown lines in Figure 37.

Site Hydrology. Pryor (1956) reported that most of Wabash County contains glacial deposits that are thin and not suitable for sand and gravel wells (Figure 38). Thin, scattered deposits of sand and gravel are present in the valley of Bonpas Creek near the site. In the Wabash River valley south of Mt. Carmel, thick sand and gravel deposits are present, so groundwater possibilities are excellent. Shallow Pennsylvanian sandstones yield water throughout most of Wabash County (Figure 39; Pryor, 1956). Many domestic wells in the area obtain water from these sandstones at depths of 30 to $120 \mathrm{~m}$ (100 to $400 \mathrm{ft}$ ).

The site is surrounded by three major rivers and streams including Bonpas Creek to the west, the Wabash River to the east and south, and the Little Wabash River, which flows farther to the west and south, beyond the western boundary of Edwards County. A USGS gauging station (station number 03378000) is located on Bonpas Creek, less than $1.6 \mathrm{~km}$ (1 mi) north of Browns. Monthly and daily streamflow data are available from the U.S. Geological Survey website (Figure 40) (http://waterdata.usgs.gov/il/nwis/sw). 


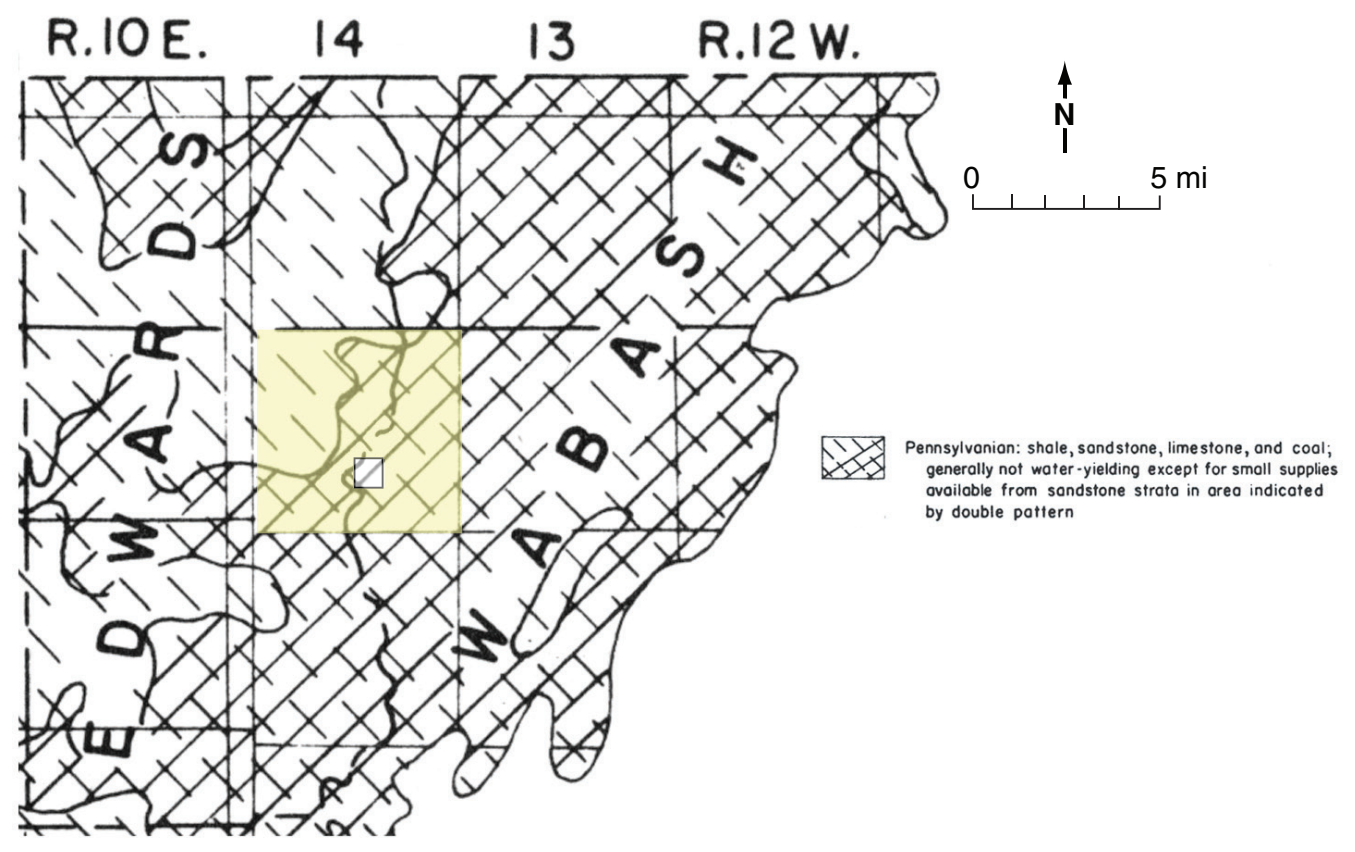

Figure 39. Potential groundwater supplies from bedrock aquifers with T1S R14W highlighted in yellow (modified from Pryor, 1956); the white box within the yellow shaded area identifies the site.

\section{Tanquary MVA Baseline}

Coal Seam Wells. No baseline Springfield Coal water samples were obtained pre- $\mathrm{CO}_{2}$ injection or subsequently. Attempts were made to acquire water samples from the DST sample chamber; however, the low permeability coal seams did not produce enough in situ water to displace the drilling fluid. Consequently, the water collected was predominantly drilling fluid. Pre- $\mathrm{CO}_{2}$ injection gas samples were not available directly from the coal seam except from the desorbed gas from the coal core samples. The desorbed gas had small amounts of $\mathrm{CO}_{2}$, but was not isotopically analyzed.

The first gas samples collected from the coal were at the surface from the M-1 and M-3 wells shortly after $\mathrm{CO}_{2}$ injection started. Unfortunately, the initial $\mathrm{CO}_{2}$ concentrations in the samples collected from the coal seam were too small to allow measurement of their radiocarbon $\left({ }^{14} \mathrm{C}\right)$ activity. The concentration of ${ }^{14} \mathrm{C}$ in the natural $\mathrm{CO}_{2}$ associated with the coal seam was expected to be small based on analyses of $\mathrm{CO}_{2}$ extracted from five different coal seams located in White and Jasper counties in Illinois that had ${ }^{14} \mathrm{C}$ activities ranging from 3.8 to $18.5 \mathrm{pMC}$ (percent modern carbon) with an average of $9.3 \mathrm{pMC}$ (MGSC, 2005), strongly contrasting with the $104 \mathrm{pMC}^{14} \mathrm{C}$ activity of the injected $\mathrm{CO}_{2}$.

A few samples did have adequate volume for determination of the $\delta^{13} \mathrm{C}$ composition. The isotopic composition of the $\mathrm{CO}_{2}$ in the observation wells prior to breakthrough was variable (Appendix 15). One gas sample from well M-1 had a very negative $\delta^{13} \mathrm{C}$ value, $-32 \%$, which was quite different from the injected $\mathrm{CO}_{2}$ isotopic composition of $-10.8 \%$. However, the $\delta^{13} \mathrm{C}$ of the $\mathrm{CO}_{2}$ prior to breakthrough at well M-3 resembled the composition of the injected $\mathrm{CO}_{2}$. The $\delta^{13} \mathrm{C}$ of three samples containing small $\mathrm{CO}_{2}$ concentrations at M-3 ranged from -4.2 to $-11.9 \%$. The reason for the variability of isotopic values is not understood, but the more negative isotopic composition, such as $-32 \%$, may be related to possible oxidation of $\mathrm{CH}_{4}$ due to the introduction of oxygen during drilling and well construction. The initial gas samples from each observation well also consistently contained greater oxygen concentrations than did most of the later samples from the observation wells (Figure 41).

Geologic and Hydrogeologic Data from the Drilling and Installation of Monitoring Wells. The groundwater monitoring wells (ECBM1, ECBM2, ECBM3, and ECBM4) were installed to provide data to determine shallow groundwater flow and quality at the site. The wells were positioned around the $\mathrm{CO}_{2}$ injection well (I-1B) to detect the $\mathrm{CO}_{2}$ plume in case of leakage (Figure 42). ECBM4 was located downgradient of the injection well, and ECBM1 was located upgradient or east of the injection well. ECBM2 was located slightly northeast of the injection well, and ECBM3 was located southwest of the injection well. All monitoring wells were located to minimize interference with agricultural activities at the site.

The first borehole (ECBM1) was drilled in April 2008 to a total depth of $30 \mathrm{~m}$ (100 ft). A summary descriptive geologic log of the wireline core recovered from this borehole is presented in Table 4. Detailed descriptive geologic logs of the two cored boreholes are in Appendix 16, and additional well construction details are in Appendix 17. Bedrock was not reached in the 


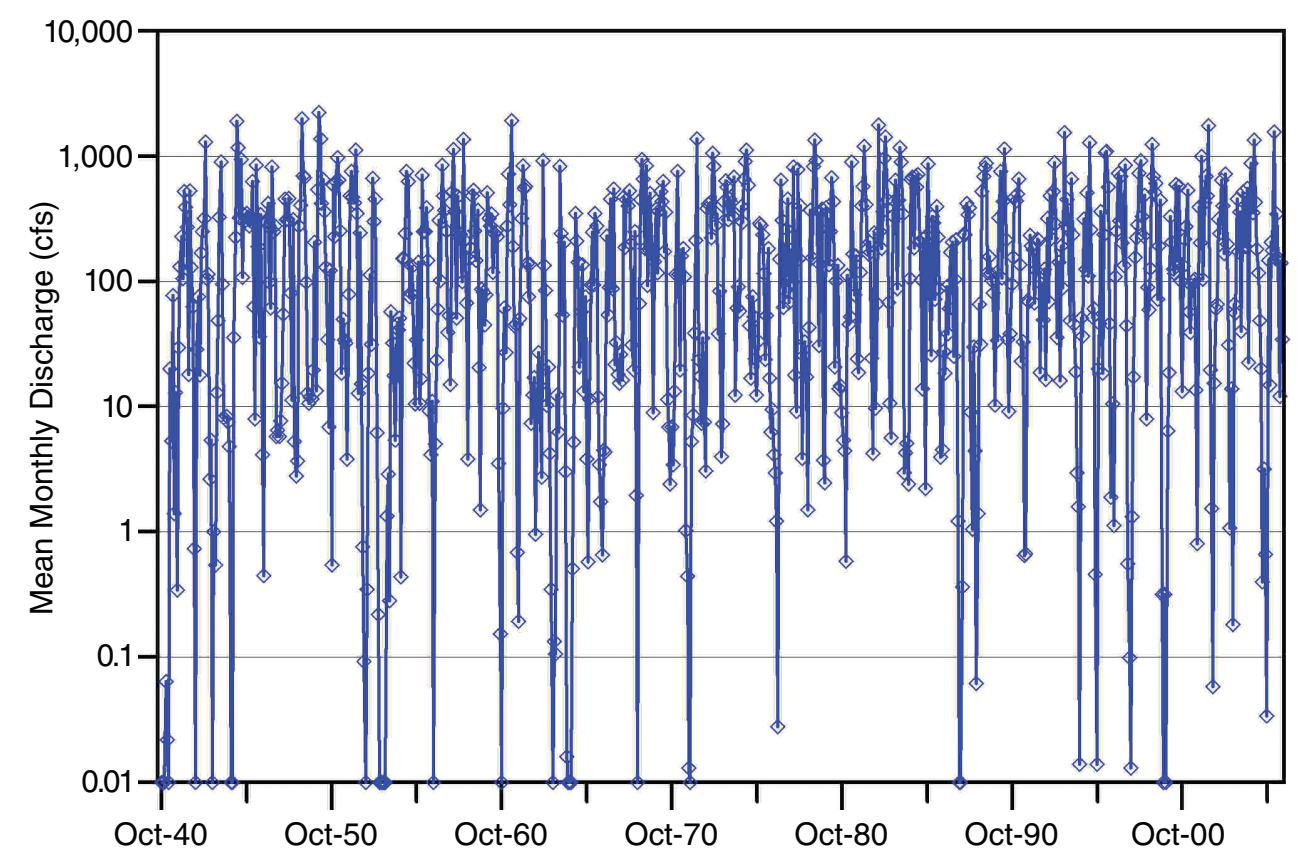

Figure 40. Mean monthly flow data for Bonpas Creek. Data are from the U.S. Geological Survey Web site http://waterdata.usgs.gov/il/nwis/monthly/?format=sites_selection_ links\&search_site_no=03378000\&amp;referred_module=sw (Notes: 0 values were transformed to 0.01 cubic feet per second [cfs] and $35.32 \mathrm{cfs}=1.0 \mathrm{~m}^{3} / \mathrm{sec}$ ).

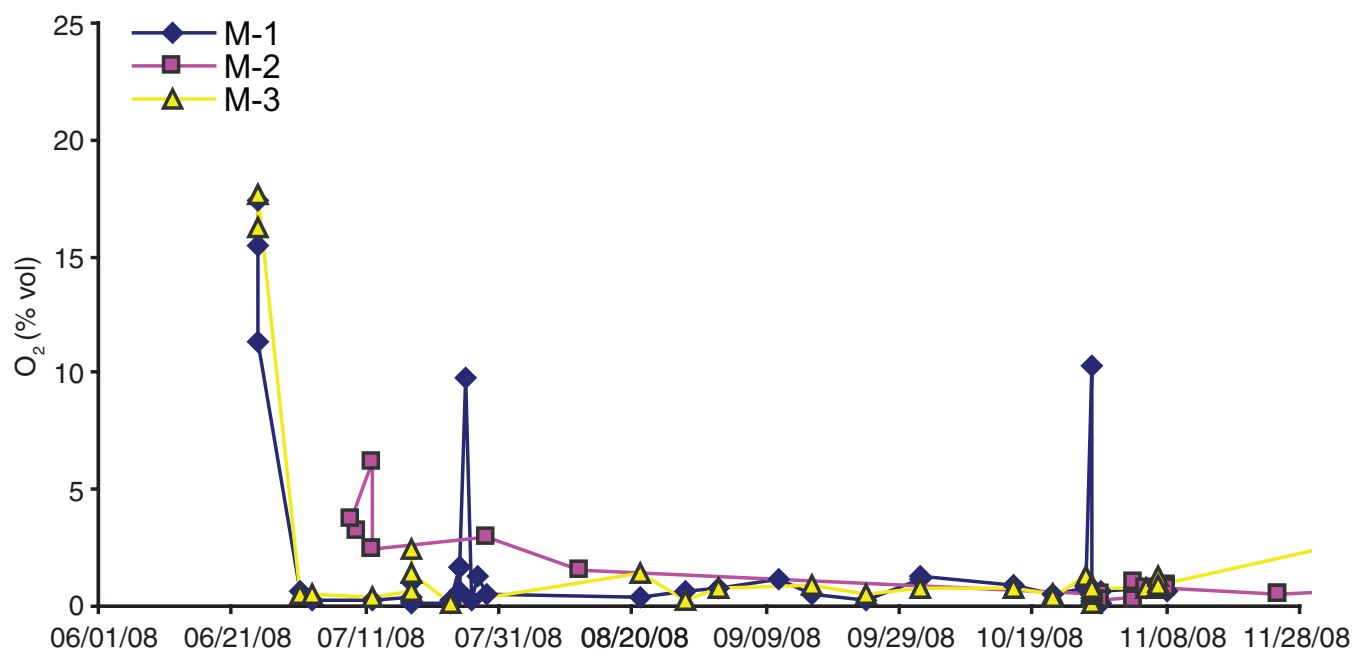

Figure 41. The $\mathrm{O}_{2}$ concentrations (\%, by volume) in gas samples collected from the coal seam observation wells at the Tanquary site.

ECBM1 borehole, but at the ECBM4 location, the bedrock was observed to be $29 \mathrm{~m}$ (94 ft) below the ground surface. Pennsylvanian bedrock was expected to be found at the bedrock surface, and the lithology of the material recovered in the core was typical for rocks of the Pennsylvanian System. The natural gamma ray logs for ECBM1 and the other three boreholes show the variability in the geologic materials in this alluvial setting (Figure 43). However, a sand and gravel layer was found in all four boreholes at an approximate depth of 26 to $27 \mathrm{~m}$ (85 to $89 \mathrm{ft}$ ). The wells were completed in this sand and gravel because some local domestic water supply wells were completed in this horizon.

The details of the monitoring well construction are shown in Figure 44 and are described in Appendix 17. After well installation, each well was developed by overpumping with a Waterra pump (with and without a surge block) and a Whale submers- 


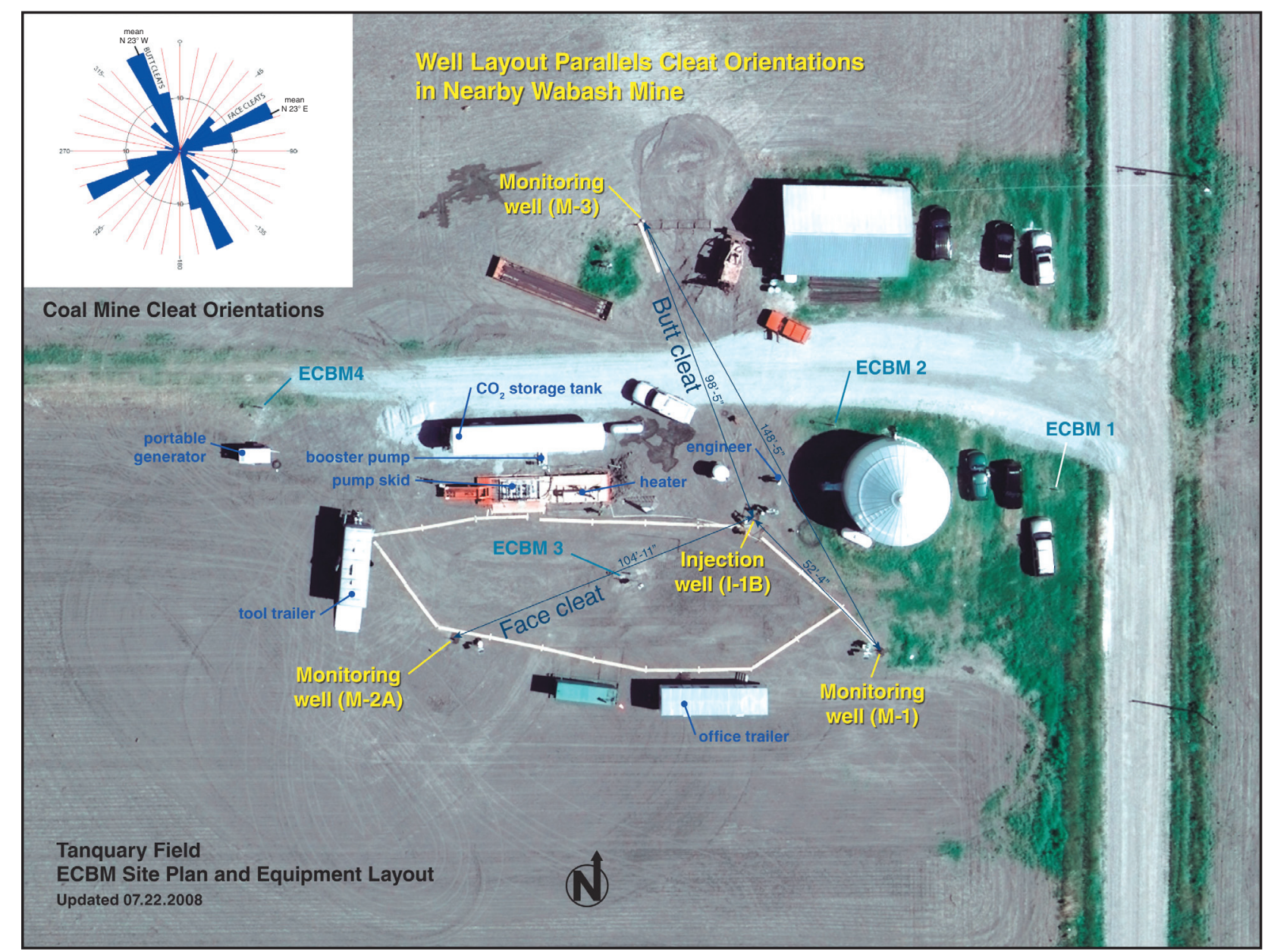

Figure 42. Tanquary site showing the location of the injection well (I-1B), coal seam observation wells (M-1, M-2, and $\mathrm{M}-3$ ), and groundwater monitoring wells (ECBM1, ECBM2, ECBM3, and ECBM4). The site is located in the northeast quarter of Section 27, T1S, R14W.

ible pump (12 V DC pump). The wells were completed with dedicated bladder pumps and pressure transducers in order to collect groundwater samples and measure water levels in each well.

Pressure transducers were installed in the four monitoring wells. Solinst Leveloggers (www.solinst.com) were installed in the four groundwater monitoring wells and programmed to record the water levels at 6-minute intervals. Because these loggers record absolute pressure, atmospheric pressure was also recorded at the site using a Solinst Barologger. These instruments measured and recorded the water levels in the wells over time. Unfortunately, the Barologger malfunctioned during the study, and required use of atmospheric data from an airport (Lawrenceville) located $40 \mathrm{~km}(25 \mathrm{mi})$ from the site. These atmospheric pressure data were processed according to the procedure in the Solinst user's manual and were used to correct the Levelogger data. Groundwater levels in monitoring wells ECBM1, ECBM2, ECBM3, and ECBM4 were monitored beginning June 4, 2008; they started the

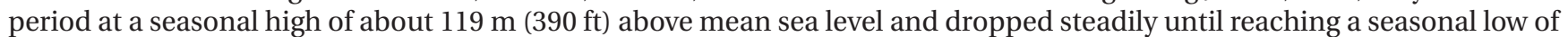
less than $118 \mathrm{~m}(387 \mathrm{ft})$ in late fall.
Table 4. Summary geologic log for geologic materials collected from ECBM1 (API 121852849000).

\begin{tabular}{|c|c|l|}
\hline $\begin{array}{c}\text { Depth } \\
(\mathbf{f t})\end{array}$ & $\begin{array}{c}\text { Depth } \\
(\mathbf{m})\end{array}$ & Description of geologic materials \\
\hline $0-5$ & $0-1.5$ & Silt (topsoil and loess) \\
\hline $5-43$ & $1.5-13.1$ & Silt and clay (alluvial/lacustrine sediments) \\
\hline $43-72$ & $13.1-21.9$ & Sand, fine-grained (alluvial sediments) \\
\hline $72-77$ & $21.9-23.5$ & Clay with silt, sand and gravel (diamicton) \\
\hline $77-83$ & $23.5-25.3$ & Silt (lacustrine) \\
\hline $83-92$ & $25.3-28.0$ & Sand and gravel (alluvial) \\
\hline $92-95$ & $28.0-29.0$ & Silt (lacustrine/alluvial) \\
\hline
\end{tabular}




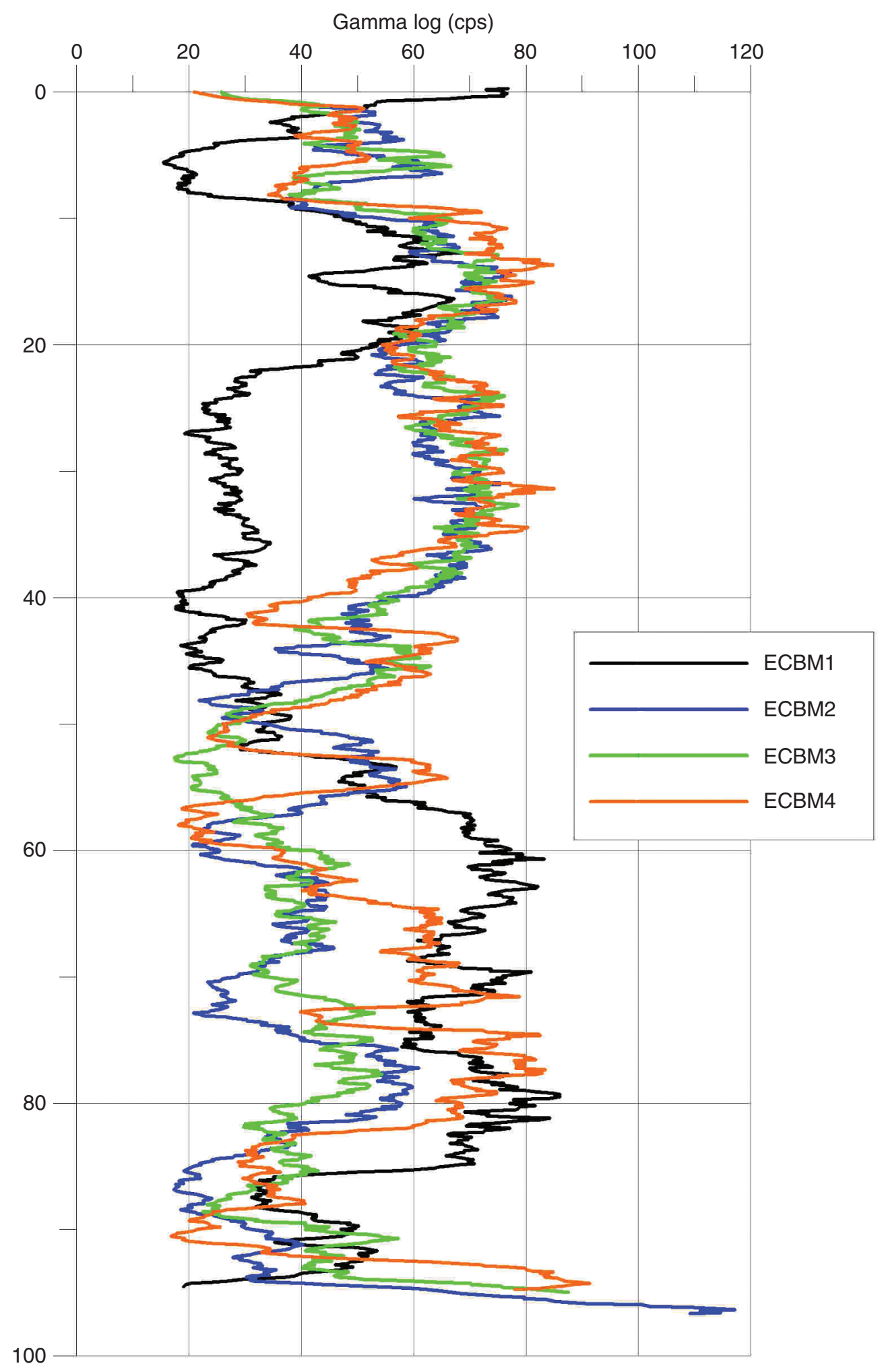

Figure 43. Natural gamma logs recorded in ECBM1, ECBM2, ECBM3, and ECBM4. 
API \# 121852849000

Date installed 04/29/2008

Hole \# ECBM1
Well TD to top of riser $93.75^{\prime}$

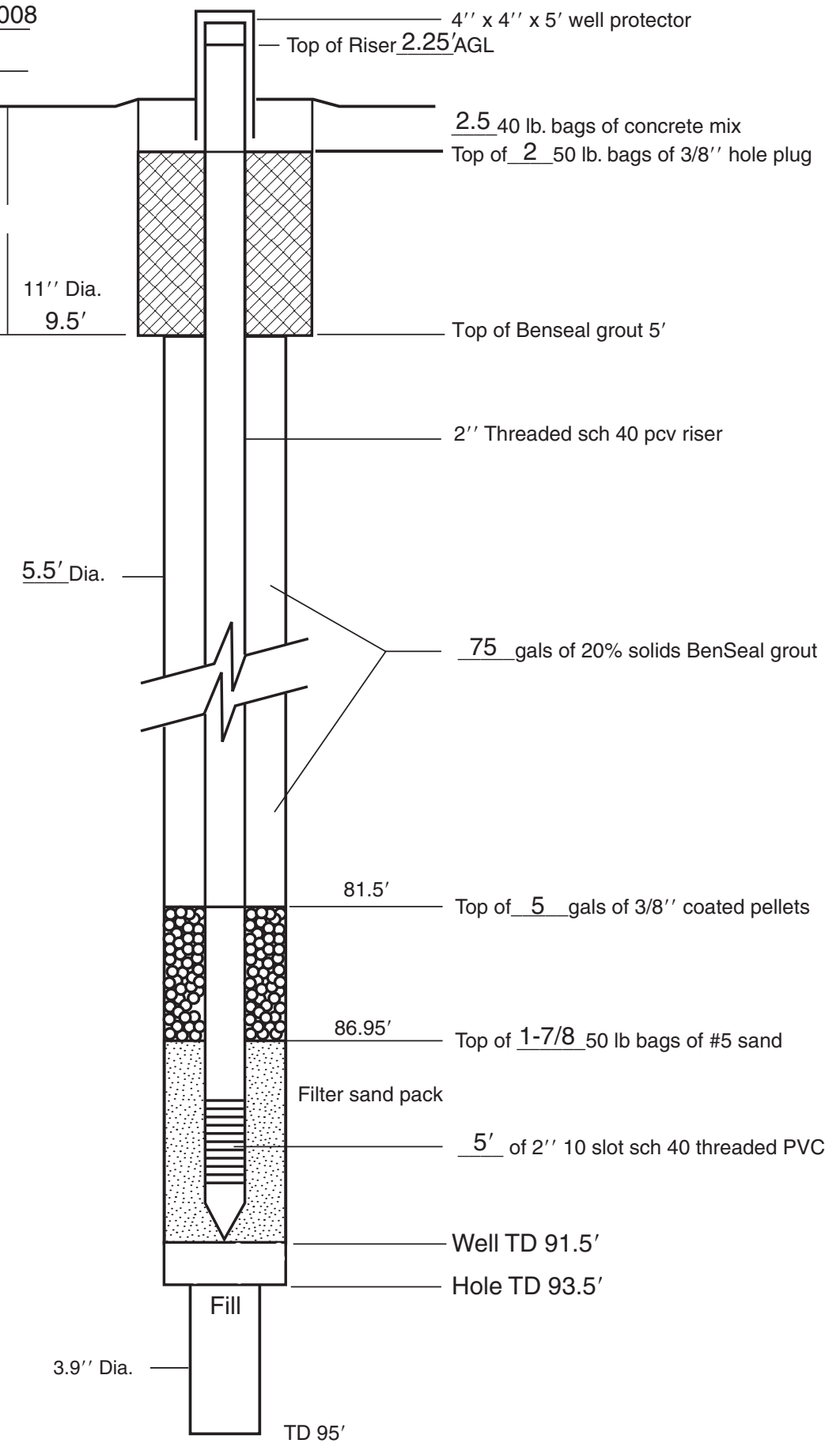

Figure 44. Construction details of groundwater monitoring well ECBM1. (Figures for the other wells appear in Appendix 17.) 
Groundwater Wells. The groundwater wells available for sampling included the four groundwater monitoring wells drilled around the $\mathrm{CO}_{2}$ injection well on the Tanquary site (Figure 42) and two existing residential wells, Hering and Kieffer, located south of the site about $1.6 \mathrm{~km}(1 \mathrm{mi})$ and $2.1 \mathrm{~km}(1.3 \mathrm{mi})$, respectively.

Chemical characterization. Groundwater samples were collected from the Tanquary site to determine potential impacts on water quality from the $\mathrm{CO}_{2}$ injection activities. Encroachment of $\mathrm{CO}_{2}$ into groundwater can result in the following reactions:

$\mathrm{CO}_{2}(\mathrm{~g})+\mathrm{H}_{2} \mathrm{O} \leftrightarrow \mathrm{CO}_{2}$ (aq)

$\mathrm{CO}_{2}(\mathrm{~g})+\mathrm{H}_{2} \mathrm{O} \leftrightarrow \mathrm{H}_{2} \mathrm{CO}_{3}$ (carbonic acid)

$\mathrm{H}_{2} \mathrm{CO}_{3} \leftrightarrow \mathrm{HCO}_{3}^{-}+\mathrm{H}^{+}$(bicarbonate)

$\mathrm{HCO}_{3}{ }^{-} \leftrightarrow \mathrm{CO}_{3}{ }^{2-}+\mathrm{H}^{+}$(carbonate)

The production of $\mathrm{H}^{+}$by the bicarbonate and carbonate reactions can cause a decrease of groundwater $\mathrm{pH}$ and subsequent dissolution of parts of the solid matrix of the aquifer. Therefore, analysis of the water quality data focused on the analytes involved in the carbonate chemistry of the water and the potential dissolution products of clay minerals. In addition, as $\mathrm{CO}_{2}$ is injected into the coal seam, connate water can be displaced from the coal and potentially enter the shallow aquifer system. Water contained in the coal and immediately above the coal was not sampled because of drilling and operational conditions that prohibited sampling of those fluids. Morse and Demir (2007) and Morse (personal communication) indicated that coal seam waters typically have total dissolved solids ranging from approximately 23,000 to 53,000 mg/L and have a brine-like composition. Predominant constituents in these fluids are $\mathrm{Ba}, \mathrm{Br}, \mathrm{Ca}, \mathrm{Cl}, \mathrm{Mg}, \mathrm{Na}$, and $\mathrm{Sr}$; solution pH values are around 7.2 .

Groundwater $\mathrm{pH}$ values varied in both the monitoring and residential wells. Residential wells were sampled for about 1 year prior to $\mathrm{CO}_{2}$ injection (June 2007 to June 2008) and exhibited decreases in pH of as much as $0.6 \mathrm{pH}$ units during that period.

Based on $\mathrm{CO}_{2}$ reactions with water, alkalinity and total dissolved carbon were expected to increase in aquifers impacted by $\mathrm{CO}_{2}$ leakage, so alkalinity was monitored throughout the project period. At the Tanquary site, the four groundwater monitoring wells (ECBM1, ECBM2, ECBM3, and ECBM4) had alkalinity levels of $463-518 \mathrm{mg} \mathrm{CaCO}_{3} / \mathrm{L}$ in the days immediately preceding $\mathrm{CO}_{2}$ injection (Figure 45). Alkalinity levels were available for the residential wells for a year before the start of injection and ranged from 612-652 $\mathrm{mg} \mathrm{CaCO}_{3} / \mathrm{L}$ at the Hering well and 449-474 $\mathrm{mg} \mathrm{CaCO} / \mathrm{L}$ at the Kieffer well (Figure 45). Chloride was also monitored in order to detect brine movement into groundwater. Because chloride is a non-reactive constituent in most natural environments and is neither degraded by nor sorbed to geologic materials, it can be used as a tracer in groundwater flow. Chloride concentrations at the ECBM1, ECBM2, ECBM3, and ECBM4 wells ranged from 15-22 mg/L in the days immediately before $\mathrm{CO}_{2}$ injection, while the Hering well had chloride concentrations in the $147-157 \mathrm{mg} / \mathrm{L}$ range. The Kieffer well had chloride concentrations in the $4.21-6.78 \mathrm{mg} / \mathrm{L}$ range in the year before injection (Figure 46).

Isotopic characterization. The concentration of $\mathrm{CO}_{2}$ in the samples of headspace gas collected from the groundwater monitoring wells was less than $0.1 \%$ for nearly all of the gas samples collected at the ECBM1 , ECBM2, ECBM3, and ECBM4 wells and the Hering well in early to mid-June 2008, before commencement of $\mathrm{CO}_{2}$ injection (Table 5). Oxygen $\left(\mathrm{O}_{2}\right)$ and nitrogen $\left(\mathrm{N}_{2}\right)$, the predominant gases in the samples, occurred at concentrations similar to normal atmospheric values. The $\mathrm{CH}_{4}$ concentrations in the monitoring well headspace samples prior to injection generally were below the detection limit. A headspace gas sample collected from the Hering residential well in early June contained $49.7 \% \mathrm{CH}_{4}$ (by volume). This large concentration suggests that the source of the $\mathrm{CH}_{4}$ in this well, which is completed in a deeper aquifer than the monitoring wells, was $\mathrm{CH}_{4}$ naturally occurring in the local groundwater (Coleman et al., 1982).

The tritium $\left({ }^{3} \mathrm{H}\right)$ concentrations on selected groundwater samples prior to injection (Table 6) all were below detection limits, indicating that the aquifers sampled have received no significant water recharge within the past 50 yr. (Tritium is a relatively short-lived isotope introduced into the atmosphere in significant quantities only by the mid-twentieth century atmospheric testing of nuclear weapons.)

The $\delta^{18} \mathrm{O}$ values of the groundwater from the monitoring wells (ECBM1, ECBM2, ECBM3, and ECBM4) were fairly similar to those from the Kieffer residential well, but were quite different from the values for the Hering residential well, which is completed in a different, deeper aquifer. Water sampling occurred from the Springfield Coal monitoring wells (M-1, M-2, and M-3) only once because of the water in the wellbores was pumped-in at the surface from freshwater sources. The single aqueous sample for isotopic analysis from the coal seam observation wells was from well M-2; it had an isotopic composition within the range of all the other wells except the Hering well (Appendix 18; Figure 47).

Mineral Equilibria of Groundwater Samples. Because $\mathrm{CO}_{2}$ influx into the groundwater from the coal seam has the potential to affect mineral equilibrium relationships in the groundwater, saturation indices for certain minerals were monitored. Groundwater samples collected at the downgradient well (ECBM3) prior to injection appeared to be in equilibrium with quartz $\left(\mathrm{SiO}_{2}\right)$ and calcite $\left(\mathrm{CaCO}_{3}\right)$ - both of which are likely common minerals in the unconsolidated glacial 


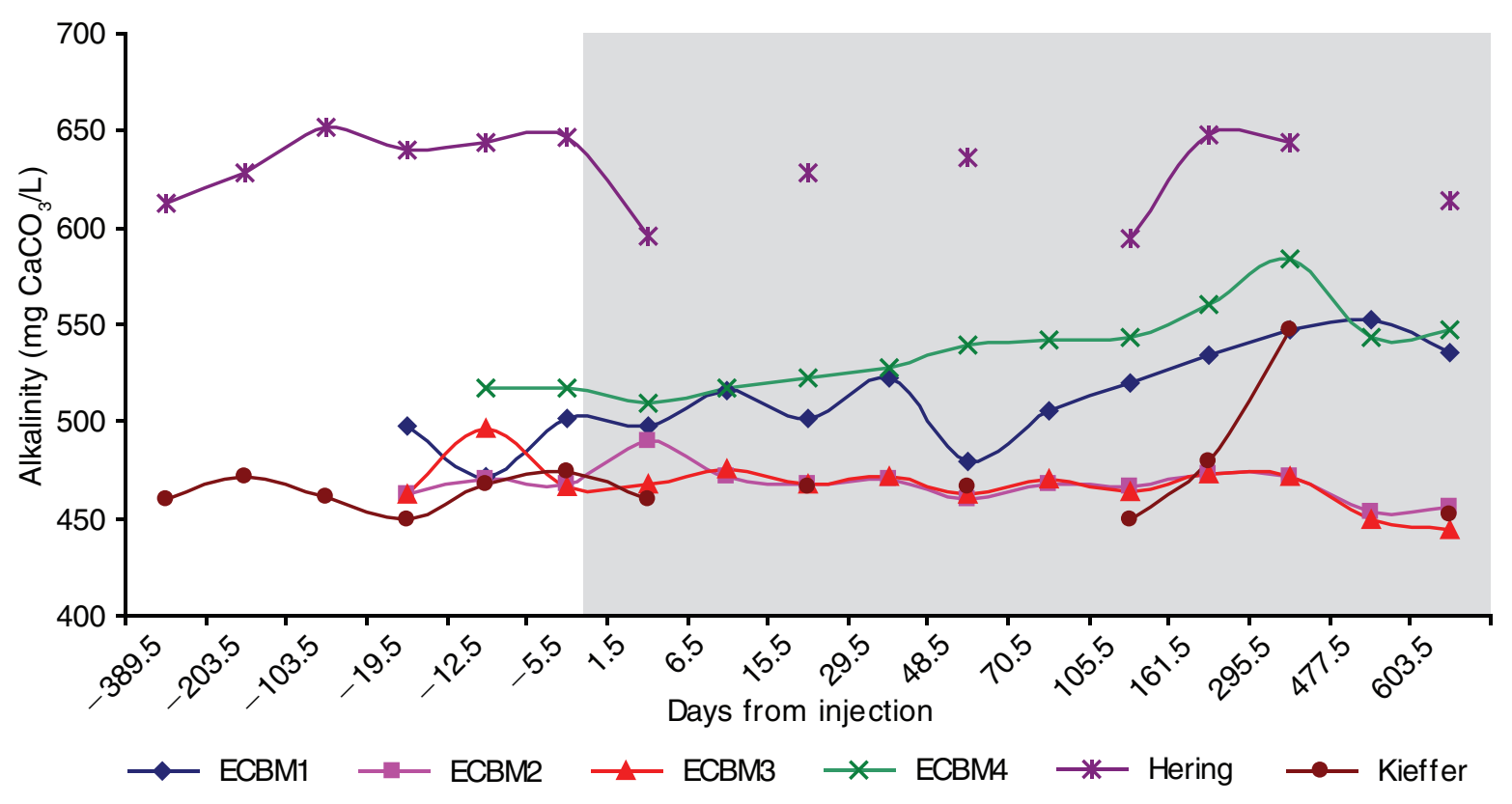

Figure 45. Alkalinity $\left(\mathrm{CaCO}_{3}\right)$ concentrations in groundwater samples collected from ECBM monitoring and residential wells at the Tanquary site. The injection and post-injection sampling periods have been shaded in order to highlight pre-injection samples. (x-axis is not to scale.)

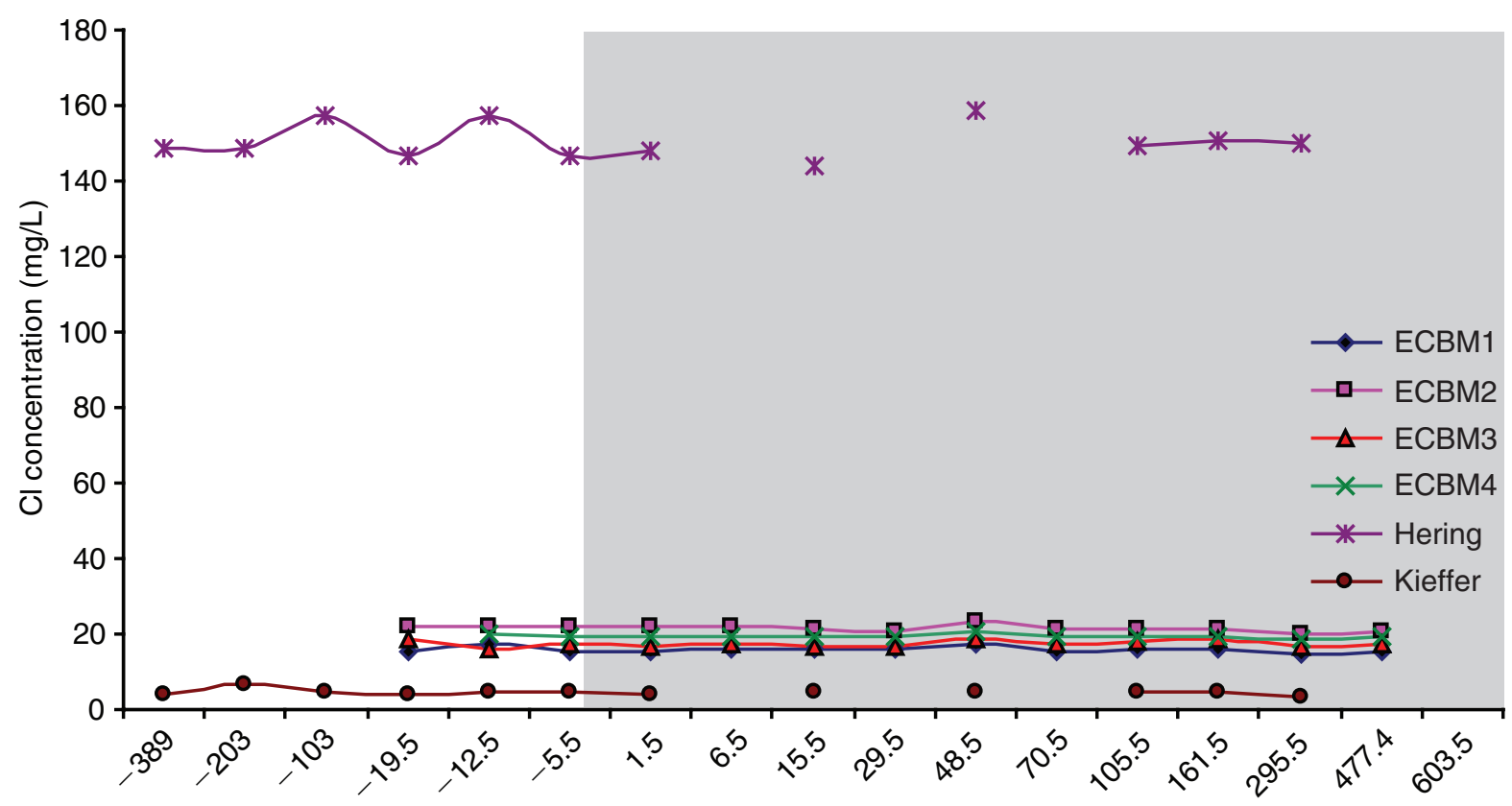

Days from injection

Figure 46. Chloride $(\mathrm{Cl})$ concentrations in groundwater samples collected from ECBM monitoring and residential wells at the Tanquary site. The injection and post-injection sampling periods have been shaded in order to highlight pre-injection samples. (x-axis is not to scale.) 
Table 5. Pre- $\mathrm{CO}_{2}$ gas chromatography results for gas samples from ECBM1, ECBM2, ECBM3, and ECBM4 groundwater wells at the Tanquary site (\% concentration normalized by volume).

\begin{tabular}{|c|c|c|c|c|c|c|c|c|c|c|c|c|c|}
\hline Well & $\begin{array}{c}\text { Sampling } \\
\text { date }\end{array}$ & Time $^{1}$ & $\mathrm{CO}_{2}$ & $\mathrm{O}_{2}+\mathrm{Ar}$ & $\mathrm{N}_{2}$ & $\mathrm{CH}_{4}$ & $\mathrm{C}_{2} \mathrm{H}_{6}$ & $\mathrm{C}_{3} \mathrm{H}_{8}$ & $\mathrm{iC}_{4} \mathrm{H}_{10}$ & $\mathrm{nC}_{4} \mathrm{H}_{10}$ & iC $_{5} \mathrm{H}_{12}$ & $\mathrm{nC}_{5} \mathrm{H}_{12}$ & $\mathrm{C}_{6} \mathrm{H}_{14+}$ \\
\hline Hering & $06 / 04 / 08$ & & 0.04 & 0.87 & 49.35 & 49.74 & $<0.01$ & $<0.01$ & $<0.01$ & $<0.01$ & $<0.01$ & $<0.01$ & $<0.01$ \\
\hline ECBM1 & $06 / 05 / 08$ & 1055 & 0.14 & 21.72 & 78.15 & $<0.01$ & $<0.01$ & $<0.01$ & $<0.01$ & $<0.01$ & $<0.01$ & $<0.01$ & $<0.01$ \\
\hline ECBM1 & $06 / 12 / 08$ & 1158 & 0.08 & 21.66 & 78.08 & 0.17 & $<0.01$ & $<0.01$ & $<0.01$ & 0.01 & $<0.01$ & $<0.01$ & $<0.01$ \\
\hline ECBM1 & 06/19/08 & 1218 & 0.05 & 21.76 & 78.19 & $<0.01$ & $<0.01$ & $<0.01$ & $<0.01$ & $<0.01$ & $<0.01$ & $<0.01$ & $<0.01$ \\
\hline ECBM2 & 06/05/08 & 1105 & 0.06 & 21.83 & 78.11 & $<0.01$ & $<0.01$ & $<0.01$ & & & & & $<0.01$ \\
\hline ECBM2 & 06/12/08 & 1145 & 0.06 & 21.73 & 78.21 & $<0.01$ & $<0.01$ & $<0.01$ & & & & & $<0.01$ \\
\hline ECBM2 & 06/19/08 & 1225 & 0.05 & 21.79 & 78.17 & $<0.01$ & $<0.01$ & $<0.01$ & $<0$ & & $<0$ & & $<0.01$ \\
\hline CBM3 & 06/05/08 & 1435 & 0.04 & 21.77 & 78.19 & $<0.01$ & $<0.01$ & $<0.01$ & $<0.01$ & $<0.01$ & $<0.01$ & $<0.01$ & $<0.01$ \\
\hline ECBM3 & 06/12/08 & 1132 & 0.07 & 21.73 & 78.04 & 0.17 & $<0.01$ & $<0.01$ & $<0.01$ & $<0.01$ & $<0.01$ & $<0.01$ & $<0.01$ \\
\hline ECBM3 & 06/19/08 & 1235 & 0.05 & 21.72 & 78.23 & $<0.01$ & $<0.01$ & $<0.01$ & $<0.01$ & $<0.01$ & $<0.01$ & $<0.01$ & $<0.01$ \\
\hline ECBM4 & 06/12/08 & 0859 & 0.08 & 21.76 & 77.94 & 0.21 & $<0.01$ & $<0.01$ & $<0.01$ & $<0.01$ & $<0.01$ & $<0.01$ & $<0.01$ \\
\hline ECBM4 & 06/19/08 & 1242 & 0.05 & 21.79 & 78.16 & $<0.01$ & $<0.01$ & $<0.01$ & $<0.01$ & $<0.01$ & $<0.01$ & $<0.01$ & $<0.01$ \\
\hline
\end{tabular}

${ }^{1}$ Collection times are given in CDT for samples collected from 03/08/08-11/02/08 and 03/08/09-11/01/09. All other times are CST. Collection times were not available for some samples. $\mathrm{iC}_{4} \mathrm{H}_{10}$ and $\mathrm{nC}_{4} \mathrm{H}_{10}$ designate different isomers of butane; iC $\mathrm{H}_{12}$ and $\mathrm{nC}_{5} \mathrm{H}_{12}$ designate different isomers of pentane.

drift-as well as siderite (Figure 48, leftmost portion of graph with pre- $\mathrm{CO}_{2}$ injection data). All of the well samples were undersaturated with respect to gypsum $\left(\mathrm{CaSO}_{4} \cdot 2 \mathrm{H}_{2} \mathrm{O}\right)$. Therefore, it is unlikely that gypsum is present in the glacial drift near the monitoring wells.

Figure 49 shows the saturation indices before and after $\mathrm{CO}_{2}$ injection for the residential well (Hering and Kieffer) samples, which were also in equilibrium with quartz and calcite before $\mathrm{CO}_{2}$ injection (points near the origin $[0,0]$ ). Values of the saturation index less than zero indicate that these pre$\mathrm{CO}_{2}$ samples were undersaturated with respect to the carbonate phases strontianite $\left(\mathrm{SrCO}_{3}\right)$, smithsonite $\left(\mathrm{ZnCO}_{3}\right)$, and witherite $\left(\mathrm{BaCO}_{3}\right)$.

CIR Imagery. Aerial flyovers of the Tanquary site were conducted multiple times each year, beginning in 2007. The health of vegetation at the site, as indicated by plant color in CIR photography, was used as a proxy for $\mathrm{CO}_{2}$ exposure. Aerial orthophotographs of the site were taken on June 11, 2007, and August 23, 2007, in order to establish baseline conditions during the growing season and after the harvest, respectively (Figures 50 and 51).
Table 6. Pre- $\mathrm{CO}_{2}$ injection isotopic results for water samples from Tanquary site.

\begin{tabular}{lcccccc}
\hline Sample ID & Location & Sampling date & $\begin{array}{c}\delta^{13} \mathbf{C} \\
(\%)\end{array}$ & $\begin{array}{c}\delta^{18} \mathbf{O} \\
(\%)\end{array}$ & $\begin{array}{c}\delta \mathbf{D} \\
(\%)\end{array}$ & $\begin{array}{c}\text { Tritium } \\
\text { (TU) }\end{array}$ \\
\hline T15-08 & ECBM1 & $06 / 05 / 2008$ & -11.8 & -5.91 & -38.6 & $<0.5$ \\
T21-08 & ECBM1 & $06 / 12 / 2008$ & -11.7 & -6.05 & -38.7 & $<0.5$ \\
T26-08 & ECBM1 & $06 / 19 / 2008$ & -11.7 & & & \\
T16-08 & ECBM2 & $06 / 05 / 2008$ & -12.3 & -5.96 & -38.8 & $<0.5$ \\
T22-08 & ECBM2 & $06 / 12 / 2008$ & -12.2 & -5.77 & -39.3 & \\
T27-08 & ECBM2 & $06 / 19 / 2008$ & -13.2 & -5.81 & -37.5 & \\
T17-08 & ECBM3 & $06 / 05 / 2008$ & -11.8 & -5.97 & -38.0 & $<0.72$ \\
T23-08 & ECBM3 & $06 / 12 / 2008$ & -11.9 & -6.05 & -38.5 & \\
T28-08 & ECBM3 & $06 / 19 / 2008$ & -12.1 & -5.95 & -37.6 & \\
T20-08 & ECBM4 & $06 / 12 / 2008$ & -12.0 & -6.06 & -39.3 & $<0.5$ \\
T29-08 & ECBM4 & $06 / 19 / 2008$ & -12.7 & -6.10 & -37.9 & \\
T7-07 & Hering & $12 / 4 / 2007$ & -8.8 & -7.40 & -47.5 & \\
T9-08 & Hering & $3 / 13 / 2008$ & -8.8 & -7.55 & -50.0 & $<0.5$ \\
T13-08 & Hering & $6 / 04 / 2008$ & -8.8 & -7.35 & -48.3 & $<0.5$ \\
T18-08 & Hering & $6 / 12 / 2008$ & -8.9 & -7.08 & -49.0 & $<0.56$ \\
T24-08 & Hering & $6 / 19 / 2008$ & -8.6 & -7.35 & -47.7 & \\
T8-07 & Kieffer & $12 / 04 / 2007$ & -11.3 & -6.56 & -42.4 & \\
T10-08 & Kieffer & $3 / 13 / 2008$ & -11.6 & -6.48 & -42.1 & $<0.5$ \\
T14-08 & Kieffer & $6 / 04 / 2008$ & -13.2 & -6.16 & -40.5 & $<0.5$ \\
T19-08 & Kieffer & $6 / 12 / 2008$ & -12.3 & -6.37 & -42.3 & $<0.5$ \\
T25-08 & Kieffer & $6 / 19 / 2008$ & -12.9 & -6.05 & -40.0 & \\
\hline
\end{tabular}

\section{Injection Equipment and Operations}

\section{Pumping Equipment}

Overview. The surface injection equipment included a portable, 54.4-tonne (60-ton) liquid $\mathrm{CO}_{2}$ storage tank, a booster pump, the main pump skid with three piston pumps capable of injecting up to $1.6 \mathrm{~m}^{3} / \mathrm{hr}$ ( 7 gpm) each, a liquid turbine flow meter, and a propane-fired line heater, along with the necessary valves, instrumentation, and safety equipment. Two additional flow meters (one gas turbine meter and one gas orifice meter) were added as process improvements during the course of the test.

The injection system was designed to be operated at all Phase II pilots. Consequently the system is capable of a wide range of injection rate and pressures. $\mathrm{CO}_{2}$ liquid flow rates of $0.05-4.8 \mathrm{~m}^{3} / \mathrm{hr}(0.2-21.0 \mathrm{gpm})$ and surface pressures ranging from 2.1 to 8.3 MPag (300 to 1,200 psig) are possible. The propane-fired line heater was rated for $263,800 \mathrm{~kJ} / \mathrm{hr}(250,000 \mathrm{Btu} / \mathrm{hr}$ ), 


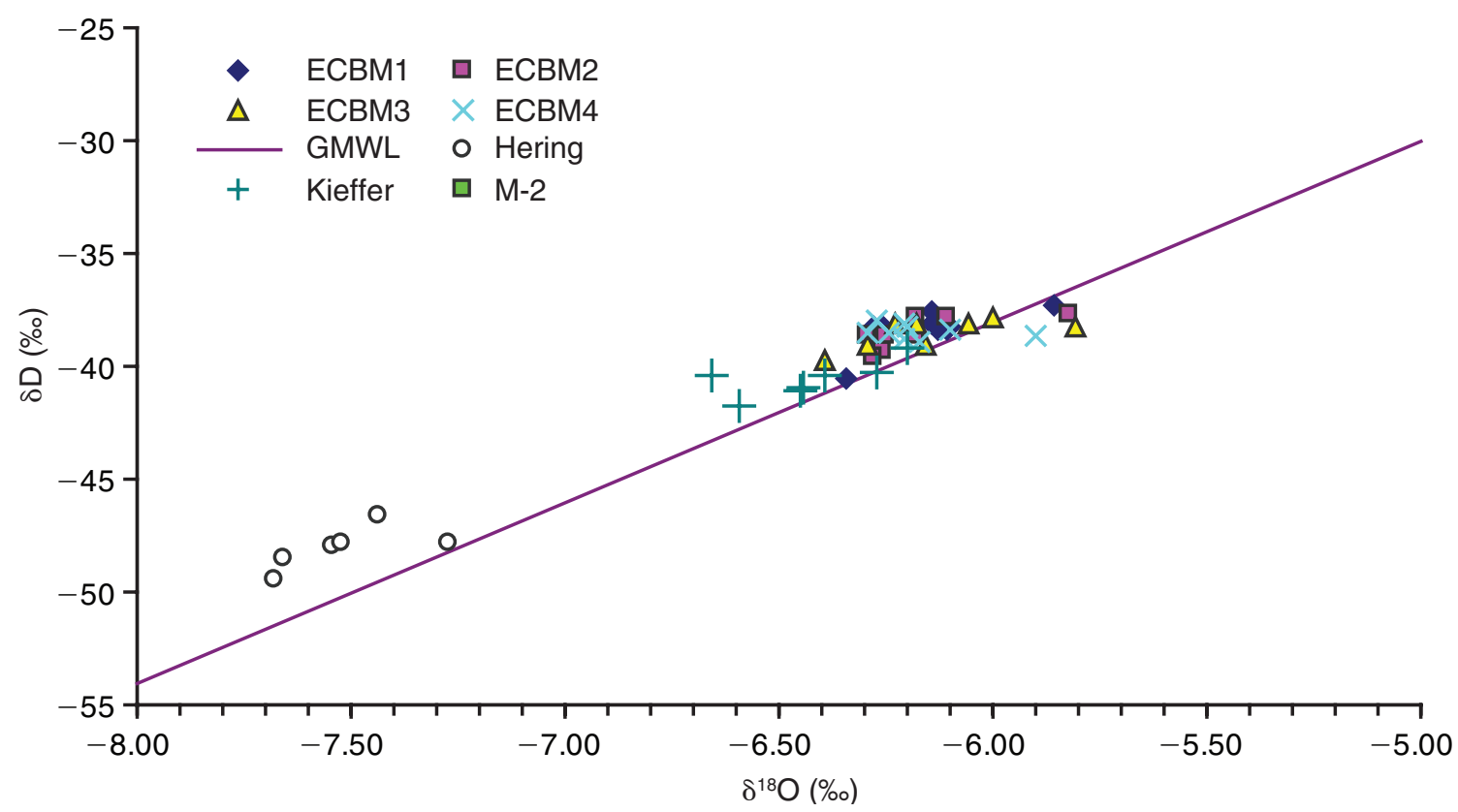

Figure 47. The $\delta^{18} \mathrm{O}$ and $\delta \mathrm{D}$ values in samples of shallow groundwater from ECBM monitoring and residential wells and from coal seam observation well M-2 at the Tanquary site.

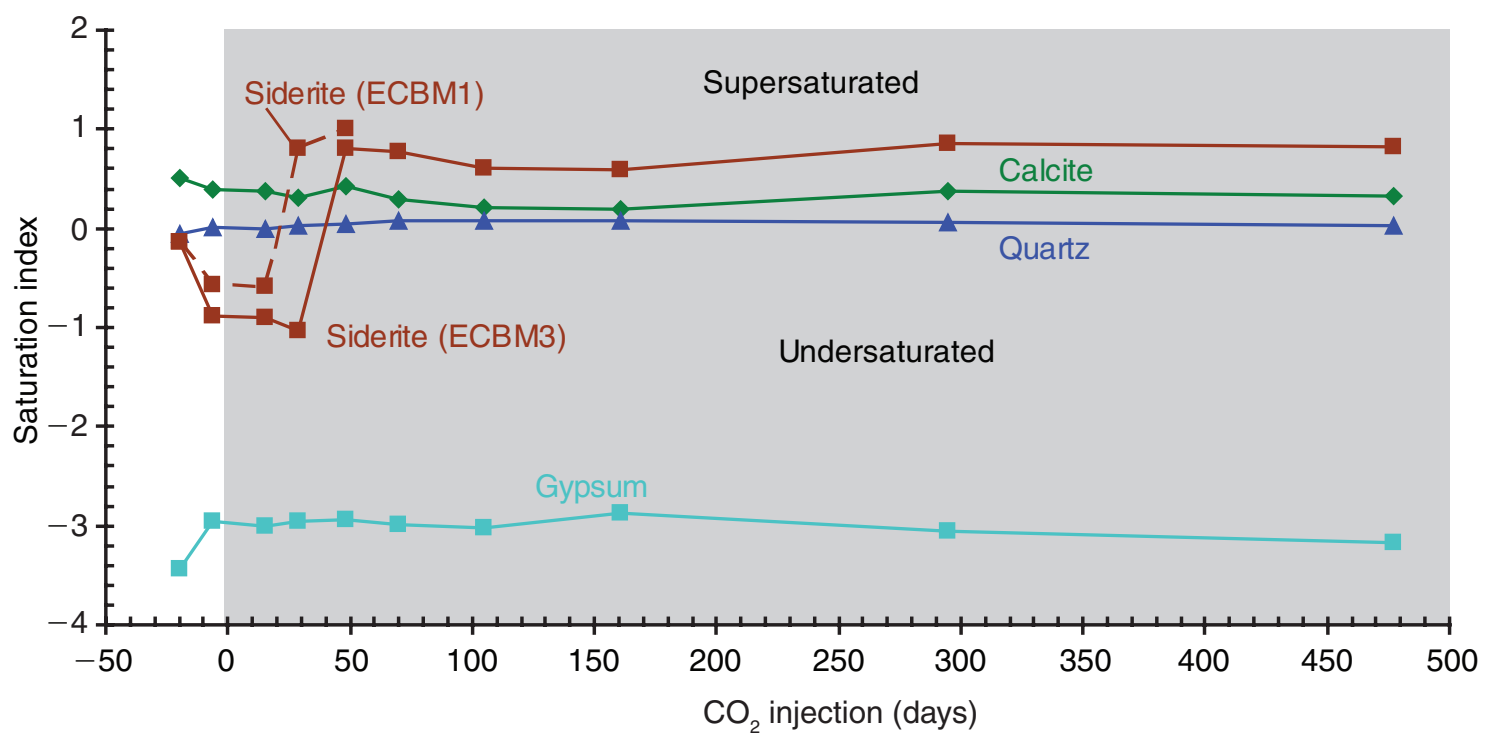

Figure 48. Saturation indices of siderite, calcite, quartz, and gypsum for groundwater samples collected at well ECBM3 (and of siderite for well ECBM1) plotted as a function of time. The injection and post-injection sampling periods have been shaded in order to highlight pre-injection samples.

which provided $\mathrm{CO}_{2}$ surface temperatures ranging from approximately 10 to $38^{\circ} \mathrm{C}$ (50 to $100^{\circ} \mathrm{F}$ ) for the conditions included in the design basis for the Phase II pilot tests. A vapor return line to the storage tank and pressure-regulating valves on the discharge side of the pumps allowed the system to be operated for either constant flow rate or constant surface pressure injection conditions. The $\mathrm{CO}_{2}$ was delivered to the site by 18-tonne (20-ton) liquid $\mathrm{CO}_{2}$ tanker trucks.

Portable Storage Tank. The pump skid received liquid $\mathrm{CO}_{2}$ from a 54.4-tonne (60-ton) portable storage tank (Figure 52) leased from Air Liquide for the MGSC Phase II project. Using a portable $\mathrm{CO}_{2}$ storage tank reduces mobilization and demobilization costs compared with costs using fixed storage tanks. The tank is used for storage only; it must be empty when transported between sites and filled once it reaches the injection site. The storage tank was insulated, but had no refrigeration 


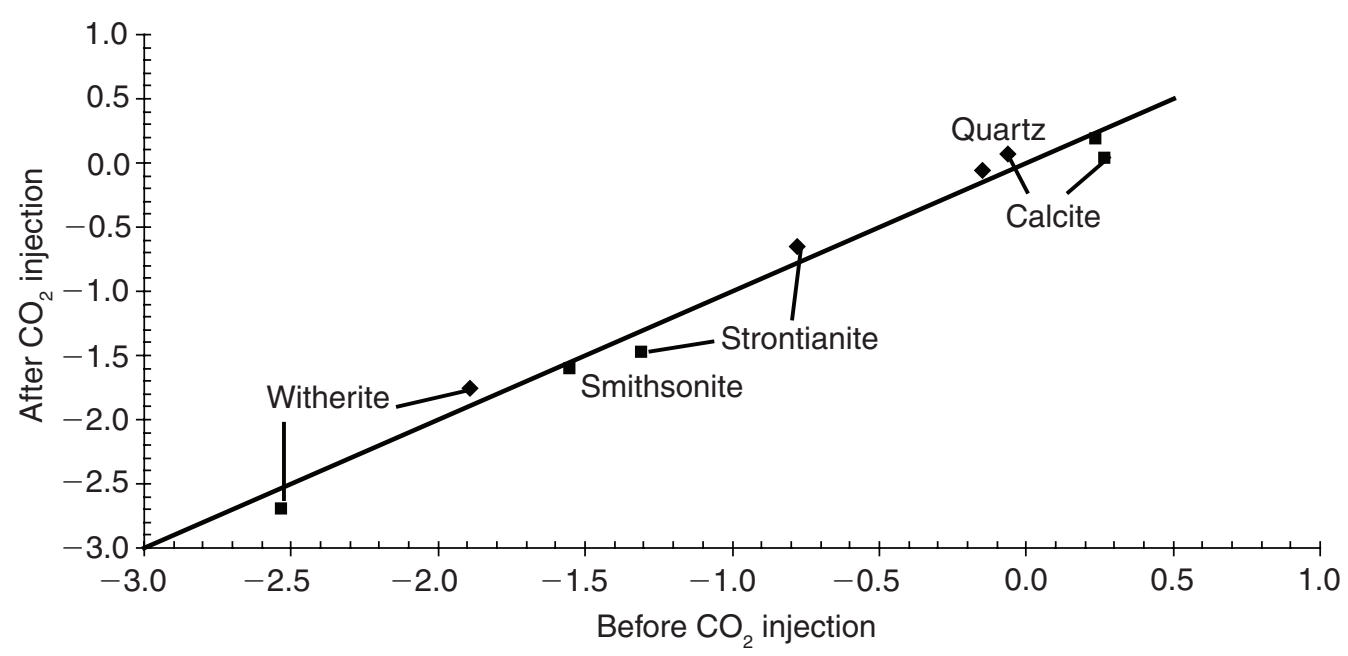

Figure 49. Saturation indices of witherite, smithsonite, quartz, and calcite for water samples collected at the residential wells. The squares represent samples collected at day -21 (before) and day 105 (after) at the Kieffer well. The diamonds represent samples collected at day -21 and day 295 at the Hering well.

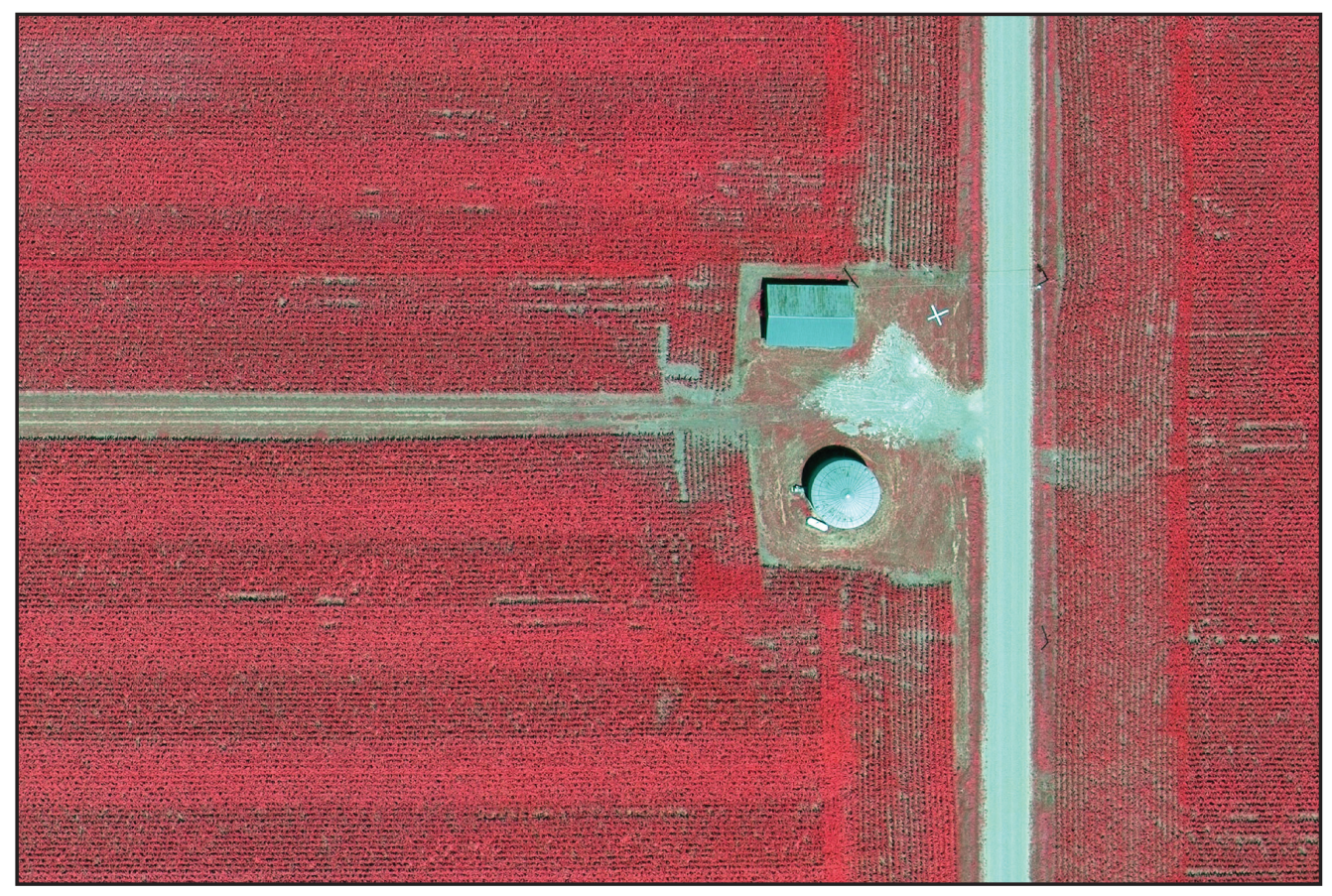

Figure 50. Color near-infrared (CIR) digital aerial orthophotography taken June 11, 2007. This aerial image illustrates the site prior to any pilot-related field activity. Corn fields surround the planned injection site situated near the two prominent structures (farm shed and grain bin). The $x$-shaped feature to the right of the shed is one of five ground control target panels used for the orthorectification of the digital mapping camera imagery. 


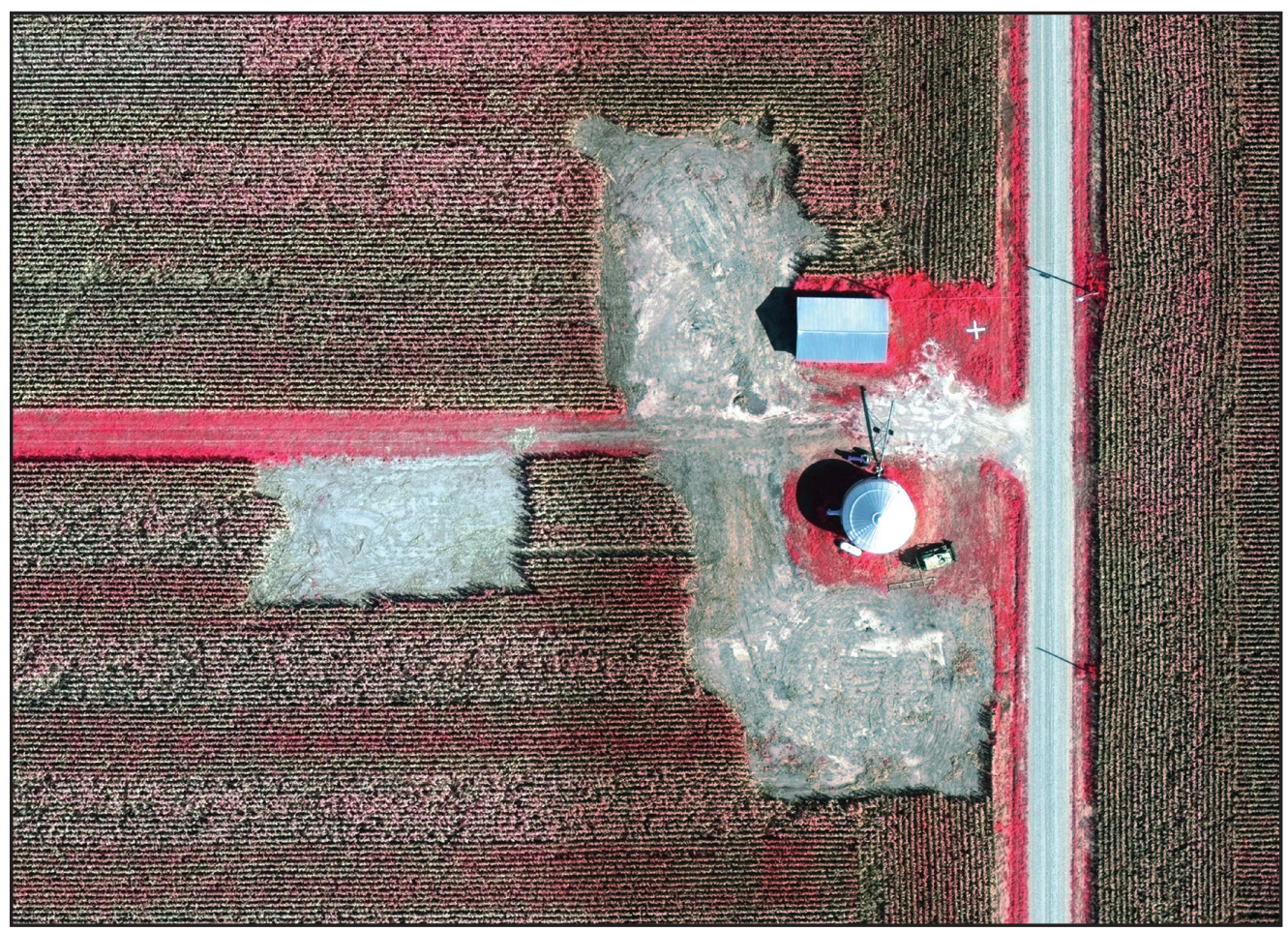

Figure 51. Color near-infrared (CIR) digital aerial orthophotography taken August 23, 2007. Crops have been cleared from the project site, and the M-1 and M-3 wells well have been drilled.

unit on site. The portable storage tank was $14.9 \mathrm{~m}$ (49 ft) long, $2.4 \mathrm{~m}$ (8 ft) wide, and $4.0 \mathrm{~m}$ (13 ft) high, and weighed 27,215 kg $(60,000 \mathrm{lb})$; the $\mathrm{CO}_{2}$ in the tank was stored at approximately $-18^{\circ} \mathrm{C}\left(0^{\circ} \mathrm{F}\right)$ and $2.1 \mathrm{MPag}(300 \mathrm{psig})$. The tank was equipped with two 101.6-mm (4-inch) liquid $\mathrm{CO}_{2}$ connections and three $50.8-\mathrm{mm}$ (2-inch) vapor $\mathrm{CO}_{2}$ connections. Bushings were used to reduce the connections to the 50.8 - $\mathrm{mm}$ (2-inch) liquid $\mathrm{CO}_{2}$ supply hose and the 25.4 -mm (1-inch) liquid/vapor return hose (Figure 53).

Booster Pump. A small booster pump skid was provided to improve the reliability of the main pumps by increasing the pressure of the feed to the main pumps to approximately $138 \mathrm{kPa}(20 \mathrm{psi}$ ) above the storage tank pressure (the vapor pressure of the liquid $\mathrm{CO}_{2}$ ), which decreased the possibility for $\mathrm{CO}_{2}$ phase change to gas and reduced vapor locking of the piston pumps. The booster pump was a model SRZS 221, horizontally mounted side channel pump manufactured by SERO Pump Systems (Figure 54). The side channel design involves fully open "star" impellers interacting with the side channel casing, creating an intense transfer of energy to the pumped liquid or liquid/gas. (The booster pump control panel is shown in Figure 55.)

The Model SRZS 221 pump is a single-stage, radially split segmented pump design that combines the functionality of a low net positive suction head (NPSH) first-stage impeller with the performance of a side-channel design. The booster pump is a self-priming pump that is able to pump two-phase $\mathrm{CO}_{2}$, and has low NPSH requirements that help to prevent cavitation. The model purchased for the $\mathrm{CO}_{2}$ injection skid is a one-stage pump that contains a single balanced mechanical seal with quench features.

The booster pump was rated for $2.04 \mathrm{~m}^{3} / \mathrm{hr}(9 \mathrm{gpm})$ of liquid $\mathrm{CO}_{2}$ at $18.3 \mathrm{~m}$ (60 ft) of head [179 $\mathrm{kPa}$ (26 psi)], requiring 0.39 $\mathrm{kW}(0.52 \mathrm{hp})$ at an impeller speed of 1,150 rpm. Minimum flow must be maintained at $0.68 \mathrm{~m}^{3} / \mathrm{hr}(3.00 \mathrm{gpm})$, and NPSH required is $0.41 \mathrm{~m}(1.35 \mathrm{ft})$. The maximum capacity of this booster pump was approximately $3.41 \mathrm{~m}^{3} / \mathrm{hr}(15 \mathrm{gpm})$ at $6.7 \mathrm{~m}$ (22 ft) of head [62 kPa (9 psi)]. The booster pump was rated for a maximum discharge pressure of $4.0 \mathrm{MPag}$ (580 psig). A 50.8$\mathrm{mm}$ (2-inch) Y-strainer from Spence Engineering prevented any particulate matter from damaging pump internals, and a $12.7-\mathrm{mm}(0.5$-inch) pressure relief valve set at $3.1 \mathrm{MPag}$ ( $450 \mathrm{psig}$ ) downstream of the pump protected the booster pump from overpressure.

Main Pump Skid. The main pump skid consisted of three single-cylinder piston pumps in parallel, a pressure-regulating valve downstream of each pump, a liquid turbine flow meter with instrumentation to measure the injection flow rate and 


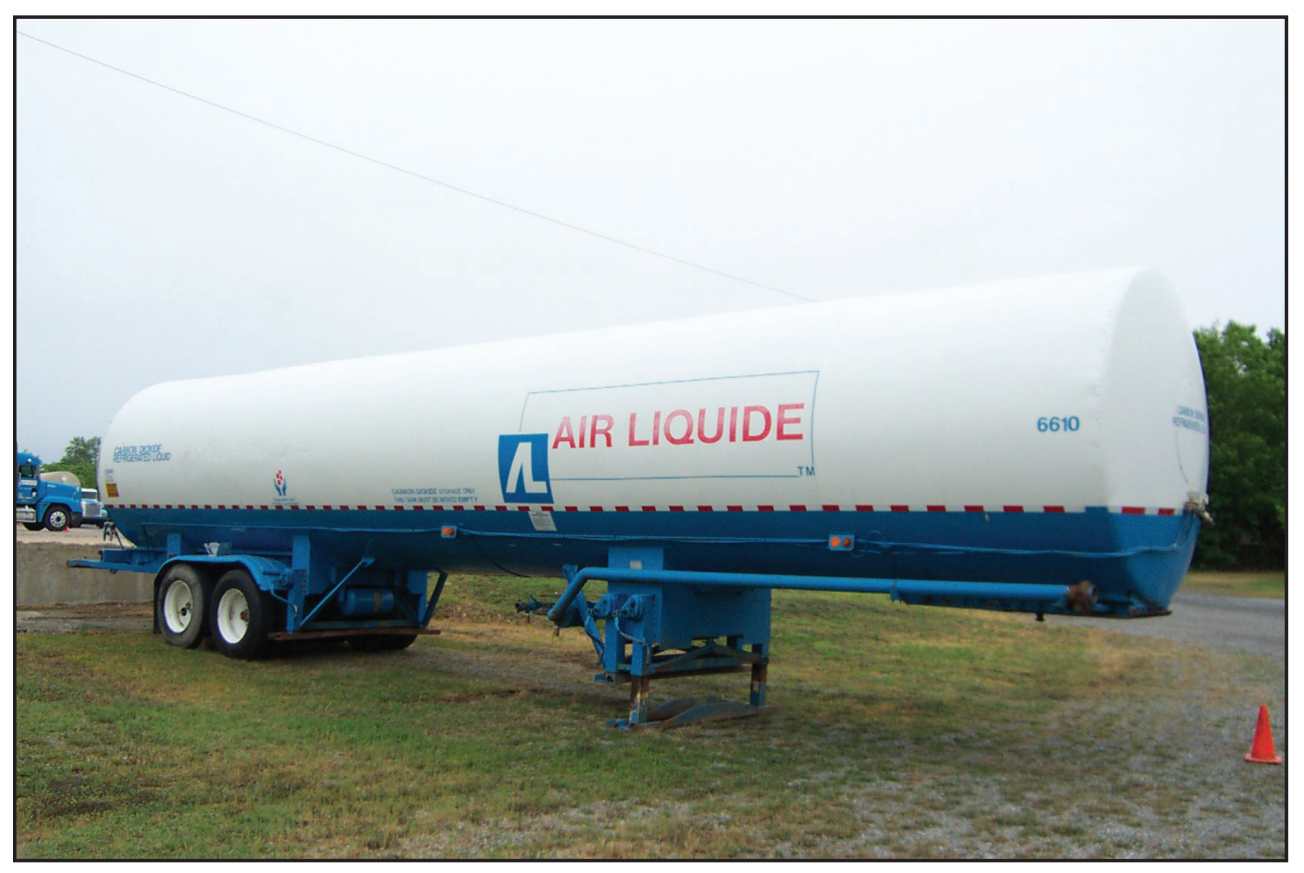

Figure 52. Air Liquide 54.4-tonne (60-ton) portable $\mathrm{CO}_{2}$ storage tank. Photograph was taken by Mike Griffith for Air Liquide.

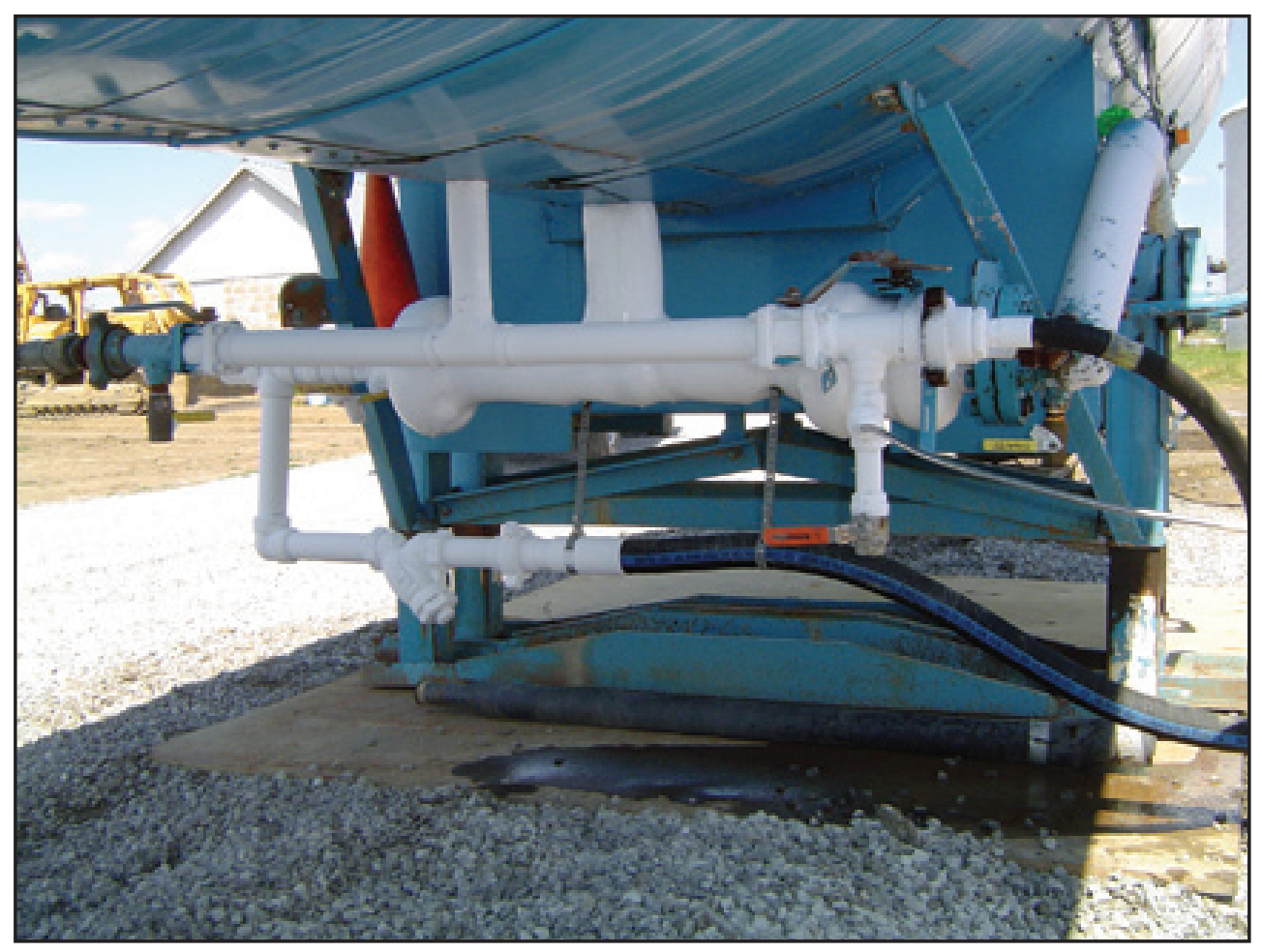

Figure 53. The outlet (bottom) and inlet (top) lines underneath the portable $\mathrm{CO}_{2}$ storage tank. The black flexible hose with blue stripe runs to the booster pump (liquid $\mathrm{CO}_{2}$ supply hose) and the solid black hose is the liquid and vapor return from the pump skid. Photograph was taken by Ray McKaskle for Trimeric Corporation. 


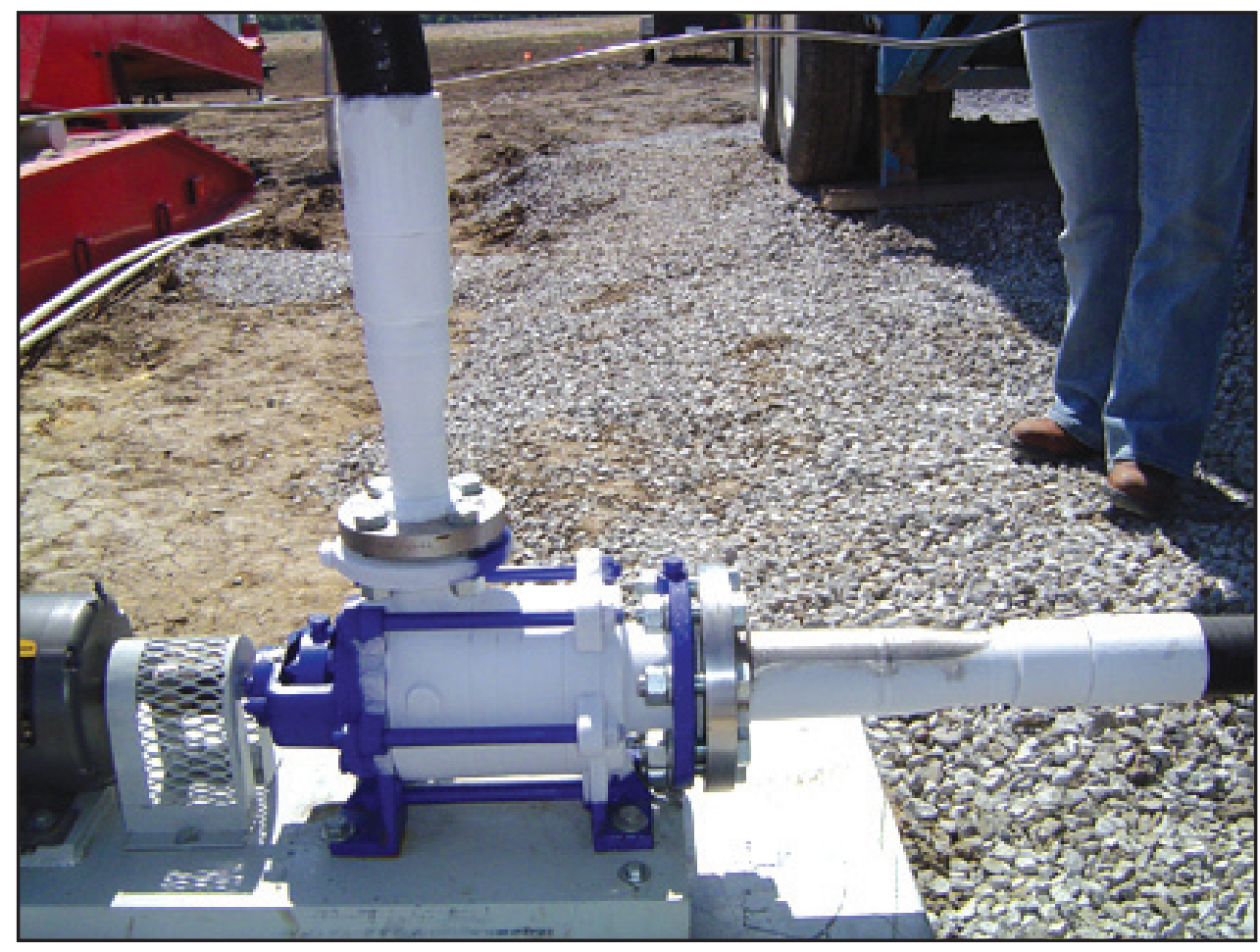

Figure 54. Booster pump model SRZS 221, horizontally mounted side channel pump manufactured by SERO Pump Systems. Photograph was taken by Ray McKaskle for Trimeric Corporation.

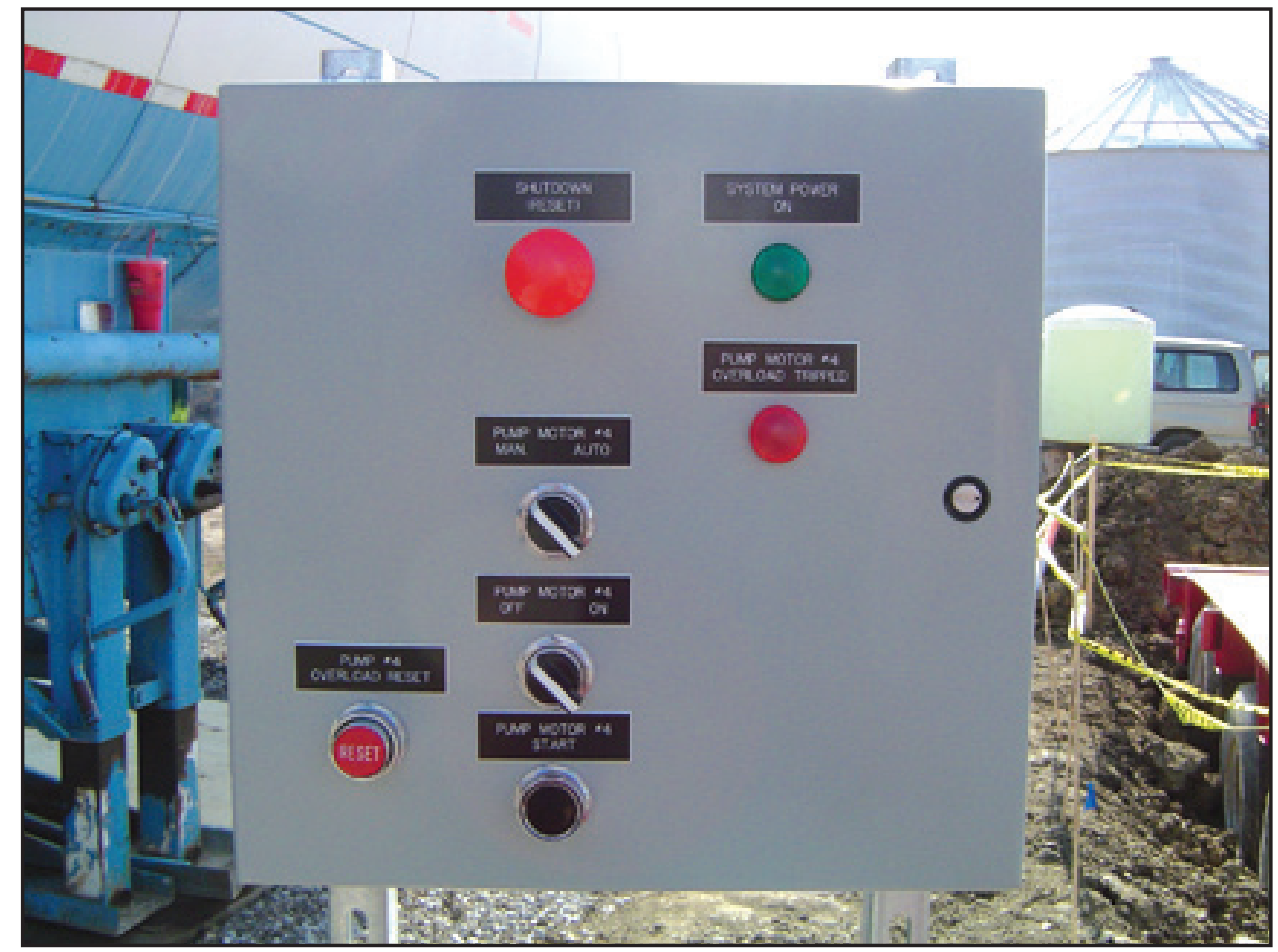

Figure 55. Booster pump control panel. Photograph was taken by Ray McKaskle for Trimeric Corporation. 


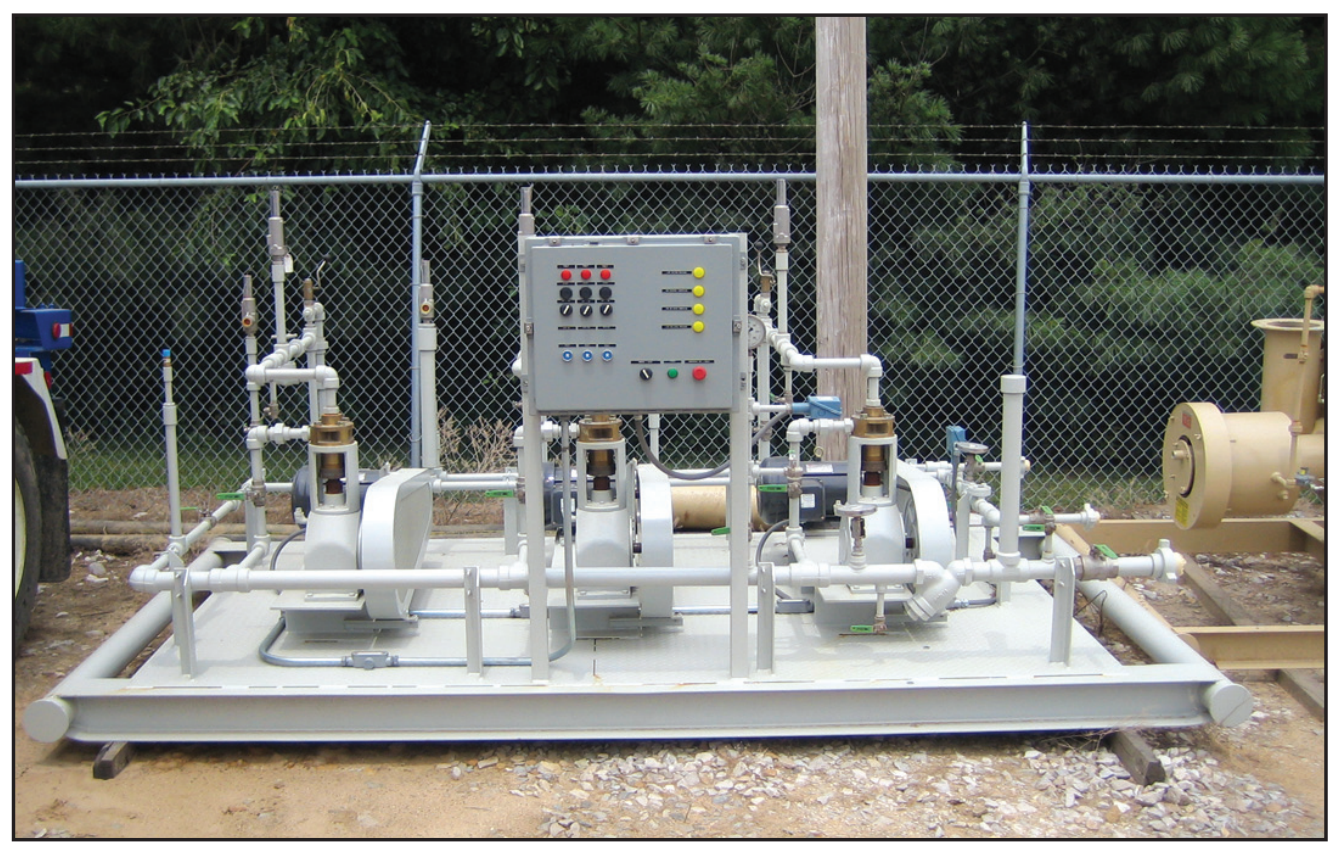

Figure 56. Front view of main pump skid with control panel in front. Inlet to skid is at right front corner of skid. Photograph was taken by Scott Frailey for Illinois State Geological Survey.

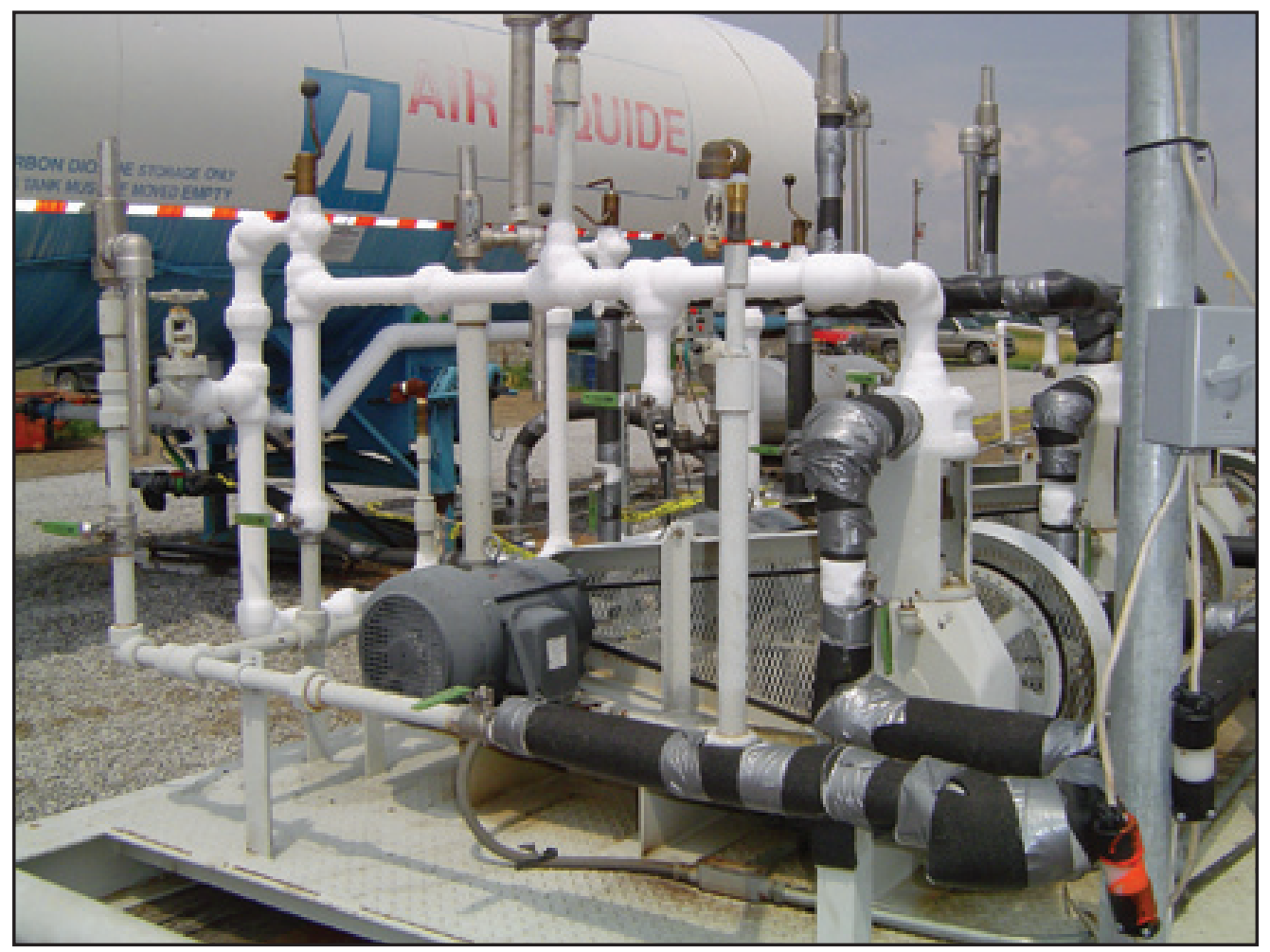

Figure 57. Main pump skid in operation (white frost on lines). Black foam insulation wrap on lines leading to pump inlet in foreground. Pump is the light gray vertical component to right; pump motor is dark gray and to the left. Black V-belt connects the pump and motor. Photograph was taken by Ray McKaskle for Trimeric Corporation. 


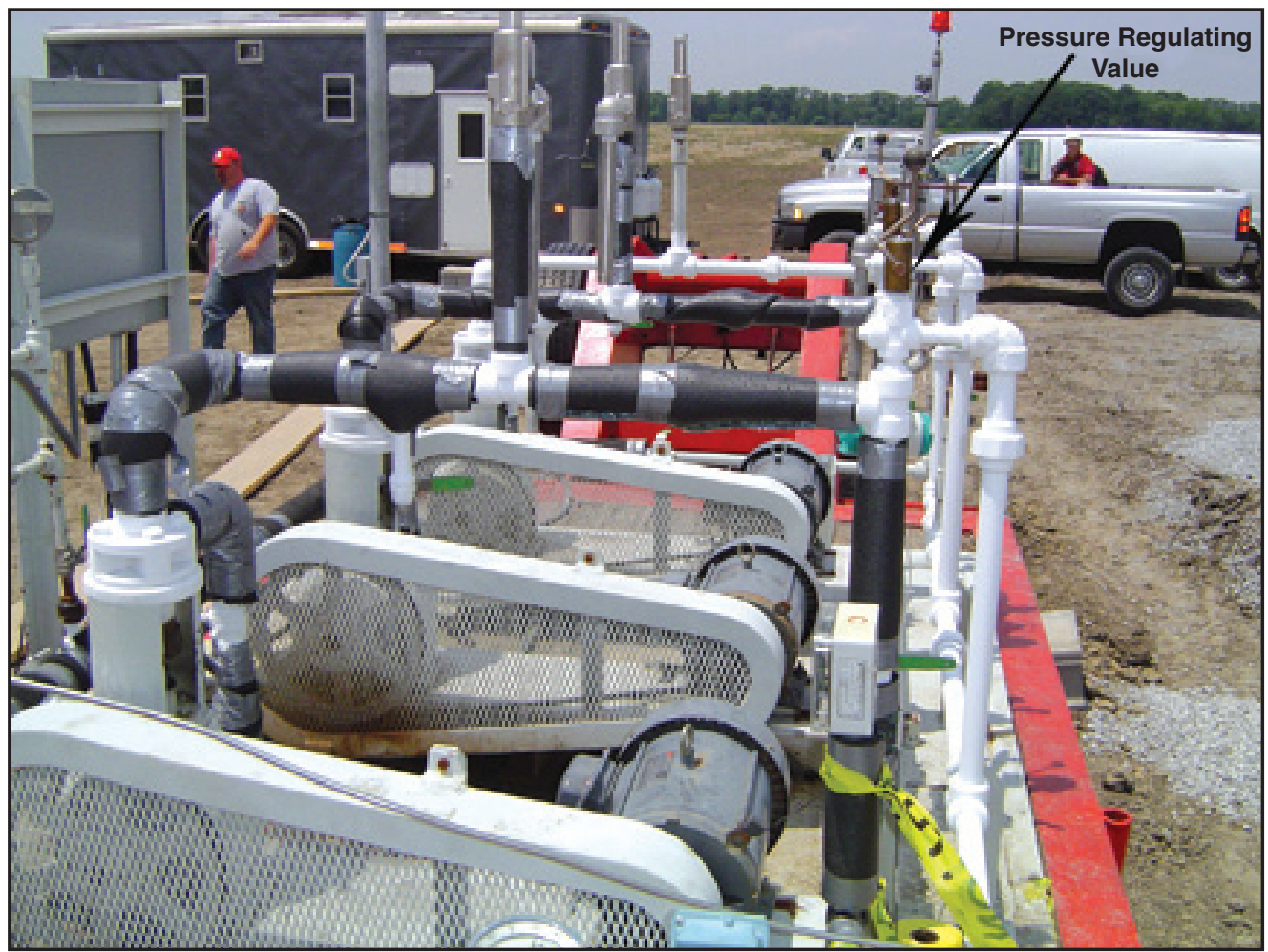

Figure 58. Pressure-regulating valves above and to the right of the Grainger motors (dark gray) above the frosted lines (see arrow, upper right). Photograph was taken by Ray McKaskle for Trimeric Corporation.

send a proportional 4-20 mA signal to a data recorder, and a control panel that could be used for either manual or automatic operation of the main pump skid. Temperature and pressure indicators were also available for manually recording suction and discharge temperatures and pressures. Figures 56 and 57 are pictures of the main pump skid.

Piston pumps. Each $\mathrm{CO}_{2}$ piston pump on the main skid was manufactured and supplied by Air Liquide. Each piston pump was fitted with operating controls designed to receive liquid $\mathrm{CO}_{2}$ at an inlet pressure of 1.4 to $2.1 \mathrm{MPag}$ (200 to $300 \mathrm{psig}$ ) and deliver the $\mathrm{CO}_{2}$ at pressures up to $8.3 \mathrm{MPag}(1,200 \mathrm{psig})$. Two sets of sheaves purchased from Motion Industries allowed the pumps to be run at either $419 \mathrm{rpm}$ or $700 \mathrm{rpm}$, which corresponded to $\mathrm{CO}_{2}$ rates of 0.91 and $1.59 \mathrm{~m}^{3} / \mathrm{hr}(4 \mathrm{and} 7 \mathrm{gpm}$ ), respectively, per pump. Each piston pump was driven by its own 7.5-kW (10-hp), 1,750-rpm, 460-V electrical motor supplied by Grainger. Pressure and temperature indicators were provided on both the suction and discharge sides of the pumps. A 50.8-mm (2-inch) Y-strainer from Spence Engineering prevented any particulate matter from damaging pump internals. This strainer was originally installed for operation of the pump skid without using a booster pump. After the booster pump was added, it became redundant to have another strainer upstream of the main pump skid. (Strainers are a source of pressure drop that could cause a change in phase from liquid to gas if the strainer becomes plugged with debris.) It was not practical to remove the strainer housing from the main pump skid after adding the booster pump since it was welded in place. Only the screen was removed from the Y-strainer on the main pump skid after the booster pump was added.

Pressure-regulating valves. The discharge line of each piston pump was equipped with a pressure-regulating valve manufactured and supplied by Air Liquide. Figure 58 shows the pressure-regulating valves above and to the right of the Grainger motors (dark gray) above the frosted flow lines. A hand-operated lever with a ball-shaped handle is on top of the valve. The valve is a ball-type relief valve, arranged to regulate discharge pressure and return $\mathrm{CO}_{2}$ back to the storage tank via the vapor/ liquid return line. When the manually-operated lever is in the "up" position, $\mathrm{CO}_{2}$ flows through the valve and into the return line that goes back to the $\mathrm{CO}_{2}$ storage tank. The valve is maintained in this position while the system pressure is increased to the desired pressure during startup and to lower the system pressure prior to shutdown.

During normal operations, when the lever is in the "down" position, the valve acts as a pressure-regulating valve that controls the pressure of the $\mathrm{CO}_{2}$ downstream of this valve on the main pump skid discharge line. There is a spring on each pressureregulating valve that was manually adjusted and set with a 9.5- $\mathrm{mm}\left(0.375\right.$-inch) Allen wrench to divert some of the $\mathrm{CO}_{2}$ 


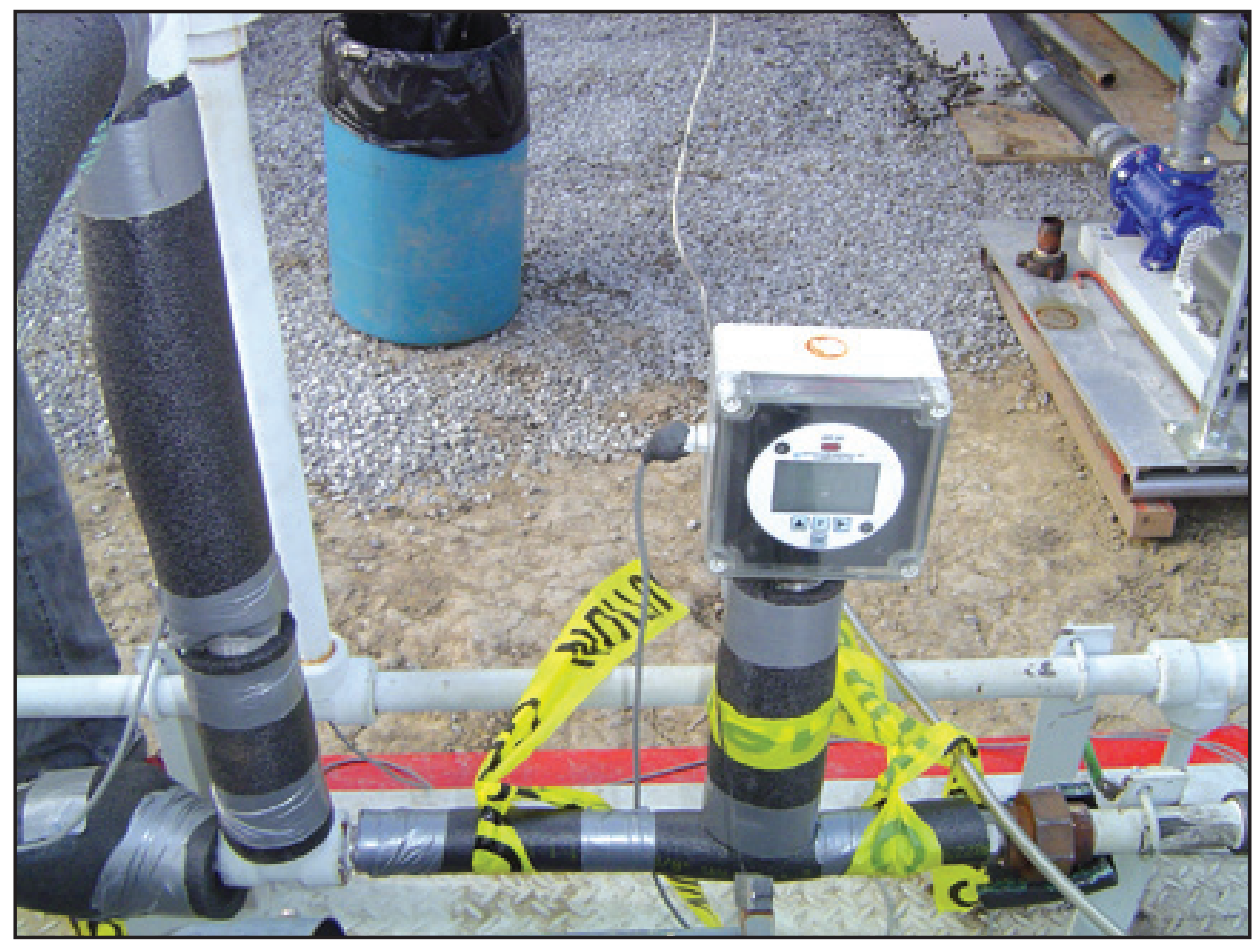

Figure 59. Flow meter on the discharge line of the main pump skid. This part of the discharge line is insulated with black foam wrap to minimize presence of two phases passing through the meter. The booster pump is in the right background. The gray pipe behind the meter is the liquid/vapor return line between the tank and pump skid. Photograph was taken by Ray McKaskle for Trimeric Corporation.

back to the storage tank in order to meet the discharge pressure requirement dictated by the tension in the spring. If the discharge/injection set pressure is not exceeded, all of the $\mathrm{CO}_{2}$ flows through the discharge line and into the line heater. If the discharge pressure is exceeded, a portion of the $\mathrm{CO}_{2}$ is diverted back to the storage tank until the pressure set point in the main pump skid discharge line is met.

The hand-operated pressure control valve also functions as a check valve to prevent backflow of fluids from the return line into the pump discharge line should a condition develop where the pressure on the pump discharge line was lower than the pressure on the vapor return line. Additionally, a 25.4-mm (1-inch) globe valve (manufactured by Bonney Forge) downstream of the pressure-regulating valves can be manually adjusted to send some or all of the pump discharge back to the $\mathrm{CO}_{2}$ storage tank without exceeding the specified pressure in the pressure-regulating valve.

Liquid Turbine Flow Meter. An HO series liquid turbine flow meter, manufactured and supplied by Hoffer Flow Controls, was located on the main pump skid discharge line. Figure 59 is a picture of the flow meter (discharge line near meter was insulated to minimize presence of two phases passing through the meter). The recommended operating temperature of the flow meter ranged from -15 to $-12^{\circ} \mathrm{C}\left(5\right.$ to $\left.11^{\circ} \mathrm{F}\right)$, and the recommended pressure ranged from 2.8-8.3 MPag $(400-1,200$ psig). The flow meter was calibrated at flow rates ranging from $0.05-4.54 \mathrm{~m}^{3} / \mathrm{hr}(0.2-20.0 \mathrm{gpm})$. A totalizer/flow indicator, also supplied by Hoffer, updated the displayed current flow rate and cumulative total flow every $2 \mathrm{sec}$. This provided a 4-20 mA output that was used for flow rate data recording.

This particular type of flow meter is a volumetric measuring turbine type; the flowing $\mathrm{CO}_{2}$ fluid engages the vaned rotor, causing it to rotate at an angular velocity proportional to the fluid flow rate. The angular velocity of the rotor generates an electrical signal. The summation of the pulsing electrical signal is directly related to the total flow. The frequency of the signal relates directly to the flow rate. Because the fluid moving through the flow meter engages the vaned rotor, "swirl" present in the fluid upstream and downstream of the meter can change the effective angle of engagement and cause a deviation from the calibration supplied by the manufacturer. The turbine meter was therefore constructed with flow straighteners to minimize the effects of fluid swirl. The outside diameter of the flow straightener element on this unit also narrowed to 15.9 $\mathrm{mm}$ from the 25.4-mm (1-in) diameter main pump skid pipe. The reduction in diameter increases fluid velocity and measurement sensitivity at low flow rates. 


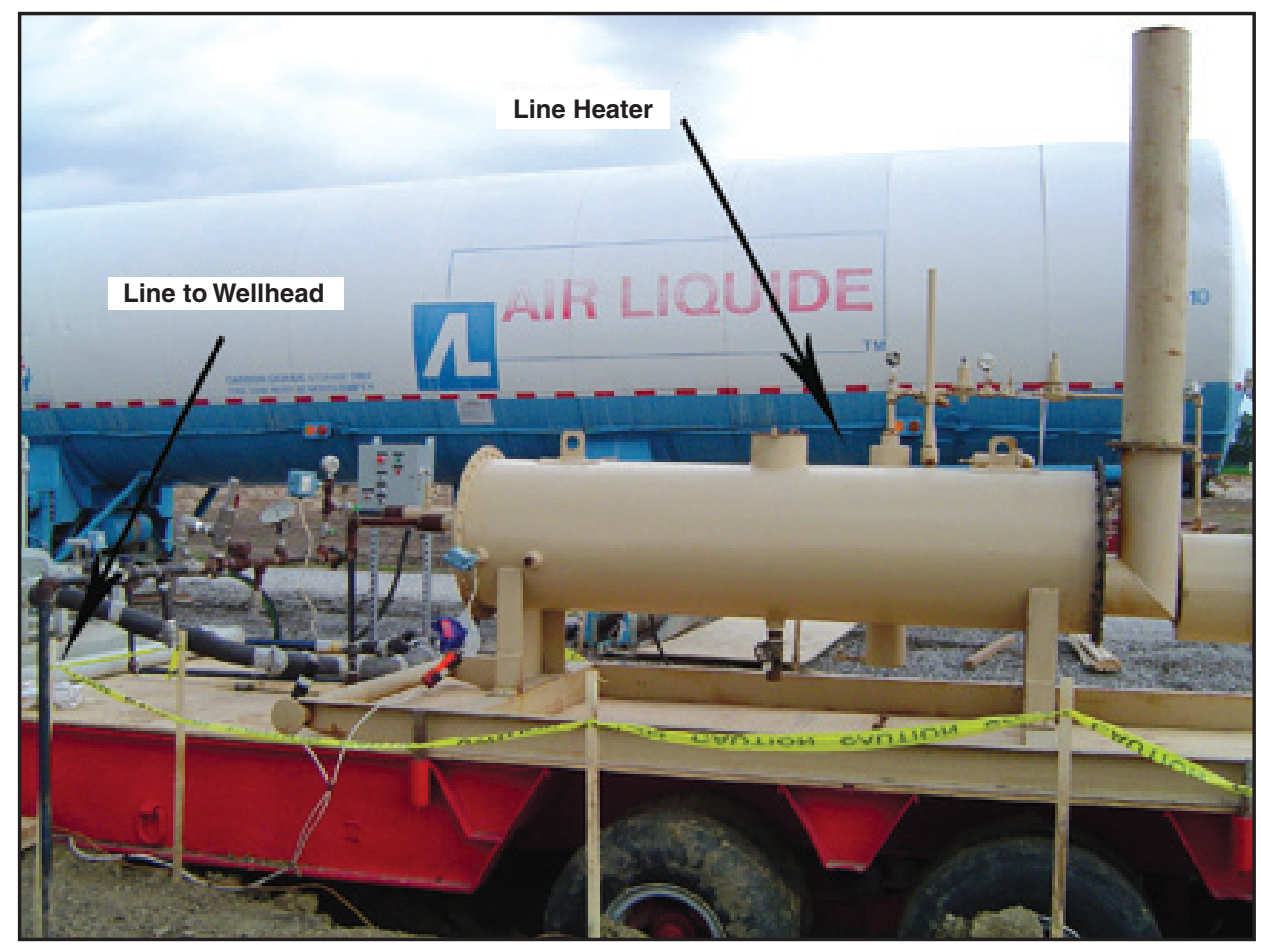

Figure 60. Propane-fired line heater placed on top of flatbed trailer. Storage tank is shown in the background. Photograph was taken by Ray McKaskle for Trimeric Corporation.

Gas Turbine Meter and Gas Orifice Meter. During the tests, it became apparent that the liquid turbine meter was not suited to measurement of the low injection rates used at the coal bed test site (see Operational Challenges section), so a gas turbine meter and gas orifice meter were added as process improvements. A Cameron NuFlo Gas Turbine Flowmeter was installed downstream from the line heater. The NuFlo is a 51-mm (2-inch) flow meter with a two-bladed, stainless steel rotor, stainless steel body, and tungsten carbide bearings and rotor shaft. The recommended operating temperature range of the flow meter was -18 to $107^{\circ} \mathrm{C}\left(0\right.$ to $\left.225^{\circ} \mathrm{F}\right)$, and the working pressure range was $0-15.3 \mathrm{MPag}(0-2,200 \mathrm{psig})$. At low gas flow range, the meter was able to measure flow rates from about 6.8-71.4 scm/hr (5-60 scf-d) at $6.0 \mathrm{kPag}$ (1 psig) to about 1,200$12,000 \mathrm{scm} / \mathrm{hr}(30,000-300,000 \mathrm{scf}-\mathrm{d})$ at $14 \mathrm{MPag}(2,000 \mathrm{psig})$. The flow meter was attached to an electromagnetic pickup (a wire coil wrapped around a magnet, inside a casing). Gas flowing through the meter caused the rotor to spin. When the steel blades passed through the magnetic field, they caused magnetic flux, which induced a voltage pulse in the coil. Measurement of the voltage pulse permitted calculation of gas volume and, hence, flow rate.

The orifice meter was simply a length of pipe with an orifice plate—a metal disc with a small hole in the middle-mounted at the end. The restriction in the flow path creates a pressure drop that increases with increasing volumetric flow, and this pressure differential is measured by a scanner, which is able to calculate an actual gas flow rate and convert it to standard gas flow rate. This project used a Cameron NuFlo Scanner 2000 microEFM to measure the gas orifice meter differential pressure, base temperature, and base pressure. The scanner had an operating temperature range of -40 to $70^{\circ} \mathrm{C}\left(-40\right.$ to $\left.158^{\circ} \mathrm{F}\right)$. It was housed in an explosion-proof package and had a keypad and LCD display for viewing data and programming the unit. The scanner converted actual gas flow rate to standard gas flow rate. The pressure and temperature recorded with the Scanner was used with the Cameron gas turbine meter also.

In-line Heater. After the liquid $\mathrm{CO}_{2}$ was discharged from the liquid turbine flow meter, it passed through a reconditioned $263,800-\mathrm{kJ} / \mathrm{hr}(250,000-\mathrm{Btu} / \mathrm{hr})$ line heater supplied by Natco (Figure 60). The line heater was $0.6 \mathrm{~m}$ (24 inches) in diameter

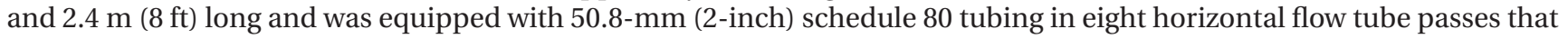
were $2.1 \mathrm{~m}(7 \mathrm{ft}$ ) long per pass with 180-degree elbows between each pass. The heater was equipped with a standard fuel gas manifold with thermostat, thermometer, regulators, and a fuel gas drip scrubber. A reducer was used to route the outlet of the line heater into 25.4 - $\mathrm{mm}$ (1-inch) schedule 80 pipe where a pressure gauge, temperature indicator, and check valve were located downstream of the heater. A skid and lifting lugs were added to the heater for increased portability. 
The shell side of the line heater was partially filled with a mixture of propylene glycol and water. Propane fuel gas was burned in a burner that discharged hot flue gas into a horizontal U-shaped fire tube immersed in the lower portion of the propylene glycol/water mixture. Heat released by burning the fuel gas was transmitted through the fire tube wall to the propylene glycol/water mixture. The desired solution temperature was maintained within upper and lower dead band limits by a thermostat that turned the propane flow to the burner on and off as needed. The $\mathrm{CO}_{2}$ flowed through the eight process tube passes in the heater that were immersed in the upper portion of the propylene glycol/water. Heat was transmitted from the mixture through the tube wall to the $\mathrm{CO}_{2}$ inside the process tubing.

The pipe from the line heater discharge to the wellhead included mechanical pressure and temperature gauges at the line heater outlet, a check valve to prevent fluids from the injection well from flowing back into the system, a 10.3-MPag (1,500 psig) pressure relief valve, and a main isolation valve immediately upstream of the inlet to the wellhead. Electronic switches for automated shutdown of the main pump skid due to low $\mathrm{CO}_{2}$ temperature out of the line heater or low pressure at the wellhead inlet were also located on this line, as well as valves used to blow down the system on shutdown. This $25.4-\mathrm{mm}$ (1-inch) pipe and its associated valves and gauges are shown in Figure 60 (left-side of picture) extending horizontally from the left end of the line heater and then toward the foreground and downward at the bottom left corner of the picture. Also between the line heater and the wellhead are the gas turbine and gas orifice meters. The discharge line of each piston pump is equipped with a pressure-regulating valve manufactured and supplied by Air Liquide. Beyond general oversight and troubleshooting, the primary requirement during active $\mathrm{CO}_{2}$ injection was adjustment of the regulating valve setting on the pump skid.

\section{Data Acquisition Equipment}

Pressure and Temperature Sensors. Surface and downhole pressures of all four Springfield Coal seam wells (M-1, M-2, M-3, and I-1B) were measured using Geokon 4500-series vibrating wire pressure transducers. Based on the manufacturer's specifications, the resolution and accuracy of the pressure transducers were at least $0.025 \%$ of full scale (FS) and $\pm 0.1 \%$ FS, respectively, with a maximum drift of $0.05 \% \mathrm{FS} /$ year. Each of the pressure transducers also contained a thermistor (type of resistor with strong temperature dependence) with a temperature range of -20 to $80^{\circ} \mathrm{C}\left(-4\right.$ to $\left.176^{\circ} \mathrm{F}\right)$ and thermal zero shift of less than $0.05 \% \mathrm{FS} /{ }^{\circ} \mathrm{C}$. The FS for all gauges was $7.6 \mathrm{MPa}(1,100 \mathrm{psi})$. (The I-1B surface sensor failed due to a freezing of water in the wellhead, and it was replaced with an available but different sensor; the FS of the replacement gauge was $12 \mathrm{MPa}$ [1,740 psi].)

Additionally, atmospheric pressure and temperature were measured at the M-3 wellhead using a Geokon 4580-1 (barometer) vibrating wire pressure transducer, which was programmed for a range of $0-17.2 \mathrm{kPa}(0-2.5$ psi). Based on the manufacturer's specifications, the resolution and accuracy of the barometer was at least $0.025 \%$ FS and $\pm 0.1 \%$ FS, respectively, with a maximum drift of $0.05 \%$ FS/year.

Data Acquisition System. Each pressure-temperature sensor was connected to a vibrating wire spectrum analyzer housed within the data acquisition enclosure at each wellhead. The analyzer measured the wire resonant frequency and resistivity of each sensor; these measurements were transmitted to a data logger and converted to digital pounds per square inch and degrees Fahrenheit. Figure 61 shows a typical data acquisition enclosure. Schematics of the data acquisition and transmission equipment can be found in Appendix 19.

Gas and liquid turbine and gas orifice meters are volumetric meters and require pressure and temperature measurements relatively close to each meter to estimate $\mathrm{CO}_{2}$ density and calculate the mass flow rate. Siemens Sitrans P Pressure Transmitters and Siemens Sitrans TK-H Temperature Transmitters were used with the Hoffer liquid turbine meter. The Cameron NuFlo Scanner 2000 microEFM was used with the gas orifice meter and gas turbine meter.

Radio transmitters connected to each datalogger sent pressure, temperature, and rate data to a common receiver, housed within the I-1B enclosure. Data collected at a 5-minute interval were then transmitted to the Illinois State Geological Survey by cellular modem once every hour. Detailed data and additional datalogger performance information were collected at a 15-sec interval and stored on removable compact flash cards within each datalogger. The data collected at a 15-sec interval were collected and uploaded to a database periodically and doubled as a backup in case of interrupted modem transmission to the Survey. Data were also transmitted by cable to a desktop computer located in the on-site office trailer. Each data logger had an independent power supply (battery) that was continually recharged by solar panel.

\section{General Operations}

Liquid $\mathrm{CO}_{2}$ was delivered in road transport tanks that had capacities of about 18 tonnes (20 tons). On site, the $\mathrm{CO}_{2}$ was transferred to the storage tank and pumped through an inline heater to ensure that the $\mathrm{CO}_{2}$ was in the gas phase before it entered the coal seam. Gaseous $\mathrm{CO}_{2}$ has lower viscosity and lower density than liquid $\mathrm{CO}_{2}$. Lower viscosity was expected to improve injectivity in the cleat system of the coal, and low density $\mathrm{CO}_{2}$ was expected to be less reactive with coal than the higher density $\mathrm{CO}_{2}$. Also, it was anticipated that commercial $\mathrm{CO}_{2}$ sequestration would be delivered into a coal seam via pipeline, so relatively higher surface injection temperatures and gas phase were an objective. 


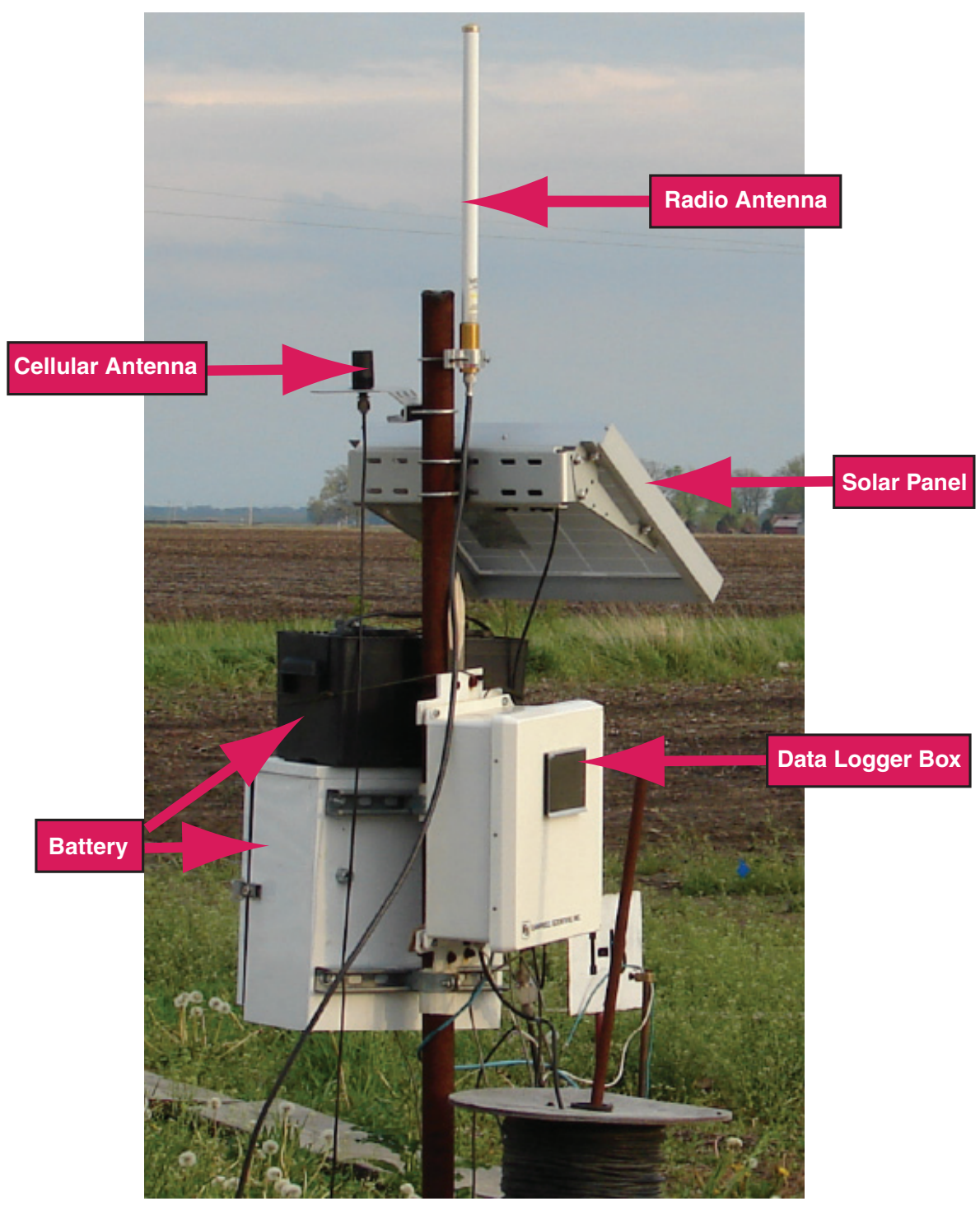

Figure 61. The I-1B data acquisition enclosure from the Tanquary site. In this picture, the battery is sitting above and outside the custom-designed enclosure that encases it during regular operations.

\section{Operational Challenges}

The $\mathrm{CO}_{2}$ injection system was designed to inject $\mathrm{CO}_{2}$ at flow rates ranging from 0.05 to $4.8 \mathrm{~m}^{3} / \mathrm{hr}(0.2$ to 21.0 gpm $)$ at discharge pressures up to $8.3 \mathrm{MPag}(1,200 \mathrm{psig})$. The operating conditions for the Tanquary pilot were frequently below the lower limit of the injection flow rate measurement capability of the liquid turbine flow meter. The maximum rate of vapor phase $\mathrm{CO}_{2}$ injection during the project was approximately 1.8 tonnes/day ( 2 tons/day), but injection rates as low as 0.45 tonne/day ( 0.5 ton/day) were not uncommon. The minimum injection rate that could be measured by the liquid turbine meter was 1.1 tonnes/day (1.2 ton/day). The objectives of injection during the Tanquary test were able to be met using the surface injection equipment with the addition of gas phase flow meters, but a number of lessons learned are included in this section of this report.

Insulation. When the $\mathrm{CO}_{2}$ injection system was initially designed, it was known from experience that a booster pump and cold insulation on the suction lines to the piston pumps were not always necessary to prevent vapor lock with the particular piston pumps that were selected. In an effort to reduce equipment costs, attempts to operate without a booster pump and insulation were made on the first Phase II test (the huff ' $n$ ' puff test at Loudon field [MGSC, 2009]). It was soon discovered, however, that vapor locking was an issue in the first test, and so a booster pump was added prior to the Tanquary pilot. 
Insulation was added at the huff ' $n$ ' puff site and some vapor was bled manually to the atmosphere at the suction to the piston pumps to prevent vapor locking during the huff 'n' puff tests.

During pre-injection equipment startup activities, even with the booster pump in operation, tests suggested that vapor locking in the piston pumps was still an issue. This problem may have been due to low pressure (about $1.7 \mathrm{MPag}$ [240 psig]) in the storage tank. A leaking valve on the storage tank prevented tank pressures from reaching the expected $2.1 \mathrm{MPag}$ (300 psig) levels. Lower-pressure liquid $\mathrm{CO}_{2}$ is relatively colder, so heat transfer from the piping to the surroundings was greater than expected prior to adding insulation. Polyurethane insulation was added, and the vapor locking issues ceased. No attempt was made to operate with the booster pump and without insulation after the expected $2.1 \mathrm{MPag}$ (300 psig) pressure was achieved in the storage tank. The insulation remained in place for the duration of the coal bed pilot test.

Booster Pump. The booster pump failed four times over the 7-months of injection. The pump seals had to be replaced at a repair shop approximately $241 \mathrm{~km}$ (150 mi) away in Bowling Green, Kentucky. In addition to the need for offsite repair, lead time and cost of replacement parts were issues that made recovery from these booster pump failures more difficult and costly. Third-party service technicians reported that the booster pump appeared to have been subjected to high temperatures that could have been due to loss of liquid $\mathrm{CO}_{2}$ flowing into the pump. Field operations personnel reported that the supply of liquid $\mathrm{CO}_{2}$ from the storage tank to the booster pump was never interrupted during normal operations. However, system performance was improved and additional booster pump failures were prevented by adding a 9.5 -mm (0.375-in) diameter recycle line back to the storage tank from the booster pump discharge that continuously recycled a slipstream of $\mathrm{CO}_{2}$ back to the storage tank. This kind of protective recycle line is recommended for future low-rate injection tests with booster pumps. If continuous operation is critical in future tests, having a spare booster pump available on-site is recommended.

$\mathrm{CO}_{2}$ Pump Pressure-Regulating Valves. During operation, attempts to achieve constant bottomhole pressure required frequent manual adjustment of the pressure-regulating valves. The response to these adjustments caused a significant time lag associated with the length of the surface injection piping and the injection well because the surface pressure set point changes were being made in an attempt to modulate the bottomhole injection pressure. When an increase in injection pressure was made, all of the $\mathrm{CO}_{2}$ from the piston pump discharge was directed to the wellhead, causing a surge in flow measured at the pump skid. When injection pressure was decreased, all of the $\mathrm{CO}_{2}$ from the piston pump discharge was momentarily directed back to the storage tank, causing a drop in measured flow at the pump skid.

The addition of an instrumented pressure control system that used a pressure transmitter, a process controller, and a control valve that diverted some $\mathrm{CO}_{2}$ back to the storage tank as needed to control surface injection pressure would alleviate this problem and would eliminate manual injection rate changes. The additional costs associated with the improved pressure control valve system are warranted given the need for precise and frequent adjustment of surface injection pressures. (At the MGSC EOR II Mumford Hills and EOR III Sugar Creek test sites, a pressure control system was used. Site operations personnel reported that the improved surface pressure control systems worked well in these tests.)

Metering Low Rate $\mathbf{C O}_{2}$. Operational experience and flow rate data analyses from the Tanquary pilot indicated that future tests with injection rates of $\leq 0.9$ tonne/day ( 1 ton/day) would require alternate flow rate measurement equipment. Various challenges were encountered with each flow rate measurement device depending on the predominant phase flowing through the meter.

The pump skid was originally designed to have a liquid $\mathrm{CO}_{2}$ turbine meter downstream of the regulating valve near the outlet of the pump skid. This location was immediately upstream of the inline heater that was used to increase the temperature of the $\mathrm{CO}_{2}$ to that of the gas phase. Because the turbine meter was calibrated for liquid flow, recorded rates would be erroneous if the $\mathrm{CO}_{2}$ were not completely in the liquid phase as it passed through the turbine meter. These rates might not be usable without a correction factor or correlation to another reliable meter.

In addition, the liquid turbine flow meter was not calibrated for the low injection flow rates that were frequently necessary in order to stay within bottomhole injection pressure requirements during active injection. Reduction in pressure or increase in temperature near the liquid turbine meter could lead to inaccurate measurements. The meter was calibrated to measure between 0.05 and $4.5 \mathrm{~m}^{3} / \mathrm{hr}(0.2$ and $20.0 \mathrm{gpm})$, and the injection rates at the coal bed test site as measured on a liquid basis at the liquid turbine flow meter were between 0.018 and $0.073 \mathrm{~m}^{3} / \mathrm{hr}(0.08$ to $0.32 \mathrm{gpm})$, or 0.45 to 1.8 tonnes/day (0.5 to 2 tons/day). At lower flow rates that required specific settings of the pressure regulating valve, the meter recorded erroneously high rates. (The manufacturer of the liquid flow meter stated that the liquid turbine flow meter was at the minimum practical measurement range of this liquid turbine flow meter.)

A gas turbine meter calibrated for $\mathrm{CO}_{2}$ gas was placed immediately downstream of the inline heater to measure the gasphase injection rates on the coal bed test. However, this meter had a minimum threshold rate below which the turbine would not rotate, and non-zero flow rates were recorded as "zero". 
A gas orifice meter calibrated for $\mathrm{CO}_{2}$ gas was placed downstream of the inline heater immediately upstream of the wellhead. In general, this type of meter proved to be most reliable in measuring rates. The only exceptions were that in the fall and winter months, especially overnight, injection rates would fall to zero (based on flow meter and injection well pressure). Based on pressure and temperature measured upstream of the orifice meter, the gaseous $\mathrm{CO}_{2}$ was likely condensing upstream of the orifice plate, blocking flow through the orifice plate, and causing an excessively large pressure differential. This situation was resolved by monitoring inline heater outlet temperature more closely and by adjusting to higher inline heater temperatures overnight to compensate for the cooler ambient temperatures.

The flow rate data reported and used for analyses are a composite of the data from the three flow meters available at the site, depending on functionality of the meters and operational conditions (pressure and temperature). In general, the liquid turbine meter did not provide reliable direct measurements; however, correlations between the liquid flow meter and the gas orifice meters were developed so that when the liquid turbine meter was the only functioning meter, an estimate of flow rate was available.

Routine Operations. Rob Lowery and William Ellis were two of the staff members responsible for daily operations at the coal bed test site. Highlights of their operating experiences and recommendations are noted in this section. (Additional details are given in a separate topical report [in progress] by Trimeric.) Daily operations involved inspecting the lines downstream of piston pumps for frost to ensure that liquid was being pumped through the piston pumps.

- The largest operational issue involved the hand-operated pressure-regulating valves.

- Frequent adjustments were required to maintain bottomhole injection pressures within desired limits.

- Condensation of atmospheric moisture was another major problem affecting the manual pressure-regulating valves. Moisture from the air would condense and freeze on the cold pipes at the base of the valve handles. The buildup of water-ice at the base of the handle would slowly push the valve handle up, eventually putting the injection skid in recycle mode.

- Condensate buildup was also an issue with the gas orifice meter. Additional heating of the $\mathrm{CO}_{2}$ in the line heater or bleeding pressure upstream of the orifice eliminated the condensate.

No corrosion associated with $\mathrm{CO}_{2}$ was detected within or on any components of the equipment.

\section{Field Observations During Active $\mathrm{CO}_{2}$ Injection}

\section{Injection Schedule}

Appendix 20 contains a timeline of events at the injection and monitoring wells. The $\mathrm{CO}_{2}$ injection began on June $25,2008$. Because of permit regulations, pumping operations were constrained by the maximum surface injection pressure of 5.07 MPag (736 psig) and maximum bottomhole pressure of 5.34 MPag (775 psig). (The maximum injection pressure specified on the original 2007 permit [Appendix 1] was 4.5 MPag [650 psi], but the permit was amended in 2008 based on a step rate test analyses of M-3.) Because of the relatively low coal permeability, most of the $\mathrm{CO}_{2}$ injection rates are pressure-constrained with variable injection rate.

To determine the significance of early alterations in flow and coal adsorption characteristics to $\mathrm{CO}_{2}$ injection, as well as onsite staff training and schedules, several $\mathrm{CO}_{2}$ pressure transient tests (injection-falloff-pulse) were conducted over the first 4 weeks of injection through July 21, 2008. Three sets of injection pulses of different duration followed by a falloff were conducted (Figure 62):

- three 8-hr injection/12-hr shut-in pulses followed by a 4-day falloff test

- two 12-hr injection/12-hr shut-in pulses followed by a 5-day falloff test

- three 24-hr injection/24-hr shut-in pulses followed by a 9-day falloff test

During the pressure transient testing period, $\mathrm{CO}_{2}$ injection rates ranged between 0.9 and 2.7 tonnes ( 1 to 3 tons)/day; cumulative injection was 12.2 tonnes (13.4 tons).

Following the transient tests, continuous $\mathrm{CO}_{2}$ injection was planned. There were four major suspensions of injection for about 1 to 2 weeks per event for a total of about 2 months. Three of these suspensions were caused by operational problems associated with seal failure on the booster pump. During one shutdown in August, a backup booster pump was installed but it also failed within a few days. The other major interruption of injection, in late October, was due to well shut-in for gas production. During the continuous injection period, July 21, 2008, through December 23, 2008, an additional 71.4 tonnes (78.7 tons) of $\mathrm{CO}_{2}$ were injected (Figure 63).

Near the end of the injection period, another series of $\mathrm{CO}_{2}$ pressure transient tests were completed. Eleven injection/shut-in pulses (of varying duration, from 7-8 hr up to $24 \mathrm{hr}$ ) were completed followed by a 4-day falloff test. During these tests an 


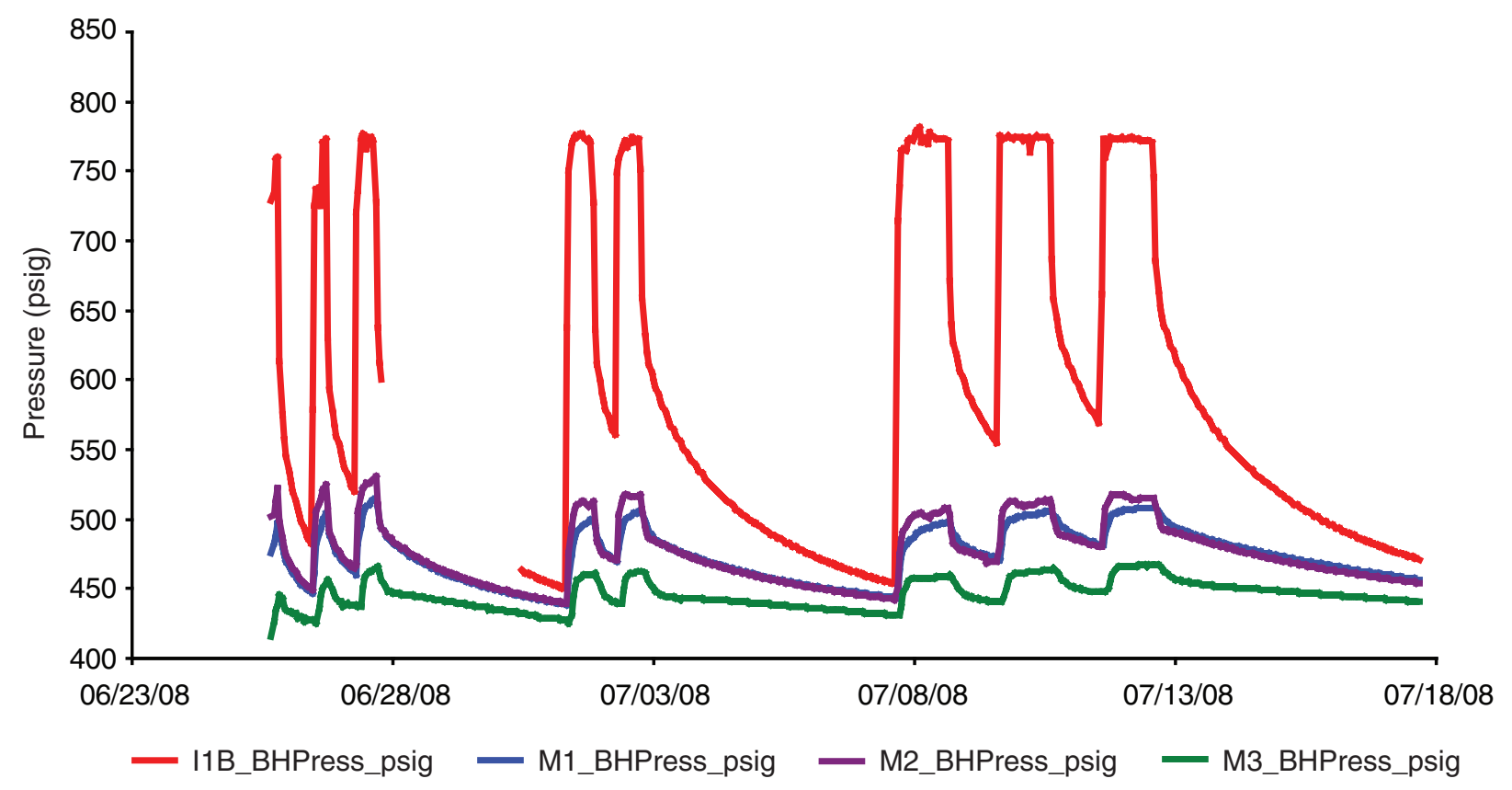

Figure 62. The $\mathrm{CO}_{2}$ injection pressure transient testing and responses of the injection and monitoring well. The red line represents the results for injection well I-1B; monitoring well results are shown in purple for $\mathrm{M}-2$, blue for $\mathrm{M}-1$, and green for M-3.

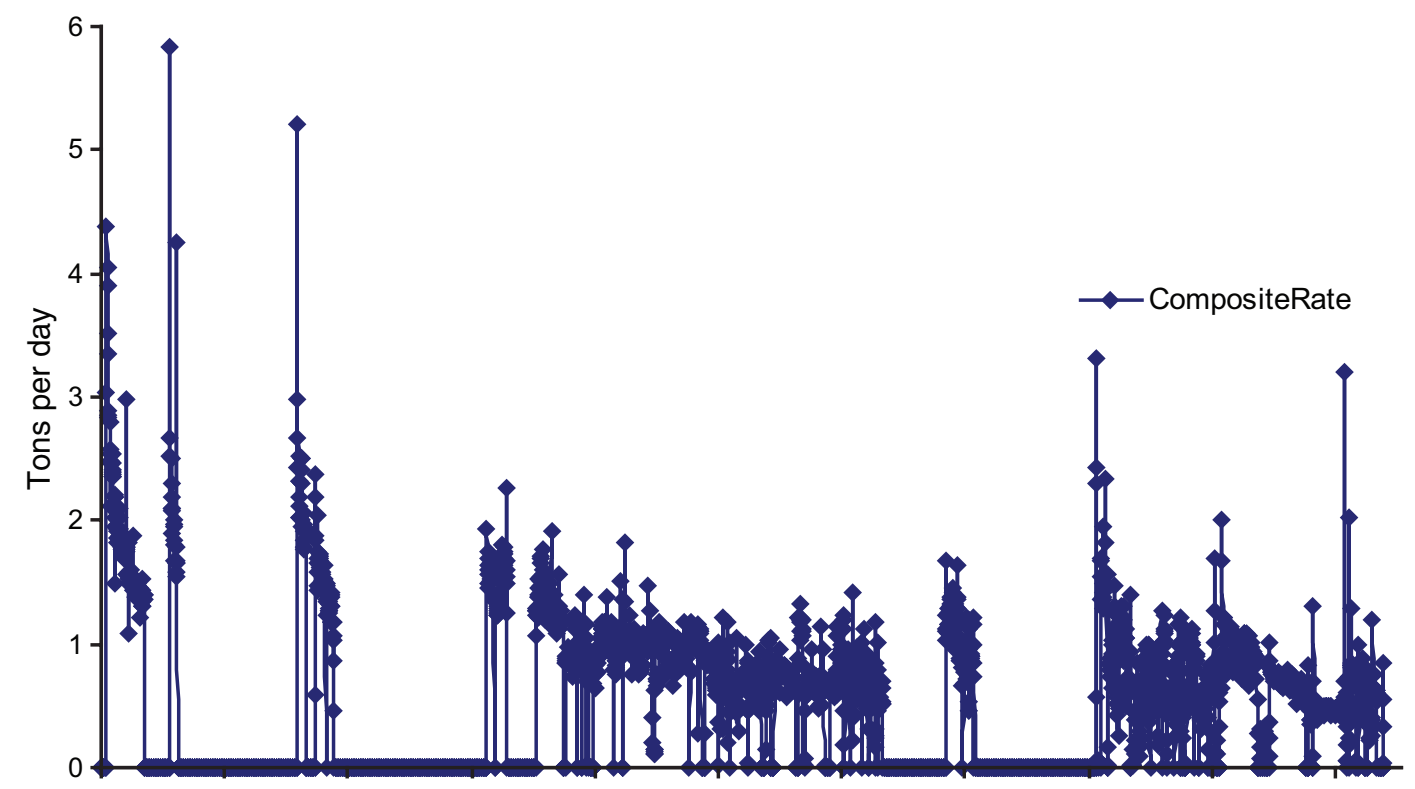

07/21/08 08/05/08 08/20/08 09/04/08 09/19/08 10/04/08 10/19/08 11/03/08 11/18/08 12/03/08 8 12/18/08

Figure 63. The $\mathrm{CO}_{2}$ injection rates during the continuous injection period. 
additional 8.7 tonnes (9.6 tons) of $\mathrm{CO}_{2}$ were injected. (Analyses and interpretation of the pressure transient tests are in a subsequent section.)

Injection was completed on January 13, 2009. Cumulative $\mathrm{CO}_{2}$ injection was 92.3 tonnes (101.7 tons). Of the 202.20 days between startup and shutdown of $\mathrm{CO}_{2}$ injection, active injection occurred over 99.73 days, at an average rate of 0.93 tonne/ day (1.02 ton/day).

\section{Injection Rate and Injectivity}

Increase and decrease in injection flow rates alone are not adequate to conclusively infer increases or decreases of $\mathrm{CO}_{2}$ injectivity due to interaction between $\mathrm{CO}_{2}$ and coal (e.g., swelling).

Injection Rate. During the pressure transient tests, injection was at constant bottomhole injection pressure; rates were at maximum and decreased with time during the injection period of each test. Maximum instantaneous rates were around 3.6-4.5 tonnes/day (4-5 tons/day) for only a few minutes. This rate could be a false rate as the $\mathrm{CO}_{2}$ within the wellbore must be compressed at the start of each test and is recorded as an injection rate at the surface. The rates that were sustained over longer periods during these tests were between 1.4 and 2.7 tonnes/day (1.5 and 3 tons/day) (Figure 64a).

During the continuous injection period, rates decreased from 1.36 tonnes ( 1.50 tons) to 0.45 tonne (0.50 ton)/day over 54 days; the bottomhole injection pressure also decreased during this time from $5.3 \mathrm{MPag}$ (770 psig) to $5.1 \mathrm{MPag}$ (740 psig), which accounts for some of the loss of injection rate. During this same period, the face cleat well's (M-2) bottomhole pressure reached a maximum of $3.38 \mathrm{MPag}$ (490 psig), and the $16 \mathrm{~m}$ (52 ft) butt cleat well's (M-1) bottomhole pressure reached $3.34 \mathrm{MPag}$ (485 psig). The $30 \mathrm{~m}$ (98 ft) butt cleat well's (M-3) bottomhole pressure reached $3.1 \mathrm{MPag}$ (450 psig).

A histogram of the entire $\mathrm{CO}_{2}$ injection rate (Figure $\left.64 \mathrm{~b}\right)$ showed that the injection rate mode was $0.60-0.70$ tonne $(0.66-0.77$ ton)/day. About $50 \%$ of the daily injection rates were between 0.50 and 0.90 tonne $(0.55-0.99$ ton)/day, and $90 \%$ of the injection rates were less than 1.60 tonnes (1.76 tons)/day.

Rate changes due to coal swelling and $\mathrm{CO}_{2}$ adsorption are likely to be more permanent, such that following a relatively short shut-in period of a few days or weeks, the injection rate should not return to the higher levels. For example, after the sustained injection period, the well was shut-in for 1 week. Upon returning to injection, the $\mathrm{CO}_{2}$ injection rate went from 0.45 tonne ( 0.50 tons) to 1.27 tonnes ( 1.4 tons)/day. Following almost every shut-in period, the injection rate increased to near the maximum initial sustained rate of 1.36 tonnes (1.5 tons)/day.

The decrease in injection rate could be from $0 \%$ up to $35 \%$ due to multiple causes. Based on the injection rate data alone, there was no obvious decrease in the $\mathrm{CO}_{2}$ injection rate that could be attributed to $\mathrm{CO}_{2}$ adsorption.

Injectivity. The injectivity index (II) is defined as the injection rate (q) divided by the pressure difference between the bottomhole injection pressure $\left(\mathrm{p}_{\mathrm{wi}}\right)$ and the initial coal pressure $\left(\mathrm{p}_{\mathrm{i}}\right)$.

$\mathrm{II}=\frac{\mathrm{q}}{\mathrm{p}_{\mathrm{wi}}-\mathrm{p}_{\mathrm{i}}}$

This index is intended to improve understanding of rate fluctuations or trends that may be due to changes in bottomhole injection pressure. It is based on Darcy's equation:

$\mathrm{q}=2 \pi \frac{\mathrm{kh}}{\mu} \frac{\mathrm{p}_{\mathrm{wi}} \mathrm{p}_{\mathrm{i}}}{\ln \frac{\mathrm{r}_{\mathrm{e}}}{\mathrm{r}_{\mathrm{w}}}+\mathrm{s}}$

or

$\mathrm{II}=\frac{\mathrm{q}}{\mathrm{p}_{\mathrm{wi}}-\mathrm{p}_{\mathrm{i}}}=2 \pi \frac{\mathrm{kh}}{\mu} \frac{1}{\ln \frac{\mathrm{r}_{\mathrm{e}}}{\mathrm{r}_{\mathrm{w}}}+\mathrm{s}}$

If pressure changes alone are affecting injection rate, then the injectivity index is a constant value. If the effective permeability k (product of relative and absolute permeability), viscosity ( $\mu$ ), or skin (s) changes, then the injectivity index changes. (This relationship assumes that coal thickness $[\mathrm{h}]$ and the external radius $\left[\mathrm{r}_{\mathrm{e}}\right]$ and wellbore radius $\left[\mathrm{r}_{\mathrm{w}}\right]$ do not change.) A decrease in injectivity index results from a decrease in $\mathrm{CO}_{2}$ relative permeability, a decrease in the absolute permeability of the coal, an increase in fluid viscosity, and an increase in the skin factor(s).

Initially the $\mathrm{CO}_{2}$ relative permeability is zero and increases with continuous $\mathrm{CO}_{2}$ injection as $\mathrm{CO}_{2}$ saturation in the cleat system increases, which would increase the injectivity index. The $\mathrm{CO}_{2}$ adsorption to coal is expected to swell the coal and 


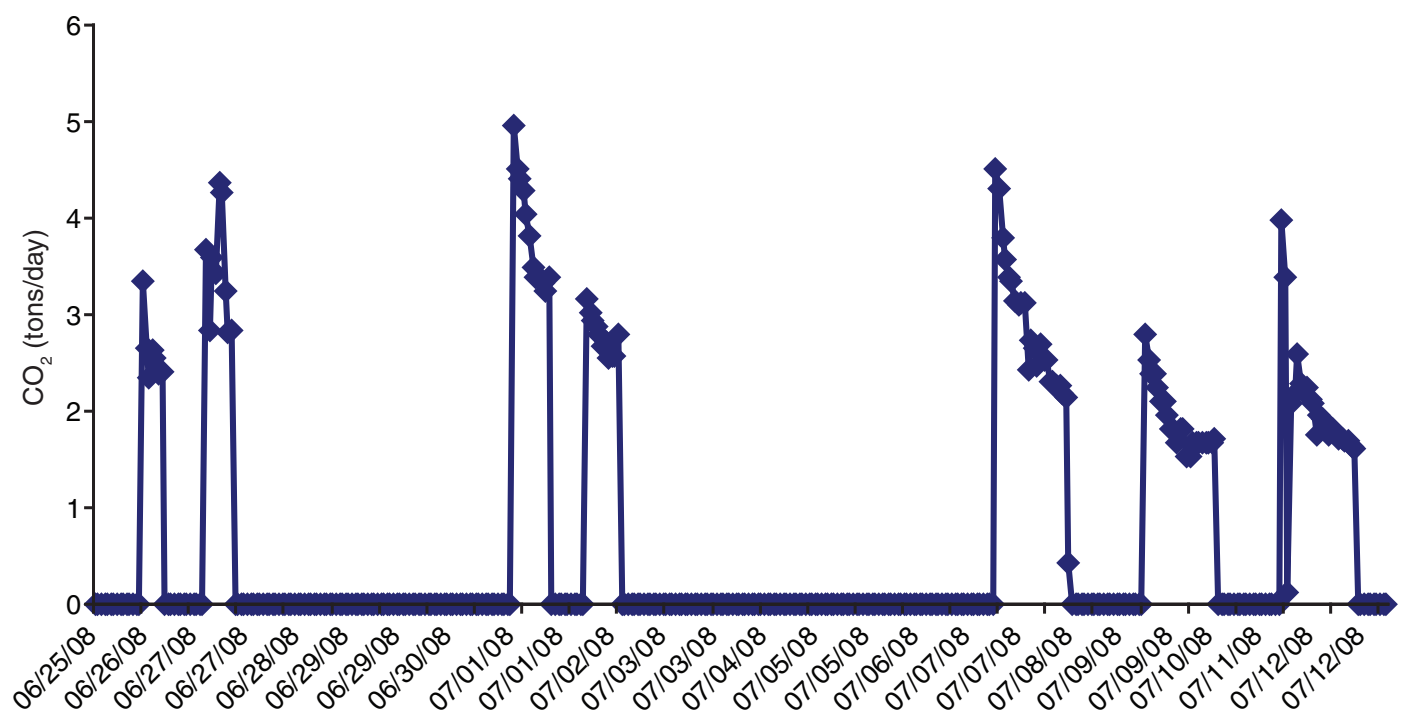

b

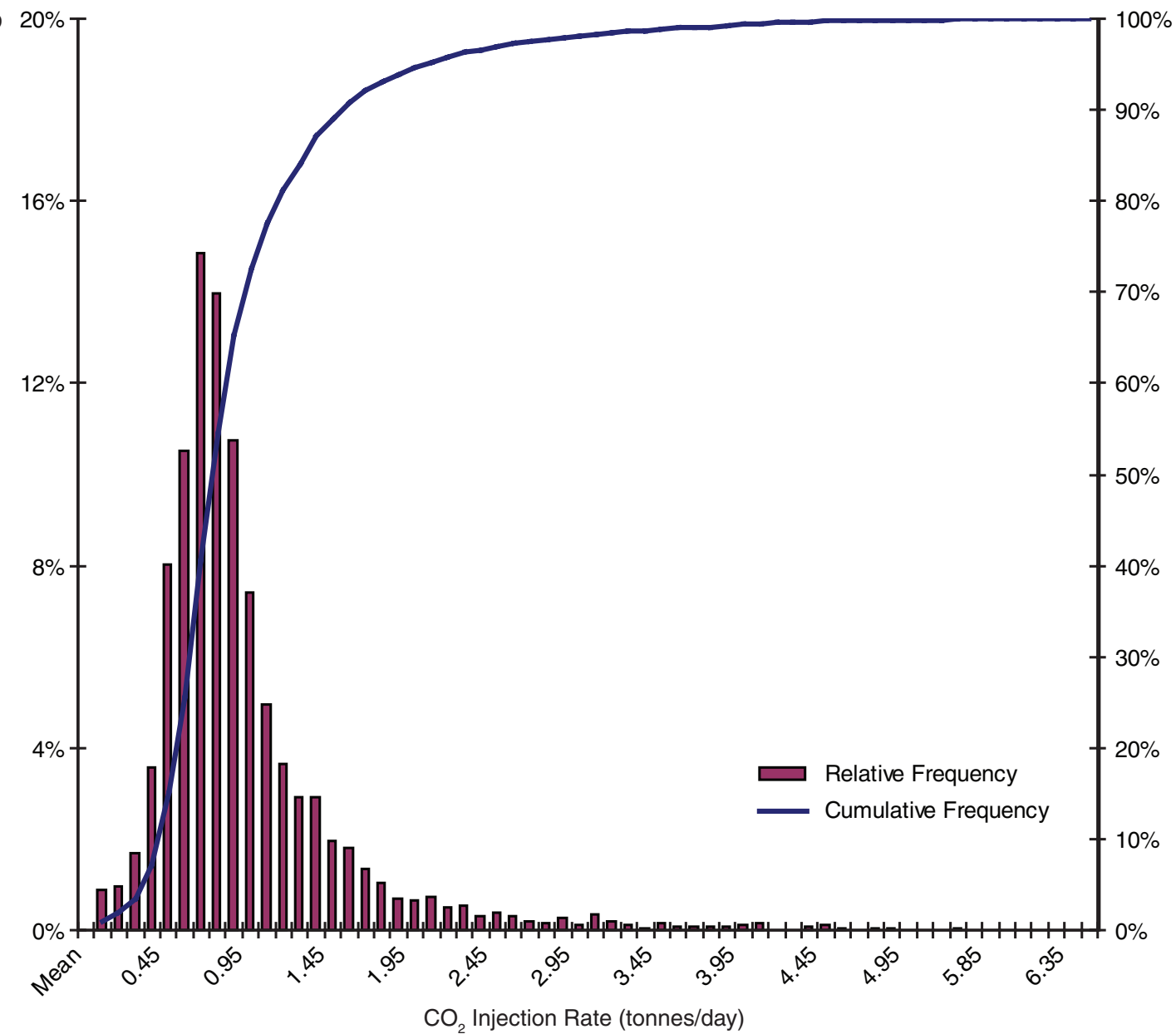

Figure 64. (a) Rates of $\mathrm{CO}_{2}$ injection during pressure transient tests. (b) Histogram of $\mathrm{CO}_{2}$ injection rates showing a mode of $0.6-0.7$ tonne $(0.66-0.77$ ton)/day. 
reduce the absolute permeability of the coal, which decreases the index. Gaseous $\mathrm{CO}_{2}$ viscosity is about an order of magnitude lower than the brine saturating the cleat system and, with increasing injection, would cause the injectivity index to increase. Coal is known to have pressure-dependent permeability. At higher injection pressure, the cleats open slightly more, which increases the absolute permeability and injectivity index.

Figure 65 is the injectivity index during the initial injection and pressure transient tests, continuous $\mathrm{CO}_{2}$ injection, and final pressure transient periods using 2.65 MPag (385 psig) initial pressure. During the early pressure transient period, the injection periods (Figure 65a) were over relatively short periods of time, and smaller volumes of $\mathrm{CO}_{2}$ saturated the coal seam. The injectivity index was $0.5-0.8$ tonne/ $\mathrm{KPa}$ (4-6 tons/psi). During the continuous $\mathrm{CO}_{2}$ injection period (Figure $65 \mathrm{~b}$ and c), the injectivity index was between 0.3 and 0.5 tonne/KPa ( 2 and 4 tons/psi).

The injectivity index shows indications of permeability changes due to pressure changes. Between September 19 and October 4,2008 , the index was about 0.46 tonne/ $\mathrm{kPa}$ (3.5 tons/psi) and between October 4 and 24, 2008, the index was about 0.33 tonne $/ \mathrm{kPa}$ (2.5 tons/psi). At first glance, these results appear as an indication of permeability reduction due to swelling. However, on close inspection of the injection pressure, during the first period the bottomhole injection pressure was about $5.34 \mathrm{MPa}$ (775 psig) and during the second period it was about $5.24 \mathrm{MPa}$ (760 psig). Also, for three rate periods between December 3 and December 19, 2008, the injectivity shows a clear decreasing trend of 0.5 and 0.3 tonne/kPa (4 and 2 tons/ psi). During these three periods, the average injection pressures were 5.5, 5.34, and 5.1 MPa (800, 775, and 740 psig). If this reduction in injectivity were due solely to swelling, it would not reflect this dependency on pressure changes. Moreover, the injectivity increased sharply at the start of each new injection period. If the reduction were solely due to swelling, the injectivity at the start of a new injection period should start close to injectivity index near the end of the previous injection period.

\section{Pressure Response of Coal Seam Monitoring Wells}

As with the water pressure transient responses of the wells, the pressure responses due to $\mathrm{CO}_{2}$ injection were similar for wells M-1, M-2, and M-3. M-2, the face cleat well, had the quickest change and largest increase in pressure, followed by M-1, the $15-\mathrm{m}(50-\mathrm{ft})$ butt cleat well. M-3 continued to have the longest lag time between injection change and pressure response and the smallest increase in pressure (Figure 62). However, the character of the pulses (shape and curvature) was different, indicating changes to the in situ properties (storativity and transmissivity).

\section{Gas Volume and Composition Field Response of Monitoring Wells}

Within hours of startup of $\mathrm{CO}_{2}$ injection, $\mathrm{CH}_{4}$ gas was detected with the field IR instrument at the surface sampling ports of the M-1 and M-3 wellheads. (Gas samples were taken periodically or when an IR reading in the field yielded an anomalous reading; the results of the gas samples are in the MVA section of this report and are in agreement with the field IR readings.) The volume of gas at the top of these wells, calculated using surface and bottomhole pressure (Figure 66), very slowly increased for about 1 week. The gas head of M-1 increased more rapidly to in excess of $30.5 \mathrm{~m}$ ( $100 \mathrm{ft}$ ) after about $25 \mathrm{days}$ of $\mathrm{CO}_{2}$ injection. The M-3 gas head increased to about $10.7 \mathrm{~m}$ (35 ft) over the same period. M-2 showed no indication of gas from the surface sampling or from the gas volume calculation. (Table 7 summarizes the periods and volumes of gas withdrawn from the observation wells.)

About 25 days after injection started, the gas volume was slowly withdrawn, sampled, and metered from M-1 and M-3. About 6.2 and 1.4

(220 and $50 \mathrm{ft}^{3}$ ) of $\mathrm{CH}_{4}$ gas were bled from each well, respectively. Water returned to surface from the coal seams within a few hours, indicating that there was adequate water volume saturating the cleat system to refill the wellbores. The gas volume started to build again in M-1 within a few hours and began in M-3 after 3 days. The gas composition was relatively the same from beginning to end of the gas withdrawal without any indication of $\mathrm{CO}_{2}$.

About one month after $\mathrm{CO}_{2}$ injection commenced, $\mathrm{CO}_{2}$ was detected at $\mathrm{M}-1$ at $11-13 \%$ concentration, which remained constant for several months. M-3 had $100 \% \mathrm{CH}_{4}$, and M-2 was water only at the surface sampling port. $\mathrm{M}-3$ had CO${ }_{2}$ breakthrough at 120-130 days after injection at about 5-8\%.

About 4 months after $\mathrm{CO}_{2}$ injection started, the calculated gas head in M-1 reached $76 \mathrm{~m}$ (250 ft) and for M-3 reached $46 \mathrm{~m}$ $(150 \mathrm{ft})$. No gas was detected at the surface of M-2. A second withdrawal of gas from M-1 (1634.1 ft $\left.\mathrm{ft}^{3}\right)$ and M-3 $\left(295 \mathrm{ft}^{3}\right)$ was successful in reducing the gas pressure to nearly atmospheric levels. (M-1 was first produced through a wet test meter and then through an orifice meter.) Water did not return to surface for these wells. The M-1 wellbore returned to a similar volume of gas; the M-3 wellbore gas volume increased but did not return to the same level. $\mathrm{CO}_{2}$ gas composition increased to $95 \%$ and $70 \%$ in $\mathrm{M}-1$ and $\mathrm{M}-3$, respectively.

At this time, M-2 was opened to allow water to flow slowly for a relatively short time in an attempt to lower the face cleat well's bottomhole pressure in order to check whether a pressure decrease would cause gas to enter the well from the coal. 
a

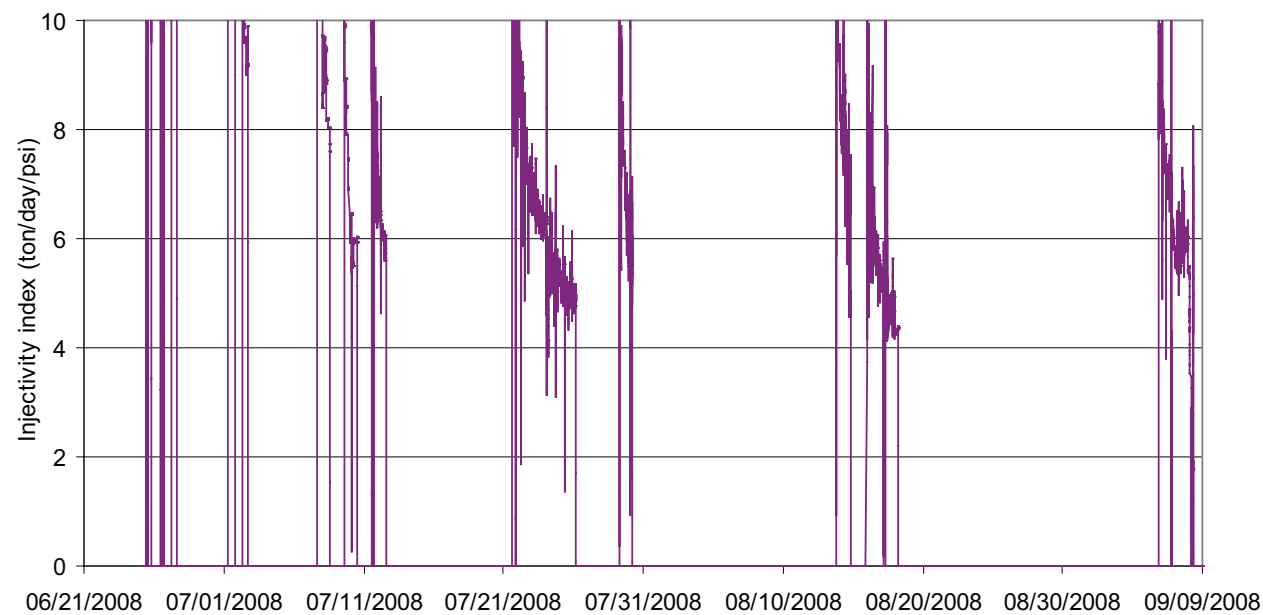

b

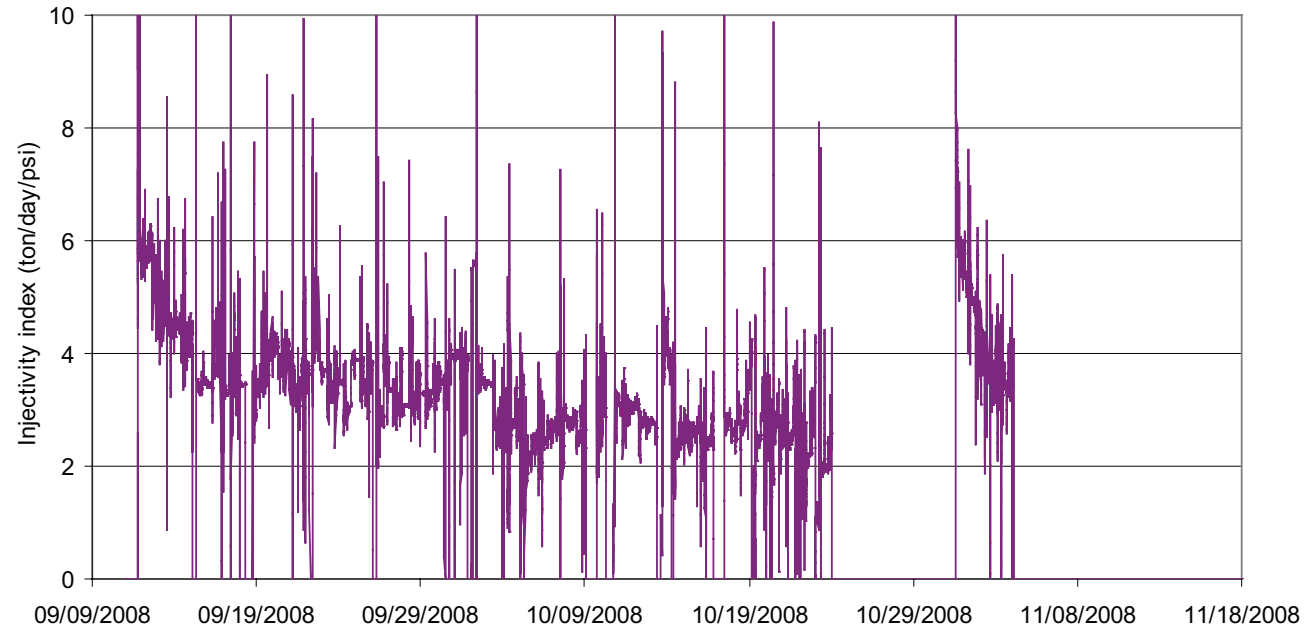

C

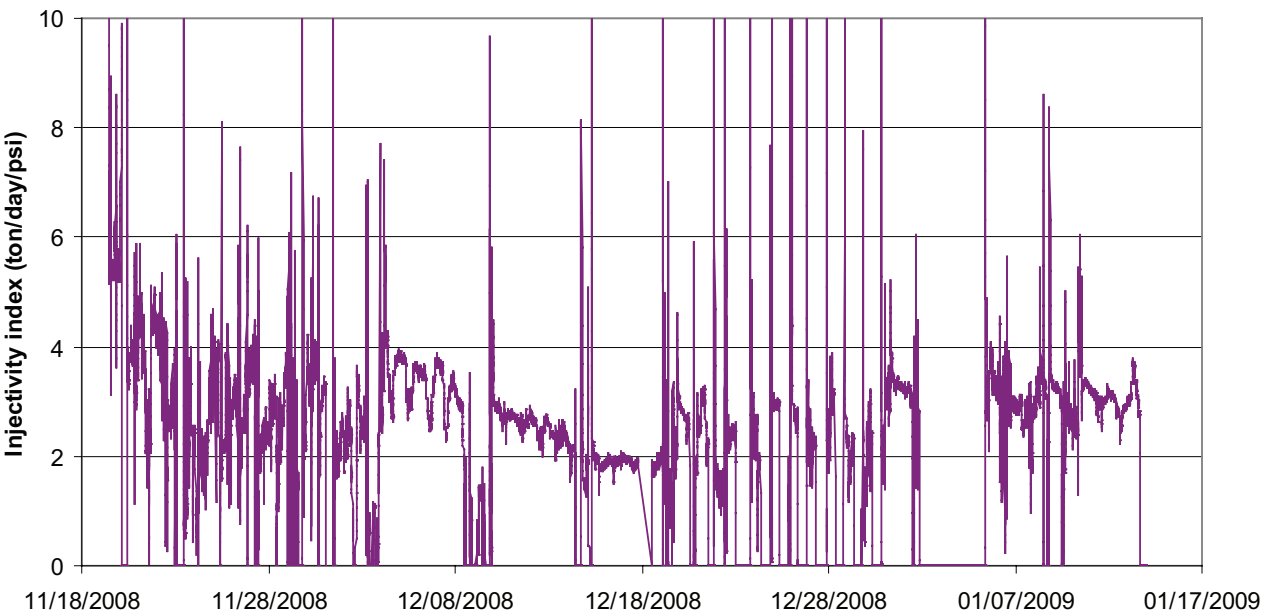

Figure 65. Injectivity index during the (a) initial injection and pressure transient tests, (b) continuous $\mathrm{CO}_{2}$ injection, and (c) final pressure transient periods using $2.65 \mathrm{MPag}$ (385 psig) initial pressure. 


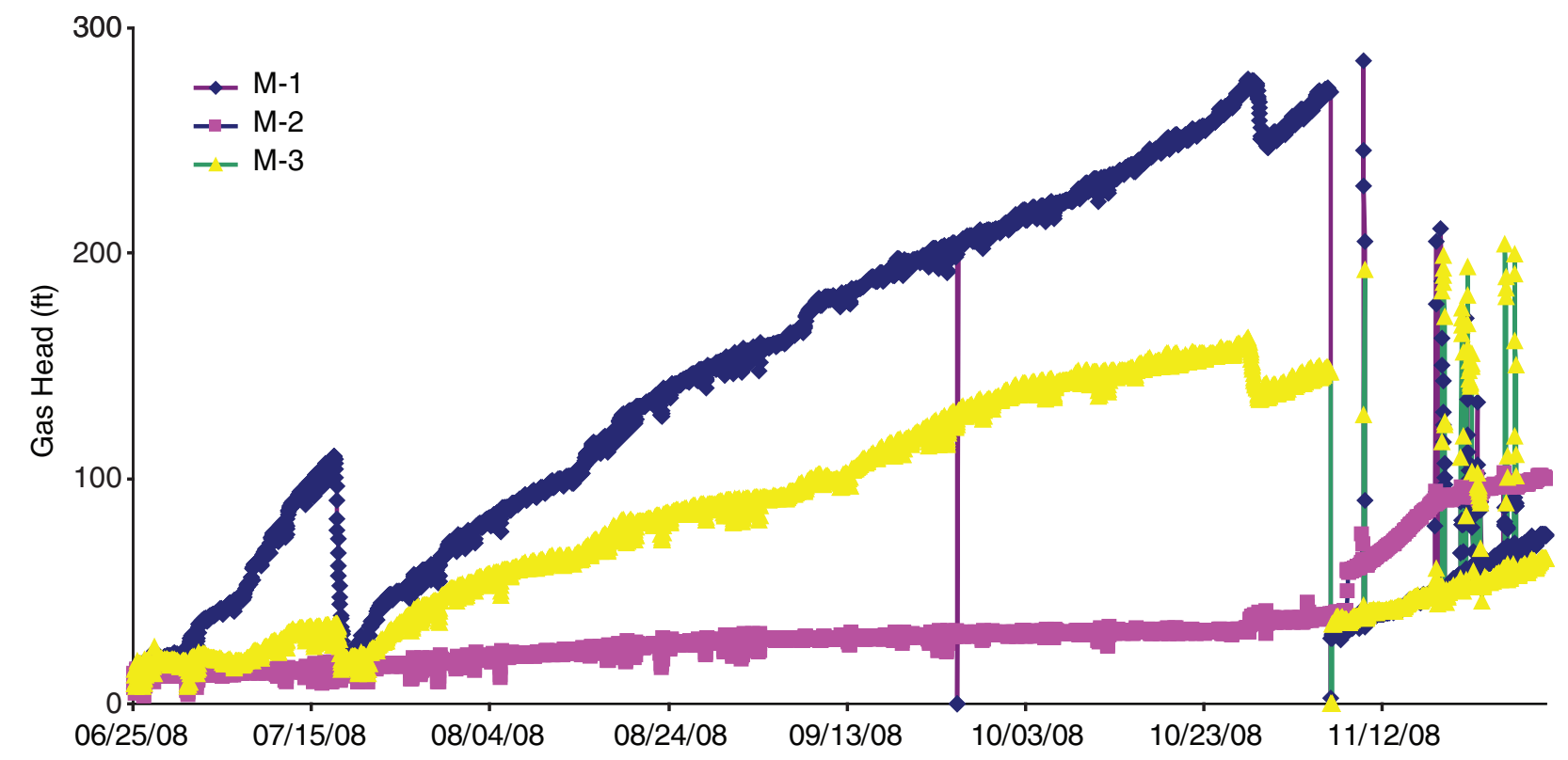

Figure 66. Gas head for each well over time. The first gas withdrawal was on July 18, 2008, and the second was on November 6, 2008. Gas column height calculation used $\mathrm{CH}_{4}$ density and freshwater density.

The surface pressure was slowly reduced, and initially only a small stream of water flowed. Within a few minutes, $\mathrm{CH}_{4}$ gas flowed from the face cleat well and continued for about $5 \mathrm{hr}$ until the well was shut-in. M-2 was produced for about $2 \mathrm{hr}$ every few days during the following 2 weeks. Eventually $\mathrm{CO}_{2}$ was detected; $\mathrm{CO}_{2}$ gas content in $\mathrm{M}-2$ reached $90 \%$. Water did not return to $\mathrm{M}-2$, and gas continued to occupy the upper part of the wellbore.

In November 2009 at M-2, the field IR detected the presence of an unknown gas that was later determined to be hydrogen from gas samples. Further discussion is in the MVA section of this report.

Figures 83, 84, and 85 show the gas composition for each well during the life of the pilot. Following these tests, $\mathrm{CO}_{2}$ gas composition for all wells decreased to $0-25 \%$.

\section{$\mathrm{CO}_{2}$ Effect on the Springfield Coal at the Tanquary Site}

\section{$\mathrm{CO}_{2}$ Injection}

Laboratory Cores: Sorption-Induced Volumetric Strain. Volumetric strain measurements (Appendix 21) were carried out on the Springfield Coal samples from M-1 and M-3 at 274.2 and $274.5 \mathrm{~m}$ (899.5 and $900.5 \mathrm{ft})$ measured depth, respectively. The samples were flooded with helium and $\mathrm{CH}_{4}$ in pressure steps of $1.4 \mathrm{MPa}(200 \mathrm{psi})$ to a final pressure of $5.5 \mathrm{MPa}$ (800 psi). The duration of each pressure step was approximately 7 days.

Figure 67 shows the mechanical compression of the coal matrix resulting from helium injection. The volumetric strain is linear with increasing helium pressure. (Results of these tests on Seelyville Coal samples from these wells are shown also.) The volumetric strain due to helium injection at $5.5 \mathrm{MPa}(800 \mathrm{psi})$ was estimated to be approximately $-0.05 \%$ for the Springfield Coal sample. Volumetric swelling due to $\mathrm{CH}_{4}$ adsorption at $5.5 \mathrm{MPa}(800 \mathrm{psi})$ was estimated to be $0.21 \%$ for the Springfield Coal samples (Figure 68).

After achieving $\mathrm{CH}_{4}$ equilibrium at $5.5 \mathrm{MPa}$ (800 psi), $\mathrm{CH}_{4}$ was displaced by $\mathrm{CO}_{2}$ by stepwise flooding, maintaining constant total pressure (Figure 69). As expected, the matrix swelling was higher with $\mathrm{CO}_{2}$ replacing $\mathrm{CH}_{4}$ than it was with pure $\mathrm{CH}_{4}$. The
Table 7. Gas production at monitoring wells, October-November 2008.

\begin{tabular}{clc}
\hline Well & \multicolumn{1}{c}{ Date } & Gas $\left(\mathbf{f t}^{3}\right)$ \\
\hline M-1 & $10 / 28 / 08-10 / 29 / 08$ & $1,634.1^{2}$ \\
M-1 & $11 / 08 / 08$ & 26 \\
M-2 & $10 / 29 / 08$ & 122 \\
M-2 & $11 / 03 / 08$ & 65 \\
M-2 & $11 / 08 / 08$ & 51 \\
M-3 & $10 / 28 / 08$ & 295 \\
M-3 & $11 / 07 / 08$ & 51 \\
M-3 & $11 / 09 / 08$ & 25 \\
\hline
\end{tabular}

${ }^{1}$ Gas volumes are in actual cubic feet. Wet emperature but not converted to standard presure and temperature.

${ }^{2}$ Predominantly vented through orifice meter. Volume is in scf. 


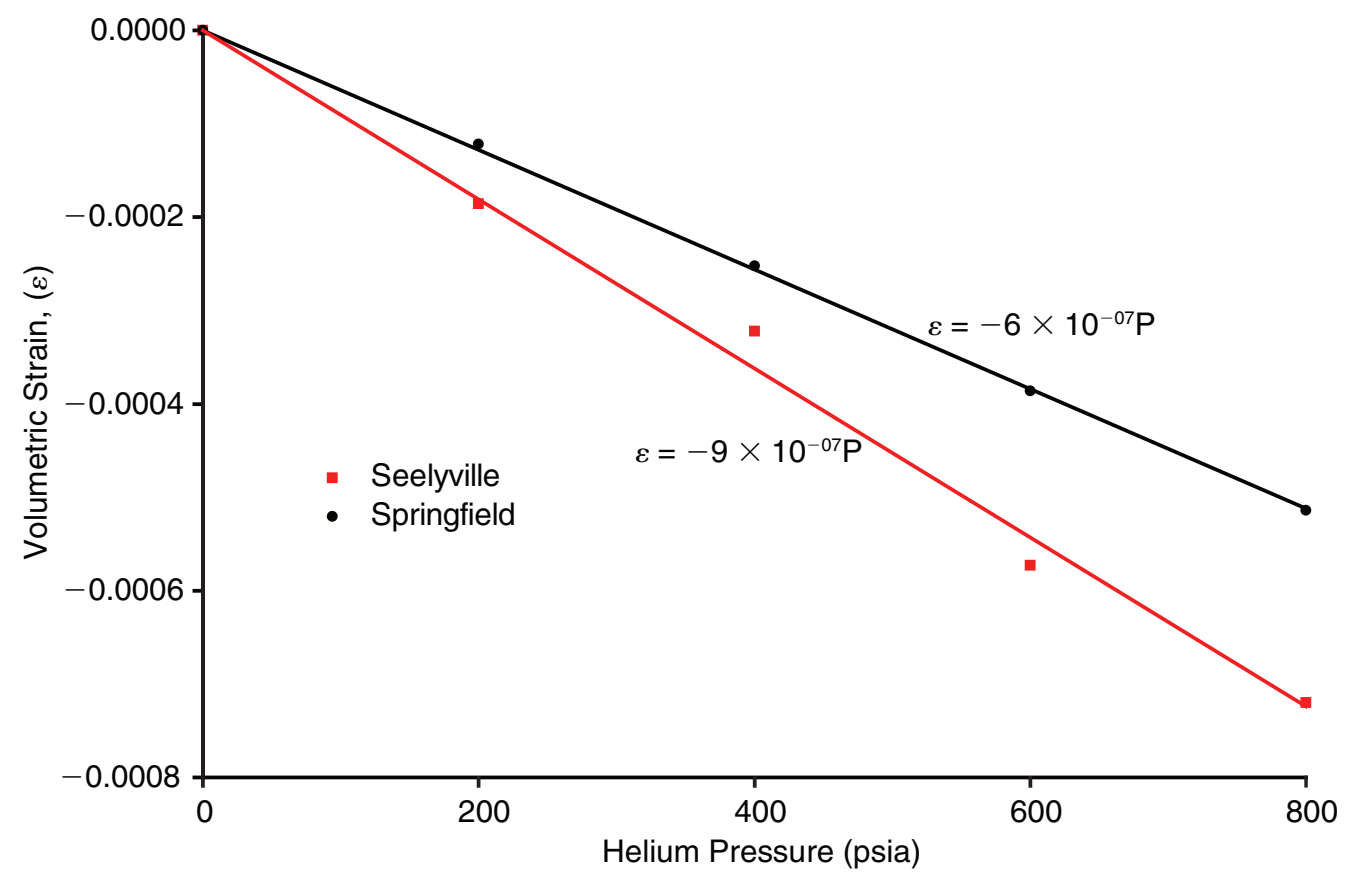

Figure 67. Volumetric strain $(\varepsilon)$ with helium injection for the Springfield and Seelyville coal seams.

volumetric strain resulting from $\mathrm{CO}_{2}$ replacement was estimated to be about four times higher than pure $\mathrm{CH}_{4}$-induced volumetric strain for the Springfield Coal. Hence, $\mathrm{CO}_{2}$ injection may significantly influence the cleat porosity and flow system.

In order to quantify the volumetric strain induced by gas pressure and adsorption/ desorption and provide a simple means to aid the use of laboratory results when simulating different alternatives, the grain compressibility $\left(\mathrm{C}_{\mathrm{g}}\right)$ and matrix swelling coefficient $\left(\mathrm{C}_{\mathrm{m}}\right)$ were calculated. These are defined as the fractional change in the volume of solid coal per unit change in pressure, given as

$\mathrm{C}_{\mathrm{g}}=-\frac{1}{\mathrm{~V}_{\mathrm{g}}} \cdot \frac{\mathrm{dV}_{\mathrm{g}}}{\mathrm{dP}}$

and

$\mathrm{C}_{\mathrm{m}}=\frac{1}{\mathrm{~V}_{\mathrm{m}}} \cdot \frac{\mathrm{dV}_{\mathrm{m}}}{\mathrm{dP}}$

where $\mathrm{V}_{\mathrm{g}}$ is the coal grain volume, $\mathrm{V}_{\mathrm{m}}$ is the coal matrix volume, $\mathrm{dV}_{\mathrm{m}}$ is the change in volume of solid matrix, and $\mathrm{dP}$ is the change in applied pressure. The measured strains were used to calculate the grain compressibility $\left(\mathrm{C}_{\mathrm{g}}\right)$ and matrix swelling coefficient $\left(\mathrm{C}_{\mathrm{m}}\right)$ using the equations 4 and 5 . (Compressibility is considered to be a positive number; hence the use of the negative size in equation 4.)

The strain measured by helium injection was used to estimate the grain compressibility for coal samples. The grain compressibility was calculated to be $8.7 \times 10^{-11} / \mathrm{Pa}\left(6 \times 10^{-7} / \mathrm{psi}\right)$ for the Springfield Coal (Figure 67 ).

It is apparent from Figure 68 that sorption-induced strain is strongly dependent on pressure and follows a trend very similar to the sorption isotherm. A Langmuir-type plot was, therefore, established, and the Langmuir-type constants were computed for the model:

$\varepsilon_{\mathrm{s}}=\varepsilon_{\max } \frac{\mathrm{P}}{\left(\mathrm{P}+\mathrm{P}_{\varepsilon}\right)}$ 


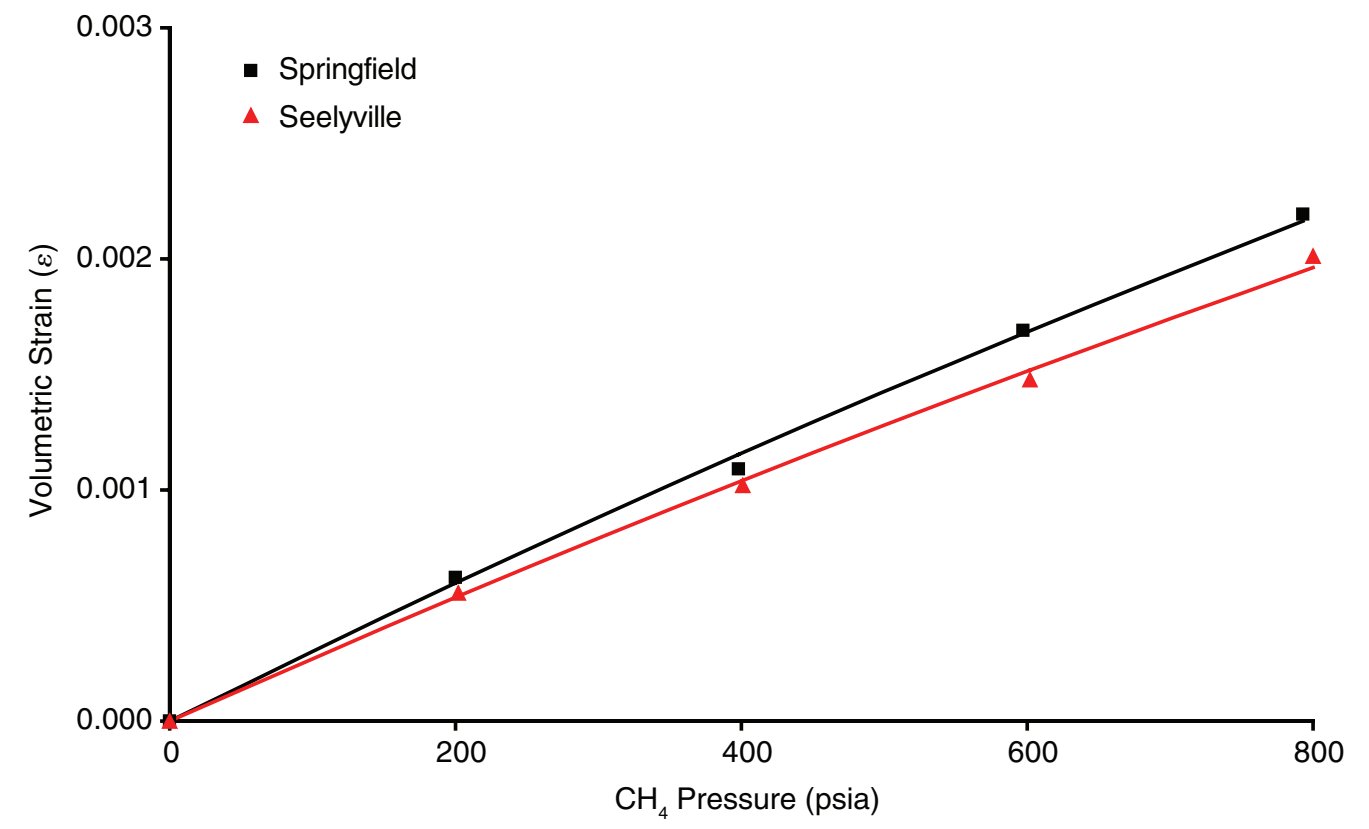

Figure 68. Volumetric strain $(\varepsilon)$ with $\mathrm{CH}_{4}$ flooding for the Springfield and Seelyville coal seams.

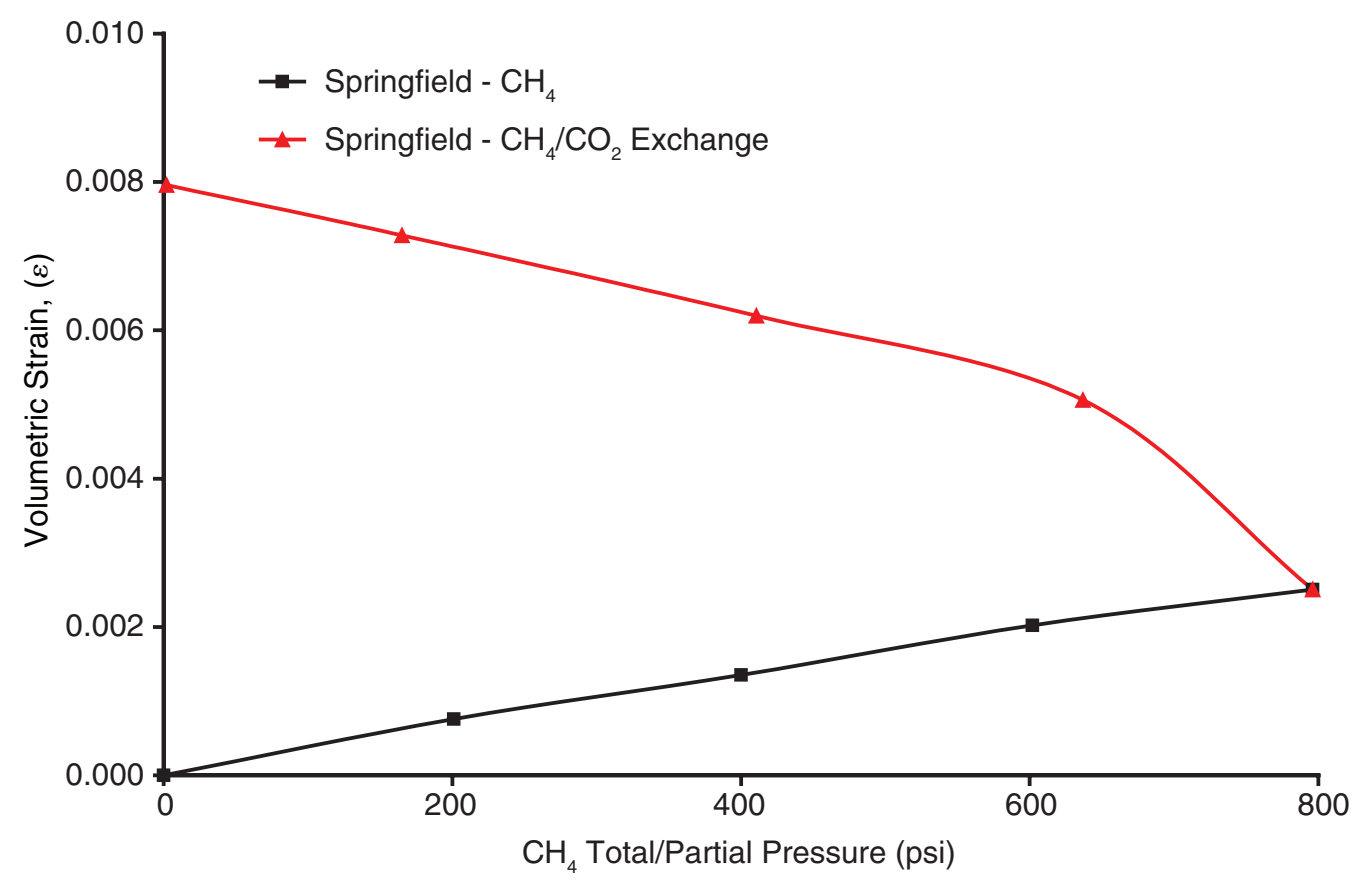

Figure 69. Volumetric strain $(\varepsilon)$ for $\mathrm{CH}_{4} / \mathrm{CO}_{2}$ exchange for the Springfield Coal seam. 


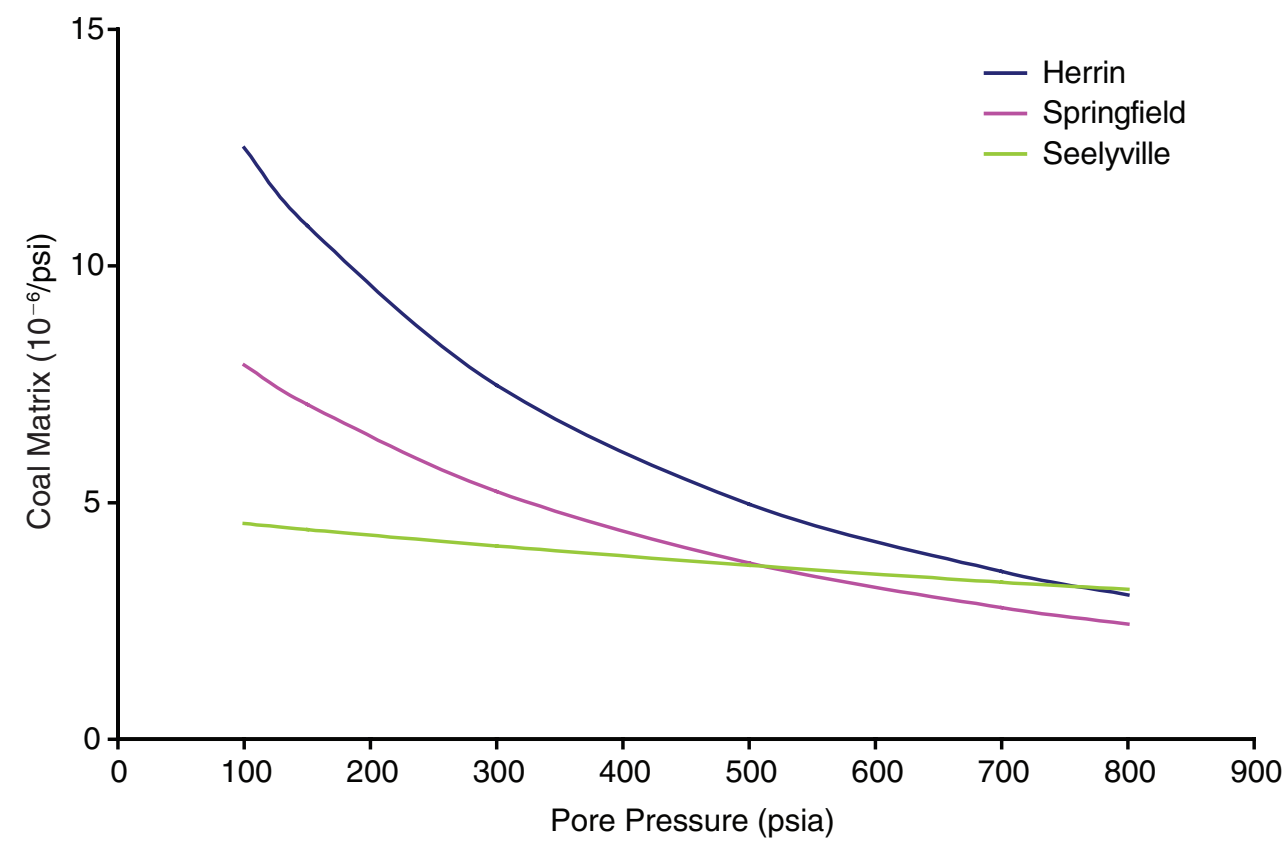

Figure 70. Coal matrix swelling coefficient for methane for the Herrin, Springfield, and Seelyville coal samples.

where $\varepsilon_{\mathrm{s}}$ is the sorption-induced volumetric strain at pressure $\mathrm{P}, \varepsilon_{\max }$ is the maximum strain that can be achieved at infinite pressure, and $\mathrm{P}_{\varepsilon}$ is the pressure at which coal attains $50 \%$ of the maximum strain. Langmuir equivalent strain constants $\left(\varepsilon_{\max }, \mathrm{P}_{\varepsilon}\right)$ for $\mathrm{CH}_{4}$ are presented in Table 8 .

The swelling coefficient was estimated using the measured volumetric strains. The calculated swelling coefficient for $\mathrm{CH}_{4}$ is shown in Figure 70. The matrix swelling coefficient increases with decreasing pore pressure. The value of $\mathrm{C}_{\mathrm{m}}$ increases from about $4 \times 10^{-10} / \mathrm{Pa}$ to about $1.2 \times 10^{-9} / \mathrm{Pa}\left(3 \times 10^{-6} / \mathrm{psi}\right.$ to about $\left.8 \times 10^{-6} / \mathrm{psi}\right)$ with reduction in $\mathrm{CH}_{4}$ pressure from 5.5 MPa (800 psi) to $0.69 \mathrm{MPa}$ (100 psi) for the Springfield Coal; the swelling coefficient is almost constant, as expected, because the volumetric strain was almost linearly dependent on gas pressure (Figure 68).
Table 8. Estimated model parameters for Springfield Coal samples.

\begin{tabular}{|c|c|c|c|c|}
\hline \multirow[b]{3}{*}{ Sample } & \multicolumn{4}{|c|}{ Model parameters } \\
\hline & \multicolumn{2}{|c|}{$\mathrm{CO}_{2}$} & \multicolumn{2}{|c|}{$\mathrm{CH}_{4}$} \\
\hline & $\mathbf{P} \varepsilon$ & $\varepsilon_{\max }$ & $\mathbf{P} \varepsilon$ & $\varepsilon_{\max }$ \\
\hline $\begin{array}{l}\text { Springfield } \\
\text { Coal }\end{array}$ & - & - & 5,988 & 0.0185 \\
\hline
\end{tabular}

During active $\mathrm{CO}_{2}$ injection at the Tanquary site, the Springfield Coal seam in situ pressure at the injection well I-1B was at a maximum of about 5.34 MPag (775 psig) and minimum of 2.65 MPa (385 psig) initial pressure. At initial pressure, the matrix compressibility is about $7.3 \times 10^{-10} / \mathrm{Pa}\left(5 \times 10^{-6} / \mathrm{psi}\right)$; however, this experiment assumes the coal is saturated with $\mathrm{CH}_{4}$ in situ coal was undersaturated by about $0.69 \mathrm{MPa}(100 \mathrm{psi})$.

Effective Permeability to $\mathrm{CO}_{2}$ (Pressure Transient Analyses). During $\mathrm{CO}_{2}$ injection, there were several planned and unplanned shut-in periods that provided pressure transient data for analyses that led to an estimate of $\mathrm{CO}_{2}$ effective permeability throughout the injection period. Because the cleats were initially $100 \%$ saturated with brine, the effective permeability to $\mathrm{CO}_{2}$ was initially zero. As the $\mathrm{CO}_{2}$ saturation increases, the effective permeability of $\mathrm{CO}_{2}$ should increase to a maximum and approach the pre- $\mathrm{CO}_{2}$ water permeability if water saturation approaches zero. However, with time as the $\mathrm{CO}_{2}$ adsorbs to the coal, the coal may swell and reduce the aperture of the cleat system and decrease the permeability.

Figure 71 is a graph of the pressure derivative of five of the falloffs during the $\mathrm{CO}_{2}$ injection period. Qualitatively, increasing values of the derivative indicate decreasing mobility, and shifts to the right with time indicate the growing size of the volume of coal contacted by $\mathrm{CO}_{2}$.

Table 9 lists chronologically the $\mathrm{CO}_{2}$ effective permeability from the falloff tests and includes the cumulative volume of $\mathrm{CO}_{2}$. The permeability increases from $0.00046 \mu \mathrm{m}^{2}(0.46 \mathrm{mD})$ to $0.0036 \mu \mathrm{m}^{2}(3.6 \mathrm{mD})$ and then starts to decrease over the remaining duration of active $\mathrm{CO}_{2}$ injection. The beginning of the permeability trend decrease is between July 7 and July 21,2008 ( 7.1 and 13.4 tonnes [7.8 and 14.8 tons] injected), which may indicate the time during active injection (11-25 days after injection started) when swelling started to dominate the permeability change and adsorption started to play an important role. 
Table 9. The effective permeability of $\mathrm{CO}_{2}$ calculated from pressure falloff tests throughout the injection period and cumulative injected mass.

\begin{tabular}{lccccccccc}
\hline & $\mathbf{0 6 / 2 6 / 0 8}$ & $\mathbf{0 6 / 2 7 / 0 8}$ & $\mathbf{0 7 / 0 1 / 0 8}$ & $\mathbf{0 7 / 0 7 / 0 8}$ & $\mathbf{0 7 / 2 1 / 0 8}$ & $\mathbf{0 8 / 1 3 / 0 8}$ & $\mathbf{0 9 / 0 5 / 0 8}$ & $\mathbf{1 1 / 1 8 / 0 8}$ & $\mathbf{0 1 / 1 5 / 0 9}$ \\
\hline Injected mass (ton) & 1.7 & 3.0 & 5.0 & 7.8 & 14.8 & 24.6 & 30.2 & 71.0 & 101.7 \\
Permeability (mD) & 0.46 & 0.55 & 1.3 & 3.6 & 2.5 & 2.0 & 1.8 & 0.71 & 0.69 \\
\hline
\end{tabular}

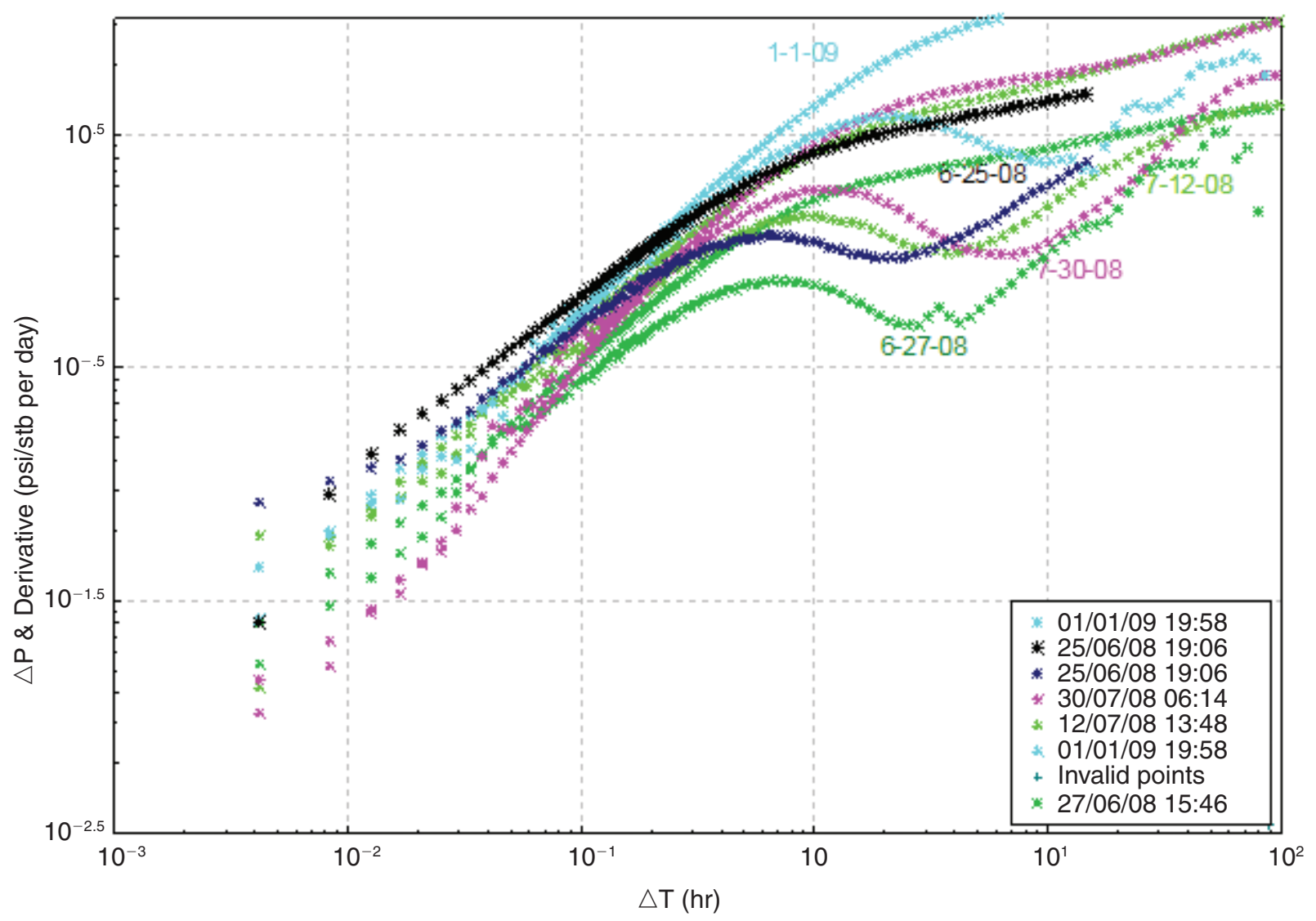

Figure 71. The pressure derivative of five of the falloffs during active $\mathrm{CO}_{2}$ injection.

CO Plume Shape and Size (Numerical Modeling). Two days after the end of the water injection, $\mathrm{CO}_{2}$ injection started at the site. A total of 92.3 tonnes (101.7 tons) was injected during a 7 -month period. After the first simulation run of the $\mathrm{CO}_{2}$ injection period, it was obvious that the gridded model area was not big enough to handle the increase in pressure in all grid blocks due to the $\mathrm{CO}_{2}$ injection and the absence of production. To remedy this problem, the grid was extended to a total area of more than 3237 ha (8,000 acres) by adding larger outer grid cells, thus replacing the aquifer function. (Figures relevant to the COMET modeling are in Appendix 22.)

In addition to the increase in the size of the model, a very small initial gas saturation (0.0001) had to be added in order to ease the start of the injection in the simulator. Due to the undersaturated condition of the coal, this very limited amount of $\mathrm{CH}_{4}$ was immediately adsorbed to the coal surface.

Finally, after several simulations were run and a good approximation of the $\mathrm{CO}_{2}$ plume size was determined, the grid was further refined (smaller cells) on the west and east side of the injector (the plume exhibits an elliptical shape along the face cleat direction). Appendix Figure 22-1 shows the full size grid (left) as well as an enlargement of the wells' area (right) illustrating the refinement.

The model was run with injector I-1B injecting on rate while matching flowing bottomhole pressures at the injector and the three monitoring wells. The injection profile is shown on Appendix Figure 22-2. The model was able to inject the actual 
volume observed in the field. Appendix Figure 22-3a-d illustrates the bottomhole pressure at the four wells with the actual field data in orange and simulated data in purple, for the best match.

It can be seen that the match is not perfect; the simulated data are lower than the actual data except for monitoring well M-3, which matches relatively well. A possible explanation would be that the actual permeability might be too high for the model (too easy for the model to inject the required volumes), but the model permeability values had to be kept within a reasonable range of those permeability values obtained from the pre- $\mathrm{CO}_{2}$ water injection history-match. Because the matched value of $0.014 \mu^{2}$ ( $14 \mathrm{mD}$ ) (during the water injection) for the face cleat permeability was slightly higher than the results from the pressure transient analysis, a small tolerance was allowed. In addition, the parameters influencing the per-

meability change versus pressure were also optimized during the history-match process while trying to increase the swelling of the coal due to the $\mathrm{CO}_{2}$ injection, thus decreasing the permeability.

The matrix compressibility parameter $\mathrm{C}_{\mathrm{m}}$ models the swelling of the coal due to $\mathrm{CO}_{2}$ being adsorbed on its surface, as several molecules of $\mathrm{CO}_{2}$ replace only one molecule of desorbed $\mathrm{CH}_{4}$. Another key parameter affecting coal permeability is the differential swelling factor $\mathrm{C}_{\mathrm{k}}$. Because the $\mathrm{CO}_{2}$ molecule is larger than the $\mathrm{CH}_{4}$ molecule, when $\mathrm{CO}_{2}$ replaces $\mathrm{CH}_{4}$ on the coal

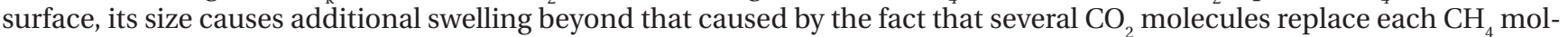
ecule. As a consequence, the differential swelling factor for $\mathrm{CO}_{2}$ is always greater than 1 .

Appendix Figure 22-4 illustrates permeability versus pressure with different values of $\mathrm{C}_{\mathrm{m}}$ and $\mathrm{C}_{\mathrm{k}}$ to better understand these concepts. The base case on the upper left graph of this figure has an average matrix compressibility value of $1.5 \times 10^{-10} / \mathrm{Pa}(1$ $\times 10^{-6} / \mathrm{psi}$ ) and a differential swelling of 1.5. By injecting $\mathrm{CO}_{2}$ under these conditions, permeability does not decrease much from 0.014 to $0.013 \mu \mathrm{m}^{2}$ (14 to $13 \mathrm{mD}$ ) at $3.45 \mathrm{MPa}$ (500 psi). In the upper right graph, the swelling is accentuated by increasing the matrix compressibility to $7.3 \times 10^{-10} / \mathrm{Pa}\left(5 \times 10^{-6} / \mathrm{psi}\right)$, which decreases the permeability to $0.008 \mu \mathrm{m}^{2}(8 \mathrm{mD})$ as soon as $\mathrm{CO}_{2}$ is injected. An increase in the differential swelling to 3.5 decreases the permeability to $0.003 \mu \mathrm{m}^{2}$ ( $3 \mathrm{mD}$ ) (lower graph). The best match was obtained with a face cleat permeability slightly decreased to $0.012 \mu^{2}$ ( $12 \mathrm{mD}$ ), a matrix compressibility of $7.3 \times 10^{-10} / \mathrm{Pa}\left(5 \times 10^{-6} / \mathrm{psi}\right)$, and a differential swelling factor of 2.5. Appendix Figure $22-5$ illustrates the evolution of permeability versus pressure in the model, and the optimized relative permeability curves are shown in Appendix Figure 22-6.

Appendix Figure 22-7 shows a face cleat permeability of $0.002 \mu \mathrm{m}^{2}(2 \mathrm{mD})$ at the injector and $0.008 \mu \mathrm{m}^{2}(8 \mathrm{mD})$ at $\mathrm{M}-2$ (unchanged at M-1 and M-3), whereas Appendix Figure 22-8 shows a butt cleat permeability of $0.0003 \mu \mathrm{m}^{2}(0.3 \mathrm{mD})$ at the injector and around $0.001 \mathrm{~mm}^{2}(1 \mathrm{mD})$ at M-2 (unchanged at M-1 and M-3). The geometric average for each well is 0.00077 $\mu \mathrm{m}^{2}(0.77 \mathrm{mD})$ for the injector and $0.0028 \mu \mathrm{m}^{2}(2.8 \mathrm{mD})$ for $\mathrm{M}-2$. Assuming that a geometric average of the butt and face cleat permeability can represent the equivalent permeability, the numerical model permeability is in very good agreement with the $\mathrm{CO}_{2}$ effective permeability in Table 9 for the injection well. Pressure transient analysis results also indicated an increased value of $2.2 \times 10^{-8} / \mathrm{Pa}\left(150 \times 10^{-6} / \mathrm{psi}\right)$ for the pore compressibility $\mathrm{C}_{\mathrm{p}}$ but at this time, COMET3 requires that $\mathrm{C}_{\mathrm{p}}$ be a constant.

Finally, Appendix Figure 22-9 shows the shape and size of the $\mathrm{CO}_{2}$ plume (gas saturation), which extends about $150 \mathrm{~m}$ (500 $\mathrm{ft}$ ) in the face cleat direction and about $55 \mathrm{~m}(180 \mathrm{ft})$ along the butt cleat direction, an area of about 6,600 $\mathrm{m}^{2}$ or $0.66 \mathrm{ha}$ (71,000 $\mathrm{ft}^{2}$ or 1.6 acres). The $\mathrm{CO}_{2}$ detected at M-1 and M-3 is in relatively good agreement with the model results; however, the $\mathrm{CO}_{2}$ present at M-2 was detected in the field only after a very short water withdrawal period.

The elliptical plume area corresponds to $140 \mathrm{~m}^{3}\left(5,000 \mathrm{ft}^{3}\right)$ of bulk coal/ton of $\mathrm{CO}_{2}$ stored or $0.382 \mathrm{~m}^{3}\left(13.5 \mathrm{ft}^{3}\right)$ of $\mathrm{CO}_{2} /$ ton of bulk coal. This value is very low compared to the $\mathrm{CO}_{2}$ adsorption predicted by the Langmuir isotherm; however, this area is for the entire plume shape. The storage within the higher saturation area is relatively closer to that predicted by the isotherm.

\section{Post-injection}

Logging. One of the tools used to monitor the movement of $\mathrm{CO}_{2}$ in the coal seam was the Schlumberger Reservoir Saturation Tool (RST). The RST is a wireline neutron logging tool that measures the macroscopic capture cross section and neutron porosity. Cased-hole RST data were measured on the injector well and the three monitor wells. The measured RST data are most influenced by geologic formations within feet of the wellbore; subsequent interpretations reflect the near wellbore region of each well.

The wireline evaluation program consisted of running open-hole logging tools normally associated with a "triple-combo" logging package on all wells. A sonic log was also run in the M-1 monitoring well. Although the open-hole logs were run in each well at the time they were drilled (M-1 and M-3, July 2007; M-2 and I-1B, May 2008), the first logging runs (base pass) of the RST cased hole logs for all wells occurred early in June 2008 prior to $\mathrm{CO}_{2}$ injection. About 10 months after $\mathrm{CO}_{2}$ injection was completed, in early October 2009, a second run of the RST log was made in each well. The open-hole logs in all wells were run by Weatherford and were part of the RST cased hole log analyses (Figures 72-75).

The primary measurement of the RST-Pulse Neutron Capture (PNC) tool is the rate at which thermal neutrons are captured by the formation. This measurement is called sigma (SIGM) and is the macroscopic capture cross section. Because chlorine 
has the greatest ability to capture thermal neutrons and hydrogen has the greatest ability to slow the high energy neutrons to the thermal level, this measurement is very responsive to the saltwater in the porosity. If the amount of saltwater decreases and is replaced by hydrocarbon or $\mathrm{CO}_{2}$, then the capture cross section of the formation will decrease, because hydrocarbons and $\mathrm{CO}_{2}$ have low sigma values compared with those of saltwater. The tool also measures thermal neutron porosity very similarly to the openhole neutron porosity tools. The RST porosity is called TPHI. This porosity responds to $\mathrm{CO}_{2}$ very much like hydrocarbon gas because they both have a very low hydrogen index. Hydrocarbon gas and $\mathrm{CO}_{2}$ both cause neutron porosity measurement to be too low compared with the actual porosity because the neutron porosity measurement is primarily responding to the hydrogen index. Because of these differences the sigma measurement and the porosity measurement from the RST tool can be combined in an analysis to determine the saturation of saltwater and hydrocarbon gas or $\mathrm{CO}_{2}$ in the formation porosity. Hydrocarbon gas and $\mathrm{CO}_{2}$ cannot be differentiated because the neutron porosity response of each is the same, and there is not enough difference between their sigma values to provide adequate differentiation. (In the log analyses section of this report the term "gas" means either hydrocarbon and/or $\mathrm{CO}_{2}$ unless explicitly stated differently.)

Methodology. The interpretation of the RST data requires use of a probabilistic computer program with a simultaneous equation solver. The evaluation is completed by optimizing simultaneous equations described by one or more interpretation models. The initial interpretation model uses the data from the open-hole logs plus the data from the RST base log. Once the analysis of the open-hole data was complete, the lithology and porosity outputs were used to build the interpretation model for the RST sigma log interpretation.

The analysis of coal from log data is something that was not very well addressed until the 1990s, when the measurement of certain elements through advances in spectral analysis provided reliable interpretations in coal beds. Prior to this time, coal was usually identified generally as "bulk" coal, but no additional computations were performed. With a combination of different measurements, current processing can evaluate the properties of coal beds, producing estimates such as volatiles, carbon content, sulfur content, and ash content. Gas content can be estimated if the Langmuir isotherm for that gas is known. However, this type of analysis does little to help identify changes in gas volumes within the pore space of a coal bed. Therefore, a new method to identify changes in the gas content in the coal needed to be developed. The following discussion explains this new interpretation method.

Coal usually has very low porosity, and the porosity that is present is quite often associated with cleats (fractures) in the coal. Log analysis of very low porosity, fractured formations is quite difficult even using a full suite of open-hole logs, but the new interpretation technique needs to identify changes in the gas saturation within the coal using the pulse neutron capture tool measurements of the RST. In low porosity formations, the calculation of water saturation is very sensitive to small variations in porosity. For example, a saturation of $2.5 \%$ gas would change water saturation almost $40 \%$ if the porosity is changed from 3 to 5 porosity units (the percentage of pore space in a unit volume of rock); this porosity change is within the resolution of log calculated porosity.

The two main measurements from the RST are SIGM, the macroscopic capture cross section, and TPHI, the neutron porosity. Of these two measurements, SIGM is the most accurate and has the best statistical precision and is therefore the best measurement to identify a change in the coal gas. The standard equation used to calculate a change in water saturation, $\Delta \mathrm{S}_{\mathrm{w}}$, is

$\Delta \mathrm{S}_{\mathrm{w}}=\left(\mathrm{SIGM}_{\text {monitor }}-\mathrm{SIGM}_{\text {base }}\right) / \phi\left(\mathrm{SIGM}_{\mathrm{w}}-\mathrm{SIGM}_{\mathrm{CO} 2}\right)$

As gas replaces water, the $\mathrm{SIGM}_{\text {monitor }}$ becomes less than SIGM $_{\text {base }}$, and the $\Delta \mathrm{S}_{\mathrm{w}}$ will therefore be negative representing a decrease in water. Because the porosity is so low and very difficult to quantify, rather than trying to calculate a change in water saturation on a pore volume basis and using a porosity measurement that may be in error, the amount of porosity that becomes filled with gas after injection is computed. Mathematically, this is represented by the product of water saturation and porosity. The equation becomes

$\Delta \mathrm{S}_{\mathrm{w}} \phi_{\text {gas } / \mathrm{CO} 2}=\left(\mathrm{SIGM}_{\text {base }}-\mathrm{SIGM}_{\text {monitor }}\right) /\left(\mathrm{SIGM}_{\mathrm{w}}-\mathrm{SIGM}_{\mathrm{CO} 2}\right)$

The SIGM ${ }_{\mathrm{CO} 2}$ value is relatively low at 0.5 , and the SIGM $_{\mathrm{w}}$ value used was calculated based on the $\mathrm{R}_{\mathrm{w}}$ values computed in the adjacent sands. The $\mathrm{R}_{\mathrm{w}}$ was determined to be 0.32 at $24^{\mathrm{O}} \mathrm{C}\left(75^{\circ} \mathrm{F}\right)$, and the $\mathrm{SIGM}_{\mathrm{wa}}$ is then 29 Capture Units. The SIGM ${ }_{\text {base }}$ and SIGM $_{\text {monitor }}$ values are those measured on the base pass and monitor pass, respectively. Any changes to porosity and gas saturation are included in the calculated value of $\Delta \mathrm{S}_{\mathrm{w}} \phi_{\text {gas/CO2 }}$, which is on a bulk volume basis.

Some outputs from the RST can be used to estimate the uncertainty in the computation of the gas volume. The output logs include the uncertainty curve of SIGM. The prescribed method for running and monitoring the quality of the RST log suggests that the uncertainty of SIGM should be about 0.25 in the zones of interest. At the well site, the main variable the logging engineer has to control SIGM uncertainty is the logging speed. The logging speed for the first run was about $1,100 \mathrm{~m} / \mathrm{hr}$ $(3,600 \mathrm{ft} / \mathrm{hr})$ and the resulting uncertainty on SIGM is close to 0.5 . The logging speed for the second run was about $300 \mathrm{~m} / \mathrm{hr}$ $(1,000 \mathrm{ft} / \mathrm{hr})$, resulting in the desired 0.25 uncertainty on SIGM. With an overall range in uncertainty of 0.75 , this equates into 
Scale : $1: 400$

L.P. DAUGHTERS ETAL \#-1B

DB :Galkghter_Datgleis (2)

DEPTH (700.FT - 950.FT)

$300201016: 13$

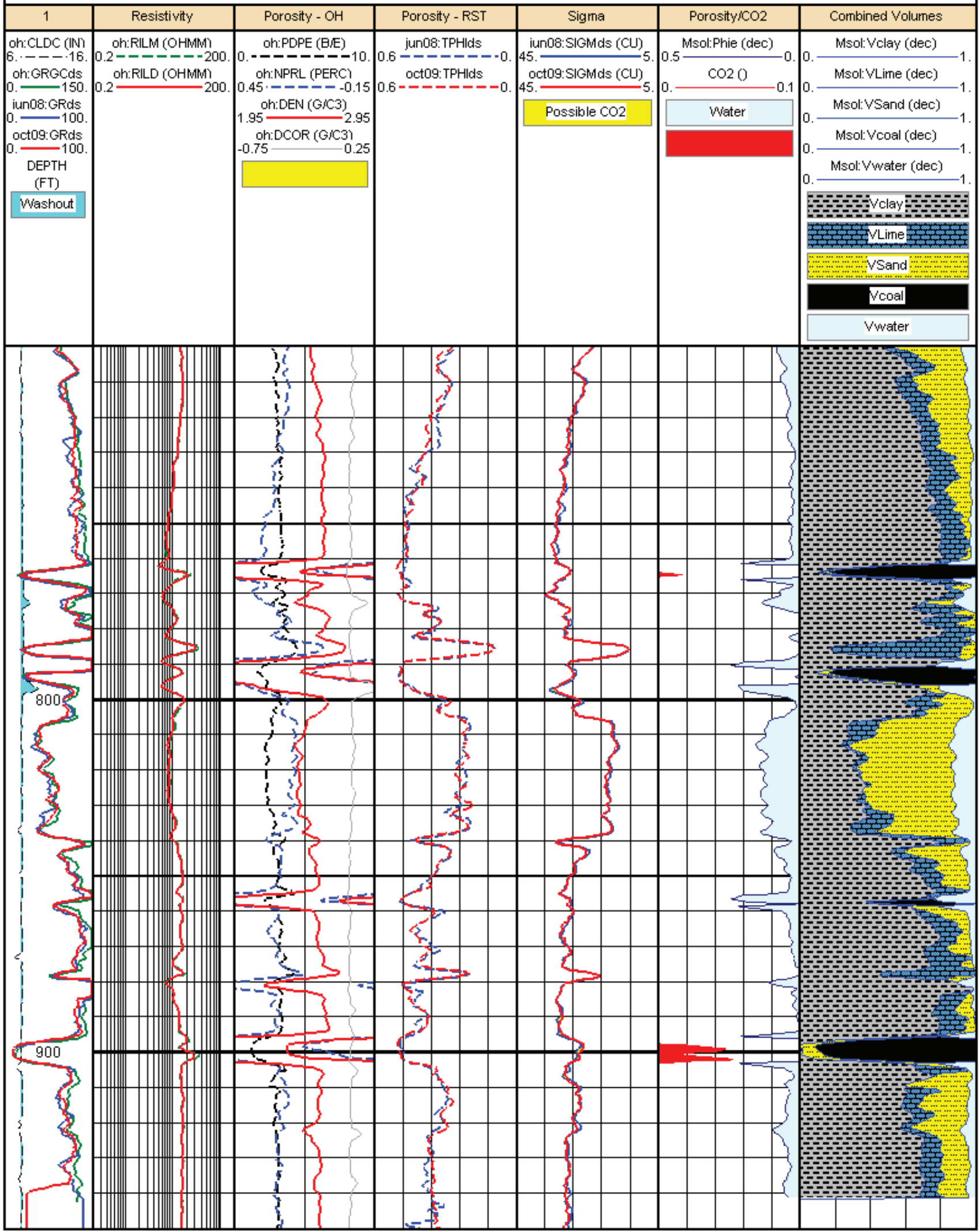


Figure 72. Log analysis of I-1B. Description of log curves:

Depth Track:

oh:GRGCds - Gamma-ray from the open-hole logging run (depth shifted). jun08:GRds - Gamma-ray from the first run using the reservoir simulation tool (RST) (depth shifted).oct09:GRds - Gamma-ray from the second RST run (depth shifted). oh:CLDC - Openhole caliper with shading to bit size indicating hole washouts.

Resistivity Track:

oh:RILM - Resistivity from medium induction measurement.

oh:RILD - Resistivity from deep induction measurement.

Porosity - OH Track:

oh:DEN - Measurement of the bulk density of the formation from open-hole logs. This measure is used in combination with the neutron and sonic for porosity, lithology identification, and fluid identification in the porosity.

oh:NPRL - Measurement of the neutron porosity of the formation from open-hole logs. This measure is used in combination with the density and sonic for porosity, lithology identification, and identification of fluids in the porosity.

oh:PDPE - Photoelectric effect. This measure is used in combination with the neutron and density for lithology identification. oh:DCOR - This measure is the amount of correction applied to the density measurement to correct for borehole and mud cake.

Porosity - RST Track:

jun08:TPHIds - Neutron porosity from the first RST run. This measure is used with the SIGM to determine the fluid volumes in the reservoir at that time.

oct09:TPHIds - Neutron porosity from the second RST run. This measure is used with the SIGM to determine the fluid volumes in the reservoir at that time.

The overlay of the two porosity curves makes it easier to identify where changes occurred between RST runs.

Sigma Track:

jun08:SIGMds - Sigma from the first RST run. This is used with the TPHI to determine the fluid volumes in the reservoir at that time.

oct09:SIGMds - Sigma from the second RST run. This is used with the TPHI to determine the fluid volumes in the reservoir at that time.

The overlay of the two sigma curves makes it easier to identify where changes occurred between RST runs.

Porosity/CO Track:

msol:PHIE - Effective porosity from the analysis of the open-hole data. The light blue shading shows the area from the effective porosity to zero porosity.

$\mathrm{CO}_{2}-$ Volume of $\mathrm{CO}_{2}$ calculated to be in the coal. The red shading indicates the area from zero $\mathrm{CO}_{2}$ to the calculated volume of $\mathrm{CO}_{2}$.

Combined Volumes Track: Volumetric display of the lithology and porosity.

a gas volume of $2.5 \%$. Therefore, any gas volumes less than $2.0 \%$ of bulk volume $\left(\Delta \mathrm{S}_{\mathrm{w}} \phi_{\text {gas } / \mathrm{CO} 2}\right)$ are likely below the interpretation resolution and may reflect no change in saturation.

Interpretation of results. In general, the greatest gas volume was detected in the injector well (I-1B) and the well in the direction of the face cleats (M-2). Gas volume was lower in the butt cleat monitoring wells. It is thought that hydrocarbon gas and $\mathrm{CO}_{2}$ remained in the Springfield Coal at about $274 \mathrm{~m} \mathrm{(900} \mathrm{ft).}$

The volume of gas in the injection well (I-1B) is as high as $5.0 \%$ of the formation bulk volume (Figure 72 ), which is the upper end of porosity found in coal and could reflect an increase in porosity and/or $100 \%$ change in water saturation. It could also be due to the resolution of the analysis. The volume of gas in the face cleat well (M-2) was about $4.3 \%$, also on the high end of porosity in coal (Figure 74). The volume of gas estimated in the other two wells was about $2.0 \%$, with M-1 being slightly higher (Figure 73) and M-3 being slightly lower than 2.0\% (Figure 75).

All of the wells' calculated logs have very low changes in gas volume that resemble values for gas in the coals above the $274 \mathrm{~m}$ $(900 \mathrm{ft})$ injection zone. In all of the wells except M-1 these values are about 1.0\%, which is interpreted as being near the limitation on the statistical precision of the measurement. This result indicates that gas is not in these zones above the Spring- 


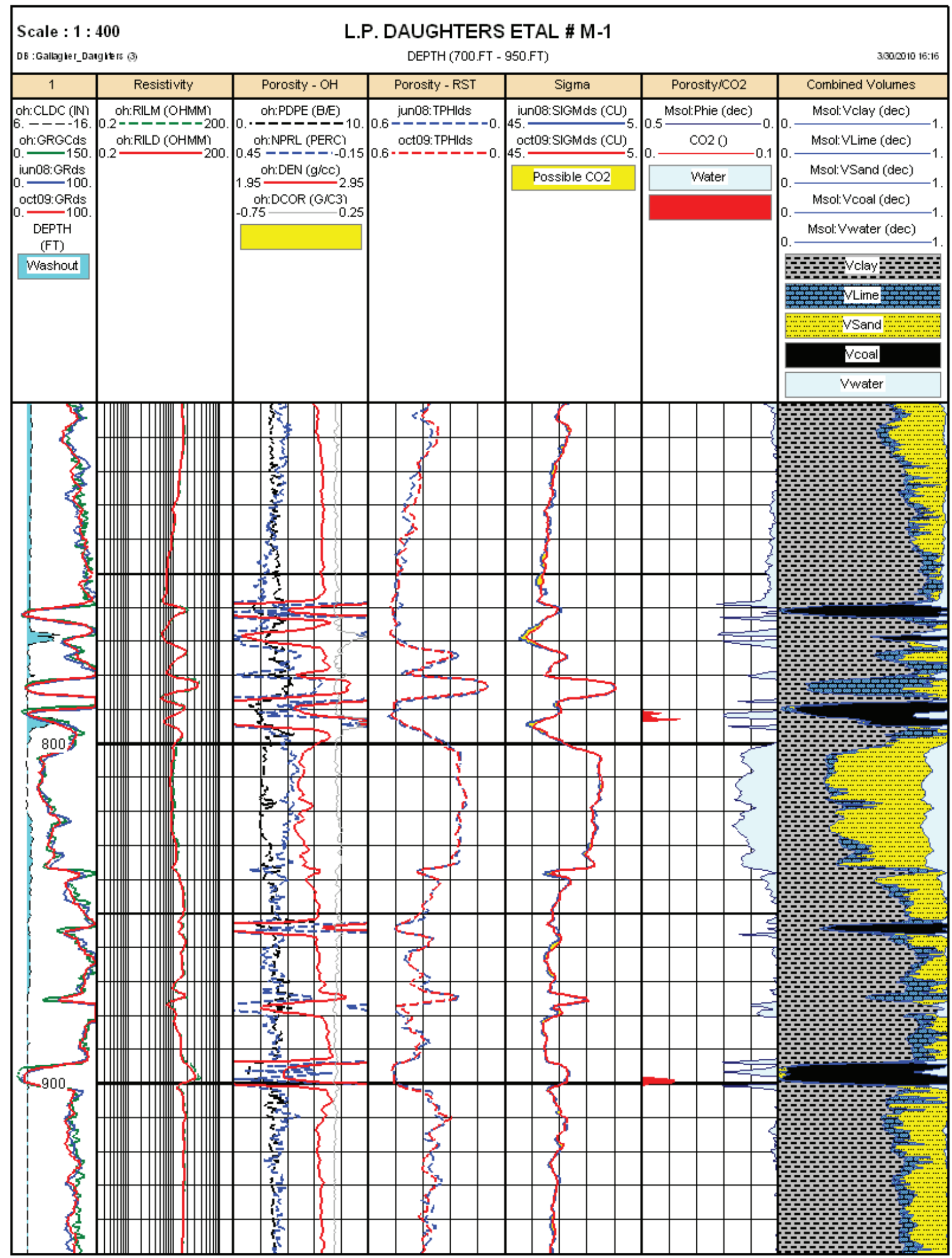

Figure 73. Log analysis for well M-1. See Figure 72 caption for explanation. 


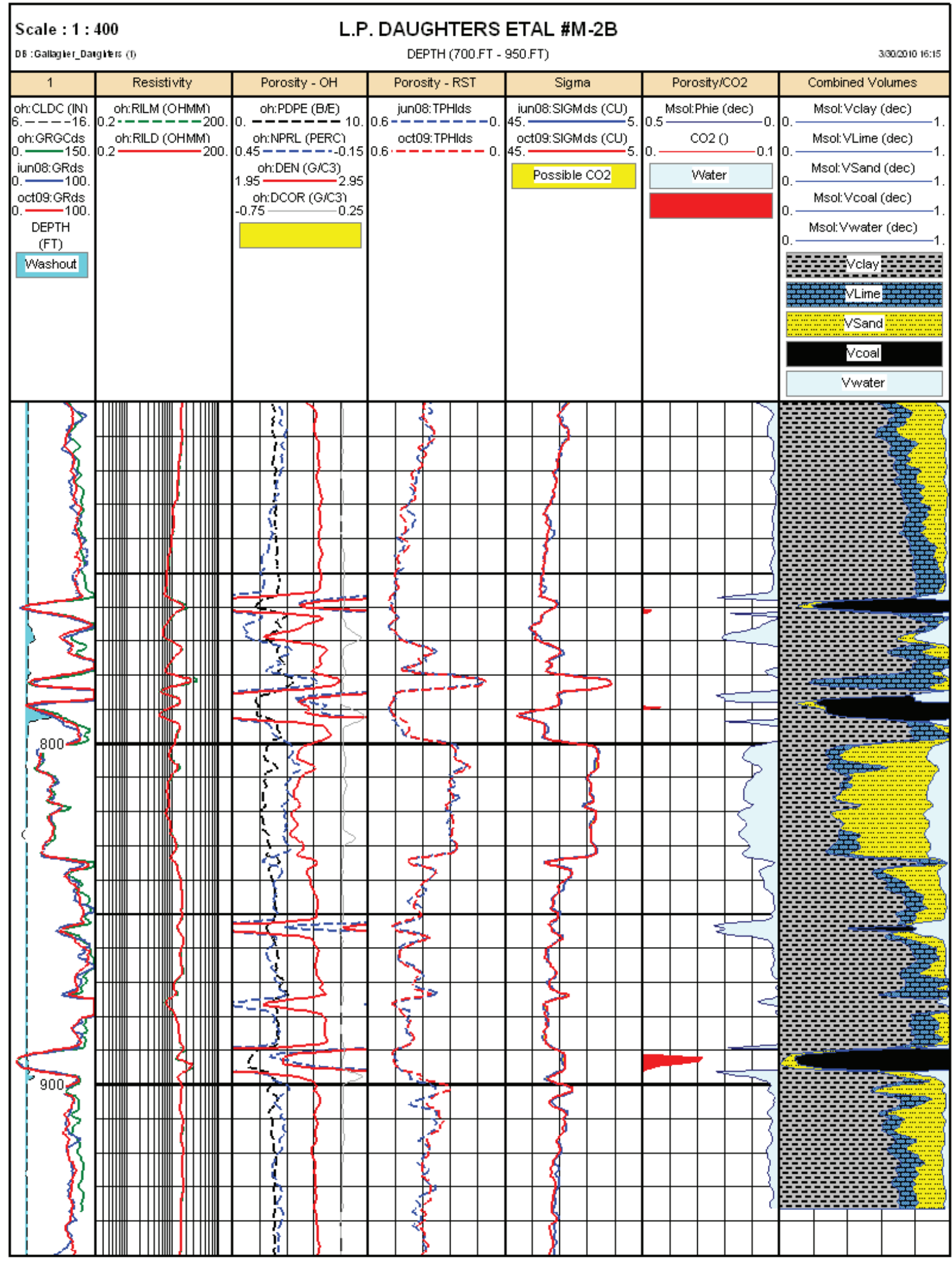

Figure 74. Log analysis for well M-2B (M-2). See Figure 72 caption for explanation. 
Scale : $1: 400$

L.P. DAUGHTERS ETAL \# M-3

DB :Galkgler_Darglters (4)

DEPTH (700.FT - 950.FT)

$300001016: 59$

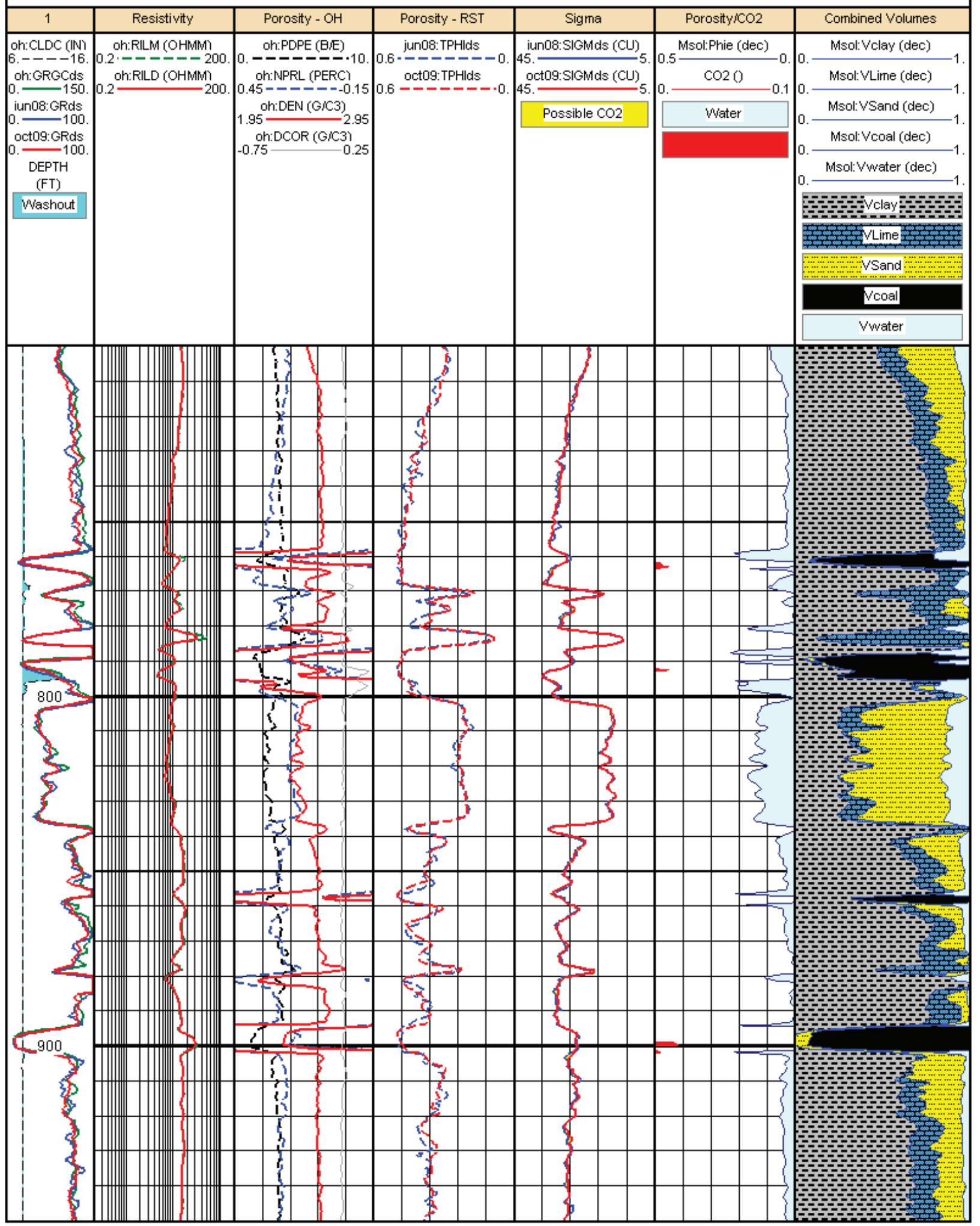

Figure 75. Log analysis for well M-3. See Figure 72 caption for explanation. 


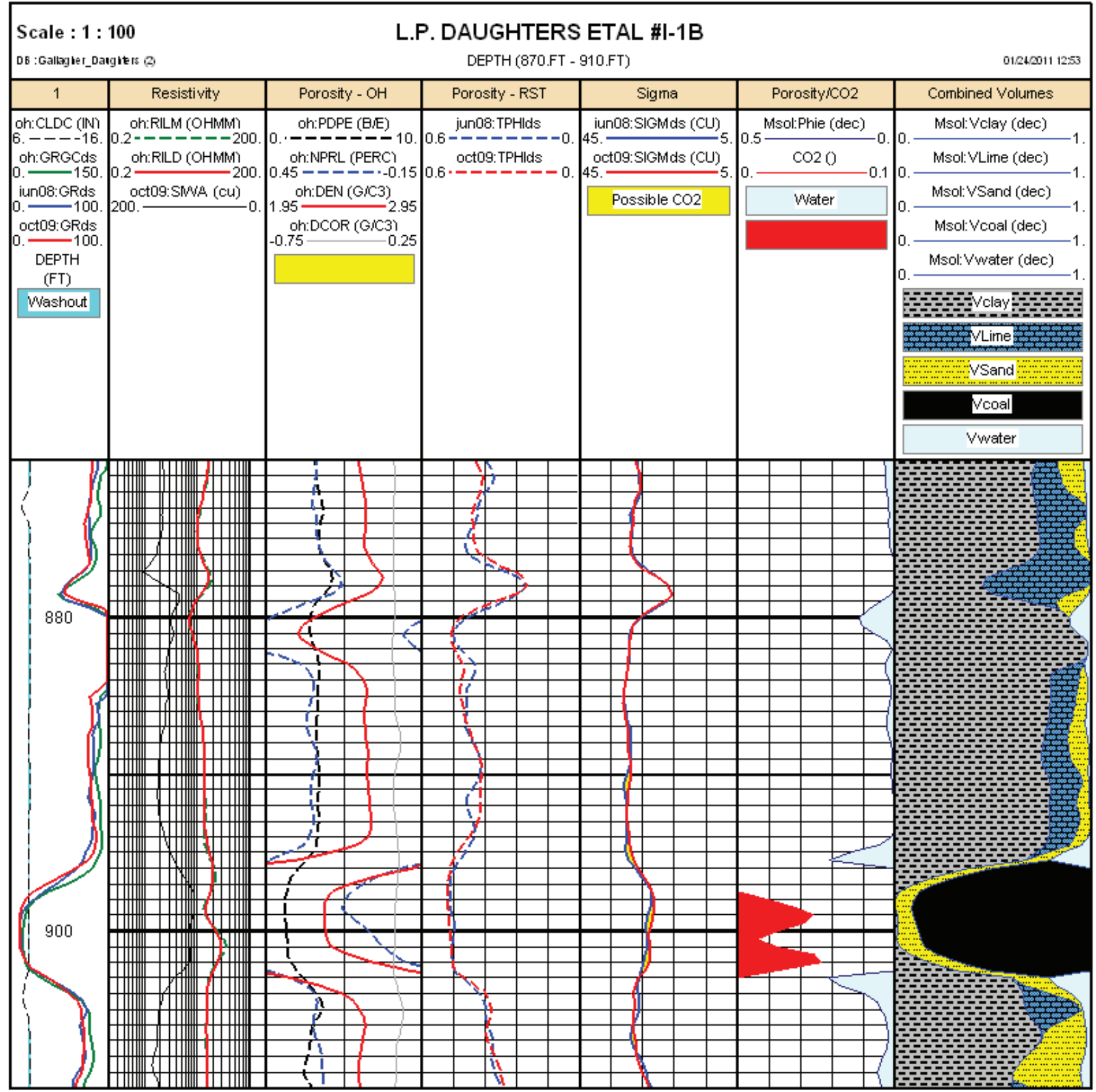

Figure 76. Log analysis for well I-1B, magnified showing two separate lobes of $\mathrm{CO}_{2}$. 


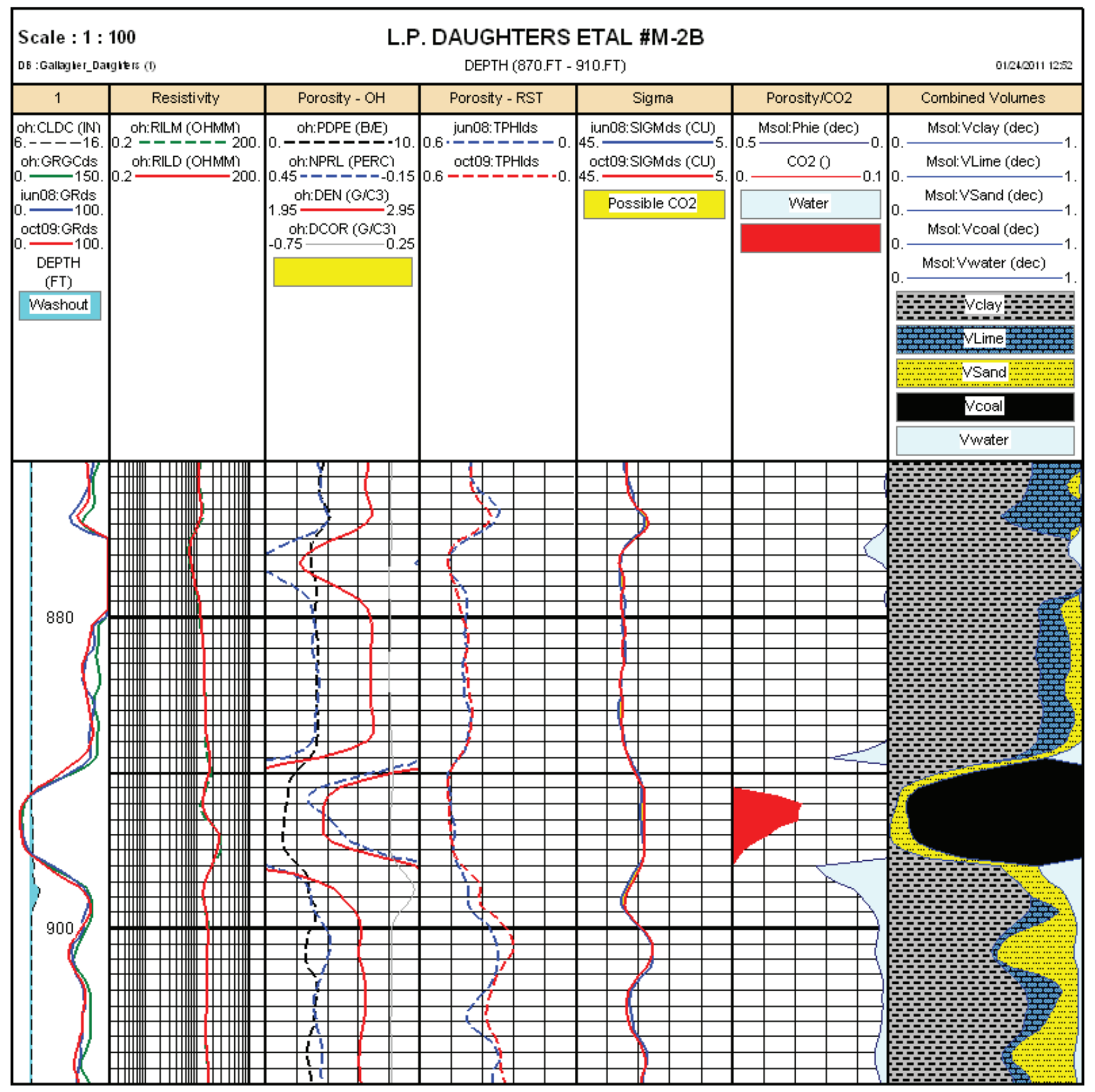

Figure 77. Log analysis for well "M-2B" (M-2), magnified showing the continuous volume of $\mathrm{CO}_{2}$. 


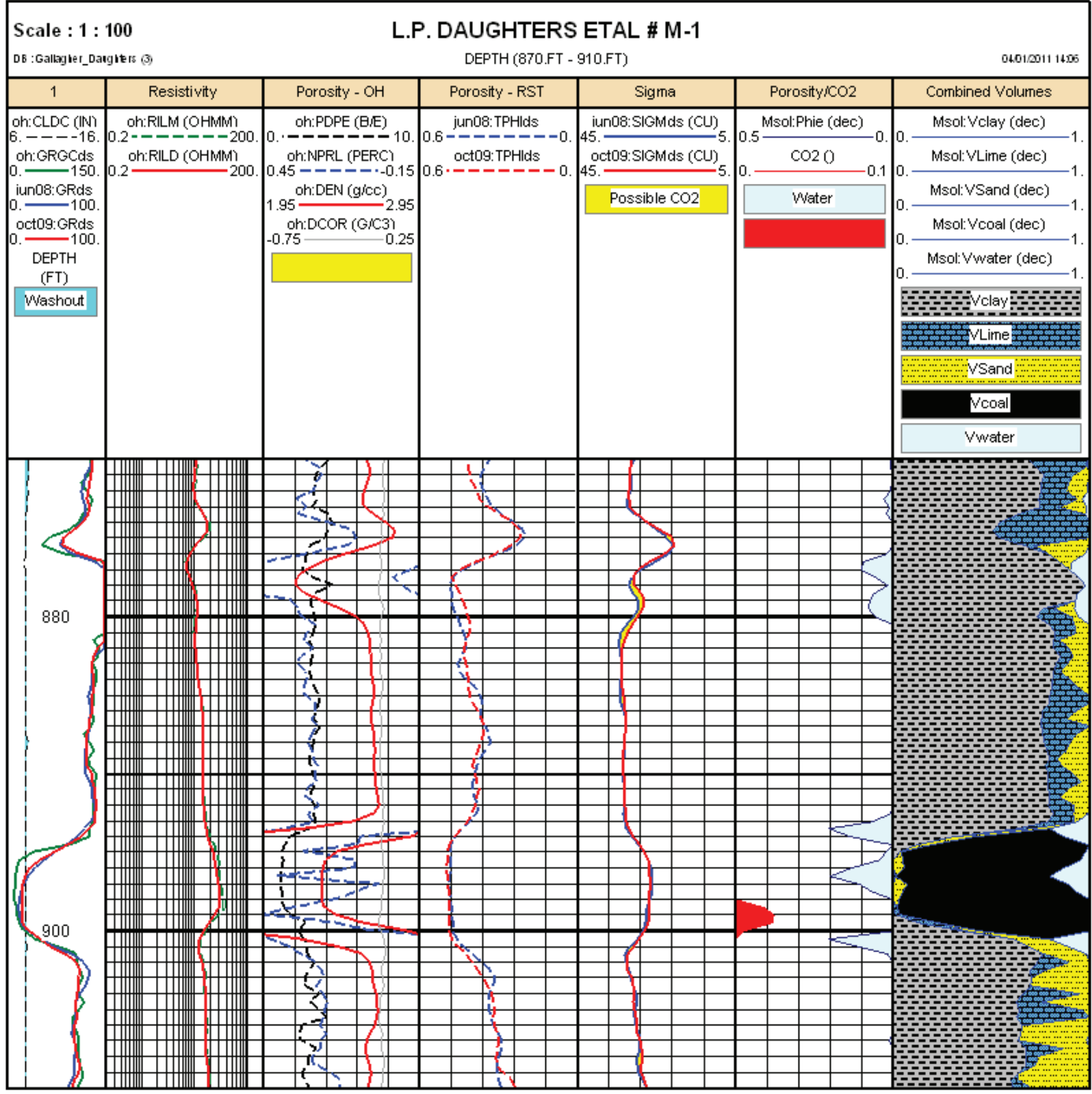

Figure 78. Log analysis for well M-1, magnified. 


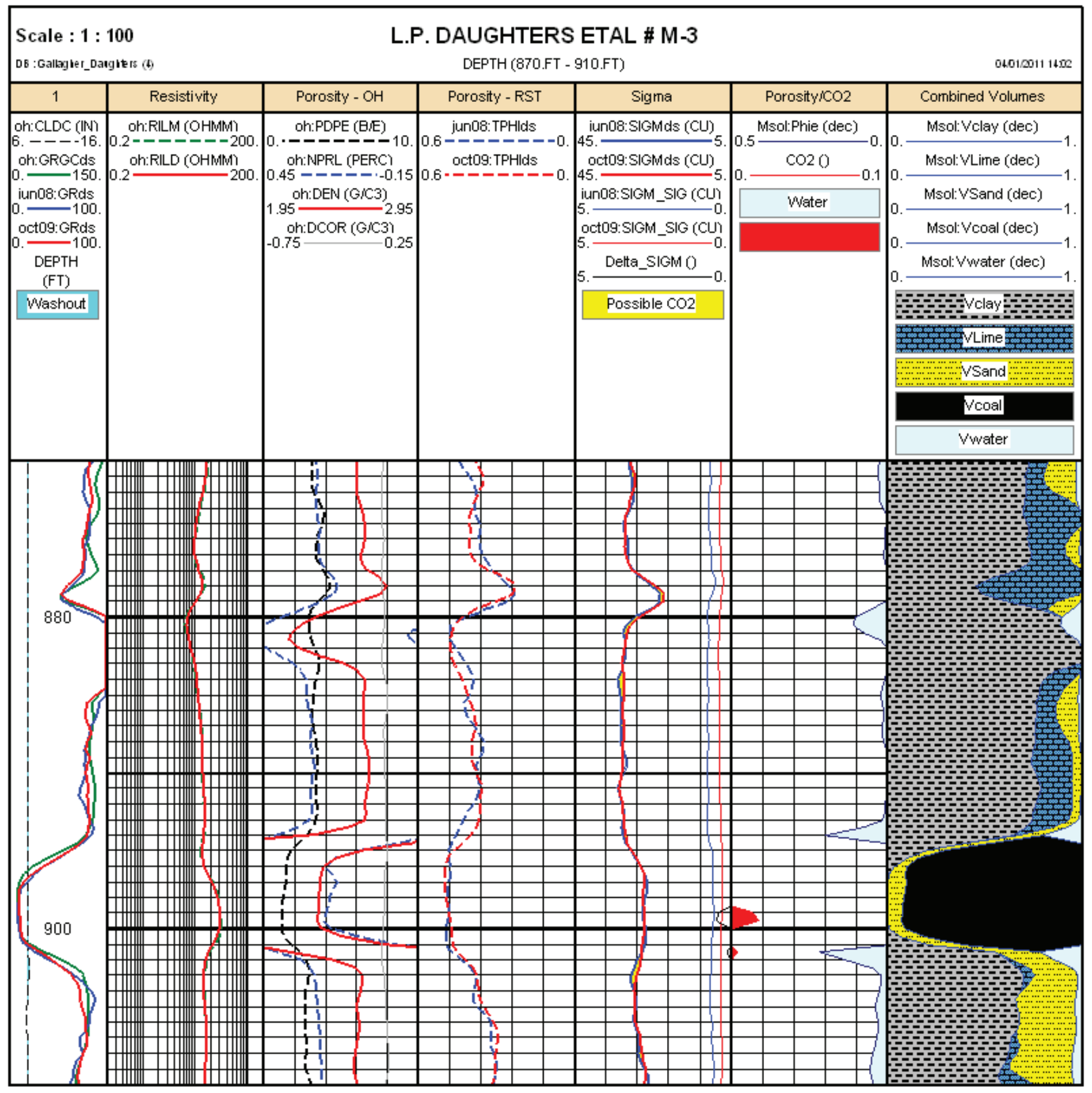

Figure 79. Log analysis for well M-3, magnified. 
field Coal. In M-1, the volume of gas spikes over $2.0 \%$ at $242 \mathrm{~m}$ (793 ft). Because the caliper shows this interval to be a washout, and because the RST is affected by changing bed boundaries, this value probably is an anomaly and no gas is likely to be present. However, if the scope of the project were larger this would certainly be of interest to see if the calculated volume of gas continues to change. If such were the case, then the interpretation would have to change to reflect that the gas had moved out of the injected zone. Additionally, if this were gas from the injection coal bed, for gas to move from the injection zone approximately $30 \mathrm{~m}$ (100 ft) vertically without any RST response would require an explanation.

A detailed analysis of the Springfield Coal at each well showed differences in the character of the volume of $\mathrm{CO}_{2}$ within each well. The injector well's RST interpretation indicates that a small interval in the center of the coal has less gas present, such that there are two separate layers of $\mathrm{CO}_{2}$-filled porosity (Figure 76). M-2 seems to have only one continuous layer of $\mathrm{CO}_{2}$ (Figure 77). The entire vertical thickness of the coal appears to have gas present for each of these wells. The smaller indication of gas in M-1 and M-3 (Figures 78 and 79) indicates the presence of gas only near the base of the coal. These vertical variations may be indicative of layering effects or preferential flow paths of hydrocarbon and $\mathrm{CO}_{2}$ between the injection and monitoring wells.

\section{Post- $\mathrm{CO}_{2}$ Injection Water Pressure Transient Analyses}

After $\mathrm{CO}_{2}$ injection was completed and the post- $\mathrm{CO}_{2}$ cased hole logs were run, a series of water injection pressure transient tests were conducted. The tests were designed to acquire pressure data that could be used to calculate the coal permeability at individual wells and the butt and face cleat permeability. The purpose of using water was to eliminate the relative permeability effect of the gas that was present. Table 10 has the pre-and post- $\mathrm{CO}_{2}$ water permeability estimates for each well. After the relatively lengthy injection periods, it was assumed that any free gas in the cleats had been displaced well beyond the immediate area surround the injection and monitoring wells.
Table 10. Effective permeability (md) to water calculated from pressure falloff tests before and at individual wells after $\mathrm{CO}_{2}$ injection (analytical solutions).

\begin{tabular}{lccccc}
\hline Period & I-1B & M-1 & M-2 & M-3 & Avg \\
\hline Pre-CO $_{2}$ & 5.0 & 4.4 & 4.8 & 3.5 & 4.4 \\
Post-CO $_{2}$ & 1.2 & 5.5 & 2.7 & 3.2 & 3.2 \\
\hline
\end{tabular}

The permeability of I-1B decreased most substantially, followed by M-2. M-1 showed an increase, and M-3 had a slight decrease. The differences in the calculated pre- and post- $\mathrm{CO}_{2}$ permeability are relatively small and may reflect the accuracy of estimating permeability from a pressure transient test, the presence of $\mathrm{CO}_{2}$ in the cleat system, and/or the swelling of coal. This statement is primarily driven by the $0.0011 \mu \mathrm{m}^{2}(1.1 \mathrm{mD})$ increase in permeability of M- 1 , which is difficult to explain, assuming that the gas adsorbed to the coal around M-1 has increased. Therefore, this indirectly gives an idea of the accuracy of these pressure transient tests.

During each well's injection falloff sequence, the pressure at the remaining wells was measured and recorded for analysis as a pulse (interference) test. Assuming a cleat orientation, a pulse test analysis estimates the butt and face cleat permeability. The equivalent permeability can be calculated using the geometric average of the two values. The results of the pre- $\mathrm{CO}_{2}$ and post- $\mathrm{CO}_{2}$ pulse test analyses are given in Table 11.

The post- $\mathrm{CO}_{2}$ injection equivalent permeability $\left(0.0019 \mu \mathrm{m}^{2}[1.9 \mathrm{mD}]\right)$ reflects a decrease from the pre- $\mathrm{CO}_{2}$ estimate. The butt and face cleat permeability decreased proportionally such that the ratio of butt to face cleat permeability remained unchanged.

The pre- and post- $\mathrm{CO}_{2}$ injection average permeability for the individual wells' falloff tests (Table 10) was higher than those equivalent permeability estimates from the pulse tests. Nevertheless, analyses of both test types support the decreases in water permeability following $\mathrm{CO}_{2}$ injection.

Storativity (porosity-compressibility product) can be estimated from pulse tests. The pre- and post- $\mathrm{CO}_{2}$ injection water injection pulse test storativity results were $1.81 \times 10^{-9} / \mathrm{Pa}\left(1.25 \times 10^{-5} / \mathrm{psi}\right)$ and $4.86 \times 10^{-9} / \mathrm{Pa}\left(3.35 \times 10^{-5} / \mathrm{psi}\right)$. These results indicated the coal was slightly more compressible with the adsorbed $\mathrm{CO}_{2}$.

\section{MVA Observations and Interpretations}

\section{Results and Discussion}

Groundwater Modeling Results. The GFLOW groundwater model was calibrated using streamflow data from Bonpas Creek (Figure 80). The streamflow for Bonpas Creek was $0.39 \mathrm{~m}^{3} / \mathrm{sec}\left(13.9 \mathrm{ft}^{3} / \mathrm{sec}\right)$. The model was most sensitive to changes in hydraulic conductivity and recharge. A 50\% change in hydraulic conductivity resulted in a twofold increase in the streamflow rate; a $1 \%$ change in the recharge resulted in a fourfold increase in the streamflow rate. The calibrated recharge rate was
Table 11. Effective permeability anisotropy to water calculated from pulse tests before and after $\mathrm{CO}_{2}$ injection (analytical solutions).

\begin{tabular}{lcccc}
\hline Period & $\mathbf{k}_{\text {butt }} / \mathbf{k}_{\text {face }}$ & $\begin{array}{c}\mathbf{k}_{\text {butt }} \\
(\mathbf{m D})\end{array}$ & $\begin{array}{c}\mathbf{k}_{\text {face }} \\
(\mathbf{m D})\end{array}$ & $\begin{array}{c}\mathbf{k}_{\text {eq }} \\
(\mathbf{m D})\end{array}$ \\
\hline${\text { Pre }-\mathrm{CO}_{2}}$ & 0.12 & 1.2 & 9.6 & 3.4 \\
Post-CO $_{2}$ & 0.12 & 0.67 & 5.4 & 1.9 \\
\hline
\end{tabular}




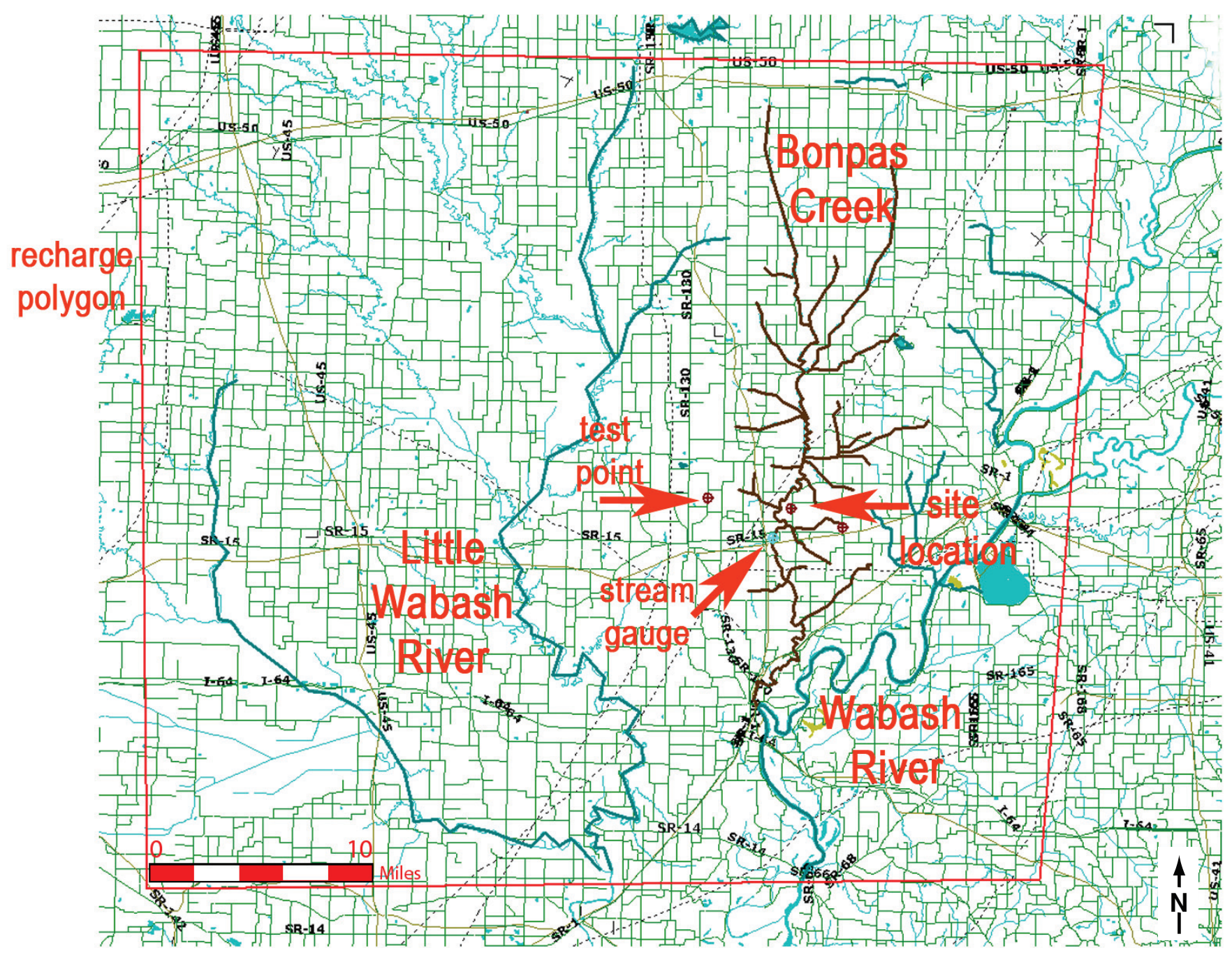

Figure 80. The enhanced coal bed methane (ECBM) site with major hydrologic features identified. The outer, red polygon designates the area where recharge is applied in the groundwater model. The brown dots (open circle with centered plus sign) designate the three test points used in the GFLOW hydrologic modeling. The ECBM field site is located by the center dot located just east of Bonpas Creek. The turquoise circle designates the U.S. Geological Survey stream gauging station north of Browns. The brown lines mark Bonpas Creek and its tributaries. Other significant streams are shown with jade-colored lines. The green lines show the road network in the area.

at $0.0091 \mathrm{~m} / \mathrm{yr}(0.36 \mathrm{inch} / \mathrm{yr})$, which is lower than expected for this site. The modeled and target streamflow for Bonpas Creek differed by $0.2 \%$. Model results indicated that groundwater flow beneath the field site was primarily to the west, towards Bonpas Creek (Figure 81).

Hydrogeologic Data from the Monitoring Wells. Figure 82 shows groundwater levels in ECBM 1-ECBM4. For the period June 4, 2008, through May 18, 2009, the groundwater level in ECBM 1-ECBM4 fluctuated seasonally from highs of approxi-

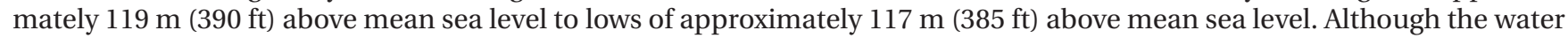
levels in the four wells were similar, the water level in ECBM1 was consistently $0.12-0.13 \mathrm{~m}(0.35-0.40 \mathrm{ft})$ higher than the other three wells. A check for common errors, such as an incorrect elevation of the well casing, was made, but none were found.

A possible explanation in this small difference in water levels is the groundwater discharge from the bedrock. The four wells were completed in a sand and gravel layer that directly overlies the bedrock. If the bedrock beneath ECBM1 has a slightly greater hydrostatic pressure and is in hydraulic communication with the sand and gravel completion, the discharge from the bedrock to the overlying sand and gravel would create a slightly higher water level. Another hypothesis could be local recharge from the surface. 


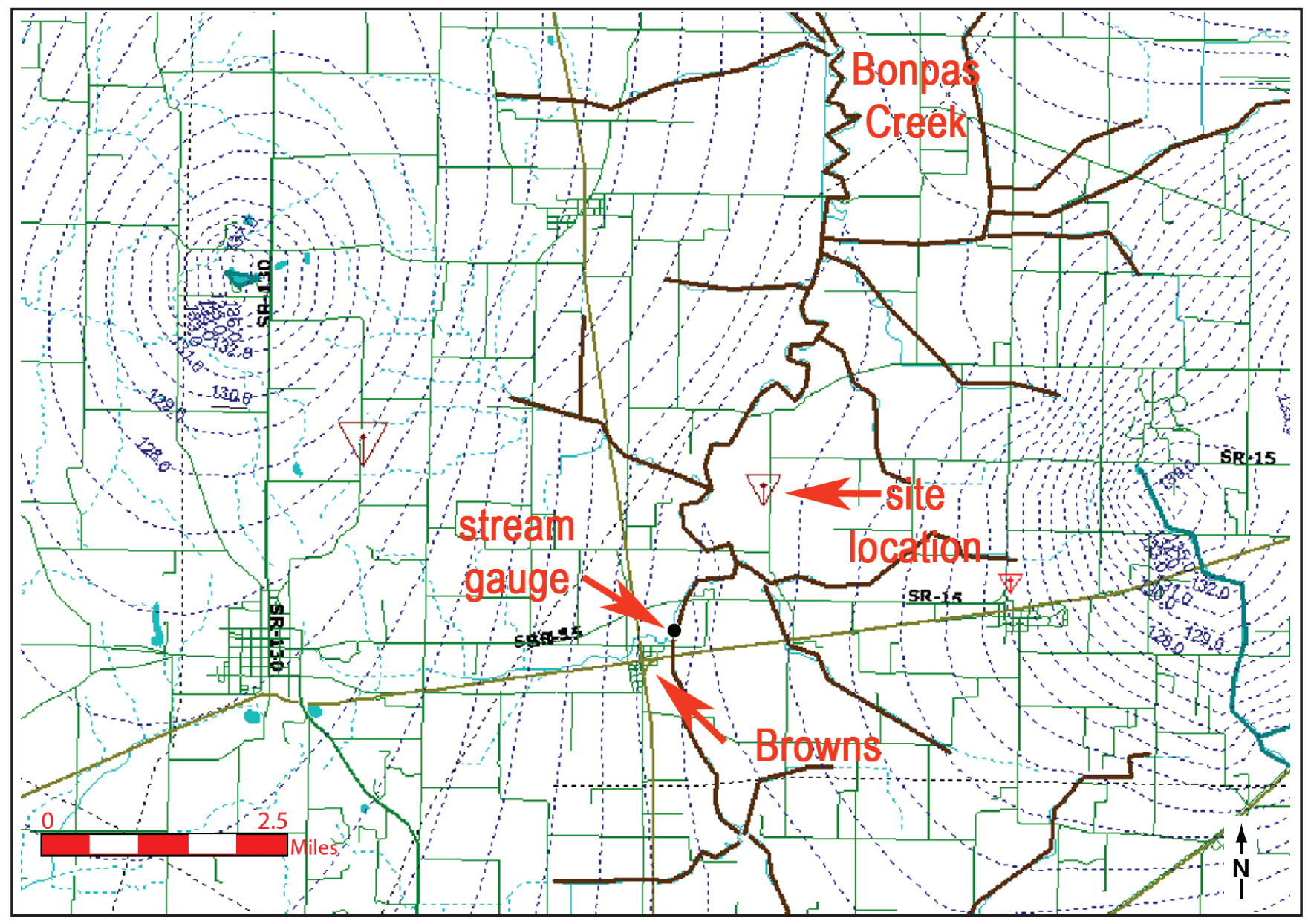

Figure 81. GFLOW model for the site. The triangles designate the three test points used. The enhanced coal bed methane (ECBM) field site is marked by the center triangle east of Bonpas Creek. The turquoise mark designates the USGS stream gauging station north of Browns. The brown lines mark Bonpas Creek and its tributaries. Other significant streams are shown with jade-colored lines. The model-predicted groundwater hydraulic heads are shown as dashed blue lines.

The higher head in ECBM1 relative to the other wells clearly indicates that groundwater in this sand and gravel aquifer flows to the west toward Bonpas Creek, which matches the flow direction predicted by the groundwater modeling discussed earlier.

Coal Seam Observation Wellhead Gas Sampling. Gas samples were collected from the coal seam observation wells once injection of $\mathrm{CO}_{2}$ began on June 25, 2008. (The gas samples were analyzed using gas chromatography techniques to confirm and correlate the field IR readings which were taken much more frequently.) Initially, $\mathrm{CO}_{2}$ concentrations ranged from less than 0.01 to about $0.2 \%$ by volume (Appendix Table A23-1-3). Breakthrough of $\mathrm{CO}_{2}$ was first detected on July 24, 2008, 29 days after injection began, in well M-1 when $\mathrm{CO}_{2}$ concentrations increased to about $12 \%$ (Figure 83 ). The $\mathrm{CO}_{2}$ concentration varied between 11 and 13\% in well M-1 until October 16, when concentrations began to gradually increase to approximately $19 \%$. On October 29, 2008, concentrations increased dramatically to $80 \% \mathrm{CO}_{2}$.

The next $\mathrm{CO}_{2}$ breakthrough was detected in well M-3, 125 days after injection began (Appendix Table A23-3, Figure 83). Concentrations in well M-3 increased from 0.01 to $3.1 \%$ and gradually increased to $6.5 \%$ within a week of initial breakthrough. A significant $\mathrm{CO}_{2}$ increase (45\%) was detected on October 28, 2008, which coincided with an attempt to remove the gas head from well M-3. Over an 8-hr period, $8.353 \mathrm{scm}$ (295 scf) of $\mathrm{CH}_{4}$ and $\mathrm{CO}_{2}$ were released and metered from the gas head of this well.

In well $\mathrm{M}-2, \mathrm{CO}_{2}$ breakthrough was not detected until November 8, 2008, 136 days after injection began (Appendix Table A23-2, Figure 83). At M-2, no $\mathrm{CH}_{4}$ gas was present until October 29, 2008, when the well was flowed for about 5 hr and produced $3.455 \mathrm{scm}$ (122 scf) of $\mathrm{CH}_{4}$ gas with no significant $\mathrm{CO}_{2}$. Concentrations of $\mathrm{CH}_{4}$ remained elevated (93 to $96 \%$ ) until November 8, when $\mathrm{CO}_{2}$ broke through (Figures 83 and 84); the $\mathrm{CO}_{2}$ concentration increased from less than $1 \%$ to $88 \%$ on 


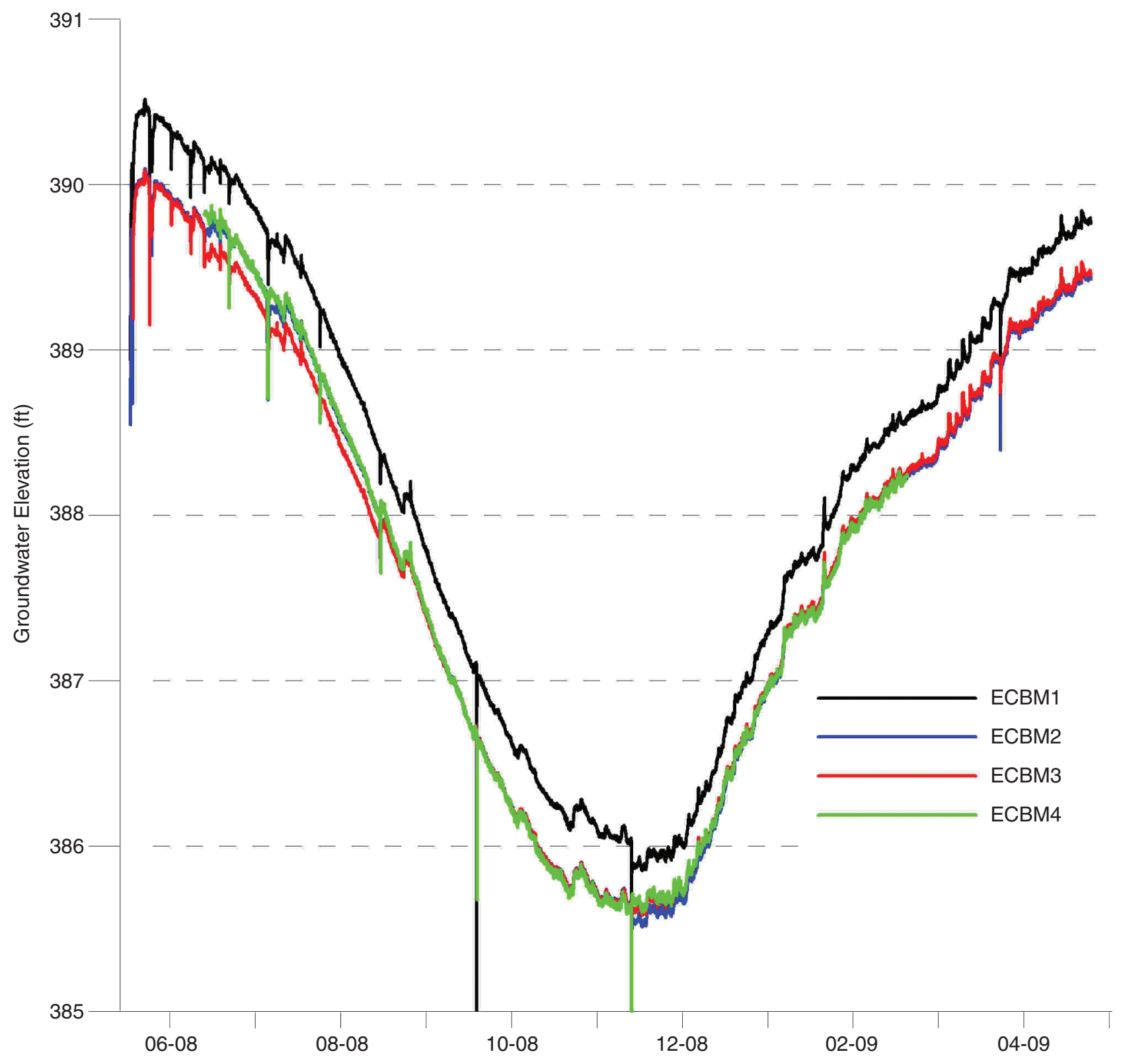

Figure 82. Water levels in the four groundwater monitoring ECBM wells at the Tanquary site.

November 8. Significant concentrations of hydrogen $\left(\mathrm{H}_{2}\right)$ were also observed in well M-2 after the initial $\mathrm{CO}_{2}$ breakthrough (Appendix Table A23-2). The $\mathrm{H}_{2}$ concentration reached approximately $43 \%$ by volume in several gas samples. The reason for the production of $\mathrm{H}_{2}$ is not clear, but it may be due to a reaction that can occur between $\mathrm{CO}_{2}$ and iron in the presence of water (Rau, 2004; Han et al., 2009):

$$
\mathrm{Fe}+2 \mathrm{CO}_{2}+2 \mathrm{H}_{2} \mathrm{O} \rightarrow \mathrm{Fe}^{2+}+2 \mathrm{HCO}_{3}^{-}+\mathrm{H}_{2(\mathrm{~g})}
$$

The $\mathrm{CH}_{4}$ concentrations in observation wells M-1 and M-3 were initially 16 and $12 \%$, respectively, but quickly increased to 80 to $90+\%$ over a few weeks (Appendix Tables A23-1 and A23-3, Figure 84). Generally, when $\mathrm{CO}_{2}$ concentrations were small, $\mathrm{CH}_{4}$ concentrations were large. In all three coal seam observation wells, $\mathrm{CH}_{4}$ was observed prior to significant $\mathrm{CO}_{2}$ detection. This relationship between $\mathrm{CO}_{2}$ and $\mathrm{CH}_{4}$ concentrations was basically linear (Figure 85).

The $\delta^{13} \mathrm{C}_{\mathrm{CO} 2}$ of the initial samples of $\mathrm{CO}_{2}$ collected from M-1 after breakthrough (July 24, 2008) was nearly identical to that of the injected $\mathrm{CO}_{2}$ (Appendix Table A15-1). However, while the $\mathrm{CO}_{2}$ concentration remained constant, the $\delta^{13} \mathrm{C}_{\mathrm{CO} 2}$ in samples 


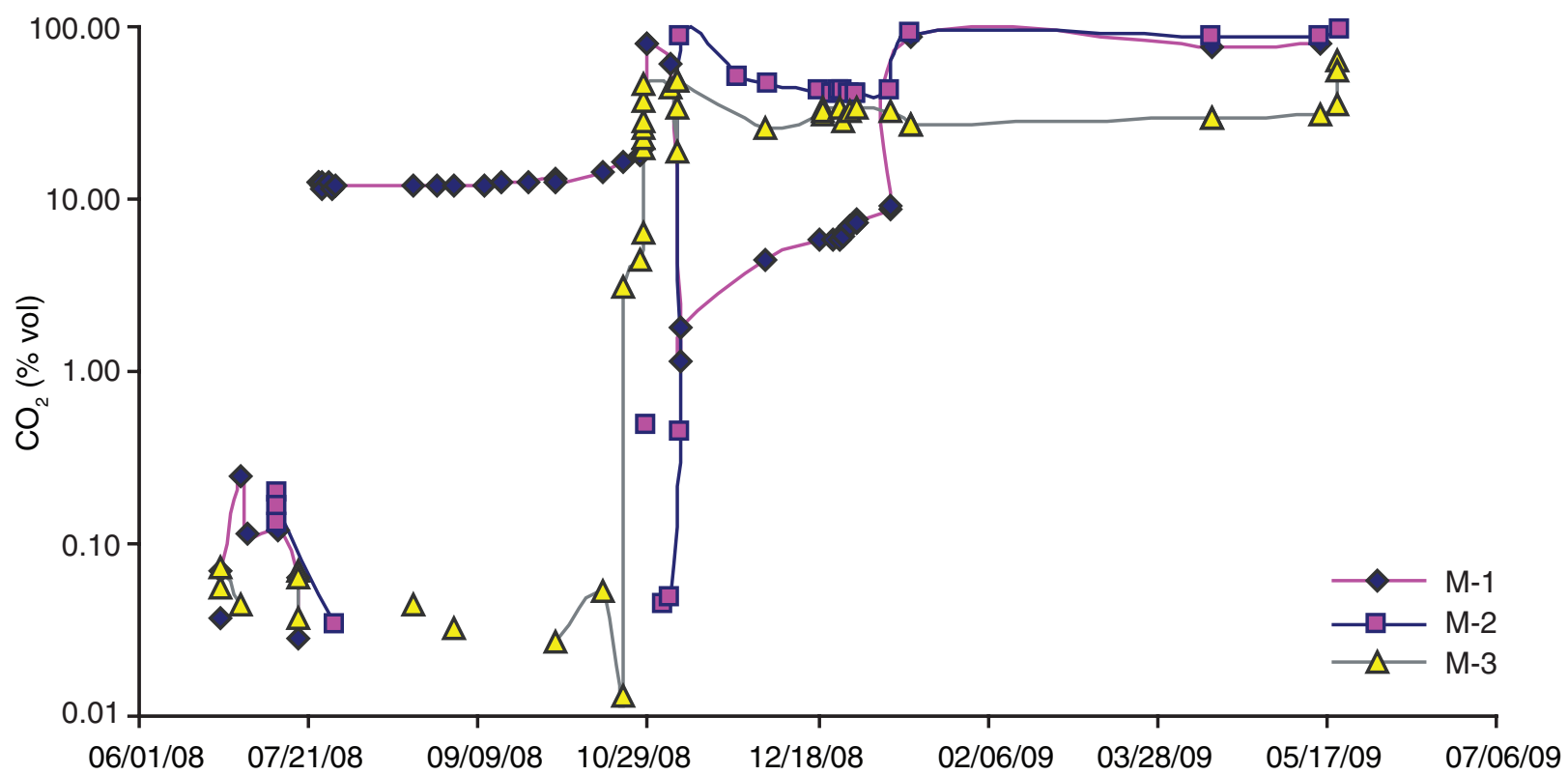

Figure 83. The $\mathrm{CO}_{2}$ concentrations in gas samples collected from the coal seam observation wells $\mathrm{M}-1, \mathrm{M}-2$, and M-3 at the Tanquary site.

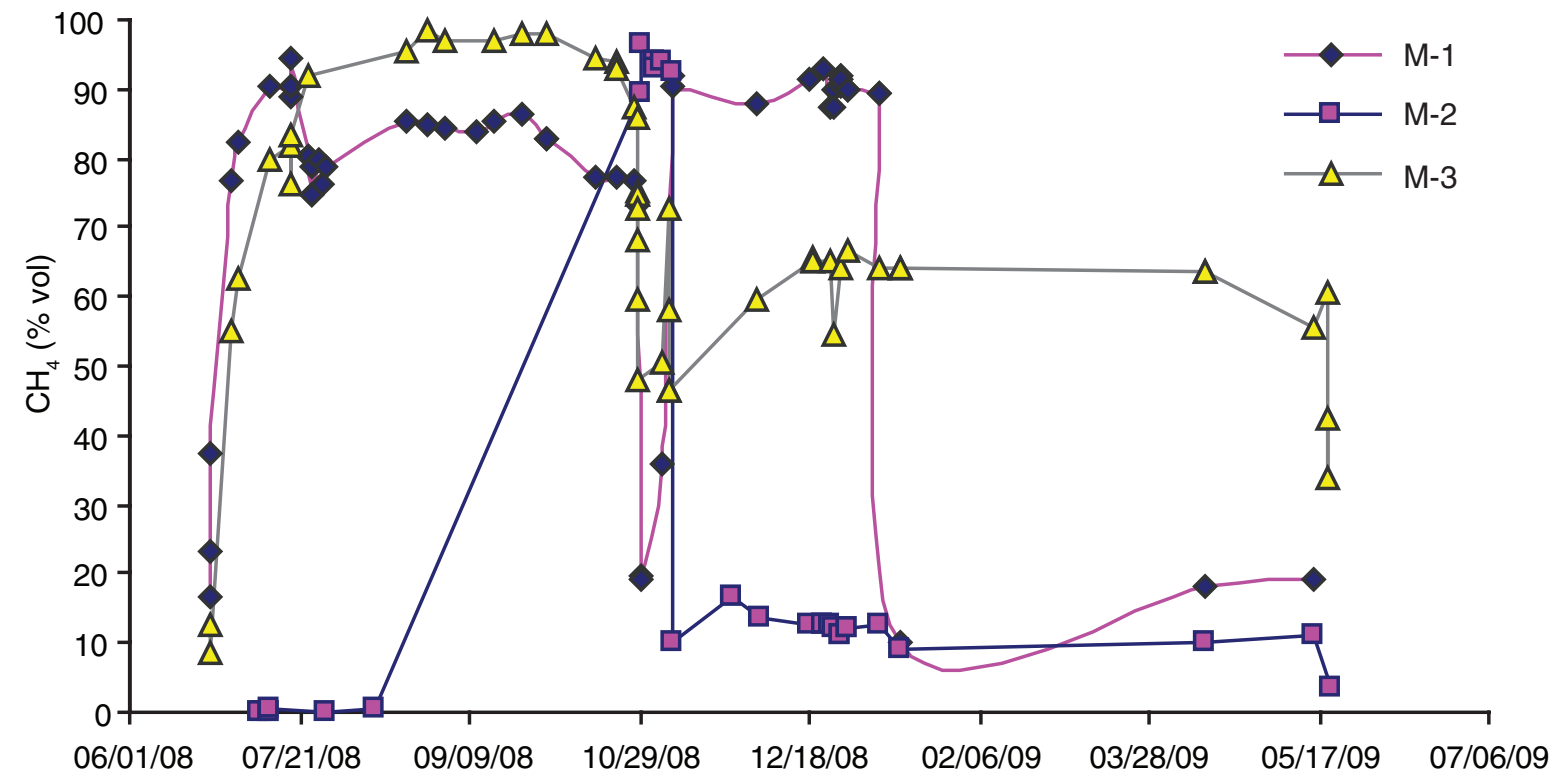

Figure 84. The $\mathrm{CH}_{4}$ concentrations in gas samples collected from the coal seam observation wells $\mathrm{M}-1, \mathrm{M}-2$, and $\mathrm{M}-3$ at the Tanquary site.

from M-1 gradually became more negative through the beginning of October, after which the $\mathrm{CO}_{2}$ began to show more positive values. The $\delta^{13} \mathrm{C}_{\mathrm{CO} 2}$ values quickly became more positive near the end of October as the concentration of $\mathrm{CO}_{2}$ also began to increase (Figure 86) with related gas sampling and gas release from the top of the well.

The pattern observed at M-1-isotopically negative $\delta^{13} \mathrm{C}$ of $\mathrm{CO}_{2}$ followed by more positive values with increasing $\mathrm{CO}_{2}$ concentration-was similar during sampling events in December and January, when M-1 was allowed to build up pressure from additional $\mathrm{CO}_{2}$ injection. A similar trend of negative to more positive $\delta^{13} \mathrm{C}$ values with time and increasing $\mathrm{CO}_{2}$ concentration was also observed for the $\mathrm{CO}_{2}$ collected from observation well M-3 after $\mathrm{CO}_{2}$ breakthrough occurred around October 


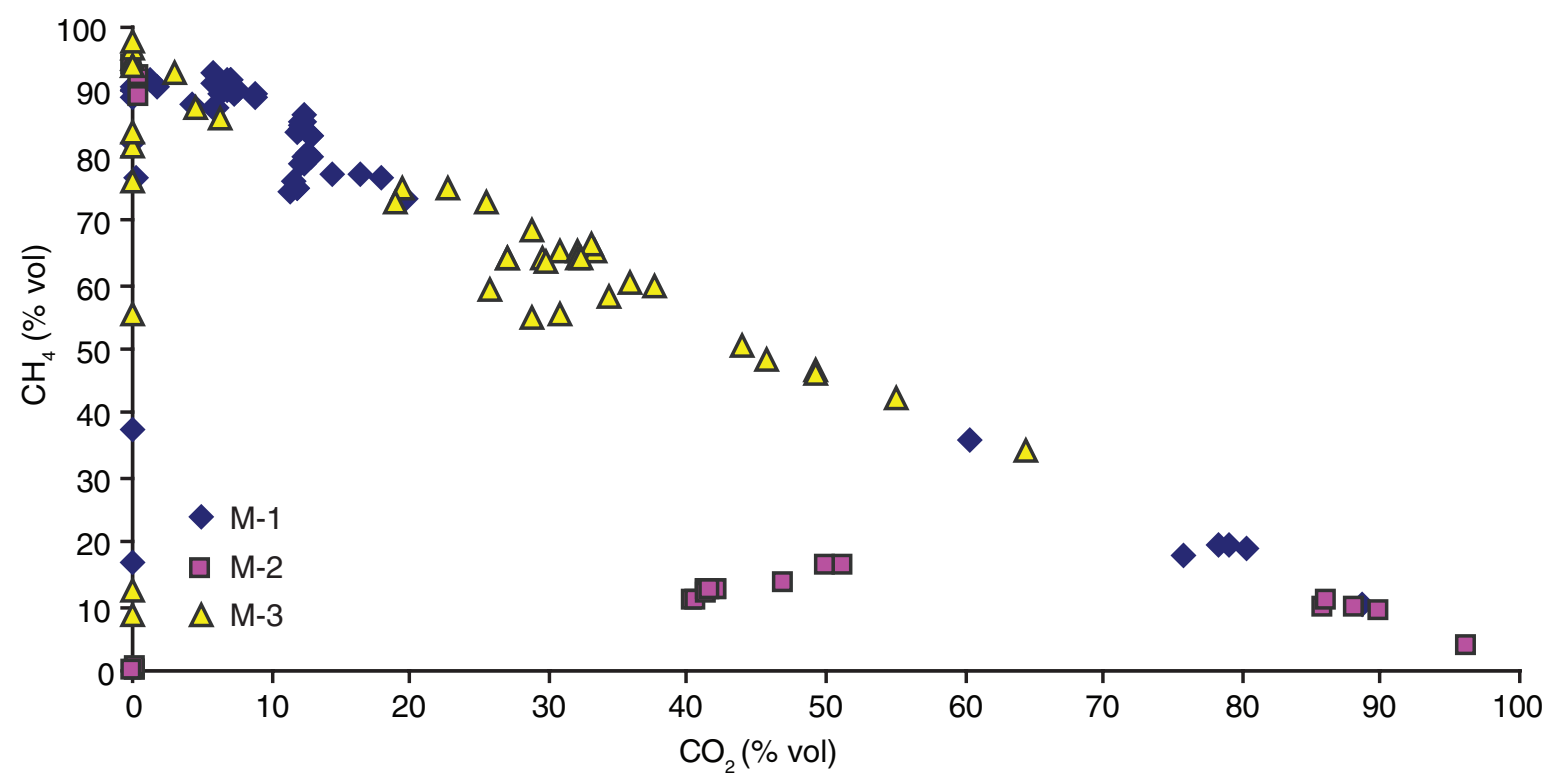

Figure 85. The $\mathrm{CH}_{4}$ and $\mathrm{CO}_{2}$ concentrations in gas samples collected from the coal seam observation wells $\mathrm{M}-1, \mathrm{M}-2$, and M-3 at the Tanquary site. Samples with small $\mathrm{CO}_{2}$ concentrations $(<1 \%)$ represent the time prior to $\mathrm{CO}_{2}$ breakthrough. $\mathrm{M}-2$ samples with small $\mathrm{CH}_{4}$ concentrations and $\mathrm{CO}_{2}$ concentrations between 40 and $52 \%$ are samples that contained significant hydrogen concentrations.

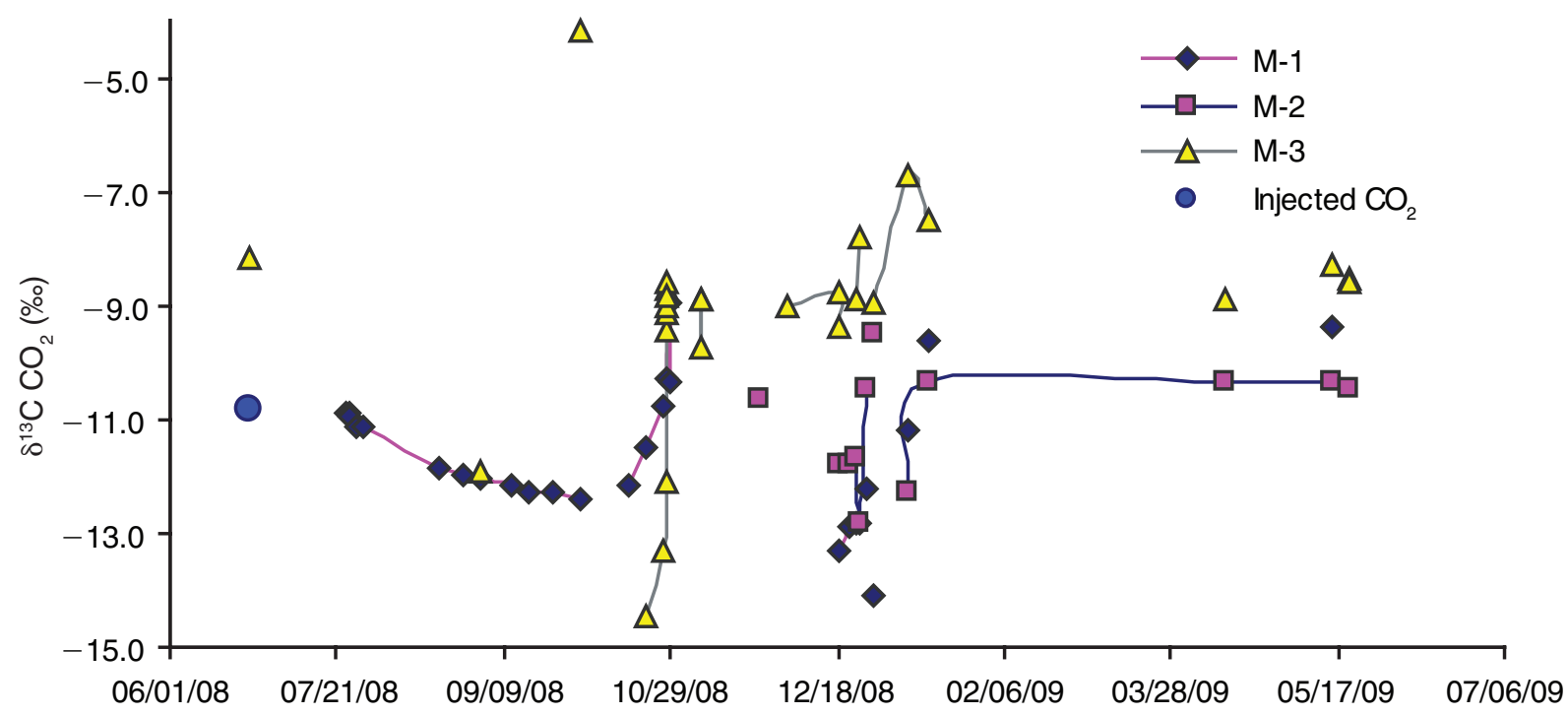

Figure 86. The $\delta^{13} \mathrm{C}$ values of $\mathrm{CO}_{2}$ in gas samples collected from the coal seam observation wells $\mathrm{M}-1, \mathrm{M}-2$, and $\mathrm{M}-3$ at the Tanquary site. Also plotted is a sample of the injected $\mathrm{CO}_{2}$ on the date of injection startup (blue dot to left).

22, 2008 (Figure 86). The isotopic composition of the $\mathrm{CO}_{2}$ that initially broke through at M-3 was negative compared with the injected $\mathrm{CO}_{2}$ and became more positive as $\mathrm{CO}_{2}$ evolved (Appendix Table A15-3). The trend of negative to more positive $\delta^{13} \mathrm{C}$ values observed for the $\mathrm{CO}_{2}$ sampled at the M-1 and M-3 observation wells can be explained by the tendency of coal to retain the isotopically heavier molecules $\left({ }^{13} \mathrm{CO}_{2}\right)$ relative to the isotopically lighter $\mathrm{CO}_{2}\left({ }^{12} \mathrm{CO}_{2}\right)$, as observed in laboratory canister desorption studies of coal (Strapoc et al, 2006). Although the initial samples from well $\mathrm{M}-1$ after $\mathrm{CO}_{2}$ breakthrough showed a trend from $-10.91 \%$ o (nearly the same as the injected $\mathrm{CO}_{2}[-10.81 \%$ o]) down to $-12.38 \%$ and back to $-8.98 \%$, the initial $\mathrm{CO}_{2}$ that broke through may not have diffused into the coal seam and was fairly representative of the isotopic composition of the injected $\mathrm{CO}_{2}$. As time passed, perhaps the $\mathrm{CO}_{2}$ was able to diffuse into the coal pores and the isotopi- 


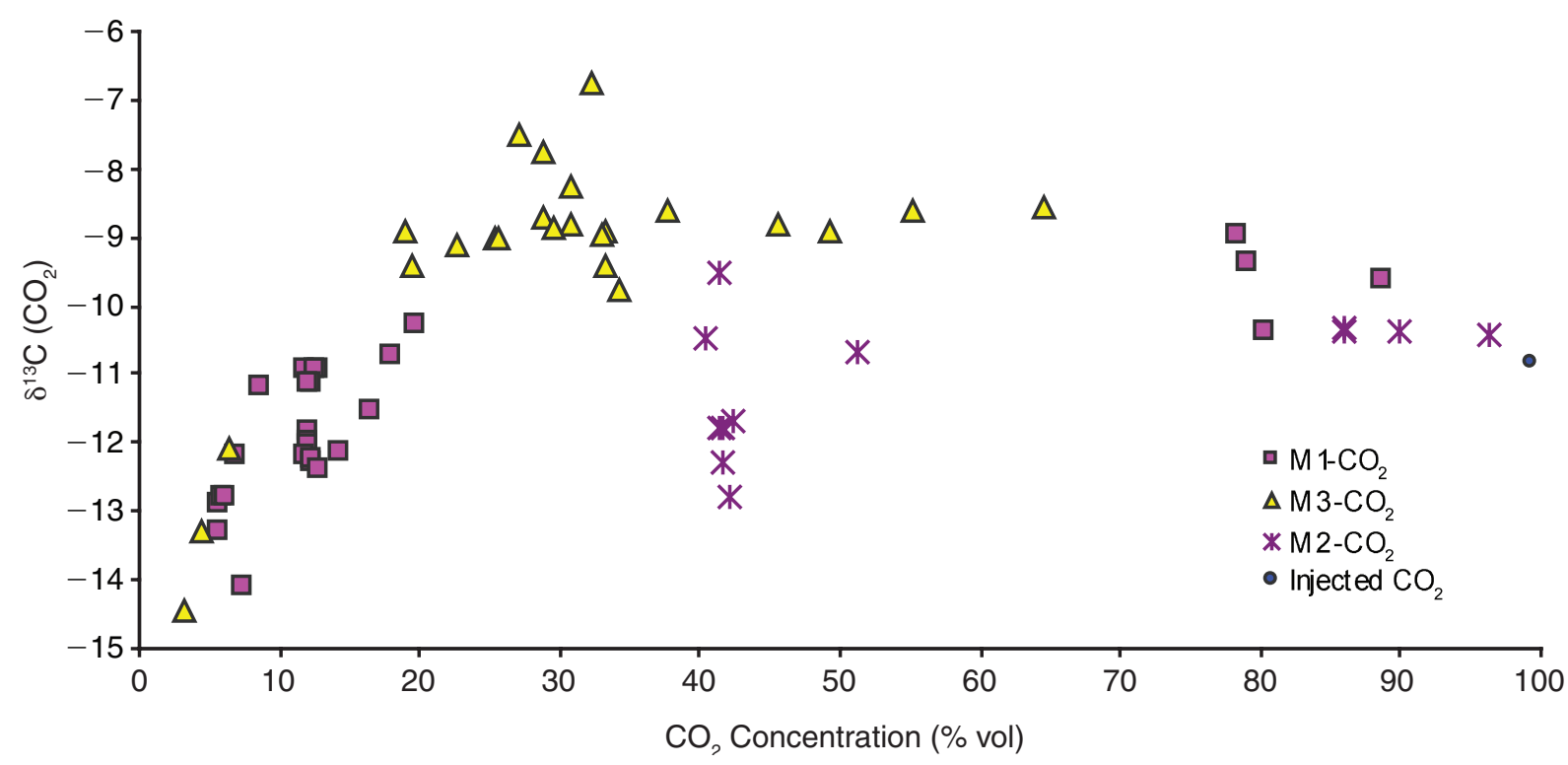

Figure 87. The $\delta^{13} \mathrm{C}$ values of $\mathrm{CO}_{2}$ versus concentrations of $\mathrm{CO}_{2}$ in gas samples collected from the coal seam observation wells at the Tanquary site. Also plotted is a sample of the injected $\mathrm{CO}_{2}$.

cally heavier molecules remained in the coal as equilibrium was established. Then, as the $\mathrm{CO}_{2}$ was continually sampled, the isotopically heavier $\mathrm{CO}_{2}$ molecules gradually diffused out of the pores after the isotopically lighter $\mathrm{CO}_{2}$ molecules. Desorption studies have shown that as the concentration of $\mathrm{CO}_{2}$ increases, the $\delta^{13} \mathrm{C}$ becomes more positive and then levels off. This phenomenon was observed at the Tanquary site, as shown in Figure 87. The gases sampled from wells M-1 and M-3 followed a pattern similar to that observed in desorption studies, whereas the gases collected from well $\mathrm{M}-2$ did not. The $\mathrm{H}_{2}$ observed in the gas samples from well M-2 (Appendix Table A23-2) showed that other reactions occurred at this observation well that did not occur at wells M-1 and M-3.

The carbon-14 $\left({ }^{14} \mathrm{C}\right)$ activity of the $\mathrm{CO}_{2}$ in some of the gas samples from the observation wells also was analyzed (Appendix 15). The ${ }^{14} \mathrm{C}$ analyses of the gas samples help confirm that the increased $\mathrm{CO}_{2}$ concentrations sampled in observation wells originated from the injected $\mathrm{CO}_{2}$. The injected $\mathrm{CO}_{2}$ was from an ethanol plant and had $\mathrm{a}^{14} \mathrm{C}$ concentration of $104 \mathrm{pMC}$ representing "modern" carbon. Previous analyses of naturally occurring $\mathrm{CO}_{2}$ extracted from seven different coal samples ranged

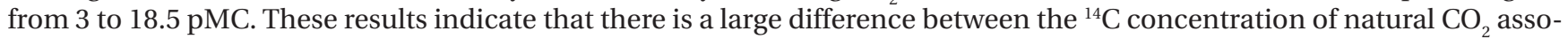
ciated with coal seams and the injected $\mathrm{CO}_{2}$ at this pilot study site. Many of the gas samples contained $25 \%$ or less $\mathrm{CO}_{2}$; however, the ${ }^{14} \mathrm{C}$ activity was very high, often greater than $95 \mathrm{pMC}$. For example, a sample from $\mathrm{M}_{-} 3 \mathrm{containing} 25 \% \mathrm{CO}_{2}$ had a ${ }^{14} \mathrm{C}$ activity of $102.3 \mathrm{pMC}$, which is nearly identical to the injected $\mathrm{CO}_{2}$ activity. Another gas sample with only $3 \% \mathrm{CO}_{2}$ from $\mathrm{M}_{-3}$ had 98.9 pMC ${ }^{14} \mathrm{C}$ activity, confirming it was injection $\mathrm{CO}_{2}$.

There were a few samples of $\mathrm{CO}_{2}$ that had lower than 90 pMC. Most of those samples with less than 90 pMC ranged from 83-89 pMC; one sample from M-1 had only $78 \mathrm{pMC}$. These samples with significantly lower ${ }^{14} \mathrm{C}$ concentration must have some contributions of $\mathrm{CO}_{2}$ from a carbon source with very little to no ${ }^{14} \mathrm{C}$ concentration. One possible source of low ${ }^{14} \mathrm{C} \mathrm{CO}_{2}$ is dissolution of carbonates typically found in coal cleats. Dissolution of carbonates would not be surprising considering that the injection of $\mathrm{CO}_{2}$ would lower the $\mathrm{pH}$ of the aqueous phase and initiate carbonate dissolution. Another possible source of low ${ }^{14} \mathrm{C} \mathrm{CO}_{2}$ would be the oxidation of hydrocarbons in the system. There is a correlation between the lower ${ }^{14} \mathrm{C}$ concentrations of the $\mathrm{CO}_{2}$ from each site and greater heavy hydrocarbons in the samples. It is also possible that both carbonate

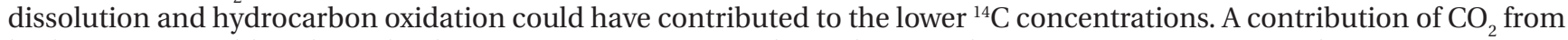
both sources would explain why there is no systematic correlation between lower ${ }^{14} \mathrm{C}$ concentration and more negative $\delta^{13} \mathrm{C}$ values. The hydrocarbons would have negative $\delta^{13} \mathrm{C}$ contribution, and the dissolution of carbonates would typically have more positive $\delta^{13} \mathrm{C}$ values. Thus, a significant change in the $\delta^{13} \mathrm{C}$ values would tend to be dampened if both hydrocarbons and carbonates were contributing to the $\mathrm{CO}_{2}$ reservoir. Some of the ${ }^{14} \mathrm{C}$ variation could be due to the physical adsorption/desorption phenomena discussed earlier in relation to the stable isotope results in which we observed the coal retaining the heavier isotopes which gradually diffused back out of the pores with time (Figure 88).

A pattern also was observed for the $\delta^{13} \mathrm{C}$ of the $\mathrm{CH}_{4}$ released from the observation wells prior to $\mathrm{CO}_{2}$ breakthrough. Isotopically heavier (less negative) $\delta^{13} \mathrm{C}$ values of $\mathrm{CH}_{4}$ were initially observed, followed by lighter values, and then eventually isotopically heavier values as time passed and as the concentration of $\mathrm{CH}_{4}$ increased (Figure 89). The initially more positive values 


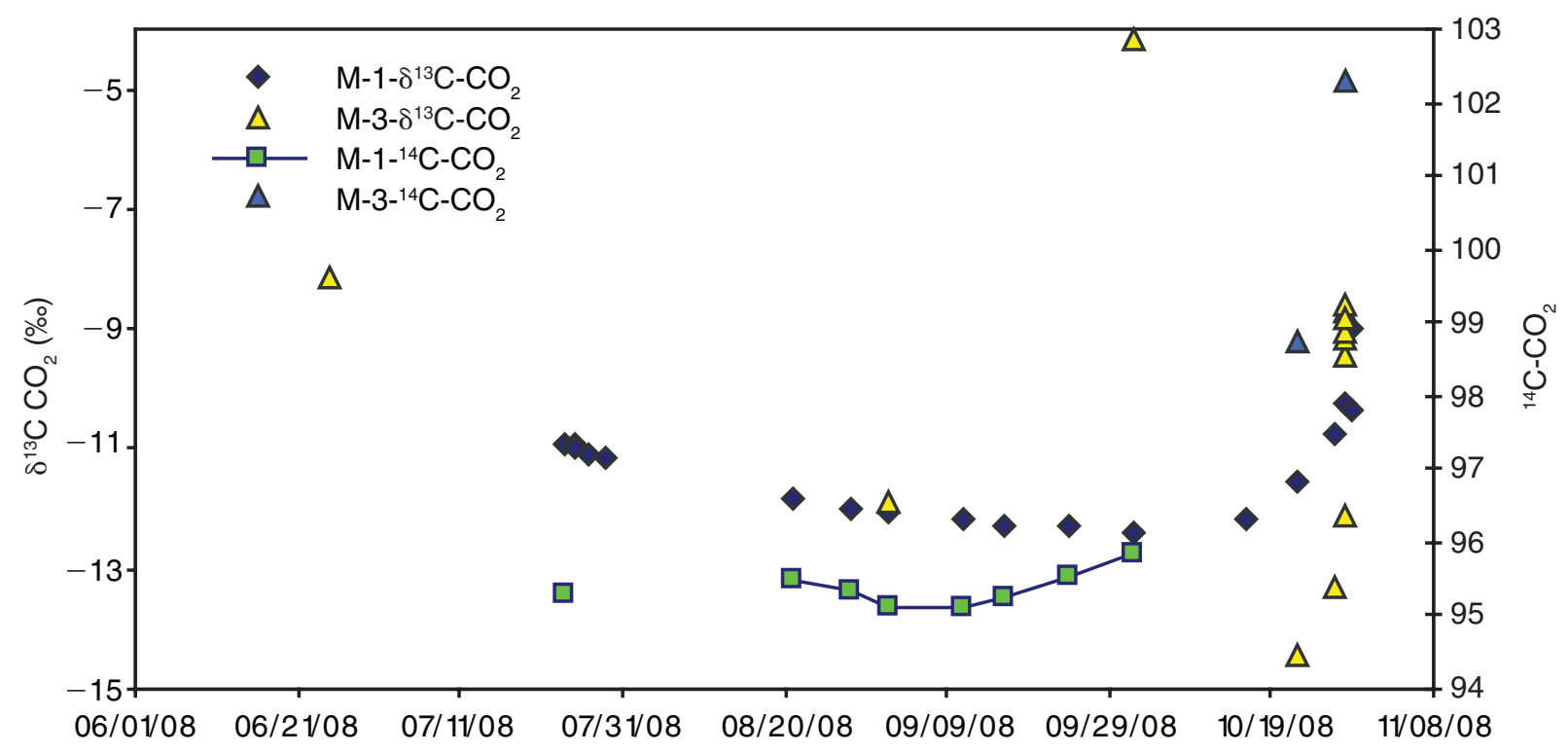

Figure 88. The ${ }^{14} \mathrm{C}$ analyses for $\mathrm{CO}_{2}$ in samples from coal seam observation wells $\mathrm{M}-1$ and $\mathrm{M}-3$. Also included is the $\delta^{13} \mathrm{C}$ composition of $\mathrm{CO}_{2}$ in the gas samples.

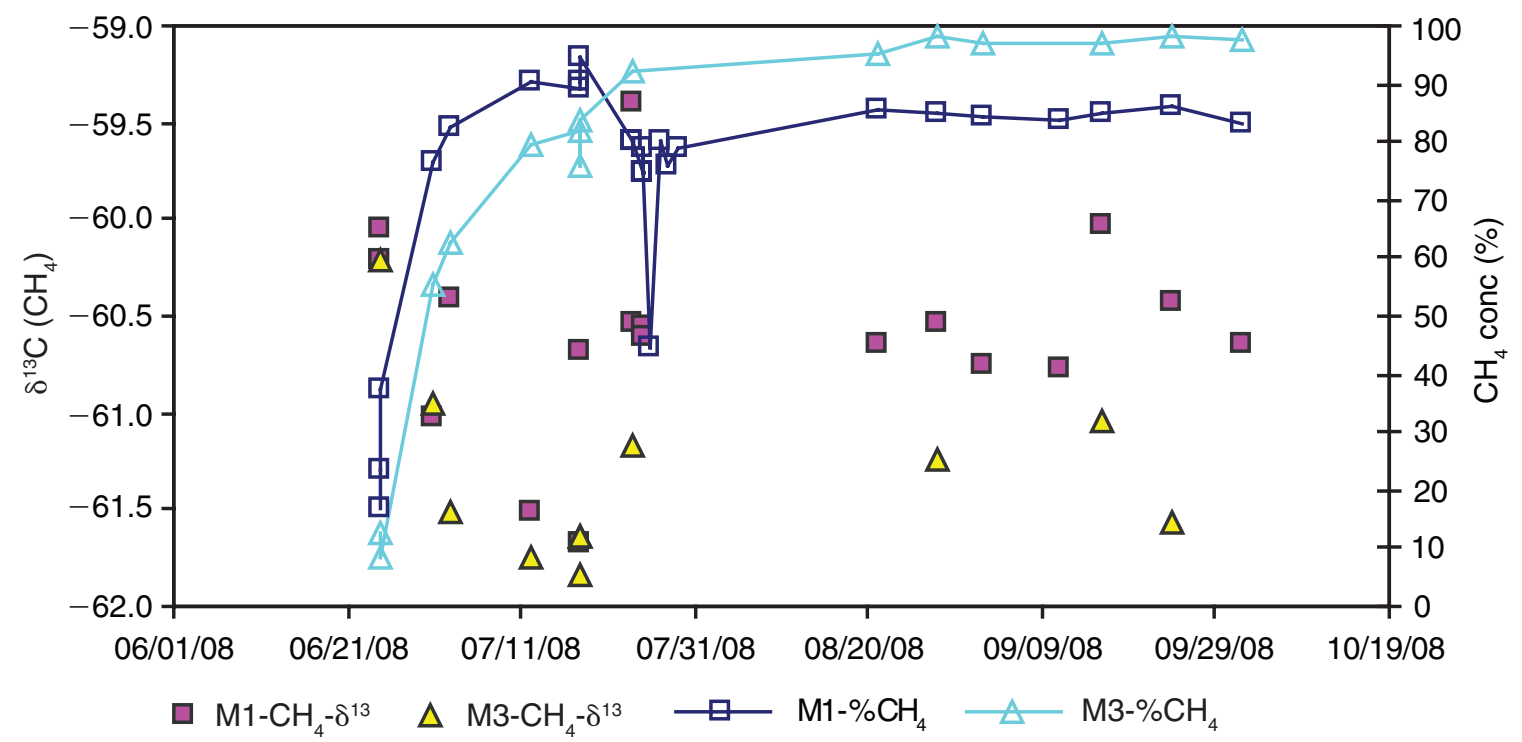

Figure 89. The $\delta^{13} \mathrm{C}$ values of $\mathrm{CH}_{4}$ versus concentrations of $\mathrm{CH}_{4}$ in gas samples from coal seam observation wells at the Tanquary site. Symbols with lines represent $\mathrm{CH}_{4}$ concentrations; symbols alone represent $\delta^{13} \mathrm{C}$ values.

for the $\mathrm{CH}_{4}$ did not fit the desorption fractionation effect, which typically results in more negative (isotopically lighter) values for the $\mathrm{CH}_{4}$ initially released from coals (Strąpoć et al, 2006, Guoyi et al., 2007). The isotopically heavier (less negative) values of the initial $\mathrm{CH}_{4}$ samples may be related to the initial drilling, well development processes, and water pressure tran-

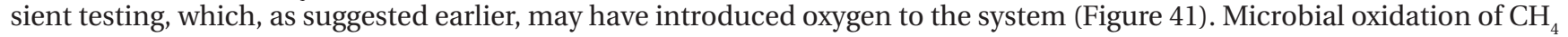
produces isotopically heavier (more positive) $\delta^{13} \mathrm{C}$ values for $\mathrm{CH}_{4}$ and isotopically lighter (more negative) values for $\mathrm{CO}_{2}$. $\mathrm{A}$ very negative $\delta^{13} \mathrm{C}$ value was observed for the initial $\mathrm{CO}_{2}$ sampled in $\mathrm{M}$-1. If oxidation had recently occurred, it could be that the initial $\mathrm{CH}_{4}$ sampled had been influenced by some oxidation; as desorption of gases from the coal continued prior to $\mathrm{CO}_{2}$ breakthrough, isotopically lighter (more negative) $\mathrm{CH}_{4}$ desorbed from the coal pores, causing the overall $\delta^{13} \mathrm{C}$ value of the $\mathrm{CH}_{4}$ to decrease (become more negative). As desorption continued, isotopically heavier (more positive) molecules began to desorb and caused the overall $\delta^{13} \mathrm{C}$ value of the $\mathrm{CH}_{4}$ to increase again. The $\delta^{13} \mathrm{C}$ of the $\mathrm{CH}_{4}$ stabilized with time. 


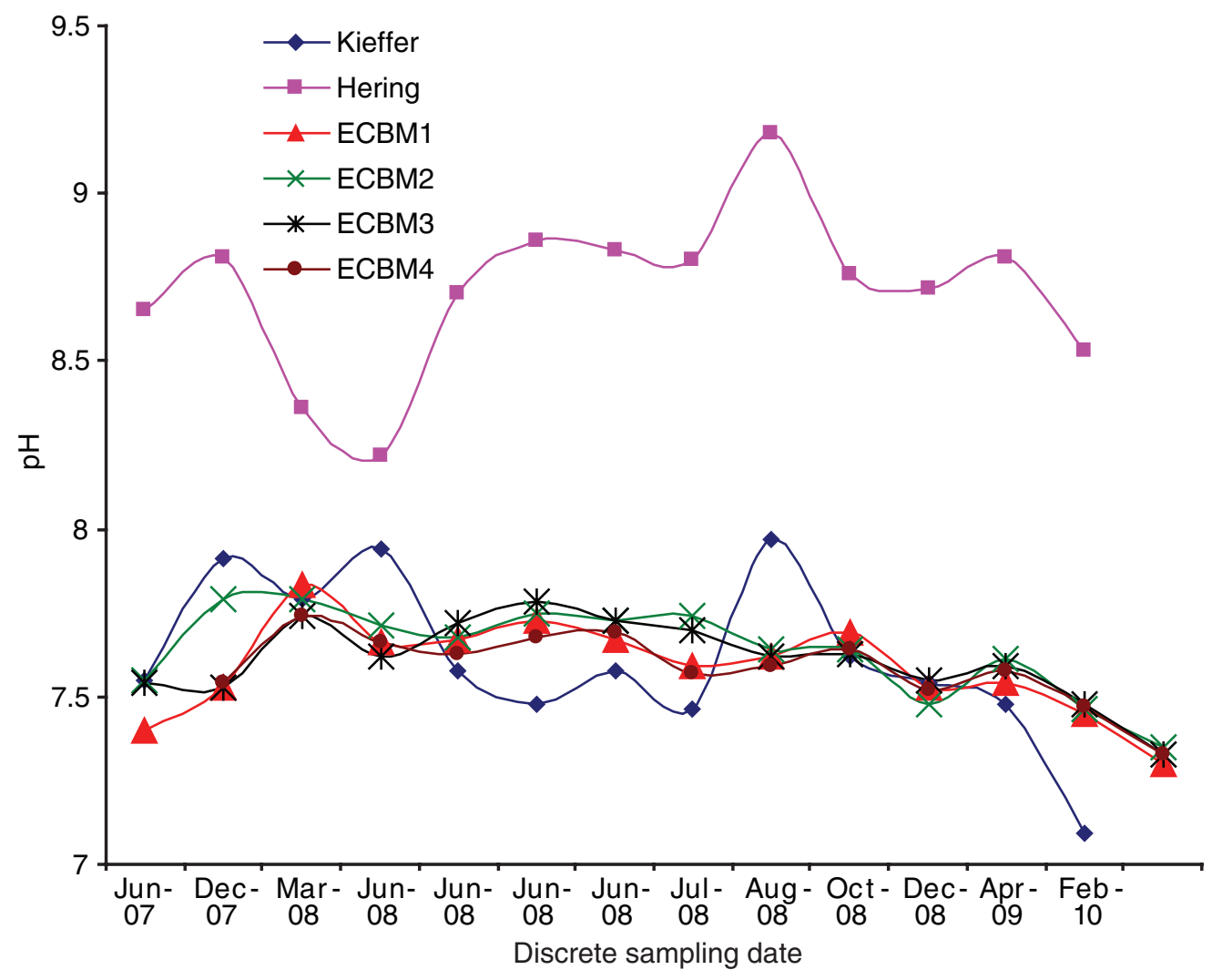

Figure 90. The $\mathrm{pH}$ of groundwater samples from groundwater ECBM monitoring and residential wells at the Tanquary site. Note that the $x$-axis shows equally spaced sampling dates and not chronological time.

Chemical Characterization of Groundwater Wells. Groundwater samples were collected from the Tanquary site to determine potential impacts on water quality from the project. Injection of $\mathrm{CO}_{2}$ into groundwater can cause a decrease in groundwater $\mathrm{pH}$ and dissolution of certain constituents of the rock matrix of the aquifer. Consequently, analyses of the water quality data focused on the analytes involved in the carbonate chemistry of the water and the potential dissolution products of clay minerals. $\mathrm{As}_{2} \mathrm{CO}_{2}$ is injected into the coal seam, connate water can be displaced and potentially enter the shallow aquifer system; thus, elements such as $\mathrm{Cl}$ and $\mathrm{Na}$, which are typical constituents of coal seam waters, were examined in the groundwater samples.

Groundwater $\mathrm{pH}$ varied in both the monitoring and residential wells. Residential wells were sampled for about 1 year prior to $\mathrm{CO}_{2}$ injection (June 2007 to June 2008) and exhibited decreases in $\mathrm{pH}$ of as much as $0.6 \mathrm{pH}$ units during that period (Figure 90). Because there were adequate background data for the residential wells, a t-test statistical analysis was applied to determine whether there were any significant changes between the means of the pre-injection and post-injection $\mathrm{pH}$ values. Despite $\mathrm{pH}$ fluctuations, there was no significant $(\alpha=0.5)$ difference between the average $\mathrm{pH}$ values prior to and after $\mathrm{CO}_{2}$ injection for either residential well's groundwater.

The Kieffer well is open at a depth similar to that of the monitoring wells at the ECBM site (28 $\mathrm{m}[93 \mathrm{ft}])$ and almost certainly draws its water from the same aquifer. The Hering well, however, is completed at a greater depth (50 $\mathrm{m}[165 \mathrm{ft}])$ and, as shown by the differences in its geochemistry, draws from a different aquifer. Despite this difference, the groundwater in all of the wells exhibited a relatively small, general decrease in $\mathrm{pH}$ with respect to time. The $\mathrm{pH}$ values for all groundwater samples from the monitoring wells were similar to the residential wells and followed the same seasonal trend. Particle tracking modeling indicated that $\mathrm{CO}_{2}$ would not migrate to the residential wells $10 \mathrm{yr}$ after a hypothetical release, also suggesting that the observed variability in $\mathrm{pH}$ values probably was not due to $\mathrm{CO}_{2}$ leakage but rather to a combination of analytical measurement and natural groundwater variability.

Based on $\mathrm{CO}_{2}$ reactions with water, it would also be expected that alkalinity and total dissolved carbon would increase in aquifers impacted by $\mathrm{CO}_{2}$ leakage. Alkalinity in ECBM wells 2 and 3 remained relatively constant throughout the project period with no significant trend observed (Figure 91). However, alkalinity concentrations in monitoring wells ECBM1 and 


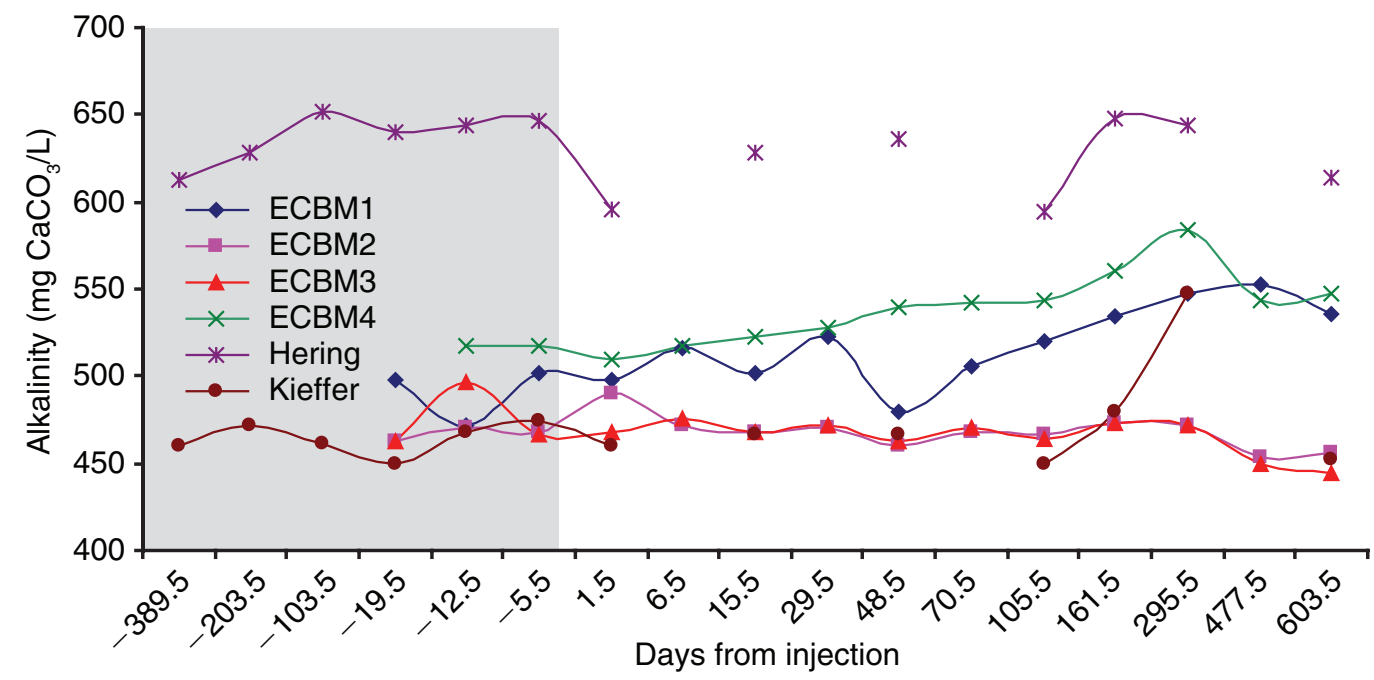

Figure 91. Alkalinity of groundwater samples collected from monitoring and residential wells at the Tanquary site. The pre-injection sampling period has been shaded in order to highlight samples taken during and post-injection. Note that the $x$-axis shows equally spaced sampling dates and not chronological time.

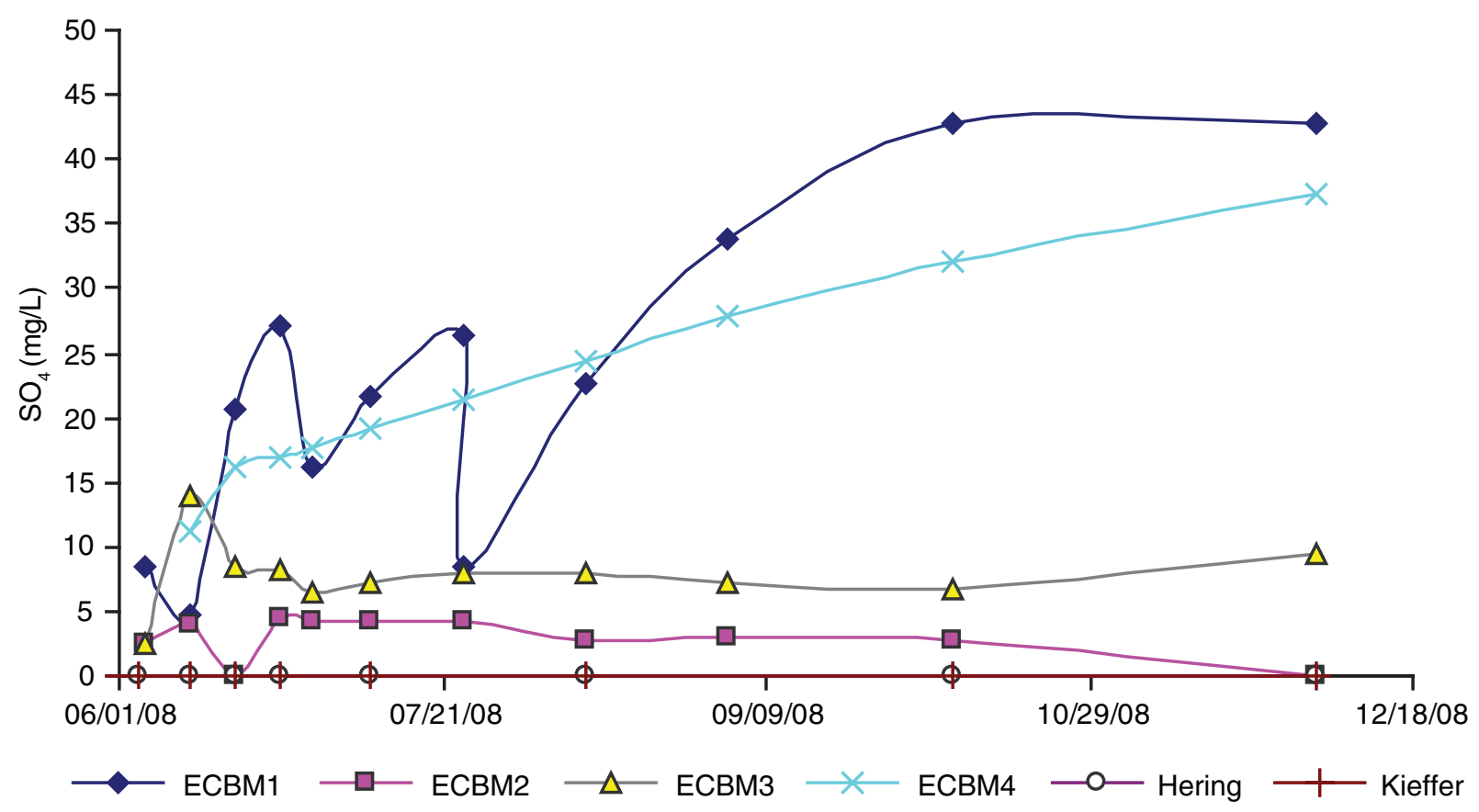

Figure 92. Sulfate $\left(\mathrm{SO}_{4}\right)$ concentrations in groundwater samples from monitoring and residential wells at the Tanquary site.

ECBM4 did show a distinct trend that could have resulted from effects from the materials used to drill the wells or from the oxidation to $\mathrm{CO}_{2}$ of organic carbon contained in the geologic material near the well (see next section). The wireline rock coring technique used in drilling wells ECBM1 and ECBM4 involved the use of a sodium bentonite mud-rotary drilling process. The $\mathrm{pH}$ of the sodium bentonite drilling mud was adjusted to approximately $\mathrm{pH} 11$ using sodium carbonate, and the coring process required longer exposure of the aquifer formation to the sodium bentonite-based drilling mud and a higher pressure in the well bore (personal communication, Jack Aud, ISGS driller). The longer exposure time and higher pressure likely resulted in more drilling mud infiltrating into the aquifer material than for the ECBM2 and ECBM3 wells, which were not cored. Although all of the wells were extensively pumped to develop them prior to sampling, it is still pos- 


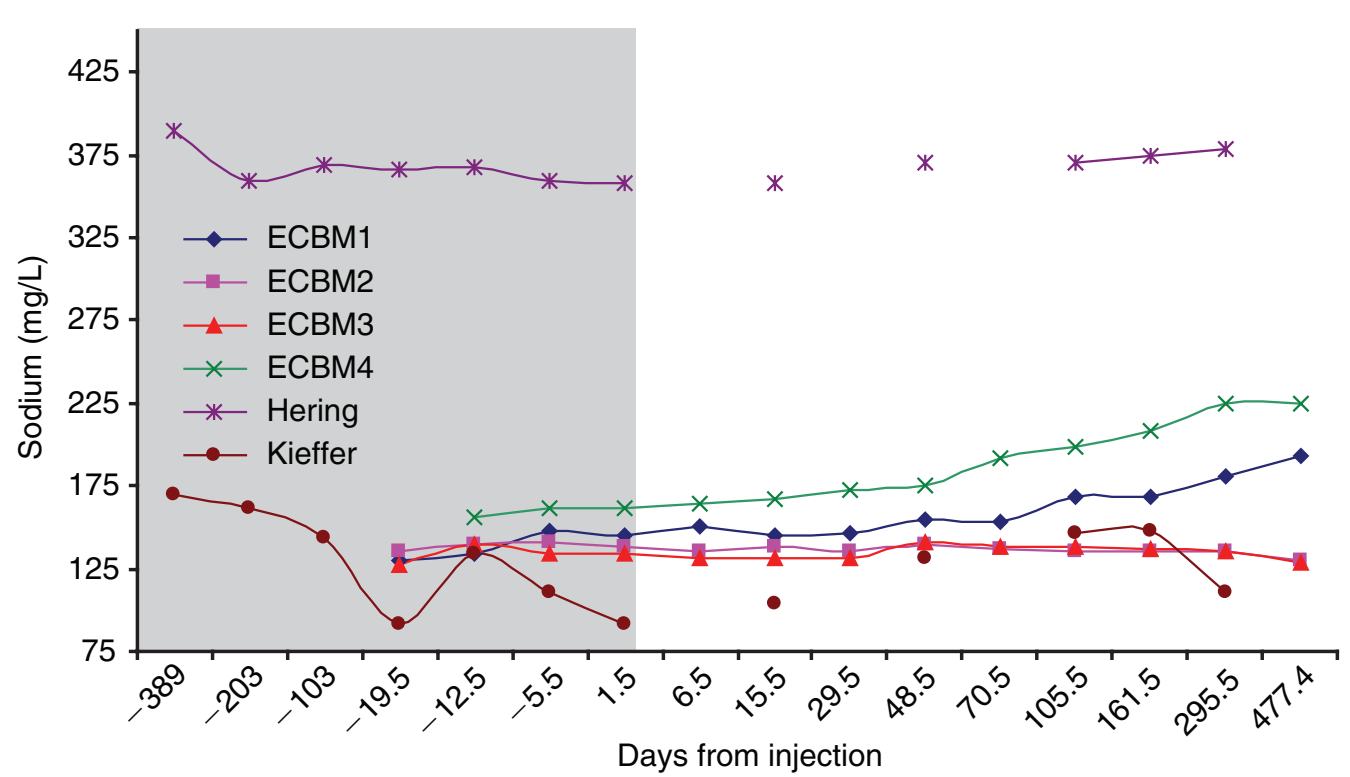

Figure 93. Sodium $\left(\mathrm{Na}^{+}\right)$concentrations in groundwater samples from monitoring and residential wells at the Tanquary site. The pre-injection sampling period has been shaded in order to highlight samples taken during and post-injection. Note that the $\mathrm{x}$-axis shows equally spaced sampling dates and not chronological time.

sible that drilling mud components entered into the aquifer, particularly around wells ECBM1 and ECBM4, continued to slowly migrate from the formation into the well bore and could have caused the observed gradual increase in groundwater alkalinity in these two holes.

Chloride concentrations remained relatively constant in all the wells during the project period, suggesting there was no detectable movement of brine from the coal seam into the shallow groundwater (Figure 46). All of the monitoring wells showed an initial increase in sulfate concentration (Figure 92), some of which could be due to oxidation of sulfide minerals. This result also agrees with the elevated oxidation reduction potential (Eh) and dissolved oxygen (DO) values observed in the initial samples of the monitoring wells. Although this increase was very slight in samples from wells ECBM2 and ECBM3, and soon stabilized in wells ECBM1 and ECBM4, the sulfate and sodium concentrations (Figures 92 and 93) increased with time and, like the increase in alkalinity with time, these increases also are likely an artifact of the core drilling process.

Isotopic Characterization of Groundwater Wells. The $\delta^{18} \mathrm{O}$ values of the groundwater from the monitoring wells ranged from -5.8 to $-6.3 \%$, and the $\delta \mathrm{D}$ values ranged from -37.5 to -40.6 . These values were fairly similar to those from the Kieffer residential well, but are quite different from the values for the Hering residential well, which is completed in a different, deeper aquifer (Appendix 18, Figure 47). Only one aqueous sample from the coal seam (M-2) was isotopically analyzed; it had an isotopic composition within the range of all the other wells except the Hering well (Appendix 18, Figure 47).

The concentration of $\mathrm{CO}_{2}$ in the samples of headspace gas collected from the groundwater monitoring wells was generally less than $0.1 \%$ (Appendix 24). The predominant gases in the samples, $\mathrm{O}_{2}$ and $\mathrm{N}_{2}$, occurred at concentrations similar to normal atmospheric values. The $\mathrm{CO}_{2}$ concentrations did not increase in the gas samples collected from the groundwater wells after the first breakthrough of $\mathrm{CO}_{2}$ in coal seam observation well $\mathrm{M}-1$. The $\mathrm{CH}_{4}$ concentrations in the monitoring well headspace samples generally were below the detection limit; the largest concentration detected was $0.3 \%$ by volume.

The $\delta^{13} \mathrm{C}$ of the dissolved inorganic carbon (DIC) from the monitoring well water samples varied during the initial sampling periods; however, the isotopic variations did not correlate with chemical evidence that would be typical of $\mathrm{CO}_{2}$ migrating from the injected coal seam into the shallow groundwater aquifer. The $\delta^{13} \mathrm{C}$ values for the DIC of the Hering residential well water samples were significantly heavier (more positive) (about-9\%o) than the other groundwater wells (about-12\%o) (Figure 94). Isotopically heavy $\delta^{13} \mathrm{C}$ values in the groundwater would be expected if the $\mathrm{CO}_{2}$ injected into the coal seam had migrated to the shallower groundwater aquifers because the $\delta^{13} \mathrm{C}$ of the injected $\mathrm{CO}_{2}(-10.8 \%$ o $)$ is more positive than typical for $\mathrm{CO}_{2}$ derived from natural infiltration from the soil zone. However, the $\delta^{13} \mathrm{C}_{\mathrm{DIC}}$ values for the Hering well were isotopically heavier prior to the start of $\mathrm{CO}_{2}$ injection and remained relatively constant throughout the project period. In contrast, the oxygen and deuterium values of the groundwater from the Hering well were isotopically lighter (more negative) than the groundwater collected from the other wells at the Tanquary site. 


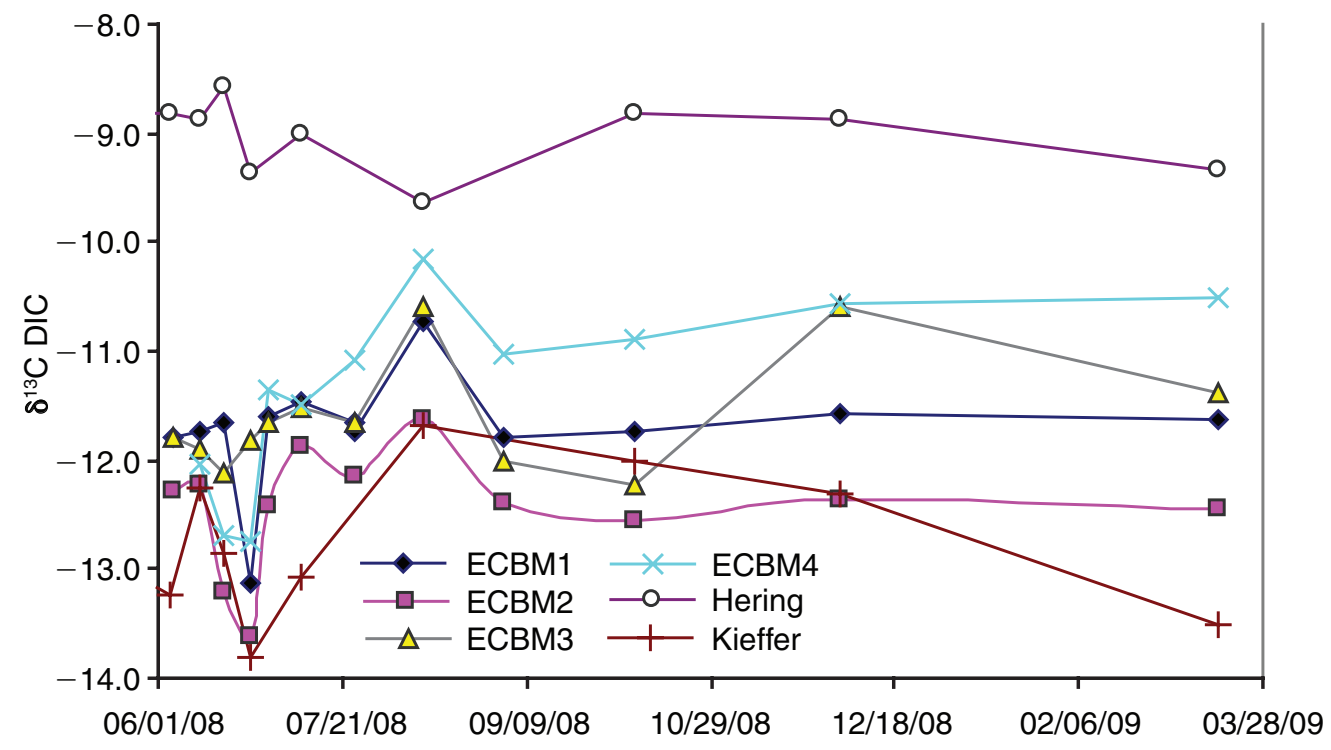

Figure 94. The $\delta^{13} \mathrm{C}$ values for dissolved organic carbon (DIC) in samples of shallow groundwater from monitoring and residential wells at the Tanquary site.

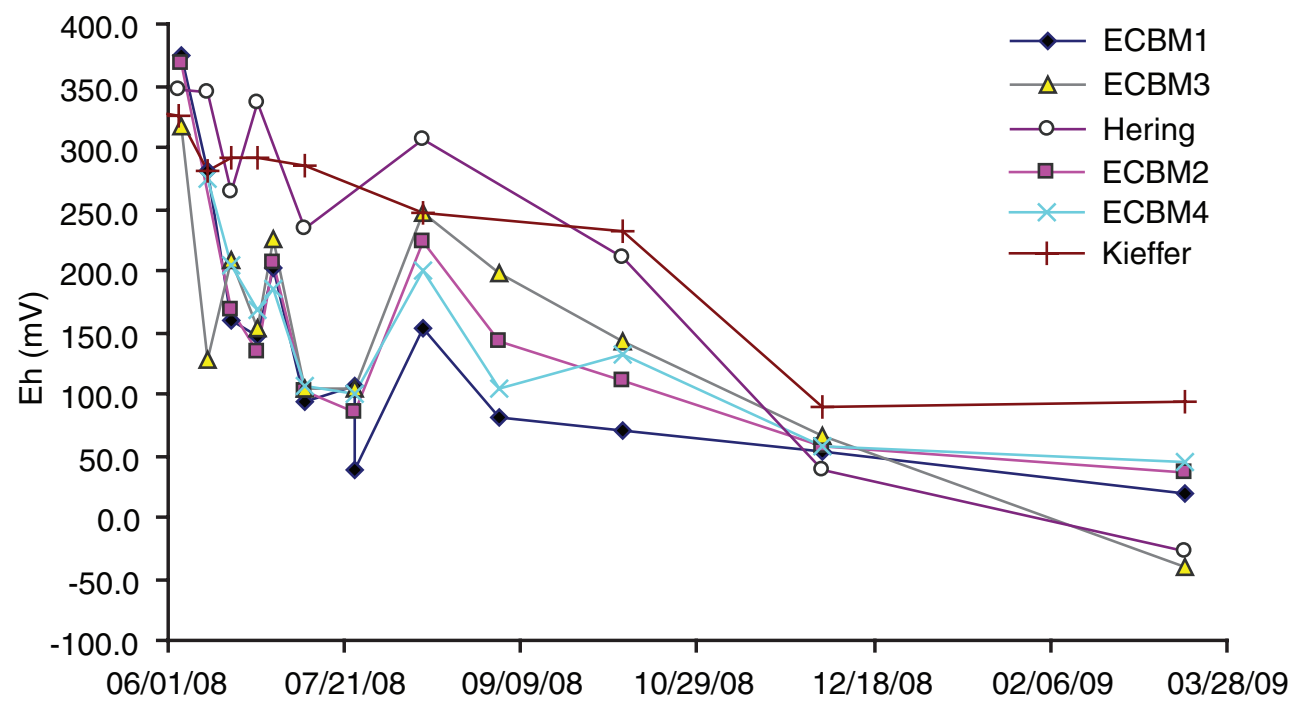

Figure 95. Redox potential (Eh) of groundwater samples collected from monitoring and residential wells at the Tanquary site.

The $\delta^{13} \mathrm{C}$ values for the DIC in the groundwater from the monitoring wells and the Kieffer residential well decreased to more negative values in the latter part of June and then increased until August 12, after which the $\delta^{13} \mathrm{C}$ returned to the initial values observed in early June (Appendix 18, Figure 94). The decrease in $\delta^{13} \mathrm{C}_{\text {DIC }}$ suggested an input of $\mathrm{CO}_{2}$ with a relatively negative isotopic composition, which could be caused by oxidation of organic carbon in the aquifer. Liu and Coleman (1981), Liu et al. (1986), and Hackley (2002) report that most buried and/or dissolved organic carbon has a $\delta^{13} \mathrm{C}$ value of approximately $-25 \%$. The possibility of initial oxidation agrees with data for the monitoring wells that showed that both the Eh and dissolved oxygen (DO) were initially elevated and then decreased with time (Figures 95 and 96). It is presumed that oxygen was introduced to the monitoring wells either through the initial drilling or the well development procedures. The fact that the Eh and DO values in the residential wells behaved in the same way even though they draw from different aquifers is puzzling. This behavior might have been caused by chemical treatment of the wells, but there is no other evidence of chemical treatment at the two residential wells. 


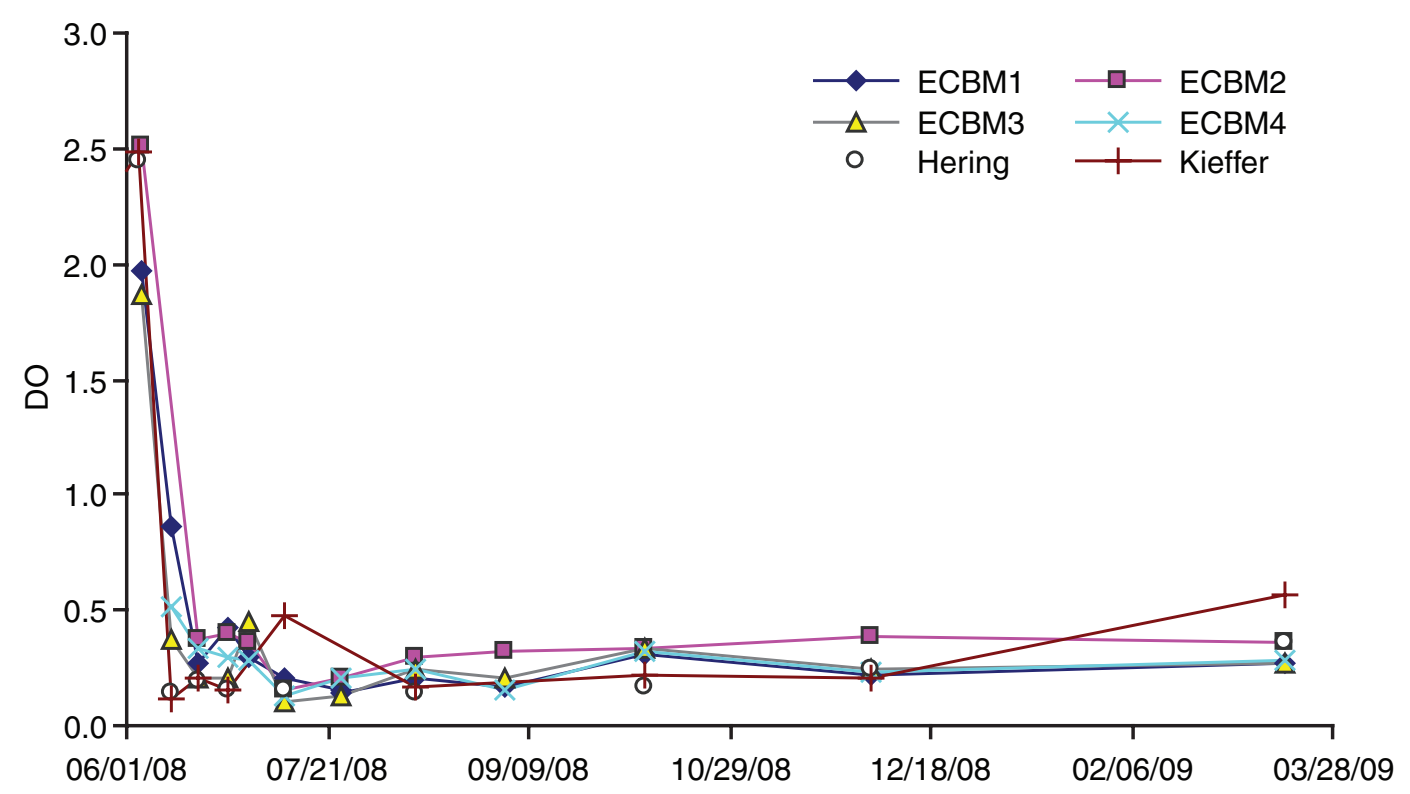

Figure 96. Dissolved oxygen (DO) concentrations in groundwater samples collected from monitoring and residential wells at the Tanquary site.

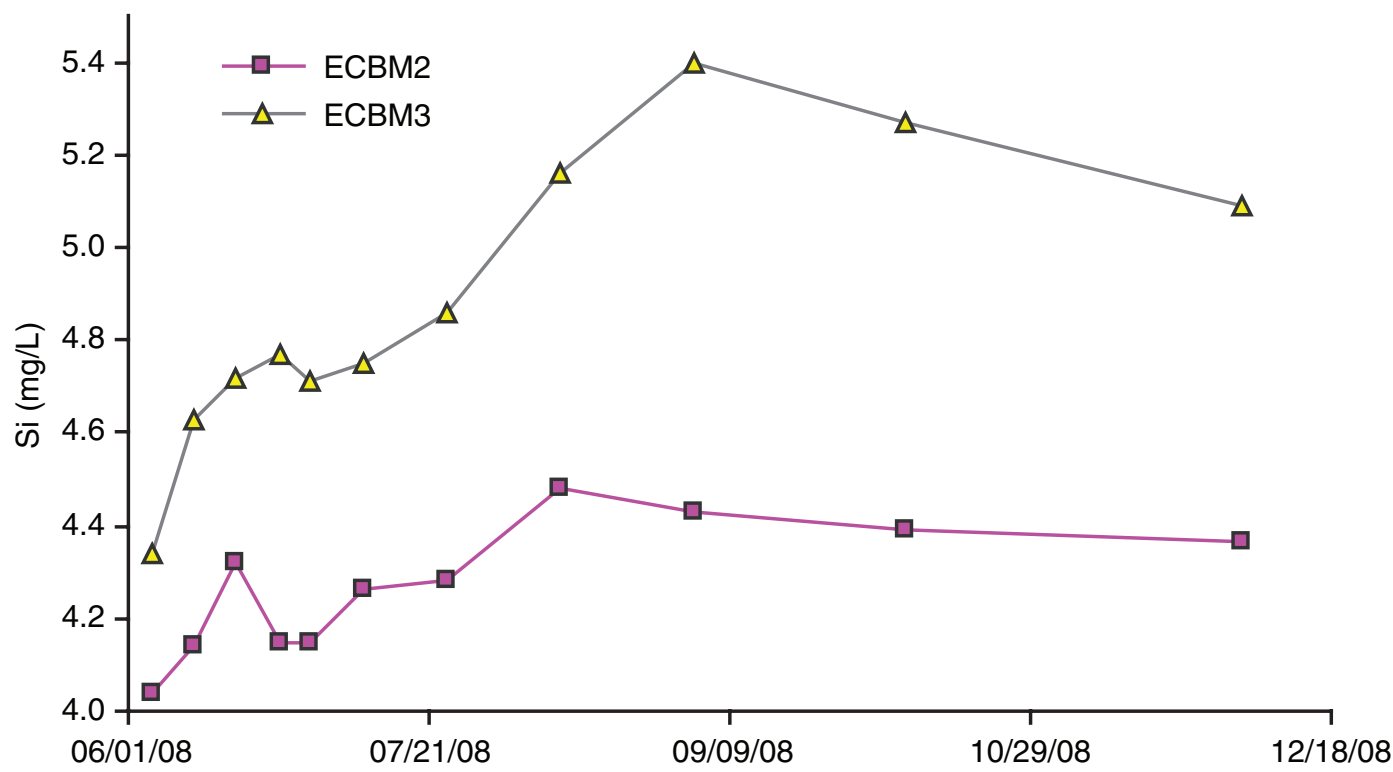

Figure 97. Silica (Si) concentrations in groundwater from two of the monitoring wells at the Tanquary site.

The initial decrease to more negative $\delta^{13} \mathrm{C}$ values followed by more positive values (Appendix 18, Figure 94) was probably associated with the initial oxidation of organic carbon to $\mathrm{CO}_{2}$ by the oxygen introduced by the drilling and well development procedures, which introduced $\mathrm{CO}_{2}$ with more isotopically negative $\delta^{13} \mathrm{C}$ values into the inorganic carbon pool of the monitoring wells. The added $\mathrm{CO}_{2}$ also would increase the carbonic acid and bicarbonate contents and decrease the $\mathrm{pH}$ of the water, which would begin to dissolve available carbonates in the system and increase the alkalinity of the water (Figure 45). The increase in carbonate and bicarbonate could have been caused by infiltration of the injected $\mathrm{CO}_{2}$ into the aquifer However, the increase in alkalinity occurred prior to the start of $\mathrm{CO}_{2}$ injection, and the isotopic composition of the DIC would have continuously become more isotopically positive, resulting in less negative $\delta^{13} \mathrm{C}$ values. After the initial oxidation of organic carbon, carbonate dissolution probably occurred and released isotopically more positive (heavier) $\delta^{13} \mathrm{C}$, 


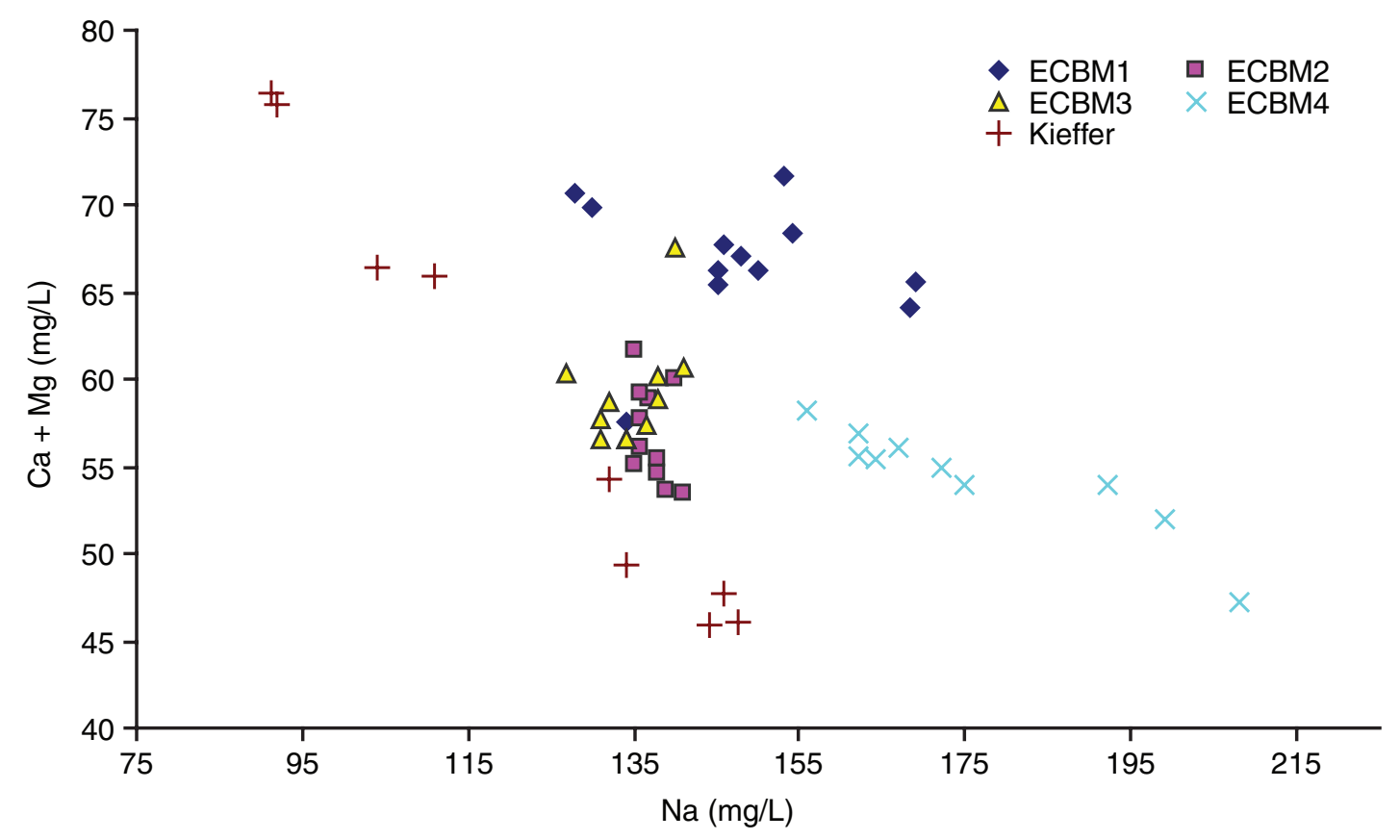

Figure 98. Calcium $\left(\mathrm{Ca}^{2+}\right)$ plus magnesium $\left(\mathrm{Mg}^{2+}\right)$ and sodium $\left(\mathrm{Na}^{+}\right)$concentrations in groundwater from the monitoring wells and one of the residential wells at the Tanquary site.

which caused the $\delta^{13} \mathrm{C}$ of the DIC to become more positive (Figure 94). The $\delta^{13} \mathrm{C}$ of DIC stabilized as the system equilibrated. In addition to carbonate dissolution, there could also have been silicate mineral dissolution due to the increased carbonic acid that would have initially occurred. Dissolution of silicate minerals would tend to increase the Si in solution, which was observed in wells ECBM2 and ECBM3 (Figure 97). The carbonate and silicate dissolution reactions also would release cations such as $\mathrm{Ca}^{2+}$ and probably $\mathrm{Mg}^{2+}$, which would promote cation exchange reactions and increase $\mathrm{Na}^{+}$concentration. A negative relationship was observed between $\mathrm{Ca}^{2+}$ plus $\mathrm{Mg}^{2+}$ and $\mathrm{Na}^{+}$ions for most of the shallow groundwater wells (Figure 98); that is, as the $\mathrm{Na}^{+}$concentration in the water increased, the concentration of $\mathrm{Ca}^{2+}$ plus $\mathrm{Mg}^{2+}$ decreased. Sodium could also be released due to silicate dissolution reactions.

Groundwater from the Hering well originates in a deeper aquifer (total well depth $50.3 \mathrm{~m}$ [165 ft]) than the monitoring and residential wells (total depth $28.4 \mathrm{~m}$ [93 ft]). The inorganic water quality from the Hering well samples also indicated that the groundwater had undergone a different geochemical evolution than the other groundwater sampled in the area.

The headspace gas from the Hering well contained a significant amount of $\mathrm{CH}_{4}(49.7 \%$ by volume), probably associated with microbial $\mathrm{CO}_{2}$ reduction, which has been documented in groundwater wells screened in Paleozoic rocks in Wabash County (Coleman et al., 1982). Past microbial activity in the aquifer also would help explain the greater concentration of DIC and the more positive $\delta^{13} \mathrm{C}_{\text {DIC }}$ composition observed in the Hering well (Grossman et al., 1989; Aravena et al., 1995; Hackley et al., 1999, 2010). The groundwater sampled from the Hering well, coming as it does from a different aquifer, may possibly have had greater contact with carbonate rocks, which would also result in more positive $\delta^{13} \mathrm{C}_{\mathrm{DIC}}$ values.

Thus, most of the isotopic and chemical variation observed in the shallow groundwater wells appears to be associated with initial oxidation and, especially in ECBM1 and ECBM4, the drilling fluids and additives used in well construction and development, particularly the sodium bentonite drilling mud and the sodium carbonate used to adjust the $\mathrm{pH}$ of the drilling mud. These two effects influenced the redox state and geochemistry of the aquifer systems near the wells, disrupting the equilibrium and causing much of the variability observed in the groundwater chemistry and isotopic composition of the DIC.

Mineral Equilibria of Samples from Groundwater Monitoring Wells. The U.S. Geological Survey's PHREEQC geochemical modeling program (Parkhurst and Appelo, 1999) was used to analyze the geochemical data. The geochemical modeling showed that the groundwater samples were relatively dilute solutions, having an ionic strength of about 0.01 . Groundwater samples collected downgradient from well ECBM3 appeared to be in equilibrium with quartz $\left(\mathrm{SiO}_{2}\right)$ and $\mathrm{calcite}\left(\mathrm{CaCO}_{3}\right)$ (Figure 48). Both minerals are common in the unconsolidated glacial drift. All of the well samples were undersaturated with respect to gypsum $\left(\mathrm{CaSO}_{4} \cdot 2 \mathrm{H}_{2} \mathrm{O}\right)$. Therefore, it is unlikely that gypsum is present in the glacial drift near the monitoring wells. 
The saturation index of the samples with respect to siderite $\left(\mathrm{FeCO}_{3}\right)$ fluctuated during the early phase of $\mathrm{CO}_{2}$ injection, which could have been linked to $\mathrm{CO}_{2}$ injection because siderite is a carbonate mineral. However, the upgradient well (ECBM1) displayed changes in the saturation index with respect to siderite (Figure 48) that perfectly paralleled the changes in the downgradient well. Therefore, these fluctuations probably were caused by natural variations unrelated to $\mathrm{CO}_{2}$ injection.

Plotting the saturation indexes for the same four minerals in the upgradient well (ECBM1) in a scatter diagram against the indexes in the downgradient well indicated that the mineral equilibrium relationships had not been impacted by $\mathrm{CO}_{2}$ leakage during the entire 497-day sampling period (Figure 99). For example, samples collected both upgradient and downgradient from the $\mathrm{CO}_{2}$ injection well were all nearly in equilibrium with calcite. Table 12 provides examples of the saturation indices for other common minerals.

In each case, a saturation index near zero indicates that the water sample was in equilibrium with that solid phase. A negative index indicates that the solution was undersaturated with respect to that mineral and suggests that the mineral is probably not present in the surrounding materials, like halite, or, that if it is present, it is thermodynamically poised to dissolve. A positive index indicates that the mineral is thermodynamically poised to precipitate from solution. When the four wells were compared, there was no indication that $\mathrm{CO}_{2}$ had migrated from the coal seam. For example, an influx of $\mathrm{CO}_{2}$ would have increased the concentration of $\mathrm{HCO}_{3}{ }^{-}$which would have caused rhodochrosite to be oversaturated and precipitate:

$$
\begin{gathered}
\mathrm{CO}_{2}+\mathrm{H}_{2} \mathrm{O}=\mathrm{HCO}_{3}^{-}+\mathrm{H}^{+} \\
\mathrm{Mn}^{2+}+\mathrm{HCO}_{3}^{-}=\mathrm{MnCO}_{3} \downarrow
\end{gathered}
$$

However, the saturation index for rhodochrosite remained negative.

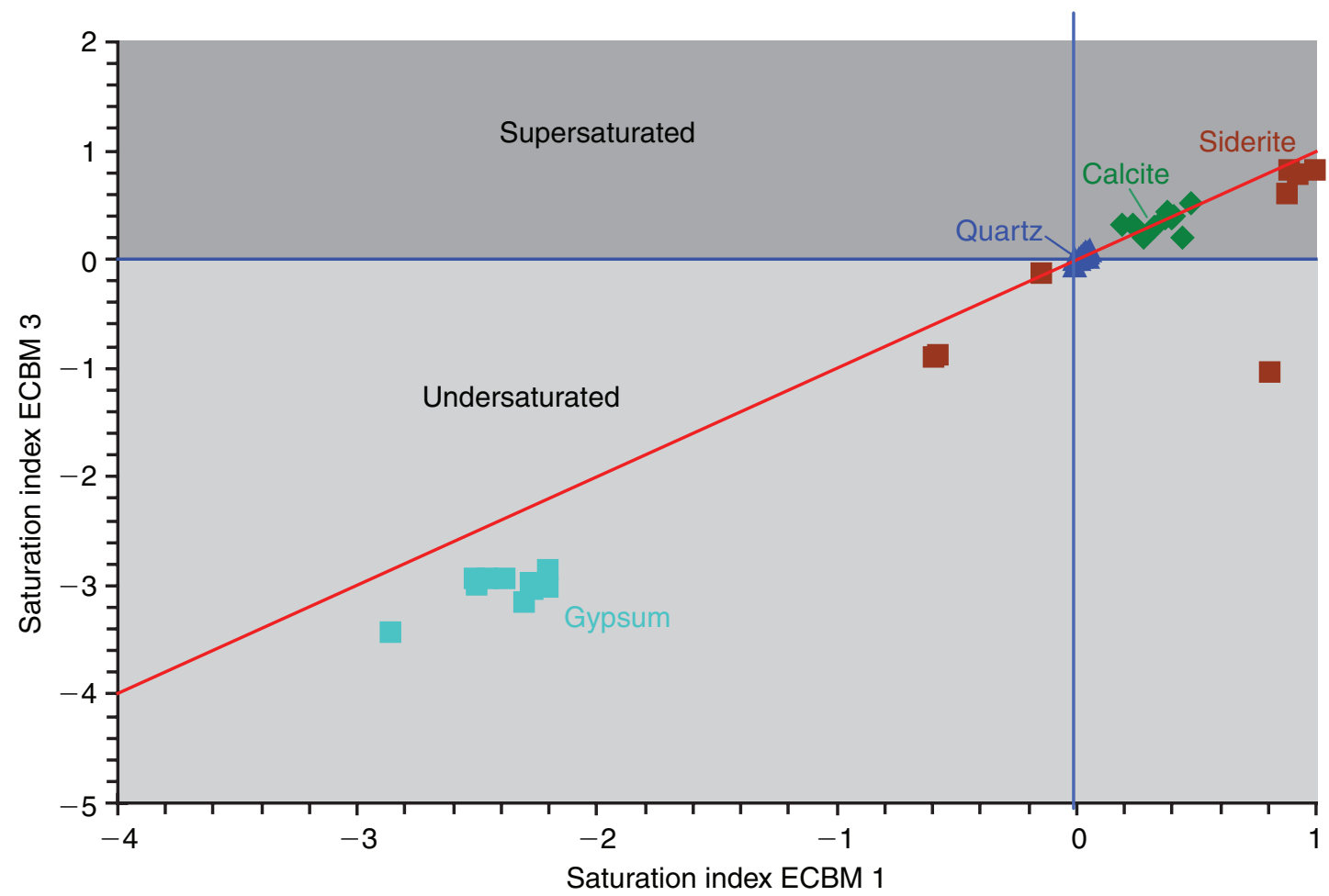

Figure 99. Saturation indices for selected minerals for samples collected from well ECBM1 (upgradient) compared with ECBM3 (downgradient). The red line is a unit slope. 


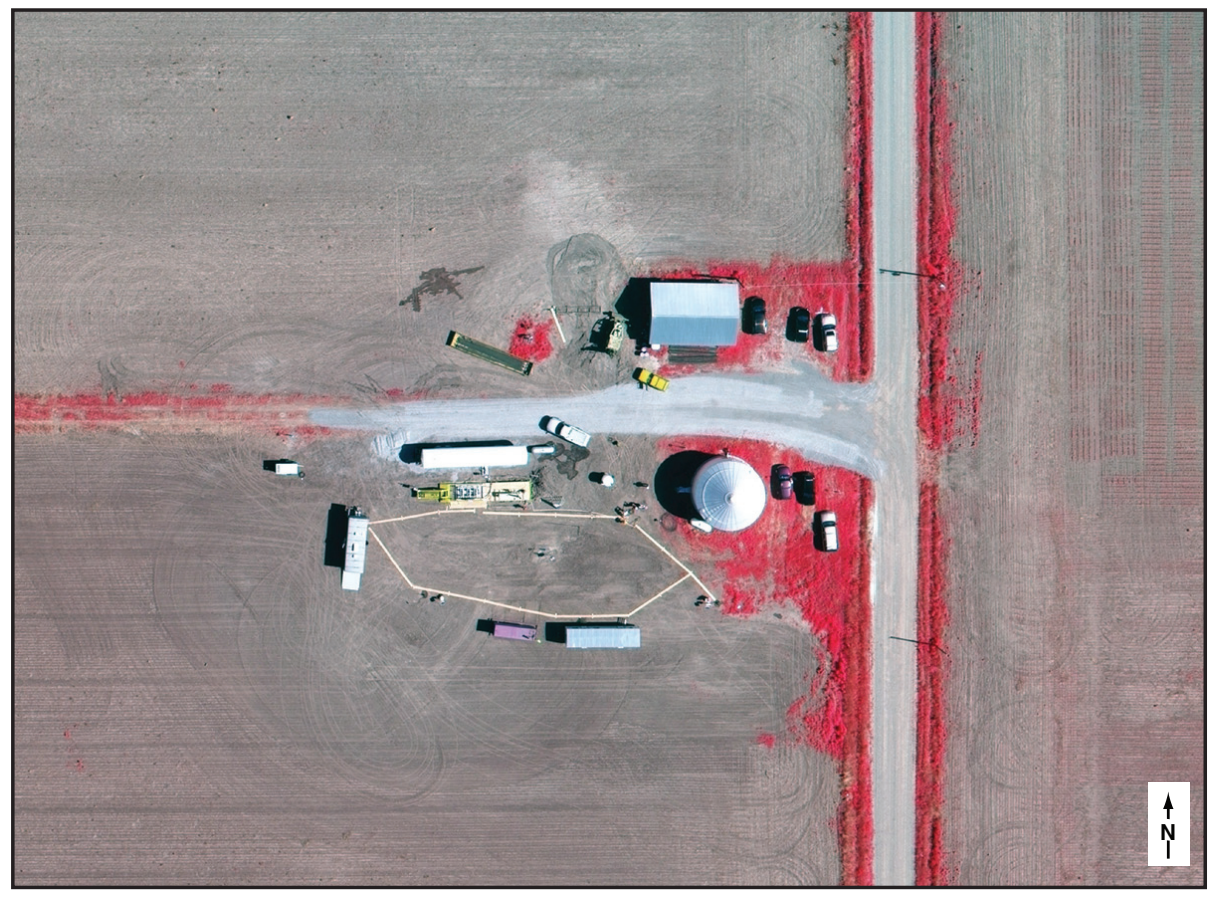

Figure 100. Color near-infrared (CIR) digital aerial orthophotograph taken June 23, 2008. The site as it appeared in full development and operation. The soybean crop has not yet been planted.

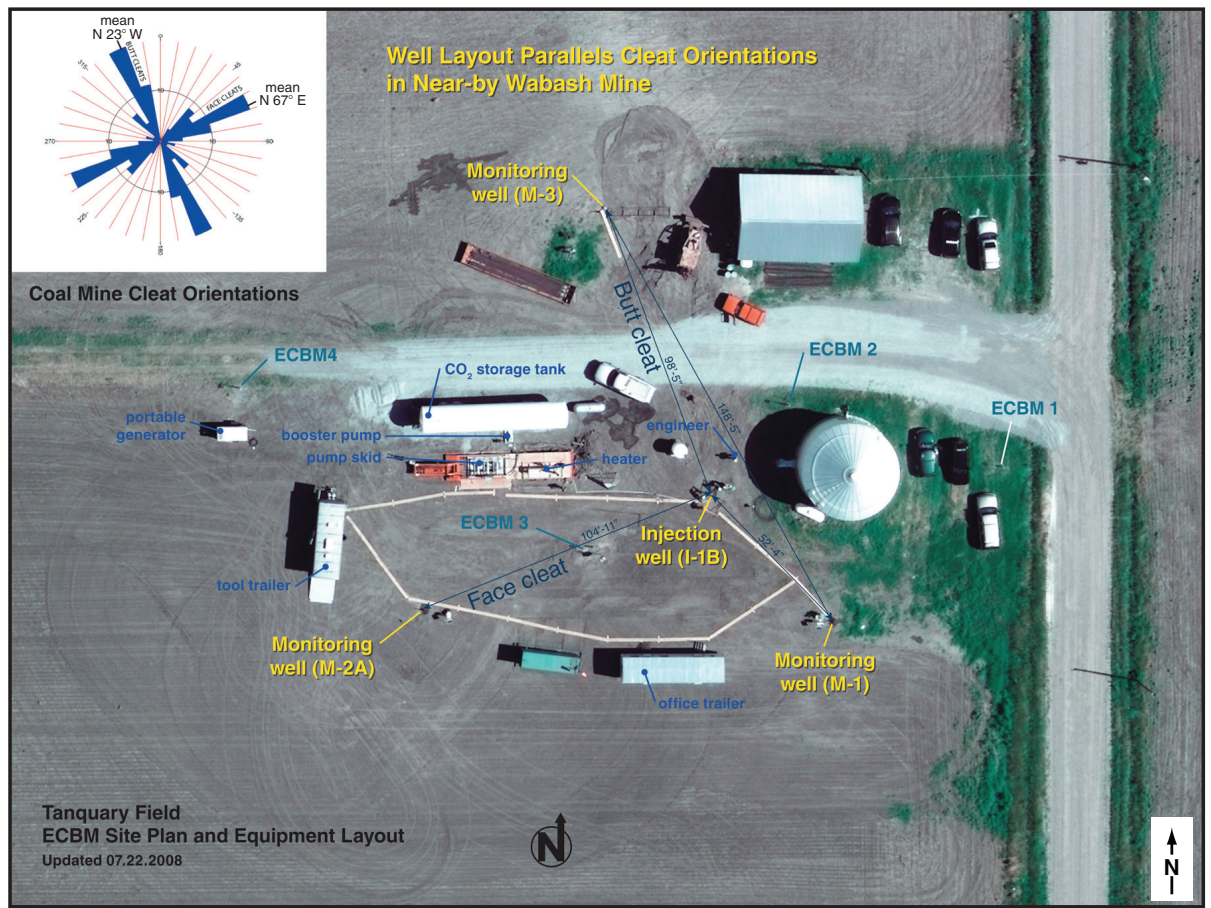

Figure 101. Color near-infrared (CIR) digital aerial orthophotograph taken June 23 , 2008. Detailed site plan and equipment layout. The CIR image shown in Figure 100 has been converted to natural color for this application. 
Mineral Equilibria of Samples from Residential Wells. The groundwater monitoring samples collected at the residential wells also were geochemically modeled. Like the groundwater samples from the ECBM wells, the residential well samples were relatively dilute, having an ionic strength of about 0.015 . The chemical equilibria of well samples collected at day -21 (Negative sign designates days before injection started) were compared with day 105 for the Kieffer well and day 295 for the Hering well (Figure 49). (Different sample dates were used because of the data available.) Similar to the samples from the ECBM groundwater monitoring wells, the residential well samples were in equilibrium with quartz and calcite before the onset of $\mathrm{CO}_{2}$ injection and for months afterward. The residential wells were undersaturated with respect to various carbonate phases such as strontianite $\left(\mathrm{SrCO}_{3}\right)$, smithsonite $\left(\mathrm{ZnCO}_{3}\right)$, and witherite $\left(\mathrm{BaCO}_{3}\right)$ before and after the onset of injection. Like the ECBM groundwater monitoring well samples, the geochemical modeling results from the residential wells provided no indication that $\mathrm{CO}_{2}$ migrated from the coal seam offsite into the unlithified aquifer materials at the two residences. (If $\mathrm{CO}_{2}$ had leaked into the groundwater at the residential wells, the 105-day Kieffer sample and the 295-day Hering sample saturation index would have plotted above the unit slope on Figure 49.)

CIR Imagery. Aerial flyovers of the Tanquary site were conducted twice each year, during the early summer and early fall, to collect images began before the drilling of the injection well and other development work at the site. Flyovers continued after the site was cleared in order to capture any changes that occurred in the two principal crop stages.

The CIR digital aerial orthophotography shown in Figures 100 through 105 documents the activity at the Tanquary site from June 2008 through October 2009. The project site was surrounded by agricultural row-crop fields and the crop rotation during that 3-year period was corn-soybeans-corn, which is the reason for the changing color and texture of the dominant vegetation in these images and the 2007 images in Figures 50 and 51. Figure 101 is distinctive in that it represents the Tanquary site at its maximum development, and this June 23, 2008, aerial image was used as the basis for a detailed annotated illustration of the project site at the height of pilot activity. Figures 101 and 104 are also distinctive in that they represent natural color renditions produced directly from the CIR aerial photography. These types of images were deemed more desirable for the purposes of general mapping and illustrations. Figure 105 was produced from the last aerial flyover on October 2,2009 , after the corn crop had been harvested. It shows the project site as it appeared near its conclusion, after the injection equipment was relocated.

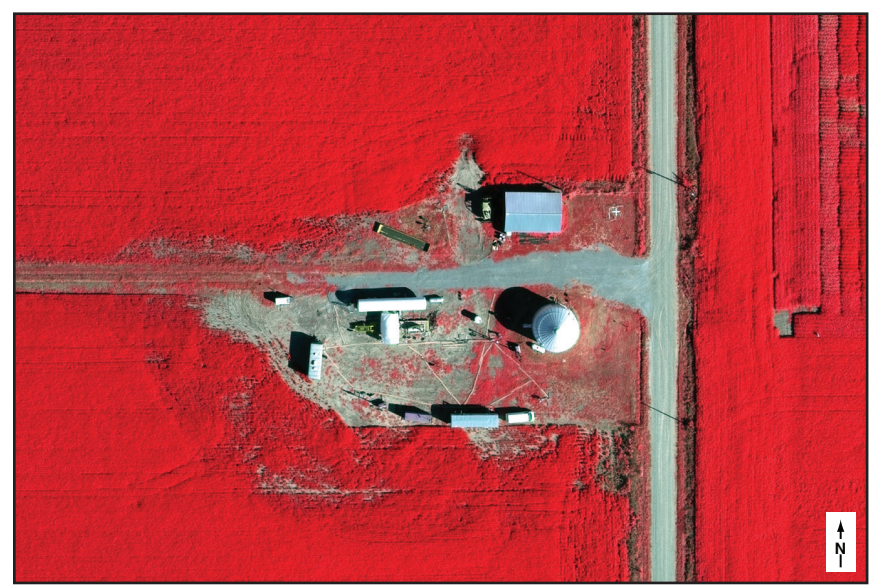

Figure 102. Color near-infrared (CIR) digital aerial orthophotograph taken September 10, 2008. Mature soybean fields surround the site prior to harvesting. The vivid magenta color of the soybeans is indicative of green, healthy plants. The dark magenta color of the plants immediately adjacent to the injection site is indicative of damaged and stressed crops due to impacts of machinery and other factors, not contamination by $\mathrm{CO}_{2}$.

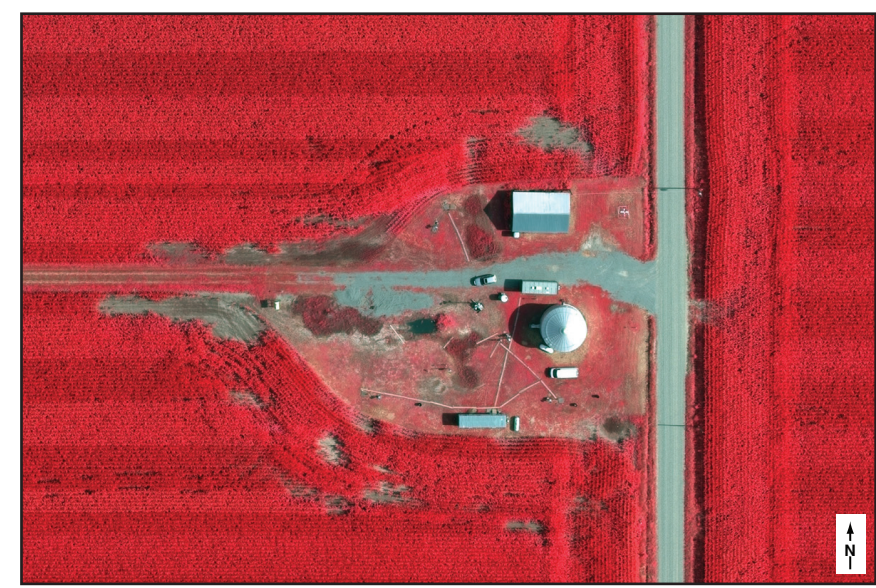

Figure 103. Color near-infrared (CIR) digital aerial orthophotograph taken June 27, 2009. The image shows the site as it appears in early summer surrounded by healthy corn fields. The distinctive bands in the corn are due to the differing cell structures of two separate corn hybrids planted in alternating rows. Although the corn leaves appear to be the same green color in the visible portion of the electromagnetic spectrum, the near-infrared reflected energy passes into the cell structure of the leaves and is re-reflected back to the DMC sensor in direct relationship to the nature and character of the differing cell structure. This image is a good demonstration of the sensitivity of CIR imagery and the value of plants as an excellent surrogate for monitoring stress. 


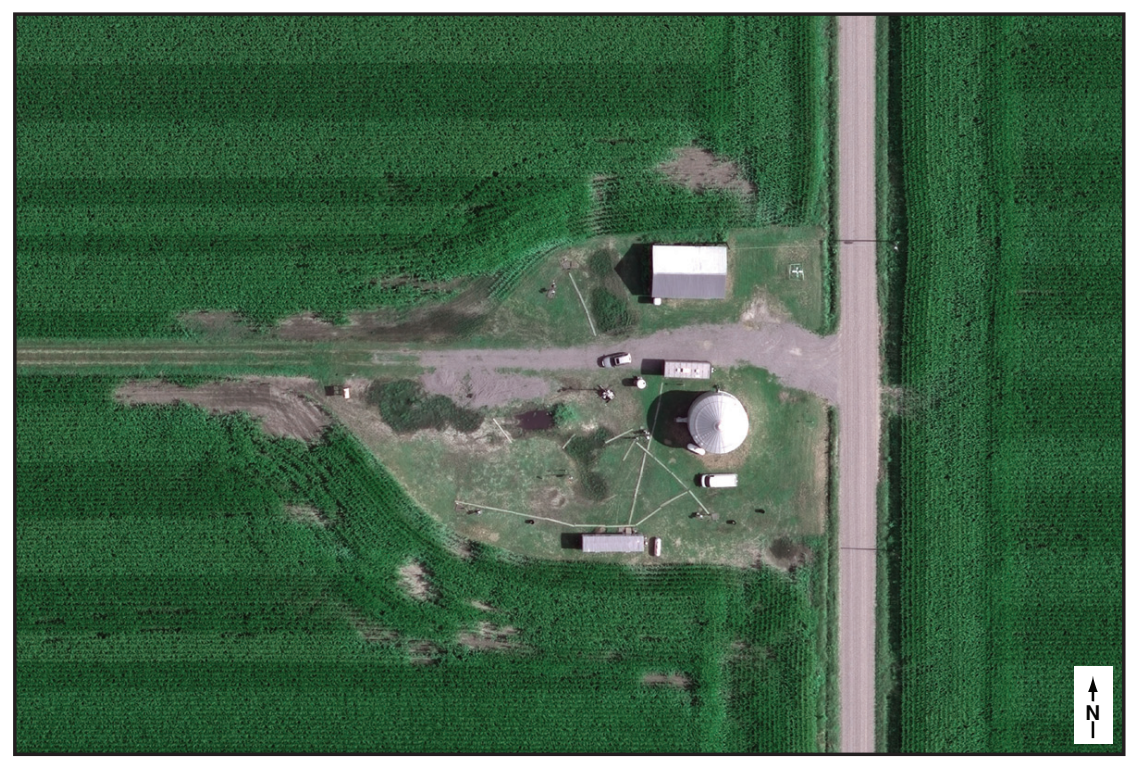

Figure 104. Color near-infrared (CIR) digital aerial orthophotograph taken June 27, 2009. Natural color rendition of the same image as in Figure 103 produced directly from the original near-infrared imagery. Although this type of natural color conversion is accepted for general purpose applications, comparison with Figure 103 shows that the subtle color variations inherent in the nearinfrared imagery, which are important for MVA interpretation, have been muted.

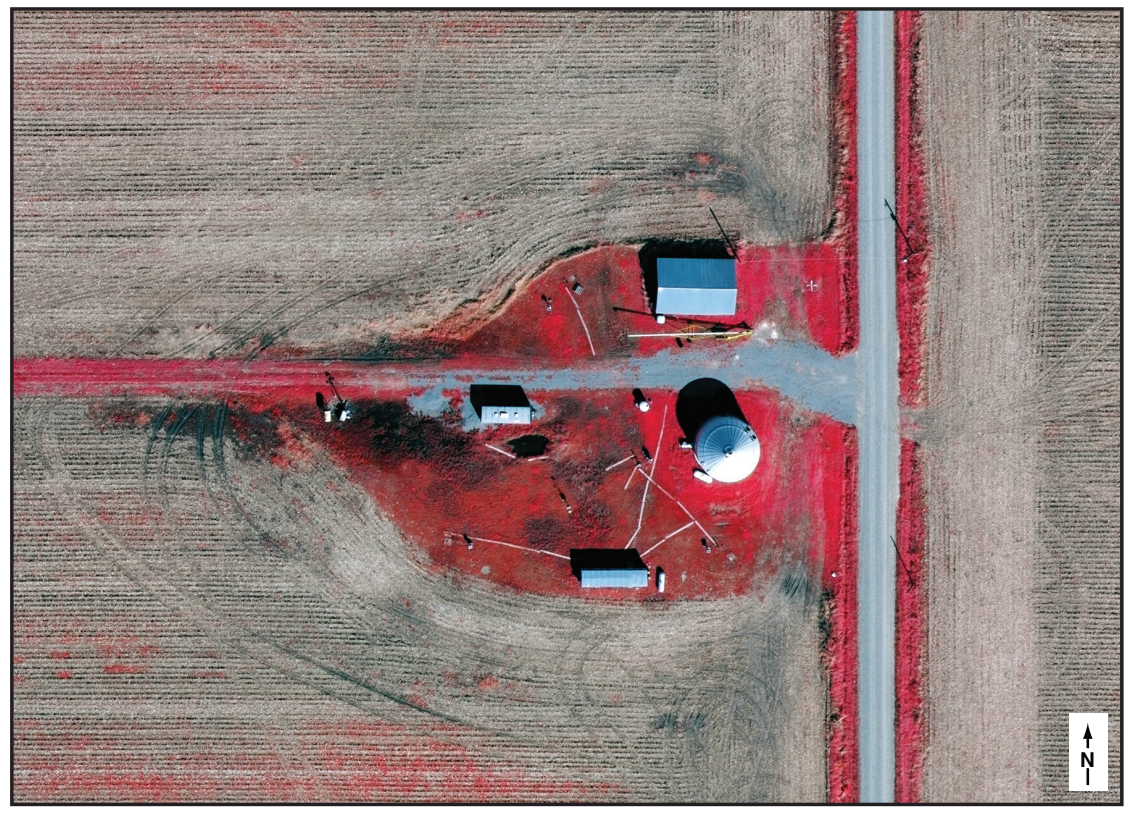

Figure 105. Color near-infrared (CIR) digital aerial orthophotograph taken October 2, 2009. The project site is shown as it appeared near the end of the three-year Mitigation, Validation, and Accounting effort. The corn crop that surrounded the site has been harvested. 
In the application of CIR photography for monitoring leaks of injected $\mathrm{CO}_{2}$ at and near the injection site, the vegetation serves as a surrogate indicator of the stressor. Prolonged exposure to elevated levels of $\mathrm{CO}_{2}$ in either the soil root zone or the atmosphere in close proximity to the plants would eventually result in a physical change in the cell structure of the plants that, in theory, should be reflected by a noticeable pattern in the CIR imagery. No such patterns were discerned during the entire 3 years of monitoring other than the normal phenological changes that occur during each crop stage. The absence of such patterns in the CIR imagery supports the findings of the groundwater modeling and the chemical and isotopic compositional data from the shallow groundwater in the near vicinity of the project site. Based on the monitoring technologies deployed at the site, leakage of $\mathrm{CO}_{2}$ from the coal seam injection zone did not occur.

\section{Interpretation, Analyses, and Modeling of Pilot Results}

Ultimately the purpose of the pilot was to design a $\mathrm{CO}_{2}$ injection test to measure and record data that could be used in analyses and models to estimate $\mathrm{CO}_{2}$ storage and ECBM without $\mathrm{CO}_{2}$ leaving the coal seam. Because of the short duration and budget of the pilot, the wells needed to be close together and consequently could not be produced without adversely moving $\mathrm{CO}_{2}$ to the monitoring wells too quickly. Numerical modeling provides a means of calibrating a model to the observed data to make simulations of larger-scale injection in a larger pattern. The following scenarios are considered:

Case 1: Produce the three coal seam monitoring wells under actual injection scenario.

Case 2: Inject/produce with an inverted five-spot pattern on 1 ha (2.5 acres).

Case 3: Inject/produce with a line drive pattern with wells aligned with the cleat orientation.

\section{Case 1: Producing Coal Seam Monitoring Wells}

For this first case, the three existing monitoring wells were converted to producers during the actual $\mathrm{CO}_{2}$ injection scenario (92.3 tonnes [101.7 tons] injected over a 7-month period), producing at 70 Pag (10 psig) bottomhole flowing pressure for a year. To evaluate the eventual incremental ECBM gas production, a non-injection or coalbed methane (CBM) case had to be run for comparison. Figure 106 shows the $\mathrm{CH}_{4}$ and $\mathrm{CO}_{2}$ production at each of the monitoring wells for the injection case $\left(\mathrm{CH}_{4}\right.$ rate in red, $\mathrm{CO}_{2}$ in purple) and the non-injection case $\left(\mathrm{CH}_{4}\right.$ rate in orange). At $\mathrm{M}-1$, a cumulative $8,880 \mathrm{scm}(314,600$ scf) of $\mathrm{CH}_{4}$ is produced while $\mathrm{CO}_{2}$ is being injected (versus $8,790 \mathrm{scm}$ [310,400 scf] with no injection) with an associated $286.2 \mathrm{~m}^{3}(1,800 \mathrm{bbls})$ of water and 4,080 scm (144,100 scf) of $\mathrm{CO}_{2}$ produced. At M-2, aligned with the face cleat orientation, a cumulative 10,470 scm $\left(369,700 \mathrm{scf}\right.$ ) of $\mathrm{CH}_{4}$ is produced while $\mathrm{CO}_{2}$ is injected (versus 11,720 scm/day [413,900 scf/day] with no injection) with an associated $197.5 \mathrm{~m}^{3}$ (1,242 bbls) of water and 13,900 scm (490,900 scf) of $\mathrm{CO}_{2}$ produced. Finally, at M-3, in the butt cleat orientation and farther away, a cumulative $8,930 \mathrm{scm}(315,400 \mathrm{scf})$ of $\mathrm{CH}_{4}$ is produced while $\mathrm{CO}_{2}$ is injected (versus $8,920 \mathrm{scm} /$ day [315,000 scf/day] with no injection) with an associated $350.0 \mathrm{~m}^{3}\left(2,200 \mathrm{bbls}\right.$ ) of water but no $\mathrm{CO}_{2}$ produced. Overall, when $\mathrm{CO}_{2}$ is being injected, less $\mathrm{CH}_{4}$ is produced than when there is no $\mathrm{CO}_{2}$ injection. Due to the proximity of the producers andthe injector, the area affected by increased pressure from the injection includes the producers, consequently desorbing less $\mathrm{CH}_{4}$. Converting the monitoring wells to producers does not seem to be a viable option for ECBM and $\mathrm{CO}_{2}$ sequestration.

\section{Case 2: Inverted Five-Spot}

For the inverted five-spot pattern, four producing wells were added to the model (two along the face cleat orientation and two along the butt cleat orientation) on a 1-ha (2.5-acre) spacing. In order to ease the injection of the $\mathrm{CO}_{2}$, the minimum grid block size was increased to $3.1 \times 3.1 \mathrm{~m}(10 \times 10 \mathrm{ft})$. A view of the model is shown in Figure 107. The model was run with an injection bottomhole pressure constraint of $5.34 \mathrm{MPag}(775 \mathrm{psig}$ ) (identical to the actual limit from the field) and a production well bottomhole pressure constraint of $70 \mathrm{Pag}(10 \mathrm{psig})$ for $3 \mathrm{yr}$. To assess the incremental gas production and $\mathrm{CO}_{2}$ sequestration, a comparative non-injection case was also run.

The injection profile at the site is shown on Figure 108a. Note that the peak injection rate of 2,000 scm/day $(70,000 \mathrm{scf} /$ day) is similar to those observed at the field (Appendix Figure 22-2) for a total volume of 850,000 scm (30 million scf) of $\mathrm{CO}_{2}$ injected. The decrease in injection rate is as expected due to the swelling of the coal. The response at the producers is shown on Figure 108b for the face cleat wells where a $\mathrm{CO}_{2}$ breakthrough is noticeable after about 3 months and on Figure $108 \mathrm{c}$ for the butt cleat wells with no $\mathrm{CO}_{2}$ breakthrough. No incremental $\mathrm{CH}_{4}$ is produced at the face cleat wells (which are actually producing less due to the rapid $\mathrm{CO}_{2}$ breakthrough), whereas an incremental 10,000 scm (400,000 scf) is produced at each butt cleat well over $3 \mathrm{yr}$. Overall, an additional 20,000 scm (700,000 scf) of $\mathrm{CH}_{4}$ was produced for a net volume (injected minus reproduced) of $570,000 \mathrm{scm}$ (20 million scf) of $\mathrm{CO}_{2}$ injected. 
a
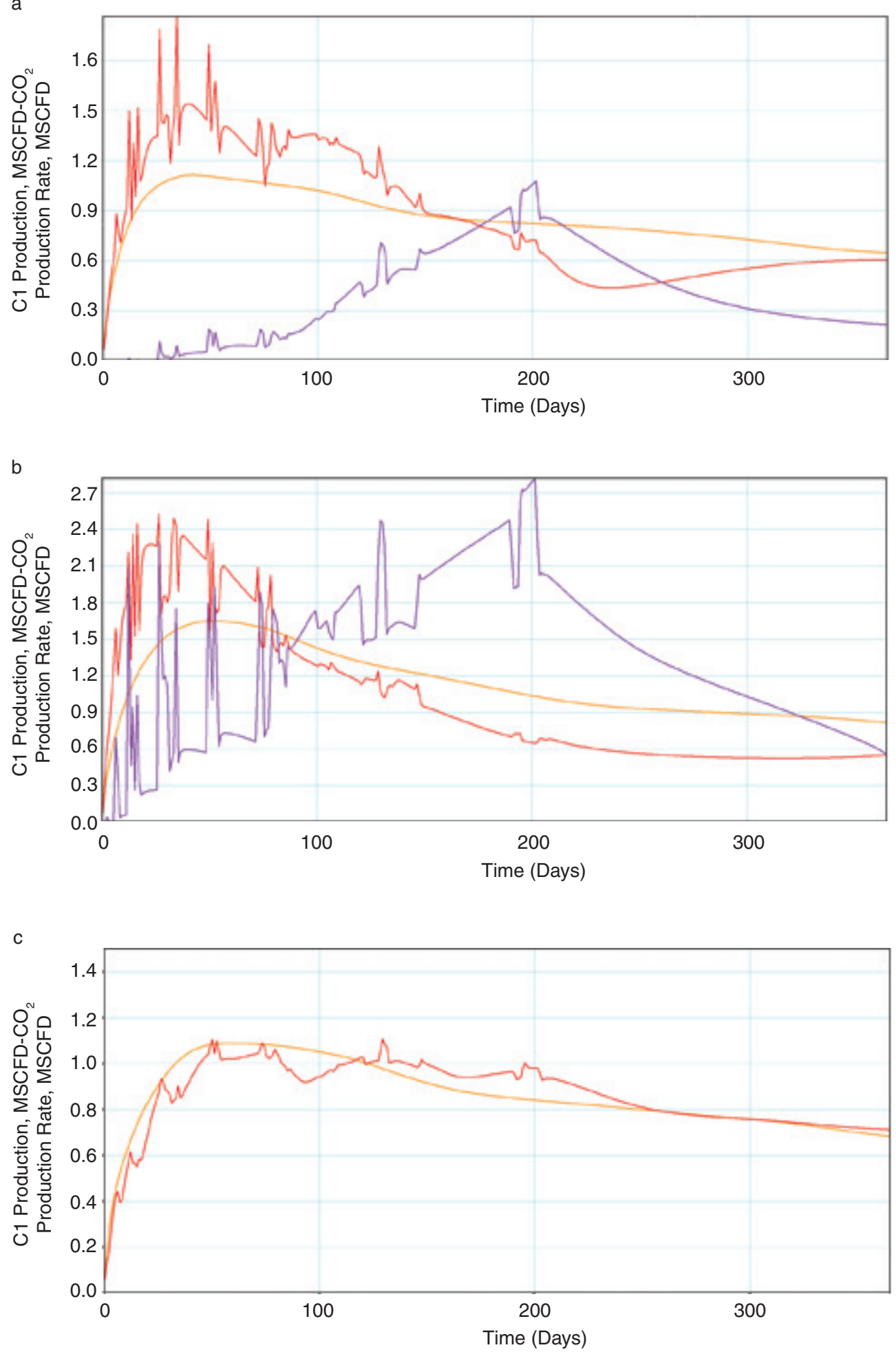

Figure 106. $\mathrm{CH}_{4}$ and $\mathrm{CO}_{2}$ production at each of the monitoring wells for the injection case $\left(\mathrm{CH}_{4}\right.$ rate in red, $\mathrm{CO}_{2}$ in purple) and the non-injection case $\left(\mathrm{CH}_{4}\right.$ rate in orange). (a) $\mathrm{M}-1$ $\mathrm{CBM}$ and $\mathrm{ECBM} \mathrm{CH} \mathrm{CH}_{4}$ and $\mathrm{CO}_{2}$ production. (b) $\mathrm{M}-2 \mathrm{CBM}$ and $\mathrm{ECBM} \mathrm{CH}_{4}$ and $\mathrm{CO}_{2}$ production. (c) $\mathrm{M}-3 \mathrm{CBM}$ and $\mathrm{ECBM} \mathrm{CH}_{4}$ and $\mathrm{CO}_{2}$ production. 

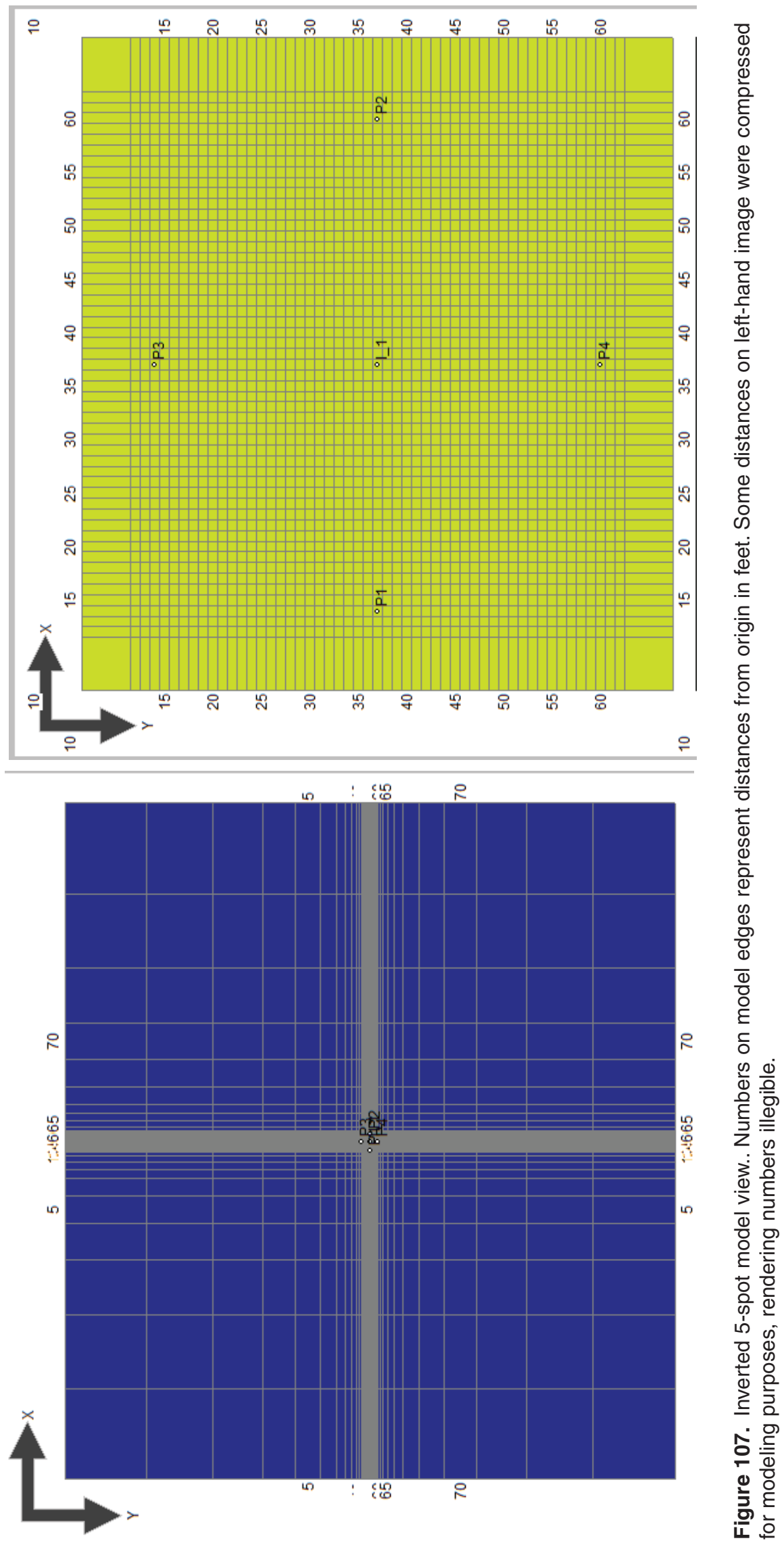
a

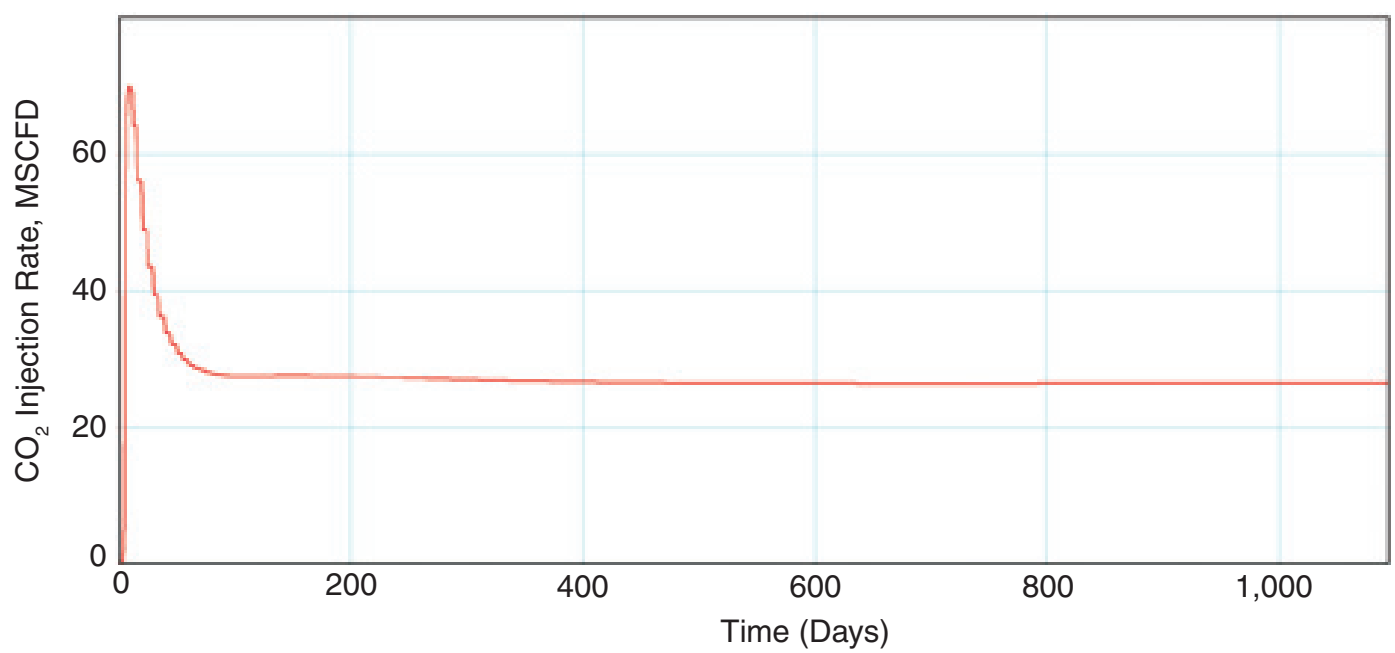

b

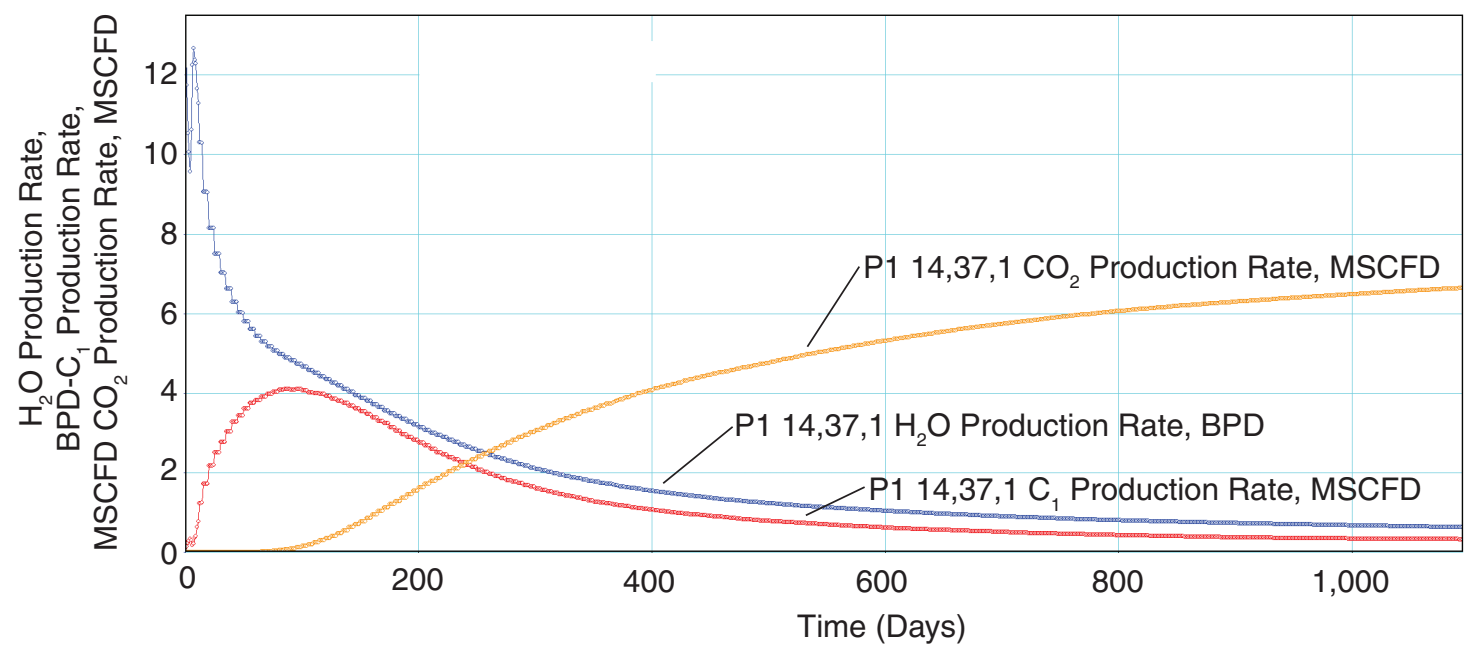

c

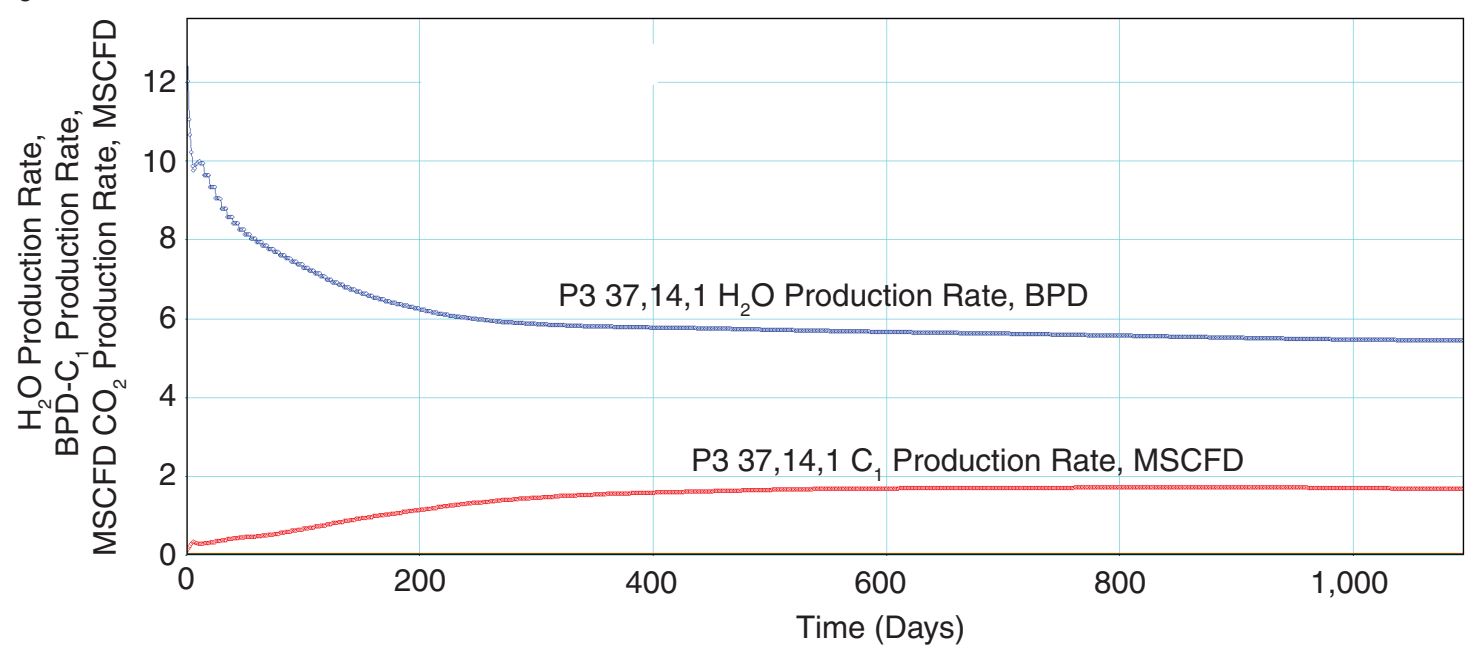

Figure 108. (a) Inverted 5-spot $\mathrm{CO}_{2}$ injection profile. (b) Inverted 5-spot face cleat well production profile. (c) Inverted 5-spot butt cleat well production profile (MSCFD-1,000 scf/d). 


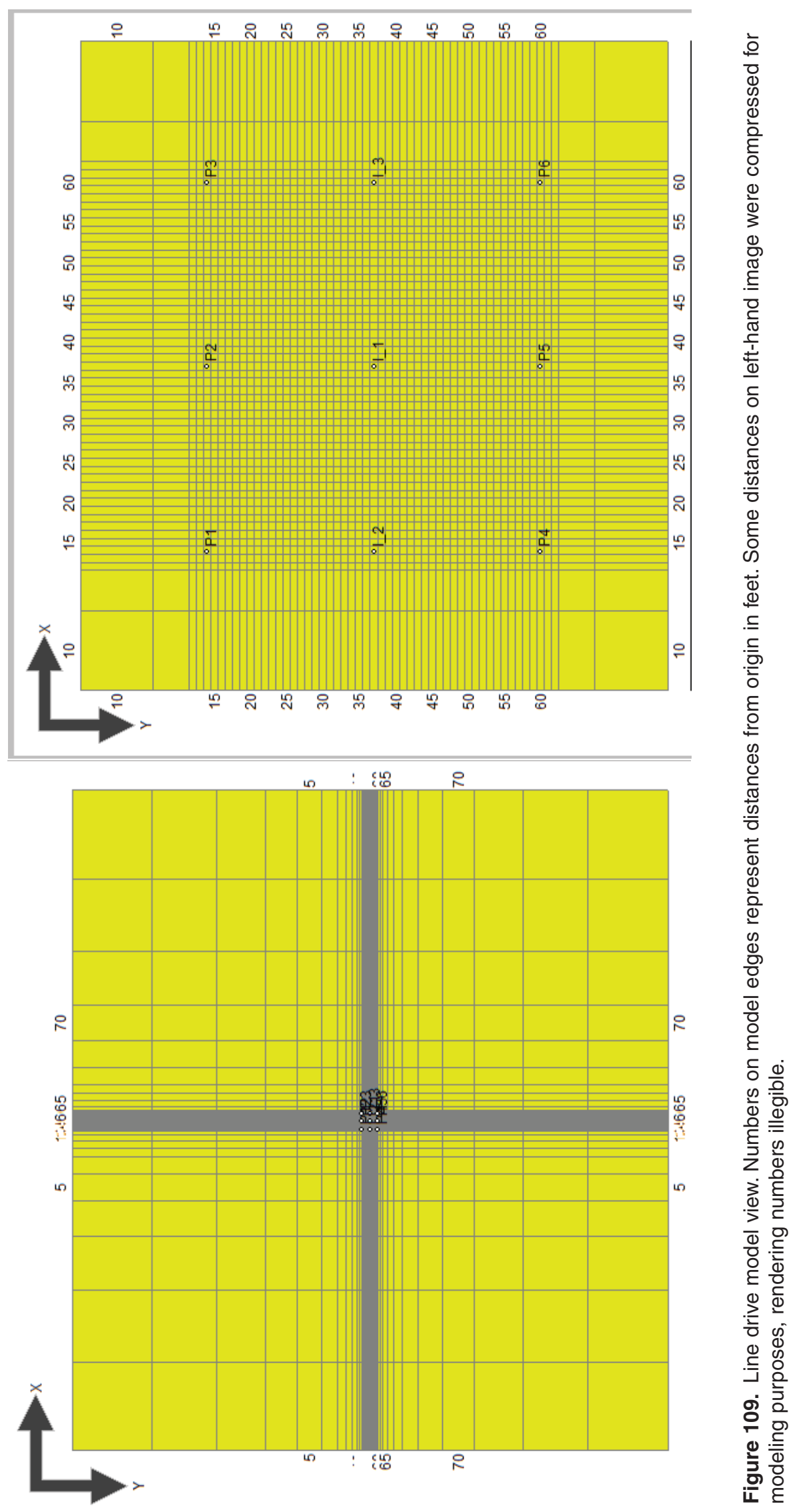


a
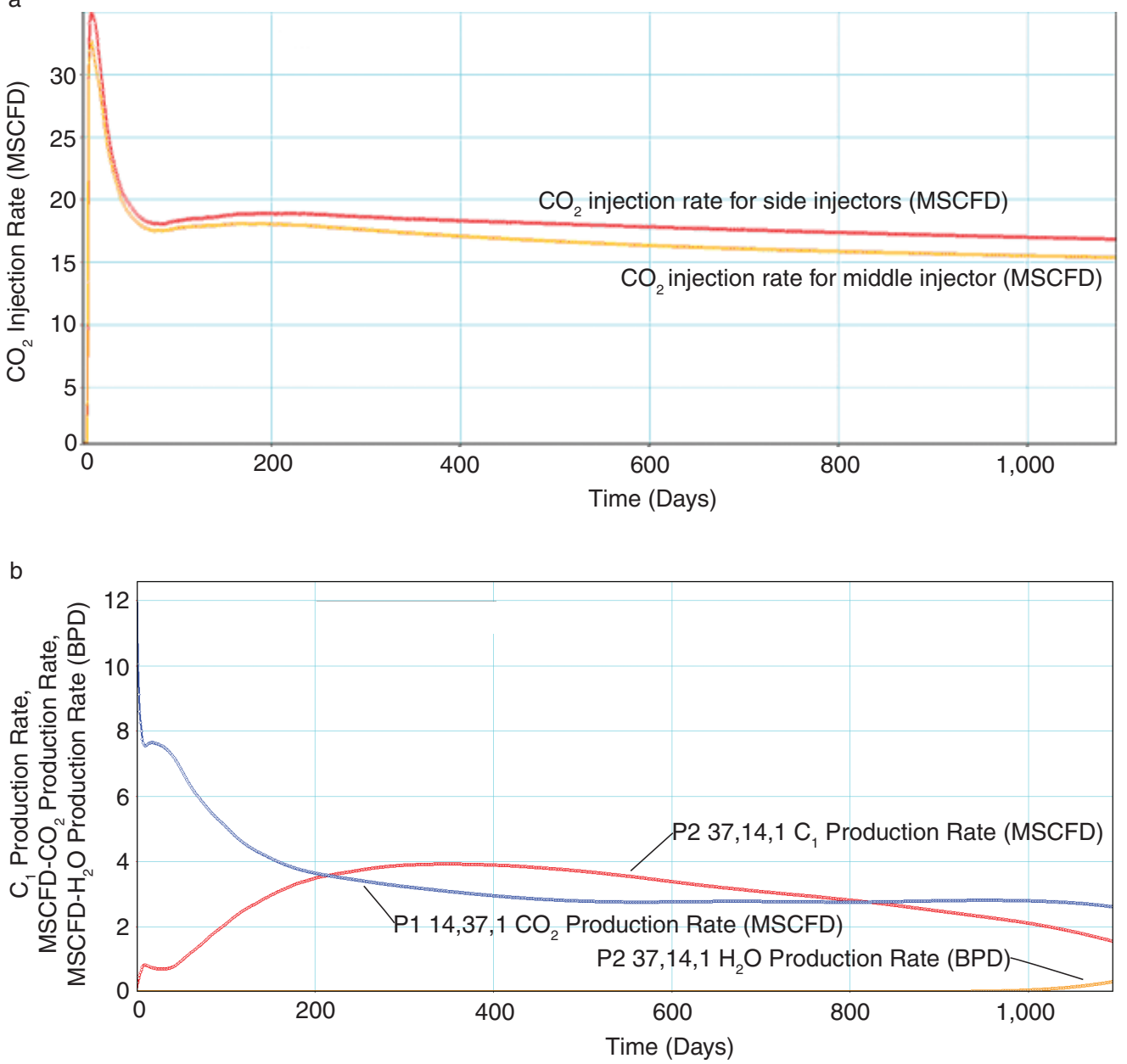

C

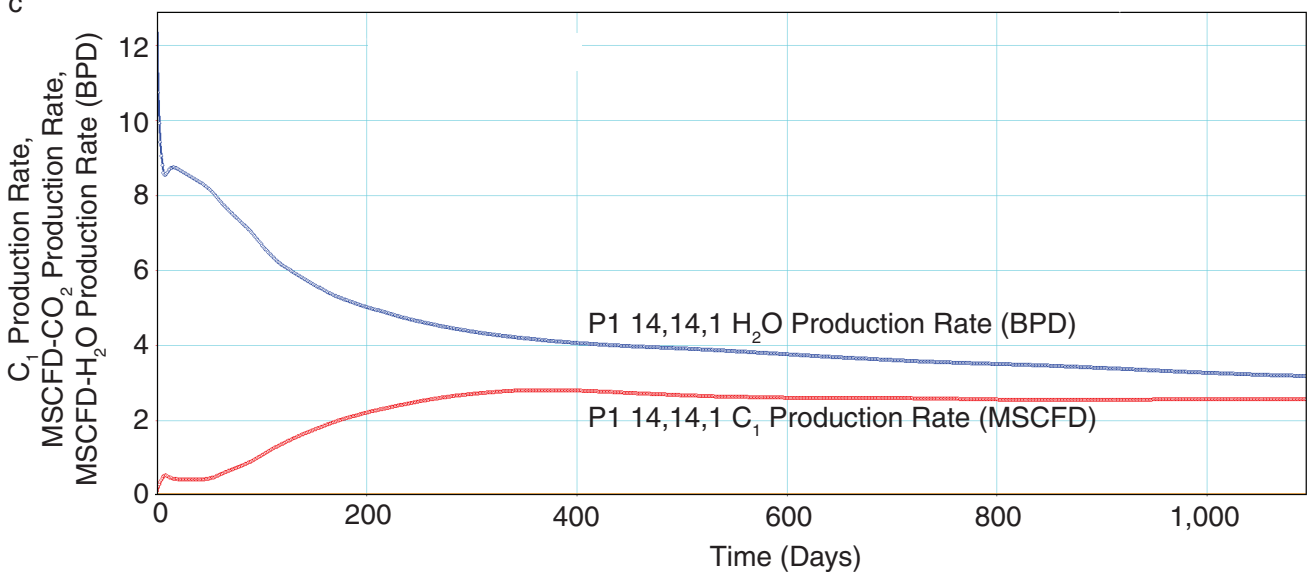

Figure 110. (a) Line drive $\mathrm{CO}_{2}$ injection profile. (b) Line drive middle well production profile. (c) Line drive corner well production profile (MSCFD-1,000 scf/d). 


\section{Case 3: Line Drive}

To limit the production of $\mathrm{CO}_{2}$ in the face cleat orientation, a line drive pattern was implemented with three injectors and a total of six producers (three on each side). The model is shown in Figure 109. The model was run with an injection pressure constraint of $4.82 \mathrm{MPag}$ (700 psig) (the highest pressure that could be reached in the simulator) and a production pressure constraint of $70 \mathrm{Pag}$ (10 psig) for $3 \mathrm{yr}$. To assess the incremental gas production and $\mathrm{CO}_{2}$ sequestration, a comparative noninjection (CBM) was also run.

The injection profile at the site is shown on Figure 110a with the injection rate for the middle injector in yellow and the injection rate for each side injector in red (similar due to the symmetry). A total volume of $1.6 \mathrm{million} \mathrm{scm}$ (58 million scf) of $\mathrm{CO}_{2}$ was injected over the 3-yr period. A decrease in injection rate is visible as expected due to the swelling of the coal and the increase in pressure of the coal. The response at the producers is shown on Figure $110 \mathrm{~b}$ for the middle wells where a $\mathrm{CO}_{2}$ breakthrough is noticeable after about $2.7 \mathrm{yr}$ and on Figure 110c for the corner wells with no $\mathrm{CO}_{2}$ breakthrough. An incremental 40,000 scm (1.4 million scf) of $\mathrm{CH}_{4}$ is produced at each middle and corner well over 3 yr. Overall, an additional 17,000 $\mathrm{scm}$ (8.6 million scf) of $\mathrm{CH}_{4}$ was produced for a net volume (injected minus reproduced) of $1.6 \mathrm{million} \mathrm{scm}$ (58 million scf) of $\mathrm{CO}_{2}$ injected, making a net $\mathrm{CO}_{2} / \mathrm{CH}_{4}$ ratio of 6.7 , with the full injected volume being sequestered as no $\mathrm{CO}_{2}$ is being reproduced.

\section{$\mathrm{CH}_{4}$ Recovery and $\mathrm{CO}_{2}$ Storage Factors}

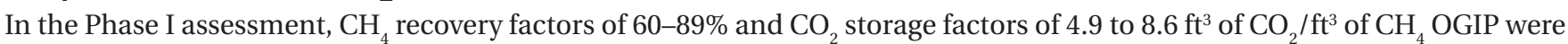
derived based on a parametric study conducted using known properties of Illinois coals and data from other basins available in the literature and staff experience. For $50 \% \mathrm{CO}_{2}$ in the gas production stream, the inverted five-spot and line drive examples gave 54.6 and $71.4 \%$ for the gas recovery and 2.5 and 2.7 for storage factors. The gas recovery compares well with the Phase I estimates; however, the $\mathrm{CO}_{2}$ storage factor is $50-75 \%$ lower than the Phase I estimate. The difference is attributed to the differences in the average pressure and the outer boundary of each model.

\section{Well Plugging and Abandonment and Site Reclamation}

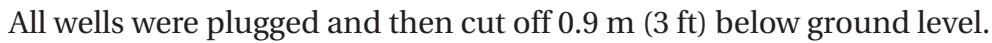
Monitoring wells M-1, M-2, and M-3 were filled with cement. Wells ECBM1-

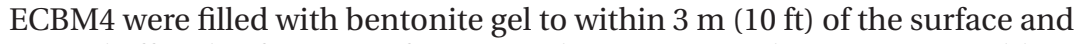
topped off with $7 \mathrm{ft}(2.1 \mathrm{~m})$ of cement. Plugging intervals are given in Table 13. Extra soil was brought in and the site was leveled to original contours. All buildings, pumps, and material were relocated offsite.
Table 13. Plugging depths.

\begin{tabular}{ll}
\hline Well & \multicolumn{1}{c}{ Plugged depth (ft) } \\
\hline M-1 & $3-1,180$ \\
M-2B & $3-895$ \\
M-3 & $3-1,020$ \\
I-1B & $3-890$ \\
ECBM1 & $3-10$ (cement), 10-80 (bentonite gel) \\
ECBM2 & $3-10$ (cement), 10-97 (bentonite gel) \\
ECBM3 & $3-10$ (cement), 10-80 (bentonite gel) \\
ECBM4 & $3-10$ (cement), 10-83 (bentonite gel) \\
\hline
\end{tabular}

\section{Conclusion}

About 100 tonnes of $\mathrm{CO}_{2}$ were injected over 100 days of active injection, averaging 0.46 tonne of coal $/ \mathrm{m} / \mathrm{day}(0.15 \mathrm{ton} / \mathrm{ft} /$ day) at this site. To reduce ambiguity of the results, a single coal seam was tested. At this site and most of the Illinois Basin, multiple coal seams are present. Assuming $\mathrm{CO}_{2}$ injection rate is proportional to the thickness of coal, two to four times the injection rate could be anticipated if multiple coal seams are completed simultaneously.

Coal characterization showed that the coals at the Tanquary site had some of the highest gas content measured in the Basin. The pre- $\mathrm{CO}_{2}$ water injection tests confirmed the face and butt cleat direction that was measured in a nearby mine. The micro-size pore system contributed significantly to the total porosity.

Through pressure transient analyses, increasing permeability was estimated followed by a series of steadily decreasing trends. If injection had been for a longer period, permeability may have increased due to continued increase in pressure of the cleat system and subsequent opening of the cleats.

The MVA program concluded that all $\mathrm{CO}_{2}$ remained within the injection coal seam.

The cased hole well log analyses, chemical and isotopic compositional data from the shallow groundwater samples, groundwater geochemical modeling, and CIR imagery were used to conclude that injected $\mathrm{CO}_{2}$ remained in the coal seam.

The numerical modeling calibrated to the $\mathrm{CO}_{2}$ injection was used to make projections of $\mathrm{CO}_{2}$ storage and $\mathrm{CH}_{4}$ production at larger well spacing and periods of injection and production. A line-drive pattern with injection and production wells aligned in the face cleat direction gave the highest ECBM estimate. The $\mathrm{CO}_{2}$ storage efficiency and $\mathrm{CH}_{4}$ production efficiency as a ratio to the original $\mathrm{CH}_{4}$ gas in place were $2.5 \mathrm{scf} \mathrm{CO}_{2} / \mathrm{scf} \mathrm{CH}$ gas in place and $71 \% \mathrm{scf} \mathrm{CH}_{4} / \mathrm{scf} \mathrm{CH}_{4}$ gas in place. 


\section{References}

American Public Health Association. 1992. Standard Methods for the Examination of Water and Wastewater, 18th ed.:Washington, DC, American Public Health Association, 1325 p.

Aravena, R., L.I. Wassenaar, and L.N. Plummer. 1995. Estimating 14C groundwater ages in a methanogenic aquifer. Water Resources Research, vol. 31, pp. 2307-2317.

ASTM Standard. 2002. Standard Practice for Low-Flow Purging and Sampling for Wells and Devices Used for Ground-Water Quality Investigations, D6771-02: West Conshohocken, PA, 7 pp.

ASTM Standard. 2006. Annual Book of ASTM Standards, Section Five: Petroleum Products, Lubricants, and Fossil Fuels. Gaseous Fuels; Coal and Coke: West Conshohocken, PA, 05.06, 705 pp.

Berg, R.C., and J.P. Kempton. 1988. Stack-unit mapping of geologic materials in Illinois to a depth of 15 meters. Champaign, IL, Illinois State Geological Survey, Circular 542, 23 pp.

Berger, P.M., W.R. Roy, and E. Mehnert. 2009. Geochemical modeling of carbon sequestration, MMV, and EOR. Energy Procedia, vol. 1, pp. 3437-3444.

Bethke, C.M., and S. Yeakel. 2007. The Geochemist's Workbench Release 7.0: Reaction Modeling Guide: Urbana, University of Illinois at Urbana-Champaign, $84 \mathrm{pp}$.

Clarkson, C.R., and R.M. Bustin. 1996. Variation in micropore capacity and size distribution with composition in bituminous coal of the western Canadian sedimentary basin. Fuel, vol. 75, pp. 1483-1498.

Clarkson, C.R., and R.M. Bustin. 1999. Effect of pore structure and gas pressure upon the transport properties of coal: a laboratory and modeling study; Adsorption rate modeling: Fuel, vol. 78, pp. 1333-1344.

Coleman, M.L., T.J. Shepard, J.J. Durham, J.E. Rouse, and G.R. Moore. 1982. Reduction of water with zinc for hydrogen isotope analysis. Analytical Chemistry, vol. 54, pp. 993-995.

Demir, I., D.G. Morse, S.D. Elrick, and C.A. Chenoweth. 2004. Delineation of coal bed methane resources of Illinois: Champaign, IL, Illinois State Geological Survey, Circular 564, 130 pp.

Epstein, S., and T. Mayeda. 1953. Variation of ${ }^{18} \mathrm{O}$ content of waters from natural sources. Geochimica et Cosmochimica Acta, vol. 4, pp. 213-224.

Frankie, W.T., R.J. Jacobson, B.G. Huff, M.B. Thompson, K.S. Cummings, and C.A. Phillips. 1996. Guide to the geology of the Mount Carmel area, Wabash County, Illinois, Illinois State Geological Survey, Field Trip Guidebook 1996D, 71 pp.

Gaus, I., P. Audigane, L. Andre, J. Lions, N. Jacquement, P. Durst, I. Czernichowski-Lauriol, and M. Azaroual. 2008. Geochemical and solute transport modeling for $\mathrm{CO}_{2}$ storage, what to expect from it? International Journal of Greenhouse Gas Control, vol. 2, pp. 605-625.

Gregg, S. J., and K.S.W. Sing. 1982. Adsorption, Surface Area and Porosity, 2nd ed. New York, Academic Press, 303 p.

Grossman, E.L., B.K. Coffman, J.S. Fritz, and H. Wada. 1989. Bacterial production of methane and its influence on groundwater chemistry in east-central Texas aquifers. Geology, vol. 17, pp. 495-499.

Guoyi, Hu, Jin Li, Chenghua Ma, Zhisheng Li, Min Zhang, and Qiang Zhou. 2007. Characteristics and implications of the carbon isotope fractionation of desorbed coalbed methane in Qinshui coalbed methane field, China. Earth Science Frontiers, v. 14, no. 6, pp. 267-272.

Hackley, K.C. 2002. A chemical and isotopic investigation of the groundwater in the Mahomet bedrock valley aquifer: Age, recharge and geochemical evolution of the groundwater. Ph.D. dissertation, Urbana, University of Illinois at UrbanaChampaign, $152 \mathrm{p}$.

Hackley, K.C., C.L. Liu, and D. Trainor. 1999. Isotopic identification of the source of methane in subsurface sediments of an area surrounded by waste disposal facilities. Applied Geochemistry, vol. 14, pp. 119-131.

Hackley, K.C., S.V. Panno, and T.F. Anderson. 2010. Chemical and isotopic indicators of groundwater evolution in the basal sands of a buried bedrock valley in the midwestern United States: Implications for recharge, rock-water interactions and mixing. GSA Bulletin, vol. 122, pp. 1027-1038.

Haitjema, H.M. 1985. Modeling three-dimensional flow in confined aquifers by superposition of both two- and three-dimensional analytic functions. Water Resources Research, vol. 21, no. 10, pp. 1557-1556. 
Haitjema, H.M. 2005. GFLOW version 2.1.0. Bloomington, IN, Haitjema Software.

Han, J., J.W. Carey, and J. Zhang. 2009. A coupled water chemistry and corrosion model for high salinity-high $\mathrm{CO}_{2}$ environments with application to wellbore integrity in $\mathrm{CO}_{2}$ sequestration. American Geophysical Union, Fall Meeting 2009, December 14-18, San Francisco, CA, Abstract \#H11J-04.

Illinois State Geological Survey. 1994. Glacial Drift in Illinois: Thickness and Character: ISGS GIS Database GISDB_QTGEO. IL_Drift_Thickness. Champaign, IL, Illinois State Geological Survey.

Illinois State Geological Survey. 1995. Stack-Unit Mapping of Geologic Materials in Illinois to a Depth of 15 Meters: ISGS GIS Database GISDB_QTGEO.IL_Stack_Units_To_15m_Py. Champaign, IL, Illinois State Geological Survey.

Illinois State Geological Survey. 2005. Bedrock Geology of Illinois: ISGS GIS Database GISDB_BEDGEO.IL_Bedrock_ Geology_500K_2005. Champaign, IL, Illinois State Geological Survey.

Jacobson, R. J., and C. P. Korose. 2007. Coal Geology of Illinois, in S. Fiscor, ed., Keystone Coal Industry Manual. Jacksonville, FL, Mining Media International, pp. 568-580.

Jin, H., A. Schimmelmann, M. Mastalerz, J. Pope, and T.A. Moore. 2010. Coalbed gas desorption in canisters: Consumption of trapped atmospheric oxygen and its implications. International Journal of Coal Geology, vol. 81, pp. 64-72.

Johnson, P., S. Fiscor, G. Tverdak, and E. Freeman. 2009. Keystone Coal Industry Manual: Jacksonville, FL, Mining Media International, $631 \mathrm{pp}$.

Karacan, C.O., and G.D. Mitchell. 2003. Behavior and effect of different coal microlithotypes during gas transport for carbon dioxide sequestration into coal seams. International Journal of Coal Geology, vol. 53, pp. 201-217.

Kolata, D.R. 2005. Bedrock Geology of Illinois. Champaign, IL, Illinois State Geological Survey, Illinois Map 14, 1:500,000.

Krooss, B.M., F. van Bergen, Y. Gensterblum, N. Siemons, H. J. M. Pagnier, and P. David. 2001. High-pressure methane and carbon dioxide on dry and moisture-equilibrated Pennsylvanian coals. International Journal of Coal Geology, vol. 51, pp. 69-92.

Liu, C.-L., and D.D. Coleman. 1981. Illinois State Geological Survey radiocarbon dates VII. Radiocarbon, vol. 23, pp. $352-383$.

Liu, C.-L., K.M. Riley, and D.D. Coleman. 1986. Illinois State Geological Survey radiocarbon dates IX. Radiocarbon, vol. 28, pp. 110-133.

Mastalerz, M., A. Drobniak, J. Rupp, and N. Shaffer. 2004. Characterization of Indiana's coal resource: Availability of the reserves, physical and chemical properties of the coal, and present potential uses. Indiana Geological Survey, Open-File Study 04-02, 74 pp.

Mastalerz, M., A. Drobniak, R. Walker, and D. Morse. 2010. Coal lithotypes before and after saturation with $\mathrm{CO}_{2}$; insights from micro- and mesoporosity, fluidity, and functional group distribution. International Journal of Coal Geology, vol. 83, no. 4, 1 September 2010, pp. 467-474.

Mastalerz, M., A. Drobniak, and J. Rupp. 2008a. Meso- and micropore characteristics of coal lithotypes; Implications for CO 2 adsorption. Energy \& Fuels, vol. 22, no. 6, pp. 4049-4061.

Mastalerz, M., A. Drobniak, D. Strapoc, W. Solano Acosta, and J. Rupp. 2008b. Variations in pore characteristics in high volatile bituminous coals; Implications for coalbed gas content. International Journal of Coal Geology, vol. 76, pp. $205-216$.

Mavor, M.J., L.B. Owen, and T.J. Pratt. 1990. Measurement and evaluation of coal sorption isotherm data. SPE paper 20728 presented at the Society of Petroleum Engineers 65th Annual Technical Conference and Exhibition, September 23-26, New Orleans, LA, , pp.157-170.

McLennan, J.D., P.S. Schafer, and T. J. Pratt. 1995. A Guide to Determining Coalbed Gas Content. Gas Research Institute Report, GRI-94/0396. Chicago, IL: Gas Research Institute, 181 pp.

Melnichenko, Y.B., A.P. Radlinski, M. Mastalerz, G. Cheng, and J. Rupp. 2009. Characterization of the $\mathrm{CO}_{2}$ fluid adsorption in coal as a function of pressure using neutron scattering techniques (SANS and USANS). International Journal of Coal Geology, vol. 77, pp. 69-79.

Midwest Geological Sequestration Consortium. 2005. An Assessment of Geological Carbon Sequestration Options in the Illinois Basin. DOE Report, DE-FC26-03NT41994, 581 pp. (Issued December 31, 2005.) 
Midwest Geological Sequestration Consortium. 2009. Enhanced Oil Recovery I: Loudon Single-Well Huff 'n' Puff. DOE Final Report, DE-FC26-03NT41994, 100 pp. (Issued December 31, 2009.)

Morse, D.G., and I. Demir. 2007. Resource assessment and production testing for coalbed methane in Illinois. Champaign, IL, Illinois State Geological Survey, Open File Report 2007-8, 165 p.

O’Dell, J.W., J.D. Pfaff, M.E. Gales, and G.D. Mckee. 1984. Test Method-The Determination of Inorganic Anions in Water by Ion Chromatography-Method 300, U.S. Environmental Protection Agency, EPA-600/4-84-017.

Orion Research Incorporated. 1990. Ammonia Electrode Instruction Manual. Boston, MA, Orion Research Incorporated, 36 pp.

Orion Research Incorporated. 2003. Carbon Dioxide Electrode Instruction Manual. Beverly, MA, Orion Research Incorporated, $37 \mathrm{pp}$.

Ostlund, H.G., and H.G. Dorsey. 1977. Rapid electrolytic enrichment and hydrogen gas proportional counting of tritium. In Low-Radioactivity Measurements and Applications, Proceedings of the International Conference on Low-Radioactivity Measurements and applications, October 6-10, 1975, The High Tatras, Czechoslovakia, Slovenske Pedagogicke Nakladatel'stvo, Bratislava, pp. 55-60.

Palmer, I., and S.R. Reeves. 2007. Modeling Changes of Permeability in Coal Seams. Final Report, DOE Contract No. DE-FC26-00NT40924, July 2007.

Parkhurst, D.L., and Appelo, C.A.J. 1999.User's guide to PHREEQC (Version 2)—A computer program for speciation, batchreaction, one-dimensional transport, and inverse geochemical calculations. Reston, VA, U.S. Geological Survey, WaterResources Investigations Report 99-4259, 310 pp.

Paul, G.W., W.K. Sawyer, and R.H. Dean. 1990. Validation 3D Coalbed Simulators. SPE 20733, SPE Annual Technical Conference and Exhibition, Houston, TX, September 23-26, 1990.

Pekot, L.J., and S.R. Reeves. 2003. Modeling the effects of matrix shrinkage and differential swelling on coalbed methane recovery and carbon sequestration. Proceedings of the International Coalbed Methane Symposium, Tuscaloosa, Alabama, May 5-7, 2003. Paper 0328.

Piskin, K., and R.E. Bergstrom. 1975. Glacial drift in Illinois: Thickness and character. Champaign, IL, Illinois State Geological Survey, Circular 490, 35 pp.

Pryor, W.A. 1956. Groundwater geology in southern Illinois, a preliminary geologic report. Champaign, IL, Illinois State Geological Survey, Circular 212, 25 p.

Puls, R.W. and M.J. Barcelona. 1996. Low Flow (Minimal Drawdown) Ground-Water Sampling Procedure. EPA Ground Water Issue \#EPA/540/S-95/504.

Rau, G.H. 2004. Fe/ $\mathrm{CO}_{2}$ fuel cells for $\mathrm{CO}_{2}$ capture and sequestration plus $\mathrm{H}_{2}$ and electricity production. American Chemical Society, Div. Fuel Chemistry, vol. 49, pp. 350-351.

Reeves, S.R., and A. Oudinot. 2005. The Allison Unit $\mathrm{CO}_{2}$-ECBM Pilot-A Reservoir and Economic Analysis. Paper 0522,2005 International Coalbed Methane Symposium, Tuscaloosa, Alabama, May 16-20, 2005.

Reeves, S.R., and L.J. Pekot. 2001. Advanced reservoir modeling in desorption-controlled reservoirs. SPE 71090, Proceedings of the SPE Rocky Mountain Petroleum Technology Conference, Keystone, May 21-23, 2001. (This paper also presented as Paper 0127 at the International Coalbed Methane Symposium, Tuscaloosa, May 14-16, 2001.)

Reeves, S.R., A. Taillefert, L. Pekot, and C. Clarkson. 2003. The Allison Unit $\mathrm{CO}_{2}$ - ECBM Pilot: A Reservoir Modeling Study. Topical Report, DOE Contract No. DE-FC26-00NT40924, February, 2003.

Sara, M., and R.D. Gibbons. 1991. Organization and Analysis of Water Quality Data, in D.M. Neilsen, ed., Practical Handbook of Ground Water Monitoring. Chelsea, MI, Lewis Publishers, Inc., pp. 557-583.

Sawyer, W.K., G.W. Paul, and R.A. Schraufnagel. 1990. Development and Application of a 3D Coalbed Simulator. CIM/SPE 90-119, presented at the 1990 CIM/SPE International Technical Conference, Calgary, June 10-13, 1990.

Strack, O.D.L., and H.M. Haitjema. 1981. Modeling double aquifer flow using a comprehensive potential and distributed singularities 1. Solution for homogeneous permeabilities. Water Resources Research, vol. 17, no. 5, pp. $1535-1549$.

Strąpoć, D., A. Schimmelmann, and M. Mastalerz. 2006. Carbon isotopic fractionation of $\mathrm{CH}_{4}$ and $\mathrm{CO}_{2}$ during canister desorption of coal. Organic Geochemistry, vol. 37, pp. 152-164. 
Strąpoć, D., M. Mastalerz, A. Schimmelmann, A. Drobniak, and S. Hedges. 2008a. Variability of geochemical properties in a microbially-dominated coalbed gas system from the eastern margin of the Illinois Basin. International Journal of Coal Geology, vol. 76, pp. 98-110.

Strąpoć , D., F. Picardal, C. Turich, I. Schaperdott, J. Macalady, J.S. Lipp, Yu-Shih Lin, T.F. Ertefai, F. Schubotz, K.U. Hinrichs, M. Mastalerz, and A. Schimmelmann. 2008b. Methane-producing microbial community in a coal bed of the Illinois Basin. Journal of Applied and Environmental Microbiology, vol. 74, pp. 2424-2432.

Strazisar, B.R., C. Zhu, and S.W. Hedges. 2006. Preliminary modeling of the long-term fate of $\mathrm{CO}_{2}$ following injection into deep geological formations. Environmental Geology, vol. 13, no. 1, pp. 1-15.

United States Department of Energy Office of Fossil Energy, National Energy Technology Laboratory. November 2010. Carbon Sequestration Atlas of the United States and Canada, $3^{\text {rd }}$ ed. $162 \mathrm{p}$.

United States Environmental Protection Agency. 1974. Methods for Chemical Analysis of Water and Wastes. EPA-625-/6-74003a, pp.vi-xii.

United States Environmental Protection Agency. 1989. Statistical Analysis of Ground-Water Monitoring Data at RCRA Facilities- Interim Final Guidance.

United States Geological Survey. 2007. PhreeqcI volume 2.13.2. Reston, VA.

Vennemann, T.W., and J.R. O’Neil. 1993. A simple and inexpensive method of hydrogen isotope and water analyses of minerals and rocks based on zinc reagent. Chemical Geology, vol. 103, pp. 227-234.

WTS Ltd. 1997. PIE well-test analysis software. London, UK, Well Test Solutions, Ltd.

Webb, P.A., and C. Orr. 1997. Analytical Methods in Fine Particle Technology. Norcross, GA, Micromeritics Instrument Co., $325 \mathrm{pp}$.

Willman, H.B., E. Atherton, T.C. Buschbach, C. Collinson, J.C. Frye, M.E. Hopkins, J.A. Lineback, and J.A. Simon. 1975. Handbook of Illinois Stratigraphy. Champaign, IL, Illinois State Geological Survey, Bulletin 95, 261 p.

Wood, W.W. 1976. Guidelines for collection and field analysis of groundwater samples for selected unstable constituents. In Techniques for Water Resources Investigations, Chapter D-2, Reston, VA, U.S. Geological Survey, 24 p.

Yeskis, D., and B. Zavala. 2002. Ground-Water Sampling Guidances for Superfund and RCRA Project Managers. EPA 542-S02-001, Washington, DC, $53 \mathrm{pp}$. 



\section{Appendix 1. State of Illinois Drilling Permits}

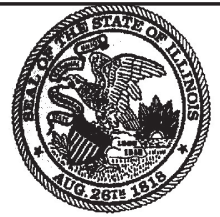

\section{STATE OF ILLINOIS \\ DEPARTMENT OF NATURAL RESOURCES \\ Office of Mines and Minerals \\ Division of Oil and Gas}

PERMIT TO DRILL AND/OR OPERATE A WELL FOR: WATER SUPPLY

PERMITTEE:

PERMITEE NO.: 287

GALLAGHER DRILLING, INC

P. O. BOX 3046

EVANSVILLE, IN 47730

$$
\text { Albion Cons - S }
$$

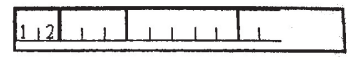

No. 058796

Date Issued: $6 / \mathbf{1 8 / 2 0 0 7}$

Reference \#: 210974

WELL NAME: L.P. DAUGHTERS ETAL \#M-2B

LOCATION: 0558S 0171W NEc NW $\angle$

SEC: 27 TWP: 01S RGE: 14W COUNTY: WABASH

LOWEST FORMATION AND MAXIMUM AUTHORIZED DEPTH: TRADEWATER 1300 FT

SURFACE ELEVATION: GL 395 FT.

TYPE OF TOOLS: ROTARY

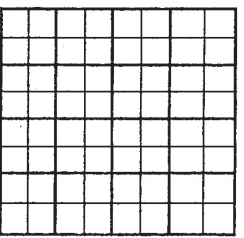

DRILLING CONTRACTOR: GOFF \& PRUITT, CARMI, IL

PERMIT CONDITIONS

1. SET AND CEMENT AT LEAST 395 FT. OF SURFACE CASING OR SET AND CEMENT ALTERNATIVE SURFACE CASING IN ACCORDANCE WITH SECTION

$240.610 \mathrm{~b})$.

2. CUTTINGS REQUIRED: FROM TO

Issuance of this permit under 225 ILCS 725/1, Illinois Oil \& Gas Act, does not in any way authorize any take of any listed species in violation of the Illinois Endangered Species Protection Act, 520 ILCS $10 / 1$ et. seq. or The Endangered Resources, Office of Resource Conservation for state listed species and the U.S. Fish and Wildlife Service for federally listed species.

This permit or a legible photocopy shall be posted at the

wellsite before drilling commence. If necessary, to plug this well, notify:

CARMI (618) 382-3150

District Office

This permit is conditioned upon compliance with the requirements of the Illinois Oil and Gas Act and the implementing regulations and authorizes the drilling and operation of the above described well.
Division of Oil and Gas

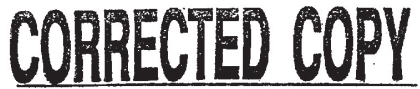

Division Supervisor
This permit expires one year from date of issuance unless drilling or conversion operation are commenced prior thereto.

Figure A1-1. The M-2 water supply well permit. 


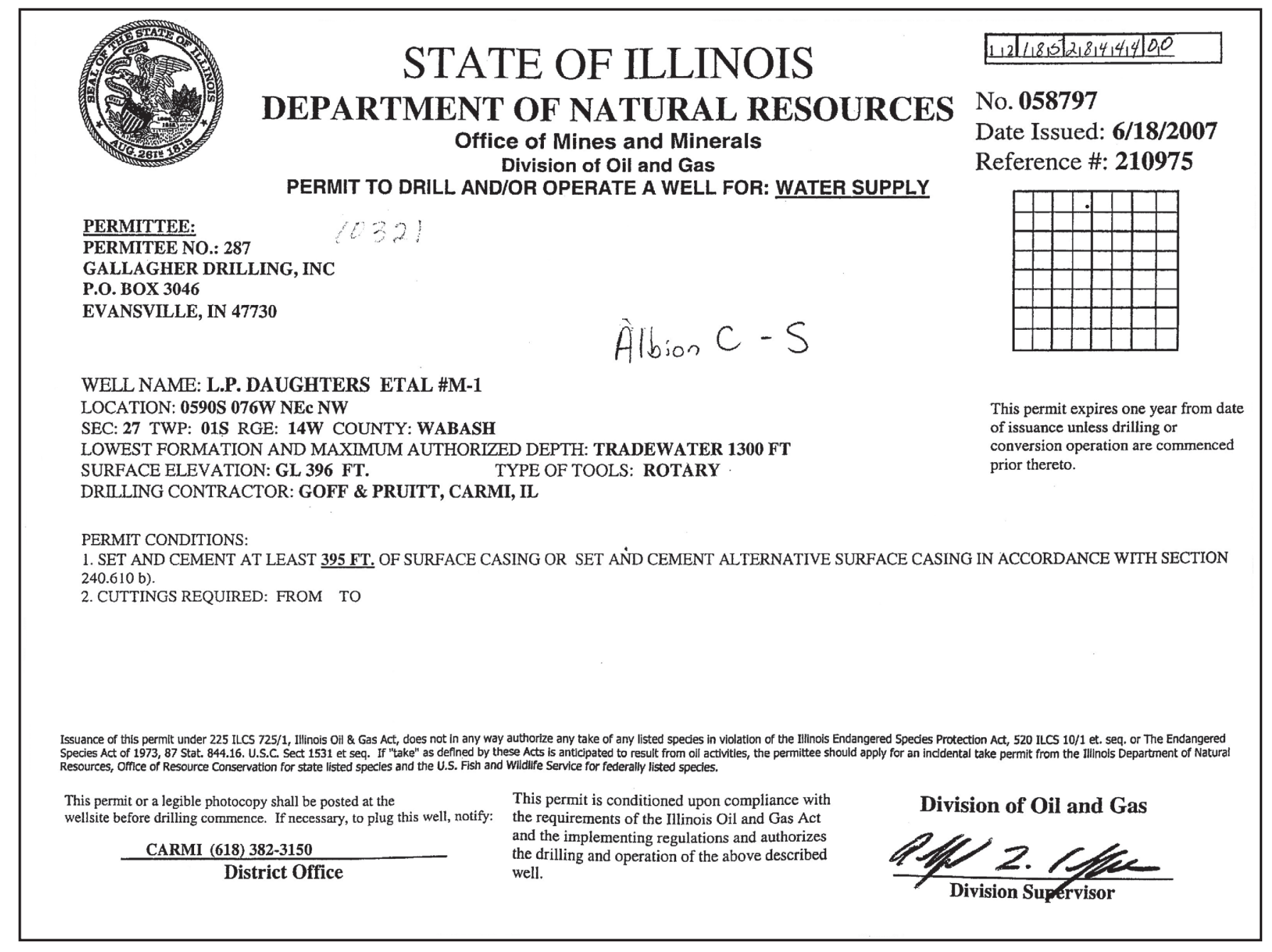

Figure A1-2. The M-1 water supply well permit. 


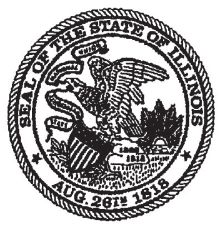

PERMITTEE NO. 287

GALLAGHER DRILLING, INC

P.O. BOX 3046

EVANSVILLE, IN 47730

WELL NAME: L.P. DAUGHTERS ETAL \#1-1A

LOCATION: 0460S 0150W NEc NW

SEC: 27 TWP: 01S RGE: 14W COUNTY: WABASH

INJECTION INTERVAL(S) AS FOLLOWS: SPRINGFIELD 890'-896' SEELYVILLE 1155'-1160'

SURFACE ELEVATION: GL 395 FT. DRILLING CONTRACTOR: GOFF \& PRUITT, CARMI, IL

Division of Oil and Gas

$$
\because 321
$$

STATE OF ILLINOIS

DEPARTMENT OF NATURAL RESOURCES

Office of Mines and Minerals

PERMIT TO DRILL AND/OR OPERATE A WELL FOR: GAS INJECTION

$$
\text { Albion Gons - S }
$$

No. 202956

Date Issued: $7 / \mathbf{1 1 / 2 0 0 7}$

Reference \#: 211043

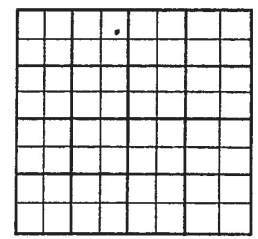

This permit expires one year from date of issuance unless drilling or conversion operation are commenced prior thereto.

PERMIT CONDITIONS:

1. INSTALL TUBING AND PACKER UNDER SUPERVISION OF DIVISION WELL INSPECTOR.

2.PRIOR TO INJECTION, CONDUCT A MECHANICAL INTEGRITY TEST A MINIMUM OF 300 PSI FOR 30 MINUTES UNDER SUPERVISION OF A DIVISION WELL 2.PRIOR TO

3. MAXIMUM INJECTION RATE AND PRESSURE: 2 MMSCF/DAY BBLS/DAY; 650 PSI.

4. SET AND CEMENT AT LEAST 395 FT. OF SURFACE CASING, OR SET ALTERNATIVE SURFACE CASING IN ACCORDANCE WITH SECTION $240.610 \mathrm{~b}$ )

Issuance of this permit under 225 ILCS 725/1, Illinois Oil \& Gas Act, does not in any way authorize any take of any listed species in violation of the Illinois Endangered Species Protection Act, 520 ILCS $10 / 1$ et. seq. or The Endangered Species Act of 1973, 87 Stat. 844.16. U.S.C. Sect 1531 et seq. If "take" as defined by these Acts is anticipated to result from oil activities, the permittee should apply for an incidental take permit from the Illinois Department of Natural Resources, Office of Resource Conservation for state listed species and the U.S. Fish and Widdlife Service for federally listed species.

This permit or a legible photocopy shall be posted at the wellsite before drilling commence. If necessary, to plug this well, notify the following District Office: CARMI (618) 382-3150

\section{District Office}

This permit is conditioned upon compliance with the requirements of the Illinois. Oil and Gas Act and the implementing regulations and authorizes the drilling and operation of the above described well.
Division of Oil and Gas

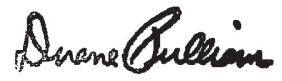

Division Supervisor

Figure A1-3. The I-1A gas injection well permit. 


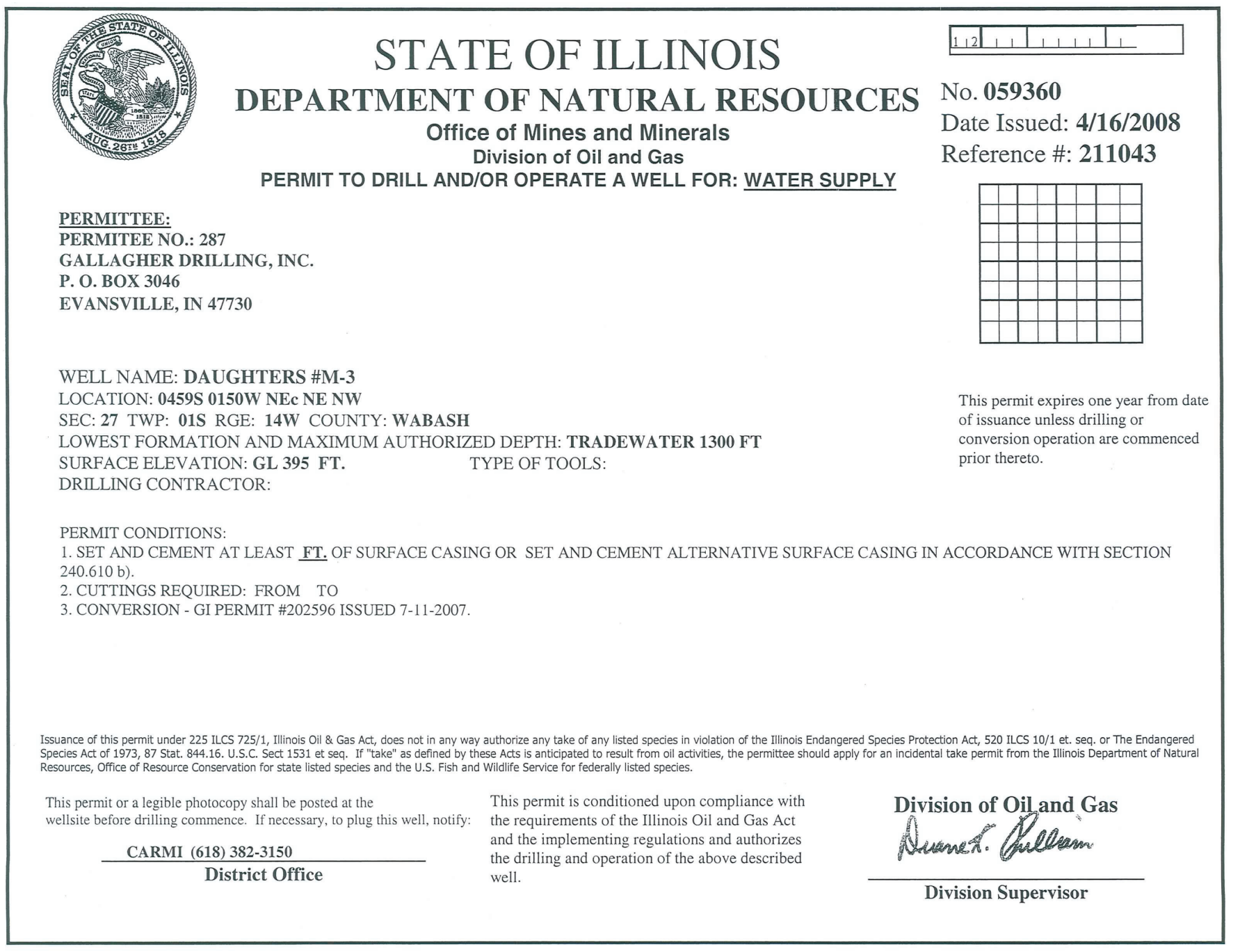

Figure A1-4. Amended M-3 (I-1A) water supply well permit. 


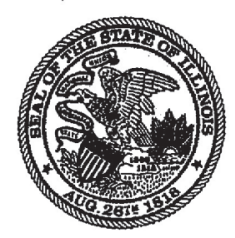

PERMITTEE NO. 287

GALLAGHER DRILLING, INC

P.O. BOX 3046

EVANSVILLE, IN 47730

WELL NAME: L.P. DAUGHTERS ETAL \#1-1B

LOCATION:

Albion Gons - S

STATE OF ILLINOIS

DEPARTMENT OF NATURAL RESOURCES

Office of Mines and Minerals

Division of Oil and Gas

PERMIT TO DRILL AND/OR OPERATE A WELL FOR: GAS INJECTION

SEC: 27 TWP: 01 S RGE: 14W COUNTY: WABASH

INJECTION INTERVAL(S) AS FOLLOWS: SPRINGFIELD 890'-896' SEELYVILLE 1155'-1160'

SURFACE ELEVATION: GL 395 FT. DRILLING CONTRACTOR: GOFF \& PRUITT, CARMI, IL

PlRMIT CONDITIONS:

1. NSTALL TUBING AND PACKER UNDER SUPERVISION OF DIVISION WELL INSPECTOR.

2.PRIOR TO INJECTION, CONDUCT A MECHANICAL INTEGRITY TEST A MINIMUM OF 300 PSI FOR 30 MINUTES UNDER SUPERVISION OF A DIVISION WELL

INSPECTOR

3. MAXIMUM INJECTION RATE AND PRESSURE: 2 MMSCF/DAY BBLS/DAY; 650 PSI.

4. SET AND CEMENT AT LEAST 395 FT. OF SURFACE CASING, OR SET ALTERNATIVẸ SURFACE CASING IN ACCORDANCE WITH SECTION 240.610 b)

Issuance of this permit under 225 ILCS 725/1, Illinois Oil \& Gas Act, does not in any way authorize any take of any listed species in violation of the Illinois Endangered Species Protection Act, 520 ILCS 10/1 et. seq. or The Isuct Endangered Species Act of 1973,87 5tat. 844.16 . U.S.C. Sect 1531 et seq. If "take" as defined by these Acts is anticipated to result from oil activities, the
Department of Natural Resources, Office of Resource Conservation for state listed specles and the U.S. Fish and Wildifife Service for federally listed species.

This permit or a legible photocopy shall be posted at the wellsite before drilling commence. If necessary, to plug this well, notify the following District Office: CARMI (618) 382-3150

District Office

This permit is conditioned upon compliance with the requirements of the Illinois Oil and Gas Act and the implementing regulations and authorizes the drilling and operation of the above described well.
Division of Oil and Gas

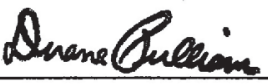

Division Supervisor

Figure A1-5. I-1B enhanced hydrocarbon recovery well permit. 


\section{Appendix 2. Geological Unit and Marker Bed Log Tops}

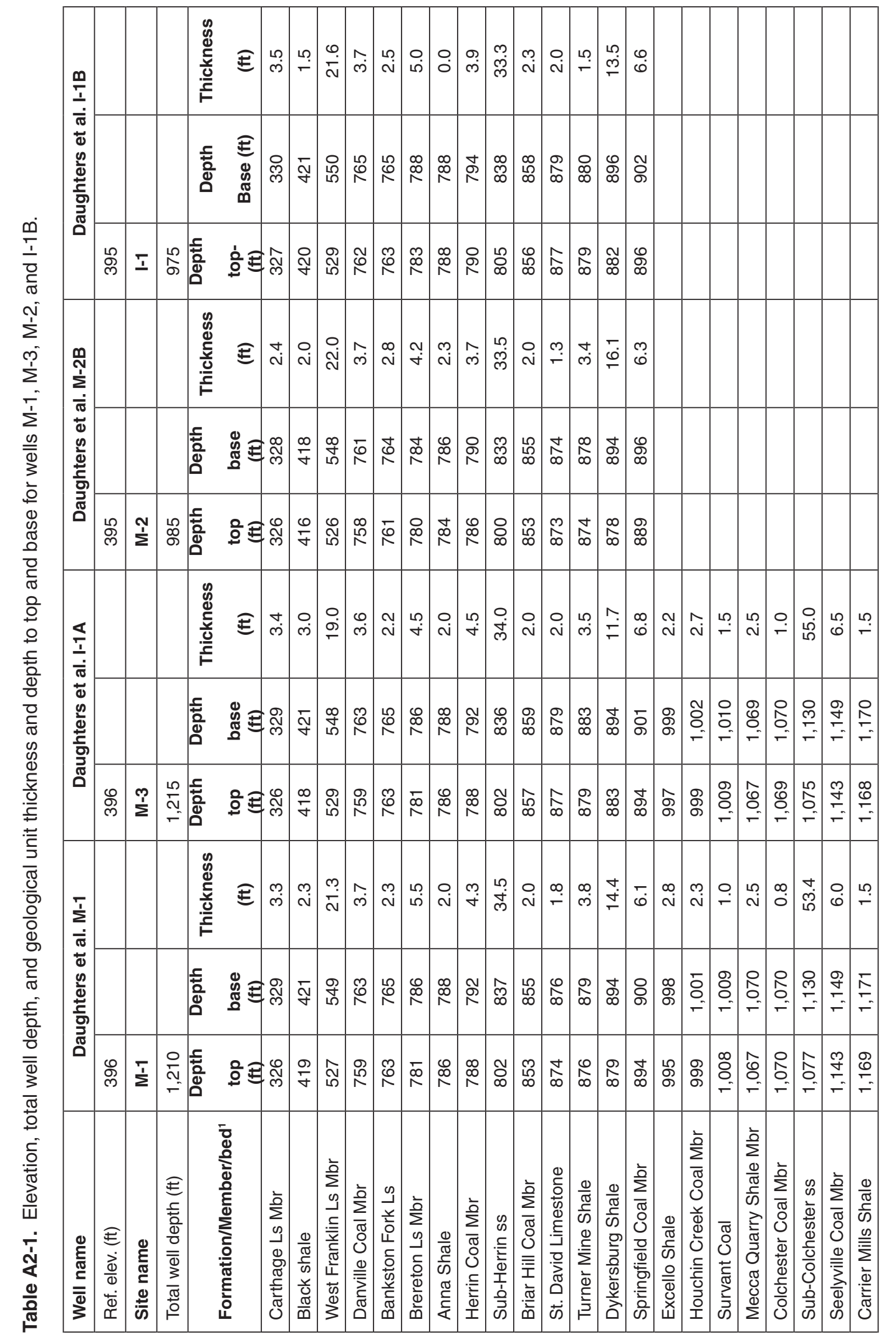




\section{Appendix 3. Geological Unit and Marker Bed Log Elevation}

Table A3-1. Total well depth and elevation of geological units for wells $\mathrm{M}-1, \mathrm{M}-3, \mathrm{M}-2$, and I-1B.

\begin{tabular}{|c|c|c|c|c|}
\hline Well name & $\begin{array}{c}\text { Daughters et al. } \\
\qquad-1\end{array}$ & $\begin{array}{l}\text { Daughters et al. } \\
\qquad \mathrm{M}-2\end{array}$ & $\begin{array}{c}\text { Daughters et al. } \\
\text { M-2B }\end{array}$ & $\begin{array}{c}\text { Daughters et al. } \\
\text { I-1B }\end{array}$ \\
\hline Ref. elev. (ft) & 396 & 396 & 395 & 395 \\
\hline Site name & $M-1$ & M-3 & $M-2$ & $\mathrm{I}-1$ \\
\hline Total well depth (ft) & 1,210 & 1,215 & 985 & 975 \\
\hline Formation/Member/bed ${ }^{1}$ & Elevation & Elevation & Elevation & Elevation \\
\hline Carthage Ls Mbr & 70 & 70 & 69 & 68 \\
\hline Black shale & -23 & -22 & -21 & -25 \\
\hline West Franklin Ls Mbr & -131 & -133 & -131 & -134 \\
\hline Danville Coal Mbr & -363 & -363 & -363 & -367 \\
\hline Bankston Fork Ls Mbr & -367 & -367 & -366 & -368 \\
\hline Brereton Ls Mbr & -385 & -385 & -385 & -388 \\
\hline Anna Shale & -390 & -390 & -389 & -393 \\
\hline Herrin Coal Mbr & -392 & -392 & -391 & -395 \\
\hline Sub-Herrin ss & -406 & -406 & -405 & -410 \\
\hline Briar Hill Coal Mbr & -457 & -461 & -458 & -461 \\
\hline St. David Limestone & -478 & -481 & -478 & -482 \\
\hline Turner Mine Shale & -480 & -483 & -479 & -484 \\
\hline Dykersburg Shale & -483 & -487 & -483 & -487 \\
\hline Springfield Coal Mbr & -498 & -498 & -494 & -501 \\
\hline Excello Shale & -599 & -601 & & \\
\hline Houchin Creek Coal Mbr & -603 & -603 & & \\
\hline Survant Coal Mbr & -612 & -613 & & \\
\hline Mecca Quarry Shale Mbr & -671 & -671 & & \\
\hline Colchester Coal Mbr & -674 & -673 & & \\
\hline Sub-Colchester ss & -681 & -679 & & \\
\hline Seelyville Coal Mbr & -747 & -747 & & \\
\hline Carrier Mills Shale & -773 & -772 & & \\
\hline
\end{tabular}

${ }^{1}$ Abbreviations: Ls, limestone; Mbr, Member; ss, sandstone. 


\title{
Appendix 4. Core Descriptions, Log Tops, and Coal Lithotypes
}

Table A4-1. Core descriptions for well M-1. CORE DESCRIPTION

\author{
Gallagher Drilling, L.P. Daughters et al. \#M-1 \\ Sec. 27, T1S, R14W 590S 76W NE/c NW \\ Wabash County, elevation G.L. 396.0' \\ Logged by D. G. Morse, July 17, 2007 \\ Core \#1 \\ Cored 883-903' Springfield Core \\ Springfield Coal 895.5 - 901.9' \\ Samples: $895.5-900.5^{\prime}$ to IGS; $900.5-901.5^{\prime}$ to ISGS
}

\begin{abstract}
Top Bottom
(ft) (ft)

$883.00 \quad 895.50 \quad$ claystone, gray, laminated to thin-bedded, slight flattening of layers; apparent horizontal fractures' spin-offs at $886.75^{\prime}, 992.05^{\prime}$, and $993.35^{\prime}$

$895.50901 .90 \quad$ coal (Springfield), large vertical cleat fractures in the middle of the coal, slightly inclined; may be induced by coring

$901.90 \quad 902.65 \quad$ claystone, gray-green, mottled with slickensides

Base of core 902.65'

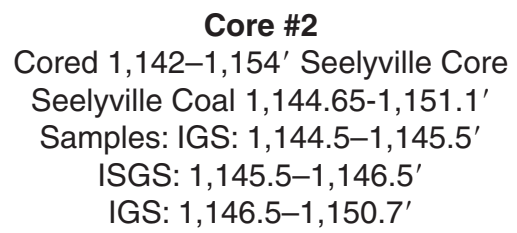

top Bottom

(ft) (ft)

$1,142.00 \quad 1,143.60 \quad$ claystone, gray, silty, laminated, very local, silt lenses-flasers; lenticular lamination at 1,142.8'

$1,143.60 \quad 1,143.80 \quad$ siltstone, finely laminated, very fine-grained, sandy, with organic partings

$1,143.80 \quad 1,144.50 \quad$ claystone, gray, laminated

$1,144.50 \quad 1,151.10 \quad$ coal, some fractures at top, broken coal, generally cored cleanly; sharp contact at base

$1,151.10 \quad 1,154.10 \quad$ siltstone, gray, mottled, calcareous blebs, and very tiny pyrite

Base of core 1,154.1'
\end{abstract}


Table A4-2. Log tops for Gallagher Drilling, L.P. Daughters et al. \#M-1.

Coal

thickness

(ft) (ft)

Top Bottom

(ft) Geological unit

$325.75 \quad 329.00$

$418.50 \quad 420.75$

$527.25 \quad 548.50$

$3.5 \quad 759.00 \quad 762.50$

$762.50 \quad 765.00$

$780.50 \quad 786.00$

$786.00 \quad 788.00$

$\begin{array}{lll}4.25 & 788.00 \quad 792.25\end{array}$

$802.00 \quad 836.50$

$\begin{array}{lll}2.00 & 853.25 & 855.25\end{array}$

$873.75 \quad 875.50$

$875.50 \quad 879.25$

$879.25 \quad 893.75$

$\begin{array}{lll}6.00 & 893.75 & 899.75\end{array}$

$994.75 \quad 997.50$

$\begin{array}{lll}2.25 & 999.00 & 1,001.25\end{array}$

$\begin{array}{lll}1.00 & 1,008.25 & 1,009.25\end{array}$

$1,067.00 \quad 1,069.50$

$\begin{array}{lll}0.75 & 1,069.50 & 1,070.25\end{array}$

$1,077.00 \quad 1,130.00$

$6.00 \quad 1,142.75 \quad 1,148.75$

$1,169.00 \quad 1,170.50$

Carthage Limestone Member

black shale

West Franklin Limestone Member

Danville Coal Member

Bankston Fork Limestone

Brereton Limestone Member

Anna Shale

Herrin Coal Member

sub-Herrin Coal sandstone

Brier Hill Coal

St. David limestone

Turner Mine Shale

Dykersburg Shale

Springfield Coal Member

Excello Shale

Houchin Creek Coal Member

Survant Coal Member

Mecca Quarry Shale

Colchester Coal Member

sub-Colchester sandstone

Seelyville Coal Member

Carrier Mills Shale

Net coal 25.75' 
Table A4-3. Core descriptions for well M-2B.

\section{CORE DESCRIPTION}

Gallagher Drilling, L.P. Daughters et al. \#M-2B

Sec 27, T1S, R14W 558S 107W, NE/c, NW

Wabash County, elevation G.L. 395'

Logged by D. G. Morse, May 21-23, 2008

\section{Core \#1 \\ 885-905.2'}

\section{Top Bottom}

(ft) (ft)

$885 \quad 888.6 \quad$ shale, gray, silty; clean horizontal fissile cracks

$888.55 \quad 894.51$ coal (Springfield), banded, shiny, 1/4" pyrite band at 889.45; some vertical cleats pyrite-filled near pyrite band $891^{\prime}$ : calcite cleat 891-894': long vertical cleat with $1 / 32^{\prime \prime}$-thick calcite vein fill $892.7^{\prime}: 1.5^{\prime \prime}$ pyrite nodule, cleats nearby; pyrite with calcite on each side 893.0': coal, quite broken up but through-going fracture noted basal 6" of coal, quite broken

894.5 898.0 gray claystone, washed out on sides, swirly; a few calcite concretions 1/4-1/2" in diameter; slickensides; grades to interlaminated silty shale with claystone interbeds at base; siltstone laminae are lenticular (ripples) and inclined

898.0 $901.0 \quad$ very fine sandstone to silty sandstone, light gray; two orthogonal stress-induced fractures; sharp base

$901.0 \quad 904.5$ gray clayey siltstone, with fine laminae at top and becomes more silty downward

$904.5 \quad 905.2 \quad$ finely interlaminated gray shale and light gray silt, some lenses (flasers) of light gray siltstone

905.2

end of core

Notes: Driller has base of hole at $905.5^{\prime}$. Some coal is thought to have been lost in coring $21^{\prime}$ in $20^{\prime}$ barrel. Coal is broken up at base, and core barrel tape was broken, producing a bulging barrel, overpacked by drilling. 
Table A4-4. Log tops for Gallagher Drilling, L.P. Daughters et al. \#M-2B.

Coal thickness

(ft)

3.8

8

784.0
$4.3 \quad 785.7$

Top

$$
\text { (ft) }
$$

326.0

416.5

526.0

757.4

761.7

779.6

785.7

799.5

2.1

853.0

873.0

874.3

877.7

6.7

889.2
Bottom

\section{(ft)}

328.5

418.3

547.7

761.2

764.0

784.0

785.7

790.0

833.1

855.1

874.3

877.7

895.5

895.9

\section{Geological Unit}

Carthage Limestone Member

black shale

West Franklin Limestone Member

Danville Coal Member

Bankston Fork Limestone

Brereton Limestone Member

Anna Shale

Herrin Coal Member

sub-Herrin sandstone

Briar Hill Coal Member

St. David limestone

Turner Mine Shale

Dykersburg Shale

Springfield Coal Member

Net coal 16.9' 
Table A4-5. Detailed lithotypes of the Springfield Coal at well M-2B.

\begin{tabular}{|c|c|c|c|c|c|c|c|c|}
\hline Top & Bottom & $\begin{array}{l}\text { Thickness } \\
\text { (ft) }\end{array}$ & $\begin{array}{l}\text { Litho- } \\
\text { type }^{1}\end{array}$ & Comments $^{2}$ & & $\begin{array}{l}\text { Cleat } \\
\text { mineral }\end{array}$ & $\begin{array}{l}\text { Range } \\
\text { cleat } \\
\text { spacing } \\
(\mathrm{mm})\end{array}$ & $\begin{array}{l}\text { Avg. } \\
\text { cleat } \\
\text { spacing } \\
(\mathrm{mm})\end{array}$ \\
\hline 888.55 & 889.17 & 0.62 & 3 & Banded & & & $3-6$ & 5 \\
\hline 889.17 & 889.31 & 0.14 & 3 & Banded & & & $10-12$ & 11 \\
\hline 889.31 & 889.44 & 0.13 & 5 & Bright, well cleated & & py & $5-10$ & 7 \\
\hline 889.44 & 889.46 & 0.02 & 0 & Pyrite band & & & & \\
\hline 889.46 & 889.77 & 0.31 & 4 & $\begin{array}{l}\text { Banded bright, frequent } \\
\text { cleats }\end{array}$ & & & $8-20$ & 14 \\
\hline 889.77 & 890.02 & 0.25 & 2 & Banded dull, few cleats & & & $7-20$ & 14 \\
\hline 890.02 & 890.28 & 0.26 & 4 & $\begin{array}{l}\text { Banded bright, frequent } \\
\text { cleats }\end{array}$ & & & & \\
\hline 890.28 & 890.34 & 0.06 & 1 & Dull, no cleats & & & none & 0 \\
\hline 890.34 & 890.51 & 0.17 & 4 & $\begin{array}{l}\text { Banded bright, frequent } \\
\text { cleats }\end{array}$ & & kaol & $10-20$ & 14 \\
\hline 890.51 & 890.71 & 0.2 & 2 & Banded dull, few cleats & & & & \\
\hline 890.71 & 890.95 & 0.24 & 3 & Banded & & & & \\
\hline 890.95 & 891.24 & 0.29 & 4 & $\begin{array}{l}\text { Banded bright/bright, well } \\
\text { cleated }\end{array}$ & cc & & $7-16$ & 12 \\
\hline 891.24 & 892.02 & 0.78 & 3 & Banded & & kaol, cc & $3-19$ & 8 \\
\hline 892.02 & 892.59 & 0.57 & 4 & Banded bright & & $\mathrm{cc}$ & & \\
\hline 892.59 & 892.71 & 0.12 & 5 & Bright & & $\mathrm{cc}$ & & \\
\hline 892.71 & 892.99 & 0.28 & 3 & Banded & & $\mathrm{cc}$ & & \\
\hline 892.99 & 893.31 & 0.32 & 2 & Banded dull & & cc & & \\
\hline 893.31 & 893.90 & 0.59 & 3 & Banded & & cc & & \\
\hline 893.90 & 894.08 & 0.18 & 5 & Bright & & cc & & \\
\hline 894.08 & 894.51 & 0.43 & 3 & Banded & & $\mathrm{cc}$ & & \\
\hline
\end{tabular}

'Lithotypes: 5, vitrain; 4, banded-bright clarain; 3, banded clarain; 2 , banded dull clarain; 1 , dull fusain. ${ }^{2}$ Abbreviations, py, pyrite; cc, calcite; kaol, kaolinite. 


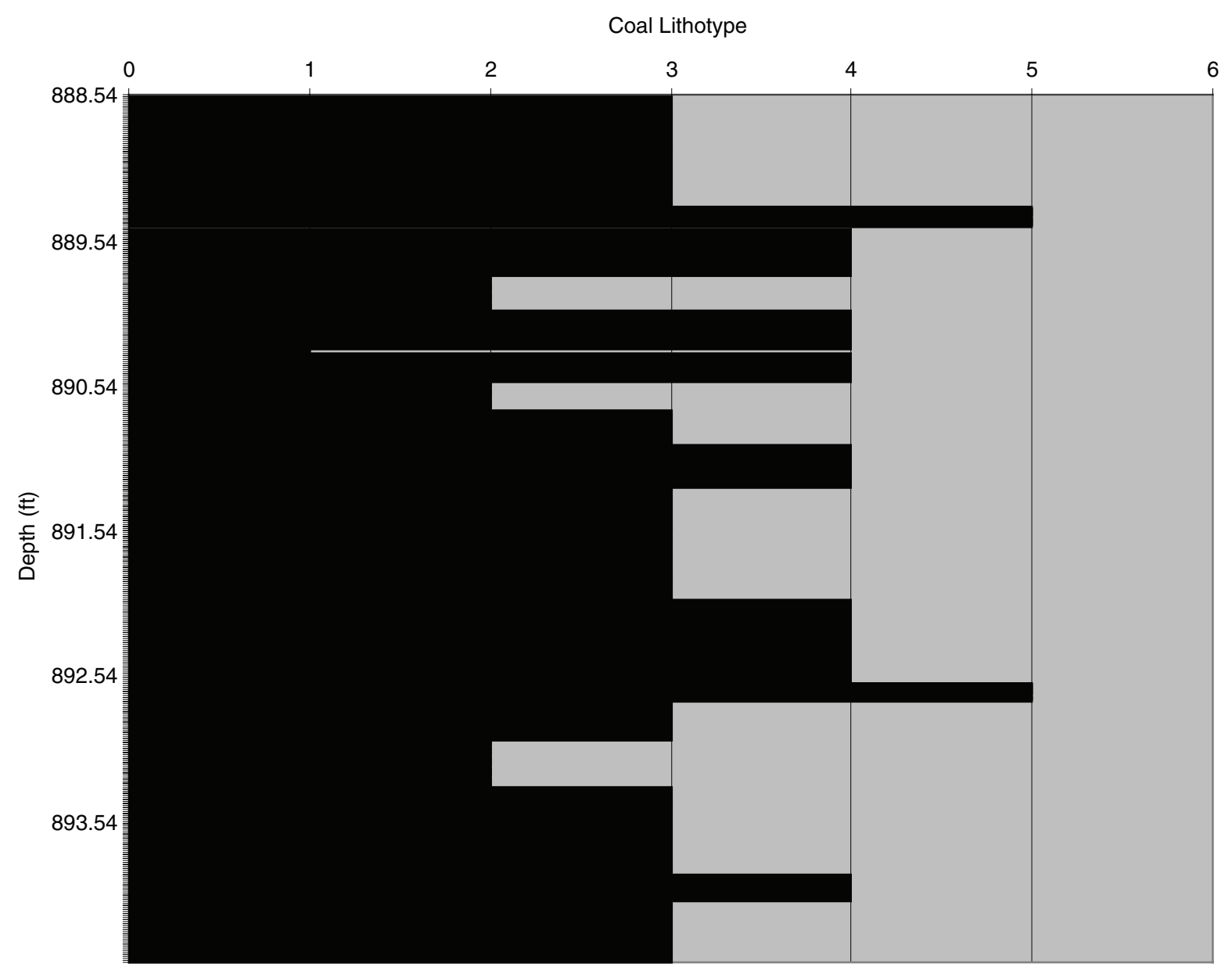

Figure A4-1. M-2 Springfield Coal lithotypes: 5, vitrain; 4, banded-bright clarain; 3, banded clarain; 2, banded dull clarain; 1 , dull fusain. 
Table A4-6. Core descriptions for well M-3 (I-1A).

\section{CORE DESCRIPTION}

Gallagher Drilling, L.P. Daughters et al. \#I-1A (M-3)

Sec. 27, T1S, R14W 460S 150W NEc NW (150 ft from \#M-1 well)

Wabash County, elevation G.L. 396.0'

Logged by D. G. Morse, July 24, 2007

\section{Core \#1}

755-772: Danville Coal Core

Danville Coal: 760.5-764.3'

Three samples: 760.5-761.5', 761.5-762.5', 762.5-763.5'

\section{Top Bottom}

(ft) (ft)

$755.00 \quad 759.80 \quad$ shale, gray, laminated with tan siderite bands and blebs

$759.80 \quad 760.50 \quad$ claystone, dark gray; brachiopods and pyrite nodules

$760.50764 .30 \quad$ coal (Danville, 3.7'); upper part has a few face cleat fractures, lower part clean cylinders of coal; local

$764.30 \quad 768.25$

$768.25 \quad 769.20$ pyrite bands to $1 / 4$ " in coal.

claystone, gray, mottled; local limey nodules

$769.20 \quad 769.40$

$769.40 \quad 770.60$

$770.60 \quad 772.00$

claystone, very dark gray to black, mottled; carbonaceous

2" siderite band

claystone, dark gray, mottled with slickensides; sharp contact at base

limestone, gray

Base of core 772.0'

\section{Core \#2}

Cored 784-797' - Herrin Coal Core

Herrin Coal: 789.5-793.45'

Four samples: 789.0-790.0' , 790.0-791.0', 791.0-792.3', 792.55-793.45'

Top Bottom

\section{(ft) (ft)}

$784.00 \quad 787.00$

$787.00 \quad 787.30$

$787.30 \quad 787.60$

$787.60 \quad 789.05$

$789.05 \quad 793.45$

limestone (Brereton), tan, fine grained limestone with light gray blotches; sharp contact at base claystone, gray; fossiliferous, calcareous shale, black; carbonaceous with small brachiopod fossils shale (Anna), black, laminated; pyrite lamination at base coal (Herrin), shiny, with calcareous cleat fill locally and goat's beard;

791.79: $1 / 20$ pyrite band 792.40-792.559: blue band

$793.45794 .60 \quad$ underclay, dark gray-black, mottled; becomes gray downward in 10 transition; slickensided (jammed core barrel); carbonaceous partings in underclay

Base of core $794.60^{\prime}$ 


\section{Core \#3}

Cored 888-908' Springfield Coal Core

Springfield Coal: 895.5-902.45' (6.95')

Samples: 895.5-896.5', 896.5-897.5', 897.5-898.5', 898.5-899.5', 899.5-901.5', 901.5-902.4'

Top Bottom

ft) (ft)

$888.00895 .50 \quad$ claystone, gray, fissile, some darker gray bands at 894.2-894.4' and 894.9-895.05'.

895.50 902.45 coal (Springfield, 6.9'), very sharp contact. Sampled all coal: 895.5-896.5', 896.5-897.5', 897.5-898.5', 898.5-899.5'

895.5': four $1^{\prime}$ samples

$899.5^{\prime}$ : one $2^{\prime}$ sample (can 37)

901.5-902.4': one 1' sample

$902.45903 .65 \quad$ claystone, mottled; slickensides; mud clots cling to core

$903.65908 .10 \quad$ siltstone, sandy, little limey blebs near top, grades to siltstone below; gray with near vertical, slightly inclined fracture 1.5' long; 1" tan band near base and swirly bed below this tan bed

Base of core $908.1^{\prime}$

Core \#4

Cored 995.0-1,105.7' Houchin Creek Coal Core

Excello Shale: $997.5-1,001.4^{\prime}$ and Houchin Creek Coal: 1,001.4-1,004.05'

Samples: Excello 999.6-1,000.65'; Houchin Creek 1,001.4-1,002.4', 1,002.4-1,003.4'

Top Bottom

(ft) (ft)

$995.00 \quad 995.70 \quad$ shale, dark gray

$995.70 \quad 996.90 \quad$ shale, very dark grayish becoming laminated black shale at base

$996.90 \quad 997.50 \quad$ limestone, gray; may be large concretion (?)

$997.50 \quad 1,001.40 \quad$ shale (Excello), black; laminated with $2^{\prime \prime} \times 3$ "'-diameter, round concretion with limestone core and pyrite(?); shale contains several small brachiopods

$1,001.40 \quad 1,004.05 \quad$ coal (Houchin Creek), with calcite along cleat faces, $1 / 2$ " pyrite band at very top—disseminated organic matter; some coal pulverized in coring

$1,004.05 \quad 1,005.40 \quad$ underclay, gray, mottled, slickensides; jammed in base of barrel terminating coring

Base of core 1,005.4' 


\section{Core \#5}

Cored 1,136-1,1549 Seelyville Coal Core

Seelyville Coal: $1,144.65-1,150.7^{\prime}\left(6.05^{\prime}\right)$

Samples: $1,144.65-1,145.7^{\prime}, 1,145.7-1,146.7^{\prime}, 1,146.7-1,147.7^{\prime}, 1,147.7-1,148.7^{\prime}, 1,148.7-1,150.7^{\prime}$

Top Bottom

(ft) (ft)

$1,136.001,137.10 \quad$ claystone, gray; laminated; $1-1 \frac{1}{2}$ " thick color variations; darker gray at top

$1,137.10 \quad 1,139.00 \quad$ claystone, gray and dark gray; laminated

$1,139.00 \quad 1,139.80 \quad$ siltstone, gray; laminated, clayey, with hard silty laminations

$1,139.80 \quad 1,142.20 \quad$ shale, gray to dark gray; laminated, fissile, some dark and light bands form laminations

$1,142.20 \quad 1,144.20 \quad$ siltstone, clayey, laminated, clean, fine-grained,

silty 1143.4-1143.6' interlaminated zone, set packer here-hard

1142.4-1142.6': fine silt laminations also, but more clay here

$1,144.20 \quad 1,144.35 \quad$ shale, gray; laminated

$1,144.35 \quad 1,146.50 \quad$ shale, dark olive-green; carbonaceous

1,144.65 1,150.70 coal (Seelyville), some calcite on face cleats; quite broken-up (from coring?), better cylinders downward; pyrite zones on veins, not along laminations; gradational contact at base

$1,150.701,151.15 \quad$ coal (Bone), shaly, coaly, dull shine, fissile; pyritiferous parallel to laminations; several white, fine laminations near base, transitional base over 1/4" interval

$1,151.15 \quad 1,152.90 \quad$ underclay, dark gray, silty, mottled, hard, possibly calcareous

Base of core 1,152.9' 
Table A4-7. Log tops for Gallagher Drilling, L.P. Daughters et al. \#I-1A (M-3).

\section{Coal} thickness

(ft)

$\begin{array}{rc}\begin{array}{c}\text { Top } \\ \text { (ft) }\end{array} & \begin{array}{c}\text { Bottom } \\ \text { (ft) }\end{array} \\ 325.0 & 329.0 \\ 418.0 & 421.0 \\ 529.0 & 548.0 \\ 759.0 & 762.5 \\ 763.0 & 765.5 \\ 781.0 & 785.5 \\ 785.5 & 787.5 \\ 787.5 & 792.0 \\ 802.0 & 836.0 \\ 856.5 & 858.5 \\ 877.0 & 879.0 \\ 879.0 & 882.5 \\ 882.5 & 894.0 \\ 894.0 & 901.0 \\ 992.0 & 999.0 \\ 999.0 & 1,001.75 \\ 1,008.5 & 1,010.0 \\ 1,066.5 & 1,069.0 \\ 1,069.0 & 1,070.0 \\ 1,075.0 & 1,130.0 \\ 1,142.5 & 1,149.0 \\ 1,168.0 & 1,169.5\end{array}$

\author{
Geological unit \\ Carthage Limestone \\ black shale \\ West Franklin Limestone \\ Danville Coal \\ Bankston Fork Limestone \\ Brereton Limestone \\ Anna Shale \\ Herrin Coal \\ sub-Herrin sandstone \\ Brier Hill Coal \\ St. David limestone \\ Turner Mine Shale \\ Dykersburg Shale \\ Springfield Coal \\ Excello Shale \\ Houchin Creek Coal \\ Survant Coal \\ Mecca Quarry Shal \\ Colchester Coal \\ sub-Colchester sandstone \\ Seelyville Coal \\ Carrier Mills Shale
}

Net coal 28.75' 
Table A4-8. Core description for well I-1B.

\section{CORE DESCRIPTION}

Gallagher Drilling, L.P. Daughters et al. \#I-1B

Sec 27, T1S, R14W 548S 170W, NEc, NW

Wabash County, elevation G.L. 395'

Logged by D. G. Morse, May 29, 2008

Core \#1

887.0-906.5

\section{Top Bottom \\ (ft) (ft)}

$887.0 \quad 887.8 \quad$ siltstone, gray clayey

$887.8 \quad 893.5 \quad$ claystone, gray, silty; lower 6 " has $1 / 8$ " pyrite clusters

893.5900 .2 coal (Springfield), desorption samples described:

893.5-894.5': Coleman "A" bright clarain-banded coal with abundance of vitrain layers; white cleat fillings (calcite, kaolinite, and pyrite) >2" high; calcite and pyrite-filled, spacing: $0.28,0.24$, and 0.39"; some pyrite dull on bedding planes; may be clayey, predominantly bright glassy bands of vitrain

894.5-895.5': average clarain-banded with vitrain bands to $8 \mathrm{~mm}$ (3.5”) thick, some dull fusain layers to 4 $\mathrm{mm}(1.7$ ") thick; cleats, commonly filled with calcite, less so with kaolinite, even less with pyrite; cleats spaced 0.35, 0.12, 0.31, 0.59, and 0.43"; dull bands (fusain) to 0.08 " thick

897.3-898.4': dull clarain- banded with some vitrain bands to 0.28 or 0.31 " interbedded with very fine $<0.04$ " bands, vitrain bands cleated with 0.16 " spacing; cleat filling is kaolinite and calcite; face cleats $>3$ " high; calcite and kaolinite on fractures diagonal to face cleat

898.35-899.05': vitrain - very bright, banded coal, predominantly; vitrain, fine white cleat fillings (kaolinite); cleat spacing: $0.35,0.31,0.39,0.20,0.28$ "; coal splits on horizontal dull layers (inertinite), calcite vein fills on 2" high-face cleats, no obvious minerals on butt cleats

900.2 901.3 claystone, dark gray, clotty, rooted carbonaceous claystone; increasing carbonaceous material up to coal layer; transitional to coal; contains tan calcareous nodules

$901.3 \quad 903.3 \quad$ siltstone, green-gray mottled with calcareous nodules decreasing downward

903.3 904.7 siltstone, gray siltstone with local laminae containing more clayey siltstone; vertical root casts (calcareous)

$904.7 \quad 905.2 \quad$ silt lenses; lenticular-bedded, light gray very fine sandy; with clayey silt interbeds

$905.2 \quad 906.5 \quad$ siltstone, gray clayey with inclined breaks; not slickensided

$906.5 \quad$ base of core 
Table A4-9. Log tops for Gallagher Drilling, L.P. Daughters et al. \#I-1B.

$\begin{array}{clll}\begin{array}{c}\text { Coal } \\ \text { thickness } \\ \text { (ft) }\end{array} & \begin{array}{l}\text { Top } \\ \text { (ft) }\end{array} & \begin{array}{l}\text { Bottom } \\ \text { (ft) }\end{array} & \text { Geological unit } \\ & 327.0 & 330.0 & \text { Carthage Limestone } \\ & 419.0 & 423.0 & \text { black shale } \\ & 529.0 & 550.5 & \text { West Franklin Limestone } \\ 3.7 & 761.5 & 765.2 & \text { Danville Coal } \\ & 770.2 & 774.3 & \text { Bankston Fork Limestone } \\ & 783.0 & 787.8 & \text { Brereton Limestone } \\ & 787.8 & 789.8 & \text { Anna Shale } \\ 4.4 & 789.8 & 794.2 & \text { Herrin Coal } \\ & 805.0 & 838.0 & \text { sub-Herrin sandstone } \\ & 855.7 & 857.9 & \text { Briar Hill Coal } \\ & 876.5 & 878.5 & \text { St. David limestone } \\ & 878.5 & 882.0 & \text { Turner Mine Shale } \\ & 882.0 & 895.5 & \text { Dykersburg Shale } \\ & 895.5 & 902.2 & \text { Springfield Coal } \\ & & & \text { Net coal 17.0' }\end{array}$




\section{Appendix 5. Springfield Coal Core from Each Well at Tanquary}

Whole core pictures were taken at the well site in the original split core barrel. The embedded core was from the M-2B well with the exception that the basal one foot of the I-1B core was substituted for the rubble in the basal foot of the M-2B in order to better represent the whole Springfield Coal. Embedding involved surrounding the coal with polyester resin and granular limestone in a sealable PVC pipe and then evacuating air from the pipe and allowing the resin to harden. The coal core could then be slabbed to view the bedding and coal lithotypes. The rubble and the numerous large fractures were induced by drilling.

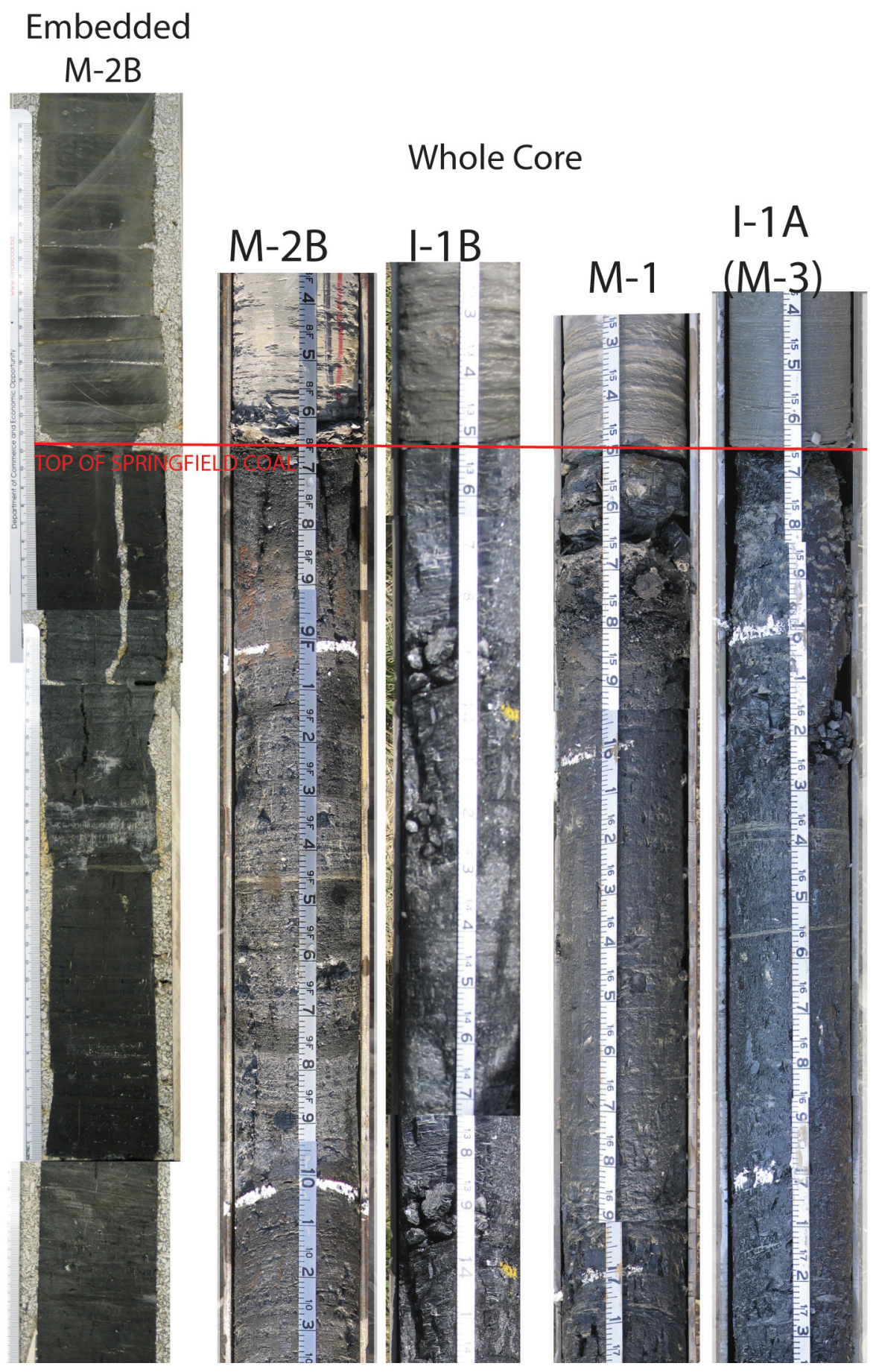




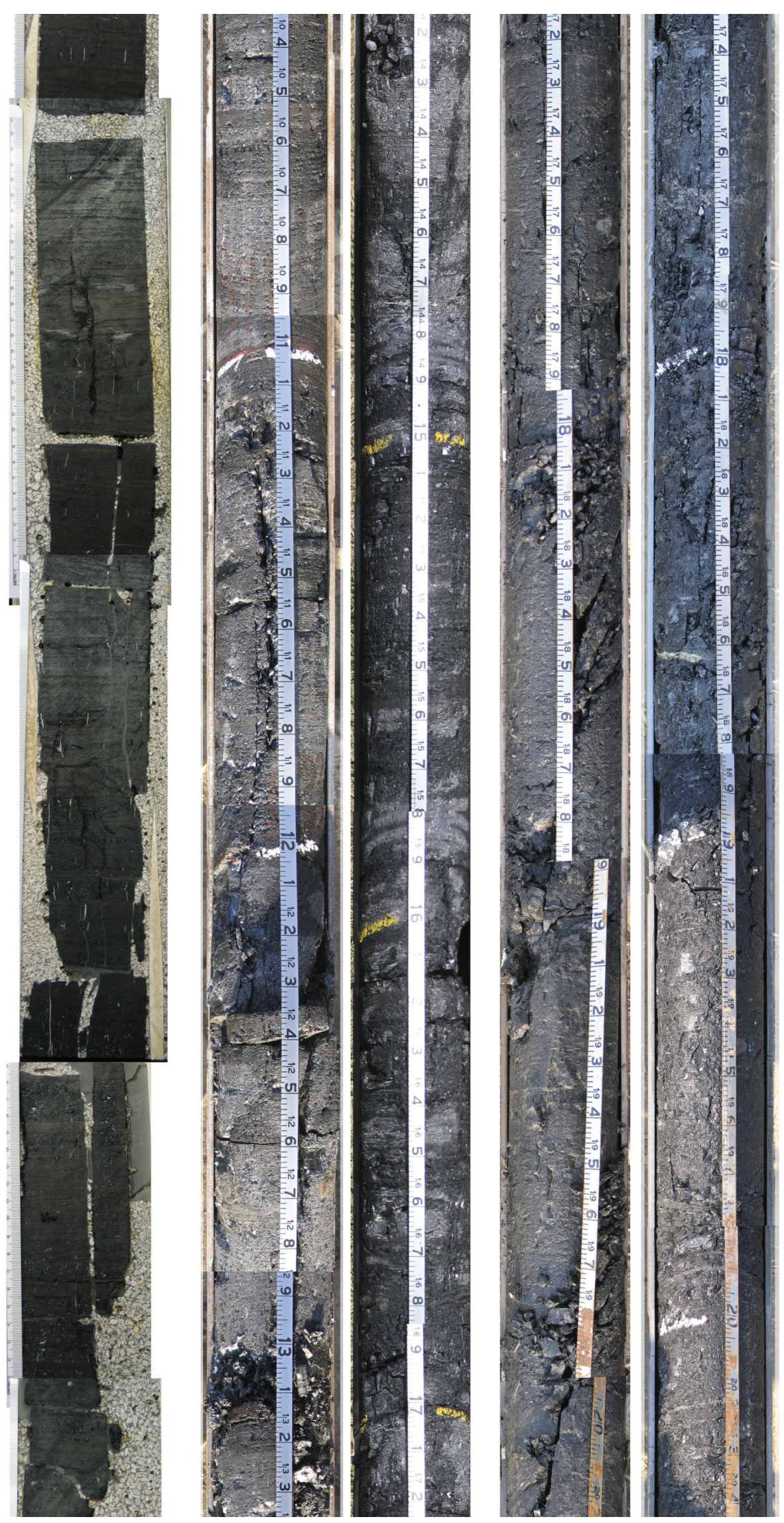



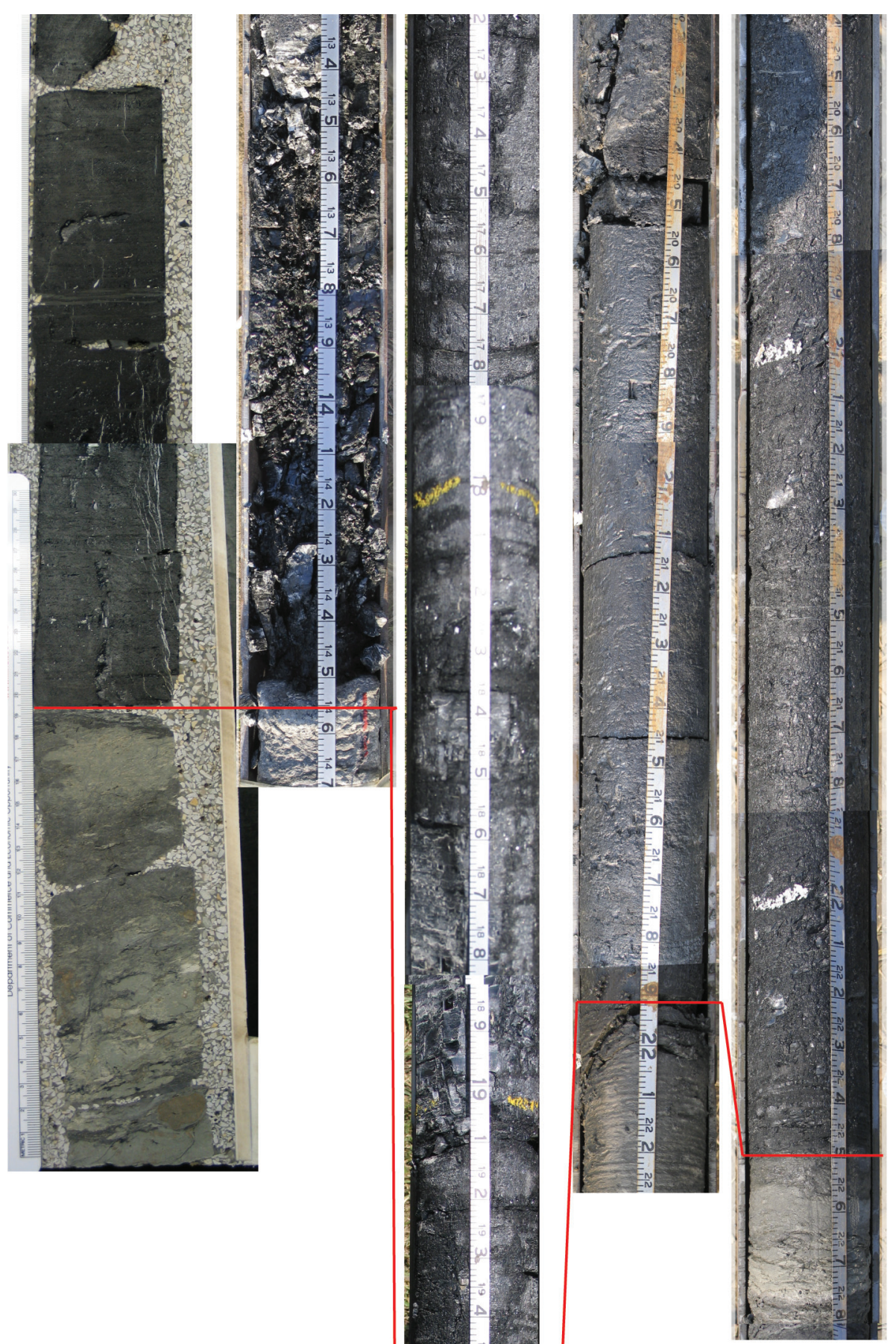

Figure A5-1. Photograph of embedded core from well $\mathrm{M}-2 \mathrm{~B}$ and whole core from well M-2B, I-1B, $\mathrm{M}-1$, and $M-3(I-1 A)$. Tape measure scale numerals are in feet and tenths of feet. Core is 3 inches wide. 


\section{Appendix 6. Experimental Details for Coal Characterization Desorbed Gas Content Measurements}

To determine the desorbed gas content of coal and shale samples, the volume of gas released from the samples that accumulated in the free space of the canisters was measured at timed intervals. The released gas was bled into a volumetric displacement apparatus, called a manometer, by opening a valve attached to the canister. The principal component of the manometer is a burette filled with sodium sulfate solution of $50 \%$ saturation to minimize dissolution of $\mathrm{CO}_{2}$ into the fluid. Time, canister pressure and temperature, barometric pressure, and ambient temperature were recorded each time the released gas volume was measured. The canisters were kept at ambient lab conditions, approximately $21^{\circ} \mathrm{C}\left(70^{\circ} \mathrm{F}\right)$. The frequency of the desorbed gas measurements depended on desorption rate and was reduced with time. Generally, measurements were made every 10 minutes during the first hour, every 15 minutes between hr 1 and 2, every 30 minutes between hr 2 and 3 , every hour between hr 3 and 6, every $2 \mathrm{hr}$ between $\mathrm{hr} 6$ and 10, and then less frequently depending on the rate of desorbed gas accumulation in the canisters. Gas desorption from samples became negligible after about 6 months. The cores were then removed from the canisters and their weight and bulk volume were measured. All relevant desorption, coal weight and volume, and canister volume data were input to a desorption analysis software application (McLennan et al., 1995) to compute desorbed and lost gas contents of each core sample of coal or shale.

\section{Residual Gas Determinations}

Samples removed from the canisters at the end of the desorption measurements were shipped to an outside lab, and a representative $100-\mathrm{g}(3.5-\mathrm{oz})$ split was ground in a sealed mill to release and capture the residual gas. The gas released from the ground coal was vented into a manometer to determine its volume. The manometer temperature and barometric pressure were then determined so that the gas volume could be corrected to standard conditions $(1$ atmosphere $=14.696$ psi $=101.3$ $\mathrm{kPa}$ and $15.5^{\circ} \mathrm{C}=60^{\circ} \mathrm{F}$ ) (Demir et al., 2004).

\section{Gas Sampling and Analysis}

Desorbed gas from each canister was periodically sampled at a port in the desorption line following the gas volume measurement procedure. The gas was collected in a pre-vacuumed serum tube with a rubber cap to which a small amount of high-vacuum silicon grease was applied in order to prevent gas leakage during storage. All gas samples were analyzed for chemical composition, and selected samples were analyzed for the carbon and hydrogen isotopic composition of the $\mathrm{CH}_{4}$ component of the gas. Chemical composition was determined by gas chromatography, and isotopic composition was determined by gas chromatography-mass spectrometry.

\section{$\mathrm{CH}_{4}, \mathrm{~N}_{2}$, and $\mathrm{CO}_{2}$ Adsorption Isotherms of Coals}

Half of the canister coal sample was crushed to $<60$ mesh after desorption. A 150- to 200-g (5.3- to 7.1-oz) representative split of the crushed sample was equilibrated with moisture according to standard procedures (ASTM, 2006) to restore its original in situ moisture, because moisture significantly affects gas adsorption by coal. The moisture-equilibrated coal was exposed to the pure gas under consideration $-\mathrm{CH}_{4}, \mathrm{~N}_{2}$, or $\mathrm{CO}_{2}$ - at a constant reservoir temperature of 20 or $23^{\circ} \mathrm{C}\left(69\right.$ or $\left.73^{\circ} \mathrm{F}\right)$ and at a series of pressures calculated to yield the desired distribution curve of equilibrium adsorption pressures. Each adsorption step consisted of charging a reference cell with the respective gas to a calculated starting pressure. After allowing for stabilization of the pressure and temperature, pressure was released from the reference vessel into the sample chamber. The resulting pressure was monitored until equilibrium was achieved. Data were analyzed using Boyle's law. Gas compressibility and changes in dead volume owing to gas adsorbing on the coal were considered in the data reduction process (McLennan et al., 1995). Langmuir parameters, $V_{L}$ and $P_{L}$, and a final isotherm curve were then prepared, showing the equilibrium gas adsorption capability at various pressures. The analysis and data collection basically followed the procedure outlined in Mavor et al. (1990).

\section{Proximate, Ultimate, and Petrographic Analysis}

Proximate and ultimate analyses were conducted according to standard procedures (ASTM, 2006). Coal composition was determined by point counting (500 points) under reflected light on a Zeiss Photoscope II. Random vitrinite reflectance ( $\mathrm{R}_{\mathrm{o}}$ ) measurements ( 25 points) were collected on each coal sample. The reported $R_{o}$ values represent the average of these percentage reflectance measurements. 


\section{Mesoporosity and Microporosity Analyses}

Low-pressure gas adsorption measurements were conducted on a Micromeritics ASAP-2020 porosimeter and surface area analyzer. Equivalent splits of coal samples weighing 1 to $2 \mathrm{~g}\left(0.04\right.$ to $0.07 \mathrm{oz}$ ) were analyzed separately with $\mathrm{N}_{2}$ and $\mathrm{CO}_{2}$ gases to obtain information about the mesopore $(2-50 \mathrm{~nm}$, accessible to both gases) and micropore structures $(<2 \mathrm{~nm}$, acces-

sible only to $\mathrm{CO}_{2}$ ). Before analysis with either $\mathrm{N}_{2}$ or $\mathrm{CO}_{2}$, the samples were automatically degassed by heating at about $110^{\circ} \mathrm{C}$ $\left(230^{\circ} \mathrm{F}\right)$ in vacuum for about $14 \mathrm{hr}$ to remove adsorbed moisture and atmospheric gases. In order to quantify $\mathrm{N}_{2}$ gas adsorption in coal, the temperature of the sample is reduced to the temperature of liquid nitrogen and incremental doses of $\mathrm{N}_{2}$ gas are admitted automatically by the computer-controlled instrument. For $\mathrm{CO}_{2}$ adsorption, the temperature of the sample is reduced to $0^{\circ} \mathrm{C}\left(32^{\circ} \mathrm{F}\right)$, and incremental doses of $\mathrm{CO}_{2}$ gas are admitted to the sample. The instrument's computer software automatically generates adsorption isotherms and calculates surface areas, pore volumes, and pore distributions based on multiple adsorption theories, including Langmuir, Brunauer-Emmett-Teller (BET), Barrett-Joyner-Halenda (BJH), DubininRadushkevich (D-R), and Dubinin-Astakhov (D-A), among others (Clarkson and Bustin, 1996, 1999; Webb and Orr, 1997). These techniques were described in detail by Gregg and Sing (1982). 


\section{Appendix 7. Proximate Analysis, Ultimate Analysis, and Vitrinite Reflectance of Springfield Coal}

Table A7-1. Proximate and ultimate analyses (weight percent) and vitrinite reflectance $\left(\mathrm{R}_{\mathrm{o}}\right)$ of the Springfield Coal samples from locations $\mathrm{M}-1, \mathrm{M}-3$ (I-1A), and I-1B.

\begin{tabular}{|c|c|c|c|c|c|c|c|c|c|c|c|c|}
\hline $\begin{array}{c}\text { Well } \\
\text { depth } \\
\text { (ft) }\end{array}$ & $\begin{array}{c}M \\
(\%)\end{array}$ & $\begin{array}{l}\text { Ash } \\
\text { (\%, } \\
\text { dry) }\end{array}$ & $\begin{array}{l}\text { HV (MJ/ } \\
\text { kg, daf) }\end{array}$ & $\begin{array}{l}\text { HV Btu/ } \\
\text { Ib (daf) }\end{array}$ & $\begin{array}{c}\mathbf{S} \\
\text { total } \\
(\%, \\
\text { dry) }\end{array}$ & $\begin{array}{l}\text { VM } \\
\text { (\%, } \\
\text { dry) }\end{array}$ & $\begin{array}{l}\text { FC } \\
\text { (\%, } \\
\text { dry) }\end{array}$ & $\begin{array}{l}\text { C (\%, } \\
\text { dry) }\end{array}$ & $\begin{array}{c}\mathbf{H} \\
\text { (\%, } \\
\text { dry) }\end{array}$ & $\begin{array}{c}\mathrm{N} \\
(\%, \\
\text { dry) }\end{array}$ & $\begin{array}{c}0 \\
(\%, \\
\text { dry) }\end{array}$ & $\begin{array}{l}R_{\circ} \\
(\%)\end{array}$ \\
\hline \multicolumn{13}{|l|}{$M-1$} \\
\hline $\begin{array}{l}895.5- \\
896.5\end{array}$ & 9.51 & 12.69 & 33.58 & 14,437 & 4.12 & 36.57 & 50.74 & 69.81 & 4.84 & 1.48 & 7.06 & 0.65 \\
\hline $\begin{array}{l}896.5- \\
897.5 \\
\end{array}$ & 10.3 & 6.51 & 34.11 & 14,666 & 1.81 & 38.99 & 54.5 & 76.97 & 5.07 & 1.67 & 7.97 & 0.63 \\
\hline $\begin{array}{l}897.5- \\
898.5\end{array}$ & 11.8 & 4.41 & 34.24 & 14,718 & 0.89 & 39.52 & 56.07 & 79.34 & 5.27 & 1.8 & 8.29 & 0.64 \\
\hline $\begin{array}{l}898.5- \\
899.5\end{array}$ & 6.23 & 5.18 & 33.76 & 14,515 & 0.87 & 39.06 & 55.76 & 78.62 & 5.2 & 1.74 & 8.39 & 0.64 \\
\hline $\begin{array}{l}899.5- \\
900.5 \\
\end{array}$ & 10.49 & 6.97 & 34.01 & 14,619 & 0.98 & 37.65 & 55.38 & 77.39 & 5.1 & 1.75 & 7.81 & 0.61 \\
\hline $\begin{array}{l}900.5- \\
901.5\end{array}$ & 10.98 & 5.94 & 33.97 & 14,605 & 1.07 & 35.24 & 58.82 & nd & nd & nd & nd & 0.63 \\
\hline $\begin{array}{l}901.5- \\
902.0\end{array}$ & 10.02 & 9.83 & 33.58 & 14,437 & 1.39 & 35.42 & 54.75 & 73.7 & 4.88 & 1.7 & 8.5 & 0.63 \\
\hline Average & 9.9 & 7.36 & 33.89 & 14,571 & 1.59 & 37.49 & 55.15 & 75.97 & 5.06 & 1.69 & 8 & 0.63 \\
\hline \multicolumn{13}{|l|}{$M-3$} \\
\hline $\begin{array}{l}895.5- \\
896.5\end{array}$ & 8.71 & 13.82 & 33.51 & 14,406 & 3.91 & 36.41 & 49.76 & nd & nd & nd & nd & 0.58 \\
\hline $\begin{array}{l}896.5- \\
897.5\end{array}$ & 9.4 & 4.55 & 32.6 & 14,685 & 1.35 & 39.18 & 56.27 & nd & nd & nd & nd & 0.63 \\
\hline $\begin{array}{l}897.5- \\
898.5 \\
\end{array}$ & 9.52 & 6.06 & 32.04 & 14,664 & 2.55 & 38.67 & 55.27 & nd & nd & nd & nd & 0.6 \\
\hline $\begin{array}{l}898.5- \\
899.5\end{array}$ & 9.66 & 5.4 & 32.26 & 14,662 & 0.95 & 37.13 & 57.47 & nd & nd & nd & nd & 0.63 \\
\hline $\begin{array}{l}901.5- \\
902.5\end{array}$ & 10.79 & 11.43 & 30.11 & 14,618 & 1.09 & 33.3 & 55.26 & nd & nd & nd & nd & 0.63 \\
\hline Average & 9.62 & 8.25 & 32.1 & 13,607 & 1.97 & 36.94 & 54.81 & & & & & 0.61 \\
\hline \multicolumn{13}{|l|}{ I-1B } \\
\hline $\begin{array}{l}893.5- \\
894.5\end{array}$ & 9.76 & 9.1 & 31.02 & 14,670 & 2.29 & 36.77 & 54.13 & nd & nd & nd & nd & 0.65 \\
\hline $\begin{array}{l}894.5- \\
895.5\end{array}$ & 9.84 & 5.75 & 31.93 & 14,563 & 2.54 & 35.81 & 58.44 & nd & nd & nd & nd & 0.66 \\
\hline $\begin{array}{l}897.4- \\
898.4\end{array}$ & 10.88 & 5.87 & 31.95 & 14,592 & 0.79 & 35.65 & 58.48 & nd & nd & nd & nd & 0.7 \\
\hline $\begin{array}{l}898.4- \\
899.1\end{array}$ & 10.84 & 6.15 & 31.88 & 14,604 & 0.9 & 34.74 & 59.12 & nd & nd & nd & nd & 0.68 \\
\hline Average & 10.15 & 6.72 & 31.7 & 14,607 & 1.63 & 35.74 & 57.54 & nd & nd & nd & nd & 0.67 \\
\hline
\end{tabular}




\section{Appendix 8. Gas Content of Coal and Shale Samples}

Table A8-1. Gas content of Tanquary Project coal and shale samples. All data were collected at $15.5^{\circ} \mathrm{C}\left(60^{\circ} \mathrm{F}\right)$ and $101.3 \mathrm{kPa}(1 \mathrm{~atm})$.

\begin{tabular}{|c|c|c|c|}
\hline $\begin{array}{c}\text { Unit and } \\
\text { well }\end{array}$ & Can & Depth (ft) & $\begin{array}{l}\text { Desorpt } \\
\text { (ml) }\end{array}$ \\
\hline$M-1$ & 32 & $895.5-896.5$ & \\
\hline $\mathrm{M}-1$ & 18 & $896.5-897.5$ & 2,2 \\
\hline \multicolumn{4}{|c|}{ Springfield } \\
\hline$M-1$ & 31 & $897.5-898.5$ & 1,4 \\
\hline$M-1$ & 12 & $898.5-899.5$ & \\
\hline$M-1$ & 17 & $899.5-900.5$ & 6,6 \\
\hline \multirow[t]{2}{*}{$M-1$} & ISGS/ & & \\
\hline & IGS-86 & $900.5-901.5$ & 5,5 \\
\hline$M-1$ & 13 & $901.5-902$ & \\
\hline $\mathrm{I}-1 \mathrm{~A}$ & $\mathrm{C}-1$ & $895.5-896.5$ & 6,8 \\
\hline $\mathrm{I}-1 \mathrm{~A}$ & $\mathrm{C}-2$ & $896.5-897.5$ & 7,3 \\
\hline $\mathrm{I}-1 \mathrm{~A}$ & $\mathrm{C}-3$ & $897.5-898.5$ & 7,1 \\
\hline $\mathrm{I}-1 \mathrm{~A}$ & C-4 & $898.5-899.5$ & \\
\hline $\mathrm{I}-1 \mathrm{~A}$ & Spr-6 & $899.5-901.5$ & 5,4 \\
\hline $\mathrm{I}-1 \mathrm{~A}$ & C-5 & $901.5-902.5$ & 5,9 \\
\hline $\mathrm{I}-1 \mathrm{~B}$ & Colmn-A & $893.5-894.5$ & \\
\hline $\mathrm{l}-1 \mathrm{~B}$ & Colmn-B & $894.5-895.5$ & \\
\hline $\mathrm{I}-1 \mathrm{~B}$ & A-2 & $897.5-898.35$ & 6,4 \\
\hline I-1B & $A-1$ & 898.35-899.05 & 4,7 \\
\hline \multicolumn{4}{|l|}{ Seelyville } \\
\hline$M-1$ & 34 & $1,144.65-1,145.65$ & 2,8 \\
\hline$M-1$ & $\begin{array}{l}\text { ISGS/ } \\
\text { IGS-10 }\end{array}$ & $1,145.65-1,146.65$ & \\
\hline$M-1$ & 23 & $1,146.65-1,147.65$ & 1,4 \\
\hline$M-1$ & 25 & $1,147.65-1,148.65$ & \\
\hline$M-1$ & 35 & $1,148.65-1,149.65$ & 6,2 \\
\hline$M-1$ & 9 & $1,149.65-1,150.65$ & 2,8 \\
\hline \multicolumn{4}{|l|}{ Danville } \\
\hline I-1A & B1 & $760.5-761.5$ & \\
\hline $\mathrm{I}-1 \mathrm{~A}$ & B2 & $671.5-672.5$ & \\
\hline $\mathrm{I}-1 \mathrm{~A}$ & B3 & $762.5-763.5$ & 5,4 \\
\hline \multicolumn{4}{|l|}{ Herrin } \\
\hline I-1A & B4 & $789-790$ & 4,5 \\
\hline $\mathrm{I}-1 \mathrm{~A}$ & B5 & $790-791$ & 4,5 \\
\hline $\mathrm{I}-1 \mathrm{~A}$ & D1 & $791-792.3$ & 6,3 \\
\hline I-1A & D2 & $792.55-793.45$ & \\
\hline \multicolumn{4}{|c|}{ Excello Shale } \\
\hline I-1A & D5 & $999.6-1,000.65$ & 4,3 \\
\hline \multicolumn{4}{|c|}{ Houchin Creek } \\
\hline $\mathrm{I}-1 \mathrm{~A}$ & D3 & $1,001.4-1,002.4$ & 5,1 \\
\hline $\mathrm{I}-1 \mathrm{~A}$ & D4 & $1,002.4-1,003.4$ & 4,5 \\
\hline \multicolumn{4}{|l|}{ Seelyville } \\
\hline I-1A & $\mathrm{A} 1$ & $1,144.65-1,145.6$ & \\
\hline $\mathrm{I}-1 \mathrm{~A}$ & $\mathrm{~A} 2$ & $1,145.7-1,146.7$ & 3,9 \\
\hline $\mathrm{I}-1 \mathrm{~A}$ & A3 & $1,146.7-1,147.7$ & 4,6 \\
\hline $\mathrm{I}-1 \mathrm{~A}$ & A4 & $1,147.7-1,148.7$ & 5,8 \\
\hline $\mathrm{I}-1 \mathrm{~A}$ & IGS-38 & $1,148-1,150.7$ & \\
\hline
\end{tabular}

\begin{tabular}{|c|c|c|c|c|c|}
\hline & $\begin{array}{l}\text { USBM }^{1} \\
\text { air-dry } \\
\text { as } \\
\text { received } \\
\text { (scf/ton) }\end{array}$ & $\begin{array}{l}\text { Lost } \\
\text { gas, air } \\
\text { air dry } \\
\text { received } \\
\text { (scf/ton) }\end{array}$ & $\begin{array}{l}\text { Residual } \\
\text { air dry as } \\
\text { received } \\
\text { / USBM } \\
\text { (scf/ton) }\end{array}$ & $\begin{array}{l}\text { Total, air } \\
\text { dry as } \\
\text { received } \\
\text { / USBM } \\
\text { (scf/ton) }\end{array}$ & $\begin{array}{c}\text { Total, } \\
\text { daf } \\
\text { basis } \\
\text { / USBM }\end{array}$ \\
\hline
\end{tabular}

Notes

\section{(2)}

\begin{tabular}{|c|c|c|c|c|}
\hline 84.0 & 5.8 & 25.5 & 115.3 & 153.3 \\
\hline 43.9 & 6.8 & 125 & 63.2 & 83.5 \\
\hline
\end{tabular}

little leak at times

$\begin{array}{rrrrrr}139.9 & 7.9 & 13.0 & 160.8 & 200.1 & 201.9\end{array}$

$31.2-15.9-100$

134.9

59.9

$\begin{array}{rr}74.0 & 74.7 \\ 208.4 & 210.8\end{array}$

Leak

little leak

at times

$5,555 \quad 111$

$\begin{array}{lll}111.2 & 2.9 & 24.0 \\ 130.6 & 0.0 & 10.9\end{array}$

125.7

138.2

146.1

121.5

cut off

6.3
7.5

$9.8 \quad 8.0$

$5.0 \quad 6.2$

17.7
-1

101.6

10
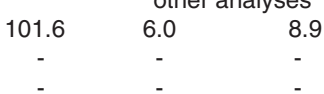

116.1

$\begin{array}{lll}130.2 & 6.9 & 17.5\end{array}$

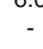

$-$

7.0

-

134.2

$\begin{array}{lll}141.5 & 179.8 & 186.9\end{array}$

$\begin{array}{lll}153.7 & 177.7 & 179.8\end{array}$

$162.1 \quad 190.7 \quad 194.7$

$\begin{array}{lll}144.2 & 168.7 & 170.4\end{array}$

$\begin{array}{llllll}59.4 & 9.0 & 16.0 & 84.4 & 109.7 & 118.5\end{array}$

$\begin{array}{llllll}107.6 & 5.1 & 10.7 & 123.4 & 128.7 & 133.3\end{array}$

$\begin{array}{llllll}35.3 & 7.4 & 17.6 & 60.3 & 70.8 & 73.4\end{array}$

$\begin{array}{llllll}135.8 & 10.4 & 18.9 & 165.1 & 196.2 & 202.1\end{array}$

$\begin{array}{llllll}114.8 & 11.2 & 26.0 & 152.0 & 198.5 & 214.2\end{array}$

$\begin{array}{llllll}58.3 & 8.2 & 17.0 & 83.5 & 98.6 & 102.4\end{array}$

Leak

$\begin{array}{rrrrrr}80.8 & 2.1 & 15.8 & 98.7 & 129.6 & 135.2\end{array}$

$\begin{array}{llllll}101.9 & 1.3 & 12.6 & 115.8 & 140.3 & 143.9\end{array}$

$\begin{array}{llllll}93.9 & 1.5 & 16.2 & 111.6 & 140.7 & 145\end{array}$

$\begin{array}{llllll}85.9 & 1.5 & 17.1 & 104.5 & 122.5 & 125.7\end{array}$

$\begin{array}{llllll}86.0 & 2.4 & 10.3 & 98.7 & 124 & 127.4\end{array}$

$\begin{array}{llllll}114.2 & 4.8 & 11.4 & 130.4 & 156.3 & 160.2\end{array}$

$\begin{array}{llllll}110.6 & 3.8 & 16.3 & 130.7 & 171.4 & 178.4\end{array}$

$\begin{array}{rrrrrr}49.8 & 2.5 & 1.3 & 53.6 & 161.3 & 197.1 \\ 89.6 & 4.2 & 14.9 & 108.7 & 124.9 & 127.5\end{array}$

$\begin{array}{rrrrrr}89.6 & 4.2 & 14.9 & 108.7 & 124.9 & 127.5 \\ 74.8 & 3.9 & 11.5 & 90.2 & 120.3 & 124.3\end{array}$

$\begin{array}{llllll}90.6 & 5.5 & 12.3 & 108.4 & 131.4 & 137.9\end{array}$

$\begin{array}{lrrrrr}73.6 & 4.2 & 11.7 & 89.5 & 111.2 & 115\end{array}$

$\begin{array}{rrrrrr}86.2 & 5.6 & 10.0 & 101.8 & 120.6 & 124.8 \\ 108.7 & 6.2 & 7.0 & 121.9 & 145.4 & 149.4\end{array}$

discontinued after 4 days, sent to SIU for other analyses

${ }^{1}$ Abbreviation: USBM, United States Bureau of Mines. 


\section{Appendix 9. Desorbed Coal Gas Composition}

Table A9-1. Composition of desorbed gases from selected coal samples from well M-1.

\begin{tabular}{|c|c|c|c|c|c|c|c|}
\hline Depth & $\mathbf{C H}_{4}$ & $\mathbf{C O}_{2}$ & $\mathbf{C}_{2}$ & $\mathbf{C}_{3}$ & $\mathbf{i C}_{4}$ & $\mathbf{N}$ & $\mathbf{C 1 / ( C 2 + C 3 )}$ \\
\hline $895.5-896.5$ & 96.735 & 1.29 & 0.235 & 0 & 0 & 1.745 & 412 \\
\hline $896.5-897.5$ & 86.3 & 1.39 & 0.4 & 0 & 0 & 11.92 & 218 \\
\hline $897.5-898.5$ & 96.38 & 0.67 & 0.31 & 0 & 0 & 2.65 & 311 \\
\hline $898.5-899.5$ & 81.05 & 1.18 & 0.37 & 0 & 0 & 17.41 & 219 \\
\hline $899.5-900.5$ & 88.88 & 0.64 & 0.35 & 0.05 & 0 & 10.09 & 228 \\
\hline $901.5-902.0$ & 98.05 & 0.35 & 0.23 & 0 & 0 & 1.37 & 426 \\
\hline Average & $\mathbf{9 1 . 2 3}$ & $\mathbf{0 . 9 2}$ & $\mathbf{0 . 3 1}$ & $\mathbf{0 . 0 1}$ & $\mathbf{0}$ & $\mathbf{7 . 5 3}$ & $\mathbf{3 0 2}$ \\
\hline
\end{tabular}




\section{Appendix 10. Langmuir Parameters of Coal Samples Run for High-Pressure Isotherms}

Table A10-1. Langmuir parameters for $\mathrm{CO}_{2}, \mathrm{CH}_{4}$, and $\mathrm{N}_{2}$ of the coal samples run for high-pressure isotherms.

\begin{tabular}{|c|c|c|c|c|c|c|c|c|}
\hline \multirow{2}{*}{$\begin{array}{l}\text { Coal seam, } \\
\text { well, } \\
\text { depth (ft) }\end{array}$} & \multicolumn{8}{|c|}{ Langmuir Parameters: $\mathrm{CO}_{2}$} \\
\hline & $\begin{array}{c}\text { Volume } \\
\text { (scf/ton, } \\
\text { as-received) }\end{array}$ & $\begin{array}{l}\text { Volume- } \\
\text { (scm/g, as } \\
\text { received) }\end{array}$ & $\begin{array}{c}\text { Volume } \\
\text { (scf/ton, daf) }\end{array}$ & $\begin{array}{c}\text { Volume } \\
\text { (scm/g, daf) }\end{array}$ & $\begin{array}{c}\text { Pressure } \\
\text { (PSIA, } \\
\text { as-received) }\end{array}$ & $\begin{array}{c}\text { Pressure } \\
\text { (MPa, } \\
\text { as-received) }\end{array}$ & $\begin{array}{c}\text { Temperature } \\
\left({ }^{\circ} \mathrm{F}\right)\end{array}$ & $\begin{array}{c}\text { Temperature } \\
\left({ }^{\circ} \mathrm{C}\right)\end{array}$ \\
\hline \multicolumn{9}{|l|}{ Springfield } \\
\hline I-1B, 893.5 & 1057 & 33.0 & 1,324 & 41.4 & 320 & 2.20 & 69 & 20.6 \\
\hline I-1B, 894.5 & 1175 & 36.7 & 1,380 & 43.1 & 329 & 2.26 & 69 & 20.6 \\
\hline I-1B, 897.3 & 1178 & 36.8 & 1,401 & 43.8 & 303 & 2.09 & 69 & 20.6 \\
\hline I-1B, 898.4 & 1152 & 36.0 & 1,381 & 43.2 & 316 & 2.18 & 69 & 20.6 \\
\hline \multirow[t]{2}{*}{$M-1,900.5$} & 767 & 24.0 & 958 & 29.9 & 187 & 1.29 & 73 & 22.8 \\
\hline & \multicolumn{8}{|c|}{ Langmuir Parameters: $\mathrm{CH}_{4}$} \\
\hline M-3, 895.5 & 353 & 11.0 & 442 & 13.8 & 395 & 2.72 & 68 & 20.0 \\
\hline M-3, 896.5 & 410 & 12.8 & 470 & 14.7 & 411 & 2.83 & 68 & 20.0 \\
\hline M-3, 897.5 & 405 & 12.7 & 464 & 14.5 & 393 & 2.71 & 68 & 20.0 \\
\hline M-3, 898.5 & 416 & 13.0 & 474 & 14.8 & 437 & 3.01 & 68 & 20.0 \\
\hline M-3, 901.5 & 383 & 12.0 & 466 & 14.6 & 408 & 2.81 & 68 & 20.0 \\
\hline I-1B, 893.5 & 390 & 12.2 & 488 & 15.3 & 489 & 3.37 & 69 & 20.6 \\
\hline I-1B, 894.5 & 423 & 13.2 & 497 & 15.5 & 476 & 3.28 & 69 & 20.6 \\
\hline I-1B, 897.3 & 412 & 12.9 & 490 & 15.3 & 433 & 2.99 & 69 & 20.6 \\
\hline I-1B, 898.4 & 397 & 12.4 & 476 & 14.9 & 449 & 3.10 & 69 & 20.6 \\
\hline$M-1,900.5$ & 347 & 10.8 & 433 & 13.5 & 353 & 2.43 & 69 & 20.6 \\
\hline \multirow[t]{2}{*}{$M-1,900.5$} & 309 & 9.7 & 386 & 12.1 & 360 & 2.48 & 73 & 22.8 \\
\hline & \multicolumn{8}{|c|}{ Langmuir Parameters: $\mathrm{N}_{2}$} \\
\hline M-1 900.5 & 186 & 5.8 & 208 & 6.5 & 788 & 5.43 & 73 & 22.8 \\
\hline Other Coals & \multicolumn{8}{|c|}{ Langmuir Parameters: $\mathrm{CH}_{4}$} \\
\hline $\begin{array}{l}\text { Danville-1, M-3, } \\
760.5\end{array}$ & 321.7 & 10.1 & 415.4 & 13.0 & 431.1 & 2.97 & 68 & 20.0 \\
\hline $\begin{array}{l}\text { Danville-2, M-3, } \\
761.5\end{array}$ & 363.0 & 11.3 & 436.2 & 13.6 & 409.9 & 2.82 & 68 & 20.0 \\
\hline $\begin{array}{l}\text { Danville-3, M-3, } \\
762.5\end{array}$ & 333.1 & 10.4 & 415.0 & 13.0 & 442.3 & 3.05 & 68 & 20.0 \\
\hline $\begin{array}{l}\text { Herrin-1, M-3, } \\
789.0\end{array}$ & 367.3 & 11.5 & 435.7 & 13.6 & 480.6 & 3.31 & 68 & 20.0 \\
\hline $\begin{array}{l}\text { Herrin-2, M-3, } \\
789.0\end{array}$ & 374.0 & 11.7 & 458.3 & 14.3 & 459.7 & 3.17 & 68 & 20.0 \\
\hline $\begin{array}{l}\text { Herrin-3, M-3, } \\
791.0\end{array}$ & 395.6 & 12.4 & 475.4 & 14.8 & 528.9 & 3.64 & 68 & 20.0 \\
\hline $\begin{array}{l}\text { Herrin-4, M-3, } \\
795.55\end{array}$ & 374.3 & 11.7 & 480.8 & 15.0 & 523.3 & 3.60 & 68 & 20.0 \\
\hline $\begin{array}{l}\text { Seelyville-2, M-3, } \\
1145.7\end{array}$ & 311.5 & 9.7 & 466.5 & 14.6 & 477.4 & 3.29 & 68 & 20.0 \\
\hline $\begin{array}{l}\text { Seelyville-3, M-3, } \\
1,146.7\end{array}$ & 355.8 & 11.1 & 426.4 & 13.3 & 457.5 & 3.15 & 68 & 20.0 \\
\hline $\begin{array}{l}\text { Seelyville-4, M-3, } \\
1,147.7\end{array}$ & 341.1 & 10.6 & 392.8 & 12.3 & 409.4 & 2.82 & 68 & 20.0 \\
\hline
\end{tabular}




\section{Appendix 11. Coal Micropore and Mesopore Characteristics}

Table A11-1. Micropore and mesopore characteristics of the coal samples from wells M-1 and M-3 (I-1A).

\begin{tabular}{|c|c|c|c|c|c|c|c|}
\hline \multirow[b]{2}{*}{ Depth (ft) } & \multicolumn{3}{|c|}{$\mathrm{N}_{2}$ adsorption } & \multicolumn{4}{|c|}{$\mathrm{CO}_{2}$ adsorption } \\
\hline & $\begin{array}{c}\text { BET }^{1} \\
\text { surface } \\
\text { area } \\
\left(\mathrm{m}^{2} / \mathrm{g}\right)\end{array}$ & $\begin{array}{c}\text { BJH } \\
\text { adsorption } \\
\text { mesopore } \\
\text { volume } \\
\left(\mathrm{cm}^{3} / \mathrm{g}\right)\end{array}$ & $\begin{array}{c}\text { Mesopore } \\
\text { size } \\
(\mathrm{nm})\end{array}$ & $\begin{array}{c}\text { D-R } \\
\text { monolayer } \\
\text { capacity } \\
\left(\mathrm{cm}^{3} / \mathrm{g}\right)\end{array}$ & $\begin{array}{c}\text { D-R } \\
\text { micropore } \\
\text { surface area } \\
\left(\mathrm{m}^{2} / \mathrm{g}\right)\end{array}$ & $\begin{array}{c}\text { D-A } \\
\text { micropore } \\
\text { volume } \\
\left(\mathrm{cm}^{3} / \mathrm{g}\right)\end{array}$ & $\begin{array}{l}\text { Micropore } \\
\text { size }(\mathrm{nm})\end{array}$ \\
\hline \multicolumn{8}{|l|}{ M-1 } \\
\hline 895.5-896.5 & 7.7 & 0.011566 & 6.60 & 25.2 & 115.0 & 0.050191 & 1.37 \\
\hline 896.5-897.5 & 19.8 & 0.023952 & 5.52 & 24.7 & 112.9 & 0.049884 & 1.35 \\
\hline $897.5-898.5$ & 24.8 & 0.025422 & 4.86 & 27.1 & 123.8 & 0.054539 & 1.37 \\
\hline 898.5-899.5 & 28.5 & 0.027578 & 4.65 & 31.5 & 144.1 & 0.063096 & 1.37 \\
\hline 899.5-900.5 & 29.5 & 0.028834 & 4.65 & 30.5 & 139.4 & 0.062581 & 1.37 \\
\hline $900.5-901.5$ & 31.2 & 0.029227 & 4.51 & 32.0 & 146.1 & 0.064865 & 1.38 \\
\hline $901.5-902.0$ & 25.6 & 0.025372 & 4.73 & 30.1 & 137.6 & 0.061160 & 1.38 \\
\hline Average & 23.9 & 0.024564 & 5.07 & 28.7 & 131.3 & 0.058050 & 1.37 \\
\hline \multicolumn{8}{|l|}{ M-3 } \\
\hline $895.5-896.5$ & 9.3 & 0.012037 & 5.84 & 24.8 & 113.3 & 0.050460 & 1.37 \\
\hline $896.5-897.5$ & 9.3 & 0.014393 & 6.83 & 26.3 & 120.1 & 0.051404 & 1.37 \\
\hline 897.5-898.5 & 8.9 & 0.013216 & 6.53 & 27.1 & 123.7 & 0.054282 & 1.37 \\
\hline 898.5-899.5 & 12.7 & 0.014491 & 5.26 & 29.9 & 136.8 & 0.060561 & 1.37 \\
\hline 899.5-901.5 & 31.9 & 0.029405 & 5.02 & 29.4 & 136.5 & 0.062854 & 1.37 \\
\hline $901.5-902.5$ & 18.5 & 0.019645 & 4.96 & 29.9 & 136.5 & 0.058831 & 1.38 \\
\hline Average & 15.1 & 0.017198 & 5.65 & 27.9 & 127.8 & 0.056399 & 1.37 \\
\hline
\end{tabular}

${ }^{1}$ Abbreviations: BET, Brunauer-Emmett-Teller; BJH, Barrett-Joyner-Halenda; D-R, Dubinin-Radushkevich; D-A, Dubinin-Astakhov. 


\section{Appendix 12. Langmuir Parameters for $\mathrm{CO}_{2}$ in Coal Lithotypes}

Table A12-1. Langmuir parameters for $\mathrm{CO}_{2}$ of isolated lithotype samples of Springfield Coal from well I-1B at $20.6^{\circ} \mathrm{C}\left(69^{\circ} \mathrm{F}\right)$.

\begin{tabular}{|c|c|c|c|c|c|c|}
\hline $\begin{array}{c}\text { Lithotype I-1B } \\
\text { Springfield }\end{array}$ & $\begin{array}{c}\text { Volume } \\
\text { (scf/ton, as } \\
\text { received) }\end{array}$ & $\begin{array}{c}\text { Volume } \\
\text { (scm/g, as } \\
\text { received) }\end{array}$ & $\begin{array}{c}\text { Volume } \\
\text { (scf/ton, } \\
\text { daf) }\end{array}$ & $\begin{array}{c}\text { Volume } \\
\text { (cm } \mathbf{3} / \mathbf{g}, \\
\text { daf) }\end{array}$ & $\begin{array}{c}\text { Pressure } \\
\text { (psia, as } \\
\text { received) }\end{array}$ & $\begin{array}{c}\text { Pressure } \\
\text { (MPa, } \\
\text { as } \\
\text { received) }\end{array}$ \\
\hline Vitrain & 744 & 23.3 & 853 & 26.7 & 248 & 1.71 \\
\hline Bright clarain & 969 & 30.3 & 1,113 & 34.8 & 242 & 1.67 \\
\hline Clarain & 914 & 28.6 & 1,029 & 32.2 & 222 & 1.53 \\
\hline Fusain & 677 & 21.2 & 807 & 25.2 & 406 & 2.8 \\
\hline
\end{tabular}




\section{Appendix 13. Pressure Transient Analysis Equipment and Modeling Water Injection Equipment}

Gallagher Drilling designed and built the water pump skid (Appendix Figure 13-1). The skid consisted of a pump attached to a DC motor that was controlled by a drive system (Appendix Figure 13-2).

The pump was a Cat Pumps Model 230, a three-frame reciprocating plunger pump that operated at 1,725 rpm and had a maximum flow rate of $12.5 \mathrm{~m}^{3} / \mathrm{d}(2.3 \mathrm{gpm})$. At the maximum flow rate, the pump required 0.12 to $1.79 \mathrm{~kW}$ ( 0.16 to $\left.2.4 \mathrm{hp}\right)$ for its pressure range of 0.7 to $10.3 \mathrm{MPa}$ (100 to 1,500 psi). The pump drew water out of a large, cylindrical plastic tank and sent it into the well. Inlet port size was $1.27 \mathrm{~cm}(0.5 \mathrm{inch})$, and discharge port size was $0.940 \mathrm{~cm}(0.37 \mathrm{inch})$.

The pump was driven by a 1.5-kW (2-hp), 24-V DC motor from Ohio Motor, model D-561562X8877A. This motor was attached to a KB Electronics KBPC-240D (9338H) FNFP drive system, which controlled speed and torque. A panel-mounted Extech 461960 tachometer with a 0.1-rpm resolution and 1-sec sampling time displayed rotation speed. A Lenz mechanical pressure gauge with a 13.8-MPa (2,000-psi) maximum pressure was also mounted on the panel.

The flow line downstream of the pump was fitted with a Hedland 1.3-cm (0.5-in) brass flow meter (model H605B-002-MR) to measure $\mathrm{H}_{2} \mathrm{O}$ injection rate and a Cameron 1-cm (0.375-inch) stainless steel NuFlo liquid turbine meter to confirm the flow rate. The Hedland flow meter had a flow range of $1.43-10.8 \mathrm{~m}^{3} / \mathrm{d}(0.26-2.0 \mathrm{gpm})$ and a maximum pressure of $24.1 \mathrm{MPa}(3,500$ psi). The turbine meter had a flow range of $1.6-16 \mathrm{~m}^{3} / \mathrm{d}(0.3-3 \mathrm{gpm})$ and a pressure drop of $28 \mathrm{kPa}(4.0 \mathrm{psi})$ at maximum flow. The turbine meter was also equipped with a NuFlo MC-III WP Flow Analyzer for data measurement (including measurement of injection rates and total amount of liquid injected) and logging.

\section{Pressure Transient Analyses: COMET3 Modeling and Baseline Water Injection Calibration Plots}

The reservoir simulator used for the study was the COMET3 (binary isotherm: $\mathrm{CH}_{4}$ and $\mathrm{CO}_{2}$ ) model. Details on the model theory are provided in the references (Sawyer et al, 1990; Paul et al., 1990; Reeves et al., 2003; Reeves and Oudinot, 2005; Palmer and Reeves, 2007). Theoretical and experimental studies investigating the effects of stress on coal permeability have been reported in the literature and indicate that coal swelling and permeability reduction occurs when $\mathrm{CO}_{2}$ replaces $\mathrm{CH}_{4}$ in the reservoir. Some theoretical models have been developed to estimate the variables that control changes in permeability as a function of pressure and gas concentration.

More specifically, analytical models relating coal permeability to pore volume compressibility $\left(\mathrm{C}_{\mathrm{p}}\right)$, matrix compressibility $\left(\mathrm{C}_{\mathrm{m}}\right)$, and differential swelling factor $\left(\mathrm{C}_{\mathrm{k}}\right)$ as well as the cubic relationship between permeability and porosity have been developed. Such a formulation has been implemented into COMET3 and, hence, adequately represents the coal behavior during depletion and enhanced production.

An example of the coal swelling process can be given using Appendix Figure A13-3. Beginning with an initial pressure of 11.0 MPa (1,600 psia), the reservoir is first dewatered. As water leaves the fractures, the reservoir is being depleted, and reservoir pressure decreases. Under this dewatering process, no resisting force opposes fracture closure; thus, fracture permeability decreases. This phenomenon is controlled in the model by the pore volume compressibility-Cp.

As soon as $\mathrm{CO}_{2}$ is injected (Appendix Figure A13-3) at $8.27 \mathrm{MPa}(1,200 \mathrm{psi})$, it is preferentially adsorbed on the coal surface and saturates the coal. Composition of the reservoir gas changes from $\mathrm{CH}_{4}$ to $\mathrm{CO}_{2}$. This gas change is illustrated by the "displace with $\mathrm{CO}_{2}$ " arrow on Appendix Figure A13-3, resulting in the reservoir's permeability dropping as it goes from the $\mathrm{CH}_{4}$ isotherm (in red) to the $\mathrm{CO}_{2}$ isotherm (in blue). Then, depending on the coal rank and capacity ratio, $\mathrm{CO}_{2}$ adsorption induces the matrix to expand or "swell", closing the fractures and ultimately decreasing permeability drastically, a phenomenon controlled by the matrix compressibility $\mathrm{C}_{\mathrm{m}}$.

Baseline (pre- $\mathrm{CO}_{2}$ ) water injection calibration plots are shown in Appendix Figures A13-3 to A13-7. 

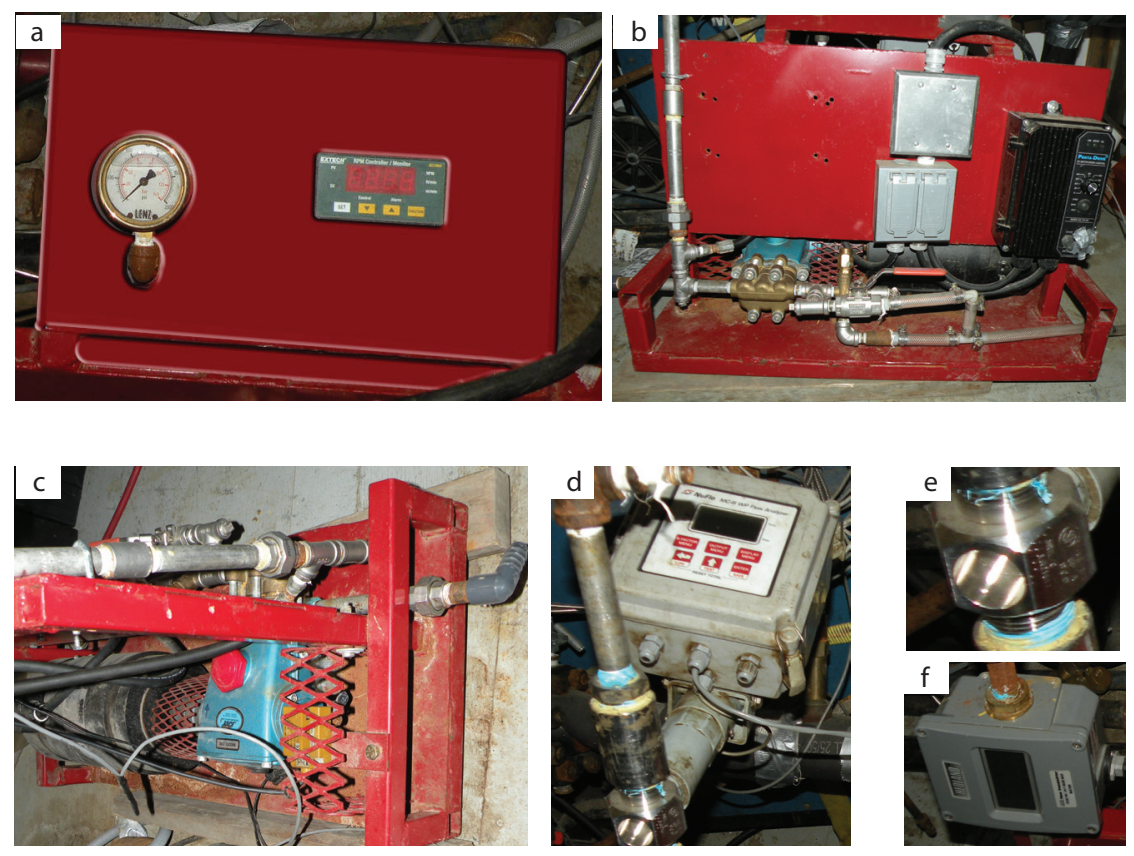

Figure A13-1. Components of water injection equipment. (a) Front of instrument panel showing mechanical pressure gauge and tachometer. (b) Rear of instrument panel showing drive system. (c) Overhead view of motor. d) Flow analyzer. e) Liquid turbine flowmeter. (f) Brass flow meter and transmitter.

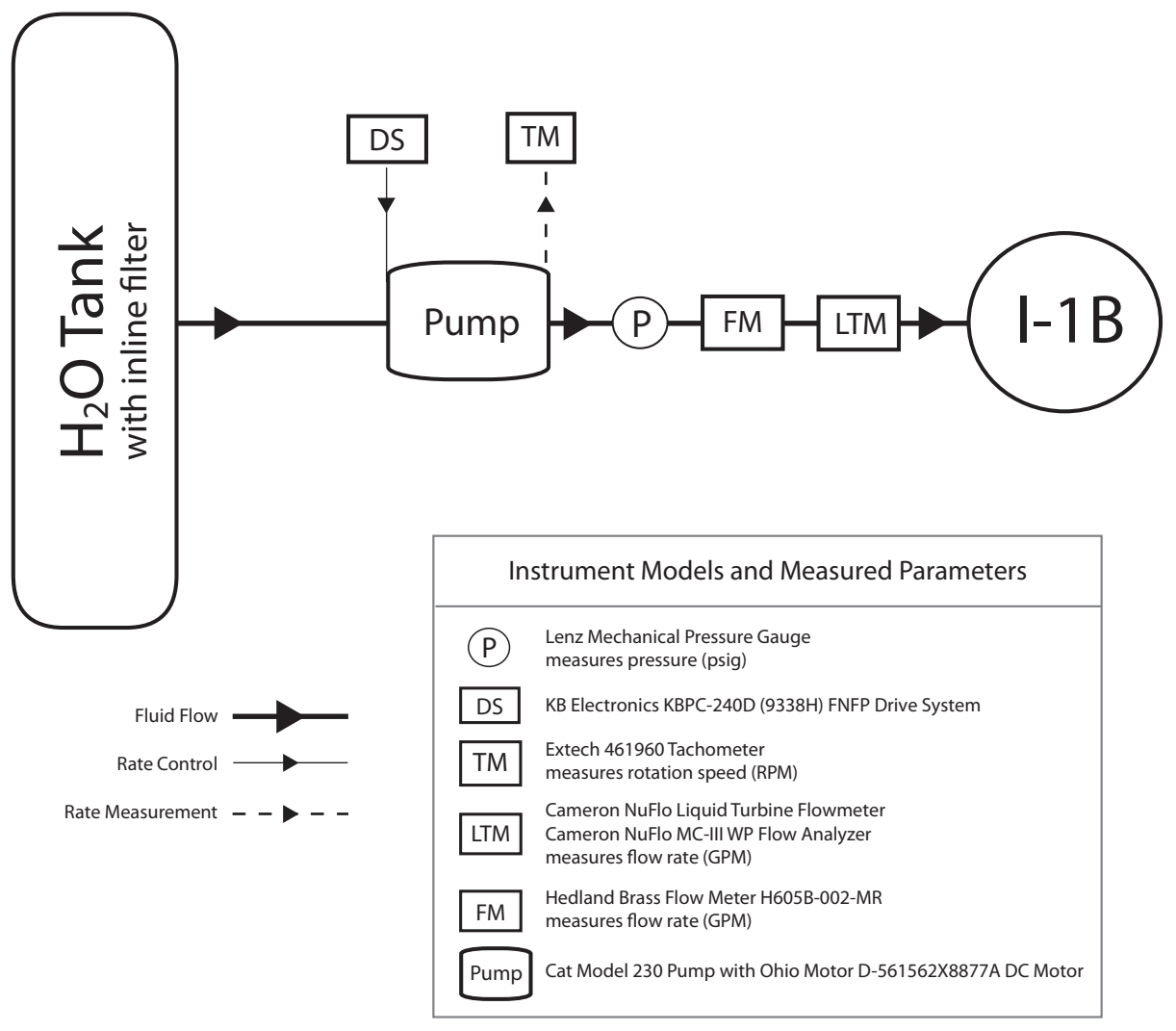

Figure A13-2. Water pump skid schematic. 


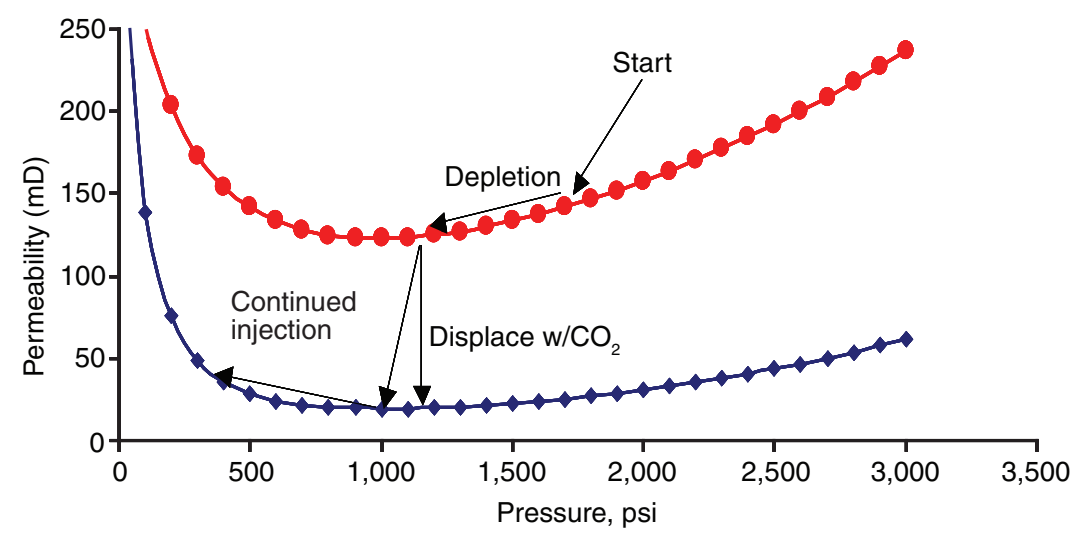

Figure A13-3. Permeability changes during $\mathrm{CO}_{2}$ injection with pressure and concentration.
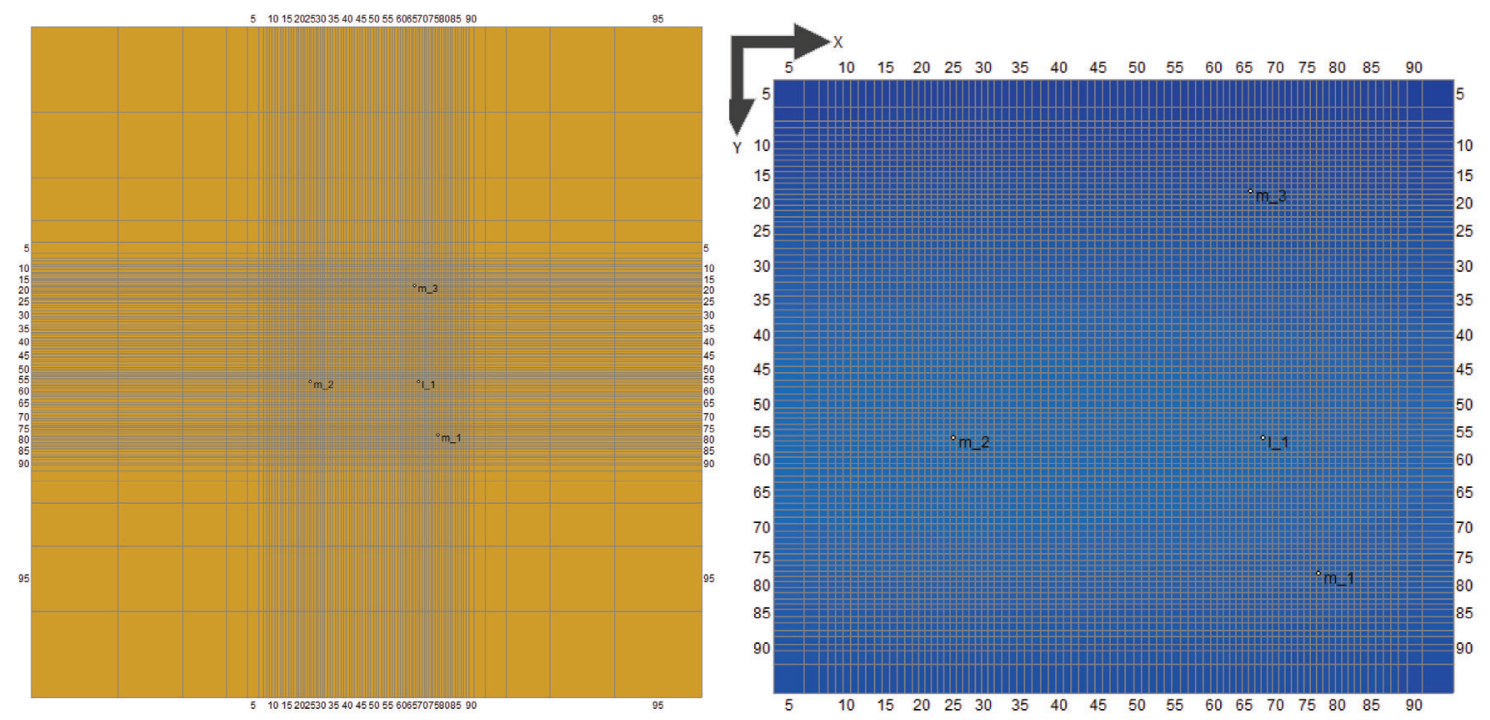

Figure A13-4. (a) Model top view; (b) Close-up view of model. Numbers on model edges represent distances from origin in feet.

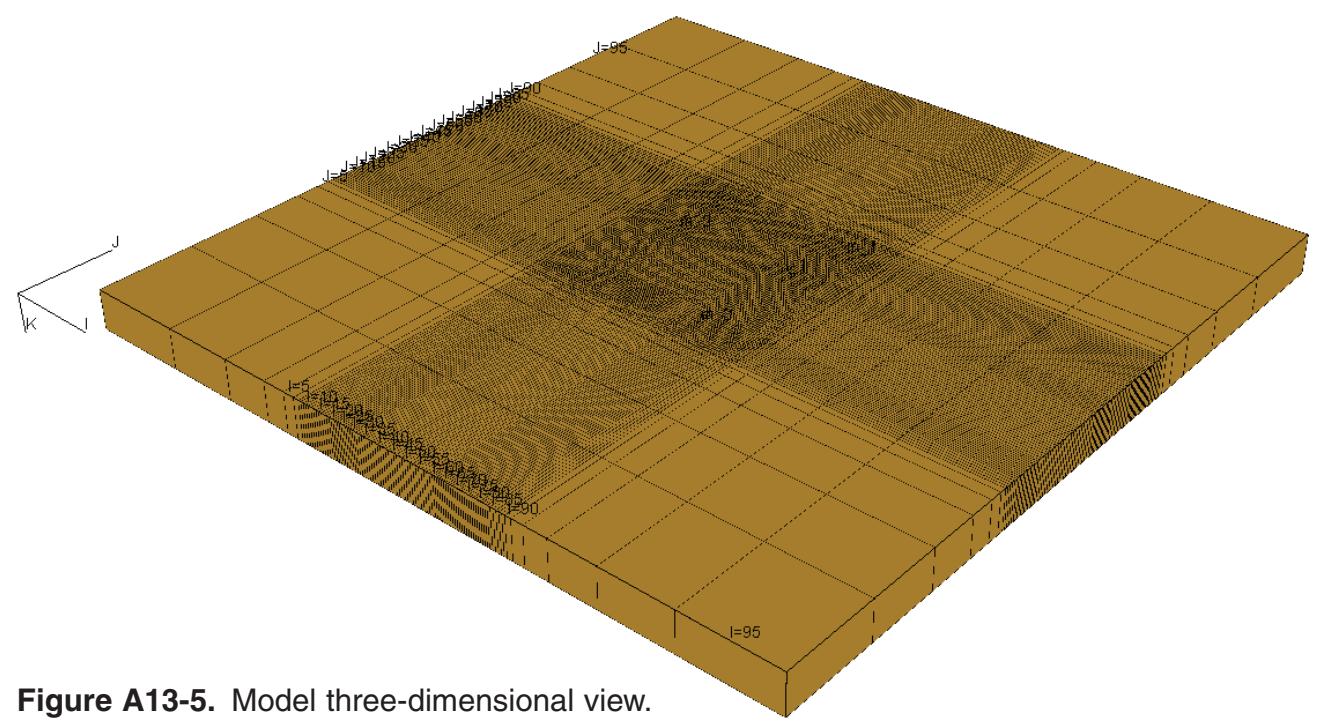




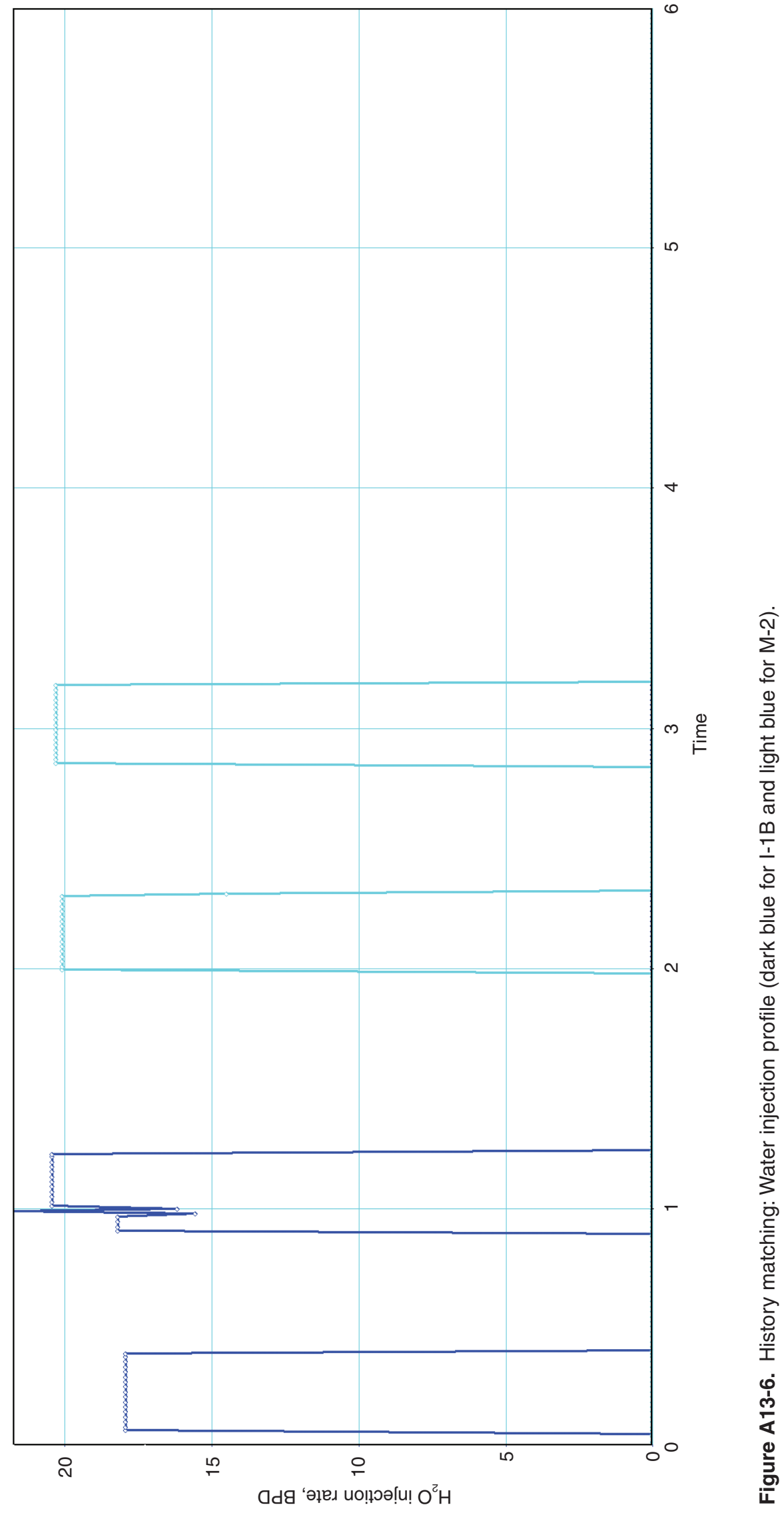



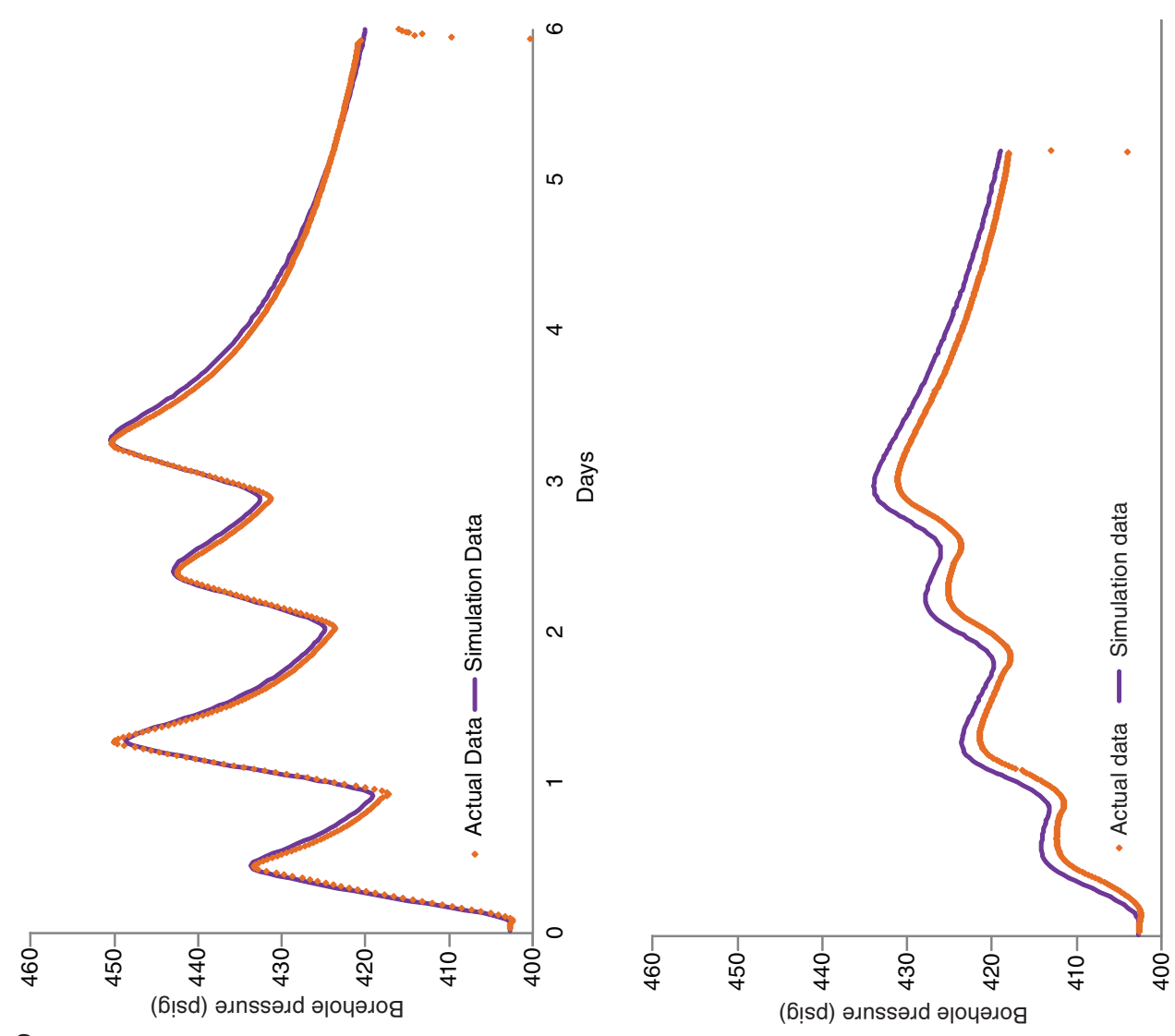

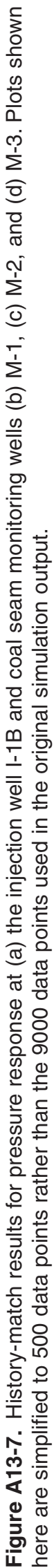

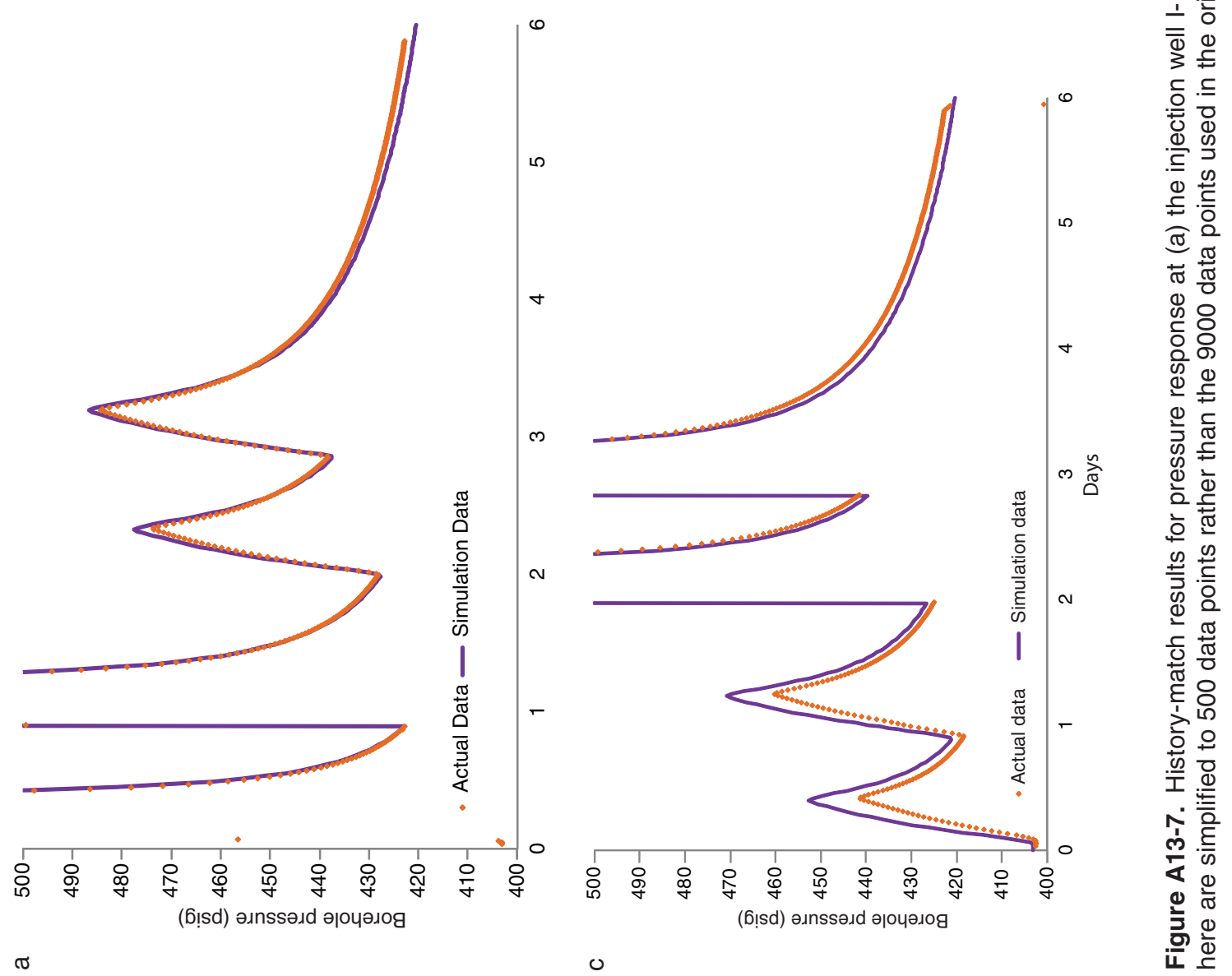




\section{Appendix 14. MVA Methods}

\section{Groundwater Modeling for the Site}

Prior to deployment of a groundwater monitoring network at the ECBM site, groundwater modeling was conducted (1) to design a groundwater monitoring system able to detect any $\mathrm{CO}_{2}$ leaked to shallow groundwater; (2) to determine the flow rate and transport direction of any $\mathrm{CO}_{2}$ leakage from the injection point; and (3) to determine the risks to human health and the environment from any $\mathrm{CO}_{2}$ leakage.

Analytic element modeling (AEM) was used for this project because shallow groundwater and surface water flow can be modeled simultaneously using a relatively simple data set. A disadvantage of the AEM method is that transient flow and three-dimensional flow can only be partially represented in the model, and gradually varying aquifer properties cannot be represented at all. However, these issues were not significant at this site.

The AEM method was developed at the end of the 1970s by Otto Strack at the University of Minnesota (Strack and Haitjema, 1981). In this method, instead of discretizing the entire groundwater flow domain, only the surface water features are discretized, entered into the model as input and represented by closed form analytical solutions or analytic elements. The solution to a complex, regional groundwater flow model is derived from the superposition of hundreds of analytic elements.

Analytic elements were chosen to best represent certain hydrologic features. For instance, stream sections and lake boundaries were represented by line sinks, and small lakes or wetlands were represented by areal sink distributions. Areal recharge was modeled by an areal sink with a negative strength. Streams and lakes that were not fully connected to the aquifer were modeled by line sinks or area sinks with a bottom resistance. Discontinuities in aquifer thickness or hydraulic conductivity were modeled by use of line doublets (double layers). Specialized analytic elements were used for special features such as drains or slurry walls. Locally, three-dimensional solutions may be added, such as a partially penetrating well (Haitjema, 1985).

\section{Model Description}

The software used for the analytic element model was GFLOW v2.1.0. Input parameters were (1) measured directly on-site, (2) estimated from available information, or (3) calibrated in the modeling process (Table A14-1). Particle tracking was used to determine the flow paths and travel time for $\mathrm{CO}_{2}$ from a hypothetical leak. The model was evaluated for impacts to the rivers and surficial aquifer from the $\mathrm{CO}_{2}$ leakage. A monitoring scheme using four monitoring wells was designed to detect $\mathrm{CO}_{2}$ leakage.

Table A14-1. Input parameters for GFLOW.

\begin{tabular}{lll}
\hline Aquifer parameters & Value & Source \\
\hline Base elevation & $92.9 \mathrm{~m}(305 \mathrm{ft})$ & Field data \\
Thickness & $20 \mathrm{~m}(66 \mathrm{ft})$ & Field data \\
Porosity & 0.2 & Estimate \\
Hydraulic conductivity & $8.35 \mathrm{~m} /$ day $(27.4 \mathrm{ft} /$ day $)$ & Model calibration \\
Recharge & $0.0091 \mathrm{~m} / \mathrm{yr}(0.36 \mathrm{inch} / \mathrm{yr})$ & Model calibration \\
\hline Bonpas Creek parameters & Value & Source \\
\hline Width & $10 \mathrm{~m}(33 \mathrm{ft})$ & Field data \\
Depth & $5 \mathrm{~m}(16 \mathrm{ft})$ & Field data \\
Resistance & 0 & Estimate
\end{tabular}

As shown in Table A14-1, the aquifer

base elevation represents a horizontal plane that acts as a no-flow boundary. The thickness of the aquifer is the actual thickness of the material above the aquifer base. Porosity is defined as the fraction of pore space present in the aquifer material. Hydraulic conductivity is a proportionality that relates the flow of water through a cross-sectional area of a geologic material under a unit hydraulic gradient; it is a measure of the ease with which water moves through a porous medium. The width and depth of Bonpas Creek are self-evident dimensions, whereas resistance describes the hydraulic resistance of the creek bed, typically due to the deposition of fine-grained materials in the creek bed.

\section{Techniques for Drilling and Groundwater Monitoring Well Installation}

Groundwater monitoring wells were drilled and completed in April and May 2008. Four boreholes were drilled by Illinois State Geological Survey staff members using the Survey's CME-75 rig. Two of the boreholes (ECBM1 and ECBM4) were drilled using wireline coring tools, which require the use of bentonite-based drilling mud for unconsolidated materials. The wireline tool provides either a 5.4-cm (2 1/8-in) or $5.7 \mathrm{~cm}(21 / 4$-in) sample in unconsolidated materials (depending on the shoe used) and a $6.4-\mathrm{cm}$ (2.5in) sample in bedrock. The cored hole was then reamed to a diameter of $14.0 \mathrm{~cm}(5.5 \mathrm{inches})$ to allow the installation of 5.1-cm (2-inch)-diameter PVC casing and screen to construct monitoring wells. The other two boreholes (ECBM2 and ECBM3) were drilled by the mud rotary method, which produced a 14.0-cm (5.5-in)-diameter borehole. No samples were collected from these boreholes. 
Geophysical logs were run in all the boreholes prior to monitoring well construction. The natural gamma log was run in each borehole using an MGX II console and 2PGA-1000 downhole tool from Mt. Sopris Instrument Company (http://www. mountsopris.com) Golden, CO) in a borehole filled with drilling mud or water. The natural gamma log provides data on the amount of gamma rays-emitting clays, primarily from the presence in the clays of naturally occurring isotopes of potassium, thorium, and uranium, which are used to identify the lithology of the geologic materials beyond the borehole.

All monitoring wells were constructed with 5-cm (2-inch)-diameter PVC casing with threaded connections. Slotted screens with $0.025-\mathrm{cm}(0.010$-inch) slots were used for the four monitoring wells. The elevations of the monitoring wells were determined by level surveying, based on the known elevation of a local benchmark. Level surveying was conducted with an automatic level (Wild Model NA2) and a micrometer or similar instrument. The micrometer allows elevations to be measured to one-tenth of a millimeter. The elevations of all wells were determined to the nearest $0.003 \mathrm{~m}(0.01 \mathrm{ft})$. The elevations of the tops of the PVC casing are $121.27 \mathrm{~m}$ (397.88 ft) for ECBM1, $121.67 \mathrm{~m}$ (399.19 ft) for ECBM2, $121.36 \mathrm{~m}$ (398.18 ft) for ECBM3, and $121.55 \mathrm{~m}(398.82 \mathrm{ft})$ for ECBM4.

After well installation, the well was developed by overpumping with a Waterra pump (with and without a surge block) and a Whale submersible pump (12-V DC pump).

\section{Hydrogeologic Data from the Drilling and Monitoring Well Installation}

Pressure transducers were installed in the four monitoring wells. Solinst Leveloggers (www.solinst.com) were installed in the four groundwater monitoring wells and were programmed to record water levels at 6 -minute intervals. Because these loggers record absolute pressure, atmospheric pressure was also recorded at the site using a Solinst Barologger. These instruments allowed us to monitor the water levels in the wells over time. Unfortunately, the Barologger malfunctioned during the study, forcing us to use atmospheric data from an airport (Lawrenceville) located $40 \mathrm{~km}$ (25 mi) from the site. These atmospheric pressure data were processed according to the procedure in the Solinst User's Manual and were used to correct the Levelogger data. Figure 82 shows the results of this monitoring of groundwater levels.

\section{Collection and Analysis of Groundwater Samples}

Once all the monitoring wells were drilled and developed, bladder sampling pumps were installed into each well. The bladder pumps minimize sample disturbance and exposure to the atmosphere, which is critical when evaluating water quality in relation to $\mathrm{CO}_{2}$ effects. Samples of residential well water were collected from faucets located outside the residences that were plumbed in such a manner as to bypass all water treatment equipment. Water levels in the site monitoring wells were determined using continuous recording pressure transducers and an electronic water level indicator prior to and during sample collection. A low flow sampling technique was used to collect groundwater samples (ASTM Standards, 2002). This method minimizes water disturbance and drawdown while optimizing water purge volumes to ensure that a representative water sample is collected from the formation (Puls and Barcelona, 1996). During the sampling process, water quality parameters such as $\mathrm{pH}$, specific electrical conductance (EC), oxidation-reduction potential (Eh), and dissolved oxygen (DO) content were continuously measured using a flow-through cell. Once these parameters became stable, samples were collected. Stabilization criteria, based on three successive measurements of each parameter (Yeskis and Zavala, 2002), were as follows: pH $\pm 0.1 \mathrm{pH}$ unit; $\mathrm{EC} \pm 3 \%$; Eh $\pm 10 \mathrm{mV}$; and DO $\pm 0.3 \mathrm{mg} / \mathrm{L}$.

The sample preservation techniques used were those outlined in publications by the U.S. Environmental Protection Agency (1974) and the American Public Health Association (1992). Non-filtered samples were used to determine ammonia and dissolved $\mathrm{CO}_{2}$ concentrations. Samples to be analyzed for alkalinity, anions, cations, tritium, and carbon/oxygen isotopes were filtered through $0.45-\mu \mathrm{m}\left(1.77 \times 10^{-5} \mathrm{in}\right)$ pore size filters. All samples were kept on ice in the field and refrigerated at $4^{\circ} \mathrm{C}\left(39^{\circ} \mathrm{F}\right)$ in the laboratory until analyzed. Anion concentrations were determined by ion chromatography ( $\mathrm{O}^{\prime} \mathrm{Dell}$ et al., 1984), and cation concentrations were determined by inductively coupled argon plasma (ICP) spectrophotometry (American Public Health Association, 1992). Detection limits were $0.01 \mathrm{mg} / \mathrm{L}$ for chloride, nitrate-N, and sulfate, and $0.05 \mathrm{mg} / \mathrm{L}$ for phosphate-P. Detection limits for the ICP analyses were in the range of $0.00037 \mathrm{mg} / \mathrm{L}$ for constituents such as Sr (strontium) to $0.217 \mathrm{mg} / \mathrm{L}$ for S (sulfur). Ammonia-N concentrations were determined by electrode and had a detection limit of $0.1 \mathrm{mg} / \mathrm{L}$

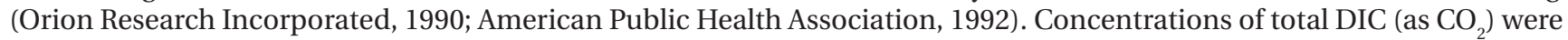
determined by electrode and had a detection limit of $4.4 \mathrm{mg} / \mathrm{L}$ (Orion Research Incorporated, 2003). A titration method with a detection limit of $2 \mathrm{mg} / \mathrm{L}$ was used to measure alkalinity (American Public Health Association, 1992). Electrical conductivity, $\mathrm{pH}$, oxidation-reduction potential, and temperature were determined in the field using electrodes according to standard methods (American Public Health Association, 1992). Oxidation-reduction potentials are reported relative to a standard ZoBell solution (Wood, 1976). 


\section{Statistical Analysis of Groundwater Quality Data}

The time between the groundwater monitoring well development and the beginning of $\mathrm{CO}_{2}$ injection was 1 month; during this time sampling occurred weekly. The pre-CO2 injection sampling period was too brief to collect enough background water quality data to apply rigorous statistical techniques in determining changes in groundwater quality. For example, relatively simple techniques, such as the use of control charts, require 6 to 8 months of background data (U.S. Environmental Protection Agency, 1989). For all statistical methods employing the use of pooled background data, the background data set should be large enough to reflect naturally occurring changes in hydrogeology. For moving background data sets, Sara and Gibbons (1991) recommend that only data from the eight most recent sampling events be used. This approach helps to minimize temporal variability (Sara and Gibbons, 1991). Simple time series charts were constructed for intrawell and interwell comparisons of groundwater quality analytes. Intrawell comparison provided a historic data review for a single well. Preand post- $\mathrm{CO}_{2}$ injection water quality data were compared by this technique. Interwell data analyses compared water quality data collected from downgradient wells to data from the background well. ECBM1 was considered as the background well based on the groundwater flow direction and the extent of the $\mathrm{CO}_{2}$ plume in the coal predicted prior to injection.

\section{Isotopic Analysis of Gas and Water Samples}

Gas samples were taken from the headspace of the coal seam observation wells (M-1, M-2, and M-3) and the groundwater monitoring wells (ECBM1, 2, 3, and 4) around the injection well. The samples were collected in 1-L (61-inch ${ }^{3}$ ) Cali-5-Bond gas sampling bags produced by Calibrated Instruments, Inc., fitted with luer valves. The gas samples were analyzed on a Varian 3800 gas chromatograph equipped with a thermal conductivity detector (TCD) for fixed gases $\left(\mathrm{CO}_{2}, \mathrm{~N}_{2}, \mathrm{O}_{2}\right.$, and $\left.\mathrm{CH}_{4}\right)$ and flame ionization detector (FID) for hydrocarbons from $\mathrm{CH}_{4}$ through hexane $\left(\mathrm{C}_{6} \mathrm{H}_{14}\right)$. Gas samples with sufficient $\mathrm{CO}_{2}$ were analyzed for stable carbon isotopes $\left(\delta^{13} \mathrm{C}\right)$. Selected samples containing sufficient $\mathrm{CH}_{4}$ were analyzed for $\delta^{13} \mathrm{C}$ and hydrogen isotopes $(\delta \mathrm{D})$. The aqueous samples were analyzed for stable carbon $\left(\delta^{13} \mathrm{C}\right)$, oxygen $\left(\delta^{18} \mathrm{O}\right)$, and hydrogen $(\delta \mathrm{D})$ isotopes as well as tritium $\left({ }^{3} \mathrm{H}\right)$. The $\mathrm{CO}_{2}$ from a few gas samples was also analyzed for radiocarbon $\left({ }^{14} \mathrm{C}\right)$ concentrations.

The gas samples were extracted from the sample bags by passing a syringe through a septum fitted onto the luer valve. For those gas samples containing very little to no hydrocarbons heavier than $\mathrm{CH}_{4}$, the extracted gas sample was then injected into a vacuum line, and the $\mathrm{CO}_{2}$ was cryogenically purified and sealed in a 6-ml $\left(0.37\right.$ - inch $\left.{ }^{3}\right)$ Pyrex tube for isotopic measurement. For those gas samples that contained heavier hydrocarbons, the samples were sent to a laboratory equipped with a gas chromatograph separation method connected to a vacuum line for $\delta^{13} \mathrm{C}$ analysis of the $\mathrm{CO}_{2}$. Due to the number of aqueous samples, some of the samples were also sent to an outside lab for $\delta^{18} \mathrm{O}$ and $\delta \mathrm{D}$ isotopic analysis. For those samples analyzed at the ISGS, the $\delta^{18} \mathrm{O}$ value was analyzed using a modified $\mathrm{CO}_{2}-\mathrm{H}_{2} \mathrm{O}$ equilibration method as originally described by Epstein and Mayeda (1953), with the modifications described by Hackley et al. (1999). The $\delta D$ values of selected water samples were determined using the Zn-reduction method described in Coleman et al. (1982) and Vennemann and O'Neil (1993), with the modifications described by Hackley et al. (1999). The $\delta^{13} \mathrm{C}$ value of DIC was determined using a gas evolution technique. Approximately $10 \mathrm{ml}\left(0.6 \mathrm{inch}^{3}\right)$ of water was injected into an evacuated vial containing crystalline phosphoric acid and a stir bar. The $\mathrm{CO}_{2}$ evolved from the water sample in the vial was cryogenically purified on a vacuum system and sealed into a Pyrex break tube for isotopic analysis.

The isotopic compositions of the samples $\left(\delta^{13} \mathrm{C}, \delta^{18} \mathrm{O}\right.$, and $\left.\delta \mathrm{D}\right)$ were determined on a dual inlet ratio mass spectrometer. Each sample was directly compared against an internal standard calibrated versus an international reference standard. The final results are reported versus the international reference standards. The $\delta^{13} \mathrm{C}$ results are reported versus the PeeDee Belemnite (PDB) reference standard. The $\delta^{18} \mathrm{O}$ and $\delta \mathrm{D}$ results are reported versus the international Vienna-Standard Mean Ocean Water (V-SMOW) standard. Analytical reproducibilities were as follows: for $\delta^{13} \mathrm{C} \leq \pm 0.15 \%$, for $\delta^{18} \mathrm{O} \leq \pm 0.1 \%$, and for $\delta \mathrm{D} \leq \pm 1.0 \%$.

The ${ }^{3} \mathrm{H}$ analyses were done by the electrolytic enrichment process (Ostlund and Dorsey, 1977) and the liquid scintillation counting method. The electrolytic enrichment process consists of distillation, electrolysis, and purification of the ${ }^{3} \mathrm{H}$-enriched samples. The results are reported in tritium units (TU), and the precision for the tritium analyses reported in this study is $\pm 0.25 \mathrm{TU}$.

The ${ }^{14} \mathrm{C}$ activity of the DIC was analyzed using acceleration mass spectrometry (AMS). The DIC was extracted from the water samples by acidification; the released $\mathrm{CO}_{2}$ was quantitatively collected on a vacuum line. The ${ }^{14} \mathrm{C}$ concentrations are reported as percent modern carbon (pMC) relative to the NBS reference material (oxalic acid \#1) which is, by convention, defined as $100 \mathrm{pMC}$.

\section{Geochemical Modeling of Groundwater Quality Data}

The groundwater quality data were input into the U.S. Geological Survey model PHrEeQCI (Parkhurst and Appelo, 1999; USGS, 2007). The software calculated the saturation index with respect to mineral phases found in the default thermodynamic database. These results allowed us to evaluate the equilibrium state of the groundwater chemistry before and after $\mathrm{CO}_{2}$ 
injection. Major changes in a saturation index could signify a shift in the groundwater/mineral phase equilibrium and resulting dominant chemical reactions of the groundwater system. Leakage of $\mathrm{CO}_{2}$ from the coal seam into the shallow groundwater could cause a change in the carbonate equilibrium and $\mathrm{pH}$ of the water that would be reflected in the modeling output. These equilibrium data could then support and help explain any observed changes in water quality that were evident from the time series analyses.

\section{Color Infrared Imagery Acquisition}

Aero-Metric, Inc. of Sheboygan, Wisconsin, has extensive experience in providing high-quality digital imagery across the United States, and they performed the MVA aerial monitoring task successfully for the entire 3 year of testing under the Sequestration and Enhanced Coal Bed Methane project. Digital color near-infrared imagery (CIR) was acquired with a Zeiss Digital Mapping Camera (DMC). Using the same contractor and imaging device throughout the project resulted in a high degree of consistency in the deliverables and eliminated one potential source of error.

An additional component of the aerial imagery acquisition was the establishment and acquisition of surveyed ground control in the images. This control was used to geometrically correct the digital imagery to create high-accuracy orthophotography for the remote sensing and geographic information systems applications conducted as part of the MVA effort. The Illinois Department of Transportation, Aerial Surveys Division contributed their time and expertise to establish the ground control for the ECBM site at no cost.

Aero-Metric established a flight plan for the ECBM site to ensure that the camera was able to acquire the digital imagery at the correct resolution, scale, and areal extent (Appendix Figure A14-1). Raw DMC imagery was downloaded at Aero-Metric's office, processed, and orthorectified using the IDOT ground control. The resulting digital orthophotography deliverables were then sent to ISGS for image interpretation.

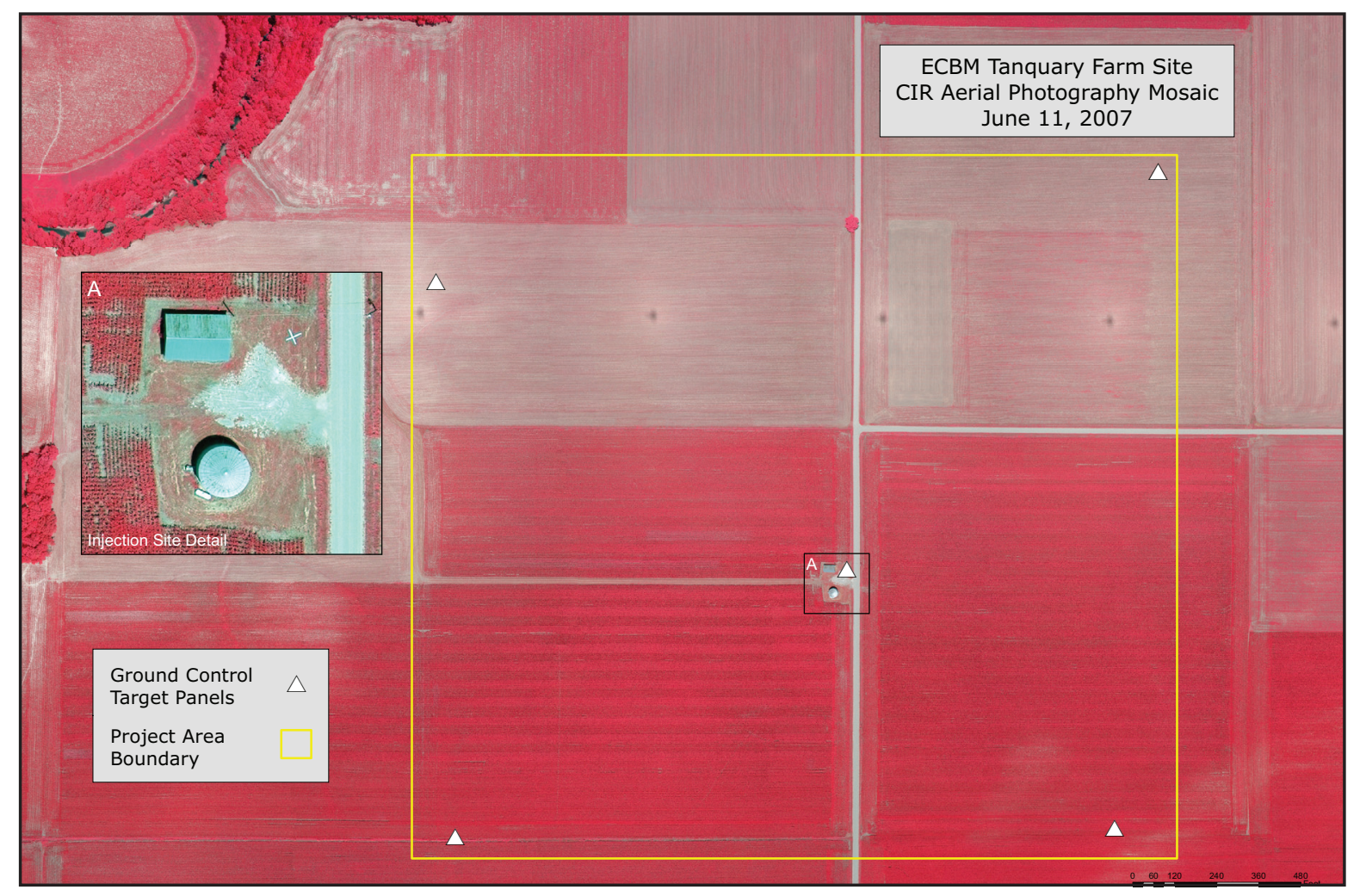

Appendix Figure A14-1. Project layout plan for color infrared imagery acquisition at the Tanquary ECBM site. This image was taken on June 11, 2007, and was the first aerial photography acquired for the project area. Bonpas Creek, a tributary to the Wabash River, is visible at the upper left. The inset enlargement shows the site as it appeared prior to any development by ISGS. One of the five ground control target panels, used for orthorectification of the aerial photography, is clearly visible at upper right of the inset. 


\section{Appendix 15. Isotopic Results for Gas Samples from Injected $\mathrm{CO}_{2}$ and Observation Wells}

Note that sample names in column 1 are labeled slightly differently depending on the field personnel's choice of using dashes between the letter and number in the well names.

Table A15-1. Isotopic results for gas samples from injected $\mathrm{CO}_{2}$ and observation well $\mathrm{M}-1$. The concentrations of $\mathrm{CO}_{2}$ were too low for isotopic analysis for many samples.

\begin{tabular}{|c|c|c|c|c|c|c|c|}
\hline Sample & Date & Time $^{1}$ & $\begin{array}{c}\delta^{13} \mathrm{C}_{\mathrm{VPDB}} \\
\text { of } \mathrm{CO}_{2}\end{array}$ & $\begin{array}{c}\delta^{13} \mathrm{C}_{\mathrm{VPDB}} \\
\text { of } \mathrm{CH}_{4}\end{array}$ & $\begin{array}{c}\delta \mathrm{D} \text { of } \\
\mathrm{CH}_{4}\end{array}$ & ${ }^{14} \mathrm{C} \mathrm{pMC}$ & $\pm p M C$ \\
\hline \multicolumn{8}{|l|}{$\begin{array}{l}\text { Injection } \\
\mathrm{CO}_{2} \\
\text { Tank }\end{array}$} \\
\hline $\mathrm{CO}_{2}$ & 06/25/08 & & -10.8 & & & 104.4 & \\
\hline \multicolumn{8}{|l|}{ Well } \\
\hline \multicolumn{8}{|l|}{ M-1 } \\
\hline$M-1-1$ & 06/25/08 & 1735 & & -60.0 & -195.4 & & \\
\hline$M-1-2$ & 06/25/08 & 1832 & & -60.2 & -199.1 & & \\
\hline$M-1-3$ & 06/25/08 & 2352 & & -60.2 & -198.5 & & \\
\hline M1-5 & 07/01/08 & 1618 & & -61.0 & -202.4 & & \\
\hline$M-1$ & 07/03/08 & 1130 & & -60.4 & -203.8 & & \\
\hline$M-1$ & 07/12/08 & 1000 & -32.4 & -61.5 & -207.8 & & \\
\hline$M-1$ & 07/18/08 & 0017 & & -61.7 & & & \\
\hline M-1 & 07/18/08 & 0336 & & -61.7 & -205.9 & & \\
\hline M-1 & 07/18/08 & 0500 & & -60.7 & -203.6 & & \\
\hline$M-1$ & $07 / 24 / 08$ & 1130 & -10.9 & -60.5 & -204.5 & 95.3 & 0.13 \\
\hline$M-1$ & 07/24/08 & 1130 & & -59.4 & -203.1 & & \\
\hline$M-1$ & 07/25/08 & 0145 & -10.9 & -60.6 & -202.2 & & \\
\hline M-1 dup & 07/25/08 & 0145 & & & & & \\
\hline M-1 & 07/25/08 & 0945 & -10.9 & & & & \\
\hline M-1 & 07/25/08 & 1845 & & & & & \\
\hline$M-1$ & $07 / 26 / 08^{2}$ & 0200 & & & & & \\
\hline$M-1$ & 07/27/08 & 1316 & -11.1 & & & & \\
\hline M-1 & 07/28/08 & 1300 & & & & & \\
\hline$M-1$ & 07/29/08 & 1140 & -11.1 & & & & \\
\hline$M-1$ & 08/21/08 & 1300 & -11.8 & -60.7 & -205.7 & 95.5 & 0.13 \\
\hline M1 & 08/28/08 & 1059 & -12.0 & -60.5 & -207.4 & 95.4 & 0.13 \\
\hline$M-1$ & 09/02/08 & 1135 & -12.1 & -60.8 & -208.8 & 95.1 & 0.15 \\
\hline$M-1$ & 09/11/08 & 1505 & -12.2 & -60.8 & -208.5 & 95.1 & 0.15 \\
\hline M-1 & 09/16/08 & 1501 & -12.3 & -60.0 & -208.5 & 95.3 & 0.14 \\
\hline$M-1$ & 09/24/08 & 1315 & -12.3 & -60.4 & -207.7 & 95.6 & 0.14 \\
\hline$M-1$ & $10 / 02 / 08$ & 1500 & -12.4 & -60.6 & -208.1 & 95.9 & 0.13 \\
\hline$M-1$ & 10/02/08 & 1500 & & & & & \\
\hline M1 & $10 / 16 / 08$ & 1445 & -12.2 & & & & \\
\hline M1 & 10/22/08 & & -11.5 & & & & \\
\hline M1 & 10/27/08 & & -10.7 & & & 97.0 & 0.13 \\
\hline M1 \#1 & $10 / 28 / 08^{2}$ & 1902 & & & & 96.7 & 0.13 \\
\hline M1 \#2 & $10 / 28 / 08$ & 2111 & -10.3 & & & & \\
\hline M1 \#4 & $10 / 29 / 08$ & 1228 & -9.0 & & & & \\
\hline M1 \#5 & $10 / 29 / 08$ & 1630 & -10.4 & & & 103.6 & 0.14 \\
\hline
\end{tabular}


Table A15-1. Continued.

\begin{tabular}{|c|c|c|c|c|c|c|c|}
\hline Sample & Date & Time $^{1}$ & $\begin{array}{c}\delta^{13} \mathrm{C}_{\mathrm{VPDB}} \\
\text { of } \mathrm{CO}_{2}\end{array}$ & $\begin{array}{c}\delta^{13} \mathrm{C}_{\mathrm{VPDB}} \\
\text { of } \mathrm{CH}_{4}\end{array}$ & $\begin{array}{c}\delta \mathrm{D} \text { of } \\
\mathrm{CH} 4\end{array}$ & ${ }^{14} \mathrm{C}$ pMC & $\pm p M C$ \\
\hline \multicolumn{8}{|l|}{ Well } \\
\hline M1 & $11 / 05 / 08$ & & & & & 103.1 & 0.17 \\
\hline M1 \#1 & 11/08/08 & 2038 & & & & & \\
\hline M1 \#2 & 11/08/08 & 2143 & & & & & \\
\hline M1 \#1 & $11 / 09 / 08^{2}$ & 1432 & & & & & \\
\hline M1 & 12/03/08 & 1432 & & & & & \\
\hline M1 & $12 / 18 / 08$ & 1445 & -13.3 & & & 93.6 & 0.14 \\
\hline M1 & $12 / 22 / 08$ & 1522 & -12.9 & & & 98.3 & 0.16 \\
\hline M1 & $12 / 24 / 08$ & 1515 & -12.8 & & & 99.8 & 0.14 \\
\hline M1 & $12 / 25 / 08$ & 0700 & -12.8 & & & & \\
\hline M1 dup & $12 / 25 / 08^{2}$ & 0700 & & & & & \\
\hline M1 & 12/27/08 & 0703 & -12.2 & & & 100.6 & 0.14 \\
\hline M1 dup & 12/27/08 & 0703 & & & & & \\
\hline M1 dup & $12 / 27 / 08$ & 0703 & & & & & \\
\hline M1 dup & 12/27/08 & 0703 & & & & & \\
\hline M1 dup & 12/27/08 & 0703 & & & & & \\
\hline M1 & 12/29/08 & 0705 & -14.1 & & & 78.1 & 0.13 \\
\hline M1 dup & $12 / 29 / 08$ & 0705 & & & & & \\
\hline M1 dup & $12 / 29 / 08$ & 0705 & & & & & \\
\hline M1 & 01/08/09 & 1415 & -11.2 & & & 99.7 & 0.14 \\
\hline M1 & 01/08/09 & 1415 & & & & & \\
\hline M1 & 01/14/09 & 1500 & -9.6 & & & 103.7 & 0.14 \\
\hline$M-1$ & 04/13/09 & 1828 & & & & & \\
\hline$M-1$ & 05/15/09 & 1426 & -9.4 & & & & \\
\hline$M-1$ & 11/28/09 & 1052 & -9.4 & -58.2 & -211 & & \\
\hline
\end{tabular}

${ }^{1}$ Collection times are given in CDT for samples collected from 03/08/08-11/02/08 and 03/08/09-11/01/09. All other times are CST. Collection times were not available for some samples.

${ }^{2}$ Results in red suggest possible air contamination.

VPDB, reference to Pee Dee Belemnite (PDB) standard. 
Table A15-2. Isotopic results for gas samples from observation well M-2. The concentration of CO2 was too low for isotopic analysis for some samples.

\begin{tabular}{|c|c|c|c|c|c|c|c|c|}
\hline Sample & Date & Time $^{1}$ & $\begin{array}{c}\delta^{13} \mathrm{C}_{\mathrm{VPDB}} \\
\text { of } \mathrm{CO}_{2}\end{array}$ & $\begin{array}{c}\delta^{13} \mathrm{C}_{\mathrm{VPDB}} \\
\text { of } \mathrm{CH}_{4}\end{array}$ & $\begin{array}{c}\delta \mathrm{D} \text { of } \\
\mathrm{CH} 4\end{array}$ & ${ }^{14} \mathrm{C} \mathrm{pMC}$ & $\pm p M C$ & Comments \\
\hline \multicolumn{9}{|l|}{ Well M-2 } \\
\hline M-2B & 07/10/08 & 1210 & & & & & & \\
\hline$M-2 B$ & 070/9/08 & 0900 & & & & & & \\
\hline $\mathrm{M}-2 \mathrm{~B}$ & 07/12/08 & & & & & & & (some air with GC injection) \\
\hline M-2B dup & 07/12/08 & & & & & & & \\
\hline M2 & 07/29/08 & 1145 & & & & & & \\
\hline M2-B & 08/12/08 & & & & & & & \\
\hline M2 \#1 & $10 / 29 / 08$ & 1213 & & & & & & \\
\hline M2 \#3 & $10 / 29 / 08$ & 1651 & & & & & & \\
\hline M2 \#1 & $11 / 03 / 08$ & 2122 & & & & & & \\
\hline M2 \#4 & $11 / 03 / 08$ & 0017 & & & & & & \\
\hline M2 \#2 & $11 / 03 / 08$ & 2132 & & & & & & \\
\hline M2 & $11 / 05 / 08$ & & & & & & & \\
\hline M2 \#1 & $11 / 08 / 08$ & 0903 & & & & & & \\
\hline M2 \#2 & $11 / 08 / 08$ & 1102 & & & & 101.3 & 0.19 & \\
\hline M2 & $11 / 25 / 08$ & 1456 & -10.7 & & & & & \\
\hline M2 & $11 / 25 / 08$ & 1456 & & & & & & \\
\hline M2-B & $12 / 04 / 08$ & 1204 & & & & & & $\mathrm{H}_{2}$ concentration estimated \\
\hline M2 & $12 / 18 / 08$ & 1450 & -11.8 & -59.20 & -216 & 86.7 & 0.15 & \\
\hline M2 & $12 / 22 / 08$ & 1514 & -11.8 & & & & & \\
\hline M2 Dup & $12 / 22 / 08$ & 1514 & & & & & & \\
\hline $\mathrm{M} 2$ & $12 / 24 / 08$ & 1520 & -11.7 & & & 88.2 & 0.16 & \\
\hline M2 & $12 / 25 / 08$ & 0700 & -12.8 & -58.70 & -215 & 87.3 & 0.16 & \\
\hline M2 & $12 / 27 / 08$ & 0701 & -10.5 & & & 102.9 & 0.21 & Air contamination? \\
\hline M2 Dup & $12 / 27 / 08$ & 0701 & & & & & & Air contamination? \\
\hline M2 & $12 / 29 / 08$ & 0710 & -9.5 & & & 88.6 & 0.19 & \\
\hline M2 Dup & $12 / 29 / 08$ & 0710 & & & & & & \\
\hline M2 & 01/08/09 & 1425 & -12.3 & -59.20 & 215 & 100.1 & 0.20 & \\
\hline M2 & 01/14/09 & 1510 & -10.4 & & & 103.4 & 0.17 & \\
\hline M-2 & 04/13/09 & 1835 & -10.4 & & & & & may contain $\mathrm{H} 2$, low raw $\mathrm{GC}$ yield \\
\hline$M-2 B$ & 05/15/09 & 1450 & -10.3 & & & & & \\
\hline M-2B & 05/21/09 & 0932 & -10.4 & & & & & \\
\hline M2 & $11 / 28 / 09$ & 1158 & & & & & & \\
\hline
\end{tabular}

${ }^{1}$ Collection times are given in CDT for samples collected from 3/8/08-11/2/08 and 3/8/09-11/1/09. All other times are CST. Collection times were not available for some samples.

VPDB, reference to Pee Dee Belemnite (PDB) standard. 
Table A15-3. Isotopic results for gas samples from observation well M-3. The concentration of $\mathrm{CO}_{2}$ was too low for isotopic analysis for some samples.

\begin{tabular}{|c|c|c|c|c|c|c|c|}
\hline Sample & Date & Time $^{1}$ & $\begin{array}{c}\delta^{13} \mathrm{C}_{\mathrm{VPDB}} \\
\text { of } \mathrm{CO}_{2}\end{array}$ & $\begin{array}{c}\delta^{13} \mathrm{C}_{\mathrm{VPDB}} \\
\text { of } \mathrm{CH}_{4}\end{array}$ & $\begin{array}{c}\delta \mathrm{D} \text { of } \\
\mathrm{CH} 4\end{array}$ & ${ }^{14} \mathrm{C}$ pMC & $\pm p M C$ \\
\hline \multicolumn{8}{|l|}{ Well M-2 } \\
\hline M-3-1 & 06/25/08 & 1130 & -8.2 & -60.2 & -205.2 & & \\
\hline M-3-1 & 06/25/08 & 1925 & & -41.3 & -196.0 & & \\
\hline M-3 & 07/01/08 & 1630 & & -60.9 & & & \\
\hline M-3 & 07/03/08 & 1145 & & -61.5 & -202.2 & & \\
\hline M-3 & 07/12/08 & 1000 & & -61.7 & -204.4 & & \\
\hline M-3 & 07/18/08 & 0846 & & -61.8 & -203.0 & & \\
\hline M-3 & 07/18/08 & 0912 & & -61.6 & -205.5 & & \\
\hline M-3 & 07/18/08 & 0941 & & -61.6 & -208.4 & & \\
\hline M-3 & 07/24/08 & 1150 & & -61.2 & -206.4 & & \\
\hline M-3 & 08/21/08 & & & & & & \\
\hline M3 & 08/28/08 & 1109 & & -61.2 & -203.9 & & \\
\hline M-3 & 09/02/08 & 1134 & -11.9 & & & & \\
\hline M-3 & 09/16/08 & 1505 & & -61.0 & -206.2 & & \\
\hline M-3 & 09/24/08 & 1335 & & -61.6 & -204.8 & & \\
\hline M-3 & $10 / 02 / 08$ & 1500 & -4.2 & & & & \\
\hline M3 & 10/16/08 & 0255 & & & & & \\
\hline M3 & 10/22/08 & & & & & & \\
\hline M3 & $10 / 22 / 08^{2}$ & & -14.4 & & & 98.8 & 0.2 \\
\hline M3 & 10/27/08 & & -13.3 & & & 98.5 & 0.22 \\
\hline M3 \#2 & 10/28/08 & 1059 & -12.1 & & & & \\
\hline M3 \#6 & 10/28/08 & 1313 & -9.4 & & & & \\
\hline M3 \#7 & 10/28/08 & 1347 & -9.1 & & & & \\
\hline M3 \#8 & 10/28/08 & 1430 & -9.0 & & & 102.3 & 0.2 \\
\hline M3 \#9 & 10/28/08 & 1515 & -8.7 & & & & \\
\hline M3 \#10 & 10/28/08 & 1610 & -8.6 & & & 101.9 & 0.21 \\
\hline M3 \#11 & 10/28/08 & 1714 & -8.8 & & & & \\
\hline M3 & $11 / 05 / 08$ & & & & & 102.4 & 0.19 \\
\hline M3 \#1 & $11 / 07 / 08$ & 2025 & -8.9 & & & 100.9 & 0.17 \\
\hline M3 \#2 & 11/07/08 & 2156 & -9.8 & & & 101.0 & 0.19 \\
\hline M3 \#3 & $11 / 07 / 08$ & 2314 & -8.9 & & & 102.1 & 0.19 \\
\hline M3 \#3 & $11 / 07 / 08$ & 2314 & & & & & \\
\hline M3 & $12 / 03 / 08$ & 1438 & -9.0 & & & 102.2 & 0.17 \\
\hline M3 & 12/19/08 & 0027 & -8.8 & & & 83.1 & 0.19 \\
\hline M3 & $12 / 19 / 08$ & 0028 & -9.4 & & & & \\
\hline M3 & $12 / 19 / 08$ & 1228 & & & & & \\
\hline M3 & $12 / 24 / 08$ & 1525 & -8.9 & & & 89.4 & 0.21 \\
\hline M3 & $12 / 25 / 08$ & 0700 & -7.8 & & & 99.9 & 0.18 \\
\hline M3 & $12 / 27 / 08$ & 0706 & & & & 90.1 & 0.22 \\
\hline M3 & $12 / 29 / 08$ & 0715 & -9.0 & & & 102.4 & 0.17 \\
\hline M3 & 01/08/09 & 1430 & -6.7 & & & 91.2 & 0.20 \\
\hline M3 & 01/14/09 & 1515 & -7.5 & & & 100.5 & 0.17 \\
\hline M3 & 01/14/09 & 1515 & & & & & \\
\hline M-3 & 04/13/09 & 1837 & -8.9 & & & & \\
\hline M-3 dup & 04/13/09 & 1837 & & & & & \\
\hline M-3 & 05/15/09 & 1525 & -8.3 & & & & \\
\hline M-3 & 05/20/09 & 0735 & & & & & \\
\hline M-3 & 05/20/09 & 0850 & -8.5 & & & & \\
\hline M-3 & 05/20/09 & 0903 & -8.6 & & & & \\
\hline M3 & 11/28/09 & 1227 & -12.2 & -58.9 & -210.0 & & \\
\hline
\end{tabular}

${ }^{1}$ Collection times are given in CDT for samples collected from 03/08/08-11/02/08 and 03/08/09-11/01/09. All other times are CST. Collection times were not available for some samples.

${ }^{2}$ No date on gas bag (date is a guess).

VPDB, reference to Pee Dee Belemnite (PDB) standard. 


\section{Appendix 16. Detailed Geologic Logs for ECBM1 and ECBM4}

Table A16-1. Sample description for samples from groundwater well ECBM1.

Well name: ECBM1

API: 121852849000

Date: $4 / 28 / 2009$

Location: Wabash County, NE $1 / 4$, Sec. 27, T1S, R14W

Personnel: Wimmer, Iranmanesh, Mehnert, Aud, Blacker, and Griest

Drilling rig (rig type and driller): CME 75 ISGS

\begin{tabular}{|c|c|c|}
\hline Core & Depth (ft) & Description (recovery, texture, color, structure) \\
\hline \multirow[t]{2}{*}{1} & $0-4.5$ & Recovery $=0.73$ \\
\hline & & 0-0.73': silt, topsoil, roots throughout, possible manganese nodules 7.5 YR $2.5 / 1$ "loess" \\
\hline \multirow[t]{5}{*}{2} & $4.5-9.5$ & Recovery = 2.03' \\
\hline & & $\begin{array}{l}0-0.2^{\prime} \text { : silt, with sand and gravel, fine to coarse grained, laminated, iron stained, slight } \\
\text { reaction to acid }\end{array}$ \\
\hline & & $\begin{array}{l}0.2-1.5 \text { ': silt, pieces of gravel, mottled, some plasticity and lamination } \\
\text { mottle: } 2.5 \text { Y } 5 / 6 \text { silt: } 2.5 \text { Y } 5 / 4\end{array}$ \\
\hline & & $1.5-1.9^{\prime}$ : sand, strong reaction to acid $2.5 Y 5 / 6$ \\
\hline & & 1.9-2.03': sand, silty, strong reaction to acid, no structure \\
\hline \multirow[t]{3}{*}{3} & $9.5-15$ & Recovery $=0.9$ \\
\hline & & 0-0.4': clay, silty, laminated \\
\hline & & $0.4-0.9$ ': silt \\
\hline \multirow[t]{5}{*}{4} & $15-20$ & Recovery $=5$ \\
\hline & & $0-0.9^{\prime}$ : silt, clayey, some roots throughout \\
\hline & & 0.9-2.3': silt \\
\hline & & 2.3-3.6': clay, laminated \\
\hline & & 3.6-5.0': clay \\
\hline \multirow[t]{3}{*}{5} & $20-30$ & Recovery $=6.8$ \\
\hline & & 0-4.9': clay, gley $15 / 10 \mathrm{Y}$ \\
\hline & & 4.9-6.8': clay, sandy, gley $15 / 10 Y$ \\
\hline \multirow[t]{2}{*}{6} & $30-35$ & Recovery $=0.85$, poor recovery, possible rock in core-catcher \\
\hline & & 0-0.85': silt, laminated, gley $15 / 10 \mathrm{Y}$ \\
\hline \multirow[t]{2}{*}{7} & $35-40$ & Recovery $=0.52$ \\
\hline & & $0-0.52$ ': silt, very plastic, gley $15 / 10 Y$ \\
\hline \multirow[t]{3}{*}{8} & $40-45$ & Recovery $=2.3^{\prime}$ \\
\hline & & 0-2.0': silt, gley $15 / 10 Y$ \\
\hline & & 2.0-2.3': sand, silty, fine-grained, sand is rounded, slight reaction to acid \\
\hline \multirow[t]{3}{*}{9} & $45-47$ & Recovery $=1.5^{\prime}$ \\
\hline & & $0-0.6$ ': sand, silty \\
\hline & & $0.6-1.5$ ': sand, silty, very fine-grained \\
\hline \multirow[t]{3}{*}{10} & $47-50$ & Recovery = 2.8 \\
\hline & & $0-1.0^{\prime}$ : sand, silty, very fine-grained \\
\hline & & 1-2.8': sand, fine-grained, white pieces of shell torn apart \\
\hline \multirow[t]{2}{*}{11} & $50-53$ & Recovery $=1.8$ \\
\hline & & $0-1.8$ ': sand, fine-grained, few shell pieces, no reaction to acid \\
\hline \multirow[t]{2}{*}{12} & $53-60$ & Recovery = 0.1': poor recovery; very fine-grained sand washes out of the core catcher \\
\hline & & $0-0.1^{\prime}:$ silt, sandy, laminated \\
\hline \multirow[t]{3}{*}{13} & $60-62$ & Recovery = 1.3' \\
\hline & & 0-0.4': sand, medium-grained, possible coal pieces \\
\hline & & $0.4-1.3$ ': sand, fine-grained \\
\hline \multirow[t]{2}{*}{14} & $62-65$ & Recovery $=0.7$ \\
\hline & & $0-0.7^{\prime}$ : sand, fine-grained, organic fragment in top, possibly a leaf, no reaction to acid \\
\hline \multirow[t]{2}{*}{15} & $65-70$ & Recovery $=0.4$ ' sand washed out \\
\hline & & $0-0.4^{\prime}$ : sand, fine-grained, no plant or shell fragments \\
\hline \multirow[t]{2}{*}{16} & $70-70.8$ & Recovery = 1.2' \\
\hline & & $0-1.2$ ': sand, fine to very fine-grained, rounded to sub-rounded \\
\hline \multirow[t]{4}{*}{17} & $70.8-75$ & Recovery = 3.6' \\
\hline & & $0-0.8^{\prime}$ : sand, fine-grained \\
\hline & & $0.8-1.2^{\prime}$ : sand and gravel \\
\hline & & 1.2-3.6': silt with sand and gravel, some plant and coal fragments, "till" \\
\hline \multirow[t]{2}{*}{18} & $75-80$ & Recovery $=1.5^{\prime}$ \\
\hline & & $\begin{array}{l}0-1.5 \text { ': silt with sand and gravel, slight reaction to acid, sand pocket at } 0.1 \text { ', gley } 13 / 10 \mathrm{Y} \\
\text { "glacial till" }\end{array}$ \\
\hline
\end{tabular}


Table A16-1. Continued.

\begin{tabular}{|c|c|c|}
\hline \multirow[t]{4}{*}{19} & $80-85$ & Recovery $=4.8^{\prime}$ \\
\hline & & 0-0.9': silt, laminated, Gley $23 / 10 \mathrm{G}$ \\
\hline & & 0.9-2.9': silt, sandy, no lamination, Gley 2 5/10G \\
\hline & & 2.9-4.8': sand, very fine-grained, rounded to sub-rounded, Gley $14 / 10 Y$ \\
\hline \multirow[t]{3}{*}{20} & $85-86$ & Recovery $=0.6$ \\
\hline & & $0-0.2$ ': sand, silty \\
\hline & & $0.2-0.6^{\prime}$ : sand, fine to coarse grained, sub-angular to sub-rounded \\
\hline \multirow[t]{3}{*}{21} & $86-87.7$ & Recovery = 1.7 \\
\hline & & $0-0.9$ ': sand, medium grained \\
\hline & & 0.9-1.7': sand, fine grained, some dark material at very base of core \\
\hline \multirow[t]{4}{*}{22} & $87.7-93$ & Recovery $=4.4^{\prime}$ \\
\hline & & 0-2.0': Sand, medium grained, Gley 1 5/5 GY \\
\hline & & 2.0-3.9': Sand and gravel \\
\hline & & 3.9-4.4': Silt, sandy, slightly laminated, organic fragments \\
\hline \multirow[t]{3}{*}{23} & $93-95$ & Recovery $=1.5$ \\
\hline & & 0-0.5': Silt, no structure, Gley 1 4/10Y \\
\hline & & 0.5-1.5': Silt, slightly laminated, Gley $13 / 10 \mathrm{Y}$ \\
\hline
\end{tabular}


Table A16-2. Description of samples from groundwater well ECBM4.

Well name: ECBM4

Location: Wabash County, NE $1 / 4$, Section 27, T1S, R14W

API: 121852849300

Dates: 4/29/08 and 4/30/08

Personnel: Mehnert, Wimmer, Iranmanesh, Aud, Blacker, Griest Drilling rig (rig type and driller): CME 75 ISGS

\begin{tabular}{|c|c|c|}
\hline Core & Depth (ft) & Description (recovery, texture, color, structure) \\
\hline \multirow{3}{*}{1} & \multirow{3}{*}{$0-4.5$} & Recovery = 3' \\
\hline & & 0-2.0': silt, blocky, root structures, 10YR 3/2 \\
\hline & & $\begin{array}{l}\text { 2.0-3.0': silt, laminated, mottled, reacts slightly with acid } \\
\text { matrix: } 10 Y R 3 / 3 \quad \text { mottle: } 10 Y R 5 / 6\end{array}$ \\
\hline \multirow{6}{*}{2} & \multirow{6}{*}{$4.5-9.0$} & Recovery $=4.4$ \\
\hline & & $0-2.2$ ': silt, laminated, 10YR 4/6 \\
\hline & & 2.2-2.5': silt with sand and gravel, some carbonate \\
\hline & & 2.5-2.8': silt, 10YR 5/8 \\
\hline & & 2.8-3.0': silt with sand and gravel, $10 \mathrm{YR} 5 / 8$ \\
\hline & & 3.0-4.4:' silt, 10YR 5/8 \\
\hline \multirow{4}{*}{3} & \multirow{4}{*}{$9-15$} & Recovery $=4.9$ \\
\hline & & $\begin{array}{l}\text { 0-1.1': silt, root channels, mottled, reaction with acid } \\
\text { matrix: } 10 \text { YR } 3 / 2 \quad \text { mottle: } 10 \text { YR } 4 / 6\end{array}$ \\
\hline & & 1.1-2.4': silt, very plastic, slightly laminated, roots, reaction with acid, $7.5 \mathrm{YR} 3 / 2$ \\
\hline & & 2.4-4.9': silt, laminated, $7.5 \mathrm{YR} 3 / 2$, sharp change in lamination at $3.7^{\prime}$ \\
\hline \multirow{3}{*}{4} & \multirow{3}{*}{$15-20$} & Recovery $=4.0^{\prime}$ \\
\hline & & $0-2.2$ ': clay, very plastic \\
\hline & & 2.2-4.0': silt, no structure \\
\hline \multirow{4}{*}{5} & \multirow{4}{*}{$20-25$} & $R=2.0^{\prime}$ \\
\hline & & $0-0.6$ ': silt, clayey, slightly laminated, gley $13 / 10 \mathrm{Y}$ \\
\hline & & $0.6-0.9$ ': clay, silty, very plastic, gley $13 / 10 \mathrm{Y}$ \\
\hline & & 0.9-2.0': silt, clayey, gley $13 / 10 \mathrm{Y}$ \\
\hline \multirow[b]{2}{*}{6} & \multirow[b]{2}{*}{$25-30$} & Recovery $=3.5$ \\
\hline & & $\begin{array}{l}0-3.5 \text { ': silt, few shell pieces, slight reaction with acid, few coarse sediments, } 10 Y R \\
3 / 1\end{array}$ \\
\hline \multirow{4}{*}{7} & \multirow{4}{*}{ 30-35 } & Recovery $=4.0$ \\
\hline & & $0-1.9^{\prime}:$ clay, mottled, gley $1,2.5 / 10 Y$ \\
\hline & & 1.9-2.1': clay, blocky structure \\
\hline & & 2.1-4.0': silt, clayey, very plastic, few shells \\
\hline \multirow{4}{*}{8} & \multirow{4}{*}{$35-40$} & Recovery = 3.0' \\
\hline & & $0-0.7$ ' silt \\
\hline & & 0.7-2.9': silt, sandy, laminated, some organic material \\
\hline & & 2.9-3.0': sand, very fine, some organic material \\
\hline \multirow{2}{*}{9} & \multirow{2}{*}{$40-45$} & Recovery $=0.8^{\prime}:$ lots of very fine sand \\
\hline & & $0-0.8$ ': sand, some silt, very fine, no reaction to acid \\
\hline 10 & $45-50$ & Recovery $=0$ ' no recovery \\
\hline
\end{tabular}


Table A16-2. Continued.

\begin{tabular}{|c|c|c|}
\hline \multirow{2}{*}{11} & \multirow{2}{*}{$50-55$} & Recovery = 1.1' \\
\hline & & $0-1.1^{\prime}$ : sand, fine grained, gley $14 / 10 \mathrm{GY}$ \\
\hline \multirow{2}{*}{12} & \multirow{2}{*}{$55-60$} & Recovery $=0.65$ \\
\hline & & 0-0.65': sand, fine grained, gley $14 / 5 \mathrm{GY}$ \\
\hline \multirow{3}{*}{13} & \multirow{3}{*}{$60-62.5$} & Recovery $=1.0^{\prime}$ \\
\hline & & $0-0.45$ ': sand, some gravel and silt \\
\hline & & $0.45-1.0^{\prime}$ : sand, silty, very fine grained, no gravel, some coarse sand \\
\hline \multirow{4}{*}{14} & \multirow{4}{*}{$62.5-65$} & Recovery = 2.9' \\
\hline & & $0-2.5$ ': sand, fine to medium grained, some shale and coal fragments \\
\hline & & 2.5-2.8': sand, medium to coarse grained \\
\hline & & 2.8-2.9': silt, with some coarse pebbles, Gley $13 / 10 \mathrm{Y}$ "till" \\
\hline \multirow{2}{*}{15} & \multirow{2}{*}{$65-67.5$} & Recovery $=0.8$ \\
\hline & & 0-0.8': silt, with coarse pebbles, Gley $13 / 10 Y$ "till" \\
\hline \multirow{2}{*}{16} & \multirow{2}{*}{$67.5-73$} & Recovery $=1.8$ \\
\hline & & $0-1.8$ ': silt with coarse pebbles and plant fragments, Gley $13 / 10 \mathrm{Y}$ "till" \\
\hline \multirow{3}{*}{17} & \multirow{3}{*}{$73-75$} & Recovery $=0.5$ \\
\hline & & $0-0.2$ ': silt, with coarse pebbles, Gley $13 / 10 Y$ "till" \\
\hline & & $0.2-0.5^{\prime}$ : sand, silty, fine grained, plant fragments, Gley $13 / 10 \mathrm{Y}$ \\
\hline \multirow[b]{2}{*}{18} & \multirow[b]{2}{*}{$75-80$} & Recovery $=5$ \\
\hline & & $\begin{array}{l}0-5.0 \text { ': silt, clayey, mottled, no reaction with acid, very dense "till" } \\
24 / 5 \mathrm{G} \text { mottle: gley } 14 / 10 \mathrm{Y}\end{array}$ \\
\hline \multirow{4}{*}{19} & \multirow{4}{*}{$80-85$} & Recovery $=3.8$ \\
\hline & & 0-2.2': silt, sandy, very fine sand, pieces of shale \\
\hline & & 2.2-2.6': sand, silty, very fine grained \\
\hline & & 2.6-5.0': sand, silty, fine grained, grains sub-angular to sub-rounded \\
\hline \multirow{2}{*}{20} & \multirow{2}{*}{$85-90$} & Recovery = 2.8 \\
\hline & & 0-2.8': sand, silty, fine grained, sub-angular to sub-rounded \\
\hline \multirow{4}{*}{21} & \multirow{4}{*}{$90-92.7$} & Recovery $=1.6^{\prime}$ \\
\hline & & $0-0.6^{\prime}$ : sand, fine to coarse with a few pieces of gravel \\
\hline & & $0.6-1.3^{\prime}$ : sand and gravel \\
\hline & & 1.3-1.6': silt, with sand and gravel "till" \\
\hline \multirow{3}{*}{22} & \multirow{3}{*}{$92.7-93.5$} & Recovery $=0.9$ \\
\hline & & $0-0.2$ ': sand, silty with some gravel "till" \\
\hline & & $0.2-0.9$ : silt, laminated, few plant fragments \\
\hline \multirow{3}{*}{23} & \multirow{3}{*}{$93.5-95$} & Recovery $=1.6$ \\
\hline & & 0-0.3': gravel, coarse \\
\hline & & 0.3-1.6': shale, clay-rich, bedrock? \\
\hline
\end{tabular}




\section{Appendix 17. Construction Details for ECBM Groundwater Monitoring Wells}

Note for all Appendix 17 tables: Some fields were intentionally left blank.

Table A17-1. Well construction details for ECBM1.

Well name: ECBM1 API: 121852849000

Well location: Wabash County, NE $1 / 4$, Sec. $27, \mathrm{~T} 1 \mathrm{~S}, \mathrm{R} 14 \mathrm{~W}$

Personnel: Mehnert, Wimmer, Iranmanesh, Aud, Blacker, Griest

Date well was constructed: 4/29/2008

Final hole depth: 91.5'

Surface completion: Stick-up

Backfilled? 2' with sand

Depth and thickness of aquifer: 5' from 92-87'

Depth of water in well: 9.07' from top of PVC riser

Screened interval: 5' (92-87'), 10-slot screen

Depth to which hole collapsed: N/A

Sand added: $80 \mathrm{lbs}$.

Bentonite (Benseal) added: $150 \mathrm{lbs}$.

Depth of backfill: 93.5-91.5'

Any additional Bentonite?

Pellets: 50 lbs.

Holeplug: 100 lbs.

Concrete: 110 lbs. (2.5 bags)
Depth: 93.5-86.95'

Depth: 81.5-5'

Texture of backfill: sand

Depth:

$86.95-81.5$

$5-2$

2'-surface

Well location:

Distance and direction from centerline: 25 ' west of centerline

Distance and direction from some landmark (ft.): 40' east of grain bin

Description of landmark: silver-colored grain bin elevator

Distance and direction from intersection (miles): CR150E, CR1300N; about 1/8 mile south of intersection

Description of intersection:

Was well developed at time of construction? Yes

Was well logged (natural gamma) at time of construction? Yes

Details of monitoring well construction: see Figure 44 
Table A17-2. Well construction details for ECBM2.

Well name: ECBM2

API: 121852849100

Well location: Wabash County, NE/4, Section 27, T1S, R14W

Personnel: Mehnert, Wimmer, Iranmanesh, Aud, Blacker, Griest

Date well was constructed: 5/1/2008

Final Depth of Hole: 93

Surface completion: stick-up

Backfilled? No

Depth and thickness of aquifer: 5' (93-88')

Depth of water in well:

Screened interval: 93-88

Depth to which hole collapsed: N/A

Sand added: $\quad 212.5 \mathrm{lbs}$ Depth: 93-80.4'

Bentonite (Benseal) added: 100 lbs. Depth: 73.3-12'

Depth of backfill:

Texture of backfill:

Any additional Bentonite?

Depth:

Pellets: 50 lbs.

80.4-73.3'

Holeplug: 150 lbs.

$12-2$

Concrete: $120 \mathrm{lbs}$.

2'-surface

Well location:

Distance and direction from centerline:

Distance and direction from some landmark (ft.): 10' Northwest of grain bin

Description of landmark: Silver-colored grain bin

Distance and direction from intersection (miles): CR $150 \mathrm{E}, \mathrm{CR} 1300 \mathrm{~N}, \mathrm{SSW}$ of intersection, $1 / 8$ mile

Description of intersection:

Was well developed at time of construction? Yes

Was well logged (natural gamma) at time of construction? Yes 
Table A17-3. Well construction details for ECBM3.

Well name: ECBM3

API: 121852849200

Well location: Wabash County, NE $1 / 4$, Sec. $27, \mathrm{~T} 1 \mathrm{~S}, \mathrm{R} 14 \mathrm{~W}$

Personnel: Mehnert, Wimmer, Iranmanesh, Aud, Blacker, Griest

Date well was constructed: 5/1/2008

Final hole depth: 93.2'

Surface completion: stick-up

Backfilled? No

Depth and thickness of aquifer: 5' (93.2-88.2')

Depth of water in well: NA

Screened interval: 93.2-88.2'

Depth to which hole collapsed: N/A

Sand added: $175 \mathrm{lbs}$.

Bentonite (Benseal) added: $112.5 \mathrm{lbs}$.

Depth of backfill:

Any additional Bentonite?

Pellets: 50 lbs.

Hole plug: $100 \mathrm{lbs}$.

Concrete: $120 \mathrm{lbs}$.

Well location:

Distance and direction from centerline:

Distance and direction from some landmark (ft.): 40' WSW of grain bin

Description of landmark: Silver-colored grain bin elevator

Distance and direction from intersection (miles): CR150E, CR1300N, $1 / 8$ mile south of intersection

Description of intersection:

Was well developed at time of construction?

Yes

Was well logged (natural gamma) at time of construction? Yes
Depth: 79.7

Depth: 73.9-8'

Texture of backfill:

Depth:

79.7-73.9'

8-2'

2'-surface 
Table A17-4. Well construction details for ECBM4.

Well name: ECBM4 API: 121852849300

Well location: Wabash County, NE $1 / 4$, Sec. $27, \mathrm{~T} 1 \mathrm{~S}, \mathrm{R} 14 \mathrm{~W}$

Personnel: Mehnert, Wimmer, Iranmanesh, Aud, Blacker, Griest

Date well was constructed: $4 / 30 / 2008$

Final hole depth: 92 Surface completion: stick-up

Backfilled?: No

Depth and thickness of aquifer: 5' (92-87')

Depth of water in well: 2.82 '

Screened interval: 92.2-87.2'

Depth to which hole collapsed: N/A

Sand added: $225 \mathrm{lbs}$.

Bentonite (Benseal) added: $100 \mathrm{lbs}$.

Depth of backfill:

Any additional Bentonite?

Pellets: 50 lbs.

Hole plug: $235 \mathrm{lbs}$

Concrete: $80 \mathrm{lbs}$.
Depth: 92.2-78.2'

Depth: 70.8-12'

Texture of backfill:

Depth:

$78.2-70.8^{\prime}$

$12-2$

2'-surface

Well location:

Distance and direction from centerline:

Distance and direction from some landmark (ft.): 180' W of grain bin

Description of landmark: Silver-colored grain bin elevator

Distance and direction from intersection (miles): CR150E, CR1300N, SW of intersection, $1 / 8$ mile

Description of intersection:

Was well developed at time of construction? Yes

Was well logged (natural gamma) at time of construction? Yes 
API \# 121852849100

Well T.D to top of riser

$95.59^{\prime}$

Date installed $05 / 01 / 2008$

Hole \# ECBM2

$4^{\prime \prime} \times 4^{\prime \prime} \times 5^{\prime}$ well protector

- Top of Riser_2.59' AGL

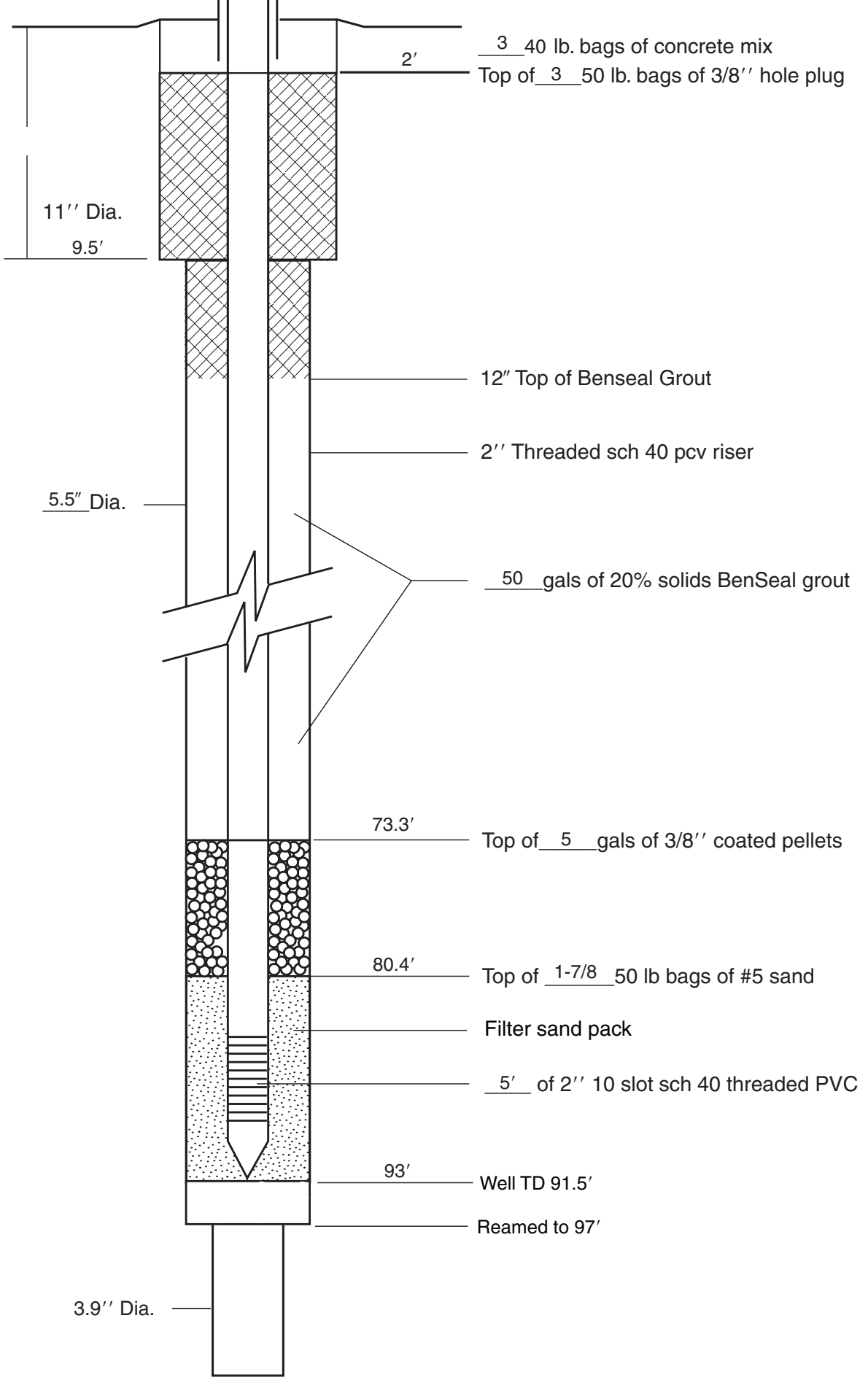

Figure A17-1. Details of groundwater monitoring well construction, ECBM2. 
API \# 121852849200

Well T.D to top of riser

$95.58^{\prime}$

Date installed $05 / 01 / 2008$

Hole \# ECBM3

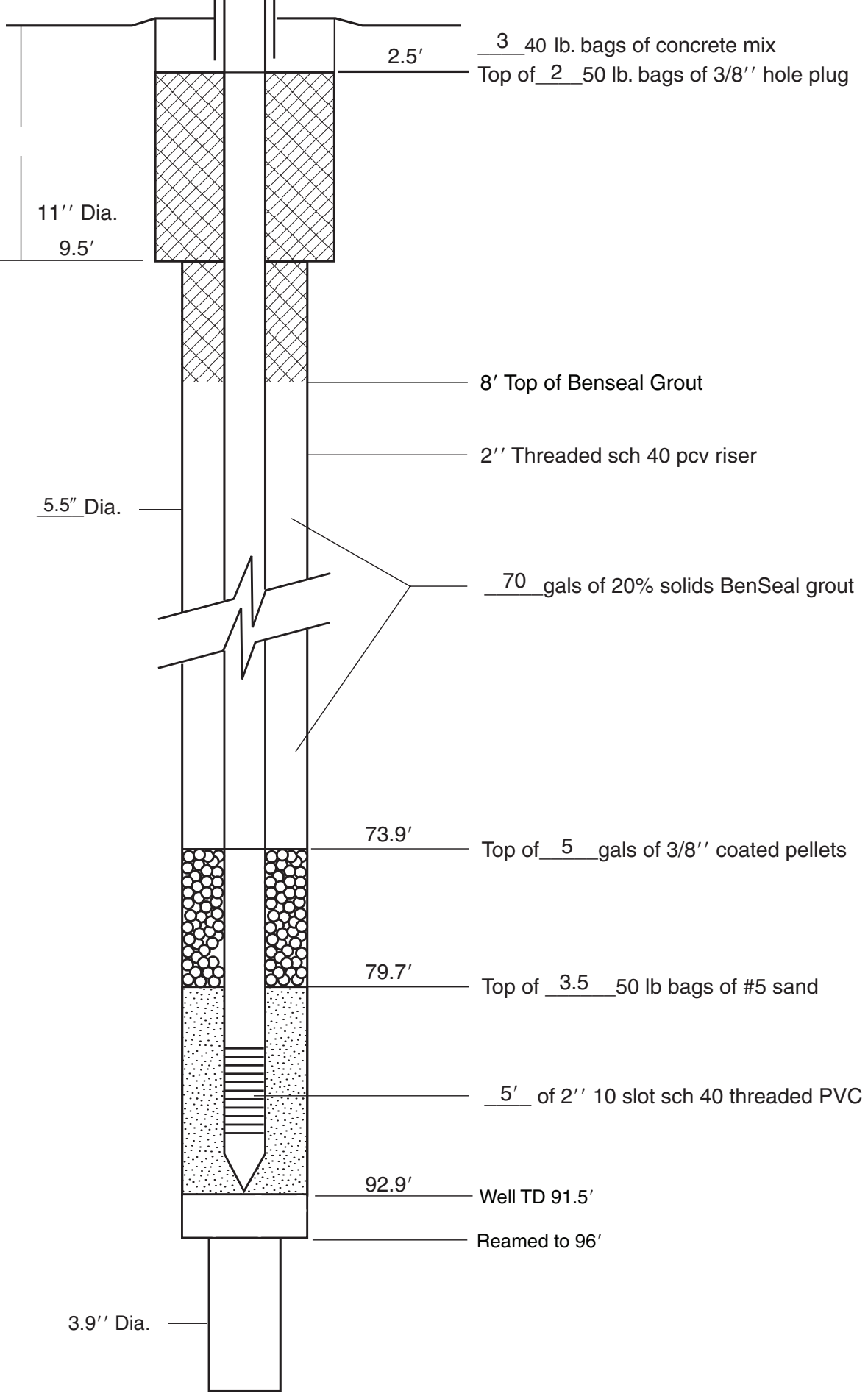

Figure A17-2. Details of groundwater monitoring well construction, ECBM3. 
API \# 121852849300

Well T.D to top of riser $95.5 \mathrm{\theta}^{\prime}$

Date installed 04 / 30 / 2008

Hole \# ECBM4

4" 4 4" $^{\prime \prime} \times 5^{\prime}$ well protector

\section{Hole \#}

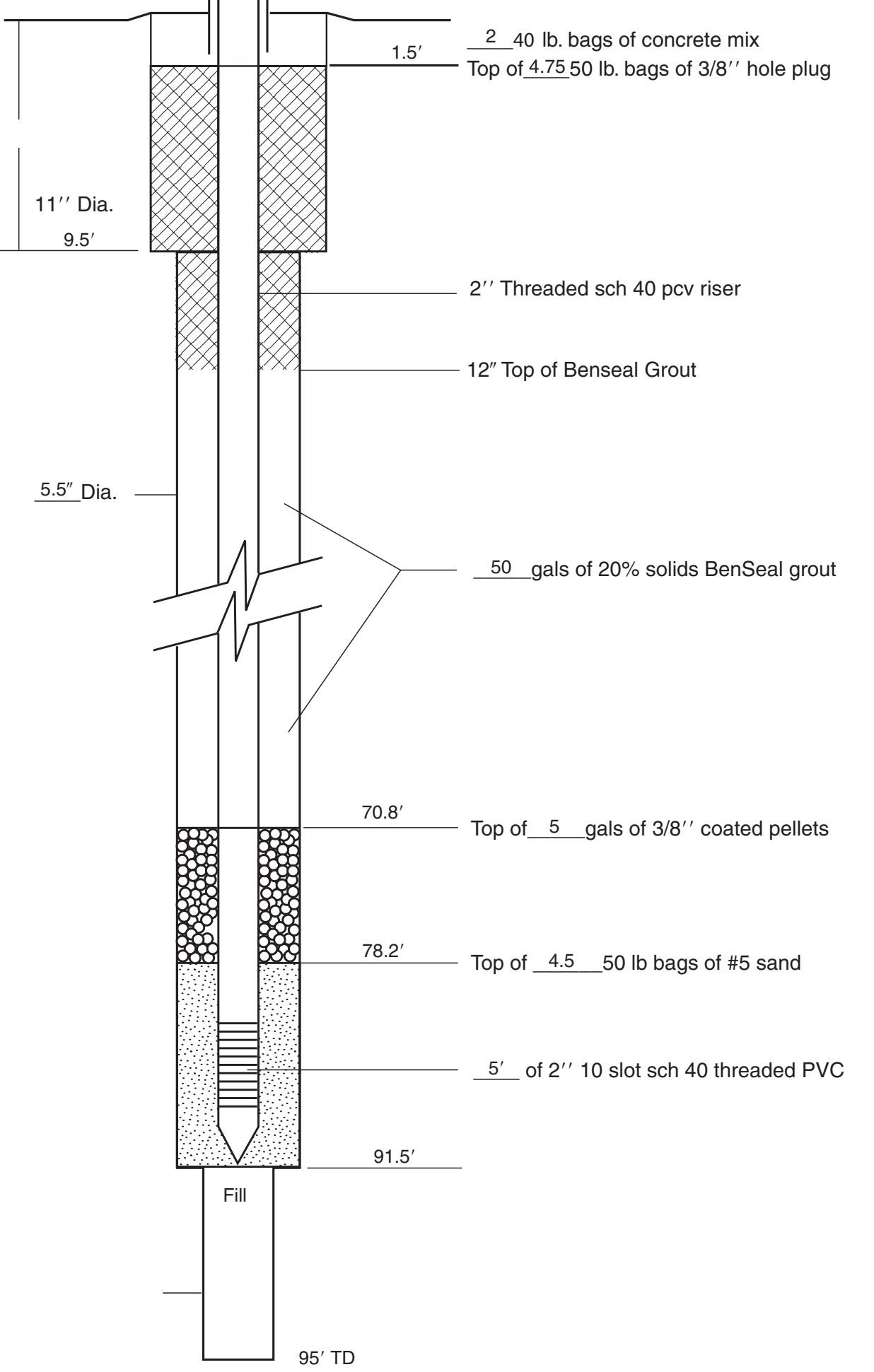

Figure A17-3. Details of groundwater monitoring well construction, ECBM4. 


\section{Appendix 18. Isotopic Results for Water Samples from the ECBM Site}

Table A18-1. Isotopic results (\%) for groundwater samples from ECBM1, ECBM2, ECBM3, ECBM4, Hering, and Kieffer wells.

\begin{tabular}{|c|c|c|c|c|c|c|}
\hline Sample & Well & $\begin{array}{c}\text { Sampling } \\
\text { date }\end{array}$ & $\delta^{13} \mathrm{C}$ & $\delta^{18} \mathrm{O}$ & $\delta D$ & $\begin{array}{c}\text { Tritium } \\
\text { unit (TU) }\end{array}$ \\
\hline T15-08 & ECBM1 & 6/5/2008 & -11.8 & -5.91 & -38.6 & $<0.5$ \\
\hline T21-08 & ECBM1 & $6 / 12 / 2008$ & -11.7 & -6.05 & -38.7 & $<0.5$ \\
\hline T26-08 & ECBM1 & $6 / 19 / 2008$ & -11.7 & & & \\
\hline T32-08 & ECBM1 & $6 / 26 / 2008$ & -13.1 & -6.28 & -38.3 & \\
\hline T36-08 & ECBM1 & 7/1/2008 & -11.6 & -6.14 & -37.5 & \\
\hline T42-08 & ECBM1 & 7/10/2008 & -11.5 & -6.22 & -36.9 & $<0.5$ \\
\hline T46-08 & ECBM1 & $7 / 24 / 2008$ & -11.7 & -5.86 & -37.3 & \\
\hline T50-08 & ECBM1 & $7 / 24 / 2008$ & -11.7 & -6.10 & -38.3 & \\
\hline T53-08 & ECBM1 & $8 / 12 / 2008$ & -10.7 & -6.11 & -38.4 & \\
\hline T57-08 & ECBM1 & $9 / 3 / 2008$ & -11.8 & -6.14 & -38.1 & \\
\hline T63-08 & ECBM1 & $10 / 8 / 2008$ & -11.7 & -6.26 & -38.2 & \\
\hline T70-08 & ECBM1 & $12 / 3 / 2008$ & -11.6 & -6.13 & -38.4 & \\
\hline T76-09 & ECBM1 & 3/16/2009 & -11.6 & -6.34 & -40.6 & \\
\hline T16-08 & ECBM2 & $6 / 5 / 2008$ & -12.3 & -5.96 & -38.8 & $<0.5$ \\
\hline T22-08 & ECBM2 & $6 / 12 / 2008$ & -12.2 & -5.77 & -39.3 & \\
\hline T27-08 & ECBM2 & $6 / 19 / 2008$ & -13.2 & -5.81 & -37.5 & \\
\hline T33-08 & ECBM2 & $6 / 26 / 2008$ & -13.6 & -6.26 & -39.3 & \\
\hline T37-08 & ECBM2 & $7 / 1 / 2008$ & -12.4 & -6.28 & -39.6 & \\
\hline T43-08 & ECBM2 & $7 / 10 / 2008$ & -11.9 & -5.75 & -36.3 & $<0.58$ \\
\hline T47-08 & ECBM2 & $7 / 24 / 2008$ & -12.2 & -6.11 & -37.8 & \\
\hline T54-08 & ECBM2 & 8/12/2008 & -11.6 & -6.25 & -38.6 & \\
\hline T58-08 & ECBM2 & $9 / 3 / 2008$ & -12.4 & -5.82 & -37.7 & \\
\hline T64-08 & ECBM2 & $10 / 8 / 2008$ & -12.6 & -6.18 & -37.9 & \\
\hline T71-08 & ECBM2 & $12 / 3 / 2008$ & -12.4 & -6.29 & -38.7 & \\
\hline T77-09 & ECBM2 & 3/16/2009 & -12.4 & -6.18 & -38.7 & \\
\hline T17-08 & ECBM3 & $6 / 5 / 2008$ & -11.8 & -5.97 & -38.0 & $<0.72$ \\
\hline T23-08 & ЕСВM3 & $6 / 12 / 2008$ & -11.9 & -6.05 & -38.5 & \\
\hline T28-08 & ЕСВMЗ & $6 / 19 / 2008$ & -12.1 & -5.95 & -37.6 & \\
\hline T34-08 & ЕСВMЗ & $6 / 26 / 2008$ & -11.8 & -6.06 & -38.1 & \\
\hline T38-08 & ЕСВМЗ & 7/1/2008 & -11.6 & -6.39 & -39.7 & \\
\hline T44-08 & ЕСВМЗ & $7 / 10 / 2008$ & -11.5 & -5.84 & -36.4 & $<0.66$ \\
\hline T48-08 & ЕСВМЗ & $7 / 24 / 2008$ & -11.6 & -6.23 & -38.1 & \\
\hline T55-08 & ЕСВM3 & 8/12/2008 & -10.6 & -6.00 & -37.8 & \\
\hline T59-08 & ЕСВМЗ & 9/3/2008 & 12.0 & -6.29 & -39.1 & \\
\hline T65-08 & ЕСВM3 & $10 / 8 / 2008$ & -12.2 & -6.18 & -38.1 & \\
\hline T72-08 & ЕСВMЗ & $12 / 3 / 2008$ & -10.6 & -5.81 & -38.2 & \\
\hline T78-09 & ECBM3 & $3 / 16 / 2009$ & -11.4 & -6.16 & -39.0 & \\
\hline T20-08 & ECBM4 & $6 / 12 / 2008$ & -12.0 & -6.06 & -39.3 & $<0.5$ \\
\hline
\end{tabular}


Table A18-1. Continued.

\begin{tabular}{|c|c|c|c|c|c|c|}
\hline T29-08 & ECBM4 & $6 / 19 / 2008$ & -12.7 & -6.10 & -37.9 & \\
\hline T35-08 & ECBM4 & $6 / 26 / 2008$ & -12.7 & -6.10 & -38.4 & \\
\hline T39-08 & ECBM4 & $7 / 1 / 2008$ & -11.3 & -6.27 & -38.0 & \\
\hline T45-08 & ECBM4 & $7 / 10 / 2008$ & -11.5 & -6.21 & -38.1 & \\
\hline T49-08 & ECBM4 & $7 / 24 / 2008$ & -11.1 & -6.20 & -38.3 & \\
\hline T56-08 & ECBM4 & 8/12/2008 & -10.2 & -6.17 & -38.9 & \\
\hline T60-08 & ECBM4 & $9 / 3 / 2008$ & -11.0 & -6.29 & -38.5 & \\
\hline T66-08 & ECBM4 & $10 / 8 / 2008$ & -10.9 & -6.24 & -38.5 & \\
\hline T73-08 & ECBM4 & $12 / 3 / 2008$ & -10.6 & -5.90 & -38.6 & \\
\hline T79-09 & ECBM4 & 3/16/2009 & -10.5 & -6.21 & -38.8 & \\
\hline T7-07 & Hering & $12 / 4 / 2007$ & -8.8 & -7.40 & -47.5 & \\
\hline T9-08 & Hering & 3/13/2008 & -8.8 & -7.55 & -50.0 & $<0.5$ \\
\hline T13-08 & Hering & $6 / 4 / 2008$ & -8.8 & -7.35 & -48.3 & $<0.5$ \\
\hline T18-08 & Hering & $6 / 12 / 2008$ & -8.9 & -7.08 & -49.0 & $<0.56$ \\
\hline T24-08 & Hering & $6 / 19 / 2008$ & -8.6 & -7.35 & -47.7 & \\
\hline T30-08 & Hering & 6/26/2008 & -9.4 & -7.68 & -49.4 & \\
\hline T40-08 & Hering & $7 / 10 / 2008$ & -9.0 & -7.28 & -46.2 & $<0.60$ \\
\hline T51-08 & Hering & 8/12/2008 & -9.6 & -7.66 & -48.5 & \\
\hline T62-08 & Hering & $10 / 8 / 2008$ & -8.8 & -7.54 & -48.0 & \\
\hline T68-08 & Hering & $12 / 3 / 2008$ & -8.9 & -7.52 & -47.9 & \\
\hline T74-09 & Hering & 3/16/2009 & -9.3 & -7.27 & -47.9 & \\
\hline T8-07 & Kieffer & $12 / 4 / 2007$ & -11.3 & -6.56 & -42.4 & \\
\hline T10-08 & Kieffer & 3/13/2008 & -11.6 & -6.48 & -42.1 & $<0.5$ \\
\hline T14-08 & Kieffer & 6/4/2008 & -13.2 & -6.16 & -40.5 & $<0.5$ \\
\hline T19-08 & Kieffer & $6 / 12 / 2008$ & -12.3 & -6.37 & -42.3 & $<0.5$ \\
\hline T25-08 & Kieffer & $6 / 19 / 2008$ & -12.9 & -6.05 & -40.0 & \\
\hline T31-08 & Kieffer & $6 / 26 / 2008$ & -13.8 & -6.20 & -39.2 & \\
\hline T41-08 & Kieffer & $7 / 10 / 2008$ & -13.1 & -6.33 & -38.7 & $<0.64$ \\
\hline T52-08 & Kieffer & 8/12/2008 & -11.7 & -6.44 & -40.9 & \\
\hline T61-08 & Kieffer & $10 / 8 / 2008$ & -12.0 & -6.27 & -40.3 & \\
\hline T69-08 & Kieffer & $12 / 3 / 2008$ & -12.3 & -6.59 & -41.8 & \\
\hline \multirow[t]{2}{*}{ T75-09 } & Kieffer & $3 / 16 / 2009$ & -13.5 & -6.45 & -41.1 & \\
\hline & Observation & & & & & \\
\hline T67-08 & well M-2 & $10 / 8 / 2008$ & -8.25 & -6.83 & -42.8 & \\
\hline
\end{tabular}




\section{Appendix 19. Schematics of Data Acquisition and Transmission Equipment}

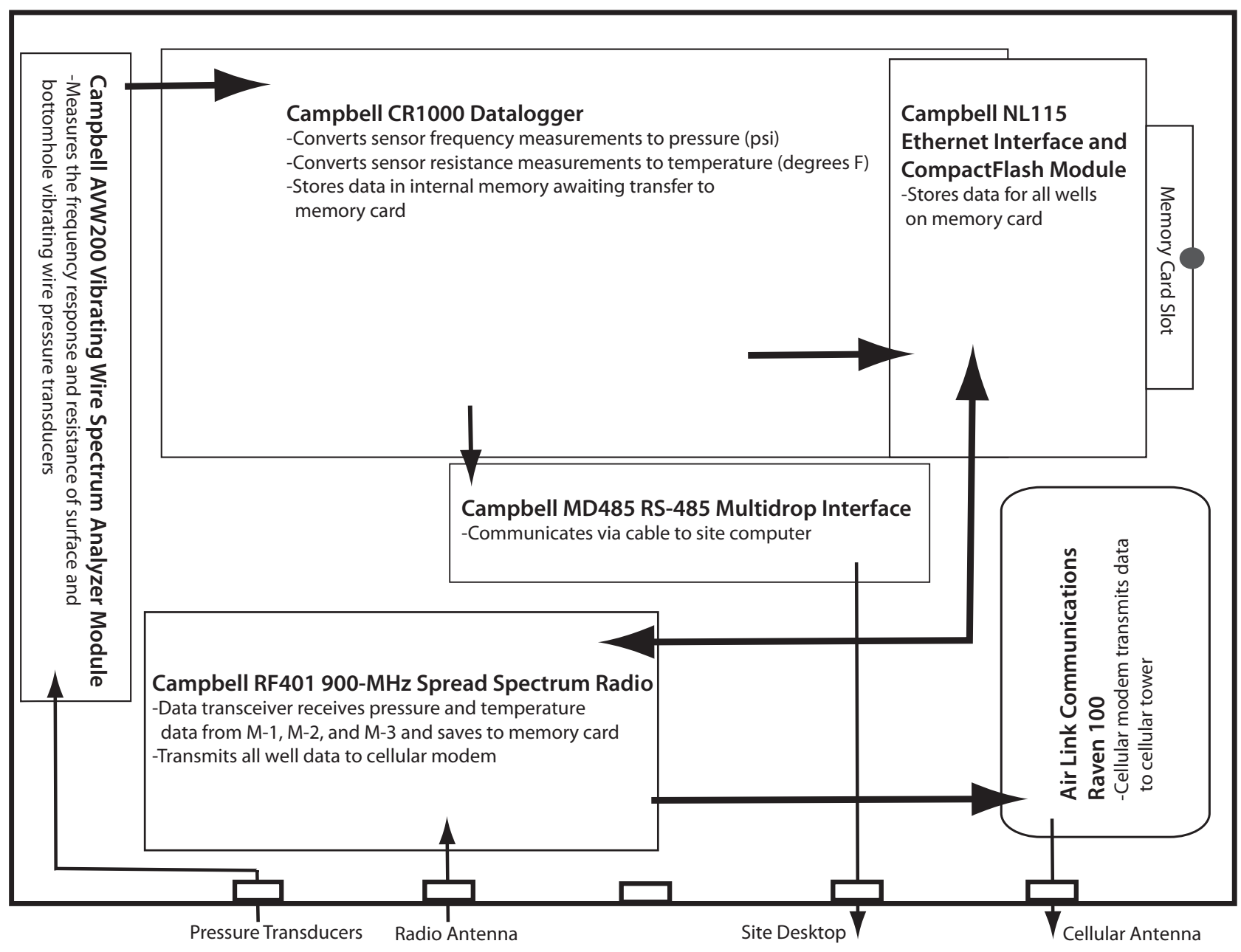

Figure A19-1. Datalogger setup for injection well l-1B. 


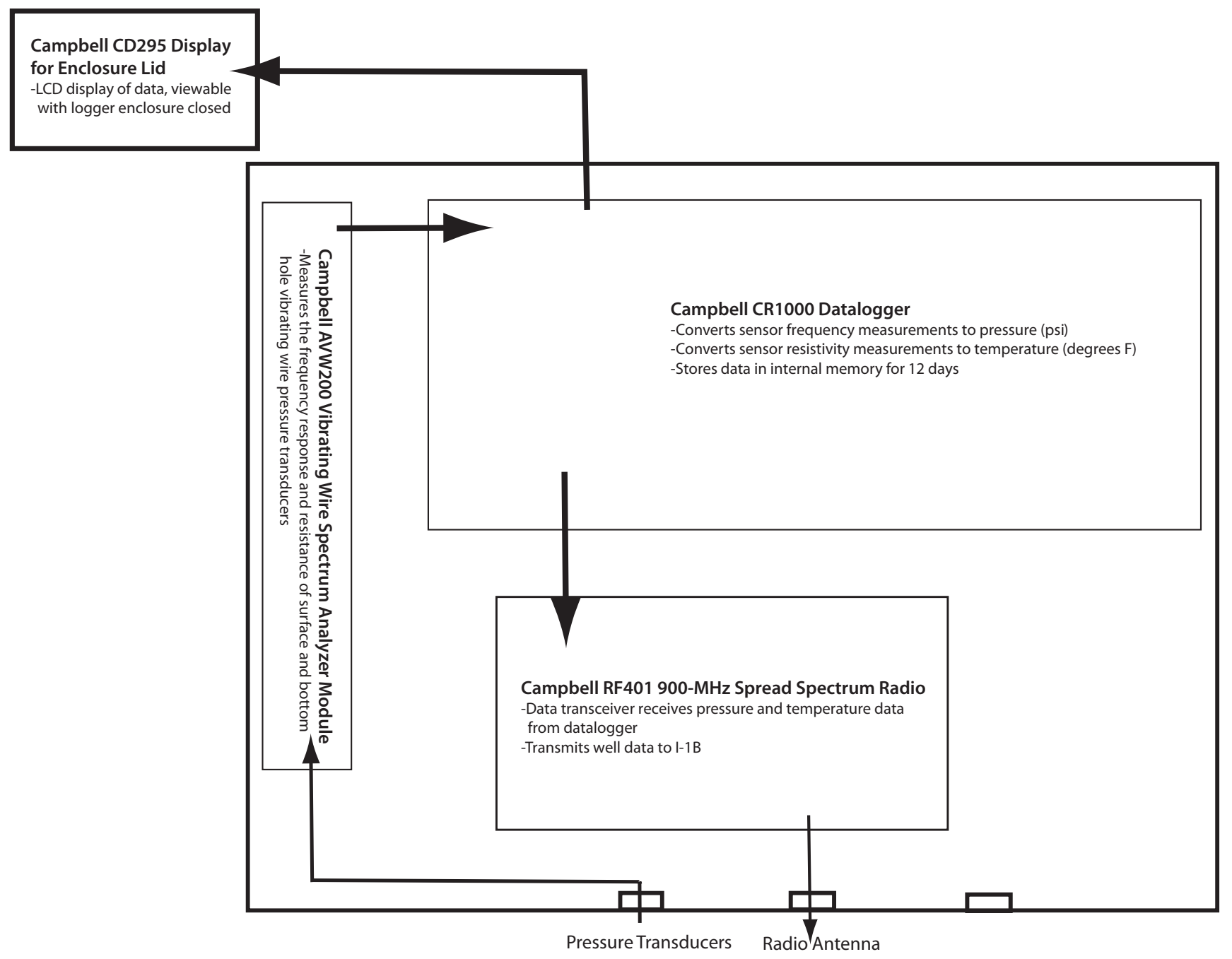

Figure A19-2. Datalogger setup for monitoring wells $\mathrm{M}-1$ and $\mathrm{M}-2$. 


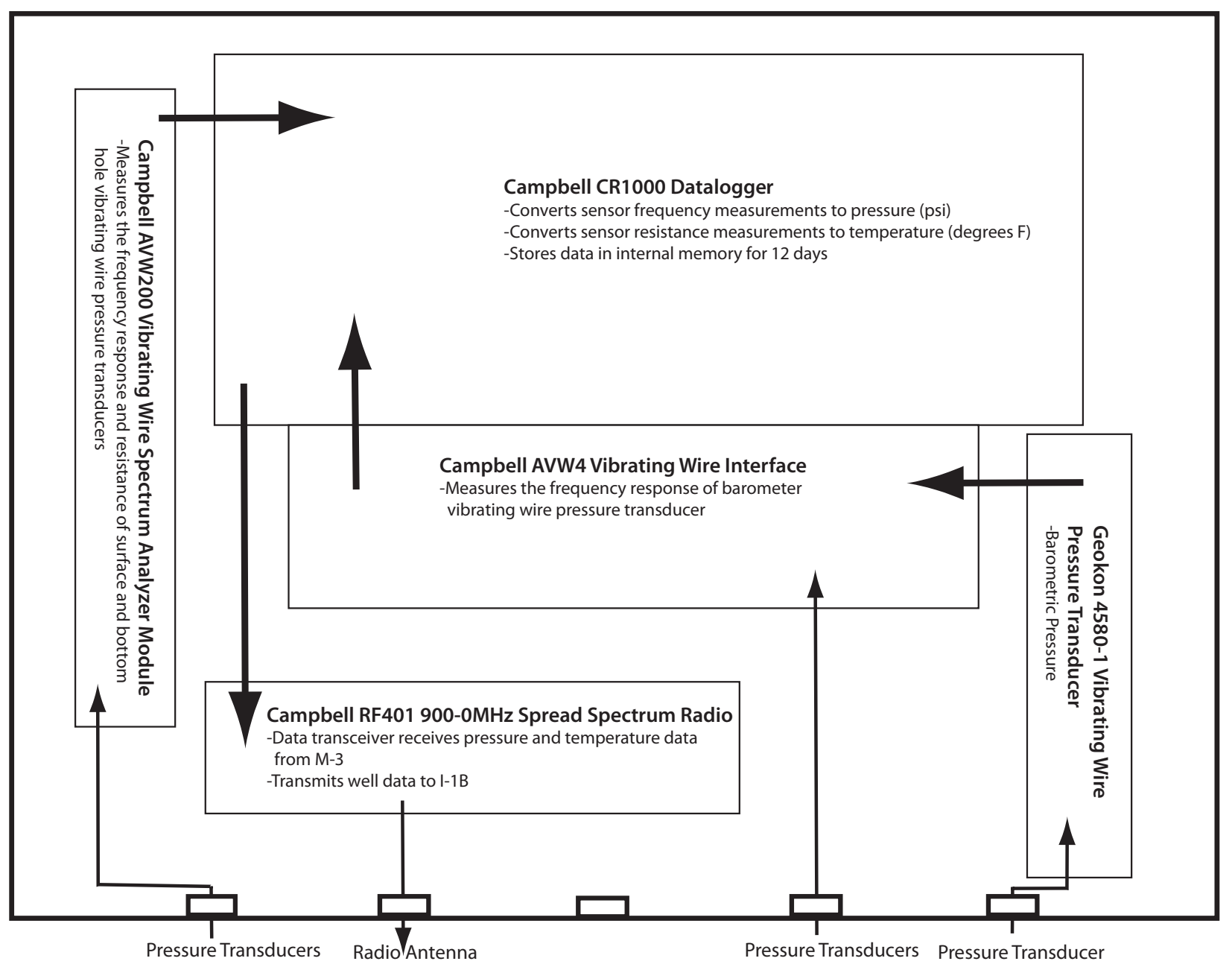

Figure A19-3. Datalogger setup for monitoring well M-3. 


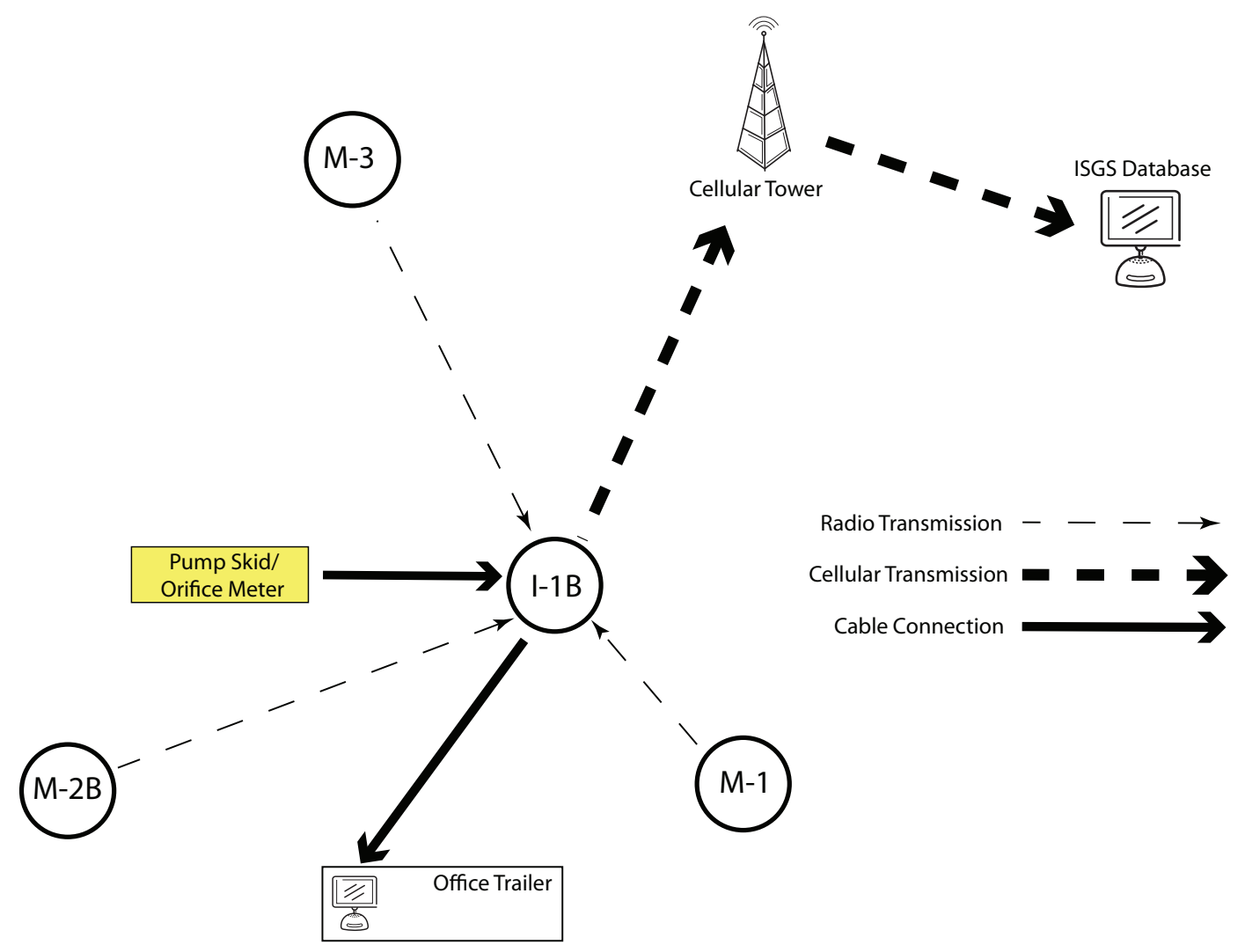

Figure A19-4. ECBM modes of data transmission. 


\section{Appendix 20. Sequence of Events}

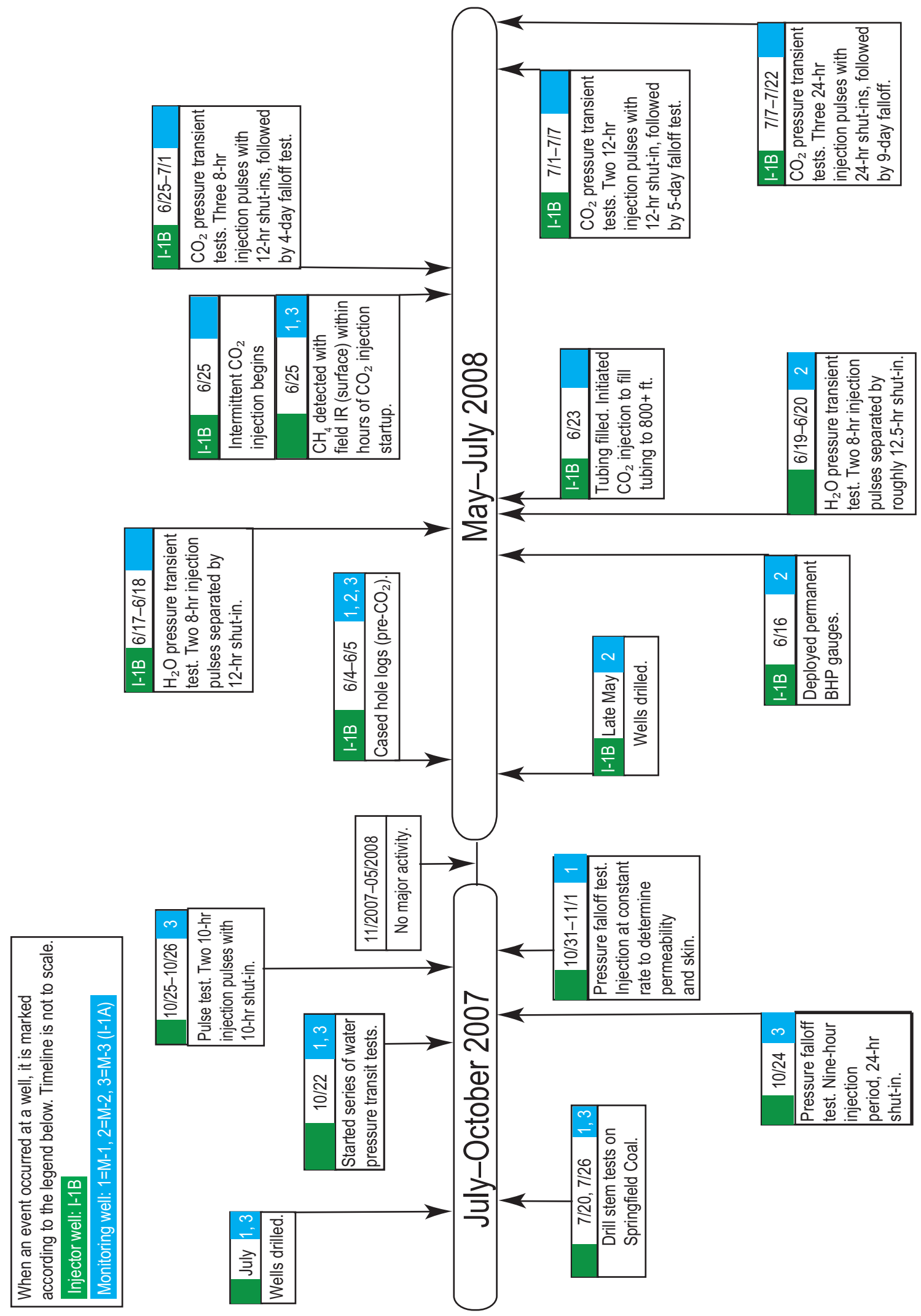




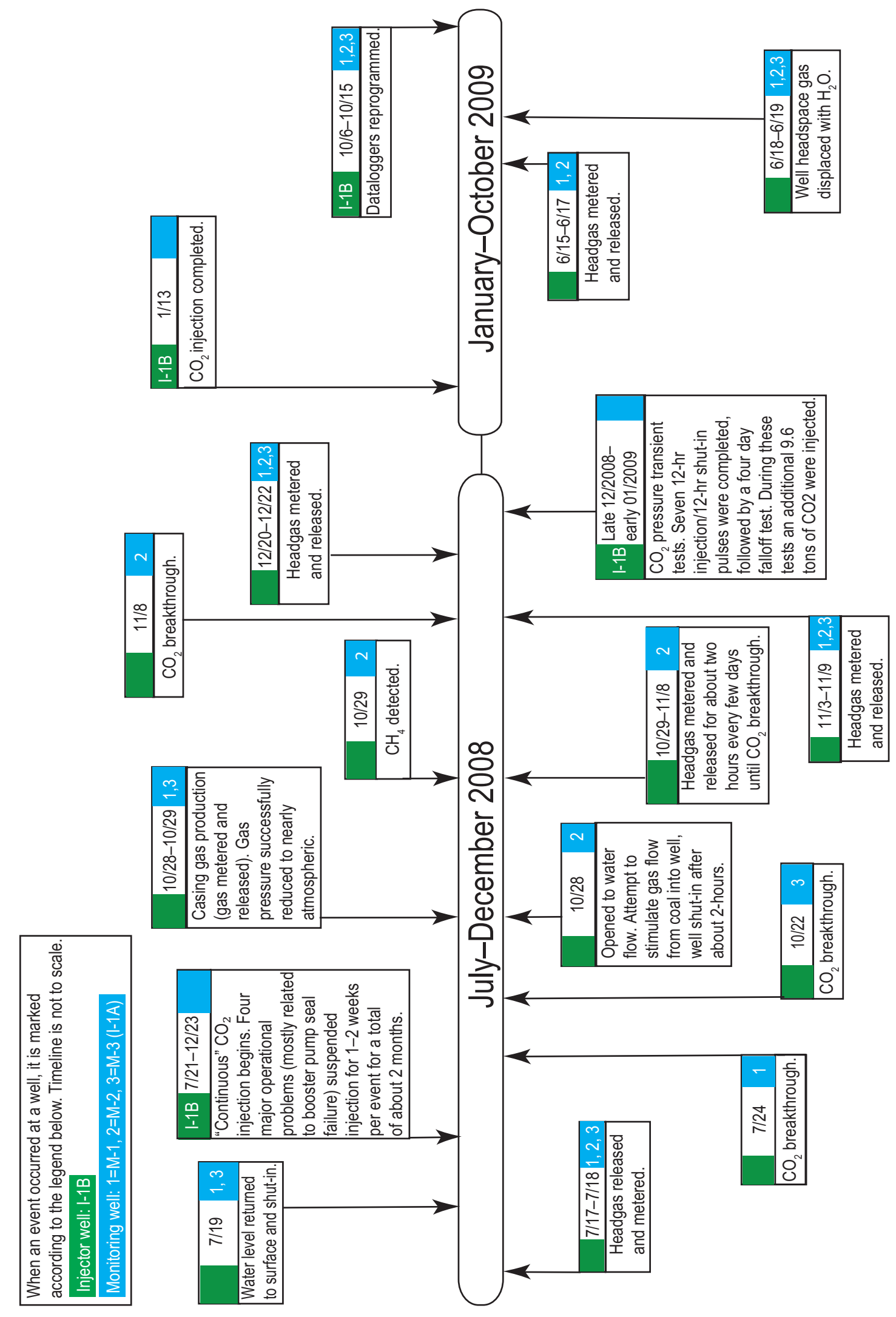




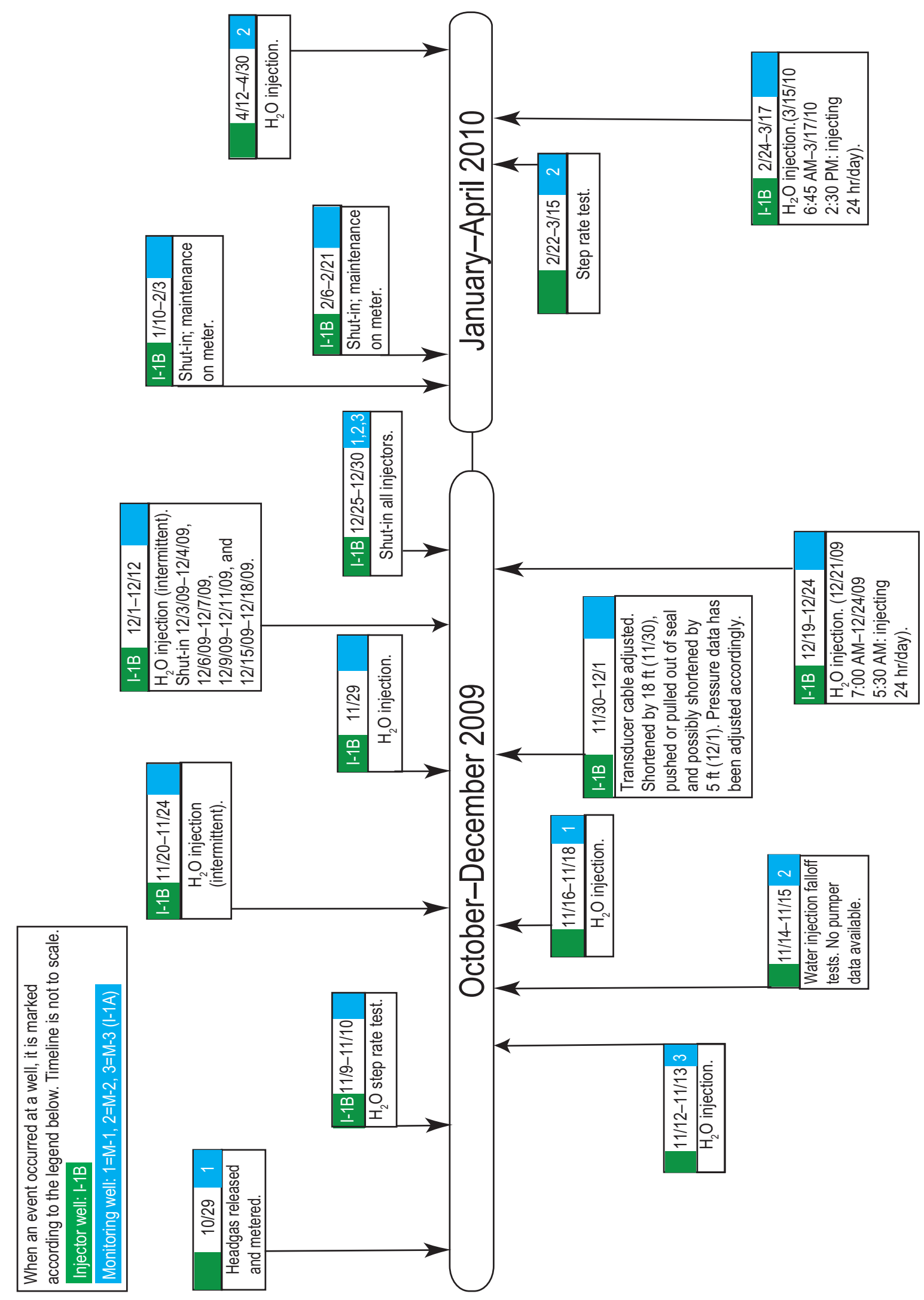




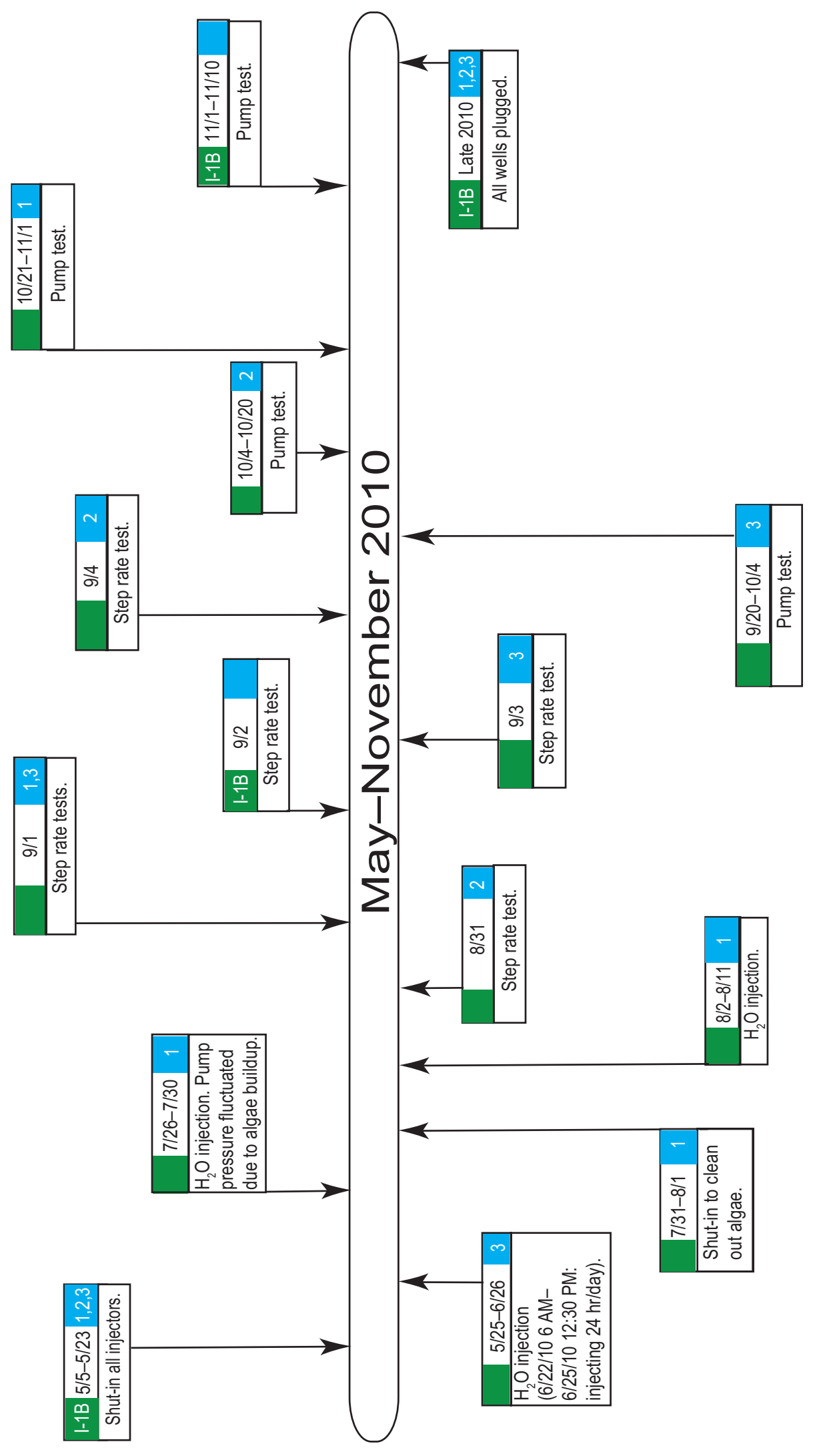




\section{Appendix 21. Procedure for Volumetric Strain Measurement during the Swelling/Shrinkage Experiment}

\section{Sample Preparation}

The coal core with the least number of cleats was selected for the experimental work. Test specimens were first cut into triangular prism shapes, and the orthogonal surfaces of the samples were polished. After the surface was prepared, three strain gages were affixed to the surface of each sample in order to monitor the strains in the three orthogonal directions ( $\mathrm{x}$, $\mathrm{y}$, and $\mathrm{z}$. The test specimens were then stored in an environmental chamber under in situ temperature and humid conditions.

\section{Experimental Setup}

The setup designed for this experiment had the capability of measuring volumetric strain with change in gas pressure and composition. The primary components of the setup were pressure vessels capable of withstanding very high pressure, a data acquisition system (DAS) to monitor the strains, and a gas chromatograph (GC) to determine the composition of the gas mixtures. For each sample, individual strain data were recorded by the DAS. The volumetric strain, $\varepsilon_{\mathrm{s}}$, for each sample tested was calculated using the following equation:

$\varepsilon_{\mathrm{s}}=\varepsilon_{\mathrm{x}}+\varepsilon_{\mathrm{y}}+\varepsilon_{\mathrm{z}}$

where $\varepsilon_{\mathrm{x}}, \varepsilon_{\mathrm{y}}$, and $\varepsilon_{\mathrm{z}}$ are the linear strains measured in the $\mathrm{x}, \mathrm{y}$, and $\mathrm{z}$ directions respectively. Maintaining a constant temperature throughout the experiment is extremely important since the adsorption/desorption of gas, and hence, the sorptioninduced strain, is very sensitive to temperature. The pressure vessels containing the samples were placed in a high-precision constant temperature water bath. A schematic of the experimental setup is shown in Figure A21-1.

\section{Experimental Procedure}

Prior to starting the experiment, each sample was removed from the environmental chamber and placed in the highpressure vessel. The experiment was initiated by first conducting the mechanical compliance test using a non-adsorptive gas, helium. For this, each sample was subjected to a stepwise increase in helium pressure up to a final pressure of 800 psi. Because helium is non-adsorptive, the volumetric strain was purely due to mechanical compression of the solid coal resulting from changes in the external pressure. The measured volumetric strain was used to obtain the grain compressibility $\left(\mathrm{C}_{\mathrm{g}}\right)$ of the sample.

Following the mechanical compliance test, helium was bled from the vessels. Two of the samples were then flooded with $\mathrm{CH}_{4}$ and one with $\mathrm{CO}_{2}$ to measure the coal matrix swelling strain for $\mathrm{CH}_{4}$ and $\mathrm{CO}_{2}$. Gas pressure in all three sample containers was gradually increased to a final pressure of $5.5 \mathrm{MPa}$ (800 psi). Using the measured strain, the matrix swelling coefficients for $\mathrm{CH}_{4}$ and $\mathrm{CO}_{2}$ were calculated.

Following the adsorption part of the experiment, one $\mathrm{CH}_{4}$ - saturated sample was selected to replicate the $\mathrm{CO}_{2}$-ECBM practice in the field. In this phase of the experiment, $\mathrm{CH}_{4}$ in one of the containers was gradually replaced with $\mathrm{CO}_{2}$, keeping the total gas pressure constant and measuring the incremental strain continuously. The procedure was continued until the gas within and surrounding the sample was pure $\mathrm{CO}_{2}$. 


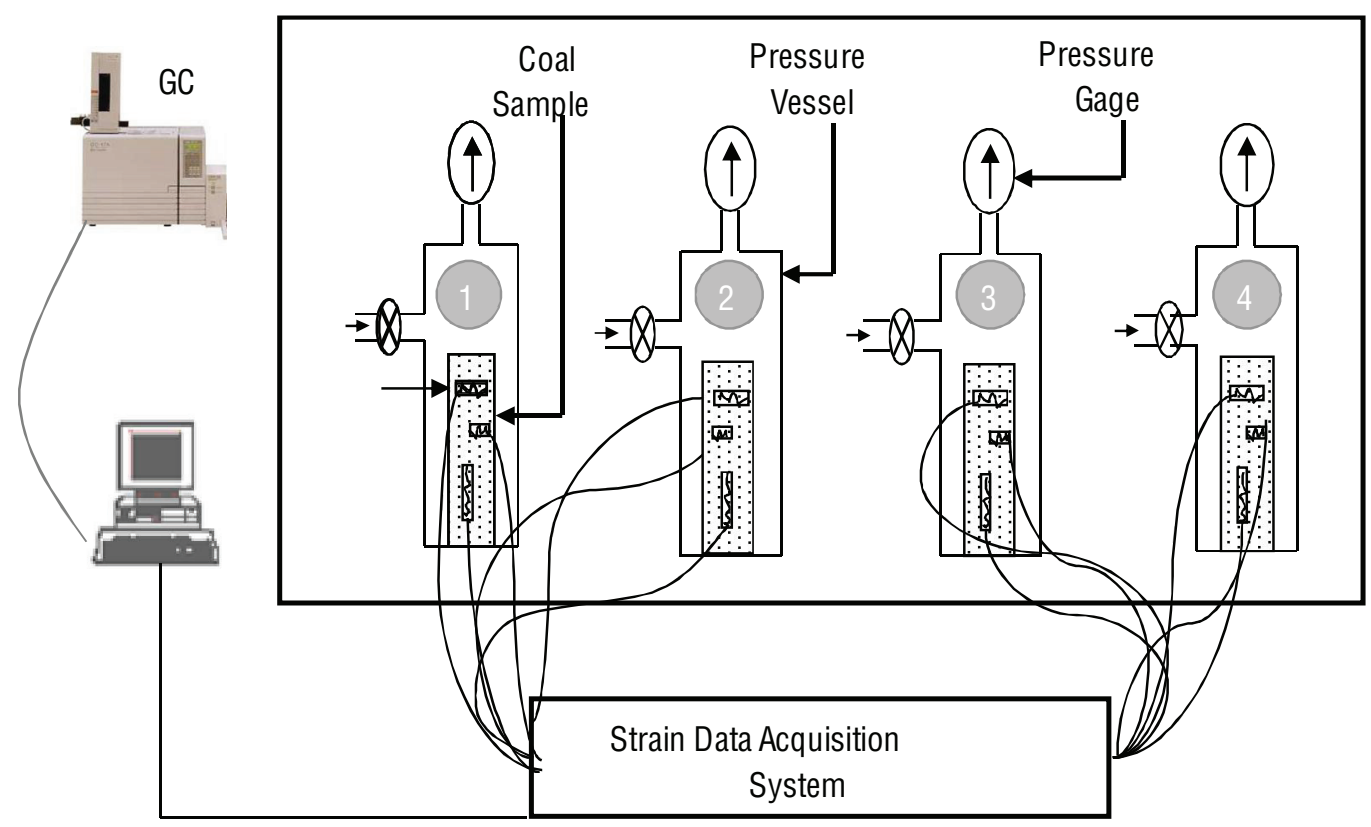

Figure A21-1. Schematic of the experimental setup to measure volumetric strain. 


\section{Appendix 22. $\mathrm{CO}_{2}$ Plume Modeling Figures}
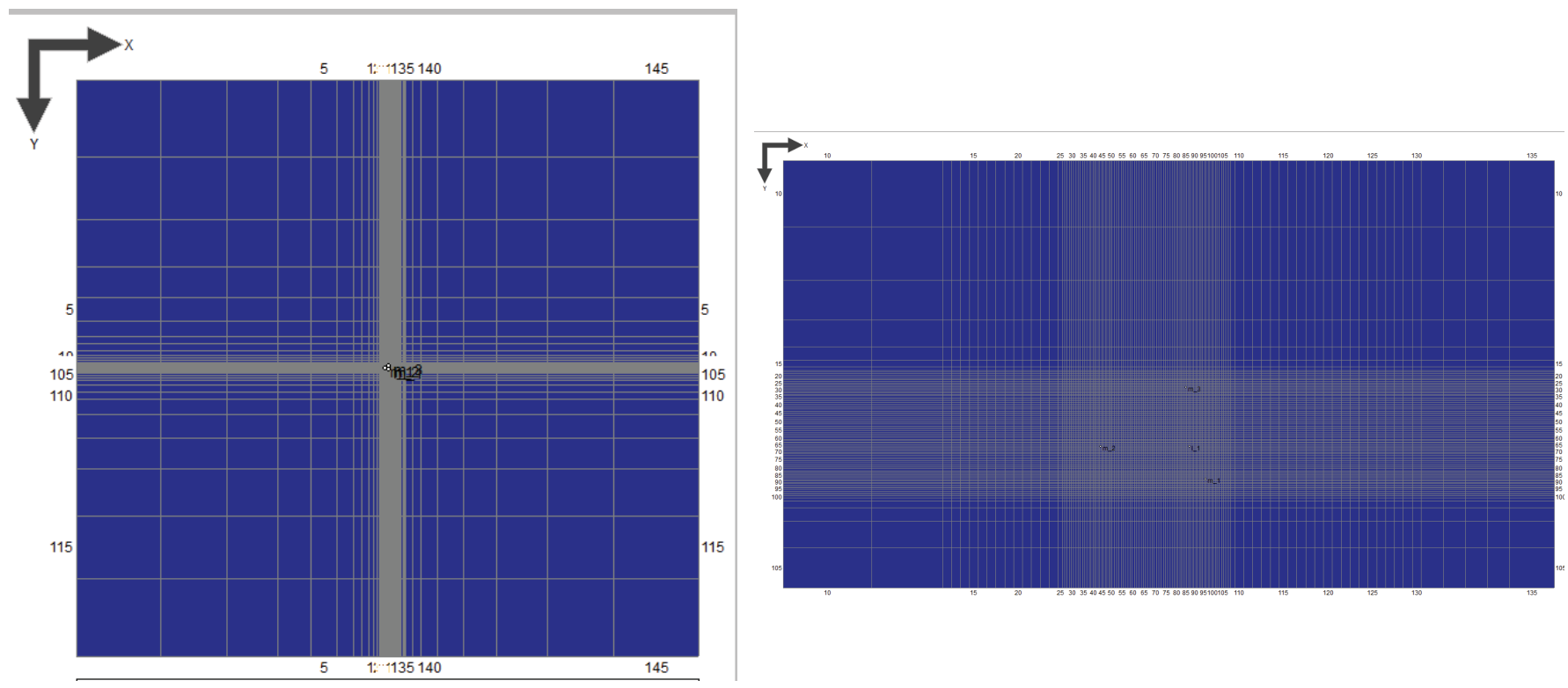

Figure A22-1. Model view: full-size grid (left) and zoom of well area (right) illustrating grid refinement after multiple simulations. Numbers on model edges represent distances from origin in feet. Some distances on left-hand image were compressed for modeling purposes, rendering numbers illegible.

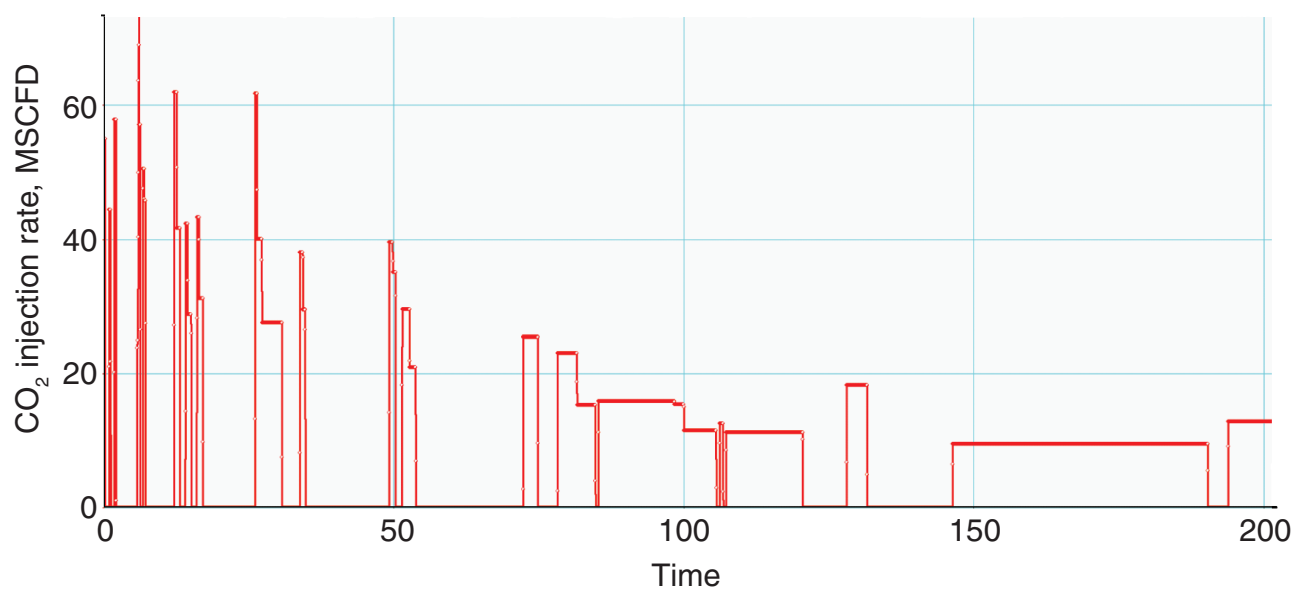

Figure A22-2. $\mathrm{CO}_{2}$ injection rate profile (MSCFD-1,000 scf/d). 


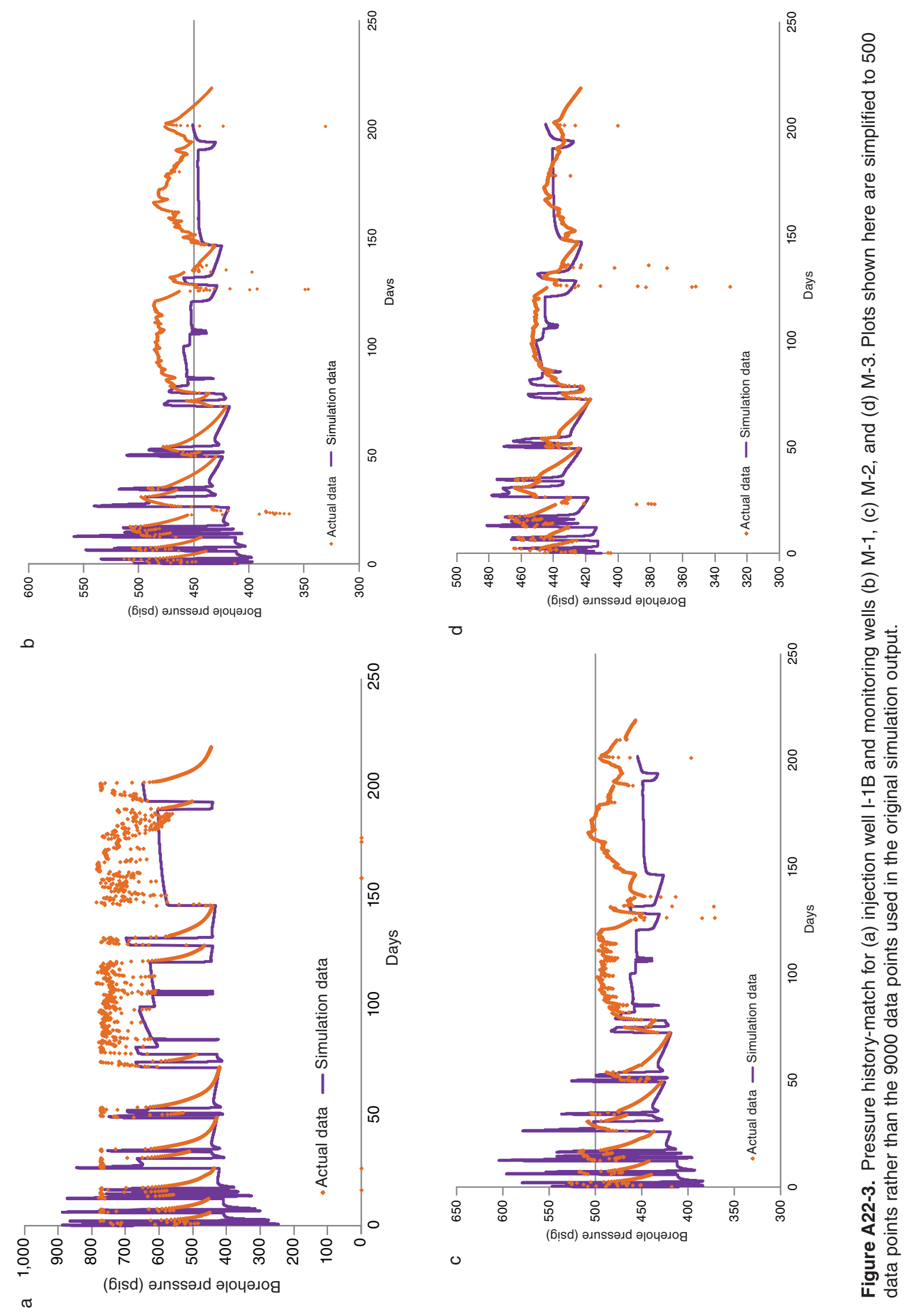



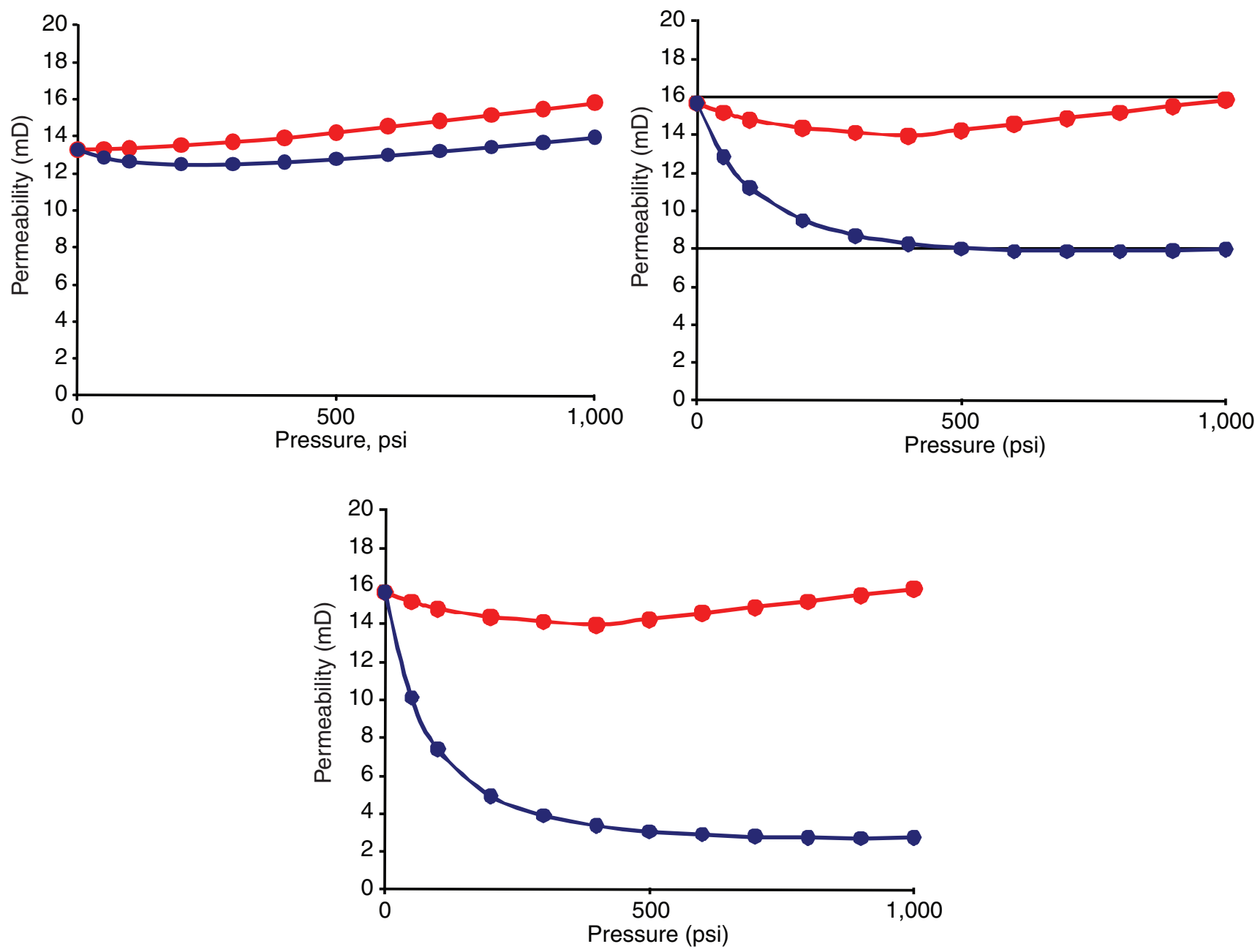

Figure A22-4. Illustration of permeability evolution due to coal swelling (increasing swelling from left to right; see text for details). Blue or lower curve is the permeability change due to $\mathrm{CO}_{2}$ only, and the red or upper curve is the permeability change due to $\mathrm{CH}_{4}$ only. 

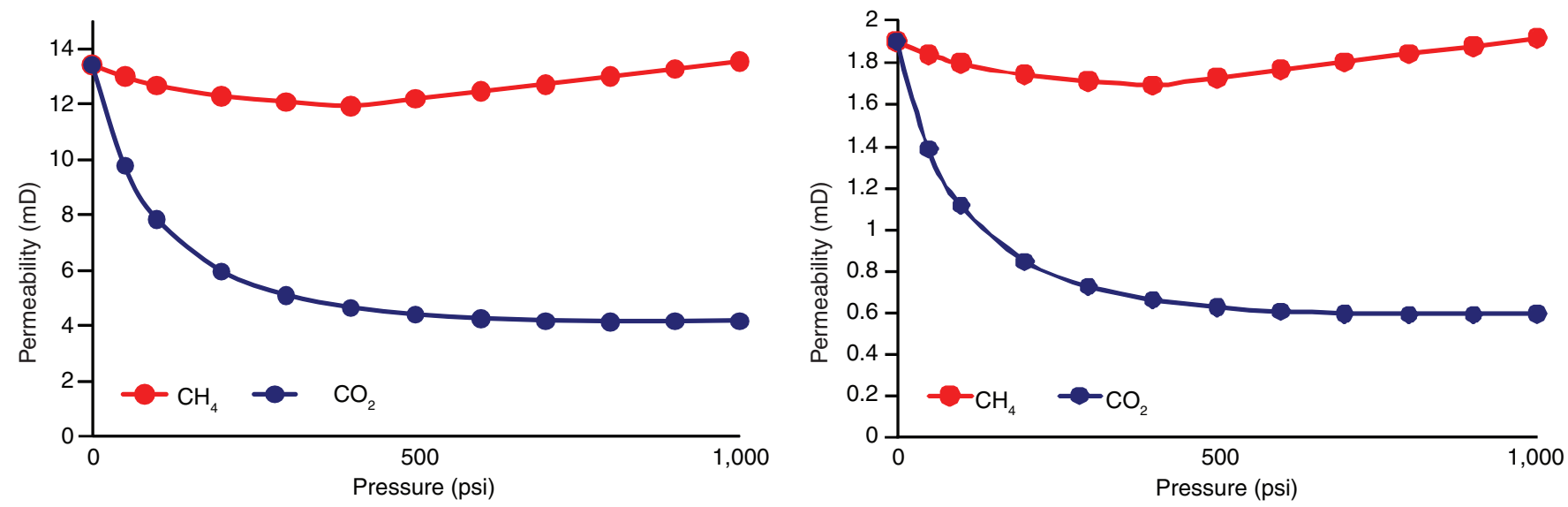

Figure A22-5. Model permeability versus pressure (face cleat at left and butt cleat at right). Blue or lower curve is the permeability change due to $\mathrm{CO}_{2}$ only and the red or upper curve is the permeability change due to $\mathrm{CH}_{4}$ only.

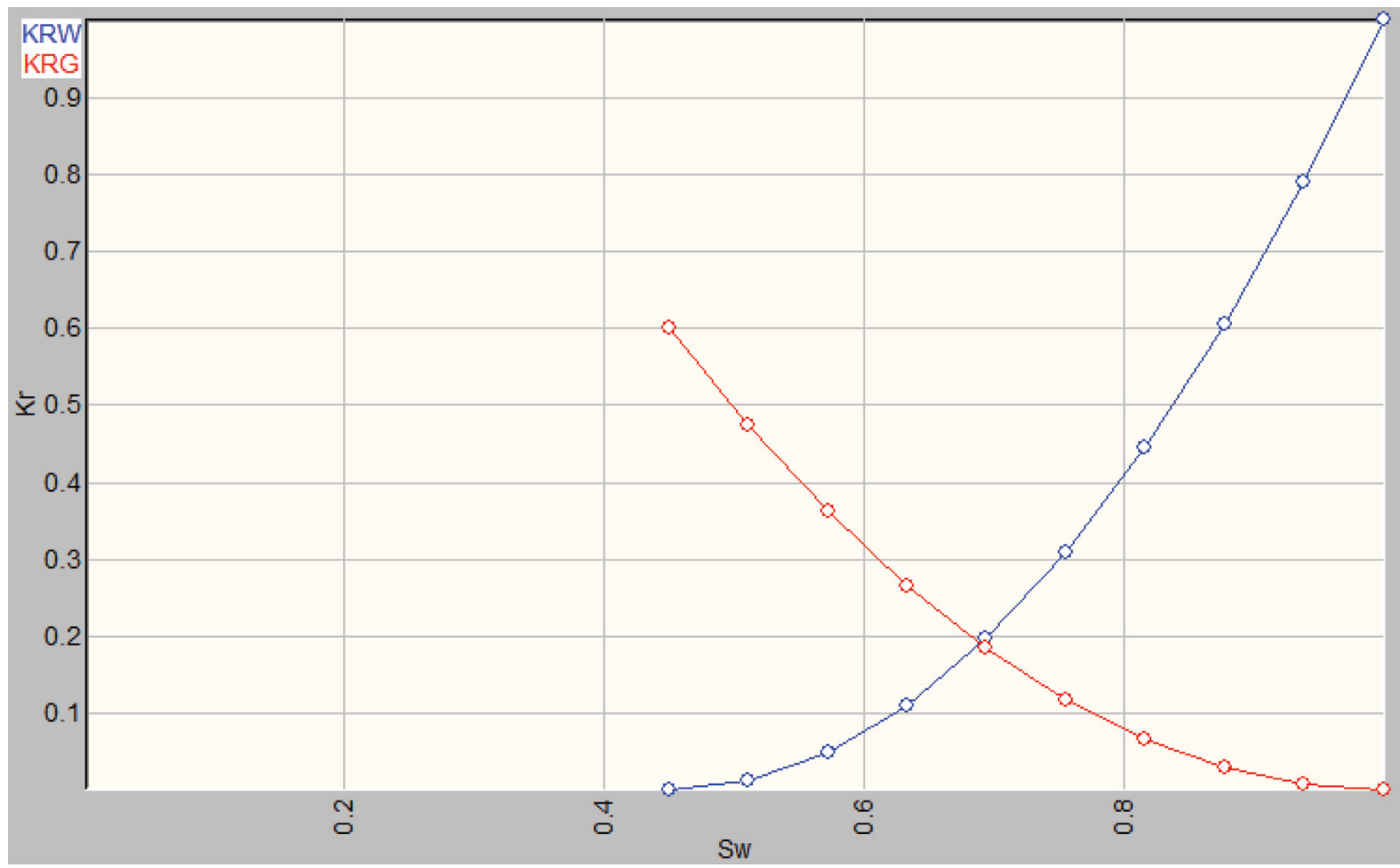

Figure A22-6. Optimized relative permeability curves. 


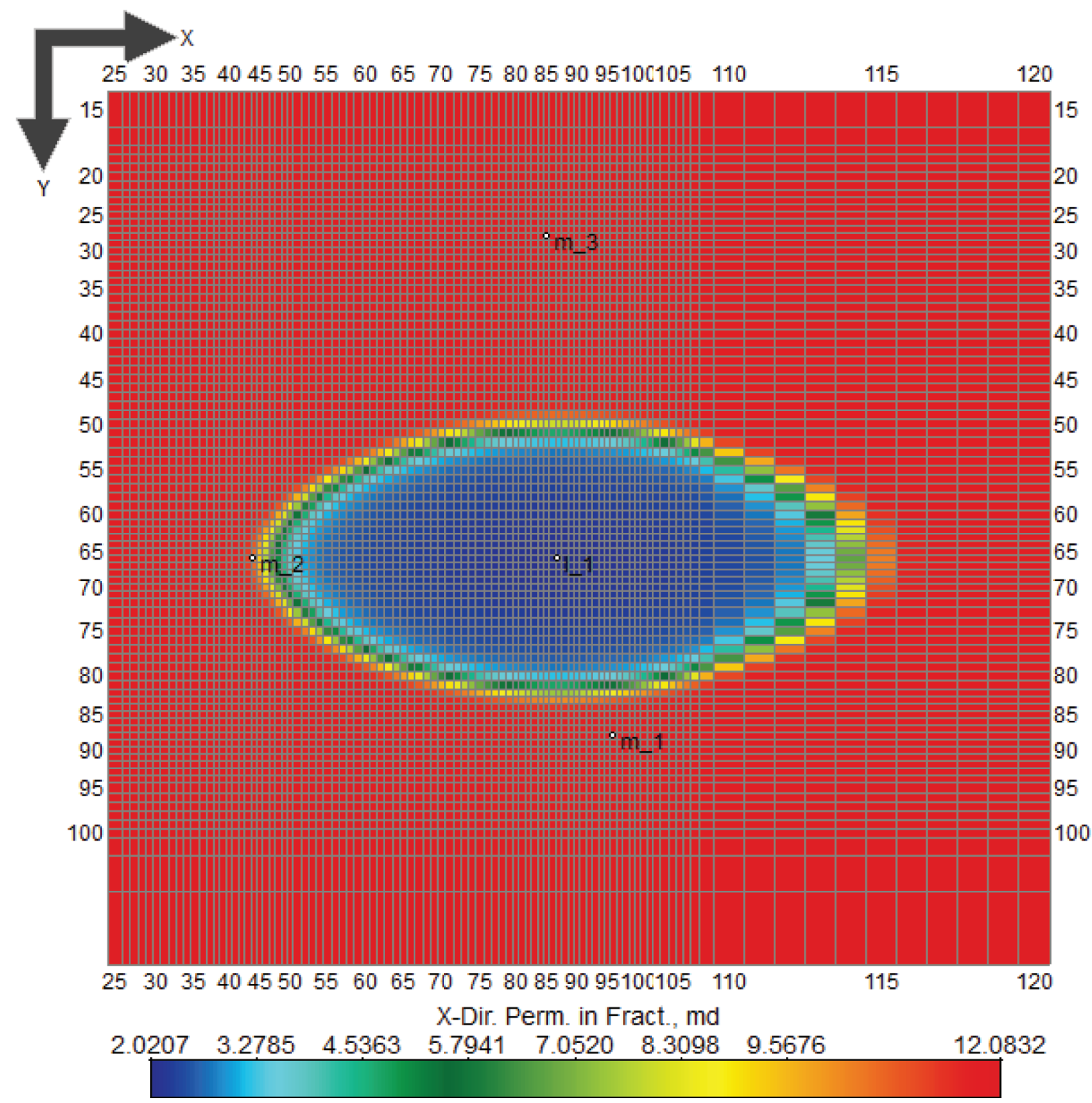

Figure A22-7. Face cleat permeability at the end of $\mathrm{CO}_{2}$ injection (not to scale). 


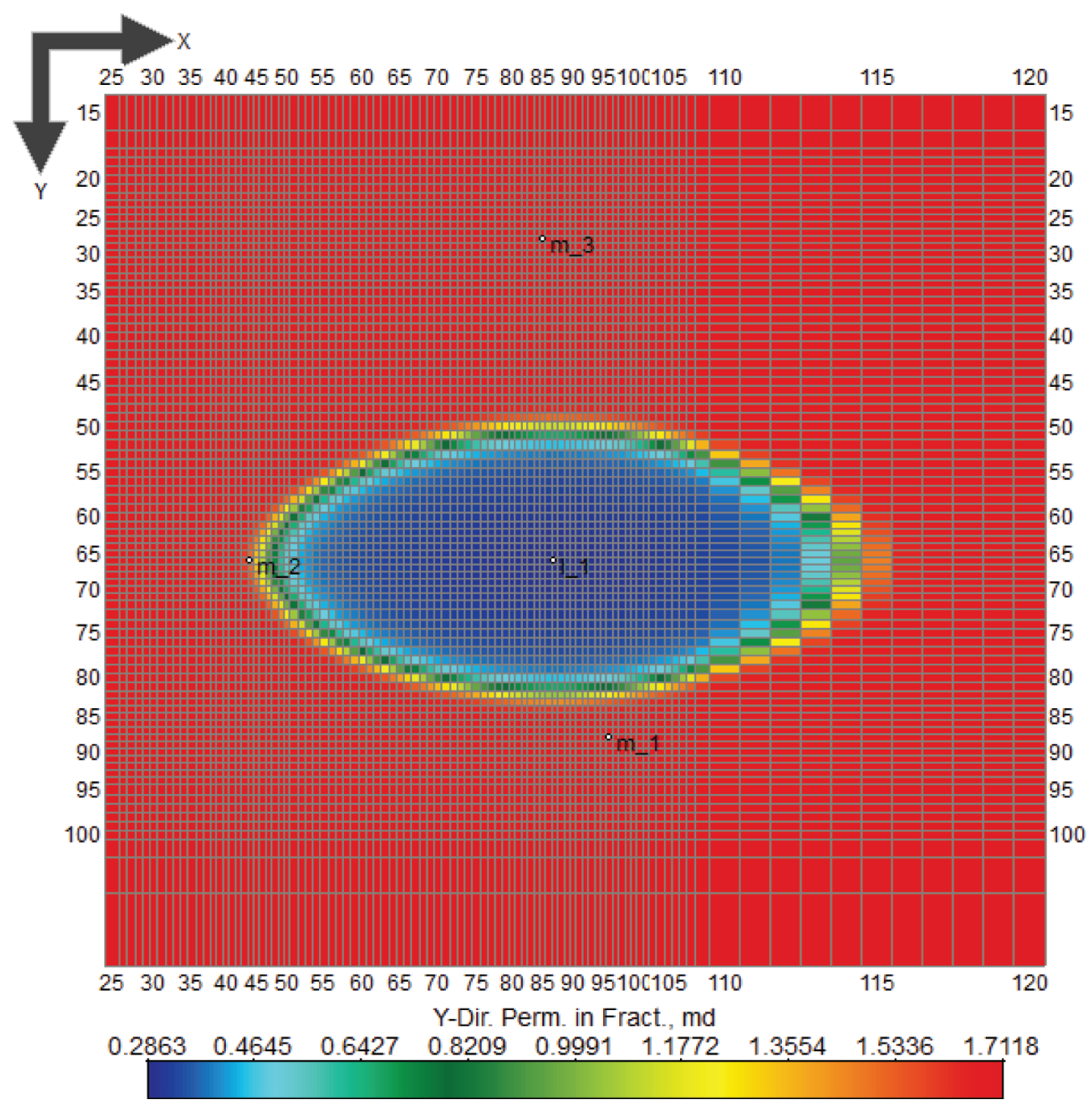

Figure A22-8. Butt cleat permeability at the end of $\mathrm{CO}_{2}$ injection (not to scale). 


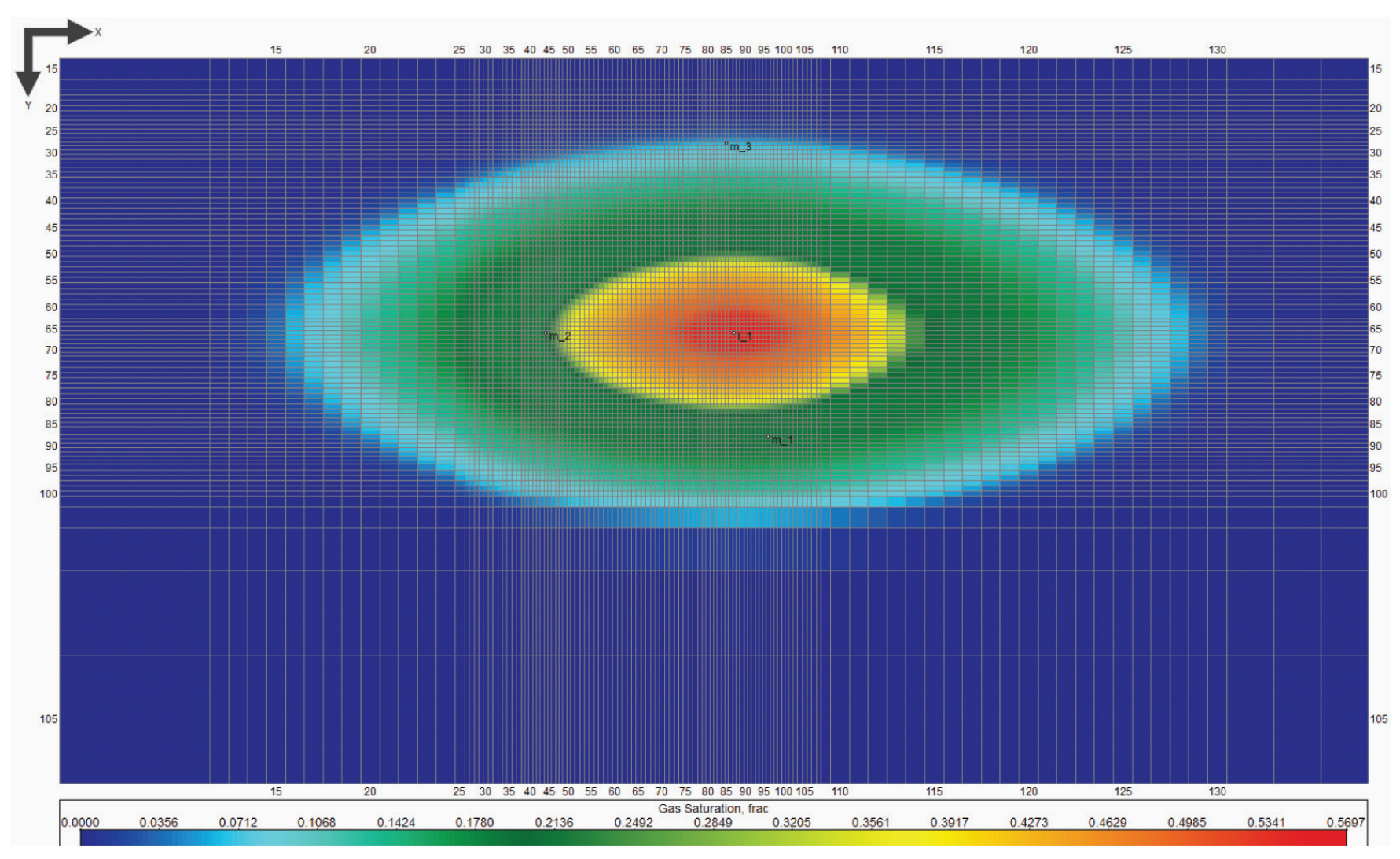

Figure A22-9. The $\mathrm{CO}_{2}$ plume view at the end of $\mathrm{CO}_{2}$ injection (not to scale). 


\section{Appendix 23. Gas Chromatography Results for Gas Samples from Injection $\mathrm{CO}_{2}$ and Coal Seam Observation Wells during and $\mathrm{Post}_{-} \mathrm{CO}_{2}$ Injection}

Table A23-1. Gas chromatography results for gas as samples from injection CO2 and observation well M-1.

\begin{tabular}{|c|c|c|c|c|c|c|c|c|c|c|c|c|c|}
\hline Sample & Date & Time $^{1}$ & $\mathrm{CO}_{2}$ & $\mathrm{O}_{2}+\mathrm{Ar}$ & $\mathrm{N}_{2}$ & $\mathrm{CH}_{4}$ & $\mathrm{C}_{2} \mathrm{H}_{6}$ & $\mathrm{C}_{3} \mathrm{H}_{8}$ & $\mathrm{iC}_{4} \mathrm{H}_{10}$ & $\mathrm{nC}_{4} \mathrm{H}_{10}$ & $\mathrm{iC}_{5} \mathrm{H}_{12}$ & $\mathrm{nC}_{5} \mathrm{H}_{12}$ & $\mathrm{C}_{6} \mathrm{H}_{14}+$ \\
\hline \multicolumn{14}{|l|}{$\begin{array}{l}\text { Injection } \\
\mathrm{CO}_{2} \\
\text { Tank }\end{array}$} \\
\hline $\mathrm{CO}_{2}$ & 06/25/08 & & 100.0 & $<0.01$ & $<0.01$ & $<0.01$ & $<0.01$ & $<0.01$ & $<0.01$ & $<0.01$ & $<0.01$ & $<0.01$ & $<0.01$ \\
\hline \multicolumn{14}{|l|}{ Well } \\
\hline \multicolumn{14}{|l|}{$M-1$} \\
\hline$M-1-1$ & 06/25/08 & 1735 & 0.04 & 17.35 & 65.80 & 16.62 & $<0.01$ & 0.07 & $<0.01$ & 0.03 & $<0.01$ & 0.04 & 0.03 \\
\hline$M-1-2$ & 06/25/08 & 1832 & $<0.01$ & 15.43 & 61.35 & 23.22 & $<0.01$ & $<0.01$ & $<0.01$ & $<0.01$ & $<0.01$ & $<0.01$ & $<0.01$ \\
\hline$M-1-3$ & 06/25/08 & 2352 & 0.07 & 11.34 & 51.04 & 37.30 & $<0.01$ & 0.03 & $<0.01$ & 0.05 & 0.03 & 0.06 & 0.08 \\
\hline M1-5 & 07/01/08 & 1618 & 0.25 & 0.66 & 22.31 & 76.78 & $<0.01$ & $<0.01$ & $<0.01$ & $<0.01$ & $<0.01$ & $<0.01$ & $<0.01$ \\
\hline$M-1$ & 07/03/08 & 1130 & 0.12 & 0.27 & 17.26 & 82.32 & 0.03 & $<0.01$ & $<0.01$ & $<0.01$ & $<0.01$ & $<0.01$ & $<0.01$ \\
\hline$M-1$ & 07/12/08 & 1000 & 0.12 & 0.20 & 9.00 & 90.33 & 0.03 & 0.03 & $<0.01$ & 0.07 & 0.04 & 0.08 & 0.10 \\
\hline$M-1$ & 07/18/08 & 0017 & 0.06 & 0.42 & 10.47 & 89.01 & 0.03 & $<0.01$ & $<0.01$ & $<0.01$ & $<0.01$ & $<0.01$ & $<0.01$ \\
\hline$M-1$ & 07/18/08 & 0336 & 0.03 & 1.02 & 8.41 & 90.50 & 0.04 & $<0.01$ & $<0.01$ & $<0.01$ & $<0.01$ & $<0.01$ & $<0.01$ \\
\hline$M-1$ & 07/18/08 & 0500 & $<0.01$ & 0.09 & 5.53 & 94.33 & 0.04 & $<0.01$ & $<0.01$ & $<0.01$ & $<0.01$ & $<0.01$ & $<0.01$ \\
\hline |M-1 & 07/24/08 & 1130 & 12.73 & 0.18 & 6.69 & 80.37 & 0.02 & $<0.01$ & $<0.01$ & $<0.01$ & $<0.01$ & $<0.01$ & $<0.01$ \\
\hline$M-1$ & 07/24/08 & 1130 & 12.80 & 0.21 & 6.84 & 80.13 & 0.02 & $<0.01$ & $<0.01$ & $<0.01$ & $<0.01$ & $<0.01$ & $<0.01$ \\
\hline$M-1$ & 07/25/08 & 0145 & 11.78 & 1.70 & 11.75 & 74.76 & 0.02 & $<0.01$ & $<0.01$ & $<0.01$ & $<0.01$ & $<0.01$ & $<0.01$ \\
\hline M-1 dup & 07/25/08 & 0145 & 11.77 & 1.66 & 11.55 & 74.99 & 0.02 & $<0.01$ & $<0.01$ & $<0.01$ & $<0.01$ & $<0.01$ & $<0.01$ \\
\hline$M-1$ & 07/25/08 & 0945 & 12.46 & 0.58 & 8.22 & 78.72 & 0.02 & $<0.01$ & $<0.01$ & $<0.01$ & $<0.01$ & $<0.01$ & $<0.01$ \\
\hline$M-1$ & 07/25/08 & 1845 & 11.42 & 1.65 & 12.34 & 74.59 & 0.02 & $<0.01$ & $<0.01$ & $<0.01$ & $<0.01$ & $<0.01$ & $<0.01$ \\
\hline$M-1$ & $07 / 26 / 08^{2}$ & 0200 & 6.84 & 9.80 & 38.49 & 44.87 & $<0.01$ & $<0.01$ & $<0.01$ & $<0.01$ & $<0.01$ & $<0.01$ & $<0.01$ \\
\hline$M-1$ & 07/27/08 & 1316 & 12.38 & 0.21 & 7.43 & 79.97 & 0.02 & $<0.01$ & $<0.01$ & $<0.01$ & $<0.01$ & $<0.01$ & $<0.01$ \\
\hline$M-1$ & 07/28/08 & 1300 & 11.51 & 1.30 & 10.99 & 76.17 & 0.02 & $<0.01$ & $<0.01$ & $<0.01$ & $<0.01$ & $<0.01$ & $<0.01$ \\
\hline$M-1$ & 07/29/08 & 1140 & 12.02 & 0.47 & 8.45 & 79.03 & 0.02 & $<0.01$ & $<0.01$ & $<0.01$ & $<0.01$ & $<0.01$ & $<0.01$ \\
\hline$M-1$ & 08/21/08 & 1300 & 12.15 & 0.40 & 1.99 & 85.45 & 0.01 & $<0.01$ & $<0.01$ & $<0.01$ & $<0.01$ & $<0.01$ & $<0.01$ \\
\hline M1 & 08/28/08 & 1059 & 12.02 & 0.69 & 2.40 & 84.87 & 0.02 & $<0.01$ & $<0.01$ & $<0.01$ & $<0.01$ & $<0.01$ & $<0.01$ \\
\hline$M-1$ & 09/02/08 & 1135 & 12.01 & 0.82 & 2.64 & 84.50 & 0.03 & $<0.01$ & 0.01 & 0.02 & $<0.01$ & 0.01 & $<0.01$ \\
\hline$M-1$ & 09/11/08 & 1505 & 11.93 & 1.20 & 3.18 & 83.67 & 0.02 & $<0.01$ & $<0.01$ & $<0.01$ & $<0.01$ & $<0.01$ & $<0.01$ \\
\hline$M-1$ & 09/16/08 & 1501 & 12.29 & 0.46 & 2.04 & 85.15 & 0.03 & 0.02 & $<0.01$ & 0.01 & $<0.01$ & $<0.01$ & $<0.01$ \\
\hline$M-1$ & 09/24/08 & 1315 & 12.40 & 0.26 & 1.18 & 86.15 & 0.02 & $<0.01$ & $<0.01$ & $<0.01$ & $<0.01$ & $<0.01$ & $<0.01$ \\
\hline$M-1$ & 10/02/08 & 1500 & 12.91 & 1.21 & 2.79 & 83.07 & 0.02 & $<0.01$ & $<0.01$ & $<0.01$ & $<0.01$ & $<0.01$ & $<0.01$ \\
\hline$M-1$ & $10 / 02 / 08$ & 1500 & 12.81 & 1.27 & 3.00 & 82.90 & 0.02 & $<0.01$ & $<0.01$ & $<0.01$ & $<0.01$ & $<0.01$ & $<0.01$ \\
\hline M1 & $10 / 16 / 08$ & 1445 & 14.36 & 0.85 & 7.44 & 77.32 & 0.03 & $<0.01$ & $<0.01$ & $<0.01$ & $<0.01$ & $<0.01$ & $<0.01$ \\
\hline M1 & 10/22/08 & & 16.42 & 0.52 & 6.01 & 77.02 & 0.03 & $<0.01$ & $<0.01$ & $<0.01$ & $<0.01$ & $<0.01$ & $<0.01$ \\
\hline M1 & 10/27/08 & & 17.97 & 0.79 & 4.64 & 76.53 & 0.04 & $<0.01$ & $<0.01$ & 0.02 & $<0.01$ & $<0.01$ & $<0.01$ \\
\hline M1 \#1 & $10 / 28 / 08^{2}$ & 1902 & 12.52 & 10.36 & 37.57 & 39.52 & $<0.01$ & $<0.01$ & $<0.01$ & $<0.01$ & $<0.01$ & $<0.01$ & 0.03 \\
\hline M1 \#2 & 10/28/08 & 2111 & 19.76 & 0.81 & 5.99 & 73.41 & 0.04 & $<0.01$ & $<0.01$ & $<0.01$ & $<0.01$ & $<0.01$ & $<0.01$ \\
\hline M1 \#4 & 10/29/08 & 1248 & 78.38 & 0.13 & 2.03 & 19.47 & $<0.01$ & $<0.01$ & $<0.01$ & $<0.01$ & $<0.01$ & $<0.01$ & $<0.01$ \\
\hline M1 \#5 & 10/29/08 & 1630 & 80.33 & 0.59 & $<0.01$ & 19.08 & $<0.01$ & $<0.01$ & $<0.01$ & $<0.01$ & $<0.01$ & $<0.01$ & $<0.01$ \\
\hline M1 & $11 / 05 / 08$ & & 60.35 & 0.81 & 2.82 & 36.02 & $<0.01$ & $<0.01$ & $<0.01$ & $<0.01$ & $<0.01$ & $<0.01$ & $<0.01$ \\
\hline M1 \#1 & $11 / 08 / 08$ & 2038 & 1.15 & 0.65 & 6.14 & 92.02 & 0.04 & $<0.01$ & $<0.01$ & $<0.01$ & $<0.01$ & $<0.01$ & $<0.01$ \\
\hline M1 \#2 & 11/08/08 & 2143 & 1.77 & 1.08 & 6.59 & 90.51 & 0.05 & $<0.01$ & $<0.01$ & $<0.01$ & $<0.01$ & $<0.01$ & $<0.01$ \\
\hline M1 \#1 & $11 / 09 / 08^{2}$ & 1432 & 1.04 & 5.67 & 23.01 & 70.24 & 0.04 & $<0.01$ & $<0.01$ & $<0.01$ & $<0.01$ & $<0.01$ & $<0.01$ \\
\hline M1 & 12/03/08 & 1432 & 4.36 & 1.12 & 6.66 & 87.82 & 0.05 & $<0.01$ & $<0.01$ & $<0.01$ & $<0.01$ & $<0.01$ & $<0.01$ \\
\hline M1 & $12 / 18 / 08$ & 1445 & 5.79 & 0.44 & 2.13 & 91.34 & 0.05 & 0.02 & $<0.01$ & 0.04 & 0.03 & 0.06 & 0.12 \\
\hline M1 & 12/22/08 & 1522 & 5.72 & 0.21 & 1.05 & 92.96 & 0.05 & $<0.01$ & $<0.01$ & $<0.01$ & $<0.01$ & $<0.01$ & $<0.01$ \\
\hline M1 & $12 / 24 / 08$ & 1515 & 5.82 & 1.07 & 5.44 & 87.62 & 0.05 & $<0.01$ & $<0.01$ & $<0.01$ & $<0.01$ & $<0.01$ & $<0.01$ \\
\hline M1 & $12 / 25 / 08$ & 0700 & 6.25 & 0.06 & 0.72 & 89.82 & 0.22 & 0.20 & 0.23 & 1.18 & 0.35 & 0.61 & 0.36 \\
\hline
\end{tabular}


Table A23-1. Continued

\begin{tabular}{|c|c|c|c|c|c|c|c|c|c|c|c|c|c|}
\hline Sample & Date & Time $^{1}$ & $\mathrm{CO}_{2}$ & $\mathrm{O}_{2}+\mathrm{Ar}$ & $\mathbf{N}_{2}$ & $\mathrm{CH}_{4}$ & $\mathrm{C}_{2} \mathrm{H}_{6}$ & $\mathrm{C}_{3} \mathrm{H}_{8}$ & $\mathrm{iC}_{4} \mathrm{H}_{10}$ & $\mathrm{nC}_{4} \mathrm{H}_{10}$ & $\mathrm{iC}_{5} \mathrm{H}_{12}$ & $\mathrm{nC}_{5} \mathrm{H}_{12}$ & $\overline{\mathrm{C}_{6} \mathrm{H}_{14}+}$ \\
\hline \multicolumn{14}{|l|}{ Well } \\
\hline M1 dup & $12 / 25 / 08^{2}$ & 0700 & 6.06 & 0.62 & 3.30 & 87.37 & 0.19 & 0.17 & 0.19 & 1.00 & 0.30 & 0.51 & 0.30 \\
\hline M1 & $12 / 27 / 08$ & 0703 & 6.88 & 0.28 & 1.47 & 91.26 & 0.05 & 0.05 & $<0.01$ & $<0.01$ & $<0.01$ & $<0.01$ & $<0.01$ \\
\hline M1 dup & $12 / 27 / 08$ & 0703 & 6.96 & 0.11 & 0.76 & 92.07 & 0.05 & 0.05 & $<0.01$ & $<0.01$ & $<0.01$ & $<0.01$ & $<0.01$ \\
\hline M1 dup & $12 / 27 / 08$ & 0703 & 6.82 & 0.51 & 2.10 & 90.47 & 0.05 & 0.05 & $<0.01$ & $<0.01$ & $<0.01$ & $<0.01$ & $<0.01$ \\
\hline M1 dup & $12 / 27 / 08$ & 0703 & 7.00 & 0.15 & 0.81 & 91.93 & 0.05 & 0.05 & $<0.01$ & $<0.01$ & $<0.01$ & $<0.01$ & $<0.01$ \\
\hline M1 dup & 12/27/08 & 0703 & 6.94 & 0.23 & 1.08 & 91.64 & 0.05 & 0.05 & $<0.01$ & $<0.01$ & $<0.01$ & $<0.01$ & $<0.01$ \\
\hline M1 & 12/29/08 & 0705 & 7.43 & 0.17 & 1.69 & 89.93 & 0.13 & 0.12 & 0.04 & 0.24 & 0.07 & 0.12 & 0.07 \\
\hline M1 dup & 12/29/08 & 0705 & 7.55 & 0.11 & 1.60 & 89.96 & 0.13 & 0.12 & 0.04 & 0.24 & 0.07 & 0.12 & 0.07 \\
\hline M1 dup & $12 / 29 / 08$ & 0705 & 7.42 & 0.16 & 1.71 & 89.92 & 0.13 & 0.12 & 0.04 & 0.24 & 0.07 & 0.12 & 0.07 \\
\hline M1 & 01/08/09 & 1415 & 8.71 & 0.17 & 1.53 & 89.48 & 0.06 & 0.05 & $<0.01$ & $<0.01$ & $<0.01$ & $<0.01$ & $<0.01$ \\
\hline M1 & 01/08/09 & 1415 & 8.96 & 0.16 & 1.49 & 89.28 & 0.06 & 0.05 & $<0.01$ & $<0.01$ & $<0.01$ & $<0.01$ & $<0.01$ \\
\hline M1 & 01/14/09 & 1500 & 88.59 & 0.16 & 0.97 & 10.28 & $<0.01$ & $<0.01$ & $<0.01$ & $<0.01$ & $<0.01$ & $<0.01$ & $<0.01$ \\
\hline$M-1$ & 04/13/09 & 1828 & 75.71 & 1.35 & 4.83 & 18.03 & 0.03 & 0.06 & $<0.01$ & $<0.01$ & $<0.01$ & $<0.01$ & $<0.01$ \\
\hline$M-1$ & 05/15/09 & 1426 & 79.11 & 0.48 & 1.03 & 19.38 & $<0.01$ & $<0.01$ & $<0.01$ & $<0.01$ & $<0.01$ & $<0.01$ & $<0.01$ \\
\hline$M-1$ & $11 / 28 / 09^{2}$ & $10: 52$ & 0.31 & 19.95 & 77.43 & 2.32 & $<0.01$ & $<0.01$ & $<0.01$ & $<0.01$ & $<0.01$ & $<0.01$ & $<0.01$ \\
\hline
\end{tabular}

${ }^{1}$ Collection times are given in CDT for samples collected from 3/8/08-11/2/08 and 3/8/09-11/1/09. All other times are CST. Collection times were not available for some samples.

${ }^{2}$ Results in red suggest possible air contamination. 
Table A23-2. Gas chromatography results for gas as samples from observation well M-2.

\begin{tabular}{|c|c|c|c|c|c|c|c|c|c|c|c|c|c|c|}
\hline Sample & Date & Time $^{1}$ & $\mathrm{CO}_{2}$ & $\mathrm{O}_{2}+\mathrm{Ar}$ & $\mathrm{N}_{2}$ & $\mathrm{CH}_{4}$ & $\mathrm{C}_{2} \mathrm{H}_{6}$ & $\mathrm{C}_{3} \mathrm{H}_{8}$ & $\mathrm{iC}_{4} \mathrm{H}_{10}$ & $\mathrm{nC}_{4} \mathrm{H}_{10}$ & $\mathrm{iC}_{5} \mathrm{H}_{12}$ & $\mathrm{nC}_{5} \mathrm{H}_{12}$ & $\mathrm{C}_{6} \mathrm{H}_{14}+$ & $\mathrm{H}_{2}$ \\
\hline M-2B & $07 / 10 / 08$ & 1210 & $<0.01$ & 3.17 & 96.68 & 0.15 & $<0.01$ & $<0.01$ & $<0.01$ & $<0.01$ & $<0.01$ & $<0.01$ & $<0.01$ & \\
\hline$M-2 B$ & 07/09/08 & 0900 & $<0.0$ & 3.70 & 6.12 & 0.09 & 0.04 & 0.01 & $<0.01$ & 0.01 & $<0.01$ & 0.02 & $<0.01$ & \\
\hline$M-2 B$ & $07 / 12 / 08^{3}$ & & 0.13 & 6.18 & 93.46 & 0.24 & $<0.01$ & $<0.01$ & $<0.01$ & $<0.01$ & $<0.01$ & $<0.01$ & $<0.01$ & \\
\hline M-2B dup & 07/12/08 & & 0.19 & 2.51 & 97.19 & 0.10 & $<0.01$ & $<0.01$ & $<0.01$ & $<0.01$ & $<0.01$ & $<0.01$ & $<0.01$ & \\
\hline M2 & 07/29/08 & 1145 & 0.03 & 2.98 & 96.98 & $<0.01$ & $<0.01$ & $<0.01$ & $<0.01$ & $<0.01$ & $<0.01$ & $<0.01$ & $<0.01$ & \\
\hline M2-B & 08/12/08 & & $<0.01$ & 1.50 & 98.15 & 0.35 & na & na & na & na & na & na & na & \\
\hline M2 \#1 & $10 / 29 / 08$ & 1213 & 0.48 & 0.52 & 9.70 & 89.27 & 0.03 & $<0.01$ & $<0.01$ & $<0.01$ & $<0.01$ & $<0.01$ & $<0.01$ & \\
\hline M2 \#3 & $10 / 29 / 08$ & 1651 & $<0.01$ & 0.26 & 3.30 & 96.39 & 0.04 & .01 & $<0$ & 0.01 & $<0.01$ & 0.01 & $<0$. & \\
\hline M2 \#1 & $11 / 03 / 08$ & 2122 & $<0.01$ & 0.40 & 5.50 & 94.06 & 0.04 & $<0.01$ & $<0.01$ & $<0.01$ & $<0.01$ & $<0.01$ & $<0.01$ & \\
\hline M2 \#4 & $11 / 03 / 08$ & 0017 & 0.04 & 1.03 & 4.91 & 93.94 & 0.07 & $<0.01$ & $<0$. & $<0.01$ & $<0.01$ & $<0.01$ & $<0$. & \\
\hline M2 \#2 & $11 / 03 / 08$ & 2132 & $<0.01$ & 0.31 & 6.54 & 93.12 & 0.04 & $<0.01$ & $<0$. & $<0.01$ & $<0.01$ & $<0$. & $<0$. & \\
\hline M2 & $11 / 05 / 08$ & & 0.05 & 0.74 & 5.21 & 93.93 & 0.07 & $<0.01$ & $<0.01$ & $<0.01$ & $<0.01$ & $<0.01$ & $<0.01$ & \\
\hline M2 \#1 & $11 / 08 / 08$ & 0903 & 0.44 & 0.96 & 5.94 & 92.60 & 0.06 & $<0.01$ & $<0.01$ & $<0.01$ & $<0.01$ & $<0.01$ & $<0.01$ & \\
\hline M2 \#2 & $11 / 08 / 08$ & 1102 & 88.18 & 0.74 & 1.07 & 10.00 & $<0.01$ & $<0.01$ & $<0.01$ & $<0.01$ & $<0.01$ & $<0.01$ & $<0.01$ & \\
\hline M2 & $11 / 25 / 08$ & 1456 & 51.34 & 0.47 & 2.25 & 16.51 & $<0.01$ & $<0.01$ & $<0.01$ & $<0.01$ & $<0.01$ & $<0.01$ & $<0.01$ & 29.4 \\
\hline M2 & $11 / 25 / 08$ & 1456 & 50.12 & 0.48 & 3.29 & 16.57 & 0.00 & $<0.01$ & $<0.01$ & $<0.01$ & $<0.01$ & $<0.01$ & $<0.01$ & 29.5 \\
\hline M2-B & $12 / 04 / 08$ & 1204 & 46.99 & 0.61 & 0.67 & 13.81 & $<0.01$ & $<0.01$ & $<0.01$ & $<0.01$ & $<0.01$ & $<0.01$ & $<0.01$ & 38.03 \\
\hline M2 & $12 / 18 / 08$ & 1450 & 41.60 & 0.34 & 1.24 & 12.40 & 0.07 & 0.06 & 0.15 & 0.70 & 0.24 & 0.38 & 0.19 & 42.6 \\
\hline M2 & $12 / 22 / 08$ & 1414 & 41.46 & 0.13 & 1.00 & 12.63 & 0.23 & 0.16 & 0.06 & 0.41 & 0.16 & 0.53 & 0.20 & 43.0 \\
\hline M2 Dup & $12 / 22 / 08$ & 1414 & 41.37 & 0.15 & 1.03 & 12.49 & 0.24 & 0.17 & 0.06 & 0.42 & 0.16 & 0.5 & 0.19 & 43.2 \\
\hline M2 & $12 / 24 / 08$ & 1520 & 42.28 & 0.08 & 1.06 & 12.64 & 0.17 & 0.13 & 0.18 & 0.82 & 0.16 & 0.22 & 0.06 & 42.2 \\
\hline M2 & $12 / 25 / 08$ & 0700 & 42.22 & 0.21 & 1.18 & 12.28 & 0.03 & 0.03 & 0.06 & 0.41 & 0.18 & 0.34 & 0.24 & 42.8 \\
\hline M2 & $12 / 27 / 08^{2}$ & 0701 & 40.45 & 6.44 & 21.06 & 11.04 & $<0.01$ & $<0.01$ & $<0.01$ & $<0.01$ & $<0.01$ & $<0.01$ & $<0.01$ & 21.0 \\
\hline M2 Dup & $12 / 27 / 08^{2}$ & 0701 & 40.58 & 6.45 & 21.12 & 10.99 & $<0.01$ & $<0.01$ & $<0.01$ & $<0.01$ & $<0.01$ & $<0.01$ & $<0.01$ & 20.9 \\
\hline M2 & $12 / 29 / 08$ & 0710 & 41.37 & 0.32 & 1.30 & 12.29 & 0.07 & 0.05 & 0.16 & 0.89 & 0.29 & 0.52 & 0.33 & 42.4 \\
\hline M2 Dup & $12 / 29 / 08$ & 0710 & 41.43 & 0.29 & 1.27 & 12.21 & 0.07 & 0.05 & 0.16 & 0.89 & 0.29 & 0.53 & 0.33 & 42.5 \\
\hline M2 & 01/08/09 & 1425 & 41.74 & 0.13 & 1.08 & 12.66 & 0.04 & 0.04 & 0.05 & 0.22 & 0.04 & 0.06 & 0.07 & 43.9 \\
\hline M2 & $01 / 14 / 09$ & 1510 & 89.79 & 0.07 & 0.97 & 9.02 & 0.00 & 0.00 & 0.00 & 0.03 & 0.02 & 0.04 & 0.06 & \\
\hline M-2 & 04/13/09 & 1835 & 85.86 & 1.03 & 3.14 & 9.97 & $<0.01$ & $<0.01$ & $<0.01$ & $<0.01$ & $<0.01$ & $<0.01$ & $<0.01$ & $?$ \\
\hline$M-2 B$ & 05/15/09 & 1450 & 86.07 & 0.99 & 1.84 & 11.10 & $<0.01$ & $<0.01$ & $<0.01$ & $<0.01$ & $<0.01$ & $<0.01$ & $<0.01$ & \\
\hline$M-2 B$ & 05/21/09 & 0932 & 96.32 & 0.08 & $<0.01$ & 3.59 & $<0.01$ & $<0.01$ & $<0.01$ & $<0.01$ & $<0.01$ & $<0.01$ & $<0.01$ & \\
\hline M-2 & $11 / 28 / 09^{2}$ & 1158 & 0.13 & 19.71 & 71.68 & 8.48 & $<0.01$ & $<0.01$ & $<0.01$ & $<0.01$ & $<0.01$ & $<0.01$ & $<0.01$ & \\
\hline
\end{tabular}

${ }^{1}$ Collection times are given in CDT for samples collected from 03/08/08-11/02/08 and 03/08/09-11/01/09. All other times are CST. Collection times were not available for some samples.

2Italicized $\mathrm{H}_{2}$ concentration estimated based on initial gas chromatographic analysis without $\mathrm{H}_{2}$ analysis; $\mathrm{H}_{2}$ later confirmed present.

${ }^{3}$ Results in red suggest possible air contamination. 
Table A23-3. Gas chromatography results for gas as samples from observation well M-3.

\begin{tabular}{|c|c|c|c|c|c|c|c|c|c|c|c|c|c|}
\hline Sample & Date & Time & $\mathrm{CO}_{2}$ & $\mathrm{O}_{2}+\mathrm{Ar}$ & $\mathrm{N}_{2}$ & $\mathrm{CH}_{4}$ & $\mathrm{C}_{2} \mathrm{H}_{6}$ & $\mathrm{C}_{3} \mathrm{H}_{8}$ & $\mathrm{iC}_{4} \mathrm{H}_{10}$ & $\mathrm{nC}_{4} \mathrm{H}_{10}$ & $\mathrm{iC}_{5} \mathrm{H}_{12}$ & $\mathrm{nC}_{5} \mathrm{H}_{12}$ & $\mathrm{C}_{6} \mathrm{H}_{14}+$ \\
\hline M-3-1 & $06 / 25 / 08^{2}$ & 1130 & 0.05 & 16.18 & 71.24 & 12.53 & $<0.01$ & $<0.01$ & $<0.01$ & $<0.01$ & $<0.01$ & $<0.01$ & $<0.01$ \\
\hline M-3-1 & $06 / 25 / 08^{2}$ & 1925 & 0.07 & 17.70 & 73.68 & 8.54 & $<0.01$ & $<0.01$ & $<0.01$ & $<0.01$ & $<0.01$ & $<0.01$ & $<0.01$ \\
\hline M-3 & 07/01/08 & 1630 & 0.04 & 0.51 & 44.15 & 55.23 & $<0.01$ & $<0.01$ & $<0.01$ & $<0.01$ & $<0.01$ & 0.03 & 0.04 \\
\hline M-3 & 07/03/08 & 1145 & $<0.01$ & 0.56 & 36.94 & 62.50 & $<0.01$ & $<0.01$ & $<0.01$ & $<0.01$ & $<0.01$ & $<0.01$ & $<0.01$ \\
\hline M-3 & 07/12/08 & 1000 & $<0.01$ & 0.40 & 20.00 & 79.59 & & $<0.01$ & $<0.01$ & $<0.01$ & $<0.01$ & $<0.01$ & $<0.01$ \\
\hline M-3 & 07/18/08 & 0846 & 0.07 & 0.67 & 17.49 & 81.74 & & $<0.01$ & & $<0.01$ & 0.01 & 0.03 & 0.07 \\
\hline M-3 & 07/18/08 & 0912 & 0.06 & 2.46 & 21.27 & & & & & & & & $<0.01$ \\
\hline M-3 & 07/18/08 & 0941 & 0.04 & 1.4 & 14.98 & 83. & .03 & & & & & & $<0.01$ \\
\hline M-3 & 07/24/08 & 1150 & $<0.01$ & 0. & 7.77 & 92.01 & 0.03 & & & & $<0$. & & $<0.01$ \\
\hline M-3 & 08/21/08 & & 0.04 & 1.44 & 3.26 & 95.22 & 0.03 & & $<0$ & $<0.01$ & $<0.01$ & 01 & $<0.01$ \\
\hline M3 & 08/28/08 & 1109 & 0.00 & 0.30 & 1.35 & 98.32 & 0.04 & $<0.01$ & $<0.01$ & $<0.01$ & $<0.01$ & $<0.01$ & $<0.01$ \\
\hline M-3 & 09/02/08 & 1134 & 0.03 & 0.83 & 2.17 & 96.93 & 0.03 & $<0.01$ & $<0.01$ & $<0.01$ & $<0.01$ & 01 & $<0.01$ \\
\hline M-3 & 09/16/08 & 1505 & 0.00 & 0.87 & 2.23 & 96.87 & 0.03 & $<0.01$ & $<0.01$ & $<0.01$ & $<0.01$ & 01 & $<0.01$ \\
\hline M-3 & 09/24/08 & 1335 & 0.00 & 0.55 & 1.27 & 98.14 & 0.03 & $<0.01$ & $<0.01$ & $<0.01$ & $<0.01$ & $<0.01$ & $<0.01$ \\
\hline M-3 & $10 / 02 / 08$ & 1500 & 0.03 & 0.72 & 1.35 & 97.86 & 0.05 & $<0.01$ & $<0.01$ & $<0.01$ & $<0.01$ & $<0$. & $<0.01$ \\
\hline M3 & $10 / 16 / 08$ & 0255 & 0.05 & 0.78 & 4.73 & 94.27 & 0.07 & 0.07 & $<0.01$ & 0.03 & $<0.01$ & $<0$ & $<0.01$ \\
\hline M3 & $10 / 22 / 08$ & & 0.01 & 0.49 & 5.62 & 93.82 & 0.05 & $<0.01$ & $<0.01$ & $<0.01$ & $<0.01$ & $<0.01$ & $<0.01$ \\
\hline M3 & $10 / 22 / 08$ & & 3.11 & 0.42 & 3.60 & 92.82 & 0.05 & $<0.01$ & $<0.01$ & $<0.01$ & $<0.01$ & $<0.01$ & $<0.01$ \\
\hline M3 & $10 / 27 / 08$ & & 4.53 & 1.28 & 6.66 & 87.48 & 0.06 & $<0.01$ & $<0.01$ & $<0.01$ & $<0.01$ & $<0.01$ & $<0.01$ \\
\hline M3 \#2 & 10/28/08 & 1059 & 6.31 & 0.96 & 6.86 & 85.82 & 0.05 & $<0.01$ & $<0.01$ & $<0.01$ & $<0.01$ & $<0.01$ & $<0.01$ \\
\hline M3 \#6 & 10/28/08 & 1313 & 19.53 & 0.42 & 4.83 & 75.17 & 0.04 & $<0.01$ & $<0.01$ & $<0.01$ & $<0.01$ & $<0.01$ & $<0.01$ \\
\hline M3 \#7 & $10 / 28 / 08$ & 1347 & 22.61 & 0.46 & 1.91 & 74.98 & 0.05 & $<0.01$ & $<0.01$ & $<0.01$ & $<0.01$ & $<0.01$ & $<0.01$ \\
\hline M3 \#8 & $10 / 28 / 08$ & 1430 & 25.43 & 0.11 & 1.73 & 72.69 & 0.04 & $<0.01$ & $<0.01$ & $<0.01$ & $<0.01$ & $<0.01$ & $<0.01$ \\
\hline M3 \#9 & $10 / 28 / 08$ & 1515 & 28.87 & 0.51 & 2.32 & 68.27 & 0.04 & $<0.01$ & $<0.01$ & $<0.01$ & $<0.01$ & $<0.01$ & $<0.01$ \\
\hline M3 \#10 & $10 / 28 / 08$ & 1610 & 37.75 & 0.59 & 1.92 & 59.71 & 0.04 & $<0.01$ & $<0.01$ & $<0.01$ & $<0.01$ & $<0.01$ & $<0.01$ \\
\hline M3 \#11 & 10/28/08 & 1714 & 45.62 & 0.81 & 5.34 & 48.20 & 0.02 & $<0.01$ & $<0.01$ & $<0.01$ & $<0.01$ & $<0.01$ & $<0.01$ \\
\hline M3 & $11 / 05 / 08$ & & 44.04 & 0.84 & 4.47 & 50.65 & $<0.01$ & $<0.01$ & $<0.01$ & $<0.01$ & $<0.01$ & $<0.01$ & $<0.01$ \\
\hline M3 \#1 & $11 / 07 / 08$ & 2025 & 19.05 & 0.99 & 6.96 & 72.93 & 0.03 & 0.03 & $<0.01$ & $<0.01$ & $<0.01$ & $<0.01$ & $<0.01$ \\
\hline M3 \#2 & $11 / 07 / 08$ & 2156 & 34.29 & 1.28 & 6.40 & 58.03 & $<0.01$ & $<0.01$ & $<0.01$ & $<0.01$ & $<0.01$ & $<0.01$ & $<0.01$ \\
\hline M3 \#3 & $11 / 07 / 08$ & 2314 & 49.30 & 0.83 & 3.30 & 46.53 & 0.02 & 0.02 & $<0.01$ & $<0.01$ & $<0.01$ & $<0.01$ & $<0.01$ \\
\hline M3 \#3 & $11 / 07 / 08$ & 2314 & 49.18 & 0.85 & 3.46 & 46.46 & 0.02 & 0.02 & $<0.01$ & $<0.01$ & $<0.01$ & $<0.01$ & $<0.01$ \\
\hline M3 & $12 / 03 / 08$ & 1438 & 25.73 & 2.61 & 12.18 & 59.43 & 0.02 & 0.03 & $<0.01$ & $<0.01$ & $<0.01$ & $<0.01$ & $<0.01$ \\
\hline M3 & $12 / 19 / 08$ & 0027 & 30.82 & 0.36 & 1.72 & 65.11 & 0.09 & 0.09 & 0.15 & 0.76 & 0.25 & 0.40 & 0.25 \\
\hline M3 & $12 / 19 / 08$ & 0028 & 33.20 & 0.16 & $<0.01$ & 65.90 & 0.07 & 0.07 & 0.03 & 0.26 & 07 & 3 & 0.10 \\
\hline M3 & 12/19/08 & 1228 & 32.05 & 0.14 & 1.70 & 65.38 & 0.07 & 0.07 & 0.03 & 0.25 & 0.07 & 0.13 & 0.10 \\
\hline M3 & $12 / 24 / 08$ & 1525 & 33.35 & 0.19 & 0.05 & 65.26 & 0.04 & 0.04 & 0.04 & 0.35 & 0.15 & 0.30 & 0.22 \\
\hline M3 & $12 / 25 / 08$ & 0700 & 28.85 & 2.89 & 13.38 & 54.66 & 0.02 & 0.02 & $<0.01$ & 0.02 & 0.02 & 0.04 & 0.09 \\
\hline M3 & 12/27/08 & 0706 & 32.18 & 0.42 & 1.55 & 64.38 & 0.11 & 0.02 & 0.11 & 0.62 & 0.16 & 0.28 & 0.15 \\
\hline |M3 & 12/29/08 & 0715 & 33.13 & 0.18 & 0.11 & 66.45 & 0.02 & 0.11 & $<0.01$ & $<0.01$ & $<0.01$ & $<0.01$ & $<0.01$ \\
\hline M3 & 01/08/09 & 1430 & 32.26 & 0.54 & 2.10 & 64.05 & 0.02 & 0.03 & 0.05 & 0.36 & 0.15 & 0.25 & 0.18 \\
\hline M3 & 01/14/09 & 1515 & 27.12 & 1.43 & 7.38 & 63.89 & 0.02 & 0.03 & $<0.01$ & 0.01 & 0.02 & 0.03 & 0.06 \\
\hline M3 & 01/14/09 & 1515 & 27.15 & 1.39 & 7.07 & 64.22 & 0.02 & 0.03 & $<0.01$ & 0.01 & 0.02 & 0.03 & 0.06 \\
\hline M-3 & 04/13/09 & 1837 & 29.65 & 0.84 & 5.60 & 63.87 & 0.03 & $<0.01$ & $<0.01$ & $<0.01$ & $<0.01$ & $<0.01$ & $<0.01$ \\
\hline M-3 dup & 04/13/09 & 1837 & 29.77 & 0.83 & 5.56 & 63.80 & 0.03 & $<0.01$ & $<0.01$ & $<0.01$ & $<0.01$ & $<0.01$ & $<0.01$ \\
\hline M-3 & 05/15/09 & 1525 & 30.89 & 2.55 & 10.99 & 55.57 & $<0.01$ & $<0.01$ & $<0.01$ & $<0.01$ & $<0.01$ & $<0.01$ & $<0.01$ \\
\hline M-3 & 05/20/09 & 0735 & 35.78 & 0.23 & 2.31 & 60.54 & 0.07 & 0.58 & 0.07 & 0.32 & 0.04 & 0.01 & 0.05 \\
\hline M-3 & 05/20/09 & 0850 & 64.42 & 0.21 & 1.40 & 33.97 & $<0.01$ & $<0.01$ & $<0.01$ & $<0.01$ & $<0.01$ & $<0.01$ & $<0.01$ \\
\hline M-3 & 05/20/09 & 0903 & 55.07 & 0.43 & 2.30 & 42.20 & $<0.01$ & $<0.01$ & $<0.01$ & $<0.01$ & $<0.01$ & $<0.01$ & $<0.01$ \\
\hline M-3 & $11 / 28 / 09^{2}$ & 1227 & 0.21 & 21.2 & 75.74 & 2.85 & $<0.01$ & $<0.01$ & $<0.01$ & $<0.01$ & $<0.01$ & $<0.01$ & $<0.01$ \\
\hline
\end{tabular}

${ }^{1}$ Collection times are given in CDT for samples collected from 3/8/08-11/2/08 and 3/8/09-11/1/09. All other times are CST. Collection times were not available for some samples.

${ }^{2}$ Results in red suggest possible air contamination. 


\section{Appendix 24. Gas Chromatography Results for Gas Samples from the ECBM Site}

${ }^{1}$ Collection times are given in CDT for samples collected from 3/8/08-11/2/08 and 3/8/09-11/1/09. All other times are CST. Collection times were not available for some samples.

Table A24-1. Gas chromatography results for gas samples from wells ECBM1, ECBM2, ECBM3, and ECBM4.

\begin{tabular}{|c|c|c|c|c|c|c|c|c|c|c|c|c|c|}
\hline Sample & Date & Time $^{1}$ & $\mathrm{CO}_{2}$ & $\mathrm{O}_{2}+\mathrm{Ar}$ & $\mathrm{N}_{2}$ & $\mathrm{CH}_{4}$ & $\mathrm{C}_{2} \mathrm{H}_{6}$ & $\mathrm{C}_{3} \mathrm{H}_{8}$ & $\mathrm{iC}_{4} \mathrm{H}_{10}$ & $\mathrm{nC}_{4} \mathrm{H}_{10}$ & $\mathrm{iC}_{5} \mathrm{H}_{12}$ & $\mathrm{nC}_{5} \mathrm{H}_{12}$ & $\mathrm{C}_{6} \mathrm{H}_{14}+$ \\
\hline Hering & 06/04/08 & & 0.04 & 0.87 & 49.35 & 49.74 & $<0.01$ & $<0.01$ & $<0.01$ & $<0.01$ & $<0.01$ & $<0.01$ & $<0.01$ \\
\hline ECBM1 & 06/05/08 & 1055 & 0.14 & 21.72 & 78.15 & $<0.01$ & $<0.01$ & $<0.01$ & $<0.01$ & $<0.01$ & $<0.01$ & $<0.01$ & $<0.01$ \\
\hline ECBM1 & 06/12/08 & 1158 & 0.08 & 21.66 & 78.08 & 0.17 & $<0.01$ & $<0.01$ & $<0.01$ & 0.01 & $<0.01$ & $<0.01$ & $<0.01$ \\
\hline ECBM1 & 06/19/08 & 1218 & 0.05 & 21.76 & 78.19 & $<0.01$ & $<0.01$ & $<0.01$ & $<0.01$ & $<0.01$ & $<0.01$ & $<0.01$ & $<0.01$ \\
\hline ECBM1 & 06/26/08 & 1325 & 0.05 & 21.96 & 77.95 & $<0.01$ & $<0.01$ & $<0.01$ & $<0.01$ & 0.02 & $<0.01$ & 0.02 & $<0.01$ \\
\hline ECBM1 & 07/01/08 & 1045 & 0.04 & 22.04 & 77.92 & $<0.01$ & $<0.01$ & $<0.01$ & $<0.01$ & $<0.01$ & $<0.01$ & $<0.01$ & $<0.01$ \\
\hline ECBM1 & $07 / 24 / 08$ & 1038 & 0.08 & 22.45 & 77.33 & $<0.01$ & $<0.01$ & 0.07 & $<0.01$ & 0.04 & $<0.01$ & 0.03 & $<0.01$ \\
\hline ECBM1 & $12 / 03 / 08$ & 1327 & 0.11 & 21.96 & 77.93 & $<0.01$ & $<0.01$ & $<0.01$ & $<0.01$ & $<0.01$ & $<0.01$ & $<0.01$ & $<0.01$ \\
\hline ECBM2 & 06/05/08 & 1105 & 0.06 & 21.83 & 78.11 & $<0.01$ & $<0.01$ & $<0.01$ & $<0.01$ & $<0.01$ & $<0.01$ & $<0.01$ & $<0.01$ \\
\hline ECBM2 & $06 / 12 / 08$ & 1145 & 0.06 & 21.73 & 78.21 & $<0.01$ & $<0.01$ & $<0.01$ & $<0.01$ & $<0.01$ & $<0.01$ & $<0.01$ & $<0.01$ \\
\hline ECBM2 & 06/19/08 & 1225 & 0.05 & 21.79 & 78.17 & $<0.01$ & $<0.01$ & $<0.01$ & $<0.01$ & $<0.01$ & $<0.01$ & $<0.01$ & $<0.01$ \\
\hline ECBM2 & 06/26/08 & 1339 & 0.04 & 21.96 & 77.99 & $<0.01$ & $<0.01$ & $<0.01$ & $<0.01$ & $<0.01$ & $<0.01$ & $<0.01$ & $<0.01$ \\
\hline ECBM2 & $07 / 01 / 08$ & 1055 & 0.11 & 21.96 & 77.94 & $<0.01$ & $<0.01$ & $<0.01$ & $<0.01$ & $<0.01$ & $<0.01$ & $<0.01$ & $<0.01$ \\
\hline ECBM2 & $07 / 24 / 08$ & 1045 & 0.06 & 22.52 & 77.42 & $<0.01$ & $<0.01$ & $<0.01$ & $<0.01$ & $<0.01$ & $<0.01$ & $<0.01$ & $<0.01$ \\
\hline ECBM2 & $12 / 03 / 08$ & 1414 & 0.07 & 21.17 & 78.75 & $<0.01$ & $<0.01$ & $<0.01$ & $<0.01$ & $<0.01$ & $<0.01$ & $<0.01$ & $<0.01$ \\
\hline ЕСВМЗ & & 1435 & & 21.77 & 78.19 & $<0.01$ & $<0.01$ & & & & & & $<0.01$ \\
\hline ЕСВМ3 & 06/12/08 & 113 & 0.0 & 21.7 & 78.04 & & & & & & & & $<0.01$ \\
\hline ЕСВМЗ & 06/19/08 & 1235 & 0.05 & 21.72 & 78.23 & $<0.01$ & $<0.01$ & $<0.01$ & $<0.01$ & $<0.01$ & $<0.01$ & $<0$ & $<0.01$ \\
\hline ECBM3 & 06/26/08 & 1345 & 0.05 & 21.95 & 78.00 & $<0.01$ & $<0.01$ & $<0.01$ & $<0.01$ & $<0.01$ & $<0.01$ & $<0.01$ & $<0.01$ \\
\hline ECBM3 & $07 / 01 / 08$ & 1059 & 0.05 & 21.92 & 78.03 & $<0.01$ & $<0.01$ & $<0.01$ & $<0.01$ & $<0.01$ & $<0.01$ & $<0.01$ & $<0.01$ \\
\hline ECBM3 & $07 / 24 / 08$ & 1055 & 0.17 & 22.45 & 77.23 & 0.14 & $<0.01$ & $<0.01$ & $<0.01$ & $<0.01$ & $<0.01$ & $<0.01$ & $<0.01$ \\
\hline ЕСВМ3 & $12 / 03 / 08$ & 1447 & 0.09 & 21.96 & 77.95 & $<0.01$ & $<0.01$ & $<0.01$ & $<0.01$ & $<0.01$ & $<0.01$ & $<0.01$ & $<0.01$ \\
\hline ECBM4 & 06/12/08 & 0859 & 0.08 & 21.76 & 77.94 & 0.21 & $<0.01$ & $<0.01$ & $<0.01$ & $<0.01$ & $<0.01$ & $<0.01$ & $<0.01$ \\
\hline ECBM4 & 06/19/08 & 1242 & 0.05 & 21.79 & 78.16 & $<0.01$ & $<0.01$ & $<0.01$ & $<0.01$ & $<0.01$ & $<0.01$ & $<0.01$ & $<0.01$ \\
\hline ECBM4 & 06/26/08 & 1355 & 0.05 & 21.92 & 78.04 & $<0.01$ & $<0.01$ & $<0.01$ & $<0.01$ & $<0.01$ & $<0.01$ & $<0.01$ & $<0.01$ \\
\hline ECBM4 & 07/01/08 & 1105 & 0.06 & 22.54 & 77.39 & $<0.01$ & $<0.01$ & $<0.01$ & $<0.01$ & $<0.01$ & $<0.01$ & $<0.01$ & $<0.01$ \\
\hline ECBM4 & $12 / 03 / 08$ & 1525 & 0.21 & 21.05 & 78.45 & 0.29 & $<0.01$ & $<0.01$ & $<0.01$ & $<0.01$ & $<0.01$ & $<0.01$ & $<0.01$ \\
\hline
\end{tabular}

${ }^{1}$ Collection times are given in CDT for samples collected from 3/8/08-11/2/08 and 3/8/09-11/1/09. All other times are CST. Collection times were not available for some samples. 

